\title{
Sociale determinanten van kennis van kankerpreventie in Vlaanderen : een empirische studie aan de hand van gestandaardiseerde interviews bij een representatieve steekproef van 1631 Vlamingen
}

Citation for published version (APA):

Deliens, L. (1998). Sociale determinanten van kennis van kankerpreventie in Vlaanderen : een empirische studie aan de hand van gestandaardiseerde interviews bij een representatieve steekproef van 1631 Vlamingen. [Doctoral Thesis, Maastricht University]. Universiteit Maastricht. https://doi.org/10.26481/dis.19980917ld

Document status and date:

Published: 01/01/1998

DOI:

10.26481/dis.19980917ld

Document Version:

Publisher's PDF, also known as Version of record

Please check the document version of this publication:

- A submitted manuscript is the version of the article upon submission and before peer-review. There can be important differences between the submitted version and the official published version of record. People interested in the research are advised to contact the author for the final version of the publication, or visit the DOI to the publisher's website.

- The final author version and the galley proof are versions of the publication after peer review.

- The final published version features the final layout of the paper including the volume, issue and page numbers.

Link to publication

\footnotetext{
General rights rights.

- You may freely distribute the URL identifying the publication in the public portal. please follow below link for the End User Agreement:

www.umlib.nl/taverne-license

Take down policy

If you believe that this document breaches copyright please contact us at:

repository@maastrichtuniversity.nl

providing details and we will investigate your claim.
}

Copyright and moral rights for the publications made accessible in the public portal are retained by the authors and/or other copyright owners and it is a condition of accessing publications that users recognise and abide by the legal requirements associated with these

- Users may download and print one copy of any publication from the public portal for the purpose of private study or research.

- You may not further distribute the material or use it for any profit-making activity or commercial gain

If the publication is distributed under the terms of Article 25fa of the Dutch Copyright Act, indicated by the "Taverne" license above,

Download date: 26 Apr. 2023 
SOCIALE DETERMINANTEN VAN KENNIS VAN KANKERPREVENTIE IN VLAANDEREN 



\title{
SOCIALE DETERMINANTEN VAN KENNIS VAN KANKERPREVENTIE IN VLAANDEREN
}

\author{
Een empirische studie aan de hand \\ van gestandaardiseerde interviews bij een \\ representatieve steekproef van 1631 Vlamingen
}

\section{PROEFSCHRIFT}

ter verkrijging van de graad van doctor aan de Universiteit Maastricht, op gezag van de Rector Magnificus,

Prof. Dr. A.C. Nieuwenhuijzen Kruseman, volgens het besluit van het College van Decanen, in het openbaar te verdedigen

op donderdag 17 september 1998 om 14.00 uur

door

\section{LUC DELIENS}


Promotores:

Praf. dr. G.d. Kak

Prof. dr. F. Louckx (Vrije Universiteit Brussel)

\section{Beoordelingscommissie:}

Prof. dr. H. Phillpsen (voorzitter)

Prof. dr. A.M. Depoorter (Vrije Universiteit Brussel)

Prof. dr. R. Drop

Prof. dr. B. van den Borne

Prof. dr. J. Weyler (Universitaire Instelling Antwerpen)

ISBN: $90-5681-038-3$

De studie gepresenteerd in dit proefschrift werd uitgevoerd aan de dienst Medisch-Sociale Wetenschappen van de VU Brussel.

Dit onderzoek werd financieel gesteund door de Vlaamse Minister voor Volksgezondheid en Preventie en de Onderzoeksraad van de VU Brussel

L. Deliens, Maastricht 1998 
aan Françoise en Quinten aan mijn ouders 



\section{Inhoudsopgave}

lnhoudsopgave

Hoofdstuk 1 Inleiding en probleemstelling

1.1 Algemene probleemstelling van het onderzoek $\quad 1$

1.2 Methodologische doelstelling 5

1.3 Sociale determinanten van kennis van kankerpreventie 6

1.4 De complexe samenhang tussen kennis en gedrag 10

1.5 Opbouw van het onderzoeksverslag 12

Hoofdstuk 2 Maatschappelijk en wetenschappelijk kader voor de studie van kennis van kankerpreventie $\quad 15$

2.1 Een groeiende aandacht voor kankerpreventie in onze samenleving 16

2.2 Ontstaan van een gezondheidsbeleid en een beleid inzake kankerpreventie $\quad 20$

2.3 Voorlichting inzake kankerpreventie aan het algemene publiek 23

2.4 De wetenschappelijke onderbouw van voorlichting inzake kankerpreventie

2.5 Waarom een meetinstrument voor "kennis wan kankerpreventie" ?

Hoofdstuk 3 Kennis van kankerpreventie: begripsanalyse en ontwikkeling van een meetinstrument

3. 1 Conceptualisering en indicering van het begrip 'kankerpreventie'

3.2 De medische kennis over kankerpreventie en de internationale medische richtlijnen inzake kankerpreventie

3.3 Bestaande methodes om kennis van kankerpreventie te meten: een kritische bespreking

3.4 Operationalisering van het onderzoeksconcept

'kennis van kamkerpreventie"

Hoofdstuk 4 Onderzoeksplan

4.1 Onderzoekselementen en participanten 68

4.2 Ontwikkeling en vittesten van de vragenlijst $\quad 74$

4.3 Dataverzameling en datacontrole $\quad 79$

4.4 Algemene principes van de statistische toetsingsprocedures $\quad 80$ 
5.1 Onderzoekswragen en -verwachtingen

5.2 Overzicht en operationalisering van het onderzoeksmateriaal: de kennisvariabelen inzake kankerpreventie

5.3 Kennis van primaire kankerpreventie

5.4. Kennis van secundaire kankerpreventie

5.5 Kennis van de richtlijnen inzake vroegtijdige opsporing van borst- en baarmoederhalskanker

5.6 Samenvatting en discussie

Hoofdstuk 6 Constructie en onderzoek van de kennisschalen

6.1 Constructie van de kennisschalen en anallyse van de kennisscores

6.2 Betrouwbaarheid van de metingen van kennis van kankerpreventie

6.3 Validiteit van de metingen van kennis van kankerpreventie

6.4 Variabiliteit van de scores en vorm van de verdeling van de schalen

6.5 Samenvatting en conclusies

Hoofdstuk 7 Kennis van kankerpreventie en het verband met socio-demografische determinanten

7.1 Probleemstelling en onderzoekshypothesen

7.1.1 Geslacht en kennis van kankerpreventie

7.1.2 Leeftijd en kennis van kankerpreventie

7.1.3 Leefsituatie en kennis van kankerpreventie

7.2 Overzicht van het onderzoeksmateriaal en de analyseopzet

7.3 Socio-demografische werschillen en kennis van kankerpreventie

7.3.1 Sekseverschillen in kennis van kankerpreventie

7.3.2 Leeftijdsverschillen in kennis van kankerpreventie

7.3.3 De invloed van de leefsituatie (partner) op kennis van kankerpreventile

7.4 De samenhang van kennis van kankerpreventie met de sociodemografische determinanten nader bekeken

7.5 Samenvatting en discussie

Hoofdstuk 8 Kennis van kankerpreventie en het verband met sociaal-economische determinanten

8.1 Probleemstelling en onderzoekshypothesen

8.1.1 Opleiding en kennis van kankerpreventie

8.1.2 Inkomen en kennis van kankerpreventie

8.1.3 Beroep en kennïs van kankerpreventie

8.1.4 Geintegreerde SES-indicatoren en kennis van kankerpreventie 
8.2 Overzicht van het onderzoeksmateriaal en de analyseopzet

8.3 Sociaal-economische ongelijkheid en kennis van kankerpreventie

8.3.1 De invloed van opleidingsniveau

8.3.2 De invloed van inkomen

8.3.3 De invloed van beroepsstatus

8.3.4 De invloed van een geïntegreerde sociaal-economische status

8.3.5 De invloeden van de sociaal-economische indicatoren op kennis van kankerprewentie onderling vergeleken

8.4 Elaboratie van de samenhang van kennis van kankerpreventie met de geintegreerdie sociaal-economische status, naar leeftijd en geslecht

8.5 De invloeden van socio-demografische en sociaal-economische determinanten onderling vergeleken en de gezamenlijke invloed van deze determinanten op kennis van kankerpreventie

8.6 Samenvatting en discussie

Hoofdstuk 9 Samenvatting en algemene discussie

9.1 Samenvatting van de anderzoeksresultaten

9.2 Restricties van het onderzoek

9.3 Implicaties voor beleid en voorlichtingspraktijk

\section{Bibliografie}

Lijst van figuren

Lijst van tabellen

\section{Bijlagen}

Bijlage 1 Verslag van de steekproeff

a. conceptsteekproef

b. gerealiseerde steekproef

Bijlage 2 Operationalisering en scoring van de belangrijkste onderzochte eigenschappen

a. kennis van kankerpreventie

b. sociaal-economische status

Bijlage 3 Bijlagen bij hoofdstuk 5

Bijlage 4 Bijlagen bij hoofdstuk 7

Bijlage 5 Bijlagen bil hoofdstuk 8

Summary

Dankwoord 



\title{
Hoofdstuk 1
}

\section{Inleiding en probleemstelling}

\author{
1.1 Algemene probleemstelling van het onderzoek \\ 1.2 Methodologische doelstelling \\ 1.3 Sociale determinanten van kennis van kankerpreventie \\ 1.4 De complexe samenhang tussen kennis en gedrag \\ 1.5 Opbouw wan het onderzoeksverslag
}

\subsection{Algemene probleemstelling van het onderzoek}

De Europese Unie is in haar volksgezondheidsbeleid vastbesloten om de strijd aan te gaan tegen kanker (Commissie van de Europese Gemeenschappen, 1989). Europa bindt in haar actieprogramma "Europa tegen kanker" deze strijd aan via twee benaderingen: enerzijds via het voorkomen van kanker door gezondheidsbevordering of gezondheidsvoorlichting (primaire kankerpreventie) en anderzijds door het vroegtijdig opsporen van kanker (secundaire kankerpreventie)'. De ontwikkelde interventiestrategieën naar de bevalking toe, zoals de gezondheidswoorlichting inzake kankerpreventie, zijn gericht op een verandering van de attitudes en het gedrag van individuen. Het verhogen van de kennis van de bevolking over kankerpreventie wordt beschouwd als een belangrijke voorwaarde om tot deze attitude- en gedragsmodificaties te komen.

Het achterliggende model van gedragsverandering dat bij deze voorlichting inzake kankerpreventie wordt gehanteerd is vrij lineair: de voorlichting beïnvloedt de kennis van mensen inzake preventie waardoor hum attitude ten aanzien van preventie wordt beïnvloed; deze attitude bepaalt op haar beurt het gedrag, dat dan moet leiden tot de preventie van de ziekte (zie figuur 1.1 ).

Toegepast op kankerpreventie betekent dit het volgende. Met de voorlichting inzake kanker en kankerpreventie aan de algemene bevolking beoogt men een verhoging van de kennis van kanker en kankerpreventie bij de bevolking. Deze verhoogde kennis moet op haar beurt bij de mensen een positieve attitude ten aanzien van kankerpreventie bewerkstelligen. Een positieve attitude moet leiden tot een medisch verantwoord preventief gedrag, dat op zijn beurt moet voorkomen dat kanker ontstaat. Dit lineaire model wordt nog steeds in zeer veel voorlichtingscampagnes gebruikt. In dit model zijn informatie- of kennisoverdracht een

De begrippen 'primaire kankerpreventie' en 'secundaire kankerpreventie." worden in deze inleiding nag niet nauwkeurig van elkaar anderscheiden. In hoofdstuk 3 worden beide begrippen gedefinieerd en zullen ze de basis vormen van de conceptualisering van het onderzoeksconcept 'kennis van kankerpreventie', Vanaf hoofdstuk 5 worden deze begrippen bil de analyse van de kennisscores systematisch onderscheiden.

- Inleirding en probleernstelling. 
terechte primaire doelstelling om het gewenste kankerpreventief gedrag te bereiken, waardoor finaal via een gedragsverandering de problematiek van kanker kan worden teruggedrongen in onze samenleving.

\section{Figuur 1.1}

Traditioneel model van gezondheidsvoorlichting

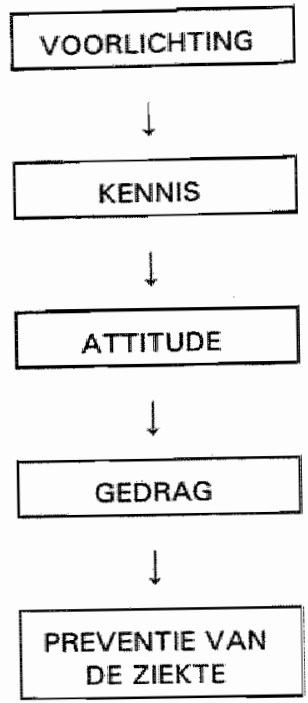

Bron: Downie e.a. $(1996: 35)$

Hoewel de voorlichtingscampagnes inzake kankerpreventie gericht kunnen zijn naar zeer uiteenlopende omgevingen (bv, een gemeente, een school, de werkplaats, het algemene publiek, een ziekenhuis, enz.), is de voorlichting steeds gericht naar twee duidelijk te onderscheiden doelgroepen. Enerzijds is zij toegespitst op gezondheidswerkers (ziekenhuisartsen, huisartsen, gynaecologen, sociaal verpleegkundigen, enz.) en anderzijds is zij gericht naar de bevolking (het algemene publiek of specifieke doelgroepen). Dit proefschrift "beperkt" zich tot de thematiek van de kennisoverdracht naar de bevolking via voorlichtingscampagnes. Deze voorichtingscampagnes worden reeds jaren georganiseerd en dit zowel vanuit de overheid als vanuit particuliere initiatieven.

Er kan worden gesteld dat in Vlaanderen sedert meerdere jaren educatieve boodschappen over kankerpreventie werden verspreid en dat bepaalde preventieve boodschappen herhaaldelijk werden verspreid. Zo wordt preventie van kanker vooral beoogd door volgende adviezen : "stoppen met roken" (ter voorkoming van longkanker), "langdurig zonnen verminderen" (ter voorkoming van huidkanker), en "matig omspringen met alcohol" 
"vetarme voeding eten", "veel fruit en graanprodukten eten" 1ter voorkoming van kankers van het maag-darmstelsell. Vroegtijdige opsporing van kanker wordt vooral beoogid voor borstkanker (door middel van borstzelfonderzoek, klinisch borstondierzoek en mammografie) en baarmoederhalskanker (door middel van het baarmoederhalsuitstrijkje) (U.S. Preventive Services Task Force, 1989; Denis, e.a., 1988).

Na vele jaren van sensibilisatie en campagnes op lokaal, provinciaal, regionaal en federaal niveau is in Vlaanderen nog steeds niet geweten of al deze inspanningen hebben geleid tot een adequate kennis van kankerprewentie bij de bevolking. Zo is er weinig geweten welke ideeën en opvattingen bij de bevolking leven over bijvoorbeeld waarschuwingssignalen, mogelijke risicofactoren en preventiemogelijkheden van kanker. Er is bijvoorbeeld niet geweten in welke mate de Vlaamse bevolking de preventieve boodschappen van de voorlichtingsorganisaties heeft ontvangen en of de bevolking deze informatie correct heeft geassimileerd.

Onderzoek in het buitenland toont nochtans aan dat de assimilatie van de preventieve boodschappen niet altijd op een doeltreffende manier verloopt en dat preventiecampagnes ook niet bedoellde neveneffecten tot gevalg kunnen hebben. Zo bijvoorbeeld wezen de resultaten van een Australlisch onderzoek uit dat (Clover, et.al., 1991) :

- de bevolking het risico op het kirigen van kanker averschat

- roken als risico van longkanker goed wordt onderkend, evenals langdurig zonnen als risico van huidkanker, doch dat deze beide kankers door een groot deel wan de bevolking niet worden gepercipleerd als te voorkomen

- de symptomen van huidkanker, darmkanker en borstkanker goed gekend zijn, doch de bestaande opsporingsonderzoeken voor deze kankers niet even goed gekend zijn

- het belang van vroegtijdige opsporing voor een toename van de overlevingsikans bij kanker in het algemeen wel werd onderkend.

Vanuit beleidsoogpunt is de vaststelling dat er in Vlaanderen zeer weinig is gekend over de wijze waarop de bevolking de voorlichting inzake kankerpreventie heeft geassimileerd op zijn minst verbazingwekkend. Een objectieve kennis over de assimilatie van de kankerpreventieboodschappen door de bevolking is immers een noodzakelijke voorwaarde om op wetenschappelijk verantwoorde wijze de bestaande voorlichtingscampagnes te kunnen evalueren, en zo mogelijk doeltreffender te maken.

Bovendien laat de relatief beperkte stroom van buitenlandse gedragswetenschappelijke publicaties op het gebied van kennis van kankerpreventie bij de bevolking fragmentarische en soms tegenstrijdige resultaten zien" "In bepaalde studies wordt een bevredigend kennisniveau vastgesteld, terwijl in andere studies dan weer een inadequate kennis wordt vastgesteld.

Zie bijvoorbeeld American Cancer Society (1980b), Berman en Wandersman (1990 en 1991), Berwick, Fine en Bolognia (1992), Bettinghaus (1986), Bostick e.a. (1993), Brown a.a. (1990), Clover e.a. (1991), Fajardo e.a. (1992), Howe (1981), Loehrer e.a. (1991), Paul e.a. (1992), Polednak (1990) en van Assema e.2. (1990). 
lin Vleanderen zijin er - voor zover bekend - welgeteld twee studies verschenen die specifiek peilen naar de kennis van kankerpreventie bij (een deel van) de bevolking. In 1991 werd er een onderzoek verricht naar de kennis over kanker bij schoolgaande jongeren in de provincie Aritwerpen (Van Hal e.a., 1991 ) en in 1992 werd er een pilootstudie verricht onder eerstejaarsistudenten aan de VU Brussel (Deliens e.a., 1994 en Maes, 1992).

De algemene conclusie uit de studie van Van Hal e.a. (1991) is dat er geen eenduidig beeld over de verschillende kennisaspecten naar voor komt. De rol van roken en zonlicht in het ontstaan van kanker blijkt redelijk goed gekend te zijn. Over de rol van alcohol en voeding blijken de jongeren everwwel veel minder te weten. Ook over preventie en behandeling van kanker blijken er nogal wat verkeerde opvattingen te bestaan bij de jongeren. Zo wordt bijvoorbeeld de mogelijkheid tot genezing en het voorkomen van kanker sterk onderschat. De jeugdige leeftijd van deze respondenten maakt veralgemening naar de totale bevolking echter onmogelijk.

Bij de eerstejaarsstudenten aan de VU Brussell werd daarentegen een vrij behoorlijke kennis van kankerpreventie vastgesteld (Deliens e.a., 1994 en Maes, 1992). Over het algemeen zijn de meest voorkomende kankers bij zowel mannen als vrouwen goed gekend. Ook de meeste waarschuwingssignalen en risicofactoren voor kanker worden wrij goed herkend. Verder werden ook de vroegtijdige opsporingsonderzoeken door een meerderheid van de studenten herkend. De onderzoeksgroep in deze studie is echter specifiek wat betreft minstens twee kenmerken die volgens de sociaal-wetenschappelijke literatuur een belangrijke determinerende rol vervullen bij kennis van kankerpreventie, namelijk leeftijd en sociaal-economische status. Eerstejaars universiteitsstudenten hebben gemiddeld een hogere sociaal-economische status dan de gemiddellde Vlaming. Op basis van de scholingsgraad kan worden verondersteld dat de gevonden kennis over kankerpreventie bij deze onderzoeksgroep hoger ligt. Anderzijds was de onderzoeksgroep ook homogeen naar leeftijdssamenstelling. Dent en Goultston (1982) hebben een significant hoger niveau van kennis over kankerpreventie gevonden bij respondenten ouder dan veertig jaar. De jeugdige leeftijd van de respondenten in de studie van Deliens e.a. (1994) zou bijgevolg ook geleid kunnen hebben tot het vaststellen van een niveau van kennis van kankerpreventie dat lager ligt dan bij de doorsnee bevolking.

Naast de hogervermelde studies worden er af en toe ook peilingen gedaan naar kennis van kankerpreventie in sociaal-wetenschappelijk onderzoek dat wordt verricht in het kader van lokale interventies rond kankerpreventie. Deze actie-onderzoeken komen meestal tot stand in opdracht van preventieverenigingen of -organisaties en de resultaten van deze studies worden meestal niet op systematische wijze gepubliceerd. Door het lakale karakter van deze studies en de specifieke omstandigheden waarin het onderzoek plaatsgrijpt (bijvoorbeeld tijdens een plaatselijke preventiecampagne), is het bovendien onmogelijk hun onderzoeksresultaten te veralgemenen naar de algemene bevolking in Vlaanderen.

Gezien het Vlaams onderzoek over kennis van kankerpreventie zeer beperkt is, maakt dit verder onderzoek zeker wenselijk. 
Uit wat wooraf ging, blijkt dat in Vlaanderen niet geweten is in welke mate de Vlaamse bevolking de preventieve boodschappen inzake kankerpreventie heeft geassimileerd en of de bevolking deze informatie op correcte wijze heeft geassimileerd. Het kan immers zijn dat de bevolking ook incorrecte kennis heeft van kankerpreventie. Eén van de onderzoekswragen van onderhavige studie is dan de volgende:

Heeft de Vlaamse bevolking een adequate kemnis van kankerpreventie?

\subsection{Methodologische doelstelling}

Om een betrouwbaar antwoord te kunnen geven op deze onderzoeksvraag en dus om een objectief beeld te kunnen vormen over de wijze waarop de bevolking de voorlichting inzake kankerpreventie heeft geassimileerd, dient men evenwel te beschikken over een betrouwbaar én geldig instrument om deze kennis van kankerpreventie te meten. In de literatuur kon geen alomvattend meetinstrument teruggevonden worden om de kennis wan kankerpreventie in haar complexiteit en globaliteit te meten. Hiermee wordt bedoeld een meetinstrument dat de kennis van kankerpreventie kan vaststellen op een wijze die rekening houdt met de belangrijkste onderscheiden componenten die kennis van kankerpreventie kan bevatten. Tevens moet dit meetinstrument in staat zijn om het "adequate" van deze kennis van kankerpreventie te meten. Hiermee wordt bedoeld een instrument dat het vermogen kan meten om medisch gewenste ('juiste') kennis inzake kankerpreventie te kunnen onderscheiden van medisch ongewenste ('foute') kennis.

Eên van de doelstellingen van dit proefschrift is dan ook het ontwikkelen van een meetinstrument dat 'kennis van kankerpreventie' in haar complexiteit kan meten. Een andere onderzoeksvraag van onderhavige studie is bijgevolg de volgende:

Hoe kan kennis van kankerpreventie fin globaliteit) op een valide en betrouwbare wijze worden gemeten?

Daarbij wordt een meetinstrument geambieerd met een grotere validiteit an betrouwbaarheid dan de instrumenten die tot nog toe over deze problematiek in sociaalwetenschappelijk onderzoek werden gebruikt. De grotere validiteit en betrouwbaarheil wordt nagestreefd door een gedocumenteerde en onderbouwde conceptualisering van het begrip 'kennis van kankerpreventie' en door het gebruik van een meetschaal met een groot aantal items die de herkenning meten wan zowel medisch "gewenste" kennis als medisch "ongewenste" kennis inzake kankerpreventie.

Met de bespreking van de meetprocedures en de ontwikkeling van dit meetinstrument wordt ook het belang aangetoond wan het gebruik van valide en betrouwbare instrumenten ter evaluatie van de GVO. Bij het opzetten en evalueren van interventies met het oog op het bevorderen van kennis inzake kankerpreventie is een dergelijk instrument noodzakelijk. Op dit moment bestaat een dergelijk gevalideerd evaluatie-instrument niet. Hoewel men zich wragen kan stellen over de zin van interventies om kennis te verhogen, is het duidelijk dat 
de facto in Vlaanderen de meeste inspanningen inzake GVO dit doen, en blijt er bijgevolg nood voor een valide en betrouwbaar evaluatie-instrument.

Het hier ontwikkelde meetinstrument zal na het onderzoek beschikbaar kunnen worden gesteld voor heel het onderzoeks-en werkveld wan de kankerpreventie. Dit instrument zal ondermeer kunnen worden gebruikt vaor een 'pre-interventie-meting' en voor de "nainterventie-meting(en)" in het kader van evaluatie-onderzoek bij voorlichting inzake kankerpreventie en bij kankerpreventiecampagnes, maar ook voor een algemene evaluatie van het beleid terzake.

\subsection{Socialie determinanten van kennis van kankerpreventie.}

Verschillende sociaal-psychologische verklaringstheorieën van (on) gezond gedrag' tonen aan dat er een relatie bestaat tussen sociale determinanten en (on)gezond gedrag, c.q. kankerpreventie of kankerpreventief gedrag. In deze verklaringstheorieën zijn het saciaalcognitieve determinanten (bv. sociale inwloed of attitude) die de invloed van de sociale determinanten op het gedrag intermediairen. Ook kennis kan als een intermediaire determinant worden beschouwd. Veel verklaringstheorieën hebben als uitgangspunt het continuüm kennis-attitude-gedrag, waarbij kennis de attitude ten aanzien van een bepaald gedrag bepaalt en de attitude op haar beurt het gedrag bepaalt (Bettinghaus, 1986). De sociale determinanten hebben in deze theorieen dus geen directe relatie met het gezondheids- of risicogedrag. Figuur 1.2 toont het achterliggend model van de samenhang tussen sociale determinanten, kennis, attitude en gedrag of leefstijl. In onderhavig proefschrift zal met name aandacht worden besteed aan de linkerhelft van dit model, namelijk de invloed van de sociale determinanten op de kennis van kankerpreventie (zie hoofdstukken 7 en 8 ).

Figuur 1.2

Samenhang tussen sociale determinanten, kennis, attitude en gedrag

\begin{tabular}{|c|c|c|c|c|c|}
\hline $\begin{array}{c}\text { Sociale } \\
\text { determinanten }\end{array}$ & Kedrag \\
Leefstijl
\end{tabular}

Zie bw. het "Health Belief Model" van Janz en Becker (1984), de "Theory of Reasoned Action' van Fishbein en Ajzen (1975) of de 'Theory of Planned Behavior" van Ajzen en Madden (1986). Voor overzichten en besprekingen van deze theorieën zie ondermeer Gochman (1997). Conner en Norman (1996), Damoiseaux, van der Molen en Kok (1993). 
Ook in het empirisch onderzoek over kankerpreventie wordt er een lineair verband vastgesteld tussen sociale determinanten, kennis van kankerpreventie en kankerpreventief gedrag. Deze lineariteit werd andermeer in de Verenigde Staten vastgesteld in een studie over de relatie tussen de sociale determinant 'etniciteit' (zwart ws blank), kennis van kankerpreventie en verschillende kankerpreventieve gedragingen, namelijk niet roken. gezonde voeding, deelname aan het mammografisch onderzoek en deelname aan de opsporing van bloed in de stoelgang (Jepson e.a., 1991). De onderzoeksresultaten waren zeer consistent voor deze vier kankerprewentieve gedragingen. Zowel de etniciteit als de kennisvariabelen correleerden significant met de verschillende gedragingen, doch wanneer de kennisvariabelen samen met etniciteit in een voorspellingsmodel werden opgenomen, was de sociale determinant 'etniciteit' geen significante predictor meer van het gedrag.

Hoewel in bepaalde empirische studies een lineair verband tussen sociale determinanten, kennis van kankerpreventie en kankerpreventief gedrag werd vastgesteld, blijft de beoordeling van de (beperkte) literatuur over sociale determinanten en kennis van kankerpreventie in het algemeen moeilijk. Door de uiteenlopende wijze waarop het onderzoeksconcept 'kennis van kankerpreventie' in de verschillende studies werd geconceptualiseerd en geoperationaliseerd zijn vergelijking en synthese heel moeilijk. Als er in verschillende studies over kennis van kankerpreventie verschillende of gelijklopende empirische relaties worden vastgesteld tussen sociale determinanten en kennis van kankerpreventie, is het bijgevolg de vraag of deze verschillen of overeenkomsten reëel zijn of kunnen worden verklaard door verschillen in meetmethode.

Bovendien gaan de meeste studies over een zeer specifiek domein van kankerpreventie, waardoor evenzeer een adequate synthese van de onderzoeksresultaten wordt bemoeilijkt. Soms wordt de kennis gemeten van de vroegtijdige opsporing van een specifiek type van kanker of een specifieke opsporingstechniek, zoals bijvoorbeeld de kennis van vroegtijdige opsporing van baarmoederhalskanker (bv. Harlan e.a., 1991; Hennig en Knowles, 1990; Ogden e.a., 1994), de kennis van het borstzelfonderzoek (bv. Champion, 1992; Howe, 1981), de kennis van het mammografisch onderzoek voor de vroegtijdige opsporing van borstkanker (bv. Basset en Butler, 1991; Bryant en Mah, 1992; Fajardo e.a., 1992), of de kennis wan de opsporingsonderzoeken voor colorectaal- of prostaatkanker (bw. Brown e.a., 1990; Polednak, 1990). Soms wordt er een zeer algemene indicator van kankerpreventie bestudeerd, zoals de kennis van de Europese kankercode, zonder daarom noodzakelijk naar de kennis van de inhoud van de code te pellen lbv. Commissie van de Europese Gemeenschappen, 1987b; Commission of EC 1989al. Soms wordt ook de kennis gemeten van een specifiek 'aandachtsweld" bij kankerpreventie, zoals bijvoorbeeld de kennis van de risicofactoren of de kennis van de waarschuwingssignalen voor kanker (bv. American Cancer Society, 1980b; Berman en Wandersman, 1991). Soms wordt de kennis gepeild van risicogedragingen wan kanker, zoals kennis van onveilig zonnen als risico voor huidkanker (bv. Berwick e.a., 1992; Cody en Lee, 1990), kennis van overmatig alcoholgebruik als risico op kanker (Rosseel, e.a., 1995; Van Assema e.a., 1990 en 1993), of kennis van ongezonde woeding (Hayes en Ross, 1987; Kristal e.a., 1990; Van Assema, 1990 en 1993\%.

Gezien de specificiteit van het aspect of domein van kankerpreventie dat onderwerp uitmaakt van de meeste van deze studies, zijn de relaties tussen de sociale determinanten 
en kennis van kankerpreventie niet eenduidig te interpreteren. Deze interpretatie wordt bovendien bemoeilijkt omdat in deze verschillende studies 'kennis van kankerpreventie' vaak op een andere wijze werd geoperationaliseerd en gemeten. De wetenschappelijke bevindingen over de relatie tussen sociale determinanten en kennis van kankerpreventie laten dan ook weinig generalisering toe. Bovendien zijn de meeste studies over kennis van kankerpreventie beschrijuend (epidemiologisch) van aard, zonder verderbouwing op voorafgaand onderzoek of op specifieke theoretische of conceptuele modellen. Kortom, uit de literatuur kon geen alomwattende theorie over de relatie tussen de sociale determinanten en kennis van kankerpreventie worden gededuceerd.

Op basis van zowel empirische gegevens alls wan de bestaande verklaringstheorieen voor conigezond gedirag is bekend dat er een relatie bestaat tussen sociale determinanten en kennis van kankerpreventie en dat er een indirecte relatie bestaat tussen de sociale determinanten en het kankerpreventief gedrag. Wat echter niet precies kan worden gededuceerd uit de literatuur is met we/ke verschillende sociale determinanten er een samenhang bestaat en hoe deze relaties eruit zien. De vorm, richting en sterkte van de relaties tussen de sociale determinanten en kennis van kankerpreventie zijn in de literatuur niet eenduidig en soms zelfs tegenstrijdig.

In onderhavig onderzoek, waarin kennis van kankerpreventie wel met een (al)omvattend instrument wordt gemeten, wordt het dan ook opportuun geacht om op systematische wijze aandacht te besteden aan de relaties tussen een aantal sociale determinanten en kennis wan kankerpreventie. De achterliggende onderzoekswraag kan als volgt worden omschreven:

Is de kennis van kankerpreventie gelijk verspreid in de Vlaamse bevolking of zijn er categorieẻn met een significant grotere of kleinere kennis van kankerpreventie dan andere categorieën ?

Deze onderzoekswraag zal worden onderzocht voor twee clusters van sociale determinanten die in de gezondheidssociologie in het algemeen en in survey-onderzoek in het bijzonder vrijwel altijd worden opgenomen om een (beschrijvende) samemhang aan te tonen tussen deze sociale determinanten en bepaalde gezondheidsindicatoren (zie ondermeer de tekstboeken van Aakster en Kuiper, 1984; Cockerham, 1992; Freund en McGuire, 1991; Klinkert, 1988; Nuyens, 1982; Rogers, 1991; Scambler, 1987):

- socio-demografische kenmerken (leeftijd, geslacht en leefsituatie)

- sociaal-economische kermerken (inkomen, opleiding en beroep).

Met de term "sociale determinanten" wordt in onderhavig proeffschrift dus meer in concreto deze set van sociale kenmerken bedoeld.

Dit onderzoek 'beperkt' zich ook tot de invloed van deze determinanten en gaat niet in op andere mogelijke determinanten van kennis van kankerpreventie, zoals andere persoonlijke factoren (bv. ervaring met kanker en kankerpreventie), familiale factoren (bv. familiestructuren, kennis van de ouders), sociaal-structurele factoren (bv. de 
toegankelijkheid van informatie en voorlichting inzake kankerpreventie, de kwaliteit van de preventieve boodschappen), institutionele factoren (bv. structuur en middelen van de preventiesector), gemeenschapskenmerken (bv. netwerkkenmerken), sociaal-culturele factoren (bv. leefstijlen, culturele normen), enz. ". Kennis van kankerpreventie kan dus ook worden bestudeerd in interactie met andere sociale factoren of sociale systemen of als de uitkomst wan voorlichting of informatie-overdracht. Anderzijds kan kennis van kankerpreventie ook worden bestudeerd als een factor die andere sociaal-cognitieve determinanten beînvloedt (bv. verwachtingen, motieven, percepties), andere persoonlijke determinanten (bv. emotionele of affectieve toestand of bedreiging) of als directe determinant van het kankerpreventief gedrag of van gerelateerde gedragspatronen (bv. leefgewoonten, eetgewoonten). Heel veel mogelijke onderzoeksvragen blijven dus onaangeroerd in deze studie.

Met het systematische gebruik van het begrip "determinant" wordt in onderhavige studie geenszins een directe 'oorzakelijkheid' tussen de sociale determinanten en kennis van kankerpreventie gesuggereerd. De sociale determinanten kunnen worden beschouwd als kenmerken die de sociale positie van personen in de samenleving bepalen en die leiden tot een bepaalde sociale predispositie ten aanzien van een bepaald kennisniveau (Boudon, 1981: 18). Deze sociale determinanten kunnen worden beschouwd als determinanten die de autonomie van het individu eerder beperken dan bevorderen. Andere determinanten daarentegen, zoals bijvoorbeeld de sociaal-cognitieve determinanten, bepalen de sociaalpsychologische positie van personen die leidt tot een bepaalde sociaal-cognitieve dispositie ten aanzien van een bepaald gedrag. In tegenstelling met de sociale determinanten kunnen sociaal-cognitieve determinanten vooral ook inzichten verstrekken in de redenen die de mens "aanzetten' tot doelgericht handelen. In die zin zijn het gedragsdeterminanten die de autonomie van het individu kunnen verruimen. Om het onderscheid tussen deze sociale en sociaal-cognitieve determinanten te verduidelijken, kan worden verwezen naar een onderscheid dat in de literatuur soms wordt gemaakt bij de identificatie van de determinanten van gezondheid of ziekte (Aakster, 1981:61-62):

1. predisponerende of voorbestemmende factoren

2. precipiterende of uitlokkende factoren.

Tot de predisponerende factoren worden meestal de socio-demografische en de sociaaleconomische kenmerken gerekend, zoals geslacht, leeftijd, ethnische groep, burgerlijke staat, beroep, opleiding, enz. Tot de precipiterende factoren worden meestal gerekend de invloed van de sociale omgeving, kernis en opinies ten aanzien van de ziekte en/of het gedrag, percepties inzake de ziekte, ervaring met de ziekte, ervaring met de ziektepreventie, stresserende levensgebeurtenissen ("life events"), enz. In onderhavig onderzoek kunnen de sociale determinanten worden beschouwd als predisponerende factoren.

Voor een overzicht van de verschillende mogelijke sociale determinanten van gezondheidsgedrag of risicogedrag, zie deel IV in Gochman (1997: 241-328). 
In hoofdstuk 7 wordt met de indicatoren geslacht, leeftijd en leefsituatie de samenhang bestudeerd tussen de socio-demografische determinanten en kennis van kankerpreventie. In hoofdstuk 8 wordt aan de hand van de sociale indicatoren inkomen, opleiding, beroep en sociaal-economische status de samenhang tussen de sociaal-economische determinanten en kennis van kankerpreventie geanalyseerd en besproken.

\subsection{De complexe samenhang tussen kennis en gedrag}

Met onderhavige studie is het geenzins de bedoeling om de indruk te wekken dat kennis, c.q. kennis van kankerpreventie, (automatisch) leidt tot participatie aan kankerpreventie. Kennis is uiteraard niet de enige voorwaarde om tot een gedragsverandering of een gedragsbestendiging te komen. Kennis over de consequenties van gedrag op gezondheid is volgens sommige onderzoekers zelfs een factor die relatief weinig invloed heeft op lemands gedrag, in vergelijking bijvoorbeeld met de invloed van gevolgen van het gedrag die niet op de gezondheid betrekking hebben of met de sociale invloed van partner, kinderen, collega's of vrienden op het gedrag (o.m. van Assema e.a ${ }_{*}, 1990$ en Ogden e.a.. 1994). Kennis over de relatie tussen gedrag en ziekte is volgens sommige onderzoekers echter wel noodzakelijk voor gedragsverandering (Bouter en van Dongen, 1990; Damoiseaux e.a., 1987 en 1993; Green e.a.. 1980; Kok, Meertens en Wilke, 19921. Het bij de doelpopulatie meten van hun kennis over het betreffende gezondheidsprobleem is bijgevolg een noodzakelijke voorwaarde ter voorbereiding van een effectieve preventieinterventie.

Niettegenstaande de aangehouden inspanningen inzake kankervoorlichting houden zeer veel mensen nog steeds geen rekening met de aanbevelingen ter voorkoming van kanker en voor de vroegtijdige opsporing van kanker. Zo bijvoorbeelld blijven, nilettegenstaande geweten is dat roken slecht is woor de gezondheid en ook kan leiden tot longkanker, nog zeer veel mensen roken. De afgelopen jaren stellen gezondheidswetenschappers en gezondheidswerkers dan ook meer en meer de vraag waarom deze preventieve boodschappen niet noodzakelijk tot gedragsverandering leiden; waarom met andere woorden kennis van kankerpreventie niet steeds leidt tot participatie aan kankerprewentie?

Hoewel er in dit proefschrift geen aandacht wordt besteed aan deze complexe onderzoekswraag, houdt dit niet in dat de invloed van kennils zou worden overschat of de invloed van andere mogelijke determinanten zou worden onderschat.

Vooral de sociaal-psychologische theorieën leveren bruikbare inzichten op voor gezondheidsvoorlichting en voor de relatie tussen kennis ten aanzien van een gedrag en het gedrag zelf " Hoewel de rol van kennis en het belang van kennis ten aanzien van

1

Voor overzichten en besprekingen wan deze thearieën zie ondermeer Conner en Norman (1996). Damoiseaux, van der Molen en Kok (1993), de Vries (1992 en 1993), Kok en Oostveen (1987). Oostveen en Kok (1987), Rogers 11991:40-70), Rutter, Quine en Chesman (1993:1-75), van der Pligt en de Vries (1995), Vinck (1995). 
gedragswerandering nog onduidelijk is', kan toch worden gesteld dat kennis slechts een indirect effect heeft op het gedrag.

Uit deze socialalpsychologische theorieen blijkt dat veranderen van gezondheidsgedrag via communicatie of voorlichting viij complex is. Als de boodschap overgekomen is bij de doelgroep, is het bovendien nog zeer de vraag of zij haar gedrag conform de medische richtlijnen gaat aanpassen. Hoewel de complexe relatie tussen kennis van kankerpreventie en kankerpreventief gedrag niet eenvoudig te verklaren is, komt uit de meeste verklaringstheorieën toch naar voor dat kennis in hoofdzaak een indirecte verklaring geeft voor gedrag. Kennis is als het ware een input die via een complex mechanisme wordt amgezet in een output, c.q. gedrag. Kennis beïnlloedt dus wel het gedrag, doch meestal niet rechtstreeks. Via meer specifieke intermediaire factoren of processen wordt kennis omgezet in gedrag. De relatie tussen kennis van kankerpreventie en kankerpreventief gedrag kan bijgevolg worden voorgesteld door een conceptueel input-output model (zie figuur 1.3).

Figuur 1.3

Samenhang tussen kennis van kankerpreventie en kankerpreventief gedrag

Input:

Intermediaire

Output:

factoren:"

\begin{tabular}{|c|c|c|c|c|}
\hline $\begin{array}{c}\text { Kennis van } \\
\text { kankerpreventie }\end{array}$ & 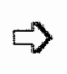 & $\begin{array}{c}\text { Sociaal-cognitieve } \\
\text { disposities }\end{array}$ & $\Rightarrow$ & $\begin{array}{c}\text { Kankerpreventief } \\
\text { gedrag }\end{array}$ \\
\hline
\end{tabular}

Kennis leidt dus niet direct tot gedrag(sverandering). Met beeldspraak zou kunnen worden gesteld dat kennis (als resultaat van de voorlichting) slechts een grondstof of een bouwsteen is waarmee de gewenste gedragsverandering tot stand kan komen. Uiteraard is kennis niet de enige inputfactor. In de gedragsverklaringsmodellen spellen nog andere inputfactoren een vooraanstaande plaats bij het verklaren van (on)gewenst gedrag. bijvoorbeeld de ervaring met de ziekte en de ervaring met de preventiemogelijkheden (cfr. Health Belief Model van Janz en Becker, 1984) of de sociale ondersteuning van een bepaald gedrag (cfr. ASE-model, de Vries, 1993).

De intermediaire factoren of processen zijn verantwoordelijk voor de omzetting van deze inputfactoren in gedrag. Zij zijn m.a.w. de motor of het productieproces waarmee gedrag(swerandering) tot stand wordt gebracht. In de sociale psychologie worden deze

1

Het is zo dat binnen de (gezondheids-y psychologie de discussie over de exacte rol van kennis bij gedragsverandering, of van de condities walarin kennis zulk effect heeft, nog nilet rond is. Eerder dan te proberen te zien welke rol kennis nu precies heeft, neigi men ertoe te zoeken naar wat nu wel een substantieel effect heeft op gedrag lzie bv. Conner en Norman, 1996\%. 
intermediaire factoren ook wel aangeduid met het begrip 'cognitieve dispositie' ten aanzien van een gedrag. In de sociaal-psychologische verklaringstheorieen voor (on)gezond gedrag worden drie vooraanstaande constructen van cognitieve disposities geídentificeerd, namelijke de persoonlijke controle (cfr. 'Health Locus of Control' van Wallston e.a., 1978; 'Theory of Self Efficacy' van Bandura, 1986), de persoonlijke evaluatie of de attitude ten aanzien van een gedrag (cfr. 'Health Belief Model' van Janz en Becker, 1984; 'Theory of Rieasaned Action" van Fishbein en Ajzen, 1975) en de "sociale norm" ten aanzien van het betrokken gedrag (cfr. "Theory of Planned Behavior" van Ajzen en Madden, 1986; "ASEmodel' van Kok en Oostveen, 1987 of de Vries, 1993).

\subsection{Opbouw van het onderzoeksverslag}

Samenvattend kan worden gesteld dat met onderhavige studie meerdere doelstellingen worden nagestreefd en dat er antwoorden worden gezocht op meerdere onderzoeksvragen. De studie heeft drie verschillende doelstellingen:

- Ontwerp van een instrument om kennis van kankerpreventie te kunnen meten en onderzoek naar de kwaliteit van dit meetinstrument.

- Evaluatie van (het niveau van) de kennis van kankerpreventie in een representatief staal wan de Vlaamse bevalking 118-70 jaar).

- Onderzoek van de spreiding van deze kennis van kankerpreventie in de Vlaamse bevolking; of m.a.w. onderzoek van de sociale determinanten van deze kennis van kankerpreventie in Vlaanderen.

In deze studie worden de volgende onderzoeksvragen behandeld:

1. Hoe kan kennis van kankerpreventie (in globaliteit) op een valide en betrouwbare wijze worden gemeten?

II. Heeft de Vlaamse bevolking een adequate kennis van kankerpreventie?

1. Zijn binnen kennis van kankerpreventie bepaalde kennisdomeinen of aspecten vain kankerpreventie beter gekend dan andere?

2. Bestaan er misvattingen over kankerpreventie?

3. Kan de Vlaamse bevolking factoren die echt iets te maken hebben met kankerpreventie goed onderscheiden van factoren die geen rol spelen bij
kankerpreventie?

III. Is kennis van kankerpreventie gelijkmatig verspreid in de Vlaamse bevolking of zijn er categorieën met een significant grotere of kleinere kennis van kankerpreventie?

1. Hangt kennis van kankerpreventie van mensen samen met hun sociodemografische positie in de samenleving? Is er m.a.w. een ongelijke verdeling van de kennis van kankerpreventie naar geslacht, leeftijd en

2. Hangt kennis van kankerpreventie van mensen samen met hun socjaa/economische status in de samenleving? Is er m.a.w. een ongelijke verdeling van de kennis van kankerpreventie naar opleiding, inkomen en
beroepsstatus?

- Sociale determinanten van kennis van kankerpreventie in Vlaanderen - 
Zoals bij zoveel proefschriften is de chronologie van de hoofdstukken niet dezelfde als de chronologie waarmee ze werden geschreven. De onderhavige volgorde van de hoofdstukken werd gekozen omdat ze het meest de consistentie van het onderzoeksverslag bevordert en omdat ze in ieder geval het meest aangewezen leek voor een vlotte lectuur.

In het volgende hoofdstuk 2 wordt het onderzoek in zijn maatschappelijk en wetenschappelijk kader geplaatst. Er wordt kort ingegaan op de maatschappelijke ontwikkeling op het wak van gezondheid en kankerpreventie. Verder staat in dit hoofdstuk de vraag centraal welke de maatschappelijke en wetenschappelijke relevantie is om kennis van kankerpreventie te (kunnen) meten. In hoofdstuk 3 wordt het begrip 'kennis van kankerpreventie' geanalyseerd en wordt het meetinstrument geconceptualiseerd. Er is daarbij aandacht voor de verschillende dimensies van het begrip kankerpreventie en de keuze voor de meetbare indicatoren van het concept 'kennis van kankerpreventie' wordt besproken. $\mathrm{Na}$ het behandelen van de bestaande methodes om de kennis van kankerpreventie te meten, wordt de ontwikkeling van het nieuwe meetinstrument beschreven. In hoofdstuk 4 wordt het onderzoeksplan weergegeven en wordt de methodologie van het empirisch onderzoek nader uitgewerkt. Hierin wordt aandacht besteed aan de selectie van de onderzoekselementen, de ontwikkeling en het uittesten van de vragenlijst, de training van de interviewers, de dataverwerking en de procedures voor de data-analyse.

In de hoofdstukken $5 \mathrm{t} / \mathrm{m} 8$ worden de empirische resultaten van deze studie gepresenteerd en besproken. In hoofdstuk 5 worden de beschrijwende resultaten wan de kennis van kankerpreventie geanalyseerd en wordt er nagegaan of er in de kennis van kankerpreventie bepaalde kennisdomeinen beter of minder gloed gekend zijn dan andere. Aan de hand van de kennisvariabelen worden in hoofdstuk 6 de kennisschalen geconstrueerd en anderzocht op hun betrouwbaarheid en validiteit. Na hoofdstuk 6 verandert het onderzoek van karakter. De kennisschalen worden in de volgende hoofdstulkken gebruilkt om de invloed na te gaan van de sociale determinanten op de kennis van kankerpreventie. In hoofdstuk 7 wordt de invloed van de socio-demografische determinanten op kennis van kankerpreventie bestudeerd en in hoofdstuk 8 de invloed van de sociaal-economische determinanten. Deze studie wordt afgesloten in hoofdstuk 9 met een samenvatting en enkle slotbeschouwingen. 


\title{
Hoofdstuk 2
}

\section{Maatschappelijk en wetenschappelijk kader voor de studie van kennis van kankerpreventie}

\author{
2.1 Een groeiende aandacht voor kankerpreventie in onze \\ samenleving \\ 2.2 Ontstaan van een gezondheidsbeleid en een beleid inzake \\ kankerpreventie \\ 2.3 Voorlichting inzake kankerpreventie aan het algemene publiek \\ 2.4 De wetenschappelijke onderbouw van voorlichting inzake \\ kankerpreventie \\ 2.5 Waarom een meetinstrument voor 'kennis van \\ kankerpreventie'?
}

Inleiding. De afgelopen jaren ben ik een geprivilegeerd waarnemer gleweest van de ontwikkelingen in de gezondheidszorg in Vlaanderen. Mlijn belangstelling voor kankerpreventie is gegroeid vanuit een sociologische verbazing voor de explosieve groel van de (kanker)preventiesector in de gezondheidszorg. Omdat een persoonlijke interesse wellicht een noodzakelijke, doch onvoldoende voorwaarde is om een onderwerp te kiezen voor een doctoraal proefschrift, wordt er in dit hoofdstuk nader ingegaan op de keuze of de motivatie om onderzoek te verrichten over kankerpreventie en meer in het bijzonder over 'kennis van kankerpreventie'. In dit hoofdstuk staat met andere woorden de vraag centraal waarom het maatschappelijk en wetenschappelijk relevant is om 'kennis van kankerpreventie' te bestuderen.

Er wordt eerst stilgestaan bij de groelende aandacht woor kankerpreventie, door deze in een historisch en maatschappelijk kader te plaatsen (paragraaf 2. 1). Vervolgens wordt er ingegaan op het ontstaan van een gezondheidsbeleid en de ontwikkeling van een beleid inzake kankerpreventie (paragraaf 2.2). In een volgende paragraaf komt de voorlichting over kankerpreventie aan het algemene publiek aan bod (paragraaf 2.3). Verwolgens wordt het wetenschappelijk kader geschetst, waarin deze gezondheidsvoorlichting inzake kankerpreventie kan worden gesitueerd (paragraaf 2.4). Tot slot staat de vraag centraal waarom het vanuit een wetenschappelijk onderbouwd concept van gezondheids voorlichting relevant is om kennis wan kankerpreventie te (kunnen) meten (paragraaf $2.6 \%$. 


\subsection{Een groeiende aandacht voor kankerpreventie in onze samenleving}

De problematiek van kanker en kankerpreventie is een alom bekend probleem in de Belgische samenleving. Eén op de dertien mannen krijgt voor zijn vijfenzeventigste longkanker (Belgisch Werk Tegen Kanker, 1986, 1988,1992). Eén op de veertien vrouwen wordt ooit met borstkanker geconfronteerd. Kanker vormt voor zowel mannen als vrouwen, na hart- en vaatziekten, de belangrijkste doodsoorzaak in Brussel, Vlaanderem, Wallonië en België (Matthijs, 1994, 31-32). Volgens de huidige stand van de medische wetenschappen meent men evenwel ongeveer één op twee kankers te kunnen voorkomen door de leef- en eetgewoonten aan te passen of door vroegtijdig bepaalde kankers op te sporen, zodat deze tijdig en met succes kunnen worden behandeld (Ashton, 1989; Ciba Foundation, 1985; Rose, 1992; WHO, 1985). Preventie en vroegtijdige opsporing van kanker krijgen dan ook een groeiende wetenschappelijke en maatschappelijke erkenning als middel om kanker te bestrijden?

In de meeste geindustrialiseerde landen is de belangstelling voor kankerpreventie sterk toegenomen en valt er meer in het bijzonder een grote mate van activiteit vast te stellen in dit domein. Zo bijvoorbeeld is in Australië de Australian Cancer Socilety ingeplent in elke staat en worden er zeer veel financiële middelen vrijgemaakt en grote inspanningen geleverd om voorlichtingscampagnes over kankerpreventie te organiseren (Clover e.a., 19911. In de Verenigde Staten doet de American Cancer Society zeer grote inspanningen om de preventiemogelijkheden van kanker te verspreiden (U.S. Preventive Serwices Task Force, 1989). Ook in Belgï̈ hebben de afgelopen tien jaar zeer veel verenigingen en organisaties aandacht besteed aan voorlichtingscampagnes en werden er preventie-activiteiten ontwikkeld rond kankerpreventie.

Bleyen e.a. (1994: 49-68) bespreken in hun overzichtsstudie niet minder dan 2 nationale Belgische initiatieven (respectievelijk het Belgisch Werk Tegen Kanker en de Vereniging voor Kankerbestrijding v.z.w.), 7 regionale initiatieven in het Vlaamse gewest, 3 provinciale initiatieven in het Vlaamse gewest en 7 andere organisaties of maatschappelijke sectoren die regelmatig aandacht besteden aan algemene kankerpreventie. Verder geven deze auteurs ook een overzicht van diverse bijkomende initiatieven die preventie van kanker op een "specifieke" manier benaderen, zoals tabakspreventie, alcoholpreventie, promotie van gezonde voeding, gezondheid op het werk, beroepskankers, gezondheid en milieu, enz.

Ook de opeenvolgende Vlaamse Ministers bevoegd voor Volksgezondheid en Preventie, de Bestendige Deputaties van de provincies en andere beleidsinstanties hebben aandacht

De groeiende belangstelling voor preventie in onze samenleving hangt uiteraard samen met meerdere factoren, waaronder zeer zeker ook de stijgende kosten van de curatieve gezondheidszorg en de groeiende moeilijkheid bij de overheid om het gezondheidsbudget in evenwicht te houden. Zle hierover ondermeer Lapré e.a. (1988) en Westendorp (1990: 25. 31). 
besteed aan kankerpreventie'. Ten einde de snel groeiende sector van de kankerpreventie te kunnen coördineren, besliste de toenmalige Vlaamse Executieve reeds in 1983 tot de oprichting van de Vlaamse Adviescommissie voor Kankerpreventie $(1985)^{2}$.

Deze stroom van kankerpreventie-initiatieven door de overheid en de particuliere sector is de afgelopen tien jaar gestaag gegroeid. Ze zorgde ervoor dat kankarpreventie niet meer weg te denken is uit onze samenleving en dat diverse preventieboodschappen zich een weg baanden naar zowel de eerstelijnsgezondheidswerkers (huisartsen, verpleegkundigen, voedingsdeskundigen, psychologen, enz. , als naar het algemene publiek. Een aantal boodschappen, zoals stoppen met roken ter voorkoming van longkanker of het vermijden wan overmatig zonnen ter voorkoming wan huidkanker, wordt reeds meer dan tien jaar verspreid. Het baarmoederhalsuitstrijkje als vroegtijdige opsporingstechniek voor baarmoederhalskanker of het borst-zelf-onderzoek ter opsporing van knobbeltjes in de borst worden reeds van in de vroege jaren 70 aanbevolen $\left(H_{i l l}\right.$ 1977).

Deze toegenomen aandacht voor preventie in onze samenleving heeft vele oorzaken. Erven (1989:9) stelt dat dit ondermeer te maken heeft met de toenemende kritiek op de curatieve gezondheidszorg, de gewijzigde opvattingen over gezondheid, de bezuinigingsdruk en de daarmee samenhangende werwachting dat preventie eén van de oplossingen is voor de kostenstijging in de gezondheidszorg. Al deze factoren zullen zeker een rol hebben gespeeld, doch zij geven op zich geen voldoende werklaring voor de gestage en structurele groei van de sector van de (kanker)preventie.

Deze stijgende aandacht woor preventie in het algemeen en voor kankerpreventie in het bijzonder is veeleer het resultaat van ongeveer een eeuw lang maatschappelijke ontwikkelingen. Meer in het bijzonder is de prominente aanwezigheid van initiatieven rond kankerpreventie in de geindustrialiseerde landen het resultaat van een ontwikkelingsproces in het denken over en in het beleid inzake "volksgezondheid" " .

Vooral in de Angelsaksische literatuur (zie o.m. Branca, 1980; Mckeown, 1976; Navarro, 1986), maar ook in ons taalgebied (zie bijvoorbeeld Velle, 1991 en Mol on van Lieshout, 1989) worden de ontwikkelingen in de gezondheidszorg en un het belleid

Zie bijvoorbeeld de Beleidsbrief Preventieve Gezondheidszorg 1993-1997, Vlaamse Raad, zitting 14 april 1993. Stuk 314 (1992-1993) - Nr. 1, 42 blz., opgesteld onder leiding van Minister L. Detiège in 1993 en de Beleidsbrief Gezondheidspromotie: een aanbod en een witdaging, Vlaamse Raad, zitting 7 juni 1991, Stuk 515 (1990-1991) - Nr, 1, 23 blz., opgesteld onder leiding van Minister $\mathrm{H}$. Weckx.

2

Voor een overzicht van haar werkzaamheden, zie ondermeer Vlaamse Adviescommissie voor Kankerpreventie (1985), Denis e.a. (1988), Eylenbosch e.a. (1988) en Bonte e.a. (1991).

3

De term "volksgezondheid' is een vertaling wan het Angelsaksisch begrip "public health". 
terzake uitvoerig beschreven in sociaall-historisch onderzoek. Deze werken hebben allemaal een dubbel uitgangspunt. Enerzijds bekritiseren ze de traditionele medischhistorische benadering waarin de ontwikkeling van het medisch bedrijf als een autonoam proces wordt geanalyseerd los van de maatschappelijke context. Hierdoor wordt de geschiedschrijving van de gezondheidszorg gereduceerd tot een geschiedenis wan de "geneeskunde:" of de geschiedenis van de grote vernieuwers in de theorie en de praktijk van de medische wetenschappen. Anderzijds bekritiseren ze het "medisch gezondheidsmodel lof het biomedisch model) als een obstakel voor de verdere ontwikkeling wan de gezondheidszorg. Het medisch gezondheidsconcept is gebaseerd op de grondbeginselen van de natuurwetenschappen. De mens wordt beschouwd als een machine en de gezondheidszorg is er op gericht de onderdelen goed lopend te houden of deze te repareren. Om de oorzaak van een gezondheidsprobleem te kunnen bepalen wordt door middel van eliminatie gezocht naar de uiteindelijke ziekteverwekker. Deze ziekteverwekker wordt dan met alle mogelijke middelen bestreden. Lange tijd is het zo geweest dat de gezondheid van de bevolking lenkel) kon worden verbeterd door het medisch gezondheidsmodel, waardoor her geloof erin onaantastbaar was. Dit gaf op zijn beurt weer een legitimatie voor de ongebreidelde groei van de diagnostische en curativeve geneeskunde. Met de opkomst van de moderne beschavingsziekten, zoals hart - en vaatziekten, kanker of verkeersongevallen werd deze benadering in toenemende mate bekritiseerd en werd steeds vaker de noodzaak aangevoeld om meer preventief te werk te gaan door leef-en werkgewoonten van de bevolking te beïnvloeden.

Sociaal-historische studies uit de jaren ' 60 -'70 laten zien dat de basis van de belangrijkste verbeteringen in de gezondheid van de bevolking (in Engeland of de Verenigde Staten) rond de eeuwwisseling al was gelegd door de algemene maatschappelijke ontwikkelingen. De grootste invloed werd daarbij toegeschreven aan de volgende verschijnselen (McKeown, 1976) ${ }^{7}$ :

- de afname van de gezinsgrootte (een gedragsverandering)

- de verbeterde voedselvoorziening, zowel kwantitatief als kwalitatief

- een gezondere omgeving en verbeterde woonomstandigheden

- specifieke preventieve en geneeskundige zorg.

Tegelijkertijd kende de medische sociologie in de jaren zestig en zeventig zowel in Amerika als in Europa een enorme ontwikkeling (zie Claus, 1982) en kreeg de kritische sociolagiebeoefening wind in de zeilen (zie o.m. Hoefnagels, 1977). Het was dan ook niet verwonderlijk dat in de jaren zestig de medische sociologie een fundamentele kritiek op de gezondheidszorg ontwikkelde. Die draaile voornamelijk rond de vraag of de bevolking wel "gezonder" werd van de alsmaar groeiende investeringen in de gezondheidssector en of niet eerder moest worden gedacht aan preventie, aan de ontwikkeling van de eerstelijnsgezondheidszorg en aan het aan bod laten komen van alternatieven (Velle, 1991: 21).

Geciteerd in Cosijn (1992: 5).

- Maatschappelijk en wetenschappelijk kader - 
Vanuit deze vruchtbare voedingsbodem ontwikkelden - bijna gelliktijdig - in het begin van de jaren zeventig verschillende auteurs een sociologische theorie over de ontwikkeling van de (westerse) samenleving, namelijk de zogenaamde "medicalisering" van de gezondheidszorg en van de samenleving (Freidson, 1970; Ilich, 1975; en Zola, 1973)". In neutrale zin betekent de term medicalisering het proces van uitbreiding waardoor steeds meer terreinen in de maatschappij onderworpen wonden aan medische definièring en jurisdictie (Velle, 1991: 30-31). Medicalisering is dus geen statisch gegeven, het is een proces dat zich afspeelt in de tijd en in een geografische en sociale ruimte. Velle 11991) heeft dit proces woor Bellgië zeer uitvoerig beschreven en geanalyseerd in zijn proefschrift. Deze kritiek vanuit de medische sociologie werd aangegrepen door politici en beleidsmensen om een pleidooi te houden voor een demedicaliseringsproces. Meer aandacht voor preventie en gezondheidspromotie waren de kerngedachten van dit pleidooi. Het kreeg gehoor bij de overheid en de ontwikkeling van de sector van preventile en gezondheidspromotie kan dan ook worden beschouwd als een reactie vanuit het belleid om de medicalisering van de samenleving tegen te gaan. Naast deze wetenschappelijke inzichten en kritieken op de gezondheidszorg van sociaal-historische en sociologische aard hebben ook de politieke ontwikkelingen in de jaren zestig een invloed gehad op de ontwikkelingen in het denken en het beleid inzake volksgezondheid.

Democratiserings- en emancipatiebewegingen ün de zestiger jaren leidden tot een toenemende bewustwording van de afhankelijkheidsrelatie die consumenten en patiënten hebben met het medisch-industrieel complex. Het gevolg was dat er enerzijds een sterke groei was van patiëntenorganisaties, belangengroeperingen en zelfhulpgroepen, terwijl anderzijds ook op academisch vlak steeds sterkere argumenten werden geformuleerd voor een nieuwe aanpak van gezondheidsproblemen (De Leeuw, 1991:12). Deze synergetische kritieken en ontwikkelingen werden geleidelijk overgenomen door het beleid en vertaald in beleidsrapporten, ondermeer in Canada [Lalonde, 1974) en het Verenigd Koninkrijk (Prevention and Health: Everybody's Business, 1976). In deze rapporten werd er op gewezen dat de volksgezondheid meer nodig heeft dan enkel een goed uitgebouwd systeem van curatieve verzorging. Het gewijzigde denken over volksgezondheid reflecteerde zich ook in de (her-lontdekking ${ }^{2}$ van de mogelijkheden van preventie en in de ontwikkeling van een "gezondheidsbeleid", een beleid gericht op het bevorderen van de gezondheid, in tegenstelling tot het bestaande beleid dat gericht was op het voorkomen en genezen van zlekten.

Voor een overzicht vam de ontwikkelingen van het begrip "medicalisering" zie ondermeer Klinkert (1988: 179-193), Fahrenfort (1984) en Branckaerts (1982).

De ontwikkellingen eind vorige eeuw op het gebied van de bacteriologie gaven een cerste aanzet tot het preventief denken en handelen. Ziekten konden doar bepaalde middelen (by. door milieu-sanitaire maatregelen zoals drinkwatervoorziening of huisvuilverwijderingl worden voorkomen of door het opsporen van de oorzaken en vroegtijdig ingrijpen worden teruggedrongen (Erven, 1989:12). Naast maatregelen tegen pokken, difterie en typhus richtten de activiteiten zich vooral op de grote zuigelingensterfte en tuberculose. 


\subsection{Ontstaan van een gezondheidsbeleid en een beleid inzake kankerpreventie}

Het gezondheidsbeleid kreeg internationaal gestalte door de doelstellingen die werden geformuleerd door de Wereldgezondheidsorganisatie in het programma "Health for all by the year 2000" dat in 1977 werd vastgellegd (WHO, 1978 en 1985), en door de Europese Gemeenschap in het programma "Europa tegen Kanker" (Commissie van de Europese Gemeenschappen, 1989).

De term 'gezondheidsbeleid' heeft sinds de publicatie in 1974 van 'A new perspective on the health of the Camadians" (Lalonde, $\$ 974$ ) door de Canadese Minister van volksgezondheid ingang gevonden in de geindustrialiseerde wereld. Dit zogenaamd Lalondemapport markeert éen van de keerpunten in het deriken over volksgezondheid (Cosijn, 1992: 4-5). In dit rapport wordt het "Health Field Concept" geformuleerd, dat uitgaat van vier categorieên of determinanten die belangrijk zijn voor de gezondheid van de mens : biologische ellgenschappen, fysische en sociale omgeving, leefwijze en gedrag van mensen en de organisatie van de gezondheidszorg. Onder de term 'gezondheidsbeleid' worden dan de maatregelen verstaan waarmee overheid, deskundigen en burgers trachten de volksgezondheid te verbeteren door, voor zover mogelijk, de oorzaken van ongezondheid in deze vier domeinen op te sporen en weg te nemen (Schaapveld, van de Water en Bergsma, 1991:1699). Dit beleid is bedoeld als een verbetering ten opzichte van de situatie waarin men zich beperkt tot het schatten van de toekomstige behoefte aan (curatieve) gezondheidszorg op basis van statistische gegevens.

De boodschap in het Lalonde-rapport was duidelijk: gezondheid is vooral beïnvloedbaar door factoren buiten de traditionele gezondheidszorg en wil men de volksglezondheid op grote schaal verbeteren, dan zal de winst met name te behalen zijn door aandacht te schenken aan vooral milieufactoren en gedragsfactoren. De inzichten beschreven in het Lalonde-rapport en gelijkaardige inzichten in andere landelijke rapporten (bv. de "primary health care act' "van het Finse Parlement in 1972 of het rapport 'Prevention and Health: Everybody's Business' uit 1976 van het Ministerie van Volksgezondheid in Engeland) werden vrij snel overgenomen door de Wereld Gezondheidsorganisatie (WHO).

In 1977 keurde de Wereldgezondheidsraad thet bestuur van de WHOl haar beleidsplan "Health for All by the Year 2000" goed. Het uitgangspunt van het Health for All-beleid van de WHO is de idee dat gezondheid moet worden bevorderd en niet alleen ziekten moeten worden bestreden. Gezondheid moet bijgevolg op een positieve wijze worden nagestreefd. De doelstellingen van het Health for All-belleid zijn als volgt samen te vatten (Cosijn, 1992: 19):

- meer nadruk op preventie naast curatie

- meer aandacht voor eerstelijnsgezondheidszorg (primary health care) en minder voor technologisch hooggespecia-

Geciteerd door Nuyens (1980: 40).

- Maatschappelijk en wetenschappelijk kader - 


\title{
liseerde zorg
}

- meer nadruk op de eigen verantwoordelijkheid en mogelijkheden van het individu voor het in stand houden en verbeteren van zijn gezondheid

- uitdrukkelijke aandacht voor sociale en fysieke factoren die de gezoncheid beïnvloeden

Deze doelstellingen werden in 1978 op de internationale WHO Conferentie in Alma-Ata (Kachazstan) bevestigd in de conferentieverklaring over 'Primary Health Care' (WHO, 1978). Deze Alma-Ata Conferentie van de WHO kan worden beschouwd als een mijlpaal in de ontwikkeling van de nieuwe visie op het gezondheidsbeleid. De conferentie formuleerde de reeds aanwezige inzichten tot een wereldwijde beleidsdoelstelling die werd erkend en onderschreven door alle deelnemende landen en hun regeringen. In de verklaring van de conferentie wordt de eerstelijnsgezondheidszorg', met daarin een belangrijke plaats voor preventle en gezondheidswoorlichting en -opvoeding (GVO), naar voor geschoven als belangrijke steunpaal voor de uitbouw van een gezondheidszorg voor iedereen (Health for All) (Tarimo en Creese, 1990:1). De slotconclusies van deze internationale WHO-conferentie stellen ondermeer (geciteerd in Nuyens, 1980: 41):

\begin{abstract}
"Firm national commitment to primary health care is vital, but it must be clear what this commitment entails ... National strategies are therefore required... Such strategies should aim at creating a climate that will make primary health care objectives, targets and activities feasible".
\end{abstract}

De nationale regeringen werden dus uitgenodigd om beleid, strategie en actieprogramma's verder uit te werken. Tevens impliceerde dit voor het beleid en voor verbeteringen in het beleid meetbaarheid en toetsbaarheid van de programma's door het stellen van duidelijke doelstellingen. Na de Alma-Ata Conferentie hebben deze gewijzigde inzichten in het gezondheidsbeleid langzaam maar zeker hun weg gevonden naar de nationale staten, waar de regeringen deze systematisch zijn gaan integreren in hun eigen landelijk gezondheidsbeleid.

Europa reageerde in tegenstelling tot bijvoorbeeld de Verenigde Staten evenwel traag in het volgen en verder uitwerken van de aanbevelingen van de AlmawAta conferentie (Weckx, 1991: 6). Pas in 1984 werd door het Regional Comité van de WHO in Europa de Health for All strategie uitgewerkt in 38 concrete gezondheidsdoelen, die in de periode tussen 1985 en het jaar 2000 dienen te worden gerealiseerd (WHO, 1985). Als onderdeel van dit beleid lanceerde de WHO in de winter van 1985-1986 haar "Gezonde Steden project" (zie ondermeer Ashton, 1992; Cosilin, 1992 en de Leeuw, 1991). Met dit laatste project beoogt men het gezondheidsbeleid zo dicht mogelijk bij de bevolking te

De term 'eerstelijnsgezondheidszorg' is de vertaling van het Angelsaksische "Primary Health Care', zoals die ondermeer door Nuyens $(1978$ en 1980) in Wlaanderen is geilntroducoerd. In Nederland spreekt men soms van 'primaire gezondheidszorg' (zie Cosijn, 1992: 4). Voor een grondige bespreking van het concept 'primary health care' kan worden verwezen natar het boek van McDonald (1993). 
brengen en de beoogde demedicalisering een steuntje in de rug te geven.

In tegenstelling tot de WHO heeft de Europese Unie (E.U.) een sterk gemedicaliseerde aanpak wan haar gezondheidsbeleid (Nuyens, 1980: 2011. Daarbij wordt de huisarts als spilfiguur binnen de eerstelijnsgezondheidszorg nadrukkelijk naar voor geschoven. Het is dan ook niet verwonderlijk dat de Europese Unie een meer ziektegericht beleid is gaan ontwikkelen. Onder deze voorwaarden kon de laatste jaren het beleid van de E.U. meer specifiek en exclusief worden gericht op kankerpreventie. De strijd tegen kanker is de afgelopen jaren topprioriteit geworden binnen het gezondheidsbeleid van de E.U. In hetzelfde jaar dat de WHO haar 38 gezondheidsdoelen voorstelde, aanvaardden de staatshoofden en regeringsleiders van de Europese Unie (toen nog Europese Gemeenschap) het beginsel van een programma voor kankerbestrijding. In 1986 lanceerde de Commissie van de Europese Gemeenschappen dan haar "Europa Tegen Kanker"-programma (Commissie van de Europese Gemeenschappen, 1987 en 1989). Het programma streeft een zeer ambitieus doel na, namelijk het terugdringen van de sterfte door kanker in de E.U. met 15\% tegen het jaar 2000. Het programma is vooral gericht. op informatie en educatie over alle aspecten die werden opgenomen in de Europese Kankercode. Deze Europese Kankercode werd opgesteld door een Comité van Kankerspecialisten uit de landen van de E.U. Ze omvat 6 aanbevelingen am kanker te helpen voorkomen, en een 4-tal aanbevelingen voor het vroegtijdig opsporen van kanker:

Betreffende het voorkomen van kanker :

1. Rook niet. Rookt u nog, stop dan zo snel mogelijk en rook zeker niet in aanwezigheid van anderen.

2. Beperk uw alcoholgebruik.

3. Vermijd overdadige blootstelling aan zonlicht.

4. Volg de veiligheidsvoorschriften voor behandeling van elke stof die kanker zou kunnen veroorzaken.

5. Eet regelmatig vers fruit, groenten en vezelrijke voedingsproducten (zoals bruin brood, ongepelde rijst, enz.).

6. Voorkom overgewicht en beperk de inname van vet voedsel.

Betreffende vroegtijige opsporing van kanker :

7. Raadpleeg uw arts als $u$ een verandering opmerkt in een moedervllek, een knobbel ontdekt, of abnormaal bloedverlies vaststelt.

8. Raadpleeg uw arts bij een aanhoudende hoest, heesheid, verandering in het ontlastingspatroon of en onverklaarbare gewichtsvermindering.

Voor wrouwen:

9. Laat regelmatig een baarmaederhalsuitstrijkje maken.

10. Controleer uw borsten regelmatig en doe mee aan borstonderzoeksprogramma's (mammografie) wanneer u 50 jaar of ouder bent.

De Europese kankercode is momenteel zeer verspreid geraakt in de meeste landen van de Europese Unie en wordt zeer actief gebruikt door alle verenigingen en organisaties voor 
kankerpreventie. De opiniepeilingen georganiseerd in opdracht van de E.U. stellen ook een toenemende kennis van de Europese kankercode vast bij de Europese Bevolking (Commission of the European Communities, 1989a).

Sinds het begin van de jaren negentig treden preventie en kankerpreventie ook in Vlaanderen sterker dan ooit op de voorgrond in het gezondheidsbeleid. De Vlaamse overheid zet daardoor in haar gezondheidsbeleid een trend voort die reeds jaren voordien werd ingezet door de W.H.O. en de E.U. (Detiège, 1993; Demeester, 1997).

\subsection{Voorlichting inzake kankerpreventie aan thet algemene publiek}

In de vorige paragraaf werd getracht een verklaring te vinden voor de toenemende aandacht voor kankerpreventie in onze samenleving. Tevens werden kort de beleidsdoelstellingen inzake kankerpreventie beschreven. Het meest in het pog springend beleidsdoel voor Europa is het terugdringen van kanker met $15 \%$ rond het jaar $2000.0 \mathrm{~m}$ dit beleidsdoel te realiseren stelt de Europese Gemeenschap zeer veel hoop in een degelijke uitbouw van de gezondheidsvoorlichting (Commissie van de Europese Gemeenschappen, 1987h. In deze paragraaf wordt nader ingegaan op deze publieksvoorlichting over kankerpreventie.

Er gaat geen dag voorbij, of er wordt in de massamedia aandacht besteed aan gezondheid en ziekte. Op radio en televisie wordt in actualiteitenrubrieken. amusementsprogramma"s of speciale gezondheidsprogramma's veelvuldig ingegaan op de progressie die de medische wetenschap de laatste tijd heeft gemaakt. Ziekten en nieuwe behandelingswijzen worden uitvoerig bediscussieerd, al dan niet met de mogelijkheid voor het publiek om vragen te stellen. Ook in de zogenaamde weekbladen, magazines of modebladen wordt veelvuldig aandacht aan gezondheidsonderwerpen besteed. Dag Allemaal, Humo, Knack, Libelle, Panorama, Onze Tijd, enz. hebben allemaal regelmatig een hoofdartikel over gezondheid of ziekte. In het bijzonder in de zgn. vrouwenbladen vormt gezondheid steeds één van de hoofdthema's, waarvoor vaak een aparte rubriek wordt voorzien waarin een huisarts of specialist de lezer nader informeert over ziekten, behandelingswijzen en de mogelijkheden om ziekten te voorkomen.

Volgens Bleyen e.a. (1994:3-60) is er een tendens merkbaiar in deze vrouwenbladen: naast schoonheid en mode wordt de aandacht progressief op gezondheid toegespitst. Gezonde voeding komt het hele jaar door aan bod en kanker wordt steeds vermeld wanneer het toepasselijk is in de context van het artikel. In de brievenrubrieken duiken nogal wat vragen op over voeding en kanker. Naar de vakantie toe wordt er steevast een bijdrage gewijd aan veilig zonnen, waarbij ook het risico op huidkanker wordt vermeld. Stoppen met roken vormt altijd een constante binnen het ruime aanbod van gezondheidsthema's. De associatie met longkanker wordt daarbij duildelijk gemaakt, alsook de diverse mogelijke middelen of methoden om ermee te stoppen. Hoewel primaire pieventie vrijwel onmogelijk is - en het bijgevolg geen lifestyle-onderwerp ils . krijgen de gynaecologische kankers toch de grootste aandacht in de vrouwenbladen. Er 
wordt veel aandacht besteed aan borstzelfonderzoek, maar ook de waarschuwingssignalen voor kanker komen aan bod.

Gezondheidsvoorlichting over kankerpreventie komt dus aan bod in de gewone programma"s of rubrieken van de massamedia. Verder worden deze massamedia ook gebruikt in het kader van allerlei soorten preventiecampagnes op het terrein van de gezondheid. Daarbij staat kankerpreventie als eerste in de rij. Zo liepen (soms gelijktijdig) op de VRT-radio diverse kankerpreventiecampagnes, ondermeer een anti-rook campagne, een campagne 'groenten en fruit: 5 porties per dag" en een campagne 'matig met zonnen" van de Vereniging voor Kankerbestrijding, alsook een rookstopcampagne van 'Kom op tegen Kanker'. Op de VRT-televisie is vooral de algemene kankerpreventiecampagne 'Kom op tegen kanker" genoegzaam bekend. In tegenstelling tat de gezondheidsrubrieken in magazines of andere media hebben deze voorlichtings campagnes uitdrukkelijk tot doel om het gedrag van de bevolking te beinvioeden.

Voortgaande op de publieke reacties op de radio- en T.V.-programma's over gezondheidsproblemen of op de lezersbrieven in kranten en magazines, blijkt dat het publiek een grote belangstelling heeft voor gezondheid en ziekte. Ook uit de kijkcijfers blijkt er een publieke woorkeur voor programma's waarin ziekte en gezondheid centraal staan. De massamedia spelen dan ook graag in op deze vraag of behoefte van het publiek. Overdracht van kennis over ziekte en gezondheid, c.q. over kankerpreventie, gebeurt dan ook zeer massaal en via zeer diverse massamedia. In figuur 2.1 blijkt dat het hier gaat om een complexe overdracht van informatie, waarbij zeer veel media, ieder met zijn oigen specifieke eigenschappen en mogelijkheden, worden betrokken?

Figuur 2.1

Massamediale voorlichting over kankerpreventie

\begin{tabular}{|c|c|c|c|}
\hline Schriftelijk & Auditief & Visueel & Audiovisueel \\
\hline $\begin{array}{l}\text { krant } \\
\text { tijoschrift } \\
\text { brochure } \\
\text { woorlichtingsbrief } \\
\text { advertentie } \\
\text { boek }\end{array}$ & $\begin{array}{l}\text { radio } \\
\text { lezing } \\
\text { cassetterecorder }\end{array}$ & $\begin{array}{l}\text { affiche } \\
\text { foto } \\
\text { dial } \\
\text { maquette } \\
\text { tentoonstelling }\end{array}$ & $\begin{array}{l}\text { film } \\
\text { televisie } \\
\text { beeldplaat } \\
\text { video } \\
\text { dia + geluid }\end{array}$ \\
\hline
\end{tabular}

Bron: Wieberdink, E.A.M. 119901, Woorlichting in de massamedia, in: Bijblijwen. Cumulatief Geneeskundig Nascholingssysteem, $6, n^{\circ} 9$, pp. 5-14.

Voor een overzilcht van mogelijkheden en beperkingen van de inschakeling van massamedia bij GVO, zile ondermeer Damoiseaux (1987: 97-122). Voor een meer uitgebreid tekstboek over gezondheidswoorlichting in de media, zie Egger, Donovan en Spark (1993). 
Het zijn evenwel niet alleen de massamedia die de belangstelling voor gezondheid en ziekte in toenemende mate aan bod laten komen. Ook gezondheidswerkers, zoals huisartsen, verpleegkundigen of kinesitherapeuten hebben een toenemende belangstelling voor het informeren van de patiënten over gezondheidsrisico"s, ziekte en preventieve maatregelen. Naast deze individuele hulpverleners wordt er in toenemende mate ook door bedrijven of organisaties aandacht besteed aan gezondheidsvoorlichting ${ }^{\prime}$.

Gezondheidsvoorlichting maakt met andere woorden gebruik van zeer uiteenlopende "communicatiekanalen". Een vaak gebruikte indeling voor gezondheidsvoorlichting is deze valgens de drie niveau's van communicatiekanalen: micro, meso en macro niveau (zie figuur 2.2).

Figuur 2.2

Communicatiekanalen voor gezondheidsvoorlichting ${ }^{2}$

\begin{tabular}{|l|l|l|}
\hline Niveau: & Communicatiekanalen : & Inhoud van de woorlichting : \\
\hline Macro & $\begin{array}{l}\text { Geplande interventies via de } \\
\text { massamedia (T.V., radio, } \\
\text { tijdschriften, kranten, folders, } \\
\text { brochures, affiches, enz.) }\end{array}$ & $\begin{array}{l}\text { Anti-raok-campagnes, gezonde } \\
\text { voeding, identificatie van } \\
\text { risicogroepen, mogelijkhedien van } \\
\text { de moderne geneeskunde, enz. }\end{array}$ \\
\hline Meso & $\begin{array}{l}\text { Geplande interventies via } \\
\text { organisaties, bedrijven of } \\
\text { instellingen (bedrijven, scholen, } \\
\text { jeugdbewegingen, sportclubs, } \\
\text { ziekenhuizen, enz.) }\end{array}$ & $\begin{array}{l}\text { GVO in relatie tot interne } \\
\text { doeleinden van het bedrijf of de } \\
\text { instelling (bv. GVO om } \\
\text { ziektewerzuim tegen te gaan, GVO } \\
\text { aan risicogroepen, enz.) }\end{array}$ \\
\hline Micro & $\begin{array}{l}\text { Geplande interventie via } \\
\text { gezandheidswerkers (huisartsen, } \\
\text { specialisten, verpleegkundigen, } \\
\text { tandartsen, enz.) }\end{array}$ & $\begin{array}{l}\text { voorlichtingsinhoud is zeer } \\
\text { specifiek en afgestemd op kleine } \\
\text { groepen of individuen (bv. } \\
\text { patiërtenvoorlichting) }\end{array}$ \\
\hline
\end{tabular}

Alhoewel zeer veel gezondheidswerkers en instanties op de én of andere wijze betrokken zijn bij gezondheidswoorlichting, ontwikkelt zich steeds duidelijker een specifieke beroepsgroep die zich hierop professioneel toelegt en die zich profileert onder verschillende benamingen zoals GVO-ers, preventiewerkers of patiëntenvoorlichters. In

Op een studiedag (30.03.95) over "De aanpak van Alcohol en andere drugs op het werk" te Antwerpen bleek hiervoor een massale belangstelling te bestaan wanuit het bedriffsleven. Uit. een onderzoek van de Vereniging voor Alcohol- en andere Drugproblemen bleek dat er op een totaal van 136 onderzochte bedrijven $53 \%$ onder eén af andere vorm ooit voorlichting over alcoholl-preventie heeft gegeven (Lambrechts, 1995).

Figuur 2.2 is een synthese wan de geschreven tekst uit het proefschrift van Seydel (1989: 9. 11). 
Nederland werd de totale omvang van deze beroepsgroep op het terrein van GVO/preventie en patientenvoorlichting in 1994 berekend op ruim 1000 personen, waarvan ongeveer 775 full-time-equivalenten (Molleman en van Nies, 1995: 12)" Hoewel de activiteiten van deze "professionals" - zoals het begrip GVO-ers doet vermoeden - ruimer zijn dan alleen het enge werkweld van de gezondheidswoorfichting, is toch (nog steeds) een zeer groot deel van deze personen actief op het terrein van de woorlichting.

Uit het voorgaande is duidelijk geworden dat gezondheidsvoorlichting en kennisoverdracht over kankerpreventie deel zijn gaan uitmaken van de dagelijkse realiteit.

De inhoud wan de voorlichting of kennisoverdracht bestaat steeds uit medischwetenschappelijke kennis, die wordt vertaald naar een voor de doelgroepen begrijpbare voorlichtingsboodschap. De gezondheidsvoorlichting richt zich op vragen als :

- Wat is gezond in biologische, psychologische en sociale zin?

- Wat is ongezond in het gedrag van mensen?

- Hoe kan een ongezond gedrag worden veranderd in een gezond gedrag?

- Wat is het (gezondheids)nut van een gedragsverandering voor het individu?

- Welke risico's kunnen worden voorkomen?

- Waarop moet men attent zijn in de leefgewoonten?

- Welke signalen of symptomen dienen in het oog te worden gehouden?

- Wat houdt het bevorderen van een gezonde leefstijl precies in?

- enz.

De informatie over kankerpreventie kan gericht zijn naar het algemene publiek, naar specifieke doelgroepen (bw. het nut van een mammografisch onderzoek voor vrouwen boven de 50 jaar) of naar hulpverleners (bv. huisartsen). Een follder, een affiche of een brochure zijn nog steeds het meest populair als woorlichtingsmateriaal. Het ontwerpen van dit voorlichtingsmateriaal is een belangrijke activiteit van veel voorlichtingsorganisaties. In een onderzoek van Peeters e.a. (1994) werd voor Vlaanderen een inventaris gemaakt van het GVO-materiaal voor secundaire kankerpreventie. Uit dit onderzoek blijkt dat de afgelopen jaren in Vlaanderen veel aandacht is besteed aan voorlichting over kankerpreventie. Verschillende organisaties hebben Gvo-rnateriaal ontworpen en op grotere of kleinere schaal verspreid. Dit GVO-materiaal wordt vaak ad hoo gemaakt voor een eenmalige actie. Slechts door een beperkt aantal organisaties wordt het ook op systematische wijze verspreid in Belgie en Viaanderen. Vooral de Vereniging voor Kankerbestrijding, de Wlaamse Kankerliga, de mutualiteiten en een aantal universitaire centra voor kankerpreventie zijn zeer actief in het verspreiden van informatie in Vlaanderen. Naast het typische GVO-materiaal worden er in Vlaanderen ook twee specifieke tijdschriften verspreid over kankerpreventie: de periodieken "Kanker Info" van de Vereniging voor Kankerbestrijding vzw en "Challenge" van het Belgisch Werk tegen
Kanker.

1

Voor Belgiè of Vlaanderen zijn geen cijfers bekend wan het aantal personen dat werkzaam is als GVO-er, preventiewerker of patiëntenvoorlichter. 
Peeters e.a. (1994: 4-36) maken naar aanleiding van hun studie van het voorlichtingsmaterial over kankerpreventie twee kritische concluderende opmerkingen en aanbevelingen over dit GVO-materiaal:

- Wanneer verschillende organisaties GVO-materiaal ontwikkelen en verspreiden over bijwoorbeeld hetzelfde opsporingsonderzoek, bestaat het gewar dat deze organisaties werschillende informatie geven. Vooral over de leeftild waarop en de frequentie waarmee een opsporingsanderzoek zou moeten plaatsgrijpen, veirschilt de informatie wel eens. Eenduidige informatie is bellangrijk om de doelgroep te bereiken en daarom moet de ontwikkeling en de verspreiding van GVO-materiaal gecoürdineerd worden.

- Hoewel veel instanties GVO-materiaal hebben ontworpen en werspreid, ontbreken onderzoeken waarin wordt nagegaan of het GVO-materiaal haar doel heeft berelkt. Het gevolg hiervan is dat niet bekend is welke GVO-strategie het meest succesvol is bij sensibilisatie en motivatie van de bevolking, specifieke doelgroepen en artsen, ondanks de veelheid aan beschikbaar materiaal. Dit heeft ook te maken met het feit dat de ontwikkeling van GVO-materiaal soms als "bijtaak" wordt gezien om het eigenlijke opsporingsonderzoek te kunnen uitvoeren.

Deze conclusies verwijzen naar twee fundamentele knelpunten in de sector van de kankerpreventie in Vlaanderen (Deliens en Schol, 1990). Ten eerste is er een manifest gebrek aan coördinatie en integratie van de sector. Hierdoor is het mogelijk dat verschillende campagnes over eenzelfde thema los van elkaar worden opgezet en gepland, zonder dat er eenduidigheid is in de preventieboodschappen. Mensen kunnen dus worden geconfronteerd met uiteenlopende en zelfs tegenstrijdige informatie. Hierdoor kan de geloofwaardigheid van kankerpreventie door de bevolking in vraag worden gesteld en zijn alle moeizaam opgebouwde en geleverde inspanningen tevergeefs. Hoe goed bedoeld alle inspanningen ook mogen zijn, op termijn dreigt een dergelijk ongecoördineerde werking van de sector de sector zelf te ondermijnen. Ten tweede is er een gebrek aan evaluatie van het GVO-materiaal en de campagnes. Ook dit tweede punt kan op termijn nefast zijn voor de sector. De kankerpreventiecampagnes kunnen immers niet op eigen houtje opereren. Ze zijn - vroeg of laat - verantwoording verschuldigd voor hun activiteiten. In de eerste plaats aan de bevolking zelf, die ten slotte het gemeenschapsgeld leverde dat aan kankerpreventie wordt besteed en die daar iets zinnigs wil tegenover zien. Verder zijn deze campagnes ook verantwoording verschuldigd aan hun (particuliere of openbare) financierders, aan onder andere de politici en beleidsvoerders die de gelden moeten beheren en die prioriteiten moeten stellen ten aanzien van het beleid in de (preventieve en curatievel gezondheidszorg.

\subsection{De wetenschappeliike onderbouw van voorlichting inzake kankerpieventie}

De aan belang toenemende plaats van voorlichting over kankerpreventie op het terrein wordt ook ondersteund door een zich snel ontwikkelende wetenschappelijke activiteit met betrekking tot gezondheidsvoorlichting en mopvoeding (GVO). Ook onderhavig onderzoek kan worden beschouwd als een bijdrage in dit onderzoeksdomein. 
GVO-activiteiten worden vanuit wetenschappelijk oogpunt beschouwd als een bijzondere vorm van "geplande interventie" om een bepaald gedrag door middel van communicatie of voorlichting te veranderen (Seydel, 1989: 9-17). Het begrip "GVO" is dus ruimer dan alleen maar de woorlichting. Het verwijst naar de volledige wetenschappelijke en organisatorische omkadering waarin de voorlichting plaatsgrijpt. Het begrip "geplande interventie" verwijst naar het feit dat de interventies afgeleid kunnen worden uit op voothand geformuleerde doelstellingen.

Voor de wijze waarop de interventies uitgewerkt kunnen worden zijn er verschillende modellen van gedragsbeinvloeding ter beschikking (Damoiseaux e.a., 1987 en 1993). De modellen komen sterk met elkaar overeen en onderscheiden allemaal een aantal fasen die doorlopen moeten worden vanaf het eerste begin tot het einde, te weten de bestendiging van de gedragsverandering (Kok, 1987a:6). Met name McGuire (1985) heeft dit praces van gedragsbeinvloeding uitputtend beschreven. Een voorlichtingsboodschap moet eerst opgemerkt worden, dat wil zeggen dat de doelgroep moet bereikt worden. De gezondheidsboodschap moet dan door de doelgroep worden begrepen. Nadien kan deze (nieuwe) informatie een attitudewijziging teweeg brengen bij de doelgroep. Daarbij moeten de overwegingen die aangevoerd worden orm het gedrag te veranderen acceptabel zijn voor de doelgroep. Daarbij spelen geloofwaardigheid van de bron, betrokkenheid van de persoon, samenstelling van het bericht, enz, een rol. De sociale omgeving moet de verandering steunen of de persoon moet weerbaar zijn tegen de nietsteunende omgeving. Bovendien moet het nieuwe gedrag ook mogelijk en liefst gemakkelijk zijn. Tenslotte moet het veranderde gedrag ook het gewenste en beoogde effect hebben; mensen moeten dus daadwerkelijk ondervinden dat de voordelen die hen werden voorgespiegeld ook werkelijk worden gerealiseerd.

De modellen van gedragsbeïnvloeding verschillen in hoofdzaak wat betreft de mate waarin de nadruk wordt gelegd op specificatie van de "inhoudelijke", de "methodische" dan wel de "procesmatige" kenmerken (zie ondermeer de handboeken van Cox, van Houtte en Rolle, 1992; Damoiseaux, van der Molen en Kok, 1993; Egger, Donovan en Spark, 1993; Kok, Meertens en Wilke, 1992). De inhoudelijke dimensie verwijst naar de aard en omvang van de noodzakelijke informatie die bij de voorlichting dient te worden aangewend ten behoeve van een bepaalde fase, de methodische dimensie beschrijft de kenmerken van de werkwijze in een bepaalde fase en de procesmatige dimensie heeft betrekking op de dynamische kenmerken van elke fase. GVO is bijgevolg een complexe activiteit die vanuit diverse wetenschappelijke disciplines en diverse theoretische kaders
kan worden bestudeerd"

GVO is een toepassingsgebied van vooral sociaal-wetenschappelijke disciplines, waarbij ook andere, zoals sociale geneeskunde, epidemiologie en experimentele psychologie een de sociale psychologie (zie bijvoore leveren. Binnen de sociale wetenschappen zijn het vooral voorlichtingskunde (zie bijvoorbeeld het handboek van van Kok, Meertens en Wilke, 1992), de communicatiewetenschappen (zie bijvoorbeeld het handox, van Houtte en Rolle, 1992) en de 1993) die een eigen specifieke bijdrage leveren tot meer inzichten in het, Donovan en Spark, 
Hoewel de GVO-activiteiten" zeer divers kunnen zijn, zowel wat de doelgroep betreft als wat het type gezondheidsproblemen betreft, zijn er een aantal kenmerken die steeds terugkomen. De Nederlandse GVO-onderzoeker Gerjo Kok (1987a:2) onderscheidt hierbij vier elementen:

1. Het betreft een gezondheidsprobleem waarbij het gedrag van de betrokkenem belangrijk is (fase 1 ).

2. Er wordt zorgvuldig gekeken naar de aorzaken en de determinanten van het gedrag (fase 2).

3. Pogingen worden ondernomen om het gedrag te beïhvloeden, met name door de betrokkenen te motiveren tot een ander gedrag (fase 3 ).

4. De effecten van die beïnvloedingspogingen worden zo goed mogelijk geëwalueerd; zodat verbeteringen worden aangebracht (fase 4 ).

Deze cyclus van GVO-activiteiten wijst op een procesmatige aanpak van een gezondheidsprobleem (bv. longkanker of borstkanker). Dit proces, waarbij een individu. groep of organisatie onderworpen wordt aan beïnloeding van het gezondheidsdenken en handellen, bestaat uit verschillende fasen en beoogt als ultieme doelstelling een gedragsverandering, waardoor het gezondheidsprableem wordt woorkomen of tijdig opgespoord (bv. stoppen met roken of participatie van vrouwen aan het mammografisch onderzoek voor vroegtijdige opsporing van borstkankerl.

De eerste twee fasen (lang) voor het feitelijke interventieproces bestaan uitsluitend uit research. De eerste fase is gericht op de analyse van het gezondheidsprobleem zelf : wat is de relatie tussen het gezondheidsprobleem en het menselijk gedrag (Nijhuis, 1987) ?

De tweede fase is gericht op het verwerven van meer inzicht in de oorzaken en determinanten van het betreffende gedrag: waarom gedragen mensen zich op de wijze zoals zij zich gedragen en hoe kunnen we dit gedrag veranderen (Oostveen en de Vries, 1987)? In de derde fase dient er op basis van de researchresultaten uit woorgaande fasen een juiste analyse worden gemaakt over de interventie en moet een interventieplan worden opgesteld (Kok, 1987b). Het vergt een synthese van de analyse, doelstellingen en mogelijke technieken en hulpmiddelen, het formuleren van de interventiedoelen, het nauwkeurig afbakenen van de doelgroep en het aangeven van de beoogde effecten van de interventie. Daarna volgt de feitelijke interventie, waarbij het actieplan - al dan niet met de nodige bijsturingen - nauwgezet wordt opgevolgd. Im een laatste fase volgt een

en de methaden woor gedragsverandering.

In de sector van de kankerpreventie kan bijwoorbeeld worden gedacht aan volgende uiteenlopende GVO-activiteiten : een folder over borstzelfonderzoek, een gesprek van de huisarts met een patiënt over stoppen met roken, een training van een groep alcoholisten in de dagelijkse ongang met alcohol en met eventuele afkick-symptomen, een beleid inzake alcoholpreventie of tabaksprewentie in bedrijven, coördinatie van kankerpreventiecampagnes tussen verschillende actoren in het werkveld, opzetten van een effectieve organisatie voor baarmoederhalsopsporing in de provincie, training van huisartsen in vroegtijdige kankeropsporing, enz. 
effectmeting en een evaluatie van de actie (Van Dongen, 1987).

Figutur 2.3

GVO-matrix van Kok (1987a: 31

\begin{tabular}{|c|c|c|}
\hline \multicolumn{2}{|c|}{$\begin{array}{l}\text { Toegepast } \\
\text { onderzoek }\end{array}$} & $\begin{array}{r}\text { Fundamentee } \\
\text { onderzoek }\end{array}$ \\
\hline $\mathbb{U}$ & $<$ & probleemanalyse \\
\hline$\|$ & 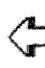 & gedragsdeterminanten \\
\hline$\Downarrow$ & $<$ & beënvloeding \\
\hline$\downarrow$ & 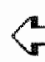 & evaluatie \\
\hline
\end{tabular}

Vooral dit laatste wordt nogal eens verwaarloosd bij veel gezondheidsvoorlichting, c.q. voorlichting over kankerpreventie. Nochtans is de evaluatie en de toetsing van de effecten een wezenlijk aspect van thet GVO-proces. De evaluatie van de interventie(s) is in het concept van GVO immers het wetenschappelijk sluitstuk van het vierstappenproces van GVO, zoals dat wordt geschetst in de GVO-matrix van Kok (1987a: 1.9) (zie figuur 2.3). De verticale pilen in figuur 2.3 geven het toegepast onderzoek aan, de horizontale pijlen het fundamenteel onderzoek. In dit complexe proces van gedragsverandering wordt GVO beschouwd ais een toepassingsgebied van diverse. vooral sociaal-wetenschappelijke vakgebieden en GVO volgt als wetenschapsgebied de cyclus die in figuur 2.3 is aangegeven. Een volledig GVO onderzoeksprogramma doorloopt dus 4 stappen:

1. Wat is de relatie tussen thet gezondheidsprobleem (bv. longkanker) en het menselijk gedrag (bv. roken) ? (probleemanalyse)

2. Wat zijn de determinanten van dat gedrag ? (gedragsdeterminanten)

3. Hoe is dat gedrag te beinvloeden? (gedragsbeinvloeding)

4. Wat is het effect van die beïnloeding ? (evaluatie) 
Bij elke stap zijn er bijdragen van andere wetenschappelijke disciplines. Bij de probleemanalyse zijn dat vooral: epidemiologie, geneeskunde en biologie. Bij de studie van de gedragsdeterminanten zijn dat vooral: experimentele psychologie, sociale psychologie, sociologie en economie. En bij de evaluatie: psychologie, sociologie, methodologie en statistiek.

\subsection{Waarom een meetinstrument voor "kennis van kankerpreventie'?}

Het meten van kennis van kankerpreventie bij de bevolking kan worden beschouwd als het meten van het "algemeen effect" van de voorlichting en de kennisoverdracht over kankerpreventie die door alle bestaande middelen en kanalen werden gerealiseerd (cfr. stap vier in het GVO onderzoeksprogramma, zie hoger).

Achiter de terechte vraag naar het effect van gezondheidsvoorlichting schuilen twee cruciale probleemstellingen, die kunnen worden beschouwd als centrale probleemstellingen binnen dit vakgebied. Toegepast op de problematiek van publieksvoorlichting over kankerpreventie, luidt dit als volgt :

1. Is de kankerpreventievoorlichting aan de bevolking effectief of met andere woorden wat levert deze voorlichting op aan beinvloeding van thet denken van mensen over (het nut van) kankerpreventie?

2. Betekent een effectieve voorlichting inzake kankerpreventie dat er (meteen) ook een gedragsverandering gaat optreden, dat met andere woorden de doelstellingen van gezondheidsvoorlichting worden bereikt?

In dit proefschrift wordt niet ingegaan op de fundamentele probleemstelling van vraag 2. Het betreft de complexe vraag naar de determinanten van kankerpreventief gedrag. Onderhavig proefschrift 'beperkt' zich tot de probleemstelling van vraag 1.

De probleemstelling van de eerste vraag staat - althans volgens sommige onderzoekers bij gezondheidsvoorlichting meer centraal dan de beoogde 'gedragsverandering' zelf. Bij gezondheidsvoorlichting heeft voor sommige onderzoekers het beînvloeden van het denken van mensen zelfs meer prioriteit dan de directe gedragsbeinvloeding zelf. Zo stelt Westendorp (1990:19) bijvoorbeeld dat "als gezondheidsbevordering erin slaagt mensen anders te doen denken of innerlijke cognities om te buigen, er een dieper en blijvender resultaat wordt bereikt dan wanneer gedragsverandering op zich centraal staat". Deze GVO-onderzoeker beveert dan ook dat het niet in de eerste plavts het gedrag is dat centraal moet staan bij gezondheidsbevordering, maar well het gezondheidsdenken. Zadra iemand eenmaal voor zichzelf overtuigd is dat gezond leven zin heeft, en weet dat gezond leven binnen zijn of haar mogelijkheden ligt en ook tot resultaten leidt, ligt de weg naar een ander gedrag al ver open.

De eerst geformuleerde probleemstelling wordt overigens niet alleen gesteld in termen van effectiviteit, maar ook in termen van efficiëntie, waarbij men dan vaker vragen stelt naar de betekenis, het potentieel of het rendement van de gezondheidsvoorlichting. Deze 
aspecten stellen aan gezondheidsvoorlichting vereisten met betrekking tot een planmatige en systematische aanpak. De link naar kostenbeheersing ligt voor GVO niet zozeer naar het soort doelstellingen dat zil tracht te realiseren. De vraag of geld besteed moet wordien aan het realiseren van bepaalde doelen is geen vakinhoudelijke, maar een politieke vraag. De link van kwalitatief goede GVO naar kostenbeheersing ligt wel daar. waar het gaat om de doelmatigheid van GVO. Doelmatigheid of efficientie verwijst naar de wijze waarop beschilkbare middelen, gegeven bepaalde doelstellingen, zo goed magelijk besteed kunnen worden.

Al deze aspecten verwijzen in feite nalar een grote behoefte aan 'evaluatie' van de interventies of naar kwaliteitsbewaking in de sector van kankerpreventie. Dergelijke vragen worden overigens niet alleen aan de gezondheidsvoorlichting gesteld, maar passen in een algemeen streven in de samenleving om meer en meer accent te leggen op een integrale kwaliteitsbewaking van producten of dienstverlening. Integrale kwaliteitszorg in de gezondheidszorg is bijgevolg slechts een verbijzondering van deze algemene maatschappelijke bezorgdheid".

Het meten van 'kennis van kankerpreventie' maakt het met name mogelijk om de effecten te meten van de voorlichtingscampagnes. Omdat het meten van kennis van kankerpreventie kan worden beschouwd als het meten van een direct effect van voorlichting inzake kankerpreventie en omdlat effect-meting en evaluatie eigen is aan het theoretisch concept van GVO, kan onderhavig onderzoek ook worden beschouwd als een onderdeel van het globale GVO-concept (zie figuur 2.3).

De vraag naar effectiviteit van GVO mag in een tijd van beperkte (overheids/middelen niet alleen vertaald worden naar de vraag: wat levert het op aan geld? De primaire vraag waar GVO zich voor gesteld ziet is: wat levert het op aan beïnloeding van gedrag dat een positieve bijdrage kan leveren aan gezondheid (Effectiviteit van GWO/Preventie, 1988: 3). Dat een gezondere bevolking een besparing kan opleveren voor de witgaven t.b.v. de volksgezondheid is in dit kader van secundair bellang. De bijdrage die GVO kan leveren aan het bevorderen van gezondheid, bepaalt in de belangrijkste mate haar effect. Dat wil overigens niet zeggen dat GVO, aok als het gaat om kosten-baten verhoudingen, niet effectief zou zijn. Er zijn wel degelijk woorbeelden te noemen, bijvoorbeeld variuit de patiëntenvoorlichting, waaruit blijkt dat voorlichting zichzelf terugbetaalt. Een gunstige toenemende belangstelling mag veokn van de redenen waarom GVO zich in een arbeidssituatie kan bijvoorbeeld een bijdrage vanuit het bedrijfsleven. GVO in de arbeidsverzuim wegens ziekte en kan een positieve leveren tot het terugdringen van eveneens op de productiviteit.

Zie bijvoorbeld in Vlaanderen het tekstboek "Integrale kwaliteitszorg in gezondheids- en welinisvoorzieningen" (1993). Een omvattende inleiding tol methodes van kwaliteitszong voor
de gezondheidszong werd ondermeer geschrewen door Ovretveit 11992$)$. 
De vraag naar het effect van GVO is allereerst de vraag naar het formuleren van concrete doelstellingen van GVO (Effectiviteit van GVOPPreventie, 1988: 4). Het stellen van de vraag naar effectiviteit is zo iets als zichzelf ertoe dwingen om aan de hand van concrete doelstellingen gerichte doelmatige interventies te ontwikkelen om deze doelstellingen te realiseren, en dan door middel van evaluatie-onderzoek na te gaan of deze doelstellingen gerealiseerd worden.

Een apart probleem bij evaluatie van GVO is nu juist de keuze van die doelstellingen (Kok, 1987a: 8). De finale GVO doelen - c.q. een daling van de morbiditeit en mortaliteit aan kanker - liggen meestal op lange termijn. Dat betekent dat de eigenlijke doelen op korte termijn niet geschikt zijn voor evaluatie-onderzoek. Voorlichting over kankerpreventie is gericht op het voorkomen van kanker "die slechts vele jaren later eventueel kan optreden. Om toch te weten te komen of men met een campagne op de "gloede" weg zit of amdat de opdrachtgevers van preventiecampagnes toch wel interesse hebben voor de effectiviteit van de door hen gefinancierde campagnes kunnen $_{i}$ subdoelen of tussendoelen worden gekozen.

Omdat de meeste kankerpreventiecampagnes in Vlaanderen - zeker wanneer het campagnes via de massamedia betreft - nog steeds zeer exclusief gericht zijn op de overdracht van (wetenschappelijke) medische kennis over de kankerproblematiek, zou zo'n tussendoel het bereikte niveau van kennis van kankerpreventie of de toename in deze kennis kunnen zijn. Om een dergelijk tussendoel te kunnen evalueren op een betrouwbare wijze, dienen deze campagnes te kunnen beschikken over een betrouwbaar instrument om kennis van kankerpreventie te meten en dienen ze ook beschikking te hebben van kennisnormen zodat - zelfs zonder voormeting - vergelijkbaarheid mogelijk wordt. Evaluatie-onderzoek met een meetinstrument dat beantwoordt aan de kwaliteitscinteria van validiteit en betrouwbaarheid kan met andere woorden aangeven of men met de kankerpreventiecampagnes op de goede weg is om de doelen te bereiken of niet. 
, 


\section{Hoofdstuk 3}

\section{Kennis van kankerpreventie: begripsanalyse en ontwikkeling van een meetinstrument}
3.1 Conceptualisering en indicering van het begrip
"kankerpreventie"
3.2 De medische kennis over kankerpreventie en de internationale medische richtlijnen inzake kankerpreventie
3.3 Bestaande methodes om kennis van kankerpreventie te meten: een kritische bespreking
3.4 Operationalisering van het onderzoeksconcept "kennis van kankerpreventie" (zie ook bijlage 2a)

\subsection{Sonceptualiserino en indicering van het begrip "kankerpireventie'}

Het onderzoeksconcept "kennis van kankerpreventie" bevat twee begripsinhouden: enerzijds het concept 'kankerpreventie' en anderzijds het concept 'kennis van... '. In deze paragraaf zal de begripsinhoud van het concept "kankerpreventie" worden geanalyseerd en in de volgende paragraaf zall de begripsinhoud van het concept 'kennis van....' worden bestudeerd. Het meest ruime begrip dat vervat zit in dit onderzoeksconcept, namelijk het begrip 'preventie" "wordt als vertrekpunt voor dle begripsanalyse van "kankerpreventie" genomen. Er zijn verschillende omschrijvingen, benaderingen, doelstellingen en (taak-) opvattingen te onderscheiden in het begrip preventie'. Dit heeft er ondermeer toe geleid dat preventie binnen de (eerstelijns-) gezondheidszorg een moeilijk te hanteren begrip is geworden (Erven, 1989: 9).

Toch wordt bij het definiëren van het begrip "preventie" in de gezondheidszorg in het algemeen de volgende onderverdeling gehanteerd: primaire preventie, secundaire preventile en tertiaire preventie (zie ondermeer Ciba Foundation, 1985: Commissie Preventie, 1990; Erven, 1989. Prevention and health: everybody"s business, 1989; Rose, 1992; Schaapveld en Hirasing, 1993; Tijmstra, 1984; Verhaak en de Vries, 1987; Verhaak, Bosman en van de Velden, 1992).

Primaire preventie omvat de activiteiten die gericht zijn op het verminderen van het optreden van nieuwe ziektegevallen of handicaps, door het verkleinen van de gezondheidsrisico's en door het bevorderen wan gezond gedrag. Deze activiteiten

Om meer inzicht te krijgen in de stand van zaken met betrekking tot de ontwikkeling van preventie in de eerstelijnszorg en in de factoren die deze ontwikkeling belemmeren, kan worden verwezen naar Erven (1989). 
situeren zich in hoofdzaak buiten de sector van de traditionele geneeskunde, namelijk in het onderwijs (bv. op schoal), de sport (bv. in sportclubsl, de cultuur (bv. in de massamedia), het gemeenschapsleven (bv. in verenigingen) of op het werk. De interventies zijn gericht op het beinvloeden van thet gedrag van mensen. De aangrijpingspunten voor primaire preventie worden ook wel determinanten van gezondheid of ziekte genoemd. Deze determinanten zijn de factoren die bepalen of iemand gezond of ziek wordt of blijft. Men kan deze determinanten positief of negatief formuleren. In het laatste geval spreekt men ook wel van "risjcofactoren". Zo is gezonde voeding een determinant van gezondheid en overgewicht een risicofactor voor gezondheid.

Bekende methoden woor primaire preventie zijn gezondheidsvoorlichting en -opvoeding, de zogenaamde GVO. De term is afgeleid van het Angelsaksisch begrip 'Health Education" en werd voor de eerste maal in 1961 in ons taalgebied geïntroduceerd door de Nederlandse 'Centrale Raad voor de Volksgezondheild' (1962) (zje ook het proefschrift van Rouwenhorst, 1981). Recentelijk heeft er in de GVO een accentverschuiving plaats van gezondheidseducatie naar gezondheidspromotie. Terwijl eerst het accent gelegen was in het aanleren van preventie via $0 . \mathrm{m}$. scholen en arbeidsplaatsen, gaat de aandacht nu meer en meer in de richting van de actieve promotie van gezond leven en denken bij alle categorieën van de bevolking. Men gaat dan ook steeds meer en meer in plaats van GVO de term "gezondheilsbevordering" gebruiken; een vertaling van het Anglelsaksisch begrip "Health Promotion".

Binnen de sector van de GVO is er een discussie gaande waarbij men een verder anderscheid wil maken tussen 'gezondheidsbescherming' (Health Protectionl. 'ziektepreventie' (Disease Prevention) en 'gezondheidsbevordering" (Health Promotion) (zie hierover Westerdorp, 1990). Voorbeelden van 'gezondheidsbescherming" zijn de vaccinatieprogramma's tegen pokken of tuberculose, de drinkwaterwoorzieningen tegen infectieziekten en de programma's voor (verkeers-) ongevallenpreventie. Voorbeelden van "ziektepreventie" zijn de anti-rookcampagnes ter preventie van longkanker of de overdraagbare het condoomgebruik ter preventie van AIDS en andere seksueel maatregelen inzake gezondheidspoorbeelden van 'gezondheidsbevordering' zijn alle alcoholconsumptie, lichaamsbeveging, enz.

Secumdiire preventie betekent het opsporen van ziekten in een vroeg, presymptomatisch stadium. Het beoogt de voortgang van een ziekte te vertragen of tot stilstand te brengen in een stadium dat de ziekte nog geen symptomen geeft en de patiênt nog geen vroeg stadium een behandeling te starten, zodat er aandoening beoogt men in dit genezing is. Deze interventie is in tegenstelling zodat er een grotere kans op volledige gesitueerd in de sector van de gezondheidszorg tot primaire preventie vrijwel exclusief buhandeling in de curatieve sector. geweest. Uitgangspunt daarbij is dat de patient begeeft. De arts stelt een diagnose en schrijtient zich met een klacht naar de arts opkomst van de secundaire preventie of de vroegtijdige opsporing therapie voor. Met de 
men niet langer op de symptomen van een ziekte, maar will men de ziekte voor ziln.

Secundaire preventie kent twee varianten: 'case-finding' en 'bevolkingsonderzoek'. Onder case-finding wordt het volgende verstaan (Commissie Preventie, 1990: 380 ):

"Case-finding betekent dat het individu dat op eigen initiatief - met klachten - naar de onderzoeker komt, tevens wordt getest met de bedoeling ziekten op te sporen die met de klacht geen verband houden."

Voorbeelden van case-finding zijn het routine-bloedonderzoek bij zwangerschap, de routinematige bloeddrukmeting bij pilgebruiksters, de hypertensie-controle door de huisarts, enz. Door de organisatie van bevolkingsonderzoek, ook wel aangeduid met de Engelse term 'screening', wordt bij secundaïre preventie nog een stap verder gezet (Tijmstra, 1984:130). Bij bevolkingisonderzoek wordt de bevolking onderzocht door middel van een bepaalde diagnostische test en zoekt men met deze methode naar één bepaalde ziekte. Het doel is zoveel mogelijk mensen op te sporen die verdacht worden van het hebben van een bepaalde ziekte-afwijking, teneinde bij hen nader onderzoek te verrichten. Bevolkingsonderzoek kan ook betrekking hebben op de risicofactoren voor bepaalde ziekten i.p.v. op de ziekte zelf (bijvoorbeeld hoge bloeddruk in verband met hart-en vaatziekten).

In de jaren zestig en zeventig ontstond er een groot optimisme over de waarde van het bevolkingsonderzoek. De screening op longtuberculase diende daarbij min of meer als voorbeeld: het regelmatig "doorlichten" van bevolkingsgroepen zou deze ziekte effectief hebben bestreden en nieuwe screeningsmethoden zouden in belangrijke mate kunnen bijdragen tot de terugdringing van andere ziekten. Het bevolkingsonderzoek deed ook haar intrede door het periodiek oproepen en onderzoeken van zuigelingen (via Kind en Gezin), schoolkinderen (via Medisch School Toezicht) en bepaalde categorieen werknemers (via de Arbeidsgeneeskunde). In de jaren zestig begon men in Vaanderen . welliswaar op beperkte schaal - ook met opsporingsacties inzake baarmoederhalskanker (Pas, 1995:53).

Tertiaire preventie is eigenlijk geen preventie in de zin van het voorkómen van ziekte. Het betreft de activiteiten die gericht zijn op het voorkomen van complicaties of verslechtering bij bestaande ziekte of invaliditeit. Men beoogt de beperking van de ongemakken van bepaalde aandoeningen, het voorkomen van mevenwerkingen of het voorkomen van de progressie van chronische aandoeningen. Vooral bij chronische zieken is er sprake van deze vorm van preventie. Bij chronische patiënten gaat het oim ziekten of gebreken die in beginsel niet meer te genezen of te verhelpen zijin, maar waarbij alleen nog ongewenste lichamelijke, psychische of sociale gevolgen voor de patiënt of voor zijn omgeving kunnen worden voorkomen. Men beoogt daarbij de kwaliteit van het leven van de patiënten de optimaliseren. Andere voorbeelden van tertiaire preventie zijn de controle van patiënten met diabetes mellitus om te voorkomen dat zich complicaties aan ogen en voeten zouden voordoen, of de palliatieve zorg bij terminale patiënten om te voorkomen dat nog onnodige zware behandelingen worden opgestart en om ervaor te zorgen dat het lijden wordt verzacht. Nog voorbeelden zijn het voorkomen van een 
blijvende handicap na ongevallenletsel, het revalideren van een reumapatient en suicidepreventie bij depressieve patienten.

Al deze voorbeelden tonen aan dat bij tertiaire preventie de curatieve en preventieve activiteiten onderling sterk verweven zijn. Dit doet sommige auteurs besluiten om bij de indeling van het begrip preventie, het begrip tertiaire preventie achterwege te laten (zie bijwoorbeeld Verhaak en de Vries, 1987 en Schaapveld en Hirasing, 1993). Zo stellen bijvoorbeeld Schaapveld en Hirasing (1993: 8) in hun Preventiegids het volgende:

\begin{abstract}
"Tertiaire preventie is eigenlijk geen preventie in de zin van het voorkomen van ziekte. De term wordt gebruikt om technieken aan te geven waarmee men probeert verergering van of invalidering door reeds opgetreden ziekten te woorkomen. "
\end{abstract}

Tertiaire preventie zal in deze studie worden beschouwd als curatie en zorg, waardoor het buiten het kader van dit proefschrift valt. In figuur 3.1 wordt duidelijk gemaakt hoe in deze gedachtengang primaire en secundaire preventie zich onderscheiden van andere functies van gezondheidszorg. Tertiaire preventie wordt ook binnen dit schema geacht onderdeel uit te maken van de curatieve zorg, de revalidatie, de nazorg of de langdurige zorg/verpleging.

Figuur 3.1

Zorgfuncties in relatie tot de fasen van het ziekteproces

\begin{tabular}{|c|c|c|c|c|c|}
\hline Fasen: & gezond & $\begin{array}{l}\text { niet meer } \\
\text { gezond }\end{array}$ & ziek & herstellend & $\begin{array}{c}\text { gehandicapt } \\
\text { of chronisch } \\
\text { ziek }\end{array}$ \\
\hline Primaire preventie & 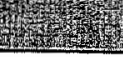 & & & & \\
\hline Secundaire preventie & & 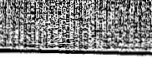 & & & \\
\hline Curatieve zorg & & & & & \\
\hline Revalidatie & & & 6 & & What \\
\hline Nazorg & & & & Mrar & \\
\hline Langdurige verzorging & & & & & 型 \\
\hline
\end{tabular}

In navalging van de hoger vermelde definitie en inperking van het begrip preventie, kan nu het begrip "kankerpreventie" worden opgedeeld in twee betekenissen:

Primaire kankerpreventie omvat de activiteiten die gericht zijn op het verminderen van het optreden van nieuwe kankers. Gezonde leef- en voedingsgewoonten zijn hierbij cruciaal. Deze zorgen ervoor dat mensen beter in staat zijn het risico op kanker te
beperken. 
Secundaire kankerpreventie beoogt kanker vroegtijdig op te sporen met een medische onderzoekstechniek. Het doel van een vroegtijdig opsporingsonderzoek is de veranderingen in lichaamsweefsel, die worden veroorzaakt door kanker of een voorstadium van kanker, wroeg te ontdekken, zodat de patiënt sneller en met meer effect een behandeling kan krijgen.

Primaire kankerpreventie komt, in tegenstelling tot secundaire kankerpreventie, minder aan bod in de traditionele geneeskunde, maar maakt eerder deel uit van de sector wam de gezondheidsbevordering of gezondheidspromotie. Het accent ligt daarbij eerder op het vermijden van risicogedrag ter bevordering van de gezondheid, dan op het vermijden van het risicogedrag ter voorkóming van kanker. In tegenstelling tot secundaire kankerpreventie, ligt bij primaire kankerpreventie het initiatief (zeker in Vlaanderen) meer bij particuliere organisaties of verenigingen.

Het bevolkingsonderzoek naar baarmoederhalskanker en racentelijk ook naar borstkanker kunnen als de belangrijkste voorbeelden van secundaire kankerpreventie: worden genoemd (zie ondermeer Bonte e.a., 1991; Denis e.a., 1988 en Eylenbosch e.a., 1988). Het vroegtijdig opsporen van kanker kan ook worden bevorderd door consultatie van de arts m.a.v. het vaststellen wan een "waarschuwingssignaal" voor kanker. Het gaat dan om symptomen die meestal aspecifiek zijn (bv. een aanhoudende hoest of heesheid, of onverklaarbare gewichtsverminderingl en waarbij het initiatie ligt bij de patiënt of de bevolking. Het bekendste voorbeeld is de ontclekking van een knobbeltje in de borst als (mogelijk) waarschuwingssignaal voor borstkanker bij vrouwen. De aandacht die aan deze waarschuwingssignalen besteed wordt is vooral ingegeven vanuit de zorg om de zgn. "patient delay' tot een minimum te herleiden. Bij secundaire preventie is het strikt genomen de bedoeling om bij symptoomvrije personen latente kanker op te sporen. Omdat de filosofie of de finaliteit van de zorg om deze waarschuwingssignalen - namelijk kanker tijdig opsporen, zodat de patiënt sneller en met meer effect een behandeling kan krijgen - dezelfde is als bij vroegtijdige opsporing, zal deze studie de beide dimensies onder eenzelfde noemer van "secundaire kankerpreventie" behandelen. In beide gevallen gaat het immers om de preventie van de kankersterfte door het reduceren van de 'patient delay'.

Hoewel de meeste tekstboeken over (kankerlpreventie zich beperken tot een siltuering van (kanker)preventie in de sector van de gezondheidszorg ${ }^{\dagger}$, blikt uit de gegeven omschrijvingen dat kankerpreventie niet zondermeer binnen de sector van de gezondheidszorg kan worden gesitueerd. Binnen de sector van de gezondheidszarg is kankerpreventie vooral patiënt- of individu gericht. Buiten de gezondheidssector is kankerpreventie eerder bevolkings- of collectief gericht. Daarom wordt het nuttig geacht in thet begrip kankerpreventie een tweede onderscheid aan te brengen (zie figuur 3.2).

Voorbeelden hiervan zijn Ciba Foundation (1985), Commissie Preventie (1990), Erven (1989), Pas (1993), Rose (1992) en Schaapveld en Hirasing (1993). 
Figuur 3.2

Onderscheid tussen de "individuele" en de "collectieve" kankerpreventie

\begin{tabular}{|c|c|c|}
\hline & Individuele kankerpreventie & Collectieve kankerpreventie \\
\hline $\begin{array}{l}\text { Analyse- en actie- } \\
\text { eentheid }\end{array}$ & net individu & $\begin{array}{c}\text { de bevolking of een } \\
\text { subpopulatie }\end{array}$ \\
\hline Gezondheidsattitude & de "wachthouding" & de "zoekhouding" \\
\hline $\begin{array}{l}\text { Plaats van de } \\
\text { interventie }\end{array}$ & de praktijkruimte & $\begin{array}{c}\text { het parlement, de school, } \\
\text { de gemeente, het werk, } \\
\text { enz. }\end{array}$ \\
\hline Type van 'professional" & $\begin{array}{l}\text { de clinicus (huisarts, } \\
\text { specialist, psycholoog, } \\
\text { verpleegkundige, enz.) }\end{array}$ & $\begin{array}{l}\text { gedragswetenschappers, } \\
\text { epidemiologen, bestuurders, } \\
\text { gezondheidseconomen, enz. }\end{array}$ \\
\hline
\end{tabular}

Er zijn vier belangrijke onderscheiden te maken tussen de individuele en de collectieve benadering van kankerpreventie (zie Sanson.Fisher, 1993: 119-120). Ten eerste is bij de collectieve - of volksgezondheidsbenadering niet het individu, maar de bevolking de analyse- en actie-eenheid. De bevolking kan daarbij worden opgesplitst volgens geografische spreiding of naar gesllacht, leeftijd, beroepsstatus of gezondheidsrisico (WHO, 1978). Eén enkele interventie bereikt op die manier veel meer mensen, dan de individuele benadering. Op de tweede plaats is er een verschil in gezondheidsattitude. Bij de individuele benadering wacht de onderzoeker vooraleer een patieznt zich aandient, bij de collectieve benadering wordt de bevolking actief opgezocht en worden de preventieve diensten aangeboden. Deze houding houdt ondermeer de identificatie van risicokenmerken van bepaalde bevolkingsgroepen in, alsook eventuele grootschalige enquetes. De interventies zelf bestaan wit voorlichting, gezondheidspromotie of milieuinterventies. De plaats wan de interventie bepaalt het derde onderscheid tussen individuele en collectieve kankerpreventie. De plaats van de interventie bij de individuele benadering is meestal de consultatieruimte van de onderzoeker larts, psycholoog, enz.) of het ziekenhuis. Bij de collectieve benadering zijn zeer uiteenlopende maatschappelijke sectoren de mogelijke plaatsen van interventie. Voorbeelden zijn het pariement bij het stemmen van wetten over kankerpreventie, de school als plaats woor gezondheidsvoorlichting en -opvoeding, de gemeente als plats voor een preventiecampagne voor bijvoorbeeld voegtijdige opsporing van baarmoederhalskanker, of het werk als lokatie voor een anti-alcoholcampagne. Tenslotte is er een onderscheid in het type van "professional" die de interventie doet. De verantwoordelijke voor de interventie bij de individuele benadering is altijd de clinicus $(b v$. de oncoloog, de huisarts, de verpleegkundige, enz.), maar bij de collectieve benadering zijn dat zeer uiteenlopende beroepen zoals bestuurders bij het ontwerpen van een preventiebeleid, gedragswetenschappers of epidemiologen bij het onderzoeken van risicofactoren of gezondheidseconomen bij het maken van een kosten-baten analyse van een preventie-
actie. 
Figuur 3.3

Typologie van domeinen in kankerpreventie

\begin{tabular}{|l|c|c|}
\hline & $\begin{array}{l}\text { Individuele } \\
\text { benadering }\end{array}$ & $\begin{array}{l}\text { Collectieve } \\
\text { benadering }\end{array}$ \\
\hline $\begin{array}{l}\text { Primaire } \\
\text { kankerpreventie }\end{array}$ & domein A & domein B \\
\hline $\begin{array}{l}\text { Secundaire } \\
\text { kankerpreventie }\end{array}$ & domein C & domein D \\
\hline
\end{tabular}

Naast het onderscheid tussen primaire en secundaire kankerpreventie, kan dus best ook het onderscheid tussen de individuele en collectieve benadering van kankerpreventie worden gehanteerd. Als het onderscheid tussen de individuele en collectieve benadering in relatie wordt gebracht tot de eerder gemaakte opdeling tussen primaire- en secundaire kankerpreventie, dan bekomt men een typologie van de kankerpreventie in vier domeinen (zie figuur 3.3).

- domein A : de individueel gerichte primaire kankerpreventie.

Het betreft hier voornamelijk individuele voorlichting, individuele counseling of training die worden verricht in de consultatieruimte van de (huis)arts of een andere gezondheidswerker (bv. psychalaog of voedingsdeskundige). De inhoud van de adviezen aan de betrakken patiënt zijn vooral gericht op de te vermijden risicofactoren. Hierbij kan gedacht worden aan bijvoorbeeld dieetadvies, rookstopadvies, enz. De preventieve benadering is hier ziektegericht en het accent ligt eerder op het afraden en afbouwen van ongewenst risicogedrag ten einde ziekte, c.q. kanker, te voorkomen.

- domein B: de collectief gerichte primaire kankerpreventie.

Hier betreft het voornamelijk collectieve voorlichting die wordt verspreid via de massamedia, via gepersonaliseerde mailings, wia het werk of via verenigingen. Hieronder kunnen alle voorlichtingsactiviteiten wan de media en de verschillende GVO-verenigingen, die gericht zijn op gezondheidspromotie, worden ondergebracht. De inhoud van de voorlichting kan niet geïndividualiseerd zijn en is ook gericht op het ongewenst risicogedrag in het algemeen en ook op wat medisch wenselijk is als preventief gedrag dat de zlekte, c.q. kanker, mee helpt te voorkomen.

- domein C: de individueel gerichte secundaire kankerpreventie.

Het betreft hier de wroegtijdige opsporingsonderzaeken die worden verricht door de Thuis/arts. Dit kan zowel een routine-onderzoek zijn, een onderzoek dat wordt aangeboden door de arts (case-finding) of een onderzoek dat door de patiënt wordt 
gevraagd. De meest frequent voorkomende onderzoeken ziln het baarmoederhalsuitstrijkje, het kllinisch borstonderzoek, de mammografie, de hemocculttest voor het opsporen wan bloed in de stoelgang of het rectaal toucher ter opsporing van darmkanker.

- domein $D:$ de collectief gerichte secundaire kankerpreventie.

Hier betreft het campagnes die in Vlaanderen verricht worden door de (universitaire) centra voor kankeropsporing of door provinciale structuren voor karikeropsporing. In Vlaanderen beperkt dit deel van het werkveld zich voornamelijk tot borstkankeropsporing via het aanbieden van een mammografie of baarmoederhals-kankeropsporing door het propageren en aanbieden van het cervixuitstrijkje. Verder betreft het alle andere informatie-overdracht over secundaire kankeropsporing via de media, via folders, affiches, enz. De inhoud van de boodschap is vooral gericht op de bestaande vroegtijdige opsporingsonderzoeken en op de vroegtijdige waarschuwingssignalen voor bepaalde vormen van kanker. Men kan hier denken aan de sensibilisatie van vrouwen om een arts te raadplegen bij het vinden van een knobbeltje in de borst.

De voorlichting bij deze vier typen van kankerpreventie is gericht op een viertal diverse clusters van voorlichtingsboodschappen die men tracht over te brengen naar de bevolking. Wordt deze voorlichtingsboadschappen gedistilleerd uit deze 4 domeinen van kankerpreventie, dan bekomt men zowel voor de primaire als voor de secundaire kankerpreventie telkens twee specifieke informatie- of 'kennisdomeinen' (zie figuur 3.4 ).

Figuur 3.4

Typologie van "kennisdomeinen" in het begrip kankerpreventie

\begin{tabular}{|l|l|}
\hline $\begin{array}{l}\text { primaire preventie van } \\
\text { kanker }\end{array}$ & - risicofactoren wan kanker \\
\cline { 2 - 2 } & - gewenst kankerpreventief gedrag \\
\hline $\begin{array}{l}\text { secundaire preventie } \\
\text { van kanker }\end{array}$ & - waarschuwingssignalen voor kanker \\
\cline { 2 - 2 } & - vroegtijdige kankeropsporingsonderzoeken \\
\hline
\end{tabular}

Om in onderhavig empirisch onderzoek het centraal onderzoeksconcept 'kennis van kankerpreventie" op een valide wilze te meten, kan de conceptualisering het best alansluiten bij deze typologie van de kennisdomeinen in het begrip kankerpreventie. De keuze voor de dimensies en indicatoren om het concept 'kennis van kankerpreventie' te meten ligt dan voor de hand (zie figuur 3.4). 


\subsection{De medische kennis over kankerpreventie en de internationale}

medische richtliinen inzake kankeroreventie.

Kennis kan enkel worden gemeten indien er een 'kennisnorm' bestaat. Dit wil zeggen dat men de kennis van iemand enkel kan meten als de vastgestelde kennis kan worden vergeleken met een bepaalde norm. Zo worden er door de inrichtende machten van het onderwijs leernormen vastgelegd en de leraars dienen aan het einde van het jaar te toetsen of de leerlingen deze leernormen hebben gehaald of niet. Als de leerling ten aanzien van een vastgestelde leernorm een voldoende kennis heeft, beheerst hij/zij in voldoende mate de leerstof en kan hil/zij naar een volgend leerjaar overstappen. Wil men kennis van kankerpreventie meten bij de bevolking, dient men bijgevolg ook te beschikken over 'kennisnormen". De kennisnormen voor kankerpreventie komen tot stand in de medische wetenschappen na zeer veel wetenschappelijke research en jaren van discussie over de gevonden onderzoeksresultaten. Op het ogenblik dat er binnen de wetenschap een consensus bereikt is over een bepaalde nieuwe ontdekking of medische toepassing inzake kankerpreventie, kan worden gesproken van het ontstaan varn een kennisnorm.

Er mag evenwel niet worden verwacht dat de bevolking op de hoogte is van all deze wetenschappelijke kennisnormen over kanker(preventie). Deze kennisnormen worden immers enkel gecommuniceerd via de vakbladen en bijgevolg zijn enkel de vakgenoten in de mogelijkheid om kennis te hebben van de (nieuwe) normen. Veronderstellen dat de bevolking op de hoogte zou kunnen zijn van deze kennisnormen, zou een verkeerd uitgangspunt zijn voor dit onderzoek. Het is bijgevolg niet relevant - als dat al zou mogelijk zijn - om via de medische literatuur een inventaris te maken van de medische kennis over kankerpreventie. Om de kennisnormen voor dit onderzoek te kunnen vastleggen, moest bijgevolg worden gezocht naar wetenschappelijke overzïchtsrapporten, consensusrapporten, protocollen, standaarden of codes waarin deze normen worden vastgellegd ten behoeve van de verspreiding - via (huis)artsen of via campagnes - naar de bevolking. Meestal wordt in zulke documenten de bestaande relevante medische kennis gesynthetiseerd in aanbevelingen of richtlijmen ('Guidelines'). Deze aanbevelingen worden opgesteld in commissies bestaande uit bevoegde artsen en wetenschappers. Deze commissies zijn ofwel officieel geìnstalleerd door de overheid " of komen tot stand op initiatief van een beroepsgroep of een wetenschappelijke vereniging ${ }^{2}$.

Zie bijvoorbeeld de Vlaamse Adviescommissie voor Kankerpreventie (1985) in Vlaanderen of de U.S. Preventive Services Task Force (1989) in de Verenigde Staten.

Zle bijvoorbeeld de Commissie Preventie 11990 die tot stand kwam op initiatief van de Wetenschappelijke Vereniging der Vlaamse Huisartsen of het ACS rapport "Guidelines for the cancer-related health checkup" dat tot stand kwam in opdracht van de American Cancer Society (1980a). 
Figuur 3.5

Chronologisch overzicht 1979-1993 van consensusrapporten of referentiewerken met richtlijnen over kankerpreventie.

\begin{tabular}{|c|c|c|c|}
\hline & Jaar & $\begin{array}{l}\text { Land of } \\
\text { regio }\end{array}$ & Referentie van het rapport \\
\hline 1 & 1979 & Canada & $\begin{array}{l}\text { Canadian Task Force on the Periodic Health } \\
\text { Examination (1979). The periodical health examination, } \\
\text { in: Canadian Medical Assaciation Journal, } 121, n^{\circ} 3 \text {, } \\
\text { pp. } 1193-1254 \text {. }\end{array}$ \\
\hline 2 & 1980 & U.S.A. & $\begin{array}{l}\text { American Cancer Society (1980a). Guidelines for the } \\
\text { cancer-related health checkup: recommendations and } \\
\text { rationale, in: } \mathrm{Ca} \text { ( } \mathrm{A} \text { Cancer Joumal for Clinicians), } 30 \text {, } \\
1980, \mathrm{pp} .194-240 \text {. }\end{array}$ \\
\hline 3 & 1985 & Vlaanderen & $\begin{array}{l}\text { Vlaamse Adviescommissie voor Kankerpreventie } \\
\text { (19851, Kanker. Vroegtijdige opsporing en preventie. } \\
\text { Brussel, } 112 \text { blz. }\end{array}$ \\
\hline 4 & 1987 & Europa & $\begin{array}{l}\text { Commissie van de Europese Gemeenschappen }(1987) \text {. } \\
\text { EEG-Programma "Europa Tegen Kanker" Cammissie } \\
\text { wan de Europese Gemeenschappen. Brussel, } 26 \text { februari } \\
1987 \text {. }\end{array}$ \\
\hline 5 & 1989 & U. S.A. & $\begin{array}{l}\text { U.S. Prevertive Services Task Force }(1989) \text {, Guide to } \\
\text { clinical preventive services, Williams and Wilkins, } \\
\text { Battimore, } 419 \text { blz. }\end{array}$ \\
\hline 6 & 1990 & Vlaanderen & $\begin{array}{l}\text { Commissie Preventie (1990), red., Algemene preventie } \\
\text { in de huisartsenpraktijk, Wetenschappelike: Vereniging } \\
\text { der Vlaamse Huisartsen (WVWH), Prima Linea. } \\
\text { Antwerpen, } 390 \mathrm{blz} \text {. }\end{array}$ \\
\hline 7 & 1993 & Nederland & $\begin{array}{l}\text { Schaapveld, K., Hirasing, } \mathrm{F} . \text { A. (1993), Preventiegids. } \\
\text { Een praktisch overzicht van preventiearogramma's voor } \\
\text { huisartsen, verloskundigen en medewerkers in de } \\
\text { jeugdgezondheidszorg, Van Gorcum, Assen/Maastricht, } \\
197 \text { blz. }\end{array}$ \\
\hline
\end{tabular}

Toelichting: het rapportnummer vermeld in de eerste kolom wordt gebruikt om in de tekst naar het betreffend rapport te verwijzen.

- Begripsanalyse en ontwikkeling van een meetinstrument - 
Wat betekent op het vlak van kankerpreventie een persoon met adequate kennis van kankerpreventie? Vanuit het perspectief van de bevolking kan adequate kennis worden gedefinileerd als kennis die aansluit bij de (huidigel medische kennis die geformuleerd is in deze richtlijnen. Om de kennisnormen te kunnen vastleggen, kan men zich bilgevolg thet best baseren op de bestaande medische richtlijnen of aanbevelingen inzake kankerpreventie.

In de literatuur werd in chronologische volgorde een aantal rapporten en referentiewerken geïnentariseerd met relevante richtlijnen inzake kankerpreventie die de afgelopen jaren zijn verschenen (zie figuur 3.5). Dit onderzoek beperkt zich daarbij tot de landen of regio's die voor Vlaanderen relevant zijn (Vlaanderen en Europa) of die in Vlaanderen valk als referentie gelden (Nederland, Canada of de Verenigde Staten).

In 1979 verscheen in Canada onder leiding van Prof. dr. W.O. Spitzer het rapport van de Canadian Task Force die haar werkzaamheden startte in 1976. De uitdaging van deze commissie was zeer ambitieus (Canadian Task Force, 1979: 1193):

"... to recommend a plan for a lifetime program of periodic health assessments for all persons living in Canada."

Een groep van clinici en wetenschappers, bijgestaan door een internationale groep van adviseurs, identificeerden 78 belangrijke te voorkomen condities of ziekten - gaande van ongevallen tot ongewenste zwangerschap, waaronder ook 9 vormen van kanker . waarmee de Canadezen anno 1979 werden geconfronteerd. De commissie onderzochit de wereldliteratuur met als onderzoeksvraag of vroegtijdige opsporing van deze ziekten of condities voordelig zou zijn voor de bevolking en kwam tot een reeks van aanbevelingen over gezondheidsbeschermende maatregelen. Eén van de bellangrijkste aanbevelingen was het voorstel tot vervanging van de op dat moment gangbare praktijk van de "jaarlijkse routine check-up" door een selectieve preventieve benadering gedifferentieerd naar leeftijd en geslacht. Ook de op dat moment bestaande traditie van een routine radiografie van de longen werd niet (meer) aanbevolen.

Eén jaar later publiceerde de American Cancer Society (1980) haar alanbovelingen voor de specifieke kankergerelateerde onderzoeken. Hierin werden 9 tests geëwalueerd op hun medische effectiviteit qua morbiditeit en mortaliteit. Er werden richtlijnen gegeven voor vroegtiijdige opsporing van baarmoederhals-, borst-, en darmkanker en er werden eveneens geslachts- en leeftijdsgebonden aanbevelingen geformuleerd voor kankerpreventie. Het tot dan gebruikelijke onderzoek van de longen door middel vam een radiografie werd in dit rapport evenmin aanbevolen.

In 1985 volgde de Vlaamse Adviescommissie voor Kankerpreventie (1985) het voorbeeld van de American Cancer Society door de publicatie van haar rapport "Kanker. Vroegtijdige opsporing en preventie". Het rapport was evenwel minder selectief bij de aanbeveling van de bestaande medische tests. Het vermeldde een aantal aanbevelingen voor baarmoederhals", borst-, en darmkanker, maar woegde daar ook richtlijnen aan toe voor huid-en prostaatkankerpreventie. 
In 1987 werd in Europa in opdracht van de Commissie van de Europese Gemeenschappen (1987) een Europese Kankercode samengesteld door een groep van Europese experten inzake kankerpreventie. De verdienste van dit rapport is minder van wetenschappelijke aard, dan wel van beleidsmatige aard. Voor de eerste maal werd er tussen (de experten van) alle landen van de Europese Unie (toen nog Europese Gemeenschap) een consensus bereikt over 10 aigemene richtijnen over kankerpreventie (zie hoger hoofdstuk 2, paragraaf 2.2).

Het meest omvattende rapport verscheen evenwel in 1989 in de Verenigde Staten, waar de U.S. Preventive Services Task Force in opdracht van de U.S. Department of Health and Human Services en onder het voorzitterschap van Prof. dr. R.S. Lawrence van de Harvard Medical School in Cambridge niet minder dan 169 preventieve interventies bestudeerde op hun medische effectiviteit. Uitgangspunt voor dit rapport was het periodiek geneeskundig onderzoek dat aangegrepen werd als preventief medisch onderzoek waarbij ook preventieve adviezen gegeven werden aan de bevolking. Het rapport identificeerde, op basis van een zeer uitvoerige literatuurstudie en een vier jaar durende dialoog onder tal van experten, de preventieve diensten die door de arts aan specifieke leeftijdscategorieën moeten worden aangeboden tijdens het "periodiek geneeskundig onderzoek" " De aanbevelingen werden samengevat in acht leeftijdsgebonden tabellen. Er werd ook éên tabel opgesteld met specifieke richtlijnen voor zwangere vrouwen. Ook in dit rapport werd ruim aandacht besteed aan kankerpreventie. Er zijn hoofdstukken gewijd aan respectievelijk borst-, colorectale, cervix-, prostaat-, long-, huid-, testes-, ovarium-, pancreas- en mondkanker. Er zijn ook specifieke hoofdstukken gewijd aan voorlichting, met name over alcoholconsumptie, rookstop en voeding. Preventieve aanbevelingen inzake secundaire kankerpreventie werden enkel gedaan voor cervix-, borst- en huidkanker (zie ook figuur 3.7).

Nadien verschenen in Vlaanderen op initiatief van de Commissie Preventie van de Wetenschappelijke Vereniging der Vlaamse Huisartsen (Commissie Preventie, 1990) en in Nederland in opdracht van het Nederlands Ministerie van Welzijn, Volksgezondheid en Cultuur (Schaapveld en Hirasing, 1993) nog twee rapporten. Deze waren in hoofdzaak geïnspireerd op de bestaande rapporten uit de Verenigde Staten en Canada. Deze rapporten hebben vooral de verdienste dat ze voor een brede groep goed toegankelijk zijn omdat ze in het Nederlands zijn opgesteld en omdat ze in ons taalgebied zeer werkers en beleidsmensen ${ }^{2}$.

Al deze rapporten hebben tot doel het geven van een overzicht van de (kanker-)

De term "periodiek geneeskundig onderzoek" is een vertaling van de Angelsaksische term
"Periadic Heaith Examination". 2 Zo bijvoorbeeld werd de monografie "Algemene preventie in de huisartspraktijk" (Commissie
Preventie, 1990) toegestuurd naar alle huisartsen in Vlaanderen. 
preventieve maatregelen die zinvol zijn om aan de bevolking in zijn geheel of aan (risico-) groepen binnen de bevolking aan te bieden. Het betreft steeds aanbevelingen voor $z g n$. "asymptomatische" of gezonde personen. All deze rapporten hebben verder met elkaar gemeen dat het zogenaamde "consensusrapporten" zijn. Dit betekent dat ze het resultaat zijn van een langdurig en breed overleg met een grote groep van experten clinici en wetenschappers - inzake (kanker)preventie. Ze baseren hun bevindingen en aambevelingen op de actuele medisch-wetenschappelijke literatuur en op de bevindingen van klinische en epidemiologische studies. Verder staan in al deze rapporten zowel richtlijnen voor primaire kankerpreventie als voor secundaire kankerpreventie. Deze rapporten kunnen bijgevolg worden beschouwd als een "state of the art" van de (kanker)preventie, waardoor ze geschikt zijn om de "kennisnormen' vast te leggen.

Er zijn ook een aantal verschillen tussen de rapporten vast te stellen. In de eerste plaats is een deel van deze studies gemaakt in opdracht van de overheid $(1,3,4,5,7)^{\prime}$ en een ander deel in opdracht van een beroepsgroep of wetenschappelijke vereniging $(2,6)$. Sommige van deze rapporten zijn specifiek gericht op kankerpreventie $(2,3,4)$, andere zijn gericht op algemene preventie $\{1,5,6,7)$. Kankerpreventie krijgt in deze laatste evenwel steeds veel aandacint. Sommige van deze rapporten zijn vrijwel exclusief gericht op de "individuele benadering" van kankerpreventie of de klinische interventies inzake secundaire kankerpreventie $(1,2,3,5)$, terwijl andere rapporten kankerpreventie eerder collectief benaderen of algemene aanbevelingen inzake zowel primaire- als secundaire kankerpreventie voor de hele bevolking voorschrijven $(4,6,7)$.

In al deze rapporten worden de richtlijnen gedifferentieerd weergegeven volgens de kankersoort of de orgaanlokalisatie van kanker. Ten einde de kennisnormen voor dit onderzoek te kuninen afbakenen op een verantwoorde manier, zal de selectie van de richtlijnen uit deze rapporten zich beperken tot de richtlijnen die staan vermeld bij de in België vijf meest voorkomende vormen van kanker ${ }^{2}$. Omdat ze veelvuldig worden gebruikt in preventilecampagnes worden ook de richtlijnen voor huidkanker opgenomen, allsook een aantal algemene richtlijnen - zoals bijvoorbeeld het met mate drinken van alcohol of vermijiden van overgewicht - die niet exclusief betrekking hebben op éen vorm van kanker, maar voor meerdere kankers van toepassing zijn.

In figuur 3.6 wordt er gedifferentieerd naar vrouwen en mannen aangegeven of er in de onderzochte rapporten al dan niet aanbevelingen staan vermeld. Het voorkomen van aanbevelingen wordt ingedeeld naar kankerlocalisaties en kennisdomeinen frisico. factoren, gewenst preventief gedrag, waarschuwingssignalen en vroegtijdige

Zie figuur 3.5 voor het overeenstemmend rapport bij deze cijfers.

2

De meest voorkomende nieuwe kankers in België zijn respectievelijk long-, darm" , borst“ , prastaat- en cervixkanker. Bij vrouwen komen respectievelijk borstkanker, darmkanker en baarmoederhalskanker het vaakst voor als nieuwe kankergevallen. Bij mannen zijn dat respectievelijk longkanker, prostaatkanker en darmkanker (Belgisch Werk Tegen Kanker, 1992; zie ook Beckers, 1994). 
opsporingsonderzoekenl, zoals deze hoger in paragraaf 3.1 werden onderscheiden. Op deze wijze wordt een inzicht verkregen in de mate van aanwezigheid van richtlijnen voor de te onderzoeken kennisdomeinen. Dit inzicht zal helpen bij de selectie van de richtlijnen als kennisnormen voor onderhavig onderzoek. Daarbij wordt naar een selectie van 7 a 8 kennisnormen per kennisdomein gestreefd. In figuur 3.6 worden enkel de in België vilf meest voorkomende kankers, alsook huidkanker nominatief vermeld, de andere richtlijnen werden opgenomen in de categorie "andere kankers".

De opgespoorde richtlijnen hebben woor twee kankers (darm- en huidkanker) zowel betrekking op risicofactoren, gewenst gedrag, waarschuwingssignalen als op bestaande vroegtijdige opsporingsonderzoeken (zie figuur 3.6). Voor alle overige kankers hebben ze betrekking op drie van de vier kennisdomeinen. In de grijsgevulde cellen staan de richtlijnen die expliciet vermeld staan in de Europese Kankercode. Deze richtijinen krijgen bijzondere aandacht omdat ze het meest verspreid zijn in Europa en ook in Vlaanderen. Er mag dus worden verwacht dat zij als kennisnorm de grootste kans hebben om herkend te worden door de bevolking.

Figuur 3.6

Richtlijnen inzake kankerpreventie voor mannen en vrouwen, volgens kennisdomein en kankerllokalisatie

\begin{tabular}{|c|c|c|c|c|}
\hline \multirow[t]{2}{*}{ Type kanker } & \multicolumn{2}{|c|}{ Primaire preventie } & \multicolumn{2}{|c|}{ Secundaire preventie } \\
\hline & $\begin{array}{l}\text { Rilsico- } \\
\text { factoren }\end{array}$ & $\begin{array}{c}\text { Gewenst } \\
\text { gedrag }\end{array}$ & $\begin{array}{c}\text { Waarschu- } \\
\text { wingssignalen }\end{array}$ & $\begin{array}{l}\text { Opsporings- } \\
\text { onderzoeken }\end{array}$ \\
\hline Borstkanker & (x) & & & 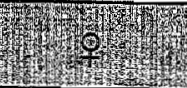 \\
\hline Cervixkanker & 9 & & & W \\
\hline $\begin{array}{l}\text { Darmkanker } \\
\text { (colon + rectum) }\end{array}$ & 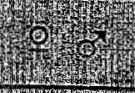 & ret & Pat & $90^{x}=$ \\
\hline Huidkanker & & (2) & 16) & fo $0^{x}$ \\
\hline Longkanker & 47 & 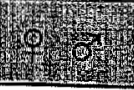 & My & \\
\hline Prostaatkanker & (x) & & 14ty & $\sigma^{7}$ \\
\hline Andere kankers & $x_{20}$ & & 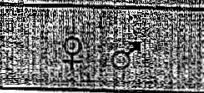 & \\
\hline
\end{tabular}

Iodichting:

Een lege cel betekent dat in de rapporten vermeld in figuur 3.5 geen richtlijnen werden richtlijnen die expliciet vermeld stand kennisdomein. In die grijsgevulde cellen staan de richtlijnen die vermeld zijn in de andere (in Europese Kankercode. De overige cellen bevatten

- Begripsanalyse en ontwikkeling van een meetinstrument - 
De richtlijnen vermeld in hoger genoemde rapporten worden respectievelijk per kennisdomein systematisch overlopen, en een keuze wordt gemaakt voor de richtlijnen die worden geselecteerd als kennisnormen voor het meten van kennis van kankerpreventie bij de bevolking.

Risicofactoren voor kanker. In de rapporten worden risicofactoren vermeld voor alle kankerlocalisaties die werden weergegeven in figuur 3.6. Obesitas wordt in alle rapporten vermeld als risicofactor woor borstkanker. Naast voedingsfactoren worden ook geslacht, leeftijd, geografische locatie, erfelijkheidsfactoren en menopauze na 50 jaar als risicofactoren voor borstkanker genoemd (5: 39). Dok een eerste zwangerschap na de leeftijd van 30 jaar geeft een verhoogd risico op borstkanker $(3: 50 ; 5: 39)$. Er worden ook uiteenlopende risicofactoren beschreven voor baarmoederhalskanker: jeugdig begonnen seksuele activiteit, wisselende seksuele partners zonder gebruik van een condoom, aanwezigheid van virale genitale infecties, en eerder aangetoonde cytologische en/of histologische afwijkingen van de cervix $(7: 26) .80$ tot $90 \%$ van de colorectale kankers zouden overwegend het resultaat zijn van omgevingsfactoren 14: 62). Van de amgevingsfactoren neemt woeding verreweg de belangrijkste plaats in. Vooral de correlatie tussen colorectale kanker en verbruik van dierlijke vetten in de voeding werd in diverse epidemiologische studies vastgesteld: in landen met een hoge vlees- en vetstoffenconsumptie komt colorectale kanker meer voor dan in landen met een lage consumptie van wlees- en vetstoffen $(4: 62)$. De relatie tussen zonlicht en huidkanker staat vast (7: 87). De relatie tussen zonlicht en melanoom - de meest levensbedreigende vorm van huidkanker - is veel minder duidelijk. Toch wordt in een aantal rapporten "overdadige blootstelling aan de zon" beschouwd als risicofactor voor huidkanker (3: 89, 4, 6: 259) en wordt in preventiecampagnes in Balgie meer en meer aandacht gevestigd op deze risicofactor ${ }^{\uparrow}$. Roken wordt in alle rapporten beschouwd als risicofactor voor longkanker. De schadelijke effecten van roken beperken zich evenwel niet tot deze vorm van kanker. Ook andere vormen van kanker Imondholte-, keelholte-, strottehoofd- of slokdlarmkanker), chronische aspecifieke respiratore aandoeningen (CARA) en hart- en vaatziekten worden geassocieerd met roken 13:95 en 7: 1411. Ook passief roken wordt in een aantal rapporten - zij het in beperktere mate dan roken aangeduid als risicofactor voor longkanker (3: 95, 4, 7:141). Voor prostaatkanker worden in een beperkt aantal rapporten risicofactoren beschreven, 0.m. genetische predispositie, voeding (vooral vetgehalte van de voeding), hormonale factoren en seksuele hygiëne $(3: 75,6: 255)$. Er is echter te weinig zekerheid om hierover zinnige preventieve adviezen te formuleren $16: 255)$, evenmin is het mogelijk om categorieên met een verhoogd risico aan te wijzen $(7: 181)$.

Verder worden in alle rapporten nog risicogedragingen baschreven die gerelateerd zijn aan diverse vormen wan kanker. Met name 'overmatig gebruik van alcohol' wordt in de meeste rapporten aangegeven als risicofactor voor kanker. Alcoholmisbruik kan leiden tot morbiditeit en voortijdige sterfte via een hele reeks van gezondheidsproblemen. waarvan de belangrijkste zijn: ongevallen, psycho-sociale klachten en een aantal min of

Zie ondermeer de campagnes van de Vereniging voor Kankerbestrijding tïjdens de zomer. 
meer specifieke afwijkingen, waaronder levercirrose, pancreatitis syndroom van Korsakow, foetaal alcohol syndroom en bepaalde vormen van kanker (vooral mond. keet en slokdarmkanker) (7: 20).

Uit al deze risicofactoren werden enkel die items geselecteerd die gedragsgebonden ziln en waarop bijgevolg (in theorie) een invloed kan worden uitgeoefend door preventiecampagnes. De volgende items werden geselecteerd als kennisnormen voor het onderzoek van de kennis van de risicofactoren voor kanker :

1. overmatig gebruik wan dierlijke vetten in de voeding

2. roken

3. passief roken (blootstelling aan tabaksrook uit de directe omgeving)

4. overdadige blootstelling aan de zon

5. overmatig gebruik van alcohol

6. obesitas of zwaarlijwigheid

7. eerste kind ha de leeftijd van 30 jaar; als risico voor vrouwen

8. seksuele ongang met meerdere partners zonder condoom; als risico voor vrouwen

Gewenst kankerpreventief gedrag. Kankerspecifieke richtlijnen voor gewenst gedrag worden in de consensusrapporten meestal samen met de risicofactoren behandeld. In beide gevallen betreft het immers factoren die gerelateerd zijn aan het ontstaan of het voorkomen van kanker. Risicofactoren hebben een negatieve correlatie en gewenst preventief gedrag een pasitieve correlatie met het voorkomen van kanker. Het gewenst preventief gedrag heeft m.a.w. een beschermend effect tegen kanker, terwijl risicofactoren kanker bevorderen.

In de rapporten worden enkel richtlijnen over gewenst gedrag vermeld voor de preventie van darm-, huid-en longkanker. Over het gewenst kankerpreventief gedrag voor borst-. baarmoederhals- of prostaatkanker wordt in deze rapporten niets vermeld. Voor longkanker is het gewenst kankerpreventief gedrag in alle rapporten zeer duidelijk: niet roken of stoppen met roken. Voor huidkanker geven niet alle rapporten een richtlijn voor het gewenst gedrag. Sommige rapporten geven onomwonden de raad aan de hele bevolking om overdadige blootstelling aan zonlicht te vermijden (4 en 3: 89). Andere rapporten beperken deze richtlijn evenwel voor risicogroepen, zoals mensen met een lichte huidskleur of mensen met huidkanker in de familie $15: 73,6: 259,7: 87$ ). Voor colorectale kanker geven de rapporten (zeer) uiteenlopende adviezen inzake gewenst preventief gedrag. De preventiegids uit Niederland is het meest expliciet gekant tegen Kalk advies hieromtrent $17: 176)$, terwijl de Vlaamse Adviescommissie voor Kankerpreventie in 1985 volgend advies verstrekte $(3: 67)$ : et bij voorkeur bruin brood
en eet meer granen, vruchten en groenten.

Deze richtlijnen werden in 1987 ook opgenomen in de Europese kankercode (4), alsook in het rapport van de Commissie Preventie van de Wetenschappelijke Vereniging der Vlaamse Huisartsen 16: 250). Als concretisering van thet advies voor meer vezeirijke woedingsproducten, vermeldt de Europese Kankercode ook het 'regelmatig eten van ongepelde rijst'. Verder werden in vrijwel alle rapporten aanbevelingen vermeld inzake 
het vermijden van 'risicogedragingen' die gerelateerd zijn aan diverse ziekten en vormen van kanker. Het betreft met name adviezen over alcoholgebruik en woeding. Hoger werd reeds aangegeven dat alcoholmisbruik ook is gerelateerd aan het ontstaan van een aantal vormen van kanker. In de meeste rapporten wordt 'matig gebruik van alcohol" aanbevolen als een gewenst (kanker)preventief gedrag (1: 1213, 4, 5: 277, 7:20). Inzake voeding wordt vooral het algemeen advies om overgewicht te vermijden beschouwd als een beschermende factor voor zeer veel ziekten, waaronder ook borst-, prostaat- en darmkamker 15: 305). Naast deze vormen van kanker hangt overgewicht ook samen met hypertensie, hypercholesterolemie, hart-en vaatziekten, diabetes type II, artrose, galstenen, psychische klachten, enz. (7:128).

Uit de consensusrapporten werden vrijwel alle richtlijnen over het gewenst kankerpreventief gedrag als kennisnormen voor het onderzoek van kennis van gewenst kankerpreventief gedrag geselecteerd :

1. regelmatig eten van vers fruit

2. regelmatig eten van verse groenten

3. overdadige blootstelling aan de zon vermijden

4. regelmatig eten van bruin brood

5. regelmatig eten van ongepelde rijst

6. met mate drinken wan alcoholische dranken

7. stoppen met roken of niet roken

B. vermijiden van overgewicht

Waarschuwingssignalen voor kanker. In de consensusrapporten worden waarschuwingssignalen beschreven voor alle kankers die zijn vermeld in figuur 3.6. De selectie van de waarschuwingssignallen als kennisnormen voor dit onderzoek werd in eerste instantie gebaseerd op het onderzoek van Berman en Wandersman (1991)'. Zij baseerden zich op de American Cancer Society voor het vaststellen van kennisnormen om kennis van waarschuwingssignalen voor kanker te kunnen meten bij de Amerikaanse bevolking. De American Cancer Society erkent 7 waarschuwingssignalen voor kanker (Berman en Wandersman ${ }_{*}$ 1991: 1245):

- a change in bladder or bowel habits (verandering in plas- of stoelgangpatroon)

- a sore that does not heal (een wonde die niet geneest)

- unusual bleeding or discharge (abnormaal bloedverlies)

- thickening or lump in the breast or elsewhere Iverdikking of knobbeltje in de borst of elders)

- indigestion or difficulty in swallowing (indigestie of doorslikprablemen)

- abvious change in wart or mole (duidelijke verandering tin wrat of moedervlek)

- nagging cough or hoarseness (aanhoudende hoest of heesheid)

Slechts éen waarschuwingssignaal, namelijk "indigestie of doorslikproblemen', komt helemaal niet voor in de Europese kankercode lCommissie van de Europese

Zie ook paragraaf 3.3 .

- Begripsanalyse en ontwikkeling van een meetinstrument - 
Gemeenschappen, 1987). Omgekeerd komt ook één waarschuwingssignaal uit de Europese code, namelijk 'een onverklaarbare gewichtswermindering', helemaal niet voor in de Amerikaanse code. Alle overige waarschuwingssignalen komen op identieke of "gelijkaardige" wijze voor in beide kankercodes. Soms is de formulering in één code genuanceerder, preciezer of lets concreter dan in de andere code. Zo is er in de Amerikaanse kankercode sprake van 'verandering in wrat én moedervlek', terwijl men in Europa alleen 'verandering in moedervlek' vermeldt. Anderzijds antbreekt in de Amerikaanse kankercode het bijvoeglijk naamwoord 'aanhoudende' in het waarschuwingssignaal 'verandering in plas- of stoelgangpatroon'. Hoewell de term 'patroon' reeds verwijst naar een systematische en aangehouden verandering, is de precisering 'aanhoudend" vanuit validiteitsoverwegingen toch aan te raden. Bij afwezigheid van dit adjectief zullen immers bepaalde mensen wel het onderscheid maken tussen een 'aanhoudende verandering' en een 'sporadische verandering"; anderen zullen dit evenwel niet doen.

Om de validiteit te optimaliseren van het instrument waarmee kennis van kankerpreventie wordt gemeten, werd steeds de keuze gemaakt voor de meest concrete formulering. Het waarschuwingssignaal 'abnormaal bloedverlies' - op deze wijze vermeld in beide codes - werd daarom ook gepreciseerd door de toevoeging van de bijwoorden "anaal of vaginaal". In de onderzochte consensusrapporten worden immers alleen deze localiseties van het bloedverlies vermeld als mogelijke waarschuwingssignalen voor kanker.

Op basis van de analyse van de Amerikaanse en de Europese kankercodes werden als kennisnormen voor het onderzoek van de kennis van de waarschuwingssignalen voor kanker de volgende items als volgt geformuleerd:

1. aanhoudende wijziging in plas" of stoelgangpatroon

2. een wonde die niet geneest

3. abnormaat anaal of vaginaal blaedverlies (bloedverlies vira de aars of de schede)

4. verdikking of knobbeltje in de borst

5. onverklaarbare gewichtsvermindering

6. duidelijke verandering in wrat of moedervlek

7. alanhoudende hoest of heesheid

Vroegtijdige kankeropsporingsonderzoeken. De vroegtijdige opsporingsonderzoeken voor kanker die vermeld zijn in de consensusrapporten worden gepresenteard in figuur 3.7. Uit dit overzicht blijkt dat er wereldwijd zeker nog geen algemene consensus bestaat over het aanbevelen van ALLE onderzoeken. Enkel voor baarmoederhalsuitstrijkje en mammografie bestaat er een consensus. Het baarmoederhalsuitstrijkje en de mammografie worden in alle onderzochte rapporten aanbevolen. De radiografie van de longen wordt in geen enkel rapport aanbevolen. De radiografie van de longen werd in het verleden weliswaar gebruikt voor opsporing van longkanker, doch men is daar van teruggekomen, omdat er nog steeds geen behandelingstechniek bestaat die toereikend is bij longkanker (Commissie Preventie, 1990). In het begin van de jaren tachtig wijzigde de American Cancer Society reeds har strategie inzake vroegtijdige opsporing van
longkanker (1980: 205): 


\begin{abstract}
"The Society has changed its policy and does not recommend any tests for the early detection of cancer of the lung, but urges a focus on primary prevention: helping smokers to stop ... and keeping nonsmokers from starting."
\end{abstract}

Het borstzelfonderzoek en het klinisch borstonderzoek worden aanbevolen in 5 van de 7 rapporten. De vroegtijdige opsporingsonderzoeken voor huid-en darmkanker worden in 3 of 4 rapporten aanbevolen en het rectaal onderzoek voor de vroegtijdige opsporing van prostaatkanker wordt slechts in 2 rapporten aanbevolen. Sigmoidoscopie wordt slechts in één rapport aanbevolen voor een algemene bevolking (2: 212 ).

Voor de selectie van de vroegtijdige opsporingsonderzoeken als kennisnormen voor het kennisonderzoek werden de volgende criteria gehanteerd:

1. het vroegtijdige opsporingsonderzoek dient minimal te worden aanbevolen in een consensusrapport uit Vlaanderen;

2. het vroegtijdige opsporingsonderzoek moet minimaal in 3 van de 7 besproken consensusrapparten vermeld staan (zie figuur 3.7 ).

Slechts twee opsporingsonderzoeken dile worden vermeld in figuur 3.7 werden hierdoor niet geselecteerd voor dit kennisonderzoek. Ten eerste gaat het om het rectaal toucher t.b.v. de vroegtijdige opsporing van prostaatkanker. Dit opsporingsonderzoek is nog steeds zeer omstreden. De epidemiologische studies tonen (nog) geen voordelig effect aan op overlevingsduur en sterfte (Schaapveld en Hirasing, 1993: 181). Er zijn ook geen categorieën met een verhoogd risico aan te wijzen. Routine preventief onderzoek naar prostaatkanker wordt dan ook afgeraden in het meest recente consensusrapport dat werd bestudeerd (Schaapveld en Hirasing, 1993). Ten tweede gaat het om de sigmoïdoscopie als vroegtijdige opsporingstechniek voor darmkanker. Dit is een inwendig onderzoek van de dikkedarm door middel van een sigmoidoscoop. Het wordt alleen vermeld in het rapport uit 1980 van de American Cancer Society en werd in Vlaanderen nog nooit opgenomen in (grootschalige) preventiecampagnes.

De volgende 7 iterns die werden vermeld in de consensusrapporten, worden als kennisnormen geselecteerd voor het onderzoek van kennis van bestaande vroegtijdige opsporingsonderzoeken voor kanker :

1. het baarmoederhalsuitstrijkje

2. het borstzelfonderzoek

3. het klinisch borstonderzoek door de arts

4. de marnmografie

5. de huidinspectie door de arts bij een veranderende moedervlek

6. de occult bloedtest

7. het rectaal toucher voor het opsporen van darmkanker 


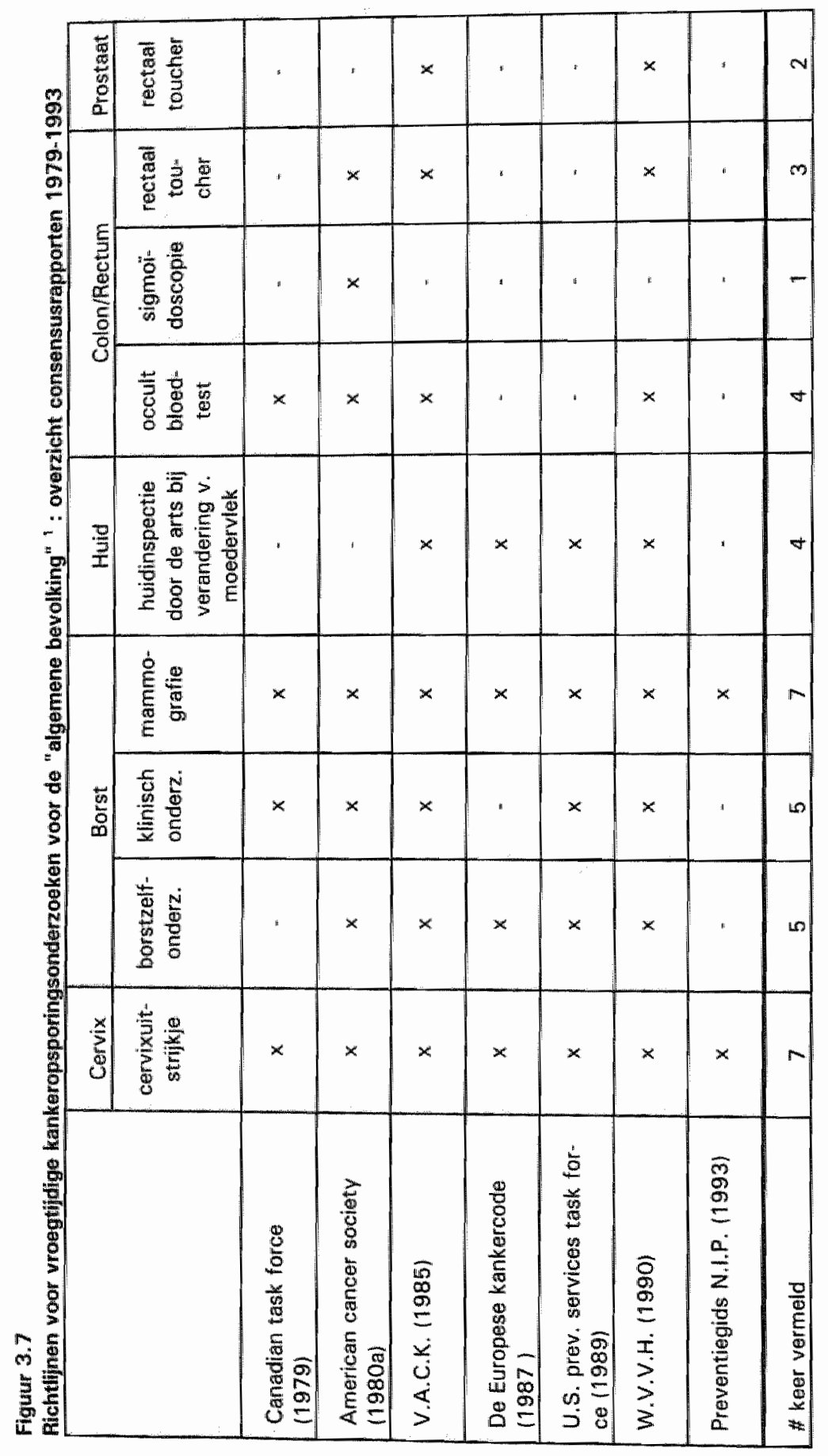

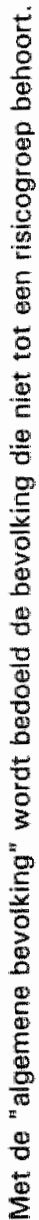




\subsection{Bestaande methodes om kennis van kankeroreventie te meten: een kritische bespreking.}

In hoofdstuk 1 werd gesteld dat de gedragswetenschappelijke publicaties op het gebied van kennis van kankerpreventie bij de bevolking fragmentarische en soms tegenstrijdige resultaten laten zien'. Deze fragmentarische en tegenstrijdige informatie kan worden verklaard door een aantal methodologische vertekeningen, waardoor er een weinig valide conceptualisering en betrouwbare meting van het complexe onderzoeksconcept 'kennis van kankerpreventien tot stand komt ${ }^{2}$.

Een eerste methodologische vertekening wordt veroorzaakt door het gebruik van één of (het naast elkaar gebruiken van) meerdere eenvoudige of enkelvoudige variabelen voor het meten van het complexe onderzoeksconcept 'kennis van kankerpreventie'. Soms wordt er een 'open vraag' gesteld naar de oorzaken van kanker (zie bijvoorbeeld Luther e.a., 1982). In andere studies wordt er bijvoorbeeld gevraagd "wat er zou kunnen gedaan worden om kanker te voorkomen' (zie bijvoorbeeld van Assema e.a., 1990). Verder werden in deze laatste studie ook vragen gesteld naar de "uitkomstverwachting" van risicogedragingen ("vindt $u$ dat ... je kans op kanker vergroot ?"l, zoals roken, alcoholconsumptie, gebruik van de zonnebank en vetconsumptie; alsook een drietai vragen over de "ernst" van kanker.

Waarom kan men zich bij het meten van kennis van kankerpreventie niet beperken tot één enkele vraag ? Het antwoord op deze vraag houdt zowel verband met de validiteit, als met de betrouwbaarheid van de meting (Billiet, 1993: 236). Eerst wordt de problematiek van validiteit of geldigheid behandeld. Door enkelvoudige variabelen als meetinstrument te nemen in onderzoek, worden enkel fragmentaire deelaspecten van kennis van kankerpreventie gemeten. Eén enkele vraag kan onmogelijk alle deelaspecten van kennis van kankerpreventie dekken. Respondenten met eenzelfde kennis zullen immers verschillende antwoorden geven, omdat ze bij die ene vraag toch nog aan verschillende aspecten denken of ze niet op dezelfde wijze begrijpen. Neem bijvoorbeeld de vraag 'wat er zou kunnen gedaan worden om kanker te voorkomen' uit het onderzoek van van Assema e.a. (1990). Het is best mogelijk dat respondenten antwoorden vanuit het oogpunt van het overheidsbeleid en dat andere respondenten een antwoord formuleren vanuit hun persoanlijk individuele oogpunt. Naast de verschillende connotaties van respondenten bij zo'n algemene vraag is er nog een bijkomend nadeel, namelijk het feit dat men op zo'n vragen meestal zeer algemene antwoorden krijgt. Zo kreeg bijvoorbeeld Luther e.a. (1982) op de vraag 'wellke de oorzaken zijn van kanker',

Zie bijwoorbeeld American Cancer Society (1980b), Berman en Wandersman (1990 en 1990 ). Berwick, Fine Bn Bolognia (1992), Bettinghaus (1986), Bostick e.a. (1993), Brown a.a. (1990). Clover e.a. (1991), Fajardo e.a. (1992), Howe (1981), Loehrer e.a. (1991), Luther e.a. (1982), Paul e.a. (1992), Polednak (1990), van Assema e.a. (1990), Van Hal e.a. (1991).

Zie ondermeer Billiet (1993: 47-81), Segers (1989: 122-149) en Swamborn (1981: 189-229) voor een overzicht van de problematiek van operationaliseren van "complexe eigenschappen". 
de volgende mogelijke antwoorden: 'eten en drinken' verontreiniging, chemicaliën, zonlicht, enz. Men kan natuurlijk tijdens het interview gaan verder vragen wat daar nu meer precies mee wordt bedoeld. Op $20^{\prime \prime} \mathrm{n}$ 'open vraag' krijgt men in een interviewcontext echter minder gemakkelijk een adequaat antwoord omdat de houding en het gedrag van de interviewer een invloed uitoefenen; en bij schriftelijke bevragingen biliven deze vragen vaak geheel onbeantwoord (Billiet, 1993: 236). De enige oplossing om dit validiteitsprobleem van dergelijke enkelwoudige vragen op te lossen, is het ontwerpen van meer-item-vragen of schalen.

De vraag "Waarom kan men zich bij het meten van kennis van kankerpreventie niet beperken tot één enkele vraag ?" kan ook vanuit de problematiek van betrouwbaarheid van de meting worden beantwoord (Billiet, 1993: 237). Bil elke meting van gedrag en zeker van houdingen of kennis via een interwiew treden er toevalsfouten op. Bij de antwoorden op éen enkele vraag kunnen er gemakkelijk $5 \%$ verkeerde classificaties zijn omwille van toevallige factoren (verstrooidheid, een verkeerd cijfer amcirkeld door de interviewer, fouten geïnduceerd door de codeerders, een foutieve code ingevoerd in de computer, enz.). Door meerdere items die hetzelfde meten in een schaal op te nemen, verhoogt bijgevolg de betrouwbaarheid van het meetresultaat, omdat de toevallige fouten zichzelf opheffen of in ornvang verminderen doordat bij analyse wordt gewerkt met gemiddelden of somscores. Bovendien kan de betrouwbaarheid van de meting worden vastgesteld bijvoorbeeld door de betrouwbaarheidstoets Cronbach's Alpha te berekenen) ${ }^{\mathrm{i}}$.

Een bijkomend voordeel van het ontwerpen van schalen is dat de onderzoeker vooraf grondig dient na te denken over het samenvoegen van schaalscores om tot ến waarde te komen voor de globale kennis. Bij het los naast elkaar gebruiken van enkelvoudige kennisvragen dient de onderzoeker immers pas bij de interpretatie van de resultaten tot een symthese van de gemeten kennis te komen. Deze laatste procedure biedt minder garanties voor betrouwbare conclusies over de globale kennis, dan wanneer deze synthese-contructie vooraf goed is geconceptualiseerd. Hiermee stelt zich de problematiek van de tweede methodologische vertekening.

De tweede methodologische vertekening betreft met name een gebrekkige conceptualisering van het complexe begrip 'kennis van kankerpreventie'. Deze gebrekkige conceptualisering ontstaat als een complexe theoretische eigenschap met meerdere dimensies, slechts door één van deze dimensies wordt geïndiceerd en er nadien conclusies worden getrokken voor heel het theoretisch concept. Zo gebruiken Berman en Wandersman (1990) wel een complexe variabele leen meetschal met 25

Cronbach's Alpha is een veel gebruikte maat van inter-itembetrouwbaarheid of interne bostat ut van een schaal (van der Pligt en de Vries, 1995: 166). Wanneer een meting bestaat uit meerdere items of vragen, moeter al deze iterns verwijzen naar eenzelfde houding. betekent dit dat de items en dus bijgevolg angeveer hetzelfde meten. Statistisch uitgedrukt het algemeen geldt dat metingen betrouweten correleren. Er kan ook gesteld worden dat over 
items) om kennis van kanker te meten, doch zij meten onder de noemer 'keninis van kanker" in feite slechts één dimensie, namelijk de kennis van de "waarschuwingssignalen" voor kanker.

In onderhavig onderzoek zal worden getracht aan beide methodologische problemen tegemoet te komen door een 'globale synthesemaat' voor kennis van kankerpreventie te ontwikkelen. Een dergelijke synthesemaat dient dus rekening te houden met de verscheidenheid van aspecten die het concept kennis van kankerpreventie bevat. Dit laatste is een noodzakelijke voorwaarde, waaraan werd beantwoord door de begripsanalyse in dit hoofdstuk.

Tot slot is er een derde methodologische vertekening, namelijk de onder of overrapportering van kennis van kankerpreventie in interviews. Kennis van kankerpreventie wordt in veel onderzoeken gemeten door een opsomming van klachten, symptomen, risicofactoren, preventiemogelijkhedien, enz. door de ondervraagde respondenten. Daarbij blijkt dat onderzochte personen op spontane wijze slechts een beperkt aantal risicofactoren of waarschuwingssignalen kunnen opsommen (American Cancer Society, 1980b; Berman en Wandersman, 1991; Clover, et.al., 1991; Van Assema e.a., 1990; Van Hal, et.al., 1991). Een bellangrijke vertekening bij dit soort onderzoek is een onderrapportering van de kennis. Mensen geven geen uitsluitsel over wat ze werkelijk in overweging nemen als ze geconfronteerd worden met klachten of symptomen. De kennis kan in de praktijk wel aanwezig zijn, doch het wordt niet gemeten op het moment van de bevraging. Als reactie op deze onderrapportering zijn sommige onderzoekers hypothetische vragen gaan ontwikkelen in de stijl van "wat zou $u$ doen indien ...". Zij maken daarbij gebruik van checklists of multiple-choice vragen. Bij gebruik van checklists worden er items gepresenteerd, waarvan de respondenten moeten aangeven of ze al dan niet kunnen worden beschouwd als bijvoorbeeld een waarschuwingssignaal voor kanker. Zo legden Bloom e.a. (1987) in de Verenigde Staten een lijst voor van symptomen of waarschuwingssignalen van kanker en vroegen de respondenten of ze "meteen naar de dokter zouden gaan" of "een tijdje het doktersbezoek zouden uitstellen". Doordat de respondent bil deze techniek altijd een reele (in dit voorbeeld $50 \%$ ) kans heeft om juist te antwoorden, treedt er bij deze kennismeting een omgekeerde vertekening op: de kennis wordt te hoog ingeschat. Deze vertekening van overrapportering wordt ook veroorzaakt door sociale wenselijkheid: mensen beweren het te weten, amdlat ze hun onwetendheid niet willen laten merken of omdat ze denken dat het toch zo hoort om naar de dokter te gaan. Het meten van kennis via deze methodes levert bijgevolg validiteitsproblemen op.

Om deze derde methodologische vertekening op te vangen, werd op zoek gegaan naar een bevragingsmethode met een grotere discriminerende impact tussen overrapportering en onderrapportering van kennis van kankerpreventie. Voor het meten van "kennis van waarschuwingssignalen" boden in de literatuur de Amerikaanse onderzoekers Berman en Wandersman (1991) een interessante methode. Ziij ontwikkelden een "Knowledge of Cancer Warning Signs Inventor" met 25 items of vragen. In deze 25 vragen bieden ze de respondenten zowel juiste $(\# 7)$, als foutieve (\# 18) waarschuwingssignalen voor kanker aan en laten elk item - dus zowel de juiste, als de foutieve items - beoordelen 
met steeds eenzelfde beoordelingsschaal (Berman en Wandersman, 1991):

1. Not ancer Warning Sign (score -2)

2. Possible a Cancer Warning Sign (score -1)

3. Probably a Cancer Warning Sign (score +1 )

4. Surely a Cancer Warning Sign (score +2 )

De beoordelingsschaal is een symmetrische vierpuntenschaal. Op basis van de antwoorden op de 25 vragen worden door de onderzoekers drie 'zekerheidsscores' berekend:

- De basisherkenning van de 7 waarschuwingssignalen van kanker, door de sommatie van alle zekerheidsscores op de 7 "juiste' waarschuwingssignalen;

- De mate waarin de foutieve waarschuwingssignalen worden beschouwd als waarschuwingssignaal van kanker ("vals-positieven"), door de sommatie van de zekerheidsscores op de 18 "foutieve" waarschuwingssignalen. Deze score is een parameter woor verkeerde informatie van de betrokkene over waarschuwingssignalen;

- De mate waarin een respondent accuraat een onderscheid weet te maken tussen de "juiste" en de "foutieve" waarschuwingssignallen laccurate kennis van kanker), door het verschil van de herkenning van de 7 waarschuwingssignalen mot de vals-positieven.

Een persoon met een adequate kennis van de waarschuwingssignalen van kanker heeft een hoge score op de basisherkenning lof heeft m.a.w. met grote zekerheid de 7 waarschuwingssignallen herkend) en een lage score op de vals-positieven lof heeft m.a.w. de 18 foutieve items aangeduid als geen waarschuwingssignaal).

Deze "Knowledge of Cancer Warning Signs Inventory" biedt een antwoord op de problematiek van onderrapportering en overrapportering van kennis van kankerpreventie door respectievelijk het vrijelijk rapporteren en het aankruisen van dichotome checklists. Door middel van dergelijke vraagstelling verwacht men van de respondenten niet alleen herkenning van de waarschuwingssignalen, maar ook accuraatheid en kunde om met een bepaalde zekerheid onderscheid te kunnen maken tussen juiste en foutieve waarschuwingssignalen.

Het meetinstrument om de "kennis van de waarschuwingssignalen" te meten is in hoofdzaak gebaseerd op de techniek uit dit onderzoek van Berman en Wandersman 19991). De items werden vertaald en grotendeels overgenomen in de vragenlijst ${ }^{1}$.

De vertaling gebeurde onder supervisie van de taalkundige dhr. F. Winter van het Institutut voor Taalonderwijs van de V.U. Brussel. De betrokkane is een Engelse "native speaker", maar spreekt aveneens perfect Nedorlends. Hij werkt en woont reeds tientallen jaren in een Nederlandstalige omgeving. 
Eên waarschuwingssignaal, namelijk "indigestion or difficulty swallowing" "werd vervangen door "een onverklaarbare gewichtsvermindering" "omdat dit laatste waarschuwingssignaal veel prominenter naar voor wordt geschoven in de Belgische en Europese richtlijnen voor kankerpreventie dan het betreffende waarschuwingssignaal uit de Amerikaanse kankercode.

Verder werd ook een belangrijke wijziging aan de gebruikte beoordelingsschaal aangebracht. De respondenten kunnen in onderhavig onderzoek bij de identificatie van de items een zekerheidsscore gevem op een symmetrische vilfpuntenschaal:

1. geen waarschuwingssignaal voor kanker

2. waarschijnlijk geen waarschuwingssignaal voor kanker

3. misschien niet, misschien wel een waarschuwingssignaal voor kanker

4. waarschijnlijk wel een waarschuwingssignaal voor kanker

5. zeker een waarschuwingssignaal woor kanker

Er wordt dus geopteerd voor de klassieke Likertschalal en niet voor de vierpuntenschaal zoals bij Berman en Wandersman (1991). De middenwaarde is toegevoegd om te vermijden dat respondenten op een artificiële wijze gedwongen worden am een keuze te maken'.

Op deze wijze wordt een vergelijking vain de scores in dit onderzoek met deze van Berman en Wandersman (1991) quasi onmogelijk, doch deze ingreep kamt de validiteit van de scoring ten goede. De in dit onderzoek gebruikte methodes om respectievelijk 'kennis van risicofactoren', 'kennis van gewenst (kankerpreventief) gedrag' en 'kennis van de vroegtijdige opsporingsonderzoeken van kanker' te meten, werden ontwikkeld naar analogie van deze methode voor het meten van kennis varn de waarschuwingssignalen van kanker. De selectie van de items en de verdere operationalisering van deze kennisschalen komen in de volgende paragraaf aan bod.

\subsection{Operationalisering van het onderzoeksconcept "kennis van kankerpreventife" 2}

Op basis van de bevindingen uit de voorgaande paragrafen ligt het voor de hand dat het onderzoeksconcept 'kennis van kankerpreventie' dient te worden gemeten met 8 Eéndimensionele meetschalen (zie figuur 3.8).

Elke schaal is een weloverwogen verzameling van items die geacht worden eenzelfde kennisdomein te meten (vergelijk Billiet, 1993:236). We hebben m.a.w. te maken met een bijzondere toepassing van een stell empirische variabelen die in combinatie een

Zie hierover verder hoofdstuk 4 (paragraaf 4.2 ).

Zie bijlage 2 a voor de schaalconstructies. 
waarde per empirische indlicator dienen op te leveren. De combinatie van de waarden wan de empirische indicatoren zal één waarde voor de kennis van primaire kankerpreventie en één waarde voor de kennis van secundaire kankerpreventie opleveren. In deze paragraaf wordt nader ingegaan op de constructie van deze schaien en op de scoreberekeningen die ervan zullen worden afgeleid.

Figuur 3.8

Indentificatie van de schalen om het concept "kennis van kankerpreventie" te meten

\begin{tabular}{|c|c|c|}
\hline Dimensies : & Indicatoren: & Schalen: \\
\hline \multirow{4}{*}{$\begin{array}{l}1 \text { Kennis van } \\
\text { primaire } \\
\text { kankerpreventie }\end{array}$} & \multirow[t]{2}{*}{$\begin{array}{l}1 \text { kennils van risico- } \\
\text { factoren van kaniker }\end{array}$} & $\begin{array}{l}1 \text { herkenning van de risicofactoren } \\
\text { van kanker }\end{array}$ \\
\hline & & 2 foutperceptie risicofactaren \\
\hline & \multirow{2}{*}{$\begin{array}{l}2 \text { kennis wan het } \\
\text { gewenst kanker- } \\
\text { preventief gedrag }\end{array}$} & $\begin{array}{l}3 \text { herkenning van de gewenste } \\
\text { kankerpreventieve gedragingen }\end{array}$ \\
\hline & & 4 foutperceptie gewenst gedrag \\
\hline \multirow{4}{*}{$\begin{array}{l}2 \text { Kennis van } \\
\text { secundlaire } \\
\text { kankerpreventie }\end{array}$} & \multirow{2}{*}{$\begin{array}{l}\text { kennis van de } \\
\text { waarschuwings- } \\
\text { signalen: voor kanker }\end{array}$} & $\begin{array}{l}5 \text { herkenning van de waarschuwings: } \\
\text { signalen }\end{array}$ \\
\hline & & $\begin{array}{l}6 \text { foutperceptie wan de waarschuwings- } \\
\text { signalen }\end{array}$ \\
\hline & \multirow{2}{*}{$\begin{array}{l}4 \text { kennis van wroeg- } \\
\text { tijdige opsporings- } \\
\text { onderzoeken }\end{array}$} & $\begin{array}{l}7 \text { herkenning van de vroegtijdige } \\
\text { opsporingsonderzoeken }\end{array}$ \\
\hline & & $\begin{array}{l}8 \text { foutperceptie van de vroegtijdige } \\
\text { opsporingsonderzoeken }\end{array}$ \\
\hline
\end{tabular}

De methode van schaalconstructie voor het meten van 'kennis van de risicofactoren', "kennis van gewenst kankerpreventief gedrag', 'kennis van vroegtijdige opsporingsonderzoeken voor kanker" en "kennis van waarschuwingssignalen", is - zoals werd aangegeven in de vorige paragraaf - gebaseerd op de Likert methode van gesommeerde beoordeling (zie Billiet, 1993: 238-246; Gadourek, 1976: 285-289; van der Pligt en de Vries, 1995: 178-183). Voor de Likert methode is het nodig om een uitgebreide lijst van vragen of items samen te stellen die allemaal hetzij de (medisch) gewenste of 'juiste' kennis, hetzij de ongewenste of 'foute' kennis ten aanzien van een kennisobject /c.q. kankerpreventie) meten. Deze lijst kan worden samengesteld, eventueel met behulp van voorgespirekken, literatuur, eerder onderzoek, enz. (vergelijk met van der Pligt en de Vries, 1995: 178-179). 
De literatuurstudie, de talrijke gesprekken met de deskundigen en een vooronderzoek bij 208 eerstejaars studenten van de V.U.B. (Deliens, Louckx en Maes, 1994) resulteerden in acht meer-item-vragenlijsten, die samen een 100 -items vragenlijst vormen". Deze "Kennis van kankerpreventie 100-items vragenlijst" bestudeert op systematische wijze twee dimensies en vier indicatoren van kennis van kankerpreventie (zie figuur 3.9).

Figuur 3.9

Schematisch overzicht van de "Kennis van kankerpreventie 100-items wragenlijst"

\begin{tabular}{|l|l|c|c|}
\hline \multirow{2}{*}{$\begin{array}{l}\text { Dimensies : } \\
\text { kennis van primaire } \\
\text { kankerpreventie }\end{array}$} & kennis van risicofactoren wan kanker & 25 & 8 juiste \\
\cline { 2 - 5 } & kennis van gewenst kankerpreventief gedrag & 25 & 8 juiste \\
\cline { 2 - 5 } & & 25 & 7 foute \\
\hline \multirow{3}{*}{$\begin{array}{l}\text { kennis van secundaire } \\
\text { kankerpreventie }\end{array}$} & \begin{tabular}{l} 
kanker \\
\cline { 2 - 5 }
\end{tabular} & $\begin{array}{l}\text { kennis van vroegtijdige } \\
\text { opsporingsonderzoeken voor kanker }\end{array}$ \\
\hline
\end{tabular}

De kennisnormen (= juiste items) die in dit onderzoek getoetst worden, zijn gebaseerd op de aanbevelingen van de volgende gezaghebbende instanties (zie ook de bespreking hoger in paragraaf 3.2 ):

- American Cancer Society (1980)

- Canadian Task Force (1979)

- Commissie van de Europese Gerneenschappen (1989)

- Commissie Preventie van de Wetenschappelijke Vereniging der Vlaamise Huisartsen (Commissie Preventie, 1990)

- Nederlands Instituut voor Praeventieve Gezondheidszorg (Schaapveld en Hirasing. 1993)

- U.S. Preventive Services Task Force (1989)

- Vlaamse Adviescommissie woor Kankerpreventie (1985)

De foutperceptie wordt in dit onderzoek getoetst door het voorleggen van foutieve items. De foutieve items van de schaal wan kennis van de waarschuwingssignalen werden (vertaald) overgenomen uit de schaal van Berman en Wandersman (1991). De

Een gedetailleerd verslag van de ontwikkeling en het vittesten van de vragen en de wragenlijst komt aan bod in hoofdstuk 4. Hier komt enkel de opbouw van de schalen an de schaalconstructie aan bod. 
foutieve items voor de owerige schalen werden samengesteld op basis van adviesgesprekken met tal van deskundigen (zie ook hoofdstuk 41 . Het waren allen items die niet werden wermeld in de consensusrapporten waaruit de "juiste items" geselecteerd werden (zie hoger). Bovendien dienden ze dicht aan te leunen bil het te onderzoeken kennisdomein. Het zijn dus items die in dezelfde sfeer (bv. voeding of seksueel gedrag) liggen als de juiste items, zodat ze geloofwaardig overkomen in het interview..

Het opnemen van een item betekende evenwel niet dat het betreffend item niet gezondheidsbevorderend of gezondheidsbedreigend mocht zijn, het betekent enkel dat het volgens de medische richtlijnen niet wenselijk is dat het in verband wordt gebracht met kankerpreventie en dat het als voorlichtingsboodschap wordt opgenomen in een kankerpreventiecampagne. Elk item wordt dus verondersteld een indicator te zijn van de foutperceptie binnen het betreffende kennisdomein. Alle foutieve items van het betreffende kennisdomeïn samen worden ook geacht om eenzelfde dimensie, namelijk de foutperceptie, te meten".

Omdlat voor de selectie van deze foutieve items in vergelijking met de selectie van de juiste items geen sluitend criterium kon worden ontwikkeld, werd ervoor gezorgo dat de lijst van foutieve items veel langer was (17) a 18) dan deze van de juiste items (7 à 8). De reden hiervoor is van puur methodologische aard: hoe langer de lijst, hoe groter de kans op betrouwbaarheid (interne consistentie) van de schaal en hoe kleiner het relatieve gewicht van elk individueel item in de schaalscore.

De inventaris van risicofactoren bestaat uit 25 items met 8 "juiste" en 17 "foutieve" risicofactoren. Van de 8 'juiste' risicofactoren voor kanker komen er 6 voor in de Europese kankercode (Commissie van de Europese Gemeenschappen, 1989). Twee bijkomende risicofactoren worden erkend als risicofactor door de Vlaamse huisartsem (Commissie Preventie, 1990) en de Vlaamse Adviescommissie voor Kankerpreventie 1985). Het betreft "promiscuitteit" als risicofactor voor baarmoederhalskanker; en "een eerste kind na de leeftijd van 30 jaar" als risicofactor voor borstkanker.

\section{Risicofactoren voor kanker :}

1. overmatig gebruik van dierlijke vetten in de voeding

2. roken

3. passief roken (blootstelling aan tabaksrook vit de directe omgeving)

4. overdadige blootstelling aan de zon

5. overmatig gebruik van alcohol

6. zwariiijvigheid

7. eerste kind na de leeftijd vam 30 jaar; als risico voor vrouwen

8. seksuele omgang met meerdere partners zander condoom; als risico voor vrouwen

3 Een exploratieve factoranalyse op de verzamelde gegevens heeft deze ééndimensionaliteit pok kunnen aantonen, zodat bij de constructie van de kennisschalen in hoofdstuk 5 al deze foutieve items kanden worden opgenomen. 


\section{Foutieve items:}

1. overmatig sporten

2. overmatig gebruik van vitaminen

3. overmatig gebruik van pasta"s (bv. spaghetti) in de voeding

4. niet verzorgen van een keelontsteking

5. overmatig gebruik van schoonlheidsproducten

6. veelvuldig zwemmen in bezoedeld water

7. niet verzorgen van een huidontstelking

8. overmatig gebruik van laxeermiddelen ter bevordering van de ontlasting

9. niet verzorgen van een aanhoudende diarree

10. langdurig werken voor een computerscherm

11. epilleren van de borstharen bij vrouwen

12. langdurige borstvoeding

13. sterilisatie bij mannen

14. seksuele omgang met meerdere partners zonder condoom; als risico voor mannen

15. gebruik van het "spiraaltje" als voorbehoedsmiddel bij vrouwen

16. overmatig gebruik van antibiotica

17. onregelmatige nachtrust.

De inventaris van de gewenste (kankerpreventieve) gedragingen bestaat uit 25 items met 8 "juiste' en 17 'foutieve' gewenste gedragingen. De 8 'juiste' gewenste gedragingen komen allemaal woor in de Europese kankercode (Commissie van de Europese Gemeenschappen, 1989).

\section{Gewenst (kankerpreventief) gedrag:}

1. regelmatig eten van vers fruit

2. regelmatig eten van verse groenten

3. overdadige blootstelling aan de zon vermijden

4. regelmatig eten van bruin brood

5. regelmatig eten van ongepelde rijst

6. met mate drinken van alcoholische dranken

7. stoppen met roken of niet roken

8. vermijden van overgewicht:

\section{Foutieve items:}

1. matig gebruik van medicijnen

2. regelmatige lichaamsbeweging

3. regelmatig gebruik van vitamine $C$

4. regelmatig eten van pasta's (bv spaghetti)

5. regelmatig goed ontspannen

6. regelmatig drinken van verse melk

7. voldoende nachtrust

8. regelmatig eten van yoghurt

9. regelmatig eten van vis

10. regelmatig wandelen

11. regelmatig sporten

12. regelmatig gebruilk van ijzerpillen 
13. dagelijks drinken van één liter water

14. vermijden van stress

15. met mate eten van zout

16. met mate drinken van koffie

17. goede huidverzorging

De inventaris van waarschuwingssignalen bestaat uit 25 items met 7 "juiste" en 18 "foutieve" waarschuwingssignalen. Van de zeven "juiste" waarschuwingssignalen komen er zes uit de Europese kankercode (Commissie van de Europese Gemeenschappen, 1989). De zes werden aangevuld met éen bijkomend waarschuwingssignaal, "een wonde die niet geneest", dat uitdrukkelijk wordt onderkend door de Wetenschappelijke Vereniging van Vlaamse huisartsen (Commissie Preventie, 1990) en ook vermeld wordt in de Amerikaanse kankercode.

\section{Waarschuwingssignalen voor kanker :}

1. aanhoudende wijziging in plas- of stoelgangpatroon

2. een wonde die niet geneest.

3. abnormaal anaal of vaginaal bloedverlies (bloedverlies via de aars of de schede)

4. verdikking of knobbeltje in de borst

5. onverklaarbare gewichtsvermindering

6. duidelijke verandering in wrat of moedervlek

7. aanhoudende hoest of heesheid

\section{Foutieve items:}

1. hoofdpijn

2. gevoel van "wegdraaien" of duizeligheid

3. pijn in de hart- of borststreek

4. lage rugpijnen

5. braakneigingen of maagstoornissen

6. spierpijnen

7. kortademigheid

8. warme of koude opwallingen (zgn. vapeurs)

9. gevolloosheid of tintelingen in bepaalde lichaamsdelen

10. zwaktegevoel in bepaałde lichaamsdelen

11. zwartegevoel in armen of benen

12. verlies van seksuele interesse

13. gevoel van verminderde energie

14. hartkloppingen of ritmestoornissen

15. gevoel van rusteloosheid

16. gebrekkige eetlust

17. rusteloze of gestoorde slaap

18. brok in de keel

De inventaris van vroegtijdige opsporingsonderzoeken van kanker bestaat uit 25 items met 7 'juiste' en 18 'foutieve' vroegtijdige opsporingsonderzoeken. Vier van de juiste opsporingsonderzoeken staan vermeld in de Europese kankercode. Het betreft "baarmoederhalsuitstrijkje", "borst-zelf-onderzoek", "mammografie" en "huidinspectie 
door de dokter bij veranderende moedervlek". De drie overige werden geselecteerd omdat ze uitdrukkelijk worden onderkend door de Wetenschappelijke Vereniging van Vlaamse huisartsen (Commissie Preventie, 1990) en ook omdat ze werden geadviseerd door de Vlaamse Adviescommissie voor Kankerpreventie (1985). Het betreft "borstonderzoek door de arts", "opsporen van bloed in de stoelgang" en "rectaal onderzoek". De laatste twee onderzoeken zijn vroegtijdige opsporingsonderzoeken voor dikdarmkanker.

\section{Vroegtijdige opsporingsonderzoeken voor kanker :}

(Tussen haakjes wordt steeds de bijkomende uitleg over het betreffende opsporingsonderzoek vermeld; deze diende aok steeds te worden voorgelezen door de interviewer.)

1. baarmoederhalsuitstrijkje (met een spatel slijm van de baarmoederhals afschrapen)

2. opsporen van bloed in de stoelgang

3. borstzelfonderzoek voor vrouwen (zelf met de vingers onderzoeken van de borst)

4. rectaal onderzoek (met een vinger onderzoeken van de dikkedarm via de aars)

5. borstonderzoek door de dokter (met de vingers onderzoeken van de borst door de dokter)

6. mammografie voor vrouwen (een radiografie van de borsten)

7. huidinspectie door de dokter bij veranderende moedervlek

\section{Foutieve items :}

1. radiografie van de longen

2. onderzoek van de longen met van een stethoscoop

3. urine-onderzoek

4. gewichtsmeting

5. bloeddrukmeting

6. electrocardiogram of EKG $($ film of registratie war de hartwerking door het plaatsen van electroden op de borst)

7. AlDS-test

8. betasten van de blaas

9. echografie (zichtbaar maken van een orgaan wia een TV-scherm)

10. syfilistest

i1. keeluitstrijkje (met spatel keelslijm afschrapen\}

12. onderzoek van het hart met een stethoscoop

13. bepalen van hormonen in het bloed

14. elektro-encefalogram of EEG (film of registratie van de hersenactiviteit door het plaatsen van electroden op het hoofd)

15. TBC- of tuberculose test (microscopisch onderzoek van opgehoeste fluimen uit de longeni)

16. zwangerschapstest

17. drukmeting van de oogbol met een klein apparaatje

18. inspanningstest door polsslagmeting na 10 diepe kniebuigingen

De volgorde van de items in de vragenlijst werd "random" bepaald, zodat de "juiste" items op louter toevallige wijze vermengd zijn met de "foutieve" items. De formu/ering 
van de items zoals hiler gepresenteerd is het resultaat wan het vooronderzoek en van het uittesten van de vragenifist (zie verder hoofdstuk 4).

Figuar 3.10

Overzicht van de itemlijsten en de afgeleide scores van de

"Kennis van kankerpreventie 100-items vragenlijst"

\begin{tabular}{|c|c|c|c|}
\hline Dimensie: & indicetor: & Vragenlijst: & Kennisscores: \\
\hline \multirow{2}{*}{$\begin{array}{l}\text { kennis van } \\
\text { primaire } \\
\text { kenkerpreventie }\end{array}$} & $\begin{array}{l}\text { kemnis van } \\
\text { risicofactoren } \\
\text { van kanker }\end{array}$ & $\begin{array}{l}25 \text { items: } \\
-8 \text { juiste } \\
-17 \text { foutieve } \\
\end{array}$ & $\begin{array}{l}\text { 1. kennis risicof actoren } \\
\text { 2. foutperceptie } \\
\text { 3. adequate kennis risicof actoren }\end{array}$ \\
\hline & $\begin{array}{c}\text { kennis van gewenst } \\
\text { kankerpreventief } \\
\text { gedrag } \\
\end{array}$ & $\begin{array}{l}25 \text { items: } \\
-8 \text { juiste } \\
-117 \text { foutieve }\end{array}$ & $\begin{array}{l}\text { 1. kennis gewenst gedrag } \\
\text { 2. foutperceptie } \\
\text { 3. adequate kennis gewenst gedrag }\end{array}$ \\
\hline \multirow{2}{*}{$\begin{array}{l}\text { kennis van } \\
\text { secundaire: } \\
\text { kankerpreventie }\end{array}$} & $\begin{array}{l}\text { kennis van waar- } \\
\text { schuwingssignalen } \\
\text { voor kanker }\end{array}$ & $\begin{array}{l}25 \text { items: } \\
-7 \text { juiste } \\
-18 \text { foutieve }\end{array}$ & $\begin{array}{l}\text { 1. kennis waar-schuwingssignalen } \\
\text { 2. foutperceptie } \\
\text { 3. adequate kennis was- } \\
\text { schuwingssignaler }\end{array}$ \\
\hline & $\begin{array}{l}\text { kennis van vroeg- } \\
\text { tijdige opsporings- } \\
\text { onderzoeken }\end{array}$ & $\begin{array}{l}25 \text { items: } \\
-7 \text { juiste } \\
-18 \text { foutieve }\end{array}$ & $\begin{array}{l}\text { 1. kennis vroegtijdige } \\
\text { opsporingsonderzoeken } \\
\text { 2. foutperceptie } \\
\text { 3. adequate kennis vroeg-tijdige } \\
\text { opsporings-onderzoeken }\end{array}$ \\
\hline
\end{tabular}

Op basis van de zekerheidsscores op de afzonderlijke items kunnen telkens kennisscores worden berekend (zie figuur 3.10) ". De kennis van de vier onderscheiden kennisdomeinen kan bijgevolg worden uitgedrukt in drie kennisscores:

- Een kennisscore (KS), gebaseerd op de sommatie van de zekerheidsscores waarmee de "juiste" iterns werden herkend;

- Een foutperceptiescore (FS), gebaseerd op de sommatie van de zekerheidssicores op de "foutieve" items;

Een adequate kennisscore (AKS), gebaseerd op het verschil tussen de juiste kennisscore en de foutperceptiescore.

De vier indicatoren samen vormen synthesematen voor kennis van kankerpreventie.

Er kunnen drie synthesematen worden berekend:

1. de symthesemaat voor kennis van primaire kankerpreventie

2. de synthesemaat voor kennis van secundaire kankerpreventie

3. de globale synthesemaat voor kennis van kankerpreventie

Zie bijlage 2 a voor de exacte scoreberekeningen.

- Begripsanalyse en ontwikkeling van een meetinstrument - 


\section{Hoofdstuk 4}

\section{Onderzoeksplan}
4.1 Onderzoekselementen en participanten
4.2 Ontwikkeling en uittesten van de vragenlijst
4.3 Dataverzameling en datacontrole
4.4 Algemene principes voor de statistische toetsingsprocedures

Inleiding". In dit hoofdstuk wordt de onderzoeksmethodologie van onderhavige studie gepresenteerd. Het ligt niet in de bedoeling om hier een technisch rapport voor te stellen. Well worden de exacte stappen beschrewen, die werden gemaakt om de onderzoeksvragen en de onderzoekshypotheses respectievelijk te kunnen beantwoorden en te toetsen. Geïnteresseerde onderzoekers zijn hierdoor in de mogelijkheid om dit onderzoek - al dan niet met methodologische verbeteringen - te repliceren.

Aangezien de beschrijvende en verklarende uitspraken over een grote populatie moeten gebeuren, werd gekozen voor een "survey-onderzoek" (zie o.m. Albinski, 1974; Billiet, 1993; Fowler, 1993). Voor het onderzoeksontwerp werd geopteerd voor een "crosssectioneel survey design" met inbegrip van een aantal survey-instrumenten. De doelstelling was het vaststellen van correlaties tussen kennis van kankerpreventile en een aantal onafhankelijke variabelen die zijn opgenomen in de analyses in hoofdstukken 7 en 8.

Het verzamelen van de gegevens voor dit onderzoek gebeurde aan de hand van een gestandaardiseerde mondelinge bevraging van 1631 personen tussen 18 en 70 jaar oud. Er werd geopteerd voor een "face-to-face" interview op het adres van de respondent. Alle respondenten waren woonachtig in Vlaanderen (vijf Vlaamse provincies, exclusief Brussell. De selectie van deze respondenten gebeurde via de techniek van een gestratificeerde tweetrapssteekproef (zie paragraaf 4.1).

Aan de opbouw van de onderzoeksinstrumenten werd er veell aandacht besteed. Het ontwerpen van de vragenlijst heeft dan ook zeer veel tijd in beslag genomen. Er werd vooronderzoek verricht en de ontwerpversies van de vragenlijst werden uitgetest op een beperkte steekproef van mensen uit de onderzoekspopulatie (zie paragraaf 4.2 ).

Om de kwaliteit van de afgenomen interviews te optimaliseren werd gebruik gemaakt van getrainde interviewers van het ISPO-interviewersnetwerk wan het Sociologisch

De indeling van dit hoofdstuk werd geïnspireerd doar de voorschiften van Rudestam en Newton (1992: 60-78). 
Onderzoeksinstituut van de K.U. Leuven' (zie paragraaf 4.3 ). In totaal werkten er 108 enquêteurs mee aan het onderzoek. De coördinatie en supervisie van deze omvangrijke data-verzameling vond plaats aan de dienst Medisch-Sociale Wetenschappen van de V.U. Brussell.

Bij een survey-onderzoek wordt de kwaliteit van de bevraging eerst en vooral bevorderd door het gebruik van een goed meetinstrument en goede interviewers. Verder werd er ook tijdens het veldwerk en bij de verwerking van de gegevens aan kwaliteitsbewaking gedaan (paragraaf 4.4).

Dit hoofdstuk wordt afgesloten met de verantwoording voor de gekozen presentatievormen voor de datalanalyse en de geselecteerde statistische analyseprocedures (paragraaf 4.5 ).

\section{1 Onderzoekselementen en participanten ${ }^{2}$}

Om bij volwassenen een representatief onderzoek te verrichten voor Vlaanderen worden twee criteria geselecteerd voor de afbakening van de onderzoekspopulatie:

- inwoner zijn van Vlaanderen én

- tussen de 18 jaar en 70 jaar zijn.

Door het leeftijdscriterium werden kinderen niet bij het onderzoek betrokken. Kanker komt immers meestal voor bij volwassenen en kankerpreventie richt zich voornamelijk tot volwassenen. Bovendien verschillen de kankers die men bij het kind aantreft van deze die men doorgaans bij de volwassene vaststelt, zowel wat betreft de aard, de oorzaak en de lokalisatie van de kanker. 70 jaar werd genomen als bovengrens voor de leeftijd omdat kankerpreventie (bv. mammografie als vroegtijdige opsporing van borstkanker) niet meer wordt gepropageerd boven de 70 jaar. Het opnemen van deze oudere leeftijdscategorie is bijgevolg voor dit onderzoek minder relevant. Bovendien was er een bijkomende methodologische reden om deze groep niet in de onderzoekspopulatie op te nemen. Personen boven de 70 jaar zijn vaak moeilijker bereikbaar dan andere mensen. Zij verblijven vaak niet op hun officiële adres of verblijven in instellingen, of zij zijn sneller geneigd om "vreemde" mensen - C.q. de interviewers - niet toe te laten tot hun woning. Hierdoor kan er een vertekening optreden in de gerealiseerde steekproef.

Het Interuniversitair Steunpunt Politieke- Opinieonderzoek (ISPO) staat onder leiding van Prof. dr. J. Billiet en het ISPO-interviewersnetwerk wordt gecoördineerd door Ann Carton. Deze latse stond in voor de recrutering en selectie van de interviewers, alsook woor het organiseren van een eendaagse algemene training van de geselecteerde interviewers.

Zie bijlage 1 voor een gedetailleerde beschrijwing van de steekproef. 
Er werd in de onderzoekspopulatie geen onderscheid gemaakt op basis van nationaliteit. De nationaliteit werd wel bevraagd in de vragenlijst.

Omdat Vlaanderen in de complexe federale structuur van België niet meteen administratief scherp te omlijnen is, diende het geagrafisch gebied nauwkeurig te worden omschreven:

"het geografisch gebied Vlaanderen wordt in dit onderzoek omschreven als de samenbundeling van alle gemeenten die behoren tot de 5 Vlaamse provincies".

Dit impliceerde dat Brussel volledig buiten het onderzoeksdomein viel. Deze ingreep is ook om anderzoekstechnische redenen te verantwoorden. Brussel, alsook de faciliteitengemeenten rond Brussel waar een groot aantal inwoners franstalig zijn, llevert met haar meertaligheid een ernstig probleem van non-respons op (Dooghe, e.a., 1988).

Rekening houdende met het kostenaspect verbonden aan grootschalige bevragingen, werd de noodzakelijke steekproefgrootte, met een maximale schattingsfout van $2.5 \%$ bij $95 \%$ betrouwbaarheid, berekend op $1537^{\prime}$.

Voor de steekproef waren er verschillende mogelijkheden om de representativiteit na te streven. Men kan een zuivere toevalssteekproef trekken of een quotasteekproef (Billiet. 1993: 117-146). Het eerste geval is statistisch gezien de beste steekproef, in het laatste geval worden de respondenten eigenlijk niet meer bepaald door de onderzoeker, maar wel door de interviewer. Tussen deze beide extreme opties zijn er een hele reeks alternatieve steekproeftechnieken.

In dit onderzoek werd geopteerd voor een gestratificeerde tweetrapssteekproeftechniek:

- Eerst werd op basis van de lijst van alle Vlaamse gemeenten een systematische toevalssteekproef gemaakt van 102 steekproefpunten. Deze steekproefpunten werden gekozen met een kans die evenredig was aan de bovolkingsomvang van de gemeenten. Hierdoor kon worden bepald in welke gemeenten deze steekproefpunten vielen. De getrokken steekproefpunten waren verspreid over 89 gemeenten. Grotere gemeenten of steden hadden een verhoogde kans om ook meerdere steekproefpunten te bevatten. Dit verklaart ook waarom in bepaalde grote gemeenten ook meerdere steekproefpunten aanwezig zijn. Antwerpen spant de kroon met 8 steekproefpunten.

- Vervolgens werd binnen deze gemeenten de respondenten getrokken volgens een toevalssteekproef. Het aantal te trekken personen per steekproefpunt bedroeg 16. Om toevalsafwijkingen te beperken werd een stratificatie doorgevoerd naar provincie en naar gemeentetype (Vanneste, 1989).

1 Zile bijlage $1 a$ 
Om de omvang van de gerealliseerde steekproef onder controle te houden, werd besloten om de non-responders te vervangen. Hiervoor werden op identieke wijze nogmaals 3 steekproeven gletrokken uit de bevolkingsregisters van deze 89 gemeenten. In totaal werden bijgevalg 4 steekproeven getrokken: 1 originele steekproef en 3 reservesteekproeven die enkel zouden worden benaderd voor eventuele vervangingen.

Ten einde de berekende steekproefgrootte wan 1537 te kunnen bereiken, zou het volstaan om 15 personen per steekproefpunt te bevragen. Dit zou de te realiseren steekproefomvang op 1530 brengen. Omdat de proportionele verdeling naar geslacht ongeveer $50 / 50$ is, was het moeilijk om met 15 personen per steekproefpunt de proportionele verdeling naar geslacht onder controle te houden. Daarom werd besloten er 16 te nemen, waardoor de te realiseren steekproefgrootte aangroeide tot 1632 .

In principe was het de bedoeling om de praktische uitvoering van de steekproef te realiseren via het rijksregister". Omdat door de ambtelijke toepassing van de nieuwe wet van 8 december 1992 tot bescherming van de persoonlijke levenssfeer geen toegang kon worden verkregen tot het federale rijksregister (Billiet, 1994), werd besloten om het steekproefkader ${ }^{2}$ samen te stellen via de bevolkingsregisters van de gemeenten. Om toegang te krijgem tot deze bevolkingsregisters dienden de burgemeesters van alle 89 betrokken gemeenten hun toelating te geven. Mede dank zij een aanbevelingsbrief van Mevr. L. Detiège, de toenmalig Minister bevaegd voor kankerpreventiebeleid in Vlaanderen, weigerden slechts twee burgemeesters hun medewerking aan dit onderzoek. De betrokken gemeenten konden evenwel warden vervangen door een andere gemeente uit dezelfde provincie en behorende tot hetzelfde gemeentetype uit de typologie van Belgische gemeenten van Vanneste (1989). Met de schriftelijke toelating van de burgemeesters kon dan in samenspraak met de verantwoordelijke ambtenaar de steekproef worden samengesteld.

De uitval van steekproefeenheden door niet-bereikbaarheid of door weigering vormt een klassiek probleem bij survey-interviews. Zij kunnen evenwel door de nodige voorzorgen tot een minimum worden beperkt. Indien de interviewers op verschillende tijdstippen van de dag drie keer terugkeren naar eenzelfde adres, dan neemt de uitval door nietbereikbaarheid gevoelig af (Billiet, 1993: 144). Weigeringen kunnen vooral door een degelijke training en supervisie van de interviewers beperkt worden.

Toch moet men blijven rekening houden met een te verwachten non-respons die

Hiertoe werden meerdere pogingen ondernomen. Hierover werd zelfs briefwisseling gevoerd mat de heer $L$. Tobback, toenmalig Minister van Binnenlandse Zaken. Dit mocht evenwel niet baten, zodat cen zeer tijdrovende en omslachtige omweg via de gemeenten diende te worden gemaakt om aan de nodige gegevens te komen. De steekproeftrekking heeft hierdoor ongeveer een half jaar in beslag genomen.

Het steekproefkader is de bestaande registratie van alle elementaire eenheden die samen de populatie vormen (Billiet, 1993:120). 
aanzienlijk kan oplopen. Op dat moment kan een vorm van selectiviteit optreden. Om die uitgelote personen die niet aan het onderzoek kunnen of willen meewerken te kunnen vervangen, werd een belangrijke reserve van personen aangelegd. Per gemeente werden 64 personen getrokken: 16 personen voor de originele steekproef en de overige personen werden gebruikt om drie vervangsteekproeven samen te stellen. Uit tabel 4.1 blijkt overduidelijk dat deze vervangingen ook effectief dienden te worden gebruikt.

Tabel 4.1

Responsratio en gebruik van vervangsteekproeven

\begin{tabular}{|l|c|c|c|}
\hline & $\begin{array}{c}\text { Absolute } \\
\text { Frequentie }\end{array}$ & $\begin{array}{c}\text { Relatieve } \\
\text { Frequentie }\end{array}$ & $\begin{array}{c}\text { Cumulatieve } \\
\text { Frequentie }\end{array}$ \\
\hline originele steekproef & 1116 & 68.4 & 68.4 \\
\hline 1ste verwangsteekproef (*) & 332 & 20.4 & 88.8 \\
\hline 2de vervangsteekproef (*) & 101 & 6.2 & 95.0 \\
\hline 3de verwangsteekproef (*) & 48 & 2.9 & 97.9 \\
\hline matching naar geslacht of leeftijd & 34 & 2.1 & 100.0 \\
\hline Totaal & 1631 & 100.0 & \\
\hline
\end{tabular}

* matching naar leeftijd én geslacht

Tijdens de data-verzameling kon slechts één respondent niet worden vervangen, omdat ook geen van de vervangsteekproeven een respons opleverde. In totaal werden bijgevolg 1631 personen bereikt en geinterviewd. 1116 personen van de originele steekproef namen deel aan het onderzoek (zie tabel 4.1). Dit is een zeer bevredigende responsratio van $68.4 \%$. 515 respondenten $(31.6 \%)$ dienden te worden vervangen door respondenten uit de eerste vervangsteekproef. Zij werden geselecteerd uit hetzelfde steekproefpunt en via matching op geslacht en leeftijd. De responsratio van deze vervangsteekproef was 332 op 515 of $64.5 \%$. Met de eerste en tweede steekproef samen kon bijgevolg reeds $88.8 \%$ van de te realiseren steekproef worden bereikt. De overblijvende respondenten werden op analoge wijze via de tweede en derde vervangsteekproef bereikt. Voor slechts 34 respondenten diende te worden afgeweken van de dubbele matching naar leeftijd én geslacht. Voor hen werd er enkel nog gernatcht naar één van beide kenmerken.

Om toch enig beeld te krijgen van de groep van de niet bereikbaren of nonresponders, werd een verwerking gemaakt van de contactbladen ${ }^{1}$. Op deze contactbladen dienden de interviewers de redenen aan te gegeven voor niet deelname. In totaal werden 821

De verwerking van de contactbladen gebeurde aan het Sociologisch Onderzoeksinstituut van de K.U.L. door Ann Carton, waarvoor danik. 
nonrespons contactbladen verwerkt. Op basis van de 13 mogelijke codes voor nonrespons werden de nonresponders gegroepeerd in drie categorieên :

- weigering (wel thuis, maar niet opengedaan of expliciet geweigerd) $(n=439)$;

- nooit thuis bil aanmelding (minimum drie aanmeldingen per adres) $(n=92)$;

- overige redenen van nonrespons loverleden, verhuisd, ziek, taalbarrière, vakantie of zakenreis, echt niet in gelegenheid tot participatie, op opgegeven adres wonen andere mensen, enz.) $(n=290)$ (zie ook tabel 4.2).

Tabel 4.2

Redenen wan nonrespons, naar steekproef

\begin{tabular}{|l|c|c|c|c|}
\hline & $\begin{array}{c}\text { Iste } \\
\text { steekproef }\end{array}$ & $\begin{array}{c}\text { 2de } \\
\text { steekproef }\end{array}$ & $\begin{array}{c}\text { 3dle } \\
\text { steekproef }\end{array}$ & Totaal \\
\hline Weigering & $56.89(289)$ & $47.70(83)$ & $48.20(67)$ & $53.47(439)$ \\
\hline Niet thuis & $10.04(051)$ & $11.49(20)$ & $15.11(21)$ & $11.21(92)$ \\
\hline Overige & $33.07(168)$ & $40.80(71)$ & $36.69(51)$ & $35.32(290)$ \\
\hline Totaal & $100.0(508)$ & $100.0(174)$ & $100.0(139)$ & $100.0(821)$ \\
\hline Chi ${ }^{2}=7.717 ; p=0.103$ &
\end{tabular}

Uit tabel 4.2 blijkt dat deze redenen voor nonrespons niet significant verschillen volgens de gebruikte steekproef.

Tabel 4.3

Verdeling van de steekproef- en onderzoekspopulatie, naar provincie

\begin{tabular}{|l|c|c|c|c|}
\hline & \multicolumn{2}{|c|}{$\begin{array}{c}\text { Steekproefpopulatie } \\
(n=1.631)\end{array}$} & \multicolumn{2}{|c|}{$\begin{array}{c}\text { Onderzoekspopulatie } \\
(\mathrm{n}=4.048 .973)\end{array}$} \\
\hline & frequentie & $\%$ & $\%$ & $\begin{array}{c}\text { verschillen } \\
\text { in } \%\end{array}$ \\
\hline Antwerpen & 448 & 27.47 & 27.81 & -0.34 \\
\hline Vlaams-Brabant & 271 & 16.62 & 16.88 & -0.26 \\
\hline West-Vlaanderen & 320 & 19.62 & 19.16 & +0.46 \\
\hline Oost-Vlaanderen & 384 & 23.54 & 23.08 & +0.46 \\
\hline Limburg & 208 & 12.75 & 13.07 & -0.32 \\
\hline Totaal & 1631 & 100 & 100 & \\
\hline Chi ${ }^{2}=0.51021 ; \mathrm{p}=0.9725$ & & & \\
\hline
\end{tabular}


In de gerealiseerde steekproef bevinden zich 813 mannen $(49.8 \%)$ en 818 vrouwen $150.2 \%)$. Deze verhouding komt quasi overeen met de verhouding in he: steekproefplan, waar $50.4 \%$ mannen en $49.6 \%$ vrouwen zijn geregistreerd in de betreffende leeftijdsklassen van de bevolkingsstatistieken. Het verschil in geslachtswerdeling tussen de steekproefpopulatie en de onderzoekspopulatie is zeer beperkt $(0.6 \%)$ en niet statistisch significant $\left(\mathrm{Chi}^{2}=0.16822 ; \mathrm{p}=0.6817\right)$.

In tabel 4.3 wordt de verdeling van de respons naar provincie gepresenteerd en vergeleken met de verdeling uit het steekproefplan.

In tabel 4.4 wordt de verdeling van de respons naar leeftijdsklassen gepresenteerd en vergeleken met de verdeling uit het steekproefplain.

Tabel 4.4

Verdeling van de steekproef-en onderzoekspopulatie, naar leeftijdscategorie

\begin{tabular}{|c|c|c|c|c|}
\hline & \multicolumn{2}{|c|}{$\begin{array}{c}\text { Steekproefpopulatie } \\
\qquad(n=1.631)\end{array}$} & \multicolumn{2}{|c|}{$\begin{array}{c}\text { Onderzoekspopulatie } \\
(n=4.048 .973)\end{array}$} \\
\hline & frequentie & $\%$ & $\%$ & $\begin{array}{l}\text { verschillen } \\
\text { in } \%\end{array}$ \\
\hline $18-19$ & 47 & 2.88 & 3.42 & -0.54 \\
\hline $20-24$ & 160 & 9.81 & 10.13 & -0.32 \\
\hline $25-29$ & 191 & 11.71 & 111.46 & +0.25 \\
\hline $30-34$ & 188 & 11.53 & 11.68 & -0.15 \\
\hline $35-39$ & 181 & 11.10 & 10.94 & +0.15 \\
\hline $40-44$ & 160 & 9.81 & 10.09 & -0.28 \\
\hline $45-49$ & 160 & 9.81 & 9.37 & +0.44 \\
\hline $50-54$ & 127 & 7.79 & 7.86 & -0.07 \\
\hline $55-59$ & 156 & 9.56 & 8.25 & +1.32 \\
\hline $60-64$ & 125 & 7.66 & 8.19 & -0.53 \\
\hline $65-69$ & 119 & 7.30 & 7.22 & +0.08 \\
\hline 70 & 17 & 1.04 & 1.40 & -0.35 \\
\hline Totaall & 1631 & 100 & 100 & \\
\hline
\end{tabular}

$\mathrm{Ch}^{2}=6.59344 ; \mathrm{p}=0.8310$ 
In tabel 4.5 worden de verdelingen naar gemeentetype vergeleken.

Uit de significantietoetsen bij tabellen $4.3,4.4$ en 4.5 blijkt dat de representativiteit van de verkregen respons met positief resultaat gecontroleerd werd voor de leeftijdsverdeling, de verdeling naar gemeentetype en de geografische spreiding naar provincie. Er worden immers geen significante verschillen aangetroffen tussen de steekproefpopulatie en de totale populatie.

Tabel 4.5

Verdeling van de steekproef- en onderzoekspopulatie, naar gemeentetype volgens Vanneste (1989)

\begin{tabular}{|l|c|c|c|c|}
\hline & \multicolumn{2}{|c|}{$\begin{array}{c}\text { Steekproefpopulatie } \\
(\mathrm{n}=1.631)\end{array}$} & \multicolumn{2}{c|}{$\begin{array}{c}\text { Onderzoekspopulatie } \\
(\mathrm{n}=4.048 .973)\end{array}$} \\
\hline & frequentie & $\%$ & $\%$ & $\begin{array}{c}\text { verschillen } \\
\text { in \% }\end{array}$ \\
\hline Cluster 1 & 399 & 24.46 & 24.39 & +0.07 \\
\hline Cluster 2 & 432 & 26.49 & 27.10 & -0.61 \\
\hline Cluster 3 & 112 & 6.87 & 7.77 & -0.90 \\
\hline Cluster 4 & 240 & 14.71 & 13.63 & +1.08 \\
\hline Cluster 5 & 320 & 19.62 & 19.72 & -0.10 \\
\hline Ciluster 6 & 128 & 7.85 & 7.39 & +0.46 \\
\hline Totaal & 1631 & 100 & 100 & \\
\hline Chi ${ }^{2}=3.29364 ; p=0.6548$ & & & \\
\hline
\end{tabular}

\subsection{Ontwikkeling an uittesten van de vrageniijst}

In deze paragraaf wordt een algemeen overzicht gegeven van de opeenvolgende stappen bij de ontwikkeling van de vragenlijst. In vorigle hoofdstukken is uiteengezet waarom voor het onderzoek van "kennis van kankerpreventie" een nieuw meetinstrument diende te worden ontwikkeld en hoe dit instrument werd geconceptualiseerd. Hier wordt nader ingeglaan op de praktische wijze waarop dit instrument werd ontwikkeld. De technische uitwerking van de verwerking en scoreberekeningen van de belangrijkste meetinstrumenten staan vermeld in bijlage 2 .

De eerste alanzet van het onderzoek over kennis van kankerpreventie is gegeven in een pilootonderzoek dat plaatsvond in mei 1992 aan de Vrije Universiteit Brussel. Er werd een schriftelijke bevraging verricht tiijdens verplichte practica of oefeningen van eerstejaarsstudenten uit de toegepaste wetenschappen $(n=84)$, communicatiewetenschappen $(n=53)$ en geneeskunde $(n=71)$. In totaal werden 208 eerstejaarsstudenten 
bevraagd, waaronder 122 mannen en 86 vrouwen. Dit onderzoek werd elders uitvoerig beschreven (Deliens e.a., 1994; Maes, 1992). Hier beperken wij ons vooral tot de methodologische aspecten voor de opbouw van de vragenlijst. Enkele fundamentele wijzigingen werden aangebracht in het hoofdonderzoek, uitgaande van de pilootstudie.

In dit pilootonderzoek werd de basis gelegd voor de in dit proefschrift ontwikkelde methode om kennis van kankerpreventie in haar globaliteit te kunnen meten. De vragenlijst van dit pilootonderzoek werd samengesteld na meerdere adviesgesprekken met de kankerpreventiecentra van de U...Antwerpen, de U.Gent en de V.U.Brussel, het Belgisch Werk Tegen Kanker, de dienst Maatschappelijke Gezondheidszorg van de V.U.Brussel en het Academisch Centrum voor Huisartsgeneeskunde van de U.Gent. Tevens werd ze in een vooronderzoek bij 22 studenten uitgetest.

Un deze pilootstudie werden drie indicatoren en vragenbatterijen gebruikt om de kennis van kankerpreventie te meten. Er werden slechts drie kennisgebieden onderzocht : de kennis over waarschuwingssignalen, de kennis over risicofactoren en de kennis over vroegtijdige opsporingsonderzoeken." Hierdoor werd een belangrijk kennisgebied over het hoofd gekeken, namelijk kennis over "gewenst kankerpreventief gedrag", waardoor de conceptualisering van "kennis van kankerpreventie" onvolledig was. In het hoofdonderzoek werd dit euvel rechtgezet. Naast deze drie kennisgebieden werden in het pilootonderzoek ook een aantal vragien opgenomen in verband met "epidemiologische" kennis over kanker en de gepercipieerde bedreiging door kanker. Doordat de initieklle wragenlijst van het hoofdlonderzoek tijdens de testing van de timing van het interview te lang uitviel, zijn deze vragen gesneuveld in het eigenlijke hoofdonderzoek.

Een tweede wijziging betreft de basisschaal waarmee de kennisscores worden geconstrueerd. In het pilootonderzoek werd met een "vierpuntenschaal" gewerkt. Bij de meting van kennis van de waarschuwingssignalen van kanker zag deze schaal er bij het vooronderzoek als volgt uit :

1. geen waarschuwingssignaal [-2]

2. waarschijnlijk geen waarschuwingssignaal [-1]

3. waarschijnlijk wel een waarschuwingssignaal [+ 1]

4. zeker een waarschuwingssignaal $[+2]$

Tijdens de afname van de enquête bleek dat bij sommige items bepaalde studenten totaal geen idee hadden of het nu al dan niet een waarschuwingssignaal voor kanker was. Zij gingen bijgevolg gokken, omdat ze de instructie hadden gekregen om altijd een antwoord te geven. Doordat goklken een weinig valide antwoord oplevert, werd dit vermeden tijdens het hoofdonderzoek. Dit probleem werd opgevangen door in plaats van een vierpuntenschaal, een vijfpuntenschaal mét middencategorie te hanteren :

1. geen waarschuwingssignaal [-2]

2. waarschijnlijk geen waarschuwingssignaal [-1]

3. misschien niet, misschien wel een waarschuwingssignaal [0]

4. waarschijnlijk wel een waarschuwingssignaal [ +1$]$

5. zeker een waarschuwingssignaal [ +2$]$ 
Het nadeel van deze schaal is wellicht dat een aantal mensen de neiging gaat hebben om naar de middencategorie te "Vluchten", eerder dan hun mening in de éên of andere richting te kennen te geven. Toch wordt de validiteit daardoor wellicht minder geschaad dan met een vierpuntenschaal, waarbij mensen verplicht worden om te gokken. Bovendien zal bij non-respons op een bepaald item een score kunnen worden gegeven die geen negatieve of positieve invloed uitoefent op de kennisscore, namelijk de waarde 0 . Op die manier zal ook het probleam van selectieve non-respons worden opgelost (zie ook hoofdstuk 5).

De specificiteit van de onderzoeksgroep in dit pilootonderzoek maakte het onmogelijk om de resultaten te veralgemenen. De onderzoeksgroep was specifiek op minstens twee kenmerken die volgens de wetenschappelijke literatuur een belangrijke determinerende rol vervullen bij kennis over kankerpreventie, namelijk leeftijd en sociaal-economische status. Eerstejaars universiteitsstudenten hebben gemiddeld een hogere sociaaleconomische status dan de gemiddelde Vlaming. Op basis van de schollingsgraad kan worden verondersteld dat de gevonden kennis over kankerpreventie bij de onderzoeksgroep hoger ligt. Anderzijds is de onderzoeksgroep homageen naar leeftijdssamenstelling. Dent en Goulston (1982) hebben een significant hoger niveau van kennis over kankerpreventie gevonden bij respondenten ouder dan vertig jaar. De jeugdige leeftijd van de respondenten in deze studie zou ook als gevolg kunnen hebben dat de kennis lager ligt dan bij de doorsnee populatie. Over deze veronderstellingen kan enkel het hoofdonderzoek bij een representatief staal van de Vlaamse bevolking uitsluitsel geven.

In de vragenlijst werden ook een aantal sociaal-demografische en sociaal-economische factoren opgenomen, zoals geslacht, leeftijd, inkomen, opleiding, enz. Het zijn de klassieke sociologische identificatiegegevens over respondent, partner en gezin die hier bevraagd worden. Naast leeftijd en geslacht, betreft het de volgende kenmerken (vergelijkbaar met Foets en van der Velden, 1990):

- burgerlijike staat en samenlevingsverband -

Er wordt gevraagd naar de formele burgerlike staat. Hoewel dit gegeven nogal eens kan afwijken van de feitelijke situatie, blijft het toch belangrijk om wergelijking met ander onderzoek mogelijk te maken. De feitelijke situatie blijkt uit de gegevens over het samenlevingsverband. Hiervoor werd gevraagd of mensen alleen wonen, met een partner, met of zonder kinderen of in een woongroep (gemeenschapshuis, klooster, bejaardentehuis, enz.). Deze vraag vormt een aanvulling bij de vraag naar de burgerlijke staat.

Gekoppelld aan de burgerlijke staat, werd ook gevraagd naar de duur van deze burgerlijke staat. Deze vraag is met name relevant voor al degenen die op de én of andere manier - door overlijden of door scheiding - afscheid hebben moeten nemen van hun partner. Hoe recenter deze ingrijpende gebeurtenis plaatsgreep, hoe meer impact dit (nog) kan hebben op de betrokkene. Deze variabele is in het onderzoek opgenomen, omdat bij onderzoek naar ziekte en gezondheid steeds meer aandacht 
wordt besteed aan de rol van zogenaamde "stressful life events" (Cockerham, 1992: 76-80). Overlijden van de partner of scheiding worden daarbij - in vergelijking met bv. ontslag op het werk, overlijden van een vriend, een zoon of dochter die het huis verlaat, moeilijkheden op het werk, enz. - beschouwd alls de meest stresserende gebeurtenissen in een mensenleven.

- onderwijsniveau -

Onderwijsniveau wordt, naast beroep en inkomen (zie verder), in dit onderzoek opgenomen als een indicator voor sociaal-economische status' (zie ondermeer Blalock, 1991; Goldthorpe, 1980; Rees e.a., 1993; van Berkel-van Schailk en Tax 1990). Het bestaan van zeer veel soorten en niveaus van onderwijs brengt met zich mee dat classificatie wan gegevens over het genoten onderwijs vaak een lastige aangelegenheid is. Daarom is besloten om te vragen naar het hoogst behaalde, dat will zeggen afgeronde onderwijsniveau. Deze werkwijze heeft welliswaar als nadeel dat alleen met een ruwe indeling van 8 categorieën gewerkt kan worden, maar als voordeel dat het relatief eenduidig en makkelijk te begrijpen is voor een grote en heterogene onderzoekspopulatie.

- arbeidssituatie en beroep -

Deze vragen zijn, zoals de vraag naar het opleidingsniveau, bedoeld om een indicatie te geven over de sociaal-economische status van de respondenten. Deze vraag werd ook ingevuld door werklozen, gepensioneerden, dienstplichtigen, mensen in ziekteverlof of arbeidsongeschikten, enz. Hoewel deze personen op het moment van het onderzoek geen beroep uitoefenden, heeft een aantal onder hen vroeger wel een beroep gehad. Hierbij wordt verondersteld dat de vroegere baan een goede indicator voor hun sociaal-economische status is. Voor gehuwde of samenwonende mensen is daarnaast ook gevraagd naar het beroep van de partner.

- woonsituatie -

Tenslotte zijn twee vragen over de woonsituatie gesteld. Ten eerste is geînformeerd naar het type huis waarin de respondent woont (kamer, flat of appartement, eenglezinswoning in de rij, vrijstaand huis enz.). Ten twoede is gevraagd of het om een huurhuis dan wel een elgendom gaat. Over de invloed van de woonsituatie is met name in Groot Brittannie vrij veel gezondheidsonderzoek gedaan (McCarthy, 1982; Morton, 1988) ${ }^{2}$.

Voor de operationalisering van sociaal-economische status, zie biflage 2.

2

Beide werken werden geciteerd in Foets en van der Veiden (1990: 29). 
- inkomen -

Zeer delicate vragen zijn de vragen ter verkrijging van informatie over de inkomenspositie van het gezin van de respondent. Zij werden - samen met andlere vrij persoonlijke vragen over de respondent en zijn tamilie - bewust achteraan de vragenlijst geplaatst. Wanneer men door middel van een interview informatie over het inkomen van de respondenten will bekomen, vangt men als onderzoeker vaak bot. Een inkomenswraag wordt als bedreigend gepercipieerd, waardoor de kans op non-respons zeer hoog is. Door deze wraag achteraan te plaatsen heeft de interviewer evenwel de tijd gehad om het vertrouwen van de respondent te winnen, zodat er kan worden overgeschakeld naar 'delicatere' vragen. Toch is een grote non-respons steeds reëel. Omdat de inkomenswraag zeer belangrijk is om ondermeer de sociaal-economische status van respondenten te kunnen operationaliseren, werd een maximale respons nagestreefd. Om dit te bereiken werd een getrapte vraagstelling gebruikt (zie figuur 4.1$)^{\prime}$.

Figutur 4. 1

Methode van vraagstelling voor het bepalen van de "inkomenspositie"

- Eerst wordt een exacte meting gedaan wan het inkomen:

"hoevael bedraagt het gezamen/ijk netto maandinkomen in uw huishouden ? U moet daarbij rekening houden met de inkomens van alle gezinsleden, alsaok alle vormen van inkomen, zoals loon, vervangingsinkomen, pensioen, eventueel kindergeld of

alimentatiegeld, beleggingen, enz."

- Vervolgens wordt begrip getoond voor de "weigeraar":

"Ik begrijp dat $U$ het moeilijk vindt om deze vraag te beantwoorden. De volgende vraag is wellicht gemakkelijker."

- Dan wordt een zeer algemene inkomensvraag gesteld:

"Is hat gezamenlik netto maandinkomen vam uw huishouden, hoger dan $80.000 \mathrm{fr}$ "

- Tot slot wordt er werer meef precisie gevraagd, namelijk het situeren van het inkomen op een ordinale schaal met 8 klassen met en inkomensspreiding varn 10.000 frank:

"Als: U de inkomenscategorieän op antwoordkaart $n^{\circ} 45$ bekijkt, in welke categorie valt dan dit gezamenlik netto maandinkomon wan uw huishouden? U kan het ciffer noemen dat voor de inkomenscategorie staat."

Deze vraagstelling werd met toelating ontleend aan een vragenlijst van het Interuniversitair Steunpunt Politieke- Opinieonderzoek van Prof, J. Billiet (Sociologisch Onderzoeksinstituut,
K.U.Leuven). 


\begin{abstract}
Uiteindelijk bleek deze techniek vrij succesvol: $47 \%$ van de respondenten gaf een exact inkomen op, $38.5 \%$ situeerde het inkomen in de vrij gedetailleerde ordinale schaal met 16 inkomenscategorieen, en van $6.5 \%$ is geweten dat ze enkel over meer of minder dan $80.000 \mathrm{fr}$ maandelijks inkomen beschikken. Met deze techniek kon het responsprobleem bij het meten van het inkomen in belangrijke mate worden ondervangen: slechts over $8 \%$ van de steekproefpopulatie kon er geen informatie over het inkomen worden verzameld en $85 \%$ kan worden gesitueerd in een vrij gedetailleerde schaal.
\end{abstract}

Door de zorgvuldige opbouw van de vragenlijst, werd gehoopt dat het interview vlot kon verlopen, dat de respondenten de vragen goed en eenduidig zouden begrijpen en dat de interwiewers de vragenlijst vlot konden invullen. Om meer zekerheid te krijgen over de kwaliteit van de vragenlijst, werd voorafgaand aan de eigenlijke bevraging een "testing" georganiseerd bij een twintigtal proefpersonen.

De meeste testinterviews waren vlot verlopen en de vragen werden in het algemeen zeer goed begrepen. Ook de meeste antwoorden werden als zeer betrouwbaar ingeschat door de interviewers.

\title{
4.3 De dataverzameling en datacontrole
}

De dataverzameling werd verricht door interviewers die getraind zijn in het surveyinterview. De recrutering van interviewers kon worden uitbesteed aan Prof. dr. J. Billiet van het Sociologisch Onderzoeksinstituut van de K. U.Leuven. Hij beschikte immers in het kader van het Interuniversitair Steunpunt Politieke- opinieonderzoek over een interviewersnetwerk gespreid over heel Vlaanderen. Omdat de interviews voor dit onderzoek ook op verschillende plaatsen in Vlaanderen plaatsvinden, was dit vanuit praktisch en financieel oogpunt een goede oplossing. De vervoerskosten konden op die manier ook onder controlle worden gehouden. Een bijkomende reden voor de keuze van deze dienst is de jarenlange ervaring met survey-interviews en met kwaliteitsbewaking bil survey-interviews (zie ondermeer Billiet, Loosvelld en Waterplas, 1984; en Billet, $1993)$.

Voorafgaand aan de data-verzameling werden al deze interviewers opgeleld. De opleiding van deze interviewers gebeurde in twee fasen. De eerste fase betrof een algemene training die ongeveer ến dag duurde". Hierin kregen de interviewers een uiteenzetting over de theorie en de doelstellingen van het survey-interview, en konden ze via video demonstraties en rollenspel vaardigheden in interviewen en in mogelike (moeilike) interviewsituaties trainen. De tweede fase bestond uit een specifieke training, die

Deze training maakt standaard deel uit wan de procedure van het interwiewernetwerk van het Interuniversitair Steunpunt Politieke opinieonderzoek (ISPO). Deze trainingen vonden plaats aan de K.U.L. en werden georganiseerd door Ann Carton, assistente van Prof, dr. J. Billiet. Zij is in de praktijk de verantwoordelijke voor het interviewernetwerk van thet ISPO. 
toegespitst was op dit onderzoek. Hierbij werden de interviewers uitvoerig gebrieft over de situering wan het onderzoek, de inhoud en opbouw van de vragenlijst, de te volgen procedures, enz. Onmiddellijk na de specifieke training konden de interviewers starten met hun interviews.

De supervisie van de interviews gebeurde vanuit de V.U. Brussel. Elke binnengestuurde vragenlijst werd gecontroleerd op geslacht en leeftijd van de respondent, alsook op de consistentie van bepaalde antwoorden. Verder werd een toevallige steekproef van respondenten (minimum één per interviewer) telefonisch benaderd voor een kort gesprek over het interview. Op die manier kon worden gecontroleerd of de interviewer daadwerkelijk de betrokken respondent had geinterviewd, hoe lang het interview had geduurd en kon sen beperkt aantal antwoorden worden getoetst op hun betrouwbaarheid.

Nal het coderen van de enquêtes volgde telkens een controle van de gecodeerde enquêtes. Op die manier kanden een groot aantal codeerfouten worden rechtgezet vooraleer de gegevens werden ingelezen in een computerbestand. Voor dit laatste deden kon worden beroep gedaan op een commercieel bedrijf met een jarenlange ervaring met het intezen data-bestanden. Dit bedrijf kreeg de opdracht een "dubbele lezing" te verrichten, zodat de garantie dat er van hun kant geen fouten werden gemaakt bij het inlezen van de gegevens maximaal was. Nadat de datamatrix was ingelezen in een computerbestand, werd een grondige controle van de consistentie van de data doorgevoerd. Hierdoor konden de overblijvende fouten - merendeels codeerfouten worden rechtgezet.

$\mathrm{Na}$ al deze controles van interne consistentie van de vragenlijsten en de interne cleaning van de dataset konden de data-analyses van start gaan. De analyses zijn verricht met de P.C.-versie van het het statistisch programma SPSS WIN (1993).

\subsection{Algemene principes voor de statistische toetsingsprocedures}

De keuze van het meest geschikt statistisch instrumentarium is van essentieel belang voor elk empirisch onderzoek. Hieronder wordt in het kort en zonder veel technische details weergegeven welke algemene principes worden gehanteerd bij de keuze van de statistische methoden die in dit onderzoek worden aangewend.

In de hoofdstukken 7 en 8 wordt er gezocht naar samenhangen tussen kennis van kankerpreventie en en hele reeks sociaal-demografische en sociaal-economische kenmerken van de populatie. De uitkomstvariabelen zijn de kennisscores die via schaalconstructie tot stand zijn gekomen. De antwoordschaal die in de vragenlijst hiervoor wordt gebruikt, is een ordinale vijfpuntenschaal (een "zekerheidsscore"):

1. zeker niet ...

2. waarschijnijik niet...

3. misschien niet, misschien wel... 


\author{
4. waarschijnlijk wel ... \\ 5. zeker ...
}

De verschillende afgeleide kennisscores, gebaseerd op 25,50 of 100 items, zijn bijgevolg ook ordinale schalen, doch met veel meer dan vijf geordende categorieën". Dit laatste is zeer belangrijk omdat men bij uitputting van de statistische analysemogelijkheden voor variabelen op ordinaal meetniveau, bij ordinalie variabelen vanaf 6 à 8 categorieèn ook gebruik kan maken van toetsen wan hogere efficiëntie, de zogenaamde parametrische toetsen (Kaufman, $1995^{2}$; zie ook Rudestam en Newton. 1992: 99). Voor bepaalde analysetechnieken (bv, berekening van gemiddelde scores) worden de kennisschalen dan ook beschouwd als quasi interval variabelen.

Men dient bij een dergelijke premisse evenwel omzichtig tewerk te gaan. In zo'n sïtuatie werd het advies in acht genomen van Gadourek (1976:388) : parametrische toetsen kunnen eventueel toegepast worden op gegevens van een lager meetniveau, maar de conclusies moeten beperkt worden tot de interpretatie die het meetniveau toelaat. Zo zal aan de hand van een regressie-analyse toegepast op twee ordinale schallen, op basis van variabele $X$ geen voorspelling voor variabele $Y$ mogelijk zijn, maar slechts een aanduiding gegeven worden van de samenhang van monotone aard: de toename van een eigenschap heeft de toename van de andere tot gevolg of gaat hiermee gepaard, zonder dat geweten is hoe en in welke mate.

Zowel op het gebied van interval schalen als op het gebied van de ordinale schalen bestaat er een spectrum van statistische maten en toetsen. In Siegel"s vermaarde handboek (1988) staan niet minder dan zestien bewerkingstechnieken voor nonparametrische statistiek beschreven. In het handboek van Blalock (1979) staan een negental bewerkingstechnieken voor interval variabelen beschreven. Uit deze talrijke analysemogelijkheden werden een aantal opties gemaakt voor deze studie. Er werd daarbij steeds een keuze gemaakt voor twee inhoudelijk verschillende statistische parameters, die bij de analyse steeds complementair zullen worden aangewend. In de eerste plaats wordt een toetsingsmethode gekozen die het mogelijk maakt am een iniet toevallige) samenhang ${ }^{3}$ vast te stellen, de zgn. significantietoetsen. In de tweede plaats

Zie bijlage 2.

2

Mondelinge mededeling op 7 juli 1995 van Prof.dr. L. Kaufman, statisticus verbonden aan de faculteit Geneeskunde en Farmacie van de V.U.Brussel.

3

Er bestaat soms een babylonische spraakverwarring over de aanduiding van verbanden. Men spreekt over associlatie, samenhang, relatie, contingentie, verband, relevantie voor, afhankelijkheid, beïnvloeding, impact, correlatie, ... (zie hierover Tacc, 1980: 3 e.w.). Omdat dit onderzoek over kennis van kankerpreventie exploratief beschrijvend van aterd is en we bijgevolg geen oorzakelijkheid wensen of trachten aan te tonen, maar ankel zoeken naar de samenhangen tussen de variabelen, gebruiken we hier de algemene termen correlatis, samenhang of associatie. Deze termen hebben een neutrale betekenis... 
wordt een complementaire keuze gemaakt voor een methode die een berekening mogelijk maakt wan de intensiterit van de samenhang tussen de variabelen, de zgn. associatiematen.

De keuze voor zowel de significantietoetsen, als voor de associatiematen werd bepaald door drie basiscriteria (zie ondermeer Tacq, 1980: 16-29; zie ook Schreuder, 1991):

1. Het meetniveau van de variabelen. Zijn de variabelen interval, ordinaal of nominalal geschaald? En indien het nominale of ordinale variabelen betreft, wit hoeveel categorieën bestaan de variabelen?

2. De populatie. Welke vorm heeft de verdeling van de populatie? Is de populatie normaal verdeeld of is ze dat niet?

3. De richting van een verband. Wordt er gezocht naar een symmetrisch of een asymmetrisch verband? Betreft het een wederzijdse samenhang of betreft het een oorzakelijk of predictief verband?

De eerste twe basiscriteria bepalen vooral de keuze tussen de parametrische of niet parametrische toetsen. De niet-parametrische toetsen stellen geen eisen aan de vorm van de verdeling van de populatie. Bekende niet-parametrische toetsen die in dit proefschrift worden gebruilkt zijn de Chi-kwadraat toets, de Mann-Whitney toets, de Kruskal-Wallis toets en de Kolmogorov-Smirnov toets.

Bij het meten wan een statistisch verband tussen twee variabelen, kunnen zich twee situaties voordoen: ofwel is de relatie van symmetrische, ofwel van asymmetrische aard. In het eerste geval wordt de richting van het verband tussen beide variabelen niet nader gespecificeerd; in het tweede geval wordt op theoretische gronden aangenomen dat er een effect uitgaat van de ene variabele op de andere variabele. Kendall's tau gaat uit van een wederzijds of symmetrisch verband tussen de variabelen. Voor dit onderzoek van de kennisschalen, wordt er veelvuldig van deze associatiemaat gebruik gemaakt.

Op basis van deze drie basiscriteria kan voor elke bivariate probleemstelling relatief gemakkelijk de meest adequate keuze worden gemaakt voor zowel de presentatietechniek, als voor de associatiemaat en de bijpassende significantietoets. De kennisschalen worden daarbij beschouwd als variabelen met minimaal een ordinaal meetriveau. Voor bepaalde analyses wordt evenwel van de premisse uitgegaan dat deze variabelen op een quasi interval niveau zijn gemeten, zodat gebruik kan worden gemaakt van toetsen van hogere efficièntie, de zogenaamde parametrische toetsen (zie hoger).

Bij de analyse van de onderzoeksresultaten wordt er meer in concreto teruggekomen op de keuze van deze analysetechnieken.

Tenslotte dient hier ook een opmerking te worden gemaakt over de toepassing van de significantietoetsen. Omdat er in dit onderzaek wordt gewerkt met een representatieve steekproef, zijn deze toetsen bijzonder belangrijk. Zij maken immers uit of de gevonden verbanden in de steekproefpopulatie al dan niet mogen worden veralgemeend naar de 
onderzoekspopulatie. De kans op het trekken van foutieve conclusies over de generalisering van de onderzoeksresultaten lde onbetrouwbaarheidsdrempel of het significantieniveaul wordt beperkt gehouden tot de in de sociale wetenschappen traditioneel aanvaarde $5 \%$ grens (alpha $=.05$ ). Als de p-waarde van de gebruikte significantietoets kleiner is dan deze alpha, zal worden besloten dat het verband significant is. Indien er andere significantieniveau's worden gehanteerd, zullen steeds volgende aanduidingen worden gebruikt :

$$
\begin{aligned}
* & =p<.05 \\
* & =p<.01 \\
* * & =p<.001
\end{aligned}
$$





\title{
Hoofdstuk 5
}

\section{Kennis van kankerpreventie: beschrijvende onderzoeksresultaten'}

\author{
5.1 Onderzoeksvragen en -verwachtingen \\ 5.2 Overzicht en operationalisering van het onderzoeksmateriaai: \\ de kennisvariabelen inzake kankerpreventie \\ 5.3 Kennis van primaire kankerpreventie \\ 5.4 Kennis van secundaire kankerpreventie \\ 5.5 Kennis van de richtlijnen inzake vroegtijdige opsporing van \\ borst-en baarmoederhalskanker \\ 5.6. Samenvatting en discussie
}

Inleiding. In dit hoofdstuk wordt er nagegaan of de Vlaamse bevolking een adequate kennis van kankerpreventie heeft. Aan de hand van het onderzoeksmateriaal is een vergelijking mogelijk tussen kennis van primaire en kennis van secundaire kankerpreventie. Er kan tevens worden nagegaan welke indicator het meest of het minst bijdraagt tot deze verworven kennis van kankerpreventie.

Met de beschrijvende analyses in dit hoofdstuk wordt een eerste aanzet gegeven tot het beantwoorden van de algemene onderzoekswraag II (zie hoofdstuk 1). In hoofdstuk 6 geven de verdergaande analyses - die zullen worden gebaseerd op meer-item-schalen definitievere en meer betrouwbare antwoorden.

Verder wordt in dit hoofdstuk de kennis van secundaire kankerpreventie ook geëxploreerd aan de hand van een aantal vragen die toetsten naar de kennis van de richtlijnen voor de vroegtijdige opsporing van borst- en baarmoederhalskanker via respectievelijk het borstzelfonderzoek, hett klinisch borstonderzoek, de mammografie en het baarmoederhalsuitstrijkje.

De keuze om borst- en baarmoederhalskankerpreventie wat meer aandachit te geven bij de exploratie van de data is niet toevallig. Het zijn immers die kennisdomeinen waaraan in Vlaanderen onder impuls van de Vlaamse Adviescommissie voor Kankerpreventie de

De volgende personen worden in het bijzonder bedankt voor hun feedback op de beschrijwendle resultaten van de "kennismetingen": Dr. W. Distelmans (Radiotherapeut) en Prof. dr. B. Van Camp (Hematoloag) van het Oncologisch Centrum van de Vrije Universiteit Brussel; Drs. M. Matthijsen (Gezondheidswetenschapper), Drs. G. Van Hal (Socioloog) en Prof. Dr. J. Weyler (Arts - Epidemioloog) wan het Centrum voor Kankerpreventie van de Uniwersitaire Instelling Antwerpen. 
afgelopen 15 jaar prioritaire aandacht werd besteed in het kader van kankerpreventiecampagnes. Deze gegevens kunnen bijgevolg worden beschouwd als potentiele parameters voor een effectevaluatie van deze campagnes.

Alvorens in te gaan op de beschrijvende analyses van kennis van kankerpreventie wordt in paragraaf 5.1 eerst ingegaan op de onderzoeksvraag die in dit hoofdstuk centraal staat. Vervolgens wordt in paragraaf 5.2 een overzicht gegeven van het onderzoeksmateriaal dat voor deze analyses beschikbaar is. In paragraaf 5.3 wordt een beschrijwende analyse gemaakt van de variabelen die kennis van primaire kankerpreventie meten en in paragraaf 5.4 komern de variabelen aan bod die kennis van secundaire kankerpreventie meten. In paragraaf 5.5 wordt verder ingegaan op de kennis van de richtlijnen inzake vroegtijdige opsporing van baarmoederhalskanker en borstkanker. Tenslotte wordt er in paragraaf 5.6 een synthese gemaakt van de gevonden resultaten en worden hieraan enige beschouwingen gewijd.

\subsection{Onderzoeksvragen en -verwachtingen}

De algemene onderzoeksvraag II "Heeft de Vlaamse bewolking een adequate kennis van kankerpreventie?" (zie hoofdstuk 1) kan worden gedifferentieerd in een aantal meer precieze onderzoekswragen :

1. Zijn er binnen de kennis van kankerpreventie bepaalde kennisdomeinen of aspecten van kankerpreventie beter gekend dan andere domeinen of andere aspecten?

2. Bestaan er misvattingen over kankerpreventie?

3. Kan de Vlaarnse bevolking factoren die echt iets te maken hebben met kankerpreventie goed onderscheiden van factoren die geen rol spelen bij kankerpreventie?

In dit hoofdstuk worden twee kennisdomeinen systematisch onderzocht: kennis van primaire kankerpreventie en kennis van secundaire kankerpreventie.

Bij de analyse van de gegevens worden twee algemene onderzoekswerwachtingen voorop gesteld:

1. In Vlaanderen wordt er reeds langer aandacht besteed aan secundaire dan aan primaire kankerpreventie, en gaat er in het kader van preventiecampagnes ook meer aandacht naar secundaire dan naar primaire kankerpreventie. Op grond hiervan wordt verwacht dat er bij de bevolking meer kennis van secundaire dan van primaire kankerpreventie aanwezig is.

- Kennis van kankerpreventie: beschrijvende onderzoeksresultaten - 
2. In de tweede plaats wordt verwacht dat op grond van de jarenlange en steeds groter wordende aandacht voor kankerpreventie in onze samenleving de medisch gewenste of "juiste" items in het algemeen beter gekend zijn dan de medisch ongewenste of 'foutieve' items. Een omglekeerd resultaat zou immers betekenen dat ofwel de doeltreffendheid van de preventiecampagnes sterk in vraag moet worden gesteld, ofwel de validiteit van deze metingen sterk moet worden betwijfeld.

De algemene onderzoeksverwachtingen worden beantwoord aan de hand van de resultaten van de beschrijvende statistische ananalyses van de herkenning van de kennisitems inzake kankerpreventie (zie hoofdstuk 3).

\subsection{Overzicht en operationalisering van het onderzoeksmateriaal: de kennisvariabelen inzake kankerpreventie}

Alle hier behandelde kennisitems zijin gebaseerd op de in hoofdstuk 3 ontwikkelde "Kennis van kankerpreventie 100 items vragenlijst". Uit de 100 kennisitems dienden de respondenten de juiste items te herkennen. De herkenning door de respondenten gebeurde met een beoordeling van de woorgelegde items aan de hand van een symmetrische Likertschaal met vijf antwoardmogelijkheden.

Op deze wijze konden de respondenten de herkenning van een item met betrekking tot kankerpreventie met een bepaalde zekerheid aanduiden en kon er een genuanceerd beeld worden verkregen van de kennis van kankerpreventie in Vlaanderen. De antwoordcodes $1 \mathrm{t} / \mathrm{m} 5$ werden t.b.v. schaalconstructie gehercodeerd tot scores gaande van -2 tot +2 .

Vrijwell alle 1631 respondenten hebben geantwaord op de 100 vragen van de 'Kennis van kankerpreventie 100 items vragenlijst'. Slechts vier vragen kenden een selectieve nonrespons van én respondent. Zoals hoger in hoofdstuk 4 aangegeven kregen deze nonresponders op het betreffende item de waarde 3 en na hercodering de neutrale score o. Bij samenvoeging (optellen of aftrekken) met andere items heeft de waarde 0 immers geen positieve of negatieve invloed op de totaalscore, zodat de kennismeting bil de nonresponders noch in positieve, noch in negatieve richting wordt beinvloed. Na deze (beperkte) ingreep hadden alle respondenten een waarde op alle 100 items, zodat hun scores met elkaar vergeleken konden worden, alsook bij elkaar samenvoegbaar werden ten behoeve van de constructie van de kennisschalen (zie hoofdstuk 6).

De kennis van de richtlijnen voor de vroegtijdige opsporing van borst- en baarmoederhalskanker kan worden onderzocht door de kennis te toetsen van enerzijds de aambevolen "frequentie" van deze opsporingsonderzoeken en anderzijds van de aanbevolen 'aanvangsleeftijd'. De kennis van de 'frequentie' of het aanbevolen interval van de vroegtijdige opsporinglsonderzoeken werd getoetst door de vraag:

\footnotetext{
"Hoe vaak dient ...[naam wan het onderzoek]... volgens u te gebeuren ?"
} 
De respondenten konden (afhankelijk van het opsporingsanderzoek) het juiste antwoord kiezen wit een lijst van 5 a 6 antwoordmogelijkheden. Ten behoeve van de analyse werden de antwoorden telkens gehercodeerd in 3 klassen:

1. "minder vaak dan aanbevolen', dit zijn bijgevolg respondenten met een verhoogde kans op onderscreening;

2. "volgens de richtlijn", dit zijn de respondenten die een antwoord hebben gekozen conform aan de richtlijn;

3. "vaker dan aanbevollen", dit zijn bijgevolg respondenten met een verhoogde kans op overscreening.

Verder werd ook de kennis van de 'aanwangsleeftijd' bevraagd voor mammografie en baarmoederhalsuitstrijkje. Deze kennis werd getoetst door de vraag:

"Vanaf welke leeftijd dient ...[naam van het anderzoek]... volgens u te gebeuren ?"

De respondenten konden het juiste antwoord kiezen uit een lijst van 9 antwoordmogelijkheden, beginnende bij 20 jaar en eindigend bij 60 jaar. Voor de analyse werden deze antwoorden gehercodeerd in de volgende 3 klassen:

1. 'oudere leeftijd dan aanbevolen', dit zijn bijgevolg respondenten met een verhoogde kans op anderscreening:

2. 'volgens de richtlijn', dit zijn de respondenten die een antwoord hebben gekozen conform aan de richtilin;

3. 'jongere leeftijd dan aanbevolen", dit zijn de respondenten met een verhoogde kans op overscreening.

\subsection{Kennis van primaire kankerpreventie}

Kennis van primaire kankerpreventie werd onderzocht door twee indicatoren, namelijk kennis van de risicofactoren voor kanker en kennis van het gewenst kankerpreventief gedrag. Beide indicatoren worden in deze paragraaf besproken.

In tabel 5.9 (zie bijlage 3) wordt in volgorde van voarkomen in de vragenlijst een overzicht gegeven van de scoreverdeling van alle - dus ook de foutieve items - aan de respondenten voorgelegde items met betrekking tot risicofactoren van kanker. In kolom 2 van tabel 5.9 wordt de rangorde van de items weergegeven. De rangorde is gebaseerd op de gemiddelde zekerheidsscore $M(\min .1, \max .5)$ die in kolom 3 wordt afgedrukt. De hoogste gemiddelde zekerheidsscore wordt toegekend aan het item dat door de onderzoeksgroep met dle grootste zekerheid wordt herkend als risicofactor voor kanker en dus het dichtst de absolute zekerheïd van score 5 benadert. De standaardafwijking van dit gemiddelde is vermeld in kolom 4. De overige kolommen geven het aantal respondenten weer, volgens de gekozen zekerheidsscire bij de herkenning van het item als risicofactor van kanker. In tabel 5.1 worden enkel de acht 'juiste' risicofactoren voor 
kanker gepresenteerd volgens de rangorde van hun herkenning door de respondenten. Deze tabel is samengesteld op basis van gegevens uit tabel 5.9 in bijlage 3 .

In de tweede kolom van tabel 5.1 wordt het percentage respondenten vermeld dat de risicofactor heeft herkend (score $4+5$ ). Zes van de acht risicofactoren worden door een meerderheid van de respondenten herkend. Roken wordt door bijna $95 \%$ van de mensen herkend als risico van kanker. Toch is het verbazend dat $5 \%$ hierover nog twijfelt of zelfs eerder geneigd is dit niet te (willen) geloven. Deze groep heeft het volgende profiel : het zijn hoofdzakelijk rokers congeveer $60 \%$, versus $30 \%$ in de totale populatie) en mannen $166 \%$, versus $49.9 \%$ in de totale populatie). Overdadige blootstelling aan de zon, passief roken en overmatig alcoholgebruik worden door meer dan tweederde van de respondenten herkend als risico van kanker.

Tabel $\mathbf{5 . 1}$

Rangorde van de acht "juiste" risicofactoren voor kanker volgens hun herkenning door de respondenten (in \%), naar zekerheidsscore $(n=1631$ )

\begin{tabular}{|c|c|c|c|c|c|c|c|}
\hline Risicofactor voor kanker : & $\%$ & $\begin{array}{c}\text { rang } \\
1.25\end{array}$ & score 1 & sicore2 & $\begin{array}{c}\text { score } 3 \\
-+\end{array}$ & $\begin{array}{l}\text { score } 4 \\
+\end{array}$ & $\begin{array}{c}\text { score } 5 \\
++\end{array}$ \\
\hline roken & 94.4 & 1 & 0.8 & 1.0 & 3.8 & 19.9 & 7.4 .5 \\
\hline overdadige blootstelling aan de zon & 81.9 & 2 & 2.6 & 3.6 & 12.0 & 47.3 & 34.6 \\
\hline $\begin{array}{l}\text { passief roken; of blootstelling aan } \\
\text { tabaksrook uit de directe omgeving }\end{array}$ & 76.8 & 3 & 1.9 & 6.0 & 15.3 & 42.9 & 33.8 \\
\hline overmatig gebruilk van alcohol & 67.9 & 4 & 3.9 & 9.1 & 19.1 & 41.9 & 25.9 \\
\hline $\begin{array}{l}\text { overmatig gebruik wan dierlijke vetten } \\
\text { in de voeding }\end{array}$ & 57.3 & 6 & 4.6 & 12.9 & 25.2 & 41.4 & 15.9 \\
\hline $\begin{array}{l}\text { seksualle omgang met meerdere } \\
\text { partners zondier condloom; als risico } \\
\text { woor vrouwen }\end{array}$ & 52.1 & 9 & 15.0 & 14.5 & 18.4 & 26.1 & 26.0 \\
\hline z.wwatarlijvigheid & 36.4 & 14 & 11.9 & 22.6 & 29.1 & 29.9 & 6.6 \\
\hline $\begin{array}{l}\text { eerste kind na de leeftijd wan } 30 \text { jaar, } \\
\text { als risico voor vrouwen }\end{array}$ & 13.5 & 20 & 24.7 & 32.6 & 29.1 & 11.5 & 2.0 \\
\hline
\end{tabular}

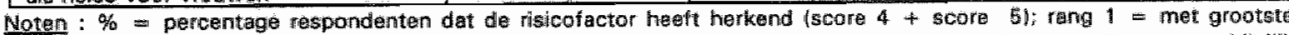

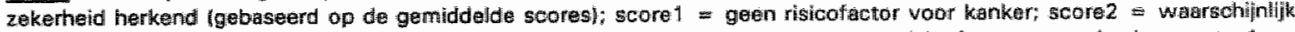
geren risicofactor voor kanker; score3 3 misschien niet, misschien wel een risicofactor voor kanker; sconed =

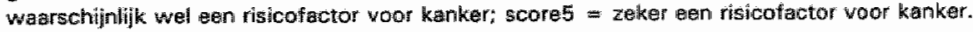

"Overmatig gebruik van dierlijke vetten" en "seksuele omgang met meerdere partners zonder condoom" (als risico voor vrouwen op baarmoederhalskanker) worden minder vaak herkend, doch halen toch nog de helft wan het aantal respondenten. Een zeer matige herkenning als risicofactor krijgen de items "zwaarlijvigheid" $(36 \%)$ en een "eerste kind na de leeftijd van 30 jaar" (als risico voor vrouwen) $(13 \%$ ). 
De laatste kolom van tabel 5.1 geeft de respondenten (in \%) weer die de overeenkomstige risicofactor enkel met 'zekerheid' hebben herkend. In tegenstelling tat de gegevens uit kolom twee, laten deze cijfers een minder gunstig beeld zien van de kennis van de Vlamingen omtrent de herkenning van risicofactoren van kanker. Van alle risicofactoren wordt enkel roken door een grote meerderheid met zekerheid herkend als risicofactor. Alle overige risicofactoren worden variërend van $35 \%$ tot amper $2 \%$ "met zekerheid" herkend.

De derde kolom van tabel 5.1 geeft de rangorde weer binnen de lijst van alle 25 items. De rangorde is gebaseerd op de gemiddelde zekerheidsscore, zoals wordt gepresenteerd in kolom 3 wan tabel 5.9. De acht juiste risicofactoren zouden bij een adequate kennis ervan door de bevolking normalal de eerste acht plaatsen moeten innemen in deze rangorde. In tabel 5.1 valt op dat de laatste drie risicofactoren buiten deze top acht vallen. Deze risicofactoren worden dus minder vaak herkend als risicofactor dan sommige foutieve risicofactoren (zie tabel 5.9 in bijlage 3). Seksuele omgang met meendere partners zonder condoom (als risico voor vrouwen) wordt voorafgegaan door drie foutieve of vermeende risicofactoren, namelijk het niet verzorgen van een huidontsteking (rang 5), het niet verzorgen van een aanhoudende diarree (rang 7) en veelvuldig zwemmen in bezoedeld watar (rang B). De risicofactor "zwaarlijvigheid" komt pas op de 14 de rang en wordt voorafgegaan door 7 foutieve risicofactoren. Een eerste kind na de leeftijd wan 30 jaar staat slechts op rang 20 en wordt dus qua herkenning door de meeste foutieve risicofactoren voorafgegaan. Eén op vier respondenten $(24.7 \%)$ denkt zelf dat dit "zeker" geen risicofactor is van kanker.

Hoewel de kennis van vijf van de acht "juiste" risicofactoren voor kanker significant verschillend is naar geslacht (zie tabel 5.13 in bijlage 3), is dit kennisverschil enkel substantieel voor de herkenning van 'overdadige blootstelling aan de zon" en 'seksuele omgang met meerdere partners zonder condoom; als risico voor vrouwen" als risico's voor kanker: deze risicofactoren worden door 10\% meer vrouwen dan mannen herkend $186.9 \%$ versus $76.9 \%$ voor 'overdadige bloatstelling aan de zon" en $57.1 \%$ versus $47.2 \%$ voor 'seksuele omgang met meerdere partners zonder condoom; als risico voor vrouwen").

In dit domein van kennis van kankerpreventie worden ook misvattingen vastgesteld. Zeven van de 17 foutieve of vermeende risicofactoren hebben een gemiddelde score groter dan 3 (zie " $M$ "in kolom 3 van tabel 5.9 in bijlage 3). Dit betekent dat de "gemiddelde respondent" denkt dat het eerder wél dan niet een risicofactor van kanker is (zie tabel 5.9 in bijlage 3). Het betreft respectievelijk in volgorde van zekerheid van (foutieve) herkenning: niet verzorgen van een huidontsteking $(M)=3.54)$, niet verzorgen van een aanhoudende diarree $(M=3.48)$, veelvuldig zwemmen in bezoedeld water $(M=3.35)$, overmatig gebruik van antibiotica $(M=3.15)$, seksuele omgang met meerdere partners zonder condoom als risico voor mannen $(M=3.11$, niet verzorgen van een keelontsteking $(M=3.08)$ en overmatig gebruik van laxeermiddelen t.b.v. de ontlasting $(M=3.002)$. Niet verzorgen van een huidontsteking en niet verzorgen van een aanhoudende diarree worden zelfs door een meerderheid van de respondenten gescoord als "wellicht wel" of "zeker" een risicofactor voor kanker (respectievelijk $60.5 \%$ en $56.0 \%$ ). 
Tabel 5.10 (zie bijlage 3 ) is opgebouwd zoals tabel 5.9 . In tabel 5.2 wordt tabel 5.10 gereduceerd weergegeven. Er worden enkel de acht gewenste kankerpreventieve gedragingen gepresenteerd volgens de rangorde van hun herkenning door de respondenten.

\section{Tabel 5.2}

Rangorde van de acht "juiste" gewenste kankerpreventieve gedragingen volgens hun herkenning door de respondenten (in \%), naar zekerheidsscore $(n=1631)$

\begin{tabular}{|l|c|c|c|c|c|c|c|}
\hline Kankerpreventilef gedrag: & $\%$ & $\begin{array}{c}\text { rang } \\
\text { K.25 }\end{array}$ & $\begin{array}{c}\text { score1 } \\
-\end{array}$ & $\begin{array}{c}\text { score2 } \\
-\end{array}$ & $\begin{array}{c}\text { score3 } \\
+\end{array}$ & $\begin{array}{c}\text { score4 } \\
+\end{array}$ & $\begin{array}{c}\text { score5 } \\
++\end{array}$ \\
\hline stoppen met roken of niet roken & 94.1 & 1 & 1.0 & 0.7 & 4.2 & 18.0 & 76.1 \\
\hline $\begin{array}{l}\text { overdadige blootstelling aan de } \\
\text { zon vermijden }\end{array}$ & 87.3 & 2 & 1.7 & 3.2 & 7.7 & 37.6 & 49.7 \\
\hline regelmatig eten van vers fruit & 82.9 & 3 & 2.1 & 5.8 & 9.2 & 34.7 & 48.2 \\
\hline $\begin{array}{l}\text { regelmatig eten van verse } \\
\text { groenten }\end{array}$ & 82.5 & 4 & 3.2 & 4.8 & 9.4 & 39.3 & 43.2 \\
\hline $\begin{array}{l}\text { met mate drinken van } \\
\text { alcoholische dranken }\end{array}$ & 71.5 & 6 & 3.4 & 9.0 & 16.1 & 40.2 & 31.3 \\
\hline $\begin{array}{l}\text { vermijden van overgewicht } \\
\text { regelmatig eten van bruin brood }\end{array}$ & 61.7 & 13 & 5.4 & 11.0 & 21.8 & 39.1 & 22.7 \\
\hline $\begin{array}{l}\text { regelmatig eten van ongepelde } \\
\text { rijst }\end{array}$ & 40.3 & 20 & 5.1 & 16.9 & 37.7 & 26.5 & 13.9 \\
\hline
\end{tabular}

Noten : \% = percentage respondenten dat het gewenst kankerpreventief gedrag heeft herkend (score $4+5 c 0 r e 5 \mathrm{k}$; rang $1=$ met grootste zekerheid herkend (gebaseerd op de gemiddelde scores); sconel = zeker geien kankerpreventief gedrag: score2 = warsichünlijk geen kankerpreventief gedrag; score3 $=$ misschien niet, misschien weil een kankerpre-ventief gedrag; score4 = waarschijnlijk wel een kankerprewentief gedrag; score5 = zeker een kankerpreventief gedrag

In de tweede kolom van tabel 5.2 wordt het percentage respondenten vermeld dat het gewenste kankerpreventieve gedrag heeft herkend (score $4+5$ ). Zeven van de acht kankerpreventieve gedragingen worden door een meerderheid wan de respondenten herkend. "Stoppen met roken" wordt door $94 \%$ van de mensen herkend als kankerpreventief gedrag. Overdadige blootstelling aan de zon vermijden, regelmatig eten van vers fruit en regelmatig eten van verse groenten worden door meer dan $80 \%$ herkend als gewenst gedrag; en met mate drinken van alcohol en vermijden van overgewicht door meer dan tweederde van de respondenten. Regelmatig eten van bruin brood $(60 \%)$ en regelmatig eten van ongepelde rijst $(40 \%)$ worden minder vaak herkend als preventief gedrag.

De laatste kolom van tabel 5.2 geeft de respondenten (in \%) weer die het gewenste kankerpreventieve gedrag enkel 'met zekerheid' hebben herkend. In tegenstelling tot de gegevens uit kolom twee, laten deze cijfers een minder gunstig beeld zjen van de kennis 
van de Vlamingen orntrent de herkenning van de gewenste kankerpreventieve gedragingen. Van alle gewenste kankerpreventieve gedragingen wordt enkel "stoppen met roken" door een grote meerderheid $(76 \%)$ met zekerheid herkend. Alle averige kankerpreventieve gedragingen worden slechts door een minderheid van de respondenten met zekerheid herkend als gewenst preventief gedrag. Het aantal varieert sterk: van $49.7 \%$ voor "overdadige blootstelling aan de zon vermijden" tot amper 13.9 $\%$ voor "regelmatig eten van ongepelde rijst".

De derde kolom van tabel 5.2 geeft de rangorde weer binnen de lijst van alle 25 items. De rangorde is gebaseerd op de gemiddelde zekerheidsscore, zoals wordt gepresenteerd in kolom 3 van tabel 5.10 in bijlage 3. De acht "juiste" kankerpreventieve gedragingen zouden bij een adequate kennis ervan door de bevolking normaal de eerste acht plaatsen moeten innemen in deze rangorde. In tabel 5.2 valt op dat de laatste drie kankerpreventieve gedragingen buiten deze top acht vallen. Deze kankerpreventieve gedragingen worden dus minder vaak herkend als gewenst preventief gedrag dan sommige foutieve vermeende kankerpreventieve gedragingen (zie tabel 5.10 in billage 3). Vermijden van overgewicht (rang g) wardt voorafgegaan door drie foutieve kankerpreventieve gedragingen, namelijk het vermijden van stress (rang 51, regelmatig eten van vis (rang 7 ) en en goede huidverzorging (rang 8). Het gewenst kankerpreventief gedrag "regelmatig eten van bruin brood" komt pas op de 13 de rang en wordt voorafgegaan door 6 foutieve kankerpreventieve gedragingen. Regelmatig eten van ongepelde rijst staat slechts op rang 20 en wordt dus qua herkenning door de meeste foutieve risicofactoren voorafgegaan. Eén op vijf respondenten ( $22 \%$ ) denkt zelf dat dit "zeker" of "wellicht" geen kankerpreventief gedrag is.

Hoewel de kennis van viff van de acht "juiste" gewenste kankerpreventieve gedragingen significant verschillend is naar geslacht (zie tabel 5.13 in bijlage 3), is dit kennisverschil enkel substantieel voor de herkenning van "regelmatig eten van bruin brood" en 'regelmatig eten van ongepelde rijst'. Regelmatig eten van bruin brood wordt door $11.6 \%$ meer vrouwen dam mannen herkend als een gewenst kankerpreventief gedrag (respectievelijk door $67.5 \%$ en $55.9 \%$ ). Regelmatig eten van ongepelde rijst wordt door $8.5 \%$ meer vrouwen dan mannen herkend als een gewenst kankerpreventief gedrag (respectievelijk $44.6 \%$ en $36.1 \%$ ).

Over de kankerpreventieve gedragingen bestaan er (nog) veel meer misvattingen dan in het kennisdomein van de risicofactoren. Niet minder dan 15 van de 17 foutieve kankerpreventieve gedragingen hebben een gemiddelde score groter dan 3 (zie " $M$ " in kolom 3 van tabel 5.10 in bijlage 3). Dit betekent dat de "gemiddelde respondent" denkt dat het eerder wél dan niet een gewenst kankerpreventief gedrag is (zie tabel 5.10 in bijlage 3). Enkel het "regelmatig gebruik van ijzerpillen" $(M=2.77)$ en "regelmatig eten van pasta's" $(M=2.47)$ worden door de gemiddelde respondent eerder niet dan wel beschouwd als een gewenst kankerpreventief gedrag. 11 van de 17 foutieve kankerpreventieve gedragingen worden zelfs door een meerderheid van de respondenten gescoord als "wellicht wel' of 'zeker' een risicofactor voor kanker (zie score 4 én score 5 in tabel 5.10 van bijlage 3 ). 


\subsection{Kennis van secundaire kankerpreventie}

Kennis van secundaire kankerpreventie werd onderzocht door twee indicatoren, namelijk kennis van de waarschuwingssignalen voor kanker en kennis van de bestaande vroegtijdigle opsporingsonderzoeken voor kanker. De uitkomstvariabelen van beide indicatoren worden in deze paragraaf besproken.

Tabell 5.11 in bijlage 3 is opgebouwd zoals tabel 5.9 . Tabel 5.3 geeft tabel 5.11 in gereduceerde vorm weer. In tabel 5.3 worden enkel de zeven 'juiste' waarschuwingssignalen voor kanker gepresenteerd wolgens de rangorde van hun herkenning door de respondenten.

\section{Tabel 5.3}

Rangorde van de zeven "juiste" waarschuwingssignalen voor kanker volgens hun herkenning door de respondlenten (in $\%)$, naar zekerheidsscore $(n=1631)$

\begin{tabular}{|l|c|c|c|c|c|c|c|}
\hline Waarschuwingssignaal : & $\%$ & $\begin{array}{c}\text { rang } \\
1.25\end{array}$ & $\begin{array}{c}\text { score } \\
-\end{array}$ & $\begin{array}{c}\text { score2 } \\
\text { weore3 } \\
+\end{array}$ & $\begin{array}{c}\text { score4 } \\
+\end{array}$ & $\begin{array}{c}\text { score5 } \\
++\end{array}$ \\
\hline verdikking of knobbeltje in de borst & 90.6 & 1 & 0.2 & 0.5 & 8.7 & 41.0 & 49.7 \\
\hline duidelijke verandering in moedervlek & 74.2 & 2 & 1.7 & 4.0 & 20.1 & 39.7 & 34.5 \\
\hline onverklaarbare gewichtsvermindering & 73.0 & 3 & 1.7 & 3.8 & 21.0 & 47.3 & 25.8 \\
\hline $\begin{array}{l}\text { abnormaal anaal of vaginaal bloed- } \\
\text { verlies (via aars of schede) }\end{array}$ & 69.4 & 4 & 1.8 & 3.9 & 24.9 & 47.5 & 21.9 \\
\hline $\begin{array}{l}\text { aanhoudende wijziging in plas- of } \\
\text { stoelgangpatroon }\end{array}$ & 57.3 & 5 & 3.5 & 7.6 & 31.6 & 44.5 & 12.8 \\
\hline $\begin{array}{l}\text { aanhoudende hoest of heesheid } \\
\text { een wonde die niet geneest }\end{array}$ & 52.1 & 6 & 4.8 & 12.3 & 30.8 & 38.4 & 13.7 \\
\hline
\end{tabular}

Naten: = percentage respondenten dat het watschuwingsignal voor kankar heoft herkend lscora $4+$ score 5 ): rang 1 met grootste zekarheid herkend lgebaseerd op de gemiddelde scoresh; score1 a zoker geen

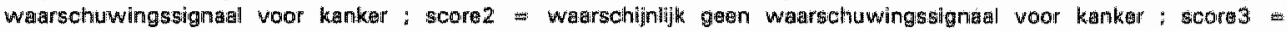

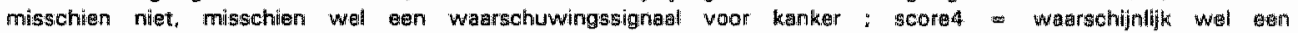

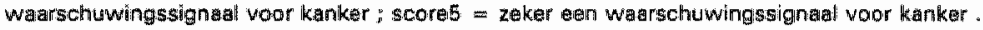

In de tweede kolom van tabel 5.3 wordt het percentage respondenten vermeld dat het waarschuwingssignaal voor kanker heeft herkend (score $4+5$ ). Alle zeven waarschuwingssignalen worden door een meerderheid van de respondenten herkend. Een verdikking of knobbeltje in de borst wordt door $90 \%$ van de personen herkend als waarschuwingssignaal voor kanker. Een duidelijke verandering in een moedervlek ${ }_{*}$ een onverklaarbare gewichtsvermindering en abnormaal anaal of vaginaal bloedverlies worden door tweederde à drie kwart van de respondenten herkend als waarschuwingssignalen voor kanker. Een aanhoudende wijziging in thet plas- of stoelgangpatroon, een aanhoudende hoest of heesheid en een wonde die niet geneest 
worden minder vaak herkend, doch halen toch nog meer dan de helft van het aantal respondenten. Deze cijfers tonen een gunstig beeld van de kennis van de waarschuwingssignalen voor kanker in Vlaanderen.

De laatste kolom van tabel 5.3 geeft de respondenten (in \%) weer die het betreffende waarschuwingssignaal enkel 'met zekerheid' hebben herkend. In tegenstelling tot de gegevens uit kolom twee, laten deze cijfers een minder gunstig beeld zien van de kennis van de Vlamingen omtrent de herkenning van de waarschuwingssignalen van kanker. Van alle waarschuwingssignalen wordt er geen enkel door een meerderheid "met zekerheid" herkend als waarschuwingssignaal. Enkel een verdikking of kobbeltje in de borst wordt (bijna) door een meerderheid van de respondenten met zekerheid herkend als. waarschuwingssignaal.

De derde kolom van tabel 5.3 geeft de rangorde weer binnen de liist van alle 25 items. De rangorde is gebaseerd op de gemiddelde zekerheidsscore, zoals wordt gepresenteerd in kolom 3 van tabel 5.11 in bijlage 3. De zeven 'juiste' waarschuwingssignalen zouden bij een adequate kennis ervan door de bevolking normaal de eerste zeven plaatsen moeten innemen in deze rangorde. Tabel 5.3 toont inderdlaad dat dit in dit onderzoek zo werd vastgesteld. Er is geen enkel foutief waarschuwingssignaal dat vaker wordt herkend als waarschuwingssignaal van kanker als de in de vragenlijst opgenomen juiste waarschuwingssignalen. In vergelijking met de risicofactoren en het gewenst kankerpreventief gedrag blijken de waarschuwingssignalen van kanker bijgevolg relatief goed gekend te zijn.

De zeven 'juiste' waarschuwingssignalen voor kanker zijn allen significant meer gekend door vrouwen dan door mannen (zie tabel 5.13 in bijlage 3). Het kennisverschil is vooral substantieel voor de herkenning van 'een aanhoudende wijziging in plas- of stoelgangpatroon" en 'duidelijke verandering in een moedervlek'. Een aanhoudende wijziging in plas- of stoelgangpatroon wordt door $8.9 \%$ meer vrouwen dan mannen herkend als waarschuwingssignaal van kanker (respectievelijk door $61.7 \%$ en $52.8 \%$ ). Een duidelijke werandering in een moedlervlek wordt door niet minder dan $20.8 \%$ meer vrouwen dan mannen herkend als waarschuwingssignaal van kanker (respectievelijk $84.5 \%$ en $63.7 \%$. Een duidelijke verklaring voor dit zeer opmerkelijk verschil hebben we niet.

In dit domein van kennis van kankerpreventie worden ook relatief weinig misvattingen over de waarschuwingssignalen van kanker vastgesteld. Slechts 3 van de 18 foutieve of vermeerde waarschuwingssignalen hebben een gemiddelde score groter dan 3 (zie " $\mathrm{M}$ " in kolom 3 van tabel 5.11 in bijlage 3), hetgeen betekent dat de "gemiddelde respondent" denkt dat het voorgelegde item eerder wél dan niet een waarschuwingssignaal van kanker is (zie tabel 5.11 in bijlage 3). Het betreft respectievelijk in volgorde van zekerheid van (foutieve) herkenning : braakneigingen en maagstoornissen $(M=3.16)$, een gevoel van verminderde energie $(M=3.14)$ en een gebrekkige eetlust $(M=3.06)$. Bovendien wordt ook geen enkel foutief waarschuwingssignaal door een meerderheid van de respondenten gescoord als "wellicht wel' of "zeker" een waarschuwingssignaal voor kanker (respectievelijk score 4 en score 5).

- Kennis van kankerpreventie: beschrijvende onderzoeksresultaten - 
Tabel 5.4

Rangorde van de zeven 'juiste' medische onderzoeken voor vroegtijdige opsporing van kanker volgens herkenning door de respondenten (in \%), naar zekerheidssicore $(\mathbf{n}=1631$ )

\begin{tabular}{|c|c|c|c|c|c|c|c|}
\hline $\begin{array}{l}\text { Vroegtiidig opsporingsonderzoelk } \\
\text { wan kanker: }\end{array}$ & $\%$ & $\begin{array}{l}\text { rang } \\
1-25\end{array}$ & score: & score 2 & $\begin{array}{c}\text { score3 } \\
++\end{array}$ & $\begin{array}{l}\text { score } 4 \\
+\end{array}$ & $\begin{array}{c}\text { scores } \\
++\end{array}$ \\
\hline $\begin{array}{l}\text { mammografie voor wrouwen; dit is een } \\
\text { radiografie van de borsten }\end{array}$ & 93.4 & 1 & 0.5 & 0.9 & 5.2 & 27.2 & 66.2 \\
\hline $\begin{array}{l}\text { baarmoederhaisuitstrijkje; dit is met een } \\
\text { spatell slijm van de baarmoederhals } \\
\text { afschrapen }\end{array}$ & 92.2 & 2 & 0.6 & 0.9 & 6.3 & 25.6 & 66.5 \\
\hline $\begin{array}{l}\text { borstonderzoek door de dokter; dit is het } \\
\text { met de vingers onderzoeken van de borst } \\
\text { door de dokter }\end{array}$ & 87.3 & 3 & 0.8 & 2.5 & 9.4 & 37.2 & 50.2 \\
\hline $\begin{array}{l}\text { borstzelfonderzoek woor vrouwen; dit is } \\
\text { het zelf met de vingers onderzoeken van } \\
\text { de borst }\end{array}$ & 82.3 & 5 & 1.1 & 2.9 & 13.7 & 36.7 & 45.6 \\
\hline $\begin{array}{l}\text { huidinspectie door de dokter, bij } \\
\text { veranouerende moedervlek }\end{array}$ & 79.6 & 6 & 1.1 & 3.8 & 15.5 & 41,6 & 38.0 \\
\hline opsporen van bloed in de stoelgang & 77.4 & 7 & 0.9 & 3.7 & 18.0 & 40.2 & 37.2 \\
\hline $\begin{array}{l}\text { rectaal onderzaek; dit is met een vinger } \\
\text { onderzoeken van de dikkedarm via de aars. }\end{array}$ & 64.2 & 10 & 3.5 & 8.1 & 24.2 & 37.2 & 27.0 \\
\hline
\end{tabular}

Noten : \% = percentage respondenten dat het vroegtijdig opsporingsanderzoek voar kanker heeft herkend iscore $4+$ score 5): rang 1 = met grootste zekerheid herkend (gebaseerd op de gemiddelde scores): scorel = zeker geen uroegtijdig opsporingsonderzoek voor kanlker; score:2 = warschijnlijk geen vroegtijd lig opsporingsonderzoek voor kanker; score 3 a misschien nigt, misschien wel een vroegtijdig opsporingsonderzoek voor kanker; score $=$ wa:arschijnlijk wiel een wroegtijdig opsporingsonderzoek vaor kanker; score5 = zekel een vroegtiliflig opsporingsonderzoelk woor kanker.

Tabel 5.12 in bijlage 3 is opgebouwd zoals tabel 5.9 . In tabel 5.4 worden uitsluitend de zeven 'juiste' vroegtijdige opsporingsonderzoeken van kanker gepresenteerd volgens de rangorde van hun herkenning door de respondenten.

In de tweede kolom van tabel 5.4 wordt het percentage respondenten vermeld dat het betreffende vroegtijdige kankeropsporingsonderzoek heeft herkend (scores $4+5$ ). Alle zeven vroegtijdige opsporingsonderzoeken van kanker worden door een meerderheid van de respondenten herkend. Mammografie en baarmoederhalsuitstrijkje worden door meer dan $90 \%$ herkend als vroegtijdig opsporingsonderzoek. Het klinisch borstonderzoek, het borstzelfonderzoek, de huidinspectie door de dokter bij een veranderende moedervlek en het opsporen van bloed in de stoelgang (zgn. hemoculttest) worden door meer dan driekwart van de respondenten herkend als vroegtijdig opsporingsonderzoek van kanker. Enkel het rectaal onderzoek ter opsporing van darmkanker wordt door lets minder personen herkend, doch bereikt toch nog een herkenningcoëfficiënt van $64 \%$.

De laatste kolom van tabel 5.4 geeft de respondenten (in \%) weer die het betreffende vroegtijdig kankeropsporingsonderzoek enkel "met zekerheid' hebben herkend. 
In tegenstelling tot de gegevens uit kolom twee, laten deze ciffers een minder gunstig beeld zien van de kennis van de Vlamingen omtrent de herkenning van vroegtijdige opsporingsonderzoeken van kanker. Van de zeven vroegtijdige opsporingsonderzoeken worden er enkel drie door een grote meerderheid met zekerheid herkend als vroegtijdige karikeropsporingsonderzoek. Het betreft respectievelijk mammografie $(66 \%)$, baarmoederhalsuitstrijkje $(66 \%)$ en het klinisch borstonderzoek (50\%). Alle overige vroegtijdige kankeropsporingsonderzoeken worden variërend van $47 \%$ tot $27 \%$ met zekerheid herkend als vroegtijdige kankeropsporingsonderzoek.

De derde kolom van tabel 5.4 geeft de rangorde weer binnen de lijst van alle 25 items. De rangorde is gebaseerd op de gemiddelde zekerheildsscore, zoals wordt gepresenteerd in kolom 3 van tabel 5.12 in bijlage 3 . De acht "juiste" vroegtijdige kankeropsporingsonderzoeken zouden bij een adequate kennis ervan door de bevolking normaal de eerste acht plaatsen moeten innemen in deze rangorde. In tabel 5.4 valt op dat slechts één vroegtijdig opsporingsonderzoek niet voldoet aan deze verwachting, namelijk het rectaal onderzoek t.b.u. de opsporing van darmkanker. Dit opsporingsonderzoek wordt dus minder vaak herkend als kankeropsporingsonderzoek dan sommige 'foutieve' of vermeende opsporingsonderzoeken van kanker (zie tabel 5.12 in bijlage 3). Het rectaal onderzoek wordt voorafgegaan door drie fautieve vroegtijdige kankeropsporingsonderzoeken, namelijk radiologie van de longen (rang 4), het keeluitstrijkje (rang 8) en de echografie (rang 9).

De 'juiste" vroegtijdige opsporingsonderzoeken voor kanker zijn allen - op uitzondering van het rectaal onderzoek - significant door meer vrouwen gekend dan door mannen fzie tabel 5.13 in bijlage 31. Het verschil tussen mannen en vrouwen in de herkenning als vroegtijdige opsporingsonderzoek varieert van minimum $2.7 \%$ tot maximum $10.3 \%$. Het verschil tussen mannen en vrouwen is vooral substantieel bij de herkenning van het baarmoederhalsuitstrijkje en de huidinspectie bij een veranderende moedervlek als vroegtijdlig opsporingsonderzaek van kanker. Het baarmoederhalsuitstrijkje wordt door $96.5 \%$ van de vrouwen en $87.8 \%$ van de mannen herkend als een vroegtijdig opsporingsonderzoek van kanker. De huidinspectie door de dokter bij een veranderende moedervlek wordt door $84.7 \%$ van de vrouwen en $74.4 \%$ van de mannen herkend als een vroegtijdig opsporingsonderzoek van kanker.

In dit kennisdomein van de vroegtijdige opsporingsonderzoeken van kanker worden duidelijk meer misvattingen vastgesteld dan bij de waarschuwingssignalen. 9 van de 18 foutheve vroegtijdige kankeropsporingsonderzoeken thebben een gemiddelde score groter dan 3 (zie " $M$ " in kolom 3 van tabel 5.12 in bijlage 3 ), hetgeen betekent dat de "gemiddelde respondent" denkt dat het eerder wêl dan niet een vroegtijdige opsporingsonderzoek van kanker is (zie tabel 5.12 in bijlage 3). Het betreft respectievelijk in volgorde van zekerheid van (foutievel herkenning: radiografie van de longen ( $M=4.30)$, keeluitstrijkje $(M=4.03)$, echografie $(M=3.86)$, urine-onderzoek $(M=3.53)$, TBC-test $(M=3.33)$, betasten van de blaas $(M=3.33)$, elektro-encefalogram $(M=3.24)$, bepalen van hormonen in het bloed $(M=3.16)$ en het onderzoek van de longen met een stethoscoop $(M=3.15)$. Vijf van deze opsporingsonderzoeken worden bovendien door een meerderheid van de respondenten gescoord als "wellicht wel" of

- Kennis van kankerpreventie; beschrijvende onderzoeksresultaten - 
'zeker' een vroegtijdige opsporingsonderzoek voor kanker (respectievelijk score 4 en score $5 \%$. Het gaat respectievelijk am de radiografie van de longen (88\%), het keeluitstrijkje $(76 \%)$, de echografie $(70 \%)$, thet urinewonderzoek $(56 \%)$ en de TBC-test $(52 \%)$.

\subsection{Kennis van de richtliinen inzake vroegtiidige opsporing van borst- en baarmoederhalskanker}

De kennis inzake secundaire preventie kan verder geëxploreerd worden door de toetsing van de kennis van een aantal basisrichtlijnen voor de opsporing van baarmoederhalskanker en borstkanker. Er werd in de bevraging gepeild naar de kennis van de voorgeschreven richtlijnen inzake "frequentie" van respectievelijk borstzelfonderzoek, borstonderzoek door de arts, mammografie en baarmoederhalsuitstrijkje. Tevens werd in de bevraging gepelid naar de kennis van de 'aanvangsleeftijd' waarop men volgens de richtlijnen dient te starten met respectievelijk mammografie en baarmoederhalsuitstrijkje.

Als "kennisnormen" voor de toetsing werden criteria geselecteerd die in Vlaanderen worden aanbevolen door de Wetenschappelijke Vereniging der Vlaamse Huisartsen, het Belgisch Werk Tegen Kanker of de Vlaamse Adviescommissie voor Kankerpreventie."

- Een borstzelfonderzoek dient valgens de richtlijnen van de Wetenschappelijke Vereniging der Vlaamse Huisartsen 'maandelijks' te gebeuren (Commissie Preventie, 1990: 238; zie ook Belgisch Werk Tegen Kanker, 19911.

- Een klinisch borstonderzoek of een borstonderzoek bij de huisarts of de gynecoloog dient "om de 1 à 2 jaar" 2 te gebeuren (V.A.C.K., 1985: 56).

- Een mammografie is pas doeltreffend 'vanaf de leeftijd van 50 jaar' en wordt met een 'interval van twee jaar' aanbevolen (Commissie Preventie, 1990: 242; zie ook Belgisch Werk Tegen Kanker, 1991).

当

Al deze richtlijnen zijn bedoeld voor een algemene asymptomatische bevolking, zodat bil de vraagformulering sytematisch de zinsnede "voor vrouwen die geen klachten of een verhoogd risico hebben" werd toegewoegd.

De antwoorden "om het jaar", "om de 18 maanden" en "om de 2 jaar' werden beschouwd als juiste antwoorden en bijgevolg gehercodeerd als "volgens richtijin". 
- Een baarmoederhalsuitstrijkje wordt aanbevolen vanaf seksueel actieve leeftijd met een interval van 3 jaar IV.A.C.K., 1985: 41; zie ook Belgisch Werk Tegen Kanker, 1991). De aanvangsleeftijd kan bijgevolg van vrouw tot vrouw verschillend zijn'.

Tabel 5.5

Kennis van de richtlijnen inzake 'frequentie' van de medische onderzoeken voor yroegtijdige opsporing van borst- en baarmoederhalskanker (in \%)

\begin{tabular}{|c|c|c|c|c|c|}
\hline & $\begin{array}{l}\text { Minder } \\
\text { vaak dan } \\
\text { aanbevo- } \\
\text { llen (1) }\end{array}$ & $\begin{array}{l}\text { Volgens } \\
\text { richthijin }\end{array}$ & $\begin{array}{c}\text { Vaker } \\
\text { dan } \\
\text { aanbewo- } \\
\text { len (2) }\end{array}$ & $N$ & $\begin{array}{l}\text { Weet het niet } \\
\qquad(\mathbb{N}=1631)\end{array}$ \\
\hline Borstzelfonderzoek & 43.9 & 42.3 & 13.8 & 1555 & $4.7 \%(76)$ \\
\hline mannen & 53.3 & 34.9 & 11.8 & \multirow{2}{*}{\multicolumn{2}{|c|}{$* * *$}} \\
\hline vrouwen & 34.8 & 49.6 & 15.6 & & \\
\hline Klinisch Borstonderzoek & 4.0 & 71.5 & 24.6 & 1584 & $2.9 \%(47)$ \\
\hline mannen & 3.7 & 70.8 & 25.4 & \multirow{2}{*}{\multicolumn{2}{|c|}{ n.s. }} \\
\hline vrouwen & 4.2 & 72.1 & 23.7 & & \\
\hline Marnmografie & 18.4 & 26.2 & 55.5 & 1563 & $4.2 \%(68)$ \\
\hline mannen & 15.4 & 25.5 & 59.1 & \multirow{2}{*}{\multicolumn{2}{|c|}{$* *$}} \\
\hline vrouwen & 21.2 & 26.8 & 52.0 & & \\
\hline Baarmoederhalsuitstrijkje & 3.5 & 6.0 & 90.5 & 1574 & $3.5 \%(57)$ \\
\hline mannen & 3.8 & 5.9 & 90.3 & \multirow{2}{*}{\multicolumn{2}{|c|}{ n.s. }} \\
\hline vrouwen & 3.2 & 6.2 & 90.6 & & \\
\hline
\end{tabular}

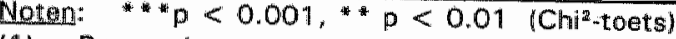

(11) Fespondenten met een verhoogde kans op 'onderscreening'.

(2) Respondenten met een verhoogde kans op 'overscreening".

Tabel 5.5 presenteert het aandeel (in \%) van de respondenten volgens hun kennis van de "frequentie" van vier onderzoeken voor vroegtijdige opsporing van borst- en baarmoederhalskanker. In deze tabel wordt in de laatste kolom ook het aantal

Verondersteld wordt dat vanaf 20 a 25 jaar vrijwel alle vrouwen seksueel actief zijn. Als "juiste" antwoorden ('volgens richtijn') werden bijgevolg de antwoorden 'vanaf 20 jaar' en 
respondenten vermell dat (spontaan) ${ }^{1}$ meldde dat ze het antwoord niet weten. De (frequentie-) antwoorden werden samengevoegd tot drie analytische categorieën, namelijk 'minder vaak dan aanbevolen', 'volgens de richtlijn' en 'vaker dan aanbevolen'. Degenen die een 'foutief' antwoord gaven, werden dus opgesplitst naar een categorie die een te lage frequentie opgaven en een categorie die een te hoge frequentie opgeven. De eerste categorie personen kan worden beschouwd als personen met een verhoogde kans op onderscreening en de tweede categorie als personen met een werhoogde kans op averscreening. Omdat het hier vroegtijdige opsporingsonderzoeken betreft voor typische vrouwellike kankers, worden deze beschrijwende gegevens niet alleen op populatieniveau gepresenteerd, doch ook opgesplitst naar geslacht.

De selectieve nonrespons bij deze vragen bleef in het algemeen vrij beperkt $(3 \mathrm{a} 5 \%)^{2}$.

De aanbevolen frequentie van het borstzelfonderzoek wordt eerder onderschat dan overschat. Vier op tien personen kenden evenwel het juiste antwoord. Er is echter een significant verschil tussen beide geslachten. Bij de vrouwen kent ongleveer de helft het 'juiste' antwoord en bij de mannen daarentegen slechts één op drie. Bij de "onderschatters" zijn het vooral de mannen die het grootste aandeel hebben. Bij de mannen zijn de onderschatters zelfs in de meerderheid $(53 \%)$. In het algemeen genomen wijzen deze resultaten op een grotere kans dat vrouwen zonder adequate kennis over deze richtlijn eerder de neiging tot onderscreening dan tot overscreening zullen hebben. Verder kan op basis van deze kennisresultaten verondersteld worden dat de vrouwen die deze aanbeveling niet kennen weinig kans hebben dat ze door (hun) mannen adequalt zullen worden geinformeerd over deze richtlijn.

De aanbevolen frequentie van het klinisch borstonderzoek is vrij goed gekend door zowel de vrouwelijke als de mannelijke respondenten. De kennis van $71 \%$ van de respondenten beantwoordt aan de richtlijn, $25 \%$ maakt een overschatting en slechts $4 \%$ een onderschatting. Er zijn geen significante verschillen naar geslacht. Wanneer de foutieve antwoorden worden vergeleken, wordt een tendens vastgesteld van overschatting van de frequentie van het klinisch borstonderzoek. De categorie 'overschatters" maakt een substantiële groep uit van respondenten, namelijk ongeveer $25 \%$.

De aanbevolen frequentie van mammagrafie is dan weer veel minder goed gekend. De aanbevolen frequentie van mammografie is in vergelijking met de andere opsporingsonderzoeken de op één na ( $\mathrm{nl}$. nà deze van baarmoederhalskanker) slechtst gekende. Ongeveer een kwart van de personen geven het "juiste' antwoord op deze

Op het antwoordkaartje werd het antwoord "weet het niet" NIET vermeld. De interviewers hadden een uitdrukkelijke instructie om alleen "weet niet' aan te duiden, wanneer dit spontaan werd vermeld door de respandenten.

2

In het vooronderzoek onder studenten - waarin weliswaar wél de mogelijk werd geboden om "weet het niet" te antwoorden - schommelde de selectieve nonrespons op dezelfde wragen tussen de $15.4 \%$ en $29.3 \%$ (Deliens, Louckx en Maes, 1994: 44). 
vraag naar de frequentie van mammografie. Wanneer de foutieve antwoorden worden vergeleken; wordt een duidelijke tendens vastgesteld van overschatting van de frequentie van de mammagrafie. Deze 'overschatters' maken zelfs een meerderheid uit van de onderzochte bevolking, namelijk ongeveer $55 \%$. Vrouwen hebben iets minder de neiging om te behoren tot de overschatters dan de mannen $152 \%$ versus $59 \%$. Het verschil in kennis tussen mannen en vrouwen over de frequentie van de mammografie is significant.

Het baarmoederhalswitstrijkje is het vroegtijdig opsporingsonderzoek waarvan de aambevolen frequentie het slechts is gekend. Slechts $6 \%$ weet het aanbevolen 'juiste" antwoord. Er werden hierbij geen significante verschillen tussen de geslachten aangetroffen. Worden de categorieen die fout antwoorden vergeleken, dan is het resultaat bij het baarmoederhalsuitstrijkje vrij uitgesproken. De meeste respondenten schatten de frequentie van het baarmoederhalsuitstrijkje te hoog in. De "overschatters' maken zelfs meer dan $90 \%$ uit van de populatie. De meeste respondenten denken dus dat er vaker dan nodig naar een huisarts of een gynecoloog moet worden gegaan voor een baarmoederhalsuitstrijkje.

Tabel 5.6 presenteert het aandeel (in \%) wan de respondenten volgens hun kennis van de 'aanvangsleeftijd" voor de vroegtijdige opsporing van borstkanker via mammografie en de vroegtijdige opsporing van baarmoederhalskanker via het uitstrijkje. In tabel 5.6. wordt in de laatste kolom ook het aantal respondenten vermeld dat (spontaan)" meldde dat ze het antwoord niet wisten. Net als bij tabel $5.5 \mathrm{kan}$ de eerste categorie personen worden beschouwd als personen met een verhoogde kans op onderscreening en de tweede categorie als personen met een verhoogde kans op overscreening. Om dezelfde hogervermelde reden - namelijk orndat het hier opsporing van typische vrouwelijke kankers betreft - worden deze beschrijvende gegevens ook opgesplitst naar geslacht.

De selectieve nonrespons (de 'weet het niet' antwoorden) bij deze vragen bleef vrij beperkt $(3 \text { à } 4 \%)^{2}$.

Wordt in kolom 3 naar de "juiste" antwoorden gekeken (dus volgens de richtlijn), dan blijkt de beginleeftijd van het cervixuitstrijkje veel beter gekend dan de leeftijd waarop men bij voorkeur start met een mammagrafisch onderzoek. De aanvangsleeftijd voor het baarmoederhalsuitstrijkje is gekend door $42 \%$ van de respondenten en de aanvangsleaftijd voor mammografie slechts door $5.6 \%$.

1

Op het antwoordkatije werd het antwoord 'weet het niet' niet vermeld. De interviawers hadden een uitdrukkelike instructie om alleen "weet niet" aan te duiden, wanneer dit spontaan werd varmeld door de respondenten.

2

In het vooronderzoek onder studenten - waarin weliswar well de mogelijk werd geboden om "weet het niet" te antwoorden - was de selectieve nonrespons voor dezelfde vragen respectievelijk $14.4 \%$ en $15.9 \%$ IDeliens, Louckx en Maes, 1994; 44 ).

- Kennis van kankerpreventie: beschrijvende onderzoeksresultaten - 
Tabel 5.6

Kennis van de richtlijnen inzake 'aanvangsleeftijd' voor de vroegtijdige opsporing van borstkanker en baarmoederhaiskanker door middel van respectievelijk cen mammografie en een baarmoederhals-uitstrij|kje laantal respondenten in \%)

\begin{tabular}{|c|c|c|c|c|c|}
\hline & $\begin{array}{c}\text { Later dan } \\
\text { aanbe- } \\
\text { volen } \\
\text { (1) }\end{array}$ & $\begin{array}{l}\text { Volgens } \\
\text { richtilin }\end{array}$ & $\begin{array}{c}\text { Vroeger } \\
\text { dan aan- } \\
\text { bevolen } \\
\text { (2) }\end{array}$ & $\mathbb{N}$ & $\begin{array}{l}\text { Weet het niet } \\
\qquad(\mathrm{N}=163) !\end{array}$ \\
\hline Mammogratie & 1.5 & 5.6 & 93.0 & 1567 & $3.9 \%(64)$ \\
\hline mannen & 1.3 & 2.3 & 97.4 & \multirow{2}{*}{\multicolumn{2}{|c|}{$* * *$}} \\
\hline vrouwen & 1.6 & 8.7 & 89.7 & & \\
\hline Baarmoederhalsuitstrijkje & 57.7 & 42.3 & $-(3)$ & 1580 & $3.1 \%(51)$ \\
\hline mannen & 61.6 & 38.4 & - & \multirow{2}{*}{\multicolumn{2}{|c|}{$*$}} \\
\hline vrouwen & 53.9 & 46.1 & - & & \\
\hline
\end{tabular}

Noten: * $\mathrm{p}<0.001, * \mathrm{p}<0.01\left(\mathrm{Chi}^{2}\right.$-toets)

(1) Respondenten met een verhoogde kans op 'onderscreening".

(2) Respondenten met een verhoogde kans op 'overscreening'.

(3) Omdat baarmoederhalsuitstrijkje wordt aanbevolen wanaf seksueel actieve leeftijd, was er bij de antwoordmogelijkheden geen onderschatting mogelijk.

Het aandeel van de respondenten met kennis van de aanvangsleeftijd van mammagrafie is dus zeer klein. Hoewel de kennis van vrouwen significant beter is dan deze van de: mannen, is het aantal vrouwen met een adequate kennis van de aarvangsleeftijd van mammografie toch maar $8.7 \%$. Degenen met een inadequate kennis schatten de beginleeftijd voor mammografie vrijwel allemaal te jong in. De vrouwen die in de realiteit handelen volgens deze kennis, zullen bijgevolg een verhoogde kans hebben op overconsumptie van dit medisch onderzoek.

Het aandeel van de respondenten met kennis van de aanbevolen leeftijd voor het starten met een baarmoederhalsuitstrijkje varieert van $38 \%$ voor mannen tot $46 \%$ bij vrouwen. Ook hier is er een significant kennisverschil tussen mannen en vrouwen. Degenen met een inadequate kennis schatten de beginleeftijd allemaal - noodgedwongen - te oud in. Omdat baarmoederhalsuitstrijkje wordt aanbevolen vanaf "seksueel actieve" leeftijd, was er bij de antwoordmogelijkheden geen onderschatting mogelijk. De vrouwen die in de realiteit handelen volgens deze kennis, zullen bijgevolg eerder een verhoogde kans hebben op "onderscreening". Zij hebben ook een geringe kans dat zij adequaat zullen worden geadvizeerd door (hun) mannen. 


\subsection{Samenvatting en discussie}

Zonder enige twijfel toonden de beschrijwende analyses in dit hoafdstuk aan dat de voorlichting inzake kankerpreventie in Vlaanderen vruchten heeft afgeworpen en dat het bij de Vlaamse bevolking heeft geleid tot een zekere mate van adequate kennis over diverse aspecten met betrekking tot kankerpreventie. Bovendien valt op dat de aanbevelingen waarrond in wetenschappelijke kringen een consensus bestaat - bv. het baarmoederhals-ultstrijkje als vroegtijdig opspringsonderzoek van baarmoederhalskanker, de mammografie als vroegtijdig opsporingsonderzoek voor borstkanker, stoppen met roken als gewenst gedrag ter voorkoming van longkanker - zeer goed gekend zijn door de bevolking, terwijl deze waarrond nog geen consensus bestaat in medische kringen bv. de richtlijnen over aanvangsleeftijd en frequentie van vroegtijdige opsporing, risicofactoren in de voeding - minder goed gekend zijn.

De twee algernene onderzoeksverwachtingen die werden voarop gesteld in dit hoofdstuk, konden aan de hand van de empirische bevindingen worden bevestigd. De kennis is vooral aanwezig in het domein van de secundaire kankerpreventie icfr. de eerste algemene onderzoeksverwachting in dït hoofdstuk). De kennis van secundaire kanker-preventie in Vlaanderen kan vooral worden toegeschreven aan een zeer behoorlijke kennis van de bestaande vroegtijdige opsporingsonderzoeken van kanker en in mindere mate aan de kennis van de waarschuwingssignalen. Ook de in dit hoofdstuk voorop gestelde tweede algemene onderzoeksverwachting, namelijk dat de "juiste items" in het algemeen beter gekend zullen zijn dan de 'foutieve" items, kon empirisch worden bevestigd.

Toch kan er op basis van de resultaten in dit hoofdstuk (nog) geen algemene uitspraak worden gedaan over het niveau van deze kennis. De resultaten geven eerder een bont geschakeerd beeld van de kennis van kankerpreventie in Vlaanderen. Een aantal concrete aspecten in verband met kankerpreventie zijn zeer goed gekend door de bevolking, andere aspecten zijn dan weer veel minder of nauwelijks gekend.

De vergelijkingen van het kennisniveau vain de vier verschillende kennisdomeinen wordt verder in detail behandeld in het volgende hoofdstuk. Hier zal de verdere bespreking worden beperkt tot de gevonden resultaten op het niveau van de individuele concrete aspecten van kankerpreventie, die aan bod zijn gekomen bij de metingen.

Kennis van primaire kankerpreventie (zie tabel 5.7)

In het overzicht van de beschrijvende resultaten over kennis van primaire kankerpreventie in tabel 5.7 valt op dat zes van de acht risicofactoren door een meerderheid van de respondenten worden herkend. Roken is door de bevolking zeer goed gekend als risico van kanker. Dit blijkt zowel uit het aantal respondenten die roken herkennen als risicofactor, als uit de gemiddelde zekerheidsscore. Overdadige blootstelling aan de zon, passief roken, overmatig alcoholgebruik, overmatig gebruik van dierlijke vetten in de voeding en 'seksuele omgang met meerdere partners zonder 
Tabel 5.7

Kennis van factoren met betrekking tot primaire kankerpreventie $(n=1631)$

\begin{tabular}{|c|c|c|}
\hline Factoren : & $\begin{array}{l}\text { Herkend door } \\
\geq 50 \% \text { der } \\
\text { respondenten }\end{array}$ & $\begin{array}{l}\text { Met "zekerheid" } \\
\text { herkend door } \\
\geq 50 \% \text { der } \\
\text { respondenten }\end{array}$ \\
\hline \multicolumn{3}{|l|}{ Kennis van risicofactoren } \\
\hline $\begin{array}{l}\text { - roken } \\
\text { - overdadige blootstelling aan de zon } \\
\text { - passief roken; of blootstelling aan } \\
\text { tabaksrook uit de directe omgeving } \\
\text { - overmatig gebruik van alcohol } \\
\text { - overmatig gebruik van dierlijke vetten in de } \\
\text { voeding } \\
\text { - seksuele omgang met meerdere partners } \\
\text { zonder condoom (risico voor vrouwen) } \\
\text { - zwaarlijvigheid } \\
\text { - eerste kind na de leeftijd van } 30 \text { jaar; als } \\
\text { risico voor vrouwen }\end{array}$ & $\begin{array}{l}2 \\
0 \\
0 \\
- \\
-\end{array}$ & $\begin{array}{l}- \\
- \\
- \\
- \\
- \\
- \\
- \\
-\end{array}$ \\
\hline \# risicofactoren herkend door meerderheid & $6 / 8$ & $1 / 8$ \\
\hline $\begin{array}{l}\text { \# factoren foutief herkend als risicofactoren } \\
\text { van kanker } \\
\text { [door } \geq 33 \% \text { der respondentem] }\end{array}$ & $\begin{array}{l}2 / 17 \\
\llbracket 6 / 17 \rrbracket\end{array}$ & {$[-]$} \\
\hline \multicolumn{3}{|l|}{ Kennis wan gewenst kankerpreventief gedrag } \\
\hline $\begin{array}{l}\text { - stoppen met roken of niet roken } \\
\text { - overdadige blootstelling aan de zon } \\
\text { vermijden } \\
\text { - regelmatig eten van vers fruit } \\
\text { - regellmatig eten van verse groenten } \\
\text { - met mate drinken van alcoholische dranken } \\
\text { - vermijden van overgewicht } \\
\text { - regelmatig eten van bruin brood } \\
\text { - regelmatig eten van ongepeide rijst }\end{array}$ & : & $\begin{array}{l} \\
- \\
- \\
- \\
- \\
-\end{array}$ \\
\hline $\begin{array}{l}\text { gewenste kankerpreventieve gedragingen } \\
\text { herkend }\end{array}$ & $7 / 8$ & $1 / 8$ \\
\hline $\begin{array}{l}\text { \# gedragingen foutief herkend als kanker- } \\
\text { preventief } \\
\text { [door } \geq 33 \% \text { der respondenten] }\end{array}$ & $\begin{array}{l}11 / 17 \\
\llbracket 15 / 17 \rrbracket\end{array}$ & {$[2 / 17]$} \\
\hline
\end{tabular}

- Kennis van kankerpreventie: beschrijvende onderzoeksresultaten - 
condoom als risico voor vrouwen worden door meer dan de helft van de respondenten herkend als risico van kanker. De zekerheid waarmee mensen deze risicofactoren herkennen is evenwel veel kleiner dan bij roken. Zwaarlijvigheid en 'een eerste kind na de Heeftifd van 30 jaar; als risico voor vrouwen"zijn onvoldoende gekend als risicofactor van kanker.

Deze laatsite risicofactor neemt een bijzondere positie in binnen de groep van 8 "juiste" risicofactoren die werden opgenomen in de vragenlijst. Er wordt aangenomen dat het volledig uitrijpen van de borsten het risico op borstkanker beînvloedt: hoe langer dit interval, hoe groter het risico. Dit uitrijpen gebeurt net voor de borstvoeding een eerste maal kan plaatsvinden, dus tijdens de eerste volledige zwangerschap. In de periode daarvoor zou het borstklierweefsel bijzonder gevoelig zijn voor kankerverwekkende factoren - die men overigens niet kent. Het betreft hier dus een quasi niet vermijdbare en vrijwel onmogelijk te beinvloeden risicofactor. Het onvoldoende kennen van deze risicofactor hoeft dus niet noodzakelijk negatief te worden geẻvalueerd. Het betreft een risicofactor voor borstkanker waarmee zeer moeilijk kan worden gewerkt in het kader van preventiecampagnes. Strikt genomen heeft deze risicofactor wel met gedrag of leefstijl van mensen te maken. Het is echter de vraag of deze factor kan en mag worden opgenomen in kankerpreventievoorlichting. Preventie van deze risicofactor zou immers inhouden dat eenmaal de eerste maandstonden voorbij zijn vrouwen (relatief) snel kinderen moeten krijgen en deze borstvoeding moeten geven. Dergelijke vorm van preventie van borstkanker is zeef moeilijk op grote schaal te organizeren en lijkt ons bovendien niet etisch te verantwoorden.

Anders is het gesteld met de ondermaatse kennis van "zwaarlijvigheid" als risico van kanker. Zwaarlijwigheid wijst immers vaak op een te grote vetopname en bijgevolg op een leefstijl van eetgewoonten, waaraan in veel gevallen wel op een bevredigende manier kan worden gewerkt. Zwaarlijvigheid komt bijgevolg in aanmerking voor preventiecampagnes. Een grotere aandacht voor deze risicofactor in voorlichting en preventiecampagnes over kankerpreventie is bijgevolg wenselijk.

Over de risicofactoren van kanker bestaan or onder de respondenten ook een aantal uitgesproken misvattingen. Zes van de 17 foutieve risicofactoren van kanker worden door $33 \%$ van de respondenten toch aangeduid als een risico voor kanker. Twee van deze factoren, namelijk het niet verzorgen van een huidontsteking en niet verzorgen van een aanhoudende diarree, worden zelfs door een meerderheid foutief aangeduid.

In de overzichtstabel 5.7 valt ook op dat zeven van de acht gewenste kankerpreven tieve gedragingen door een meerderheid van de respondenten worden herkend. Slechts eén wordt er "met zekerheid" herkend door een meerderheid namelijk stoppen met roken.

Stoppen met raken is dus zeer goed gekend als wenselijke gedrag ter voorkoming van kanker. Overdadige blootstelling aan de zon vermijden, regelmatig eten van vers fruit, regelmatig eten van verse groenten, met mate drinken van alcoholische dranken en vermijden van overgewicht zijn gedragingen die door meer dan tweederde van de 
respondenten werden herkend als gewenst kankerpreventief gedrag.

Regelmatig eten van 'ongepelde rijst' en (in mindere mate) regelmatig eten van 'bruin brood" is onvoldoende gekend als kankerpreventief gedrag. Dit is een vrij verrassend resultaat, omdat een "vezelrijke voeding" toch al verscheidene jaren wordt aanbevolen in de voorlichting over kankerpreventie. Wellicht is "vezeirijke voeding" een te abstract begrip en wordt dit in voorlichtingscampagnes te weinig vertaald naar concrete voedingswaren. Bovendien is de prevalentie van 'ongepelde rijst' in de Belgische keuken relatief klein. Hierdoor kan de bevolking onvoldoende kennis nemen van de diversiteit aan de voedingswaren waarin deze vezelrijke voeding aanwezig is. Andere vezelrijke voedingswaren, zoals vers fruit en verse groenten, staan daarentegen dan weer wel goed gekend als kankerpreventieve voeding. Zij worden door meer dan $80 \%$ van de respondenten herkend.

Over het gewenste kankerpreventieve gedrag bestaan er in vergelijking met het kennisdomein van de risicofactoren duidelijk meer misvattingen. Niet minder dan 11 van de 17 foutieve factoren worden door een meerderheid "foutief" herkend als gewenst kankerpreventief gedrag. 15 op de 17 factoren wordt door minimum én derde van de onderzoekspopulatie foutlief aangeduid als gewenst kankerpreventief gedrag. Twee gedragingen, namelijk 'regelmatig eten van vis' en 'vermijden van stress" worden zelfs met "zekerheid" door minimum $33 \%$ aangeduid als kankerpreventief gedrag.

Kennis van secundaire kankerpreventie (zie ook tabel 5.8 ).

In de overzichtstabel 5.8 valt op dat alle waarschuwingssignalen voor kanker door een meerderheid van de respondenten worden herkend, doch dat geen enkel met "zekerheid" wordt herkend door de meerderheid. Een verdikking of knobbeltje in de borst blijkt nog het best gekende waarschuwingssignaal, dat door ongeveer de helft van de onderzoekspopulatie met "zekerheid" werd herkend. De "zekerheid" van de herkenning van alle overige waarschuwingssignalen is echter kleiner.

Er moet bij deze waarschuwingssignalen echter worden opgepast met de interpretatie van het verschill tussen de antwoordscores "waarschijnlijk" en "zeker". Veel waarschuwingssignalen (bv. een knobbeltje in de borst) maken een grote kans dat er bij verder diagnostisch onderzoek geen kanker wordt vastgesteld. Deze waarschuwingssignalen kunnen dan worden beschouwd als valspositieve signalen. Omdat bij het beantwaorden van de kennisvragen over de waarschuwingssignalen de respondenten wellicht ook rekening hebben gehouden met de reële kans dat het gesignaleerde probleam helemaal niets met kanker te maken heeft, zal men eerder geneigd zijn geweest om de antwoordcategorie "waarschijnlijk wel een waarschuwingssignaal voor kanker" aan te duiden, dan de antwoordcategorie "zeker een waarschuwingssignaal voor kanker" wel. Dit laatste wordt trouwens ook bevestigd door de empirische gegevens gepresenteerd in tabel 5.3.

In het algemeen kan worden gesteld dat de empirische gegevens over de kennis van de waarschuwingssignalen voor kanker een gunstiger beeld geven dan respectievelijk de 
kennis van de risicofactoren van kanker en de kennis van het gewenste kankerpreventieve gedrag.

Tabel 5.8

Kennis van factoren met betrekking tot secundaire kankerpreventie $(n=1631)$

\begin{tabular}{|c|c|c|}
\hline Factoren: & $\begin{array}{l}\text { Herkend door } \\
\text { ¿ } 50 \% \text { der } \\
\text { respondenten }\end{array}$ & $\begin{array}{l}\text { Met "zekerheid" } \\
\text { herkend door } z \\
50 \% \text { der respon- } \\
\text { denten }\end{array}$ \\
\hline \multicolumn{3}{|l|}{ Kennis van waarschuwingssignalen } \\
\hline $\begin{array}{l}\text { - verdikiking of knobbeltje in de borst } \\
\text { - duidelijke verandering in moedervlek } \\
\text { - onverklaarbare gewichtsvermindering } \\
\text { - abnormaal anaal of vaginaal bloed-verlies } \\
\text { (via aars of schede) } \\
\text { - aanhoudende wijziging in plas- of } \\
\text { stoelgangpatroon } \\
\text { - aanhoudende hoest of heesheid } \\
\text { - cen wonde die niet geneest }\end{array}$ & : & $\begin{array}{l}- \\
- \\
- \\
- \\
-\end{array}$ \\
\hline \# waarschuwingssignalen herkend & $7 / 7$ & 0,7 \\
\hline $\begin{array}{l}\text { \# factoren foutiof herkend als } \\
\text { waarschuwingssignaal wan kanker } \\
\text { [door } 233 \% \text { der respondenten] }\end{array}$ & {$[2 / 18]$} & {$[-$} \\
\hline \multicolumn{3}{|l|}{ Kennis van vroegtijdige opsporingsonderzoeken } \\
\hline $\begin{array}{l}\text { - mammografie voor vrouwen } \\
\text { - baarmoederhalsuitstrijkje } \\
\text { - borstonderzoek door de dokter } \\
\text { - borstzelfonderzoek voor vrouwen } \\
\text { - huidinspectie door de doktter, biij } \\
\text { veranderende moedervlek } \\
\text { - opsporen van bloed in de stoelgang } \\
\text { - rectaal onderzoek van de dikkedarm }\end{array}$ & : & $\begin{array}{l}0 \\
- \\
- \\
-\end{array}$ \\
\hline \# opsporingsonderzoeken herkend & $7 / 7$ & $3 / 7$ \\
\hline $\begin{array}{l}\text { \# factoren foutief herkend als vroegtijdig } \\
\text { opsporingsonderzoek van kanker } \\
\text { [door } 233 \% \text { der respondenten] }\end{array}$ & $\begin{array}{l}5 / 18 \\
{[10 / 18]}\end{array}$ & $(3 / 18)$ \\
\hline
\end{tabular}

'Een wonde die niet geneest' wordt het slechtst herkend. Het is een waarschuwingssignaal voor kanker dat in de Amerikaanse kankercode is opgenomen, doch niet in de Europese kankercode. Dit onderzoeksresultaat is vermoedelijk een rechtstreeks gevolg van het feit dat de Europese kankercode als basis heeft gediend

- Kennis van kankerpreventie: beschrijvende onderzoeksresultaten - 
voor zeer veel preventiecampagnes van de afgelopen vijf jaar in Vlaanderen. Er mag dan ook theoretisch niet worden verwacht dat dit waarschuwingssignaal in Vlaanderen zeer goed gekend is. In het algemeen geldt echter dat alle waarschuwingssignalen voor kanker vaker worden herkend door de onderzoeksgroep dan de foutieve waarschuwingssignalen. Hieruit kan worden geconcludeerd dat de inspanningen van de kankerpreventiecampagnes ook op het vlak van kennis over waarschuwingssignalen effectief zijn geweest.

Over de waarschuwingssignalen woor kanker bestaan er onder de respondenten aok weinig uitgesproken misvattingen. Er is geen enkel foutief item dat door een meerderheid van de respondenten wordt herkend als waarschuwingssignaal voor kanker. En er zijn slechts 2 van de 18 foutieve waarschuwingssignalen die door minimum $33 \%$ van de respondenten werd aangeduid als een waarschuwingssignaal voor kanker. Het betreft met name 'braakneigingen of maagstoornissen' en 'een gevoel van verminderde energie".

In de tabel 5.8 valt op dat alle vroegtijdige opsporingsonderzoeken voor kanker door een meerderheid van de respondenten wordt herkend én dat drie op de zeven door een meerdlerheid "met zekerheid" wordt herkend. Dit is in vergelijking met alle voorgaande kennisdomeinen zonder enige twijfel het meest gunstige resultaat. Mammografie en baarmoederhalsuitstrijkje worden door meer dan $90 \%$ herkend als vroegtijdig opsporingsonderzoek en door tweederde met "zekerheid" herkend. Dit zeer gunstig resultaat is zeer zeker het gevolg van de relatief grote aandacht voor deze twee specifieke opsporingstechnieken bij programma's voor vroegtijdige kankeropsporing in Viaanderen.

Dit vrij gunstig beeld wordt evenwel niet bevestigd door de gegevens van de foutpercepties. In dit kennisdomein zijn er in vergelijking met het kennisdomein van de waarschuwingssigmalen duidelijk meer misvattingen terug te vinden. Vijf van de 'foutieve' opsporingsonderzaeken werden door een meerderheid van de respondenten foutief herkend als een vroegtijdige opsporingsonderzoek voor kanker. Het betreft respectievelijk de radiografie van de longen, het keeluitstrijkje, de echografie, het urine/ onderzoek en de TBC-test. De eerste drie van deze onderzoeken worden zelfs door een derde van de respondenten met "zekerheid" aangeduid als vroegtijdige kankeropsporingsonderzoeken. De verklaring voor deze misvattingen liggen niet voor de hand.

Radiografie van de longen kan weliswaar als diagnostisch onderzoek worden gebruikt voor het opsporen van longkanker, doch het wordt momenteel zeker niet gebruikt voor screening of vroegtijdige opsporing wan longkanker bij een asymptomatische bevolking. De radiografie van de longen is in het verleden in Vlaanderen echter wel gebruikt als screeningsonderzoek voor TBC. Wellicht is de associatie van radiografie met een algemene screening van de bevolking blijven hangen in het collectieve geheugen van de Vlaamse bevolking, waardoor een deel van de respondenten heel waarschijnilik sneller geneigd zullen zijn geweest om eveneens de associatie te maken naar wroegtijdige kankeropsporing. 
De hoge herkenningsscore var het keeluitstrijkje dient vermoedelijk verklaard te worden vanuit een puur taalkundigle associatie met het goed gekende baarmoederhalsuitstrijkje, in de volksmond ook bekend als "het uitstrijkje".

De echografie is een vrij algemene techniek van medische beeldworming die niet orgaanspecifiek is. Hoewel deze techniek niet wordt gebruikt in de vroegtilidige opsporingscampagnes naar een algemene bevolking toe, komt het wel voor dat deze techniek in ziekenhuizen wordt gebruikt voor diagnose van verschillende vormen van kanker (bv. borstkanker en ovariumkanker). Bovendien heeft het veelvuldig gebruik van deze medische techniek voor andere doeleinden (bv. bil zwangere vrouwen) de bevolking algemeen vertrouwd gemaakt met dit onderzoek. Verder wordt vermoed dat er bij de bevolking ook een verwarring kan bestaan met andere beeldvormingstechnieken, zoals de radiografie en de mammografie. Al deze aspecten maken dat de respondenten vermoedelijk lets germakkelijker de associatie tussen echografie en vroegtijdige kankeropsporing leggen.

Welke verklaringen er ook magen worden gegeven voor deze misvattingen, het blijen in ieder geval opvattingen die niet conform zijn met de medische aanbevelingen inzake kankerpreventie en die bijgevolg beter niet worden geassocieerd met kankerpreventie. Voorts kan er hier ook sprake zijn van vertekeningen die zorgen voor een "overrapportering" bij de meting van kennis van de vroegtijdige opsporingsonderzoeken voor kanker. Op deze problematiek van overrapportering wordt uitvoerig teruggekomen in het volgende hoofdstuk.

Tot slot van dit hoofdstuk wordt nog een beschouwing gewijd aan de resultaten die werden gevonden bij de metingen over de kennis van de richtlijnen inzake vroegtijdige opsporing van borst- en baarmoederhalskanker wia respectievelijk het borstzelfonderzoek, het klinisch borstonderzoek, de mammografie en het baarmoederhalsuitstrijkje. Omdat er de afgelopen 15 jaar in preventiecampagnes zeer veel aandacht is besteed aan deze vormen van kankerpreventie en omdat de Vlaamse overheid in samenwerking met de provincies en de universitaire centra voor kankerpreventie terzake een beleid ontwikkelen, hebben deze resultaten ook beleidsrelevantie.

Bij de onderzoeksgroep wordt de aanoevolen frequentie van borstzelfonderzoek eerder onderschat dan overschat; zowell door mannen als door vrouwen. Deze resultaten wijzen dus op een cognitieve dispositie die bij vrouwen eerder zal leiden tot onderscreening dan tot overscreening. De aanbevolen frequentie van het klinisch borstonderzoek is vrij goed gekend door zowel de mannen als de vrouwen.

Met betrekking tot de ewee meest aanbevolen screeningsonderzoeken, namelijk het baarmoederhalsuitstrijkje en de mammografile, is er zeer duidelijk een verkeerde perceptie van de richtlijnen inzake zowell "aanvangsleeftijd" als "frequentie:. Voor het baarmoederhalsuitstrijkje wordt de beginleeftijd, alsook de frequentie te hoog ingeschat. Voor de mammografie wordt de beginleeftijd te laag ingeschat en de frequentie te hoog. Dat deze cognitieve dispositie aanleiding kan geven tot een overconsumptie van dit preventief geneeskundig onderzoek, hoeft geen verder betoog. 


\section{Hoofdstuk 6}

\section{Constructie en onderzoek van de kennisschalen"}

6.1 Constructie van de kennisschalen en analyse van de kennisscores

6.2 Betrouwbaarheid van de metingen van kennis van kankerpreventie

6.3 Validiteit van de metingen van kennis wan kankerpreventie

6.4 Variabiliteit van de scores en vorm van de verdeling van de schalen

6.5 Samenvatting en conclusies

\subsection{Constructie van de kennisschalen en analyse van de kennisscores.}

In hoofdstuk 3 werd een methode ontwikkeld om kennis van kankerpreventie te kwantificeren aan de hand van de "Kennis van kankerpreventie 100 iterns-vragenlijst". Op basis van deze 100 items kunnen een aantal maten of somscores voor kennis van kankerpreventie worden geconstrueerd. Om de interpretatie te vereenvoudigen werden de scores steeds gestandaardiseerd naar eenzelfde meetschaal van - 100 (laagste kennisscore) tot +100 (hoogste kennisscore) $)^{2}$.

Door middel van de scores kan worden afgeleid hoe veel of hoe weinig ladequate) kennis iemand heeft van kankerpreventie. Hierdoor worden ook vergelijkingen van personen betreffende hun kennis van kankerpreventie mogelijk; ook kunnen groepen (bijvoorbeeld vrouwen versus mannen of jongeren versus oudleren) met elkaar worden vergeleken. De verschillen in kennis van kankerpreventie kunnen ook worden gerelateerd aan andere kenmerken van de respondenten of van groepen, zoals bv. leeftijd of sociaal-economische status.

Het uitgangspunt voor de berekening van de scores is de ordinale viffpuntenschaal waarmee de respondenten de 100 items konden beoordelen. Op basis van de zekerheidsscores op deze 100 vragen konden 15 kennisschalen worden geconstrueerd (drie per indicator van kennis van kankerpreventie, alsook drie syntheseschalen van kennis van kankerpreventie) (zie hoger in hoofdstuk 3). De gemiddelde somscores worden gepresenteerd in tabel 6.1.

1 Met dank aan Prof. dr. L. Kaufman (statisticus, VU Brussel) voor zijn feedback op de consitructie van deze kennisschalen.

2 Zie bijlage 2 a voor meer details over de operationalisering en de constructie van de kennisschalen en de kennisscores. 
In totalal worden er 12 specifieke indicatorgebonden somscores gepresenteerd. Daarnaast worden ook 3 synthesescores gepresenteerd. In figuur 6.1 worden de gemiddelde schaalscores weergegeven in een staafjesdiagram, zodat de hoogte van de verschillende scores beter kunnen worden vergeleken.

Bij de foutperceptiescores werden de schalen omgedraaid zodat eenzelfde interpretatie mogelijk werd. De oorspronkelijke hoge score op een foutperceptieschaal betekende immers zeer veel fouten bij de beoordeling van de foutieve items, hetgeen overeenkomt met weinig (adequate) kennis.

De adequate kennisscores' worden verkregen door de oorspronkelijke foutperceptiescore ${ }^{2}$ af te trekken van de kennisscore op de juiste items en te delen door twee. Als de oorspronkelijke foutperceptiescore negatief en groter is dan de kennisscore, betekent dit dat de adequate kennisscore groter zal zijn dan de kennisscore die alleen gebaseerd is op de scores op de juiste items. Is de oorspronkelijke foutperceptiescore daarentegen positief. dan maakte de respondent veel fouten bij de beoordeling van de foutieve items, zodat dit kan worden beschouwd als een lage kennis van kankerpreventie. Bijgevolg zal zo'n score in combinatie met de kennisscore op de juiste items leiden tot een 'adequate kennisscore" die lager is dan de kennisscore op de juiste items.

De synthesescore 'kennis van primaire kankerpreventie' werd berekend door sommatie van de adequate kennisscores van respectievelijk kennis van risicofactoren en kennis van gewenst kankerpreventief gedrag en te delen door twee. De synthesescore "kennis van secundaire kankerpreventie' werd berekend door sommatie van de adequate kennisscores van kennis van de waarschuwingssignalen van kanker en kennis van de vroegtijdige opsporingsonderzoeken van kanker en te delen door twee. Tot slot werd de globale kennis van kankerpreventie gesynthetiseerd in één kennisscore 'kennis van kankerpreventie'. De score werd berekend door een sommatie van de vier scores van adequate kennis en te delen door vier.

Er worden in tabel 6.1 respectievelijk gegevens gepresenteerd over het aantal items waarop de sichaalscore gebaseerd is, de centrale tendentie en de variabiliteit van de somscore. In de laatste kolom wordt een rangorde gepresenteerd. De ordening geeft de hoogte op de kennisschalen weer, gebeseerd op de gerniddelde scores zoals weergegeven in de derde kolom. Rang 1 stemt overeen met de hoogste kennisscore en rang 15 met de laagste kennisscore.

1 Een adequate kennisschaal is evenwichtig gebaseerd op zowel de herkenningsscores wan de juiste als van de foutieve items. 'Evenwichtig' betekent in deze context dat de beoordeling van de juiste items - die minder talrijk dan de foutieve items aanwezig zijn in de vragenlijst - enzelfde gewicht krijgen als de beoordeling van de foutieve items in de constructie van de adequate kennisschaal.

2 Met de 'oorspronkelijke' foutperceptiescore wordt de foutperceptieschaal bedoeid vooraleer die werd omgekeerd. Een negatieve waarde op deze oorspronkelijke schaal kon worden geinterpreteerd als veel kennis en een positieve waarde als weinig kennis. 
Tabel 6.1

Overzicht van de kennisschalen en kennisscores met hun centrale tendentie, spreiding en rangorde $(\mathrm{n}=1631$ )

\begin{tabular}{|c|c|c|c|c|}
\hline & items & Mean & SD & Bang \\
\hline \multicolumn{5}{|l|}{ KENINIS VAN PRIMAIRE KANKERPREVENTIE } \\
\hline \multicolumn{5}{|l|}{ Kennis van risicofactoren van kanker } \\
\hline Herkenning van de "juiste" items & 8 & 29,17 & 27.53 & 7 \\
\hline Foutperceptie & 17 & 15,92 & 28,41 & 12 \\
\hline Adequate kennis & 25 & 22,55 & 12,58 & 9 \\
\hline \multicolumn{5}{|c|}{ Kennis van gewenste kankerpreventieve gedragingen } \\
\hline Herkenning van de "juiste' items & 8 & 49,24 & 33,48 & 2 \\
\hline Foutperceptie & 17 & $-20,74$ & 35,01 & 15 \\
\hline Adequate kennis & 25 & 14,25 & 11,53 & 13 \\
\hline \multicolumn{5}{|l|}{ KENNIS VAN SECUNDAIRE KANKERPREVENTIIE } \\
\hline \multicolumn{5}{|l|}{ Kennis van de waarschuwingssignalen van kanker } \\
\hline Herkenning van de 'juiste' items & 7 & 39.2 & 30,28 & 3 \\
\hline Foutperceptie & 18 & 19,15 & 29,88 & 10 \\
\hline Adequate kennis & 25 & 29,18 & 15,46 & 6 \\
\hline \multicolumn{5}{|c|}{ Kennis van de yroegtijdige ogsporingsonderzoeken van kanker } \\
\hline Herkenning van de 'juiste' items & 7 & 61,93 & 27,99 & 1 \\
\hline Foutperceptie & 18 & $-1,3$ & 32,15 & 14 \\
\hline Adequate kennis & 25 & 30,32 & 17,28 & 4 \\
\hline \multicolumn{5}{|c|}{ SYNTHESE VAN KENNIS VAN KANKERPREVENTIE } \\
\hline Kennis Primaire Kankerpreventie & 50 & 18,4 & 9,88 & 11 \\
\hline Kennis Secundaire Kankerpreventie & 50 & 29,75 & 14,04 & 5 \\
\hline Kennis van Kankerpreventie (globale meting) & 100 & 24,07 & 10.25 & 8 \\
\hline
\end{tabular}

Noot: - De kennisscores lopen van - 100 (zeer inadequate kennis van kankerpreventie) tot +100 (zeer adequate kennis van kankerpreventie).

- De gemiddelde scores warden gebruikt om de rangorde te bepalen. 
Worden de gemiddelden en hun rangorde in tabel 6.1 en figuur 6.1 bekeken, dan kunnen belangrijke vaststellingen worden gedaan.

Eerst worden de kennisscores op de 'juiste items' vergeleken met de 'foutperceptiescores". Op die manier kan worden nagegaan of de onderzoekspopulatie de factoren die echt iets te maken hebben met kankerpreventie goed kunnen onderscheiden van factoren die geen rol spelen bij kankerpreventie (zie ook hoofdstuk 5).

Als eerste observatie valt op dat voor alle vier indicatoren van kennis van kankerpreventie, de kennisscore van de juiste items steeds substantieel hoger is dan de foutperceptie-score. Dit wijst erop dat de onderzoekspopulatie de juiste items steeds met grotere zekerheid kan herkennen dan de foutieve items. Of met andere woorden de respondenten weten met grotere zekerheid dat iets wel met kankerpreventie te maken heeft, dan dat iets niet met kankerpreventie te maken heeft. Het verschil varieert (zeer sterk) van ongeveer 13 schaalpunten (29.17-15.92) bij kennis van de risicofactoren voor kanker tot ongeveer 70 schaalpunten $(49.24+20.74)$ bij de kennis van de gewenste kankerpreventieve gedragingen. Ook bij de kennis van de vroegtijdige opsporingsonderzoeken van kanker zijn er sterk uiteenlopende scores tussen de beide schalen van ongeveer 63 schaalpunten $(61.93+1.3)$. Bij de kennis van de waarschuwingssignalen is het verschil 20 schaalpunten $(39.20-19.15)$.

Niettegenstaande de relatief hoge score voor de herkenning van het gewenst kankerpreventief gedrag, wordt er zeer slecht gescoard op de foutperceptie van het gewenst kankerpreventief gedrag. Er zijn bijgevolg zeer veel miswattingen over het gewenst kankerpreventief gedrag. De respondenten blijken zeer veel misvattingen te hebben over wat wel en wat niet wenselijk gedrag is ter voorkoming van kanker. Belangrijke misvattingen zijn ook - zij het minder uitgesproken - aanwezig in het kennisdomein van de vroegtijdige opsporingsonderzoeken. Blijkbaar denken de respondenten ook van heel veel medische onderzoeken die niet in aanmerking komen voor vroegtijdige kankeropsporing, dat ze geschikt zijn om kanker vroegtijdig op te sporen. De belangrijkste misvattingen over kankerpreventie situeren zich dus in de kennisdomeinen van het gewenst gedrag en wan de vroegtijdige opsporingsonderzoeken. Foutieve risicofactoren en foutieve waarschuwingssignalen worden minder in verband gebracht met kankerpreventie.

Wellicht treedt bij deze meetresultaten ook een vertekenend effect op. Mensen die twijfelen over een item kunnen het zekere voor het onzekere nemen en bij twijfel eerder geneigd zijn om een verband met kankerpreventie te leggen. Hierdoor is er zowell bij de juiste als bij de foutieve items een 'overrapportering'. Deze overrapportering leidt bij de herkenning van de juiste items tot een hogere kennisscore en bij scoreberekening van de foutperceptie ook tot een hogere foutperceptiescore of een lagere kennis. Hierdoor worden ook de verschillen tussen kennisscore (juiste items) en foutperceptiescore groter.

Deze overrapportering komt ook duidelijk tot uiting in de rangordeciiffers (zie tabel 6.1). Hier valt op dat dle top drie van de gemiddelde scores (met ruime voorsprong) wordt gevormd door de kennisscores op de juiste items. Enkel de kennisscore van de juiste risicofactoren staat op een lagere 7 de rang, doch wordt maar nipt (minder dan 2 schaalpunten verschil) 
voorafgegaan door de scores voor de adequate kennis van respectievelijk de vroegtijdige opsporingsonderzoeken en de waarschuwingssignalen van kanker, alsook de synthesescore voor kennis van secundaire kankerpreventie.

Figuur 6.1: Kennis van kankerpreventie

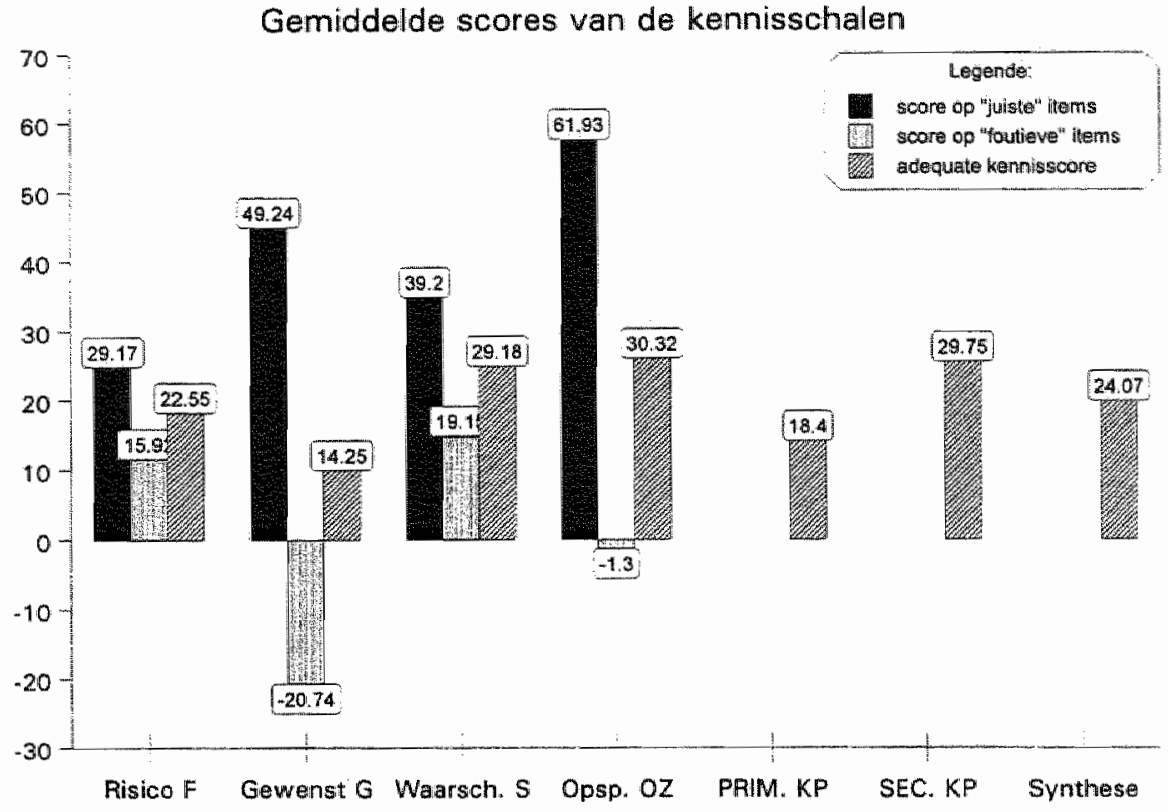

Deze vertekening door overrapportering was één van de uitdrukkelijke redenen om een 'adequate kennisscore' te gaan construeren (zie hoofdstuk 3), waardoor deze vertekening zichzelf grotendeels gaat opheffen. Bij de adequate scores valit duidelijk het resultaat van deze correctie op. Het effect van deze correctie kan het best worden afgeleid van de verschuiving in rangorde of in hoogte van kennis. Als de rangorde van de gemiddelde scores met elkaar wordt vergeleken, dan verschilt de onderlinge rangorde van de scores op de juiste items van de onderlinge rangorde van de scores op de foutieve items.

Wordt geen rekening gehouden met de foutperceptiescores, dan kent de onderzoekspopulatie respectievelijk het best :

1. vroegtijdige opsporingsonderzoeken van kanker (gemiddelde score 61.93 )

2. gewenst kankerpreventief gedrag Igemiddelde score 49.24 》

3. waarschuwingssignalen van kanker (gemiddelde score 39.2 )

4. risicofactoren van kanker (gemiddelde score 29.17). 
De verschillen in kennisniveau tussen de verschillende kennisdomeinen zien er zeer aanzienllijk uit. Op basis van deze gegevens zou er kunnen worden geconcludeerd dat de Vlaamse bevolking twee keer meer weet van wroegtijdige opsporingsonderzoeken dan van de risicofactoren van kanker.

Deze kennis gaat - zoals hoger aangetoond - evenwel gepaard met zowel misvattingen ower kankerpreventie, als met een bepalde vertekening door overrapportering. Vooral bij de kennis van het gewenst kankerpreventief gedrag en in mindere mate ook bij de kennis van de wroegtijdige opsporingsonderzoeken blijken er zeer hoge foutscores te zijn. Wordt rekening gehouden met deze foutpercepties over kankerpreventie en met het probleem van overrapportering, dan ziet de volgorde van beste kennis er anders uit :

1. vroegtijdige opsporingsonderzoeken van kanker (gemiddelde score 30.23 )

2. waarsichuwingssignalen van kanker (gemiddelde score 29.18)

3. risicofactoren van kanker (gemiddelde score 22.55)

4. gewenst kankerpreventief gedrag (gemiddelde score 14,25 ).

Kennis van de vroegtijdige opsporingsonderzoeken blijft weliswaar nog het best gekend, doch alle andere domeinen veranderen van rang. Tevens worden de verschillen tussen de kennisdomeinen in schaalpunten veel minder uitgesproken. Het verschil tussen de beste en slechtste score wordt gehalveerd (van ongeveer 32 schaalpunten naar ongeveer 16 schaalpunten). Het gewenst kankerpreventief gedrag is nu het slechts gekend.

Door onderlinge vergelijking van deze adequate kennisscores kan worden vastgesteld welke kennisdomeinen of aspecten van kankerpreventie nu beter gekend zijn dan andere domeinen of aspecten.

Er is ongeveer een gelijke kennis van de vroegtijdige opsporingsonderzoeken van kanker en van de waarschuwingssignalen van kanker. Deze twee domeinen zijn duidelijk beter gekend door de onderzoekspopulatie dan de risicofactoren van kanker en het gewenst kankerpreventief gedrag. Dit laatste kennisdomein is uitgesproken het minst goed gekend. Opvallend bij deze ordening is dat de twee domeinen die indicatilef zijn voor de kennis van secundaire kankerpreventie beter gekend zijn dan de twee domeinen die indicatief zijn voor de kennis van primaire kankerpreventie. Dit wordt ook weerspiegeld in het verschil in kennisscore tussen de gemiddelde scores op de synthesematen 'kennis van primaire kankerpreventie' en 'kennis van secundaire kankerpreventie". Secundaire kankerpreventie $(29.75)$ is meer dan 11 schaalpunten beter gekend dan primaire kankerpreventie $(18.40)$.

De kennis wan secundaire kankerpreventie kan worden toegeschreven aan een evenwichtige spreiding van de kennis over de twee indicatieve kennisdomeinen. Hetzelfde kan evenwel niet worden gezegd van de kennis van primaire kankerpreventie. De score wordt gevormd door een relatief hoge kennis van de risicofactoren en een relatief lagere kennis van het gewonst preventief gedrag.

Tot slot van deze paragraaf worden de standaardafwijkingen (SD) van de gemiddelden in tabel 6.1 bekeken. Hierbij valt op dat alle adequate kennisscores, alsook de drie 
synthesescores van kennis van kankerpreventie een substantieel k/einere standaardafwijking hebben dan alle overige gemiddelde scores (respectievelijk de kennisscores op de juiste items en de foutperceptiescores). De standaardafwijkingen van de adequate kennisscores zijn twee tot drie maal kleiner dan hun respectievelijke kennisscores op de juiste items en hun foutperceptiescores. Het meest uitgesproken is dit voor de kennis van het gewenst kankerpreventief gedrag met een standaardafwijking van 11.53 voor de adequate kennisscore en een standaardafwijking van 33.48 en 35.01 voor respectievelijk de kennisscore op de juiste items en de foutperceptiescore. De standaardafwijkingen van alle adequate kennisscores - inclusief de synthesematen ${ }^{1}$ - variëren van 9.88 voor kennis van primaire kankerpreventie tot 17.28 voor de adequate kennis van de vroegtijdige opsporingsonderzoeken. De adequate kennisscores vertonen dus een kleinere spreiding dan de kennisscores op de juiste items en de foutperceptiescores. Dit betekent dat de respondenten homogener scoren op de kennisschalen waar zowel wordt rekening gehouden met de juiste als met de foute items, dan op de atzonderlijke schalen.

Dit wijst erop dat de gemiddelden van deze adequate maten betere schatters zijn van de werkelijke waarden van de respondenten, dan de gemididelden van de scores op alléen de juiste items of alléén de foutieve items. Er kan bijgevolg worden geconcludeerd dat het toetsen van kenmis van kankerpreventie door het gemengd voorleggen van zowel juiste als foutieve items leidt tot metingen die (veel) nauwkeuriger ${ }^{2}$ zijn dan metingen die alleen gebaseerd zijn op het voorleggen van juiste items met betrekking tot kankerpreventie. In vergelijking met de adequate scores op de afzonderlijke indicatoren van kennis van kankerpreventie, neemt bil de synthesematen de nauwkeurigheid van de metingen ook nog zij het zeer beperkt - toe.

Als verder de standaardafwijking van kennis van primaire kankerpreventie wordt vergeleken met deze van kennis van secundaire kankerpreventie, dan valt het op dat deze iets kleiner is 19.88 versus 14.04$)$. De spreiding van de kennis van secundaire kankerpreventie is bijgevolg groter dan deze van kennis van primaire kankerpreventie. De kennis van secundaire kankerpreventie is weliswar groter dan deze van primaire kankerpreventie (zie hoger in deze paragraaf), doch de kennisverschillen in de bevolking zijn ook groter.

1 De synthesescores worden hier ook beschouwd als "adequate' kennismaten, omdat ze immers zijn gebaseerd op de adequate kenmismaten.

2 De term 'nauwkeuriger' wordt hier in een statistische betekenis gebruikt. Doordat de standaardafwijking van de adequate kennisscores kleiner is dan deze van de schalen die alleen gebaseerd op de 'juiste' kennisitems, kan worden gesteld dat het gemiddelde van de adequate kennisscores eem betere schatter is van de reële waarde van de respondent, dan het gemiddelde van de andere kennisscores. 


\subsection{Betrouwbaarheid van de metingen van kennis van kankeroreventie}

Aan welke $k$ waliteitswoorwaarden dienen de kennismetingen te voldoen? In het algemeen dienen metingen te voldoen aan twee kwaliteitseisen, met name de betrouwbaarhejd en de validiteit. Daarbij gaat het nooit om een absolute norm, doch wel om een relatieve norm. Bij elke meting dient men te streven naar een zo groot mogelijke betrouwbaarheid en een zo groot mogelijke walliditeit. Elke meting, hoe goed ook geconstrueerd en uitgevoerd, staat echter bloot aan verschillende mogelijke foutenbronnen. Het is de kunst om zo weinig mogelijk fouten toe te laten, waardoor het uiteindelijk meetresultaat zo weinig mogelijk in negatieve zin beinvloed wordt. In paragraaf 3.3 werd reeds een eerste aanzet gegeven om de betrouwbaarheid en de validiteit van het concept "Kennis van kankerpreventie" te onderbouwen. In de volgende paragrafen worden beide kwaliteitseisen verder onderzocht.

Betrouwbaarheid van een meting verwijst naar de vraag of de resultaten van een meting reproduceerbaar en repliceerbaar zijn". Als de metingen van kennis van kankerpreventie betrouwbaar zijn, dienen verschillende kennismetingen bij eenzelfde persoon eenzelfde resultaat op te leveren, ongeacht wie de meting verricht en ongeacht de omstandigheden van het interview. De betrouwbaarheid van een meetschaal kan met andere woorden worden aangeduid als de mate waarin de meetuitkomsten ongevoelig zijn voor toevalsfactoren of voor onsystematische fouten ${ }^{2}$.

In geheel het proces van een surveyonderzoek kunnen deze onsystematische fouten optreden. Zo kunnen bijvoorbeeld de interviewsituaties verschillen en wordt er gewerkt met verschillende enquetteurs die op hun beurt bepaalde fouten kunnen maken. Ook eenzelfde interviewer kan al eens een mindere dag hebben en wat minder attent zijn tijdens een interview, zodat de kwaliteit van de registratie van interview tot interview kan verschillen. Het is daarom van belang om inzicht te kirijgen in de mate wan betrouwbaarheid van dit centraal meetinstrument.

De evaluatie van de betrouwbaarheid van een meetinstrument kan worden verricht via twee verschillende methoden (Streiner en Norman, 1989:7, zie ook DeVellis, 1991: 24-42; Spector, 1992: 29-45 \& 65-68 en Streiner en Norman, 1989: 79-961: "stabiliteit van dle meting" en "interne consistentie" (of inter-itembetrouwbaarheid).

De stabiliteit van een meting kan worden nagegaan via enerzijds de test-hertestbetrouwbaarheid en anderzijds via de onderzoeker-betrouwbaarheid lof inter-beoordelaarbetrouwbaarheid). Omdat onderhavig onderzoek een cross-sectioneel onderzoek betreft door middel van een eenmalig interview, kan het effect van de tijd niet worden onderzocht

1 Voor een bondig overzicht over de problematiek van betrouwbaarheid van metingen zie ondermeer de handboeken van Segers (1989: 207-213) en van der Pligt en de Vries (1995: 166-172). Voor een uitvoeriger overzicht zie het handboek van Streiner en Norman (1989).

$z$ Met 'onsystematische' fouten worden de toevallige afwijkingen in het meetresultaat bedoeld. Hoe meer van deze afwijkingen er optreden, des te onbetrouwbaar is het meetinstrument (zie
ondermeer Segers, 1989:198-200). 
en is de controle van de betrouwbaarheid via test-hertestbetrouwbaarheid niet mogelijk. Met een cross-sectioneel onderzoek is het evenmin mogelijk om de onderzoekerbetrouwbaarheid na te gaan.

Het onderzoek van betrouwbaarheid is in deze studie wel mogelijk vila de controle van de interne consistentie van een schaal. Het betreft de homogeniteit van de reeks vragen in eenzelfde schaal. Er wordt vanuit gegaan dat een schaal een bepaalde dimensie van kennis van kankerpreventie meet en dat bijgevolg alle items van die schaal verwijzen naar eenzelfde kennisdimensie. Statistisch uitgedrukt betekent dit dat de antwoorden op de vragen die worden gebruikt om een schaal te construeren met elkaar moeten correleren. Betrouwbaarheid in deze context wordt dan vaak uitgedrukt als een maat lbv. Cronbach"s Alpha) voor de proportie van de variantie in de scores die kan worden verklaard door echte verschillen tussen de respondlenten. De betrouwbaarheid kan dan worden uitgedrukt in een cijfer van 0 tot 1.

Duidelijkheid over wat aanvaardbaar of noodzakelijk is als minimale Cronbach's Alphacoëfficiënt is er in de literatuur niet. Sommige auteurs zeggen te streven naar een coëfficiënt van 0.80 (König-Zahn e.a., 1993: 19). Andere auteurs vinden waarden boven de 0.65 al 'acceptabel' en waarden boven de 0.75 vinden ze 'goed' Ivan der Pligt en de Vries, 1995: 181). Ware (1993: 7/2) en Wilkin, Hallam en Doggett (1992: 30) refereren in hun handboeken zelfs naar een alpha-waarde van 0.50 als 'acceptabel'.

Sommige auteurs vermijden echter het stellen van een duidelijke norm voor de betrouwbaarheidscoëfficiënt (zie bv. Streiner en Norman, 1989: 891. Zil gaan ervan uit dat er geen basis is voor een duidelijke norm, doch dat betrouwbaarheid dient gerellateerd te worden aan de doelstelling en de omvang van het onderzoek: een test die wordt gebruikt om een individu te beoordelen dient betrouwbaarder te zijn dan een test die wordt gebruikt voor groepsbeslissingen of woor populatie-onderzoek. Er worden twee argumenten gegeven om dit onderscheid te rechtvaardigen (Streiner en Norman, 1989: 89). Ten eerste zall men in populatie-onderzoek uitspraken doen op basis van gemiddelde scores van zeer veel individuen en de steekproefomvang zal ervoor zorgen dat meetfouten worden beperkt in vergelijking met de eigenliike verschillen tussen groepen of subpopulaties. Ten tweede zullen beslissingen over anderzoeksresultaten zelden worden genomen op basis van eén waarneming. Conclusies worden pas getrokken na een reeks van gelijkaardige resultaten in gerepliceerde onderzoeken. Wat de aanbeveing over de betrouwbalheidsnorm ook mogen zijn, in jeder geval staat het vast dlat een steekproef van 1000 individuen een meetinstrument kan tolereren met een kleinere betrouwbaarheid dan een steekproef van 10 individuen.

Tabel 6.2 presenteert de berekende alpha-waarden woor de geconstrueerde meer-item kennisschalen, alsook de gegevens over centrale tendentie en spreiding. Vrijwel alle alpha. waarden in tabel $6.2 \mathrm{kunnen}$ hoog tot zeer hoog worden genoemd. De alpha-waarden lopen van minimum 0.63 tot maximum 0.95 . Twaalf van de vijftien coëfficiënten zijn groter dan 0.80 en halen bijgevolg de strenge norm vermeld in het handboek van König-Zahn e.a. (1993: 19). Van de overige drie coëfficiënten zijn er twee - respectievelijk 0.78 en 0.79 die deze norm benaderen. Ze zijn ook groter dan 0.75 en kunnen in de termen van 
Tabel 6.2

Betrouwbaarheid (Cronbach's Alpha) en spreiding (standaardafwijking, minimum en maximum waarde) van de kennisschalen $(N=1631)$

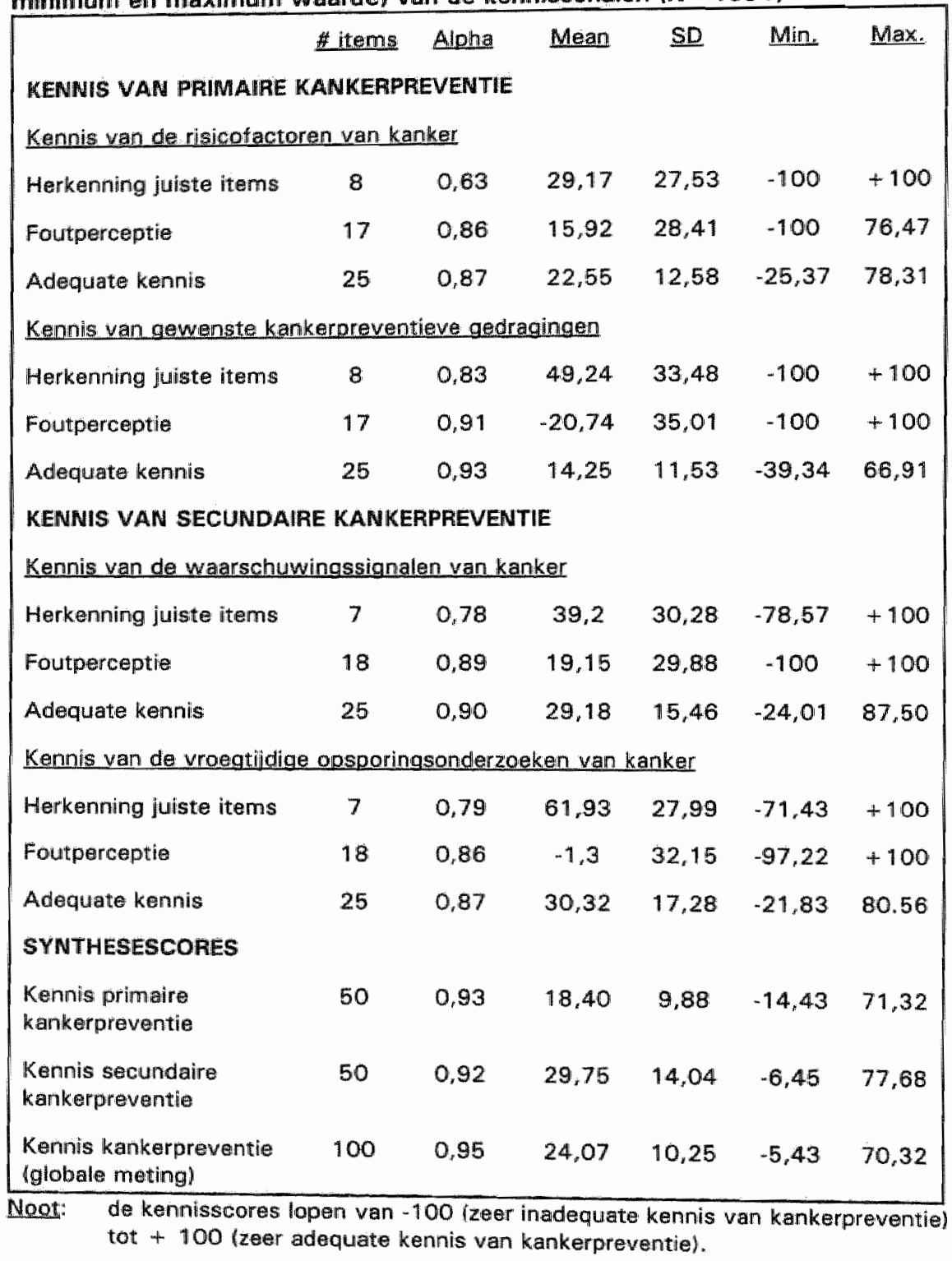

- Constructie en onderzoek van de kennisschalen - 
van der Pligt en de Vries (1995: 181) 'goed' worden genoemd. Van al deze schalen kan worden besloten dat de gemeten kennis van kankerpreventie goed betrouwbaar is geconstrueerd.

Enkel de alpha-waarde 0.63 van de schaal "kennisscore van de risicofactoren van kanker" is - hoewel ze de acceptabele norm van 0.65 benadert (van der Pligt en de Vries, 1995 : 181) - eerder aan de lage kant. Om - indien mogelijk - de betrouwbaarheid van deze schaal te verhogen, wordt deze schaal verder bestudeerd in tabel 6.3. Deze tabel geeft de correlaties weer tussen de acht gebruikte items, alsook in de laatste koiom de Cronbach's alpha-waarden bij weglating van het overeenkomstige item. Vooral die items 2 en 3 correleren relatief laag met de andere items. Het betreft respectievelijk "seksuele omgang met meerdere partners zonder condoom' en 'een eerste kind na de leeftijd van 30 jaar". Weglating van deze items zou evenwell de betrouwbaarheid van de schaal niet doen verhogen. De alpha-waarden zijn allemaal lager dan de oorspronkelijke alpha-waarde van 0.63 . Op basis van deze informatie kan dus niet worden besloten om één van de items buiten de schaal te laten. Er kon evenmin een verhoogde alpha-waarde worden bereikt bij weglating van zowel item 2 als item 3.

Tabel 6.3

Correlatiematrix van de 8 items van de schaal 'kennisscore risicofactoren'

\begin{tabular}{|c|c|c|c|c|c|c|c|c|c|}
\hline Item & 1 & 2 & 3 & 4 & 5 & 6 & 7 & 8 & $\begin{array}{c}\text { Cronbach's } \\
\text { alpha }\end{array}$ \\
\hline 1 & 1.000 & & & & & & & & 0.62 \\
\hline 2 & .075 & 1.000 & & & & & & & 0.62 \\
\hline 3 & .007 & 295 & 1.000 & & & & & & 0.62 \\
\hline 4 & .199 & .121 & .085 & 1.000 & & & & & 0.60 \\
\hline 5 & .246 & .033 & .004 & .474 & 1.000 & & & & 0.61 \\
\hline 6 & .211 & .130 & .126 & .185 & .211 & 1.000 & & & 0.57 \\
\hline 7 & .078 & .181 & 219 & .122 & .117 & .387 & 1.000 & & 0.59 \\
\hline 8 & .218 & .249 & .152 & .213 & .217 & .308 & .275 & 1.000 & 0.57 \\
\hline
\end{tabular}

Noot: Cronbach"s alpha bij weglating van het betreffende item.

In tabel 6.2 worden er ook gegevens van de spreiding vermeld, namelijk de standaardafwijking, alsook de minimum en maximum waargenomen waarde. De standaardafwijking werd hoger reeds besproken. De extreme waarden -100 en +100 wijzen vermoedelijk op de problematiek van een "response-set" - zoals in de volgende paragraaf wordt besproken - waarbij de respondenten eerder sociaal wenselijk antwoorden. Bij de adequate kennisschalen valt op dat deze extreme waarden geheel verdwijnen. Er mag bijgevolg worden besloten dat er door samenvoeging van de kennisscore met de 
foutperceptiescores in een adequate kennisschaal een correctie is van deze vertekening.

Zelfs wanneer er - zoals hier het geval is - vrij hoge betrouwbaarheidscoëfficiënten worden bereikt bij de initiele analyse van de kennisschalen, is het nog zeer de vraag of deze hoge waarden worden gerepliceerd in subpopulaties (Spector, 1992: 65). Bil de analyse van de betrouwbaarheid van de geconstrueerde schalen kan men bijgevolg ook onderzoeken in welke mate de toepassing van deze schalen nog steeds betrouwbaar is in bepaalde subpopulaties. Er wordt dan nagegaan hoe consistent of robuust de gevonden betrouwbaarheid var de schalen is.

De robuustheid wan de betrouwbaarheid kan worden nagegaan door de interne consistentie (Cronbach's alpha) van de schalen na te gaan voor subpopulaties. Omdat er in deze studie wordt verwacht dat kennis van kankerpreventie samenhangt met geslacht, leeftijd en sociale klasse (zie hypothesen in hoofdstukken 7 en 8 ) is het aangewezen om de robusstheid van de betrouwbaarheid na te gaan voor de subpopulaties die kunnen worden onderscheiden op basis van deze drie variabelen.

De resultaten van de betrouwbaarheidsanalyse yan de kennisschalen voor de verschillende subpopulaties worden weergegeven in tabel 6.4 voor respectievelijk mannen $(n=814)$, vrouwen $(n=817)$, jongeren van 18 tot 34 jaar $(n=586), 35-50$ jarigen $(n=535), 51-70$ jarigen $(n=510)$, respondenten van de lagere sociale klasse $(n=408)$, respondenten van de middenklasse $(n=468)$ en respondenten van de hogere klasse $(452)^{\prime}$. De alpha-waarden worden voor de overzichtelijkheid gepresenteerd in vier categorieën: een zwarte cirkel komt overeen met een zeer hoge alpha-waarde $(z \quad 0.90)$, een zwarte halve cirkel komt overeen met een hoge alpha-waarde 10.80 tot 0.90 , een lachende cirkel met een (zeer) aanvaarolbare alpha-waarde 10.75 tot 0.80 ) en een lege cirkel met een matige alpha-waarde $(0.55$ tot 0.70$)$.

Een zeer verheugende vaststelling is dat voor alle synthesescores van kennis van kankerpreventie en voor alle subpopulaties een zeer hoge alpha-waarde wordt bereikt. Tevens bereiken de adequate kennisscores van alle vier de indicatoren van kennis van karkerpreventie een hoge tot zeer hoge alpha-waarde. Anderzijds worden er aanvaardbare tot matige allpha-warden bereikt bij wrijwel alle subpopulaties voor drie van de vier kennisscores op de juiste items. Deze lagere alpha-waarden zijn geen verrassing, want ze werden ook reeds bereik.t bij de initiele analyse bij de totale populatie.

In het algemeen kan worden vastgesteld dat de interne consistentie hoog of zeer hoog is voor de verschillende steekproeven of subpopulaties. Op basis van deze gevonden alphawaarden kan worden besloten dat de betrouwbaarheid van de geconstrueerde schalen van kennis van kankerpreventio zeer robuust is. 1 Voor verdere informatie over samenstelling en operationalisering van het begrip 'sociale klasse'
wordt verwezen naar hoofdstuk 4 en bijlage $2 \mathrm{~b}$. 
Tabel 6.4

Betrouwbaarheid (Cronbach"s Alpha) van de kennisschalen, naar subpopulaties ( $N=1631)$

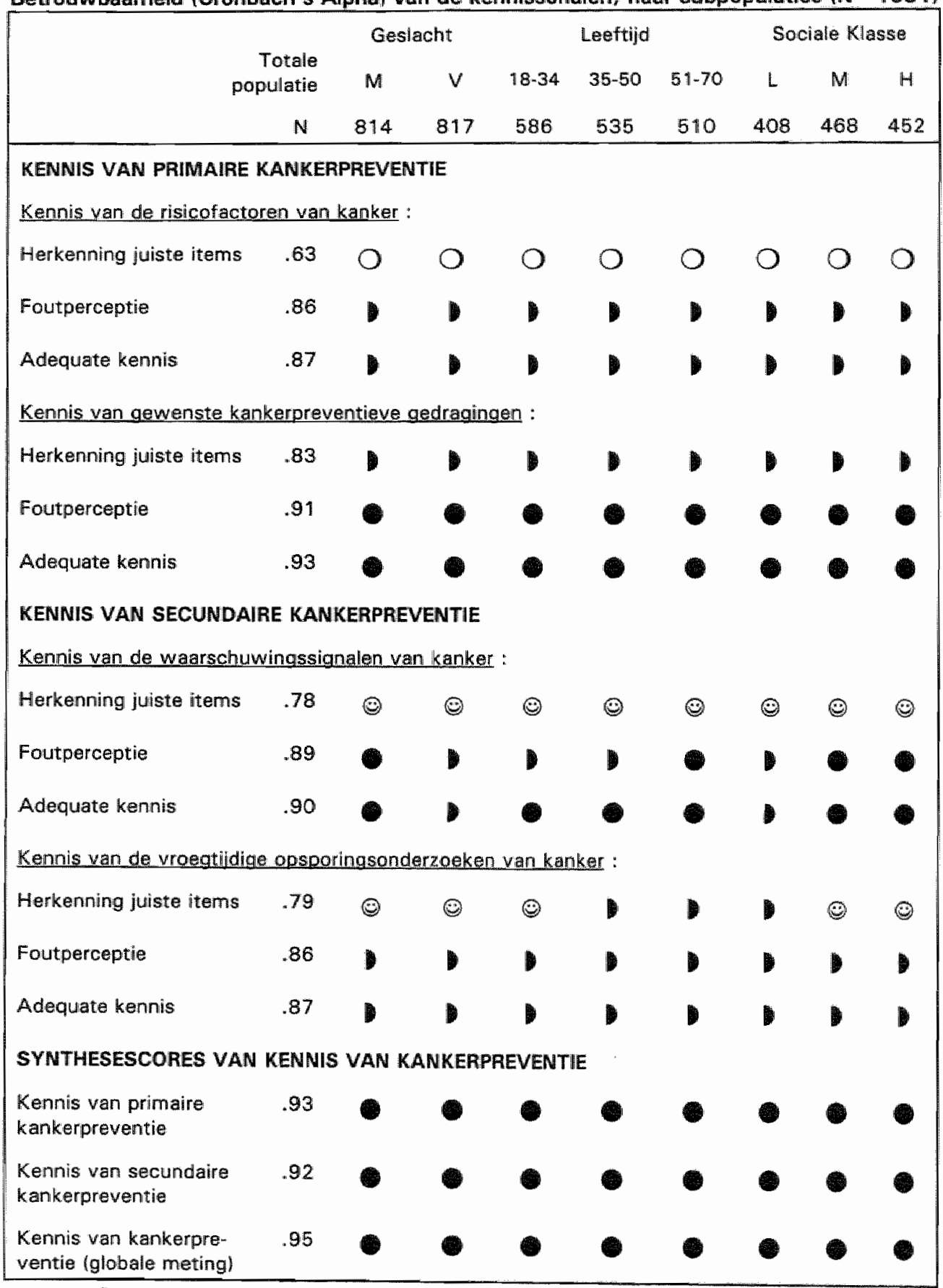

Noot: $\alpha 2.90 \quad .80 \leq \alpha<.90 \quad 0.75 \leq \alpha<.80 \quad 0.55 \leq \alpha<.70$ 
Tevens kan worden besloten dat enige terughoudendheid aan de dag moet worden gelegd woor het gebruik bij "subpopulaties" van de sichalen van kennis van kankerpreventie die alleen maar gebaseerd zijn op juiste items. Dit resultaat wijst er immers op dat bij voorkeur enkel de syntheseschalen en de adequate kennisschalen kunnen worden gebruikt bij analyse op subpopulatieniveau.

\subsection{Validiteit van de metingen van kennis van kankerpreventie}

In de vorige paragraaf werden de meetschalen geêvalueerd volgens het criterium van de betrouwbaarheid. In deze paragraaf wordt nader ingegaan op de geldigheid of validiteit van de metungen. Validiteit is een zeer complex begrip, met variërende begripsinhouden' en variërende methoden om de validiteit van een meetinstrument na te gaan. Algemeen gesproken verwijst validiteit naar de vraag of het instrument daadwerkelijk meet wat het pretendeert te meten.

Als de kennisschalen intern consistent zijn, zoals werd aangetoond in de vorige paragraaf " is er in leder geval zekerheid dat deze kennisschalen 'iets' meten. Het vaststellen van wat ze nu juist meten is echter een veel moeilijkere onderneming. De moeilijkheid schuilt deels in het feit dat bij validering van meetschalen beroep moet worden gedaan op de verwachte verbanden van de schalen met andere eigenschappen (bv. leeftijd, geslacht, enz.). Nu werden de schalen juist (en pas) ontwikkeld omdat er geen valide meetinstrument voor handen was om de hypothesen te toetsen, waardoor het resultaat van de toetsing empirisch niet gekend is. Het testen van validiteit veronderstelt bijgevolg het gelijktijdig uittesten van de kwaliteit van de meting of de schaal én van de onderzoekshypothesen die men juist met deze metingen wilde toetsen. Het testen van de validiteit van meetschalen wordt dan ook niat ten onrechte soms beschouwd als het moeilijkste aspect van schaalconstructie (Spector, 1992:46). Het verdient in dit hoofdstuk dan ook de nodige aandacht.

De validiteit van een meting kan worden aangeduid als de mate waarin de meetuitkamsten ongevoelig zijn voor systematische fouten ${ }^{2}$. Systematische fouten zijn die fouten in het meetinstrument die het meetresultaat continu in één bepaalde richting beïnvloeden (Segers, 1989:195). Het instrument vertekent de meting dan steeds in dezelfde richting doordat bij alke meting dezelfde (onbedoelde) bijverschijnselen worden meegeregistreerd.

I In de literatuur worden zeer uiteenlopende termen gebruikt, zoals 'face validity", "content validity', "sense validity", "construct validity", "trait validity", 'factorial validity', "criterion validity", validiteitsaspecten bedoeld, soms ook zeer uiteenlopende aspecten van validiteit. gelijkaardige Zie ondermeer Segers (1989:192-200) of Swanborn (1981: 201-224) voor een overzicht wan de
foutenbronnen in de meetprocedure. 
In het bijzonder bij het gebruik van schallen tijdens een survey-interview, dat ook in onderhavig onderzoek van toepassing is, kan er een belangrijke vorm van systematische vertekening aptreden, namelijk de responsbias of de response-set. Er zijn twee frequent voorkomende vormen van response-set, namelijk de "sociale wenselijkheid" en de "instemmende response-set".

De neiging die sommige respondenten vertonen om onathankelijk van de inhoud steeds akkoord te gaan met elke uitspraak in een vragenlijst noemt men de 'instemmende response-set'. Het is bekend dat ook bij niei-suggestieve vragen gemakkelijker met 'ja' wordt geantwoord dan met 'nee' (Segers, 1989: 196/. In de vragenlijst kan dit worden begrepen als die respondenten die onafhankelijk van de inhoud van het voorgelegde item met betrekking tot kankerpreventie steeds hetzelfde antwoord op de Likertschaal kiezen. Hierdoor verkrijgen deze mensen eenzelfde (extreem) antwoordpatroon in de vragenlijst. Dat dit wertekenend effect optrad in dit onderzoek wordt bewezen door het feit dat bepaalde respondenten de minimum $(-100)$ of de maximum $(+100)$ schaalwaarde scoren (zie tabel 6.2). Een minimum (of maximum) score op de schaal is immers het resultaat van eenzelfde minimum (of maximum) score op alle schaalitems. Door deze response-set gaat automatisch ook de standaardafwijking van het gemiddelde toenemen (zie hoger).

De tweede categorie van systematische vertekening van de respons is de 'sociale wenselijkheid". Dit is de neiging van respondenten om niet of minder bereid te zijn om gevoelens of gedragingen te rapporteren die ze zelf als sociaal onwenselijk beschouwen. Bij het formuleren van hun antwoord zullen zij dan ook de neiging vertonen om hun gevoelens of gedragingen sociaal beter voor te stellen dan ze in werkelijkheid zijn. Ook bij het toetsen van kennis zoals in onderhavig onderzoek, kan dit fenomeen zich voordoen. Mensen zullen niet zo gemakkelijk toegeven dat ze jets niet weten, waardoor ze geneigd zijn bij het woorleggen van de kennisitems eerder positief ("waarschijnlijk wel" of 'zeker") darn wel negatief ('waarschijnlijk niet' of 'zeker niet') te antwoorden. Dit verklaart wellicht waarom de verdelingen van de meeste kennisschalen van de echte items en de vier foutperceptieschalen (licht) scheef of asymmetrisch zijn (zie figuren $1 \mathrm{t} / \mathrm{m} 15$ in bijlage 2a). De scheefheidsmaat (skewness) vertoont dlaarbij in zes van de acht schalen een - zij het klleine - negatieve waarde 2 .

2. Het begrip 'instemmende response-set' is de vertaling van het angelsaksische begrip 'acquiescent response-set" (zie Wilkin, Hallam en Doggett, 1992:33).

2 Een verdeling wordt symmetrisch genoemd als de verdeling dezelfde vorm heeft aan beide zijden van de mediaan. In een symmetrische verdeling is de mediaan gelijk aan het rekenkundig gemiddelde (Schreuder, 1991, 75-76). Bij een negatieve waarde van de scheefheidsmaat (skewness) is de verdeling linksscheef of negatief scheef. De top ligt rechts van het midden en de verdeling heeft een lang uiteinde naar links. Bij een positieve waarde van de scheefheidsmaat is dit net omgekeerd. 
Hoe kan de validiteit nu empirische worden getest? In de literatuur worden er drie basistypen van validering onderscheiden (Segers, 1989:201; zie ook Billiet, 1993: 105 $112)^{\prime}$ : inhoudsvaliditeit, criteriumvaliditeit en begripsvaliditeit.

\section{- Inhoudsvalidering -}

Met validiteit van de metingen wordt er in de meest algemene betekenis inhoudsvaliditeit bedceld (in het Engels 'content validity'). Met inhoudsvaliditeit wordt de logische geldigheid van de meting bedoeld. Lijkt de "inhoud' van de empirische variabele of indicator op de 'inhoud" van de theoretische eigenschap of begrip (Segers, 1989:202). Of om het in de termen van Swanborn (1981: 189) te stellen : een meetprocedure is geldig als het kenmerkzoals-bedoeld wordt gemeten door het kenmerk-zoals-bepaald. Het komt er dus op aan om op logisch deductieve wijze vast te stellen of de 'inhoud' van de gebruikte indicatoren overeenkomt met de 'inhoud' van het theoretisch concept. Het begrip geldigheid kan daarbij in algemene termen worden aangeduid als de mate waarin de theoretisch bedoelde eigenschap, c.q. Kennis van kankerpreventie, daadwerkelijk via de gekozen meetprocedure en de gekozen empirische variabelen wordt gemeten (vergelijk Segers, 1989: 186 e.v.). Wordt er met andere woorden met de 100-items vragenlijst kennis van kankerpreventie en niets anders dan dat gemeten?

Bij inhoudsvalidering gaat het erom dat men door beargumenteren kan aannemelijk maken dat het meetinstrument daadwerkelijk het theoretische concept meet (Segers, 1989:202203). De onderzoeker legt daarom verantwoording af van de beslissingen omtrent het tot sitandkomen van het meetinstrument. Inhoudsvaliditeit slaat op de inzichtelijkheid en de plausibiliteit van zowel indicering, operationalisering als vraagformulering. De methode van inhoudsvalidering houdt de volgende stappen in (Segers, 1989:202):

a. Theoretische bezinning over de inhoud van het te onderzoeken begrip of concept;

b. In het verlengde hiervan het onderkennen en specificeren van de dimensies van het begrip;

c. Het doordacht kiezen van indicatoren voor elk van de onderscheiden dimensies. Dit veronderstelt een grondige beoordeling wan de magelijke empirische verschịinselen die als 'representant' van het bedoelde theoretische begrip kunnen worden beschouwd;

d. Het beoordelen wan de wijze walrop de verschillende indicatoren moeten worden samengevoegd tot tén wardebepaling van de variabele.

Deze vorm van geldigheid of validiteit kan men dus niet loszien van het meetdoel en de theoretische indicering en operationalisering zoals die werden ontwikkeld in hoofdstuk 3 . In dat hoofdstuk werd verduidelijkt hoe enerzijds door de indicering en anderzijds door de operationalisering het theoretisch concept "kennis van kankerpreventie" werd vertaald in empirisch vast te stellen variabelen, vragen en kennisitems. Voor uitwoeriger besprekingen van het begrip 'validiteit' en van de techirieken van validering, zie
ondermeer DeVellis $11991: 43-50 \%$, Spector $(1992: 46-64)$ en Streiner en Norman $(1989: 106$ -
125). 
De geldigheid wan de metingen van kennis van kankerpreventie heeft in de eerste plaats betrekking op het indiceren en pas op de tweede plaats op de operationalisering. Met een systematische begripsanalyse werd in hoofdstuk 3 aangetoond dat er bij de keuze van de empirisch waarneembare verschijnselen vier indicatoren werden geselecteerd, die als representant voor het te meten theoretische concept kunnen worden beschouwd. Daarbij werd eveneens rekening gehouden met het onderscheid tussen twee duidelijk onderscheiden dimensies in het concept kennis van kankerpreventie, namelijk de kennis van primaire kankerpreventie en de kennis wan secundaire kankerpreventie. Tevens werd een gemotiveerde keuze gemaakt om het aspect "tertiaire kankerpreventie' buiten beschouwing te laten. Deze globale indicering bakende vooral de grenzen af waarbinnen valide en betrouwbare uitspraken kunnen worden gedaan en legde de basis voor de geldigheid van de totale meetprocedure.

Ook bij de operationalisering van dit meetinstrument van kennis van kankerpreventie konden er fouten worden gemaakt die consequenties zouden hebben voor de geldigheid van de metingen. Er zijn twee soorten tekortkomingen bij de operationalisering die een meetprocedure ongeldig kunnen maken (Segers, 1989:192): systematische en onsystematische afwijkingen van de meetprocedure. In het laatste geval is er in feite een onbetrouwbare meetprocedure en komt dit overeen met wat hoger werd besproken bij de problematiek wan de betrouwbaarheid. Onsystematische afwijkingen zullen bij opeenvolgende metingen bij eenzelfde persoon immers leiden tot een verschillend meetresultaat. Systematische afwijkingen zullen bij opeenvolgende metingen bij eenzelfde persaon echter niet leiden tot een verschillend meetresultaat en zijn in principe dus niet onbetrouwbaar. Zij leiden echter wel tot een meetresultaat dat niet geldig is.

Een gedeelte van de systematische afwijkingen werd door het gemengd voorleggen van 'juiste' en 'foutieve' items reeds opgelost. Hoger werd bij de bespreking van tabell 6.1 gewezen op de vaststelling dat de standaardafwijkingen van de adequate kennismaten beduidend kleiner zijn dan deze van de kennisscores op de juiste items en de foutperceptiescores (zie hoger paragraaf 6.1). De respondenten die hopen om zeker geen item te missen. zullen sytematisch geneigd zijn om items in verband te brengen met kankerpreventie. Doordat de items random - de juiste items gemengd met de foute items - werden voorgelegd, zullen sommige respondenten extremere waarden scoren op de afzonderlijke

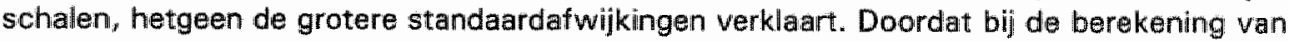
de adequate kennisscore de foutperceptiescore wordt afgetroklken van de kennisscore van de juiste items worden deze extremen weggewerkt in de adequate kennisschaal. Dit kan erop wijzen dat door samenvoeging van de belde schalen een deel van de systematische fouten (door instemmende response-set of door sociale wenselijkheid) wardt uitgeschakeld of gecorrigeerd. Omdat het voorkomen van systematische fouten bij de kennismeting eén van de uitdrukkelijke doelstellingen was bij de conceptie van deze kennisschalen (zie hoofdstuk 3), is deze vaststelling dan ook verheugend.

Er kan worden geconcludeerd dat het gebruik van de adequate kennisschalen - en dus van de combinatie van juiste en fautieve items bij de kennismeting - leidt tot een meer valide meting van kennis van kankerpreventie dan het afzonderlijk gebruik wan een kennisschaal 
waarmee alleen kennis van juiste items wordt getoetst.

Het opbouwen van validiteit wordt bij inhoudsvalidering getoetst op een logisch deductieve wijze. Validiteit kan evenwel ook empirisch en statistisch worden getoetst, namelijk vila criteriumvaliditeit en begripsvaliditeit.

\section{- Criteriumvalidering -}

In hoofdstuk 3 is een kennisvragenlijst ontwikkeld die niet meer is dan een indicatie van een hypothetisch (kernis van kankerpreventie) 'construct'. Dit (kennishconstruct is op haar beurt weer ingebed in een netwerk van relaties met andere constructen of eigenschappen van de onderzoekselementen (leeftijd, determinanten van kankerpreventie, ervaring met kanker, enz.). Om als valide beschouwd te kunnen worden zou deze indicator zich zo moeten gedragen alls de theorie aangeeft. Criteriumvalidering (in het Engels 'Criterion-Related validation') gaat na of de schaall meet wat ze moet meten volgens de theorie.

Bij criteriumvalidering vergelijkt men de scores van het nieuwe meetinstrument met de scores van een externe stanclaard. Deze standaard kan bijvoorbeeld een reeds eerder bestaand meetinstrument voor hetzelfde theoretisch concept zijn, maar ook een te verwachten relatie met een andere meting. Met behulp van een externe maatstaf tracht men dus een uitspraak over de geldigheid van een meetprocedure te ondersteunen. Dit impliceert dus dat er voor het theoretische concept een criterium of "gouden standaard" bestaat.

Een onderzoek van de criteriumvaliditeit kan bijvoorbeeld vertrekken vanuit de voorspellingen over de meetresultaten wan het 'construct'. Omdat over het complexe concept 'kennis van kankerpreventie' in de literatuur geen meetinstrument werd teruggevonden, kunnen hierover geen voorspellingen worden gemaakt en kan de criteriumvalidering niet worden getest door vergelijking met een instrument dat hetzelfde theoretisch concept meet.

Een andere methode voor criteriumvalidering betreft het vergelijken van de schaalscores met scores op andere variabelen of criteria (Spector, 1992:47-50). Een onderzoek van de criteriumvaliditeit kan dus ook vertrekken vanuit de voorspellingen over de relatie van het construct met andere constructen. Deze vergelijkingen kunnen statilstisch worden verricht via correlatie-analyse of via het vergelijken van schaalscores van groepen.

Hier wordt het onderzoek van de criteriumvaliditeit beperkt tot het toetsen van werbanden waarover eenduidigheid bestaat in de empirische literatuur terzake '. Er wordt onderzocht of het construct "kennis van kankerpreventie' empirisch gerelateerd is aan enkele sociale factoren. De voorspellingen betreffen te verwachten verschillen in de gemiddelde kennisscores tussen categorieën, die worden gevormd door de variabelen geslacht en

Voor de literatuurbespreking, zie de hoofdstukken 7 en 8 . 
opleiding". De theoretische voorspellingen zijn dat vrouwen een betere kennis van kankerpreventie hebben dan mannen (Berman en Wandersman, 1991; Bostick e.a., 1993; Clover e.a., 1991; Commissie van de Europese Gemeenschappen, 1987; Dent en Goulston, 1982; Michielutte en Diseker, 1982 en van Assema, 1990) en dat er ook significante kennisverschillen zijn naar opleidingsniveau (Berman en Wandersman, 1991 ; Berwick e.a. 1992; Brown e.a., 1990; Dent en Goulston, 1982; Loehrer e.a., 1991 en Polednak, 1990).

De verbanden die werden teruggevonden in onderhavig onderzoek, worden weergegeven in tabel 6.5. In tabel 6.5 valt op dat alle kennisverschillen tussen de onderzochte subpopulaties significant zijn. De verbanden die werden gevonden waren zoals verwacht: respondenten met een hogere opleiding kennen meer van kankerpreventie dan respondenten met een lagere opleiding; en vrouwen kennen meer dan mannen ${ }^{2}$. Al deze bevindingen stemmen overeen met wat eerder in onderzoek werd aangetroffen. Op basis van deze criteria (geslacht en opleiding) werd de criteriumvalidering met goed gevolg doorstaan.

\section{Tabel 6.5}

Samenhang (Mann-Whitney toets en Kruskal Wallis toets) van de adequate kennisschalen met sociale factoren $(\mathbb{N}=1631)$

\begin{tabular}{|c|c|c|}
\hline Adequate kennisschalen & Gesilacht & $\begin{array}{l}\text { Opleiding } \\
\text { (3 klassen) }\end{array}$ \\
\hline Kennis van risicofactoren & 米洋 & 橉米米 \\
\hline Kennis gewenst kankerpreventief gedrag & $* * *$ & 米米 \\
\hline Kennis waarschuwingssignalen & $* * * *$ & 米萗 \\
\hline Kennis opsporingsonderzoeken & 料潘 & 料橉 \\
\hline Kennis van primaire kankerpreventie & 米米米 & 米来橉 \\
\hline Kennis van secundaire kankerpreventie & 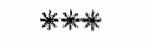 & 米来繁 \\
\hline $\begin{array}{l}\text { Kennis van kankerpreventie } \\
\text { (globale meting) }\end{array}$ & $* * *$ & 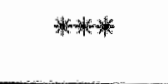 \\
\hline
\end{tabular}

"Deze valideringsmethode staat in het Nederlands ook bekend als "discriminante validiteit" en in het Engels als de "known-groups method".

2 Zoals reeds hoger aangegeven, sluiten deze resultaten aan bij de toetsing van onderzoekshypothesen van de volgende hoofdstukken. Daarom worden deze verbanden hier niet verder geanalyseerd. 


\section{- Begripsvalidering.}

Begripsvalidering (in het Engels "construct validity') kan worden nagegaan door te toetsen of er een hoge correlatie bestaat tussen gelijkwaardige indicatoren van het (kennis)construct - convergente validiteit - en of er lagere correlaties zijn tussen deza indicatoren en indicatoren van andere (kennis)constructen - divergente validiteit - (KönigZahn, Furer en Tax, 1993: 18).

Naar dit onderzoek vertald, betekent dit de volgende verwachtingen over de correlaties tussen de geconstrueerde schalen :

1. de schaalscores van kennis van kankerpreventie correleren allemaal positief met elkaar;

2. de correlatiecoëfficiënten tussen scores die eenzelfde dimensie meten van kennis van kankerpreventie zijn hoog (cfr. convergente validiteit);

3. de correlatiecoëfficiënten tussen scores die verschillende dimensies meten van kennis van kankerpreventie zijm laag of minstens lager dan de correlatiecoëfficiënten bedoeld in punt 2 (cfir. divergente validiteit).

Deze verwachtingen kunnen worden getoetst door een correlatiematrix op te stellem tussen de schalen van kennis van kankerpreventie onderling. Deze correlaties tussen de ladequate) kennisscores zijn allemaal weergegeven in tabel 6.6 .

Alle correlatiematen in tabel 6.6 zijn inderdaad significant ên positief (verwachting 1).

In de correlatiematrix in tabel 6.6 is de mate van convergente validiteit af te leiden uit de correlatiecoëfficiënten die zich bevinden in de vijf "grijs gekleurde" rechthoeken (verwachting 2). Vooral de globale kennismaat blijkt behoorlijk te correleren met alle andere subschalen. Het zijn evenwel de correlatiecoëfficiēnten tussen de dimensies van kennis van kankerpreventie en hun respectievelijke indicatoren die de hoogste correlaties hebben. De kennisdimensie 'kennis van primaire kankerpreventie" heeft een correlatiecoëfficiënt van 0.64 en 0.59 met respectievelijk 'kennis van risicofactoren van kanker' en 'kennis van het gewenste kankerpreventief gedrag". De kennisdimensie "kennis van secundaire kankerpreventie' heeft ean correlatiecoüfficiënt van 0.63 en 0.69 met respectievelijk 'kennis van de waarschuwingssignalem van kanker' en 'kennis van de vroegtijdige opsporingsonderzoeken". De correlatiecoëfficiënten tussen de twee indicatoren die cenzelfde kennisdimensie meten zijn nog steeds significant, doch minder substantieel, namelijk respectievelijk 0.23 en 0.32 . Uit deze gegevens kan worden besloten dat de gevonden correlatiewaarden een zekere mate van "convergente validiteit" aangeven.

De mate van divergente validiteit kan worden afgeleid uit de correlatiecoëfficiënten die zich buiten de vijt "grijs gekleurde" rechthoeken bevinden. Het zijn de correlaties tussen verschillende deelaspecten van het construct 'kennis van kankerpreventie'. Hoe lager deze coëfficiënten, hoe groter de divergente validiteit (verwachting 3 ). Deze correlatiecoefficiënten variëren van 0.13 tot 0.30 , hetgeen aanzienlijk lager is dan de meeste 
convergente correlaties. Worden de correlatiecoëfficiënten tussen de indicatoren en hun dimensiemaat vergeleken (cir. de coefficiënten in de rechthoeken op regels 5 en 6 ) met de correlatiecoëfficiënten tussen de undicatoren en de andere dimensie (cfr. de coefficiënten 'buiten' de rechthoeken op de regels 5 en 6), dan zijn de eerste correlaties veel sterker dan deze in de tweede groep correlaties, en zijn de verschillen zeer substantieel.

Tabel 6.6

Correlaties tussen de "adequate" schalen van kennis van kankerpreventie (Kendall's Tau, alle correlaties significant met $p<0.001$ )

\begin{tabular}{|c|c|c|c|c|c|c|}
\hline Kennisschallen : & 1 & 2 & 3 & 4 & 5 & 6 \\
\hline \multicolumn{7}{|l|}{ 1. Risicofactoren } \\
\hline \multicolumn{7}{|l|}{ 2. Gewenst Gedrag } \\
\hline 3. Waarschuwingssignalen & 0.13 & 0.21 & & & & \\
\hline 4. Opsporingsonderzoeken & 0.21 & 0.29 & 7. & & & \\
\hline 5. Primaire Kankerpreventie & 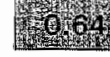 & 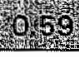 & 0.21 & 0.30 & & \\
\hline 6. Secund. Kankerpreventie & 0.20 & 0.29 & & & 0.30 & \\
\hline 7. Kankerpreventie (globaal) & & & & & & \\
\hline
\end{tabular}

Noot: alleen de adequate kennismaten worden gepresenteerd.

Als de correlatiecoëfficiẻnten tussen de indicatoren van eenzelfde dimensie (cfr. de coëfficiënten in de rechthoekjes op regels 2 en 4) worden vergeleken met de correlatiecoëfficiënten tussen de ündicatoren van een verschillende dimensie (cfr. de coëfficiënten buiten de rechthoekjes op regeis $3 \mathrm{t} / \mathrm{m}$ 4), dan zï̈n de verschillen weliswaar minder substantieel, doch de coëfficiënten van convergente validiteit zijn toch steeds - zij het in zeer beperkte mate - groter dan de respectievelijke coefficiënten voor de divergente waliditeit. Zo is de correlatie van de kennis van risicofactoren met kennis wan gewenst kankerpreventief gedrag (0.23) sterker dan de correlaties met respectievellik de kennis van de waarschuwingssignalen 10.13 ) en de kennis wan de vroegtijdige opsporingsonderzoeken (0.21). Anderzijds is de correlatie van de kenris van de vroegtijdige opsporingsonderzoeken met de kennis van de waarschuwingssignalen voor kanker $(0.32)$ eveneens sterker dan de correlaties met respectievelijk de kennis van het gewenst kankerpreventief gedrag 10.29 ) en de kennis van de risicofactoren voor kanker $(0.21)$. 


\subsection{Variabiliteir van de scores en vorm van de verdeling van de schalen}

Een goed meetinstrument dient scores op te leveren die verspreid zijn over de gehele schaal en die 'normaal' zijn verdeeld (Wilkin e.a., 1992: 28). Eén van de grootste problemen bij het meten van gezondheid is dat scores de neiging hebben om een scheve verdeling te wertonen. Dergelijke scheve verdelingen zijn problematisch om twee redenen.

Ten eerste laat een meetinstrument met een scheve verdeling niet toe om veranderingen of verbeteringen vast te stellen bij de subjecten die extreem scoren of de maximum lof minimum) waarde van de schaal hebben bereikt. De schaal discrimineert m.a.w. onvoldoende voor deze extreme scores.

Ten tweede bepaalt de problematiek van de normaalverdeling in belangrijke mate de keuze tussen parametrische of non-parametrische toetsen (Schreuder, 1991: 88; zie ook Siegel en Castellan, 1988). Is aan de premisse van de normaalverdeling voldaan, dan kan bij de analyse van de centrale onderzoekshypothesen over mogelijke verbanden van de externe variabelen met de kennisschalen gebruik worden gemaakt van parametrische statilstische toetsen (zie aok hoofdstuk 4, paragraaf 4.5). Indien dat niet het geval is, dient bij toetsing van de bivariate onderzoekshypothesen bij voorkeur gebruik te worden gemaakt van nietparametrische toetsen. De niet-parametrische toetsen worden ook wel de verdelingsvrije toetsen genoemd. Zij stellen geen eisen aan de vorm van de verdeling van de populatie. De toetsen die eisen stellen aan de vorm van de verdeling van de populatie zijn de parametrische toetsen. Parametrische toetsen stellen dus hogere eisen aan de gegevens dan niet-parametrische toetsen. Wordt aan de eisen van een parametrische toets voldaan, dan wordt in principe altijd gekozen voor een parametrische toets (bijvoorbeeld de $\mathbf{Z}$ - $t$-, of Ftoets) en niet woor een niet-parametrische toets.

Het is bijgevolg in dit onderzoek waar kennis van kankerpreventie wordt gemeten zeer zeker aangewezen om na te gaan welke vorm de verdeling van de onderzoekspopulatie op de geconstrueerde kennisschalen heeft en of de geconstrueerde kennisschallen een normaal verdeelde populatie vertonen.

Als de kennisschaien worden uitgezet in staafjesdiagrammen (zie figuren $1 \mathrm{t} / \mathrm{m}$ 15 in bijlage 2a) en vergeleken met de curve van een normale verdeling, dan lijken vrijwel al de kennisschalen normaal verdeold te zijn. Op het eerste gezicht is dit een bevredigende vaststelling. Visuele toetsing van de verdeling van een variabele is evenwel weinig betrouwbaar en geeft zeker geen garantie op een normaal verdeelde variabele. Het statistisch pakket SPSS/WIN biedt de mogelijkheid om de verdeling van variabelen op een meer betrouwbare wijze te toetsen.

In dit onderzoek werd de controle op normaliteit van de verdelingen van de kennisschalen gecontroleerd via de Kolmogorov-Smirnov (Goodness-of-fit) toets (SPSS WVIN, 1993). Van alle goadness-of-fit toetsen wordt de Kolmogorov-Smirnov toets beschouwd als de meest krachtige niet-parametrische toets (Schreuder, 1991: 105). 
Tabel 6.7

De verdeling (Kolmogorov-Smirnov Goodness of Fit test) van de kennisschalen $(N=1631)$

\begin{tabular}{|c|c|c|c|}
\hline Kennisschalen & $K-S Z$ & sign. toets & N \\
\hline \multicolumn{4}{|c|}{ KENNIIS VAN PRIMAIRE KANKERPREVENTIE } \\
\hline \multicolumn{4}{|c|}{ Kennis van risicofactoren van kanker } \\
\hline Herkenning juiste items & 3,25 & *** & 1631 \\
\hline Foutperceptie & $2,2 \sharp$ & $* *$ & 1631 \\
\hline Adequate kennis & 1,23 & n.s. & 1631 \\
\hline \multicolumn{4}{|c|}{ Kennis van gewenste kankerpreventieve gedragingen } \\
\hline Herkenning juiste items & 4,29 & $* *$ & 1631 \\
\hline Foutperceptie & 2,52 & ** * & 1631 \\
\hline Adequate kennis & 2,11 & $* * *$ & 1631 \\
\hline \multicolumn{4}{|c|}{ KENNIS VAN SECUNDAIRE KANKERPREVENTIE } \\
\hline \multicolumn{4}{|c|}{ Kennis van de waarschuwingssignalen van kanker } \\
\hline Herkenning juiste items & 2,69 & * * & 1631 \\
\hline Foutperceptie & 1,47 & * & 1631 \\
\hline Adequate kennis & 1,96 & $* *$ & 1631 \\
\hline \multicolumn{4}{|c|}{ Kennis van de vroegtiidige opsporingsonderzoeken van kanker } \\
\hline Herkenning juiste items & 3.67 & $* *$ & 1631 \\
\hline Foutperceptie & 1.85 & ** & 1631 \\
\hline Adequate kennis & 1,32 & n.s. & 1631 \\
\hline \multicolumn{4}{|c|}{ SYNTHESE VAN KENNIS VAN KANKERPREVENTIE } \\
\hline Kennis Primaire Kankerpreventie & 1,60 & * & 1631 \\
\hline $\begin{array}{l}\text { Kennis Secundiaire } \\
\text { Kankerpreventie }\end{array}$ & 1,45 & * & 1631 \\
\hline $\begin{array}{l}\text { Kennis van Kankerpreventie } \\
\text { (globale meting) }\end{array}$ & 1,38 & * & 1631 \\
\hline
\end{tabular}

- Constructie en onderzoek van de kennisschalen - 
De Kolmogorov-Smirnov toets wordt gebruikt om te toetsen of de waargenomen verdeling van de kennisschalen overeenkomt met een theoretische verdeling, c.q. een normale verdeling (Huizingh, 1989: 243-245: Schreuder, 1991: 102-105). Een ordinale schaling van de variabele is daarbij voldoende en de verdeling van de onderzoeksvariabele moet continu zijn. Aan beide voorwaarden is voldaan voor de kennisschalen.

SPSS berekent de parameters van de normaalverdeling uit de steekproef en vergelijkt deze met de waargenomen verdeling. De nulhypothese van de toets stelt dat de variabele normaal verdeeld is. Indien de overschrijdingskans p kleiner is dan alpha (5\%), dan dient de nulhypothese verworpen te worden en moet de alternatieve hypothese worden aanvaard, namelijk dat de variabele niet normaal verdeeld is.

In tabel 6.7 merkt men dat slechts twee kennisschalen de statistische vergelijking met de normale verdeling doorstaan. Het betreft de adequate kennisscore van de risicofactoren van kanker en de adequate kennisscore van de vroegtijdige opsporingsonderzoeken van kanker. Deze twee schalen kunnen bijgevolg onderworpen worden aan statistische analyses met krachtige toetsen op parametrisch niveau. De meeste 'adequate' kennisschalen benaderen wel de normaalverdeling. Alle andere kennisschalen zijn echter niet normaal verdeeld, zodat zij in principe niet onderworpen kunnen worden aan statistische analyses op parametrisch niveau.

\subsection{Samenvatting en conclusies}

In dit hoofdstuk werden de schalen geconstrueerd waarmee het niveau van kennis van kankerpreventie kan worden vastgesteld. Uit de analyse van de geconstrueerde schalen kan een (vervolg van/ antwoord op onderzoeksvraag I worden gegeven, dat al een eerste aanzet heeft gekregen in hoofdstuk 3. Op basis van de gemiddelde scores op de geconstrueerde schalen kunnen ook definitievere antwoorden worden gegeven op onderzoeksvraag 11 , die reeds een aanzet tot antwoord kreeg in hoofdstuk 5. Bij wijze van samenvatting worden deze onderzoeksvragen nu systematisch overlopen.

- ad. onderzoeksvraag ( (zie hoofdstuk 1) -

De eerste onderzoeksvirag is zeer omvattend en kan niet worden beantwoord zonder veneens hoofdstuk 3 in beschouwing to nemen.

Het was niet de bedoeling om in dit hoofdstuk een definitieve of absolute uitspraak te doen over de betrouwbaarheid en de validiteit van de metingen van kennis van kankerpreventie. Dit is in de gedragswetenschappen bij meting van complexe eigenschappen van mensen of groepen quasi onmogelijk. Wel werd er door bestudering van de onderzoeksresultaten aangetoond in welke mate de metingen als betrouwbaar en
valide kunnen worden beschouwd. 
In het algemeen kan worden gesteld dat de geconstrueerde schalen goede resultaten geven op het getoetste betrouwbaarheidcriterium van de interne consistentie van de meetschalen. De zeer hoge Cronbach's alpha watden blijken bovendien consistent of robuust bij analyse van de betrouwbaarheid voor de onderzochte subpopulaties. De betrouwbaarheid van de schalen werd met gunstig resultaat getest vor subpopulaties gedefinieerd naar respectievelijk geslacht, leeftijd en sociale klasse.

Ook het validiteitsonderzoek gaf bevredigende resultaten. Het gebruik van zowvel 'juiste' als 'foutieve' items in de adequate kennisschalen leidt tot minder systematische fouten en bijgevolg tot een meer valide meting van kennis van kankerpreventie dan het afzonderlijk gebruik wan een kennisschaall waarmee alleen de herkenning van juiste items wordt getoetst. De validering van de adequate kennisschalen werd verder met bevredigende resultaten empirisch-statistisch onderzocht door respectievelijk de methode van criteriumwalidering en begripsvalidering. De criteriumvalidering werd met succes getoetst en leverde de verwachte significante groepswerschillen op. Tevens werden er goede waarden gevonden voor zowel de "convergente" als de "divergente" validiteit.

Om nu de betekenis van de kennisscores van individuen of groepen te kunnen interpreteren, is het noodzakelijk dat er meer inzicht wordt verworven in de verdeling van de scores in de totale bevolking. Pas indien de positie van een individu of groep t.o.v. de algemene verdeling kan worden bepaald, kan worden geëvalueerd of iemand veel of weinig afweet van kankerpreventie. Een kennisscore is hoog als ze groter is dan de meerderheid in de populatieverdeling en is laag indien ze kleiner is dan de meerderheid in de populatieverdeling. Om de verdeling van schaalscores te kunnen bepalen voor een bevolking is het noodzakelijk om te beschikken over een grote en representatieve steekproef. De meeste meetschalen in de gedragswetenschappen die zich intensief met schaalconstructies bezighouden (bv. psychologie en pedagogie) zijn echter ontwilkkeld en genormeerd bij studentenpopulaties, waardoor de generaliseerbaarheid vaak te wensen overlaat.

Een groot voordeel van onderhavig onderzoek is inderdaad dat er wordt gewerkt met een omvangrijke representatieve steekproef uit de Vlaamse bevolking. Hierdoor kunnen de schalen van kennis van kankerpreventie worden 'genormeerd' en worden er betrouwbare analyses van subpopulaties mogelijk. Deze normen zullen kunnen worden gebruikt om gevonden resultaten inzake kennis van kankerpreventie te toetsen, bijvoorbeeld naar aanleiding van een lokale of regionale preventiecampagne. Het gebruilk van deze normen maakt met andere woorden een betrouwbare evaluatie mogelijk van de effecten van een voorlichtingscampagne inzake kankerpreventie.

Doordat de gemiddelde schaalscores in dit hoofdstuk werden berekend is het ook mogelijk om betrouwbare antwoorden te formuleren op de onderzoeksvragen 11.1 tot 11.3 (zie hoger). 
- ad. onderzoekswraag $1 / .1$ -

Uit de onderzoeksresultaten blijkt dat er in Vlaanderen een duidelijk verschil is in kennisniveau tussen kennis van primaire kankerpreventie en kennis van secundaire kankerpreventie. Het laatste kennisdomein is beduidend beter gekend dan het eerste. Secundaire kankerpreventie is meer dan 10 schaalpunten beter gekend dan primaire kankerpreventie. De Vlaamse bevolking is dus duidelijk beter vertrouwd met secundaire kankerpreventie dan met primaire kankerpreventie. Deze resultaten bevestigen de resultaten van de beschrijvende statistische analyses in hoofdstuk 5 .

De kennis van secundaire kankerpreventie is evenwichtig gespreid over de twee indicatieve kennisdomeinen. De respondenten kennen namelijk angeveer evenveel van de vroegtijdige opsporingsonderzoeken van kanker als van de waarschuwingssignalen van kanker. Hetzelfde kan evenwel niet worden gezegd van de kennis van primaire kankerpreventie. De score wordt gevormd door een relatief hoge kennis van de risicofactoren en een relatief lagere kennis van het gewenst preventief gedrag.

Dit verschil kan vermoedelijk worden verklaard doordat jarenlang in preventiecampagnes in hoofdzaak nadruk werd gelegd op wat zgn. 'verboden' is, dus op wat ongezond is in de leef-en eetgewoonten, en veel minder op de mogelijke en gewenste alternatieven. De boodschappen waren eerder negatief van teneur en minder positief. Pas in de afgelopen jaren wordt de bevolking ook meer en meer benaderd met positieve preventieboodschappen, dus met boodschappen van wat men wél bij voorkeur mag eten of doen. Zo wordt bij dieetadvies niet alleen meer gezegd dat men geen of minder vet mag eten, doch ook dat men bij voorkeur meer vezelrijke voedingstoffen kan eten.

Deze verschuiving van aandacht in voorlichting is een resultante van een gewijzigd gezondheidsdenken in de samenleving. Deze accentverschuiving in het gezondheidsdenken is inmiddells op verschillende terreinen merkbaar'. De definitie van gezondheid kende in de afgelopen decennia een geleidelijke overgang van een negatieve naar een positieve invulling. Ook institutioneel gaat er in Vlaanderen - ondermeer door de oprichting in 1991 van het Vlaams Instituut voor Gezondheidspromotie - meer en meer aandacht naar gexondheid, in tegenstelling tot de vrijwel exclusiove aandacht voor ziektegerichte preventie uit het verleden.

- ad. onderzookswraag 11.2 .

In het vorige hoofdstuk is reeds gebleken dat er zeer veel misvattingen zijn over kankerpreventie. Zo denkt bijvoorbeeld een meerderheid van de bevolking ten onrechte dat niet verzorgen van een huidontsteking, en niet verzorgen van een aanhoudende diarree 'risicofactoren' zijn voor kanker. Regelmatig eten van wis, regelmatig sporten, regelmatig 1 Voor een overzicht van de verschuivingen in thet gezondheidsdenken, zie Westendorp (1990: 6 .
18 ). 
eten van yoghurt, het wermijden van stress, enz. worden dan weer door zeer veel mensen ten onrechte beschouwd als 'gewenst kankerpreventief gedrag'. Inzake waarschuwingssignalen voor kanker zijn de misvattingen minder uitgesproken aanwezig. Een radiografie van de longen, een keeluitstrijkje, een urine-onderzoek, een echografie en een tuberculosetest worden dan weer ten onrechte door een Igrotel meerderheild van de respondenten beschouwd als een vroegtijdig opsporingsonderzoek van kanker.

in dit hoofdstuk werd ook vastgesteld dat deze misvattingen over kankerpreventie niet kunnen gelokaliseerd worden in één kennisdomein. Zowel over primaire als over secundaire kankerpireventie bestaan er veel misvattingen.

Als elk kennisdomein afzonderlijk wordt bekeken door de foutperceptiescores van de afzonderlijke indicatoren met elkaar te vergelijken, dan zijn er toch wezenlijke verschillen. In het domein 'primaire kankerpreventie' situeren de meeste misvattingen zich vooral bij de kennis van het gewenst kankerpreventief gedrag en minder bij de kennis van de risicofactoren. Mensen denken vooral inzake 'gewenst kankerprewentief gedrag' dat alles en nog wat 'goed" is tegen kanker. In het domein "secundaire kankerpreventie" situeren de meeste misvattingen zich vooral bij de kennis van de vroegtijdige opsporingsonderzoeken en minder bij de kennis van de waarschuwingssignalen van kanker.

\section{- ad. onderzoeksvraag II.3 -}

In deze studie kon het vermogen om factoren die echt liets te maken hebben met kankerpreventie goed te onderscheiden van factoren die geen rol spelen bij kankerpreventie warden onderzocht door de score op de herkenning van de 'juiste' items te vergelijken met hun respectievelijke score op de foutperceptieschaal. Hoe groter het verschil tussen de kennisscore (exclusief gebaseerd op alléen de juiste items) en de "oorspronkelijke' foutperceptiescore" , hoe groter dit vermogen.

De "juiste" items werden in dit onderzoek steeds met grotere zekerheid herkend dan de 'foutieve' items. De respondenten weten dus met grotere zekerheid dat iets wel met kankerpreventie te maken heeft, dan dat iets niet met kankerpreventie te maken heeft.

Het onderscheidingsvermogen verschilt evenwel sterk naargelang het domein van de kennis van kankerpreventie. Het is relatief klein bij de kennis van de primaire kankerpreventie en vrij groot bij de kennis van secundaire kankerpreventie.

I Met de "oorspronkelijke" foutperceptiescore wordt thier bedoeld de foutperceptieschaal vooraleer die werd omgekeerd. 



\title{
Hoofdstuk 7
}

\section{Kennis van kankerpreventie en het verband met de socio-demografische determinanten}

\author{
7.1 Probleemstelling en onderzoekshypothesen \\ 7.1.1 Geslacht en kennis van kankerpreventie \\ 7.1.2 Leeftijd en kennis van kankerpreventie \\ 7.1.3 Leefsituatie en kennis van kankerpreventie \\ 7.2 Overzicht van het onderzoeksmateriaal en de analyseopzet \\ 7.3 Socio-demografische verschillen en kennis van kankerpreventie \\ 7.3.1 Sekseverschillen in kennis van kankerpreventie \\ 7.3.2 Leeftijdsverschillen in kennis van kankerpreventie \\ 7.3.3 De invloed van de leefsituatie (partner) op kennis van \\ kankerpreventie \\ 7.4 De samenhang van kennis van kankerpreventie met de socio- \\ demografische determinanten nader bekeken \\ 7.5 Samenvatting en discussie
}

\subsection{Probleemstelling en onderzoekshypothesen}

De leefomstandigheden van mensen zijn sterk verbonden met hun positie in de samenleving. Dat geldt ook voor ziekte en gezondheid. Jongeren hebben andere ziekten dan ouderen, ouderen hebben een andere beleving van ziekte dan jongerem, vrouwen hebben andere gezondheidsrisico's dan mannen, vrouwen hebben ook andere gezondheidsklachten dan mannen, getrouwde mensen kunnen bij ziekte terugvallen op de steun van hun partner en alleenstaanden kunnen dat niet, enz. Al deze verschillende leefomstandigheden hebben te maken met de structuur van de samenleving en met een andere socio-demografische positie in de samenleving.

Die socio-demagrafische positie in de samenleving kan worden beschreven aan de hand van een aantal criteria, de zgn. socio-demografische achtergrondgegevens van de respondenten. In de Angelsaksische literatuur worden deze socio-demografische achtergrondgegevens van de respondenten aangeduid met de term "Standard Demographic Terms". De persoonsgebonden eigenschappen die men daarbij meestal onderscheidt zijn : geslacht, leeftijd en leefsituatie. Aan de hand van deze drie socio-demografische achtergrondgegevens van de respondent kan de invloed van de socio-demografische determinanten op de kennis van kankerpreventie systematisch worden onderzocht. In de volgende paragrafen worden eerst de hypothesen ontwikkeld over de invloed van respectievelijk geslacht, leeftijd en leefsituatie op de kennis van kankerpreventie. 
Voor de ontwikkelling van de onderzoekshypothesen werd er vertrokken vanuit het bredere kader van de relaties tussen de socio-demografische determinanten en kennis wan kankerpreventie. Voor elke socio-demografische determinant wordt eerst de meer algemene relatie met (on)gezondheid besproken en vervolgens worden de uit de literatuur naar voor komende empirische relatie met kennis van kankerpreventie nader toegelicht. Tot slot wordt hieruit de concrete formulering van de onderzoekshypothesen gededuceerd. Indien er in de literatuur geen specifiek of geen eenduidig verband werd aangetroffen, zal gebruik worden gemaakt van de numypothese, namelik dat er geen verband wordt verwacht.

\subsubsection{Geslachten kennis van kankerpreventie}

Tussen mannen en vrouwen blijken de levensomstandigheden zowel biologisch, cultureel als socio-economisch sterk te verschillen. Vooral door de vrouwenbeweging is er veel belangstelling ontstaan voor de verschillende omstandigheden waarin mannen en vrouwen leven. Deze verschillende levensomstandigheden hebben ook consequenties op de ziekte en de gezondheid van mannen en vrouwen. Uit tal van onderzoekingen in het binnen-en buitenland is immers gebleken dat er verschillen in gezondheid bestaan tussen mannen en vrouwen. Uit vele studies komt naar voor dat de sterftecijfers bil mannen hoger zijn dan bij vrouwen. Hoewel de sterftecijfers van mannen en vrouwen de afgelopen 100 jaar convergeren, is ook in Vlaanderen nog steeds het sterftecijfer van mannen 112,3 per 1000 in 1994) hoger dan dat van wrouwen 17,4 per 1000 in 1994) (Aelvoet e.a., 1996: 17). Er is ook een duidelijk verschil in levensverwachting tussen mannen en vrouwen. En dat verschil is in België de afgelopen eeuw aanzienlijik groter geworden. Tussen 1900 en 1990 steeg de levensverwachting bij geboorte van mannen van 43,6 tot 72,4 jaar en bij vrouwen van 46,9 tot 79,1 jaar (Matthijs, 1994: 30). In het begin van de eeuw was er dus een verschil in levensverwachting van 3,3 jaar in het voordeel van de vrouw en in 1990 was dit verschil uitgegroeid tot 6,7 jaar.

Ook de gezondheidsrisica's van mannen zijn verschillend van deze van vrouwen. Zo bijvoorbeeld zijn er in België meer mannen (1991: 33\%) dan vrouwen (1991:24\%; bron: Matthijs, 1994:58) die roken en worden in Nederland meer mannen dan vrouwen het slachtoffer van bedrijfsongevallen (Van Pernis, Keukens en Stapel, 1986: 291). Verder worden er ook bil medische consumptie geslachtsverschillen vastgesteld. Zo is in Nederland de ziekenhuisopnamen bij vrouwen hoger dan bij mannen, terwijl vrouwen ook vaker gezondheidsklachten hebben en meer gebruik maken van medische voorzieningen dan mannen (de Bakker, Claessens en van der Velden, 1992).

If een representatieve survey in Vlaanderen werden er significante geslachtsverschillen vastgesteld in de 'gepercipieerde gezondheid' (Deliens, 1995b; De Nooze en Deliens, 1996). De verschillen tussen mannen en vrouwen zijn het grootst in de leeftijdscategorie 51-70 jaar. $12 \%$ meer vrouwen dan mannen rapporteren beperikingen in fysiek functioneren en $6 \%$ meer vrouwen dan mannen rapporteren lichamelijke pijn. Meer vrouwen dan mannen voelen zich emotioneel minder goed (16\% meer vrouwen dan mannen) en warden door hun emotioneel onwelbevinden beperkt in hun werk of in hun dagelijkse activiteiten $18 \%$ meer vrouwen dan mannen). Ook vermoeidheid en een gebrek aan energie worden door $8 \%$ meer 
vrouwen dan door mannen gerapporteerd.

Voor de gezondheidsverschillen tussen mannen en vrouwen worden in de literatuur een veelvoud aan verklaringen gegeven. Al deze verklaringen kunnen worden gerubriceerd onder een drietal noemers : biologische, psychologische en maatschappelijke factoren'.

Biologische factoren kunnen genetisch, hormonaal en/of anatomisch van aard zijn. Zo zou een hogere oestrogeenspiegel vrouwen tot de overgang beschermen tegen cardiovasculaire aandoeningen. De hogere morbiditeitscijfers voor vrouwen worden toegeschreven aan de extra risico's van de zwangerschap en de bevalling, maar ook aan de complexe anatomile van de vrouwelijke geslachtsorganen. Psychologische theorieen benadrukken de rol van persoonlijkheidskenmerken (bv. zelfwaardering, afthankelijkheid) en psychopatologische factoren (bv. hypochondrie, depressie) in de etiologie van (medisch onverklaarde) lichamelijke klachten en ziekten. Verder staan vrouwen eerder stil bij signalen van stress, memen rust, praten met anderen over problemen, enz.

De maatschappelijk georiënteerde theorieën gaan ervan uit dat de traditionele vrouwenrol leidt tot conflicten en emoties, die gesomatiseerd worden en zich presenteren als psychosomatische klachten. Zo veronderstelt men bijvoorbeeld dat vrouwen ten gevolge van hun verzorgende rol in een slechtere geestelijke gezondheid verkeren en ten gevolge van hun verzorgende rolverplichtingen niet toekomen aan hun eigen verzorging en rust, zodat het resulteert in een slechtere algemene gezondheid. Een aanvullende maatschappelijke theorie zoekt de verklaringen in een verschillend socialisatieproces. Meisjes leren in hun opvoeding hun gevoelens te uiten, mogen emotioneel zijn en huilen. Agressief handelen is taboe voor meisjes. Jongens kunnen hun agressie dan weer makkelijker uiten via spel en sport. Jongens leren dat het uiten van gevoelens en het laten blijken van problemen 'onmannelijk' en kinderachtig is. Klagen en hulpvragen is mannen daardoor volgens de socilale norm minder toegestaan dan vrouwen. De traditionelle socialisatie tot vrouw maakt vrouwen gevoeliger voor de herkenning van symptomen van ziekte en biedt ook ruimte om hierover te praten met (of zich te beklagen bij) anderen.

De theorie dat vrouwen gevoeliger zijn dan mannen voor de herkenning van symptomen ván ziekte, biedt een directe aanknoping om te kunnen veronderstellen dat wrouwen ook meer kennis gaan hebben van bijvoorbeeld de "waarschuwingssignalen" van kanker dan mannen. Verder kan op grond van de dominante aanwezigheid van gynaecologische kankers bij de vroegtijdige opsporing, ook worden verondersteld dat wrouwen een betere kennis hebben van de 'vroegtijdige kankeropsporingsonderzoeken' dan mannen. Zeker waer het de kennis van secundaire kankerpreventie betreft, kan dus op theoretische gronden worden verwacht dat wrouwen een betere kennis zullen hebben dan mannen.

Welke zijn nu de meer specifieke empirische gegevens die er uit de literatuur naar voor komen over de relatie tussen geslacht en kennis van kankerpreventie?

1. Voor een uitvoeriger overzicht van deze varklaringen, zie de Bakker, Claessens en van dar Velden (1992: 2-7). 
In onderzoeken bij een algemene bevolking werden uitgesproken kennisverschillen tussen mannen en vrouwen vastgesteld inzake kankerpreventie. In de Verenigde Staten stelde een publieke opiniepeiling in opdracht van het National Cancer Institute (1986) vast dat de gepercipieerde doelmatigheid van kankerpreventie en kankertherapie significant correleerde met geslacht. Vrouwen bleken meer dan mannen te geloven dat gezondheidsgedrag een bijdrage kan leveren in het verkleinen van het risico op kanker. Deze resultaten zin consistent met de resultaten van andere surveys. Ook Berman en Wandersman (1991) stelden een significante correlatie $(r=.23$ ) wast tussen geslacht en herkenning van de waarschuwingssignalen van kanker. Bostick e.a. (1993) stelden in hun survey een open vraag over kennis van waarschuwingssignalen van kanker en stelden ook een significant verschil vast tussen mannen en vrouwen: vrouwen waren in staat om substantieel meer waarschuwingssignalen of symptomen van kanker op te sommen dan mannen.

Deze samenhang van kennis van kankerpreventie met geslacht staat evenwel in interactie met de invloeden van leeftijd, etniciteit en sociale status. Zo zijn het in de Verenigde Staten vooral blanke vrouwen van boven de 40 , met een hogere opleiding en die zich bevinden in de hogere inkomenscategorieën, die de grootste kennis van kankerpreventie hebben (Dent en Goulston, 1982; Michielutte en Diseker, 1982). In Amerika hebben zwarte mannen met een lage sociaal-economische status de meest beperkte kennis van de waarschuwingssignalen van kanker, van de prevalentie van kanker, van de mortaliteitscijfers en van de waarde van vroegtijdige kankeropsporing (American Cancer Society, 1980b, $1984 \mathrm{en} 1991$ ).

Geslachtsverschillen in kennis van kankerpreventie werden ook teruggevonden in Australie (zie bv. Clover e.a., 1991) en Europa (zie bv. Commissie van de Eurapese Gemeenschappen, 1987 en van Assema, 1990). In onderzoek in Vlaanderen werden bij eerstejaars VUB-studenten (Deliens, Louckx en Maes, 1994; Maes, 1992) daarentegen niet zo'n opvallende geslachtsverschillen in kennis van kankerpreventie vastgesteld. Geslacht had geen invloed op de kennis van de meest voorkomende vormen van kanker. Vrouwelijke studenten bleken niet significant meer te weten van waarschuwingssignalen dan mannelijke studenten. Het geslacht had evenmin een invloed op de kennis van de risicafactoren van kanker en de kennis van de vroegtijdige opsporingsonderzoeken voor kanker. Uit dit onderzoek bleek daarentegen wel dat vrouwelijke studenten een betere kennis hebben vain de vroegtijdige opsporingsonderzoeken voor typisch vrouwelijke kankers, zoals het baarmoederhalsuitstrijkje voor de vroegtijdige opsporing van baarmoederhalskanker en het borstzelfonderzoek. Ze zijin ook beter op de hoogte van de kankerincidentie in de Belgische bevolking dan hun mannelijke collega's. Hoger werd reeds gesteld dat het betreffende onderzoek werd verricht bij een zeer selecte groep van respondenten, waardoor deze resultaten zeer voorzichtig dienen te worden gehanteerd. Veralgemening naar de algemene bevolking is vitgesloten.

Op basis van de resultaten van de surveys over kennis van kankerpreventie bij een algemene bevolking, kan worden vastgesteld dat de invloed van geslacht op de kennis van kankerpreventie meestal in dezelfde richting gaat: vrouwen blijken een grotere kennis van kankerpreventie te hebben dan mannen. 
Aan de hand van zowel de theoretische verwachtingen ${ }_{*}$ als de empirische precedenten kan de volgende onderzoekshypothese over de invloed van geslacht op kennis van kankerpreventie worden geformuleerd:

\author{
Hypothese 1: "Vrouwen hebben een grotere kennis van \\ kankerpreventie dan mannen."
}

\title{
7.1.2 Leeftiid en kennis van kankerpreventie
}

Gezondheid, ziekte en dood zijn sterk leeftijdsgebonden. Net zoals het geboortecijfer wordt ook het sterftecijfer sterk beïnvloed door de leeftijdsstructuur van de bevolking. Vandaar ook dat meestal leeftijdsspecifieke of leeftijdsgestandaardiseerde sterftecijfers worden berekend. In Amerika stijgen de sterftecijfers van volwassenen gradueel tot de leeftijd van veertig, daarna verdubbelen ze voor elke daaropvolgende leeftijdsdecade (Freund en McGuire, 1991: 24). In België liggen bij de geboorte de sterftecijfers vrij hoog: de kans dat een 0 -jarige jongen overlijdt vóor thet eerste levensjaar is even hoog als deze van een 57 . jarige man vóór zijn 58ste llevensjaar (Matthijs, 1988: 32). Vanaf de leeftijd van één jaar daalt de sterftekans aanzienlijk, om een minimum te bereiken rond 10 jaar voor jongens en 12 jaar voor meisjes. Daarna stijgen de sterftekansen progressief met stijgende leeftijd. De kankersterfte stijgt progressief met de leeftijd tot 65 jaar, om nadien weer te dalen (Matthijs, 1988: 35). Terwijl de overlijdens in België in de leeftijdscategorie 45-64 jaar ongever evenveel kunnen worden toegeschreven alan kanker $(34.8 \%)$ als aan ziekten van de bloedsomloop $(36.2 \%)$, zijn na de leeftijd van 65 jaar vooral de ziekten van de bloedsomloop verantwoordelijk voor de sterfte $(44.6 \%$ vs $26.2 \%)$.

Ook de gezondheidsrisico's zijn verschillend naargelang van de leeftijdscategorie. Zo bijvoorbeeld is in België het rookgedrag sterk leeftijdsgebonden. In 1991 werden er voor de categorieën 15-17 jaar, 18-24 jaar, 25-34 jaar, 35-44 jaar en + 44 jaar respectievelijk 3 $\%, 15 \%, 27 \%, 21 \%$ en $35 \%$ dagelijkse rokers geteld (Matthijs, 1994: 58). Roken kent dus een stijgende trend volgens leeftijd. In 1984 werden er in België bij de huisartsen per 10.000 inwoners gemiddeld 246 ongevallen gerapporteerd, die zich voordeden in de woning, de annexen (tuin, garage, kelder, enz.) of de toeglangswegen. Naarmate de leeftijdscategorie liepen de gemiddelden van het aantal ongevallen sterk uiteen: 0-4 jaar: 468 ongevallen, $5-9$ jaar: 368 ongevallen, $10-19$ jaar: 215 ongevallen, $20-39$ jaar: 207 ongevallen, 40-59 jaar: 192 ongevallen en 60 jaar of ouder: 285 ongevallen (Matthijs, 1994: 611. Ongevallen in de privésfeer hebben dus eerder een dalende trend naar leeftijd. De werkeersslachtoffers komen dan weer het vaakst voor bij jongeren tussen 15 en 25 jaar en minder bij ouderen (zie: Matthijs, 1994: 62).

In een representatieve survey in Vlaanderen werden er ook significante lleeftijdswerschillen vastgesteld in de gerapporteerde of "gepercipieerde gezondheid", gemeten aan de hand van 
de SF-36 gezondheidsschaal (Ware, 1993)'. De samenhang tussen leeftijd en gepercipieerde gezondheid is lineair en negatief: hoe hoger de leeftijd hoe vaker een "slechte gezondheid' wordt gerapporteerd. Zo bijvoorbeeld werden beperkingen in het fysiek functioneren in de leeftijdscategorie $51-70$ jaar door $26 \%$ meer respondenten gerapporteerd dan in de leeftijdscategorie 35-50 jaar en in deze laatste categorie door $7 \%$ meer dan in de leeftijdscategorie 18-34 jaar. Lichamelijke pijn werd in de leeftijdscategorie $51-70$ jaar door $6 \%$ meer respondenten gerapporteerd dan in de leeftijdscategorie 35-50 jaar en in deze laatste categorie nog eens $6 \%$ meer dan in de leeftijdscategorie $18-34$ jaar. Biil de specifieke "psychische" gezondheidsschalen l'emotioneel wellbevinden" en 'rolbeperking door emotionele problemen') werden er in de gerapporteerde gezondheid evenwel geen significante leeftijdsverschillen vastgesteld.

De samenhang tussen leeftijd en gezondheid, gezondheidsbeleving, ziekte en doad laat vooraanstaande methodologen inzake gezondheidsonderzoek bij de bevolking dan ook besluiten dat geen enkel gezondheidsonderzoek bij de bevolking de factor leeftijd mag negleren (zie Dean, 1993). Voor deze samenhang worden er in de literatuur echter diverse verklaringen gegeven. Twee hoofdtheorieën kunnen worden onderscheiden, namelijk een theorie die refereert naar leeftijd als indicator van het verouderingsproces en alles wat dat met zich meebrengt, en een theorie die refereert naar leeftijd als indicator van het behoren tot een zekere leeftijdscohorte die specifieke ervaringen theeft die verschillend zijn van deze van andere leeftijdscohortes (zile ondermeer Riley, 1993; Wadsworth, 1991; Wolinsky, $1993)$.

De eerste theorie zoekt verklaringen bij de klassieke problematiek van het ouder worden. Leeftijd of ouder worden is daarbij niet alleen een natuurlijk biologisch gegewen, waardoor een toename optreedt van allerlei fysieke ongemakken en waardoor er beperkingen optreden in de dagelijkse bezigheden of in het functioneren op het werk. Leeftijd brengt ook met zich mee dat de kansen groeien op specifieke gebeurtenissen in het leven die een belangrijke impact kunnen hebben op het algemeen welbevinden van de betrokkene. In de gezondheidssociologie wordt dan ook aparte aandacht besteed aan de problematiek van onaangename of stresserende levensgebeurtenissen - de zgn. 'life events' - , zoals daar zijn cen verhuis naar een nieuwe woonomgeving, het verlies van werk, een scheiding of overlljiden van een partner, een gevangenisstraf, enz.. Onderzoek over de samenhang van deze "life events" met gezondheid richt zich echter niet alleen op éen particuliere gebeurtenis, doch eerder juist op de cumulatie van deze gebeurtenissen (zie Cockerham, 1992: 76-80). Onderzoek naar de invloed van "life events" op de gezondheid van mensen is gebaseerd op de assumptie dat de accumulatie van verschillende 'life events' in de loop van iemands leven zall leiden tot een significante toename van stress, waardoor er (eventueel) ook een significante achteruitgang plaatsgrijpt van de gezondheid van de persoon. In zeer veel empirische studies is deze relatie tussen onaangename gebeurtenissen

3 Eigen ruwe data. Deze gegevens zijn gebaseerd op dezelfde survey waarmee in dit onderzoek "kennis van kankerpreventie" wordt getoetst bij de Vlaamse bevolking (zie hoger hoofdstuk 4). De gepercipieende gezondheid werd in deze survey gemeten met een gevalideerde gezondheldsvragenlijst, namelijk de MOS SF-36 schaal van Ware (1993). 
en een verandering in ziekte of gezondheid vastgesteld. Gebeurtenissen die door mensen worden beschouwd als zeer onaangenaam en oncontroleeerbaar werden gevolgd door een significante verhoging van gerapporteerde ongemakken, ziektesymptomen en een toename van het consulteren van artsen.

Kanker en kankerpreventie zijn ook gebeurtenissen waarmee men in de loop van het leven (cumulatief) wordt geconfronteerd. Hoe ouder men wordt, hoe vaker men ze meemaakt in de socialle omgeving, bij vrienden of in de eigen familiekring. Dus de confrontatie met zowel kanker, als kankerpreventie - zeker wat betreft de ervaring met secundaire kankerpreventie is dus lineair gerelateerd aan leeftijd : hoe ouder men wordt, hoe meer ervaringen men heeft. Op grond van deze overwegingen zou men bijgevolg kunnen veronderstellein dat er ook een positief lineair verband bestaat tussen leeftijd en kennis van kankerpreventie.

De tweede theorie over de samenhang tussen leeftijd en gezondheid geeft eerder macrosociologische verklaringen. Leeftijd brengt niet alleen mee dat de betrokkene geconfronteerd wordt met onaangename gebeurtenissen in het persoonlijke leven, ook het bredere maatschappelijke en culturele kader waarin iemand opgroeit heeft eem impact op de gezondheidszorg en op de (gepercipieerde) gezondheid van de betrokkene. De cultuur en de historische periode waarin iemand opgroeit, drukken een stempel op de betrokkene, zowel sociaal of historisch als biologisch (Wadsworth, 1991: 199). De generatie bijvoorbeeld die werd geboren net voor of tijdens WO II groeide op in een totaal andere maatschappij met een andere gezondheidszorg dan de huidige opgroeiende jeugd. Kinderen die werden geboren net voor of tijdens WO II hadden andere kansen en andere ervaringen met kinderziekten, met voeding, met de school en een (eventulel hagere opleiding, met roken en andere gezondheidsgerelateerde gedragingen. Zij hadden ook andere kansen om te (over)leven, om geconfronteerd te worden met de dood van hun ouders of met scheiding van de ouders, in vergelijking met de jongeren die tien, twintig of dertig jaar later werden geboren.

De oudste leeftijdscohortes in onze samenleving werden nog geconfronteerd met levensbedreigende ziekten die voor de jongste cahortes minder belangrijk zijn, zoals bijvoorbeeld tuberculose. Daartegenover staat dat een nieuwe ziekte, zoals bilivoorbeeld AIDS, voor de jongste cohortes een veel grotere impact op hun leven en gedrag zal hebben dan voor de oudlere cohortes.. De oudste cohortes werden geconfronteerd met veel nieuwe ontwikkelingen in de gezondheidszorg die voor de jongste cohortes evident zijn. De oudste cohortes groeiden op in een tijd van snelle technologische en medische ontwikkelingen met uitgesproken veranderingen en dit niet alleen op materieel vlak. Belangrijke sociale aspecten ondergingen evenzeer veranderingen, zoals de relatie tussen de geslachten, de relatie tussen de beroepsgroepen en last but not least de relatie tussen arts en patient. Ook opvattingen en waarden waren onderhevig aan ingrijpende veranderingen, zoals de waarde wan vorming en onderwijs en de wijze waarop mensen proberen om in goede gezondheid te blijven. Kortom, de economische, sociale en culturele omstandigheden waarin mensen opgroeien, kunnen een invloed hebben op de opwattingen over ziekte en gezondheid 
(Wadsworth, 1991). Opgroeien in een bepaalde historische en culturele context leidt bijgevolg tot verschillen in opvattingen over ziekte en gezondheid tussen de generaties of leefrijdscategorieün.

Samenvattend kan worden gesteld dat leeftijd niet alleen indicatief is voor de problematiek van veroudering en de gevolgen ervan, maar ook voor verschillen in ervaringen tussen opeenvolgende leeftijdscohortes. De beide leeftijdsgebonden verklaringen tonen een eigen specifieke impact aan van leeftijd op gedrag en houdingen t.a.v. gezondheid en gezondheidszorg.

Welke zijn nu de meer specifieke empirische gegevens die bekend zijn over de relatie tussen leeftijd en kennis van kankerpreventie?

Over de specifieke samenhang tussen leeftijd en kennis en opvattingen over kankerpreventie komen de meeste survey-resultaten uit de Verenigde Staten. Nationale surveys in de Verenigde Staten hebben een positief lineair verband aangetoond tussen leeftijd en kennis van kankerpreventie (American Cancer Society, 1981, 1984 en 1991). In drie "upper-midwestern" staten van V.S. vonden Bostick e.a. (1993) in een toevalssteekproef van een populatie van personen van 25-74 jaar oud een duidelijk lineair verband tussen leeftild en het aantal respondenten dat akkoord ging met de uitspraak " $\mathrm{Er}$ is weinig dat een persoon kan doen om zijn/haalr kansen op kanker te verkleinen": naarmate men ouder werd, ging men meer akkoord met de uitspraak.

Er zijn in de Verenigde Staten evenwel ook survey-resultaten die wijzen op een andere samenhang tussen leeftijd en kennis van kankerpreventie. Zo bijvoorbeeld constateerden Dent en Goulston (1982) dat mensen ouder dan 40 jaar een gratere kennis van kankerpreventie hebben dan mensen jonger dan 40 jaar. Een publieke opiniepeilling in opdracht van het National Cancer Institute (1986) stelde daarentegen vast dat bij het herkennen van aspecten met betrekking tot kankerpreventie de "slimste" respondenten zïch in de leeftijdscategorie 31-40 jaar bevonden. De kennis van de waarschuwingssignalen voor kanker is dan weer het grootst in de leeftijdscategorie 30-49 jaar (American Cancer Society. 1984). Terwil Berwick e.a. (1992) in hun studie over huidkanker-preventie zelfs een negatief lineair verband aantroffen tussen leeftijd en de "solar knowledge index", een index die werd gebruikt om de kennis van huidkankerpreventie te meten. Verder stelden deze latste onderzoekers ook vast dat de betekenis van de protectiefactor vermeld op zonneprodukten significant beter gekend is door jongeren $(-40$ jaar $)$, dan door ouderen $1+$ 40 jaar).

Wadsworth (1991) beschrifft aan de hand van een indrukwekkende panel-studie de ontwikkeling van ongeveer 2.500 Britten van hun geboarte in 1946 tot de leeftijd van 43 jaar. In deze studie wordt uitvoerig aandacht besteed aan de ervaringen van deze generatie met ziekte en gezondheid. De gegevens werden op 20 verschillende tijdstippen verzameld; 11 keer tijdens hun jeugd en 9 keer in hun volwassenenfase. 
Over de samenhang tussen leeftijd en kennis van kankerpreventie zijn er voor Vlaanderen geen gegevens bekend. De bestaande surveys zijn exclusief gericht op jongeren (Van Hall e.a., 199 \% l of jongvolwassenen (Deliens e.a., 1994), waardoor de invioed van leeftijd niet kon worden onderzocht. Wel zijn er representatieve empirische gegevens bekend over de relatie tussen leeftijd en kennis van ziekte en gezondheid in het algemeen. Deze dateren evenwel al van de gezondheidsenquete die werd verricht eind van de jaren zeventig in het kader van het Nationaal Onderzoeksprogramma in de Sociale Wetenschappen over "Eerstelijnsgezondheidszorg" (Nuyens e.a. "1978; zie ook Nuyens, 1980 en 1982l. In dit grootschalig onderzoek werd een gedetailleerde beschrijving gegeven van ondermeer het niveau van kennis en opvattingen over ziekte en gezondheid van de Vlaamse bevolking, alsook van de kennis van het aanbod van de gezondheidszorgen. De aandacht was voorall gericht op de mate waarin de kennis en opvattingen van de Vlaamse bevolking al dan niet overeenkwamen met de zogenaamde rationele medische cultuur van deskundigen. Hier worden alleen die resultaten gerapporteerd die in het kader van deze studie relevant zijn.

In de studie van Nuyens e.a. (1978) bleek dat de kennis over zilekte en gezondheid differentieel verspreid was naargelang van de leeftijd. Medische kennis is groter bij jongeren dan bij ouderen. Men stelde vast dat een (uiteraard) grotere ervaring met ziekte bij ouderen niet resulteert in meer medische kennis. Wat de kennis van medische voorzieningen betreft, blijkt dat vooral voorzieningen met een somatische, curatieve inslag goed gekend zijn, in tegenstelling tot voorzieningen die eerder gericht zijn op psychosociale problematiek. Bovendien stelde men vast dat precies de ouderen over de minste informatie hierover beschikken. Ook ziekteopvattingen werden onderzocht. De onderzoekers stelden vast dat er bij de bevolking medisch-wetenschappelijk gezien vooral irrationele opvattingen bestaan. Deze irrationele ziekteopvattingen lagen evenmin gelijk gespreid naar leeftijd. Ook hier komen irrationele ziekteopvattingen vaker voor bij ouderen dan bij jongeren.

De studie van Nuyens e.a. (1978) samenvattend, komt er een beeld naar voor dat jongeren zich karakteriseren door meer kennis over ziekte en gezondheidsvoorzieningen dan ouderen. De kennis van de jongeren sluit het nauwst aan bij de wetenschappelijke normen van het professionele gezondheidszorgsysteem. Voor de ouderen geldt het omgekeerde: hun kennis wijkt sterk af van de gangbare rationele normen en waarden van het profiessionele gezondheidszorgsysteem, wat resulteert in een grotere afstand tussen beide groepen. De auteurs besluiten hieruit dat er voor ouderen dan ook meer sociale drempels zijn naser het gezondheidszorgapparaat dan voor de jongeren.

Samengevat kan worden gesteld dat de onderzoeksresultaten over de samenhang tussen leeftijd en kennis van kankerpreventie die uit dit overzicht van bestaande surveys naar voor

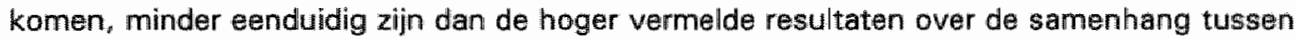
geslacht en kennis van kankerpreventie. Soms zijn de resultaten zelfs tegenstrijdig. Aan de hand van zowel de theoretische verwachtingen over de rol van leeftijd als de empirische onderzoeksresultaten is het bijgevolg zeer moeilij om een eenduidige hypothese te formuleren over de inwloed van de factor leeftijd op kennis van kankerpreventie. Als algemene hypothese kan dan ook de numypothese worden geformuleerd. 
Hypothese 2: "Er bestaat geen relatie tussen leeftijd en

kennis van kankerpreventie (globale meting)."

\subsubsection{Leefsituatie en kennis van kankerpreventie}

Een derde socio-demografische determinant die werd opgenomen in dit onderzoek is de leefsituatie. Deze sociale determinant wordt in empirisch onderzoek meestal geïndiceerd door de burgerlijke staat. Het effect van de burgerlijke staat op de gezondheid van mensen is minder evident dan deze van leeftijd of geslacht. Statistieken over ziekten en doodsoorzaken worden meestal niet opgesplitst naar huwelijksstaat. Toch bestaan er onderzoeken waaruit blijkt dat het huwelijk in het algemeen een positief effect heeft op de gezondheid". Het al dan niet gehuwd zijn zou dus ook een invloed kunnen hebben op de kennis van kankerpreventie.

Gehuwden rapporteren minder fysieke klachten dan ongehuwde of gescheiden mensen en gehuwden scoren hoger op maten voor mentale gezondheid en voor algemeen welbevinden Ivan der Zee e.a., 1995). Bovendien blijken gehuwden minder gebruik te maken van voorzieningen in de gezondheidszorg. In een aantal studies werd ook aangetoond dat de positieve gezondheidseffecten van het huwelijk sterker zijn voor mannen dan voor vrouwen (van der Zee e.a., 1995: 230).

Ook volgens Joung (1996), die aan de Erasmus Universiteit Rotterdam promoveerde met een proefischrift over burgerlijke staat en gezondheid, heeft de burgerlijke staat een invloed op de gezondheid van mensen. Uit dit proefschrift blijkt bijvoorbeeld dat gehuwden minder gezondheidsproblemen hadden dan nooit-gehuwde, gescheiden en verweduwde personen. Na uitgebreide controle voor sacio-demografische determinanten bleek verder dat nooitgehuwden een lagere, en gescheiden en verweduwden een hogere medische consumptie hebben dan gehuwde personen. De verschillen blijken in Nederland ook uit de sterftecijfers. De sterftecijfers ander ongehuwden zijn hoger dan onder gehuwden. Verder plegen in Nederland ongehuwden ook vaker zelfmoord dan gehuwden. Ongehuwden bliken in Nederland ook vaker dan gehuwden longkanker, cervixkanker, ziekten van de luchtwegen, en levercirrose te hebben.

In een representatieve survey in Vlaanderen werden er ook significante verschillen naar burgerlijke staat vastgesteld in de gerapporteerde of 'gepercipieerde gezondheid", gemeten aan de hand van de MOS SF-36 gezondheidsschaal (Ware, 1993 ) $^{2}$. De samenhang tussen

1 Voor dit literatuuroverzicht over de invloed van het huwelijk op de gezondheid werd dankbaar gebruik gemaakt van een overzichtsartikel van wan der Zee, Bakker en Sanderman (1995) en van het proeffschrift van Joung (1996). Voor meer referenties over deze problematiek wordt verwezen naar deze auteurs.

2 Eigen ruwe deta. Deze gegevens zijn gebaseerd op dezelf́de survey waarmee in dit onderzoek "kennis van kankerpreventie" wordt getoetst bij de Vlaamse bevolking (zie hager hoofdstuk 4). 
burgerlijke staat en gepercipieerde gezondheid gaat altijd in dezelfde richting: gehuwden rapporteren een betere gezondheid dan gescheiden mensen. Zo bijvoorbeeld werden beperkingen in het fysiek functioneren gerapporteerd door $23.9 \%$ van de gehuwden en $35.8 \%$ van de gescheiden respondenten. Belangrijke rolbeperkingen $n$.a.v. de fysieke gezondheid werden gerapporteerd door $25.7 \%$ van gehuwden en $33.8 \%$ van de gescheiden respondenten. Lichamelijke piin werd gerapporteerd door $26.9 \%$ van gehuwden en $36.4 \%$ van de gescheiden respondenten. Ook bij de specifieke "psychische" gezondheidsschalen ('emotioneel welbevinden' en 'rolbeperking door emotionele problemen") rapporteerden de gehuwden een betere gezondheid dan de gescheiden personen. $43.7 \%$ van de gescheidenen rapporteerde een 'matig' emotioneel welbevinden, tegenover $24.7 \%$ bij de gehuwden. $28.5 \%$ van de gescheiden respondenten ervoer door emotionele problemen ook rolbeperkingen, tegenover $15.2 \%$ bij dle gehuwden.

Hoe valt de samenhang tussen burgerlijke staat en gezondheid te verklaren? In de literatuur worden er verschillende theorieën naar voor geschoven.

De positieve effecten van het huwelijk op de gezondheid worden vooral toegeschreven aan de grotere beschikbaarheid van sociale steun die verbonden is aan het huwelijk (van der Zee e.a., 1995: 230). In verschillende studies is immers gevonden dat gehuwden meer sociale steun ontvangen en daardoor een hager niveau van welbevinden ervaren en minder gebruik maken van medische voorzieningen dan ongehuwden. Volgens Joung (1996) leven gehuwden vaak ook gezonder dan alleenstaanden en voelen ze zich ook prettiger bij elkaar.

Hoe valt dan te verklaren dat mannen meer baat zouden hebben bij het huwelijk dan vrouwen (van der Zee e.a., 1995: 230) ? Een eerste verklaring is dat mannen vooral op hun partner zijn aangewezen woor sociale steun en dat dit veel minder het geval is bij vrouwen. Vrouwen hebben over het algemeen een uitgebreider sociaal netwerk waarop zij een beroep kunnen doen voor sociale ondersteuning bij moeilijkheden. In de tweede plaats impliceert de huwelijkse relatie ook belangrijke roleisen, die lijken te verschillen voor mannen en vrouwen. Zo wordt nog steeds meer van vrouwen dan van mannen verwacht dat zij een "verzorgende rol" op zich nemen in het gezin. Uit onderzoek is inderdaad gebleken dat het graotste deel van de verantwoordelijkheid voor het huishouden en voor de kinderen nog steeds bil de vrouw berust en dat gehuwde vrouwen thuis veel meer roleisen ervaren dan gehuwde mannen. De zorgende rol zal ondermeer met zich meebrengen dat vrouwen meer dan mannen zowel voor zichzelf als voor andere gezinsleden alerter en attenter zullen zijn voor waarschuwingssignalen of ziektesymptomen, en dat ze deze gezondheidsproblemen ook sneller gaan toetsen bij de directe sociale omgeving, inclusief bij de partner. Vanuit deze theorie kan ook worden verwacht dat vrouwen meer dan mannen hun partner informeren over de diverse aspecten over kanker en kankerpreventie. Mannen hebben dus bij deze verzorgende rol van hun partner meer baat dan de vrouwen.

De gepercipieerde gezondheid werd in deze survey gemeten met een gevalideercle gezondheidsvragenlijst, namelijk de MOS SF-36 schaal van Ware (1993). 
Volgens Joung is er (deels) ook een totaal andere verklaring voor de samenhang tussen leefsituatie en gezondheid, die in vroeger onderzoek vaak onderbelicht is gebleven. De oorzakelijkheid of het effect kan ook gaan in de andere richting : gezonde mensen hebben een kleinere kans dat hun huwelijk strandt in een echtscheiding dan zieke mensen (Joung, 1996). Gehuwden met twee of meerdere chronische alandoeningen, zoals bijvoorbeeld een hoge bloeddruk, kanker of astma, hebben volgens de gegevens van deze auteur twee keer zoveel kans op een echtscheiding. Ziekte leidt met andere woorden ook tot een andere huwelijksstaat.

Samengevat wijst onderzoek in het algemeen op een samenhang tussen leefsituatie en gezondheid. Meestal heeft het huwelijk positieve gezondheidseffecten, waarbij de effecten voor mannen sterker zijn dan voor vrouwen.

Welke zijn nu de meer specifieke empirische gegevens die bekend zijn over de relatie tussen leefsituatie en kennis van kankerpreventie?

Hierover kan men kort zijn. Over de specifieke samenhang tussen leefsituatie en kennis van kankerpreventie werden in de literatuur niet zoveel empirische gegevens teruggevonden. De empirische gegevens die hierover werden teruggevonden, hadden enkel betrekking op kennis van preventie van colorectaalkanker en prostaatkanker. In de Verenigde Staten stelden Brown e.a. (1990), op basis van gegevens verzameld uit 1987 van de representatieve 'National Health Interview Survey', een invloed vast van de partner op de kennis van preventie inzake colorectaalkanker en prostaatkanker. Getrouwd zijn en leven met een parther is positief gerelateerd aan kennis van de 'fecal occult blood test' en aan kennis van 'prostoscopy', twee medische technieken voor de vroegtijdige opsporing van colorectale kanker.

Aan de hand van de hogervermelde literatuurgegevens over de relatie tussen huwelijksstaat en gezondheid kan de volgende onderzoekshypothese over de invloed van leefsituatie op kennis van kankerpreventie worden geformuleerd:

Hypothese 3: "Respondenten die gehuwd zijin, hebben een grotere kennis van kankerpreventie dan respondenten die niet gehuwd zijn. Bovendien is dit effect van de leefsituatie voor mannen sterker dan voor vrouwen.."

Uit deze hypothese blijkt dat in thet huidig onderzoek niet alleen de invloed van leefsituatie op kennis van kankerpreventie zal worden nagegaan. Er zal eveneens aandacht zijn voor de interactie van de factor geslacht op de samenhang tussen de leiefsituatie en kennis van kankerpreventie.

\subsection{Dverzicht van het onderzoeksmateriaal en de analyseopzet}

Voor de vaststelling van verschillen in kennis van kankerpreventie tussen diverse subpopulaties, die worden gedefinieerd volgens deze socio-demografische determinanten. 
kan worden gebruik gemaakt van de kennisschalen zoals die in hoofdstuk 6 werden geconstrueerd. Zowel het betrouwbaarheidsonderzoek als het validiteitsonderzoek in hoofdstuk 6 gaven echter aanwijzingen om niet te werken met de afzonderlijke schalen (kennis van de 'juiste' items en de foutperceptie), doch wel met de adequate kennisschalen, alsook met de synthesematen. Er werd bovendien aangetoond dat de nauwkeurigheid van de adequate kennismaten veel beter is dan deze van de afzonderlijke schalen.

In dit hoofdstuk zal dan ook enkel worden gewerkt met de zeven "adequate kennisschalen" (zie hoofdstuk 6).

Tabel 7.1

Frequentieverdeling van de socio-demografische kenmerken $(n=1631)$

\begin{tabular}{|l|c|c|}
\hline & $\begin{array}{c}\text { Absolute } \\
\text { frequentie }\end{array}$ & $\begin{array}{c}\text { Relatieve } \\
\text { frequentie }\end{array}$ \\
\hline $\begin{array}{l}\text { Geslacht } \\
\text { man } \\
\text { vrouw }\end{array}$ & 814 & 49.9 \\
\hline Leeftijd & 817 & 50.1 \\
18-30 jaar & & \\
31-40 jaar & 433 & 26.5 \\
41-50 jaar & 359 & 22.0 \\
51-60 jaar & 329 & 20.2 \\
61-70 jaar & 272 & 16.7 \\
\hline Leeftijd & 238 & 14.6 \\
18-34 jaar & & 35.9 \\
35-50 jaar & 586 & 32.8 \\
51-70 jaar & 535 & 31.3 \\
\hline Burgerlike staat & 510 & 23.4 \\
ongehuwd & & 67.4 \\
gehuwd & 381 & 5.6 \\
gescheiden & 1099 & 3.7 \\
weduwle)-naar & 91 & 83.9 \\
\hline Leefsituatie & 60 & 16.1 \\
met partner & & \\
zonder partner & 1368 & \\
\hline
\end{tabular}

De socio-demografische determinanten werden in de enquête uitvoerig bevraagd. Voor deze analyses werden volgende determinanten weerhouden: geslacht, leeftijd en leefsituatie. Geslacht en leeftijd zijn duidelijke eigenschappen van de socio-demografische positie in de samenleving. De indicator "leefsituatie" vraagt om wat meer toelichting. Als indicator van de eigenschap leefsituatie wordt traditioneel de 'burgerlike staat' giekozen. Door de sterke toename van het aantal ongehuwd samenwonenden en van het aantal (feitelijke) 
scheidingen sternt deze indicator, namelijk de formele burgerlijke staat, minder en minder overeen met de reéle leefsituatie van betrokkenen. Daarom wordt er in survey-onderzoek meer en meer, naast de burgerlijke staat, ook gevraagd naar de reële aanwezigheid van een partner. Zeker in het kader van onderhavig onderzoek, waarin het studieobject een mogelijke 'kennisoverdracht' betreft tussen personen, is de keuze voor een indicator die directer aansluit bij de reäle leeisituatie eerder aangewezen dan een indicator die de formele huwelijksstatus weergeeft. Daarom werd gekozen voor de analyses van de invloed van de leefsituatie op de kennis van kankerpreventie voor de indicator 'al dan niet aanwezigheid van een partner' en niet voor de formele huwelijksstaat.

De gevonden frequenties van deze socio-demografische kenmerken worden weergegeven in tabel 7.1. De formele burgerlijke staat wordt ook gepresenteerd, zodlat de discrepantie met de feitelijke leefsituatie, namelijk al dan niet aanwezigheid van een partner, duidelijk wordt geillustreerd. De leeftijdsverdeling wordt zowel gepresenteerd in vijf categorieën als in drie categorieên. De leeftijdsverdeling in vijf categorieën wordt gebruikt om de invloed van leeftijd op kennis van kankerpreventie te onderzoeken. De leeftijd in drie categorieën zal enkel worden gebruikt bij de elaboratie van gevanden verbanden naar leeftijd (zie verder).

Van welke analysemethoden zal er worden gebruik gemaakt in dit hoofdstuk?

De meeste van de in dit hoofdstuk geformuleerde hypothesen kunnen worden getoetst door een vergelijking van de gemiddelde kennisscores van de verschillende onderscheiden subpopulaties. Dit is het geval voor deze hypothesen die uitspraken doen over verschillen tussen subpopulaties, met name het verband tussen geslacht en kennis van kankerpreventie, alsook de invloed van een partner op de kennis van kankerpreventie. De hypothesen hebben dan de vorm van: "De subpopulatie $X$ heeft een grotere (of kleinere) kennis dan de subpopulatie $Y^{\prime \prime}$. Omdat de hypothese over de invloed van leeftijd op kennis van kankerpreventie de vorm aanneemt van "Hoe hoger $X$, des te hoger (of lager) $Y$ ", zou deze in principe kunnen worden getoetst met een berekening van een associatiemaat tussen twee variabelen (zie ook hoofdstuk 8\%. Omwille van de vergelijkbaarheid met de analyses naar geslacht en leefsituatie, gaan wordt dit hier niet gedaan en wordt gebruik gemaakt van dezelfde analysemethode als bij geslacht en leefsituatie. Door het onderscheiden van vijf leeftijdscategorieün kan evenwel toch nog vrij goed de lineariteit van de relatie worden nagegaan. Omwille van de vergelijkbaarheid van de bivariate analyses, wordt bijgevolg steeds volgens dezelfde systematiek geanalyseerd.

Om te bepallen of de onderscheiden subpopulaties inzake kennis van kankerpreventie statistisch significant van elkaar verschillen, wordt gebruik gemaakt van de Mann-Whitney test" (bij dichotome kenmerken) of de Kruska/-Wallis test (bij kenmerken met $2+$ categorieênn). Beide testen zijn geschikt on de verdeling van populaties op ordinale variabelen met elkaar te vergelijken. Bovendien zijn deze tests ongevoelig voor variabelen met scheve of niet-normale verdelingen. Met deze testen kan worden getoetst of twee (Mann-Whitney) of meerdere (Kruskal-Wallis) onafhankelijke steekproeven uit populaties hetzelfde gemiddelde vertonen (Huizingh, 1989:246). Deze toetsen worden meestal gebruikt in plaats van de t-toets, als niet aan een voorwaarde van die t-toets kan worden 
woldaan (interval variabelen). Deze technieken worden toegepast wanneer bijvoorbeeld de kennisscores van vrouwen worden vergeleken met deze van de mannen of bij analyse van 'alleenstaand vs. met partner'.

De associatiemaat die wordt gepresenteerd om de sterkte van het verband tussen twee of meerdere onderscheiden subpopulaties weer te geven, is de associatiemaat eta. Deze maat is een adequate associatiemaat om het verband tussen een nominale en een interval variabele of een ordinale en een interval variabelle na te gaan (zie tabel 5.5 in hoofdstuk 4). Omdat de kennisschalen strikt genomen ordinaal geschaald zijn (zie hoger hoofdstuk 4), kan in principe de associatiemaat Eta niet worden gebruikt. Omdat er (noodgedwongen) gebruik wordt gemaakt van gemiddelde scores om het kennisniveau aan te duiden en te vergelijken, worden de rangen van deze kennisschalen echter wel als kwantitatieve variabelen beschouwd, zodat de Eta-coëfficiënt op basis van de 'gekwantificeerde' rangen kan worden berekend. Er wordt echter steeds het reeds hoger vermeld advies (zie hoofdstuk 4) in acht genomen van Gadourek (1976:388): parametrische toetsen kunnen eventueel toegepast worden op gegevens van een lager meetniveau, maar de conclusies moeten beperkt worden tot de interpretatie die het meetniveau toelaat. Er zal bijgevolg geen absolute waarde kunnen worden gehecht aan deze Eta-coëfficiënten. De presentatie van de Eta-coëfficiënten is vooral nodig om de interpretatie mogelijk te maken bij de "elaboratietechniek" (zie verder). Enkel door de veranderingen van deze coëfficiënt te analyseren, kan worden nagegaan of de gevonden verbanden robuust zijn, dan wel of we te maken hebben met schijnverbanden of specificaties van de verbanden.

Ter verfijning van de gevonden verbanden zijn de volgende vragen essentieel: Hoe algemeen is een gevonden verband? Blijft het verband bestaan voor de meeste typen respondenten of is het eerder specifiek voor een bepaalde subpopulatie ? Om op deze vragen een antwoord te kunnen formuleren, werd de invloed van de socio-demografische determinanten op de kennis van kankerpreventie verder geanalyseerd met de elaboratietechniek. Dat betekent dat een vastgesteld verband (of afwezigheid van een verband) verder werd onderzocht door het verrichten van een controle door een testvariabele. Als de invloed van leeftijd onder controle werd gehouden, dan werd niet gewerkt met de hogervermelde leeftijdsindeling volgens vijf klassen. Met een opsplitsing naar de hogervermelde leeftijdsindeling volgens vijf klassen zouden immers de subpopulaties te klein uitvallen voor verdere statistische analyse. Daarom werd gekozen voor een opsplitsing in drie leeftijdscategorieën, zodat ook nog een verdere opspliting naar bv. geslacht mogelijk blijft (zie frequentieverdeling in tabel 7.1). Hierdoor bestaat elke subpopulatie naar geslacht nog uit 250 of meer respondenten.

De elaboratietechniek laat evenwel niet $z 0$ gemakkelijk toe om het relatieve belang van de drie socio-demografische variabelen in hun effect op kennis van kankerpreventie te vergelijken. Om deze relatieve invloed van de drie socio-demografische determinanten te onderzoeken werden de partiële correlatiecoëfficienten geanalyseerd. 
In principe mag de partiële associatiemaat van Pearson"s $r^{i}$ echter enkel berekend worden tussen twee intervalvariabelen. Nu is enkel leeftijd strikt genomen gemeten op intervalniveau. De leefsituatie en het geslacht zijn niet metrisch, maar nominaal. Strikt genomen zoud dan een 'zwakkere' associatiemaat moeten worden geselecteerd die geschikt is voor nominale variabelen. Omdat het echter 'dichotome' variabelen betreft, zal in navolging van het advies van de Vaus 11991: 171) over statistische analyse van twee variabelen bij verschillend meetniveau, het meetniveau van deze dichotome variabelen worden genegeerd en zal het meetniveau van de afhankelijke variabele, namelijk kennis van kankerpreventie primeren bij de keuze van een adequate correlatiecoëfficiënt. Hoger werd reeds gesteld dat de kennisschalen ook kunnen worden beschouwd als metrische variabelen, zodat het gebruik van de partiële correlatie van Pearson's r verantwoord is.

\subsection{Socio-demografische verschillen in kennis van kankerpreventie}

\subsubsection{Sekseverschillen in kennis van kankerpreventie}

Tabel 7.2 presenteert de onderzoeksresultaten van kennis van kankerpreventie naar geslacht op populatieniveau. Er wordt een overzicht gegeven van gemiddelde scores van kennis wan kankerpreventie naar geslacht, samen met de zero-order correlaties (Etacoëfficiënten) en het resultaat van de significantietoets (Mann-Whitney test).

Op populatieniveau werd voor elke onderzochte indicator van kennis van kankerpreventie een significant verband met geslacht vastgesteld. Het verband gaat daarbij consistent in dezelfde richting: wrouwen hebben voor alle kennismetingen een significant hogere kennis van kankerpreventie dan mannen.

Bij de twee indlicatoren voor kennis van primaire kankerpreventie zijn deze verschillen weliswaar statistisch significant, maar het verschil in kennisscore is vrij beperkt. Deze kleine verschillen tussen de gemiddelde kennisscores leiden eveneens tot vrij kleine etacoëfficiënten, namelijk 0.07 en 0.09 . Bij de twee indicatoren voor kennis van secundaire kankerpreventie zijn de verschillen meer uitgesproken. Het niveau van kennis van de waarschuwingssignalem verschilt het meesit tussen de twee geslachten, namelijk meer dian 5 punten op de kennisschaal. Deze grotere verschillen tussen de gemiddelde kennisscores leiden ook tot grotere eta-coëfficiènten, namellik 0.18 en 0.11 . Deze samenhang van de variabele geslacht met kennis van kankerpreventie wordt ook teruggevonden bij de synthesematen kennis van secundaire kankerpreventie (Eta $=0.17$ ) en de globale meting van kennis van kankerpreventie 1 Eta $=0.16$ ).

i De partiële correlatiemaat Pearson's $r$ is de enige partiële correlatileprocedure die beschikbaar is in het statistisch pakket SPSS-WIN. 
Tabel 7.2

Gemiddelde scores van kennis van kankerpreventie, naar geslacht

\begin{tabular}{|c|c|c|c|c|}
\hline Kennisschallen : & $\begin{array}{c}\text { Man } \\
(n=814)\end{array}$ & $\begin{array}{l}\text { Vrouw } \\
(n=817)\end{array}$ & Eta & $\begin{array}{c}\text { Manny } \\
\text { Whitney } \\
\text { tesst }\end{array}$ \\
\hline \multicolumn{5}{|c|}{ KENNIS VAN PRIMAIRE KANKERIPREVENTIE : } \\
\hline Risicofactoren & 21.62 & 23.47 & 0.07 & $* *$ \\
\hline Gewenst gedrag & 13.21 & 15.29 & 0.09 & *** * \\
\hline \multicolumn{5}{|c|}{ KENNIS VAN SECUNDAIRE KANKERPREVENTIE : } \\
\hline Waarschuwingssignalen & 26.41 & 31.94 & 0.18 & **** \\
\hline Vroegtîjdige opsporing & 28.34 & 32.29 & 0.11 & $* *$ \\
\hline \multicolumn{5}{|c|}{ SYNTHESE VAN KENNIS VAN KANKERPREVENTIE : } \\
\hline Primaire Kankerpreventie & 17.41 & 19.38 & 0.10 & $* * *$ \\
\hline Secundaire Kankerpreventie & 27.38 & 32.11 & 0.17 & $* * *$ \\
\hline Globale meting & 22.39 & 25.75 & 0.16 & $* *$ \\
\hline
\end{tabular}

Naot: de kennisscores lopen van -100 (zeer inadequate kennis van kankerpreventie) tot +100 (zeer adequate kennis van kankerpreventie)

Hieruit kan worden geconcludeerd dat de geslachtsverschillen in kennis van kankerpreventie in de eerste plaats worden veroorzaakt door een verschil in kennis van secundaire kankerpreventie en pas in de tweede plaats door een verschil in kennis van primaire kankerpreventie.

Er kan nu de vraag worden gesteld of dit verband tussen geslacht en kennis van kankerpreventie vrij stabiel is, of m.a.w. dit verband zich repliceert bij specifieke categorieën. Zo dit het geval is, dan is dit een robuust verband. Er wordt hier gecontroleerd door een opsplitsing naar leeftijdsklassen. De resultaten worden vermeld in tabel 7.3 lzie bijlage 4). Ter vergelijking werden de gemiddelde scores en de zero-order correlaties (Etacoëfficiènten) uit tabel 7.2 herhaald in tabel 7.3 (bijlage 4).

Een eerste belangrijke observatie is dat vrouwen steeds een hogere gemiddelde kennisscore hebben dan mannen. Hoewel de vrouwen in alle leeftijdsklassen steeds een hogere kennisscore hebben dan de mannen, zijn in een aantal gevallen de verschillen evenwel niet meer statistisch significant en daalt in een aantal gevallen het significantieniveau. Voor de drie synthesematen van kennis van kankerpreventie worden de drie op populatieniveau significante verbanden met geslacht gereproduceerd in alle leeftijds-klassen. Het significantieniveau is vrij stabiel bij kennis van secundaire kankerpreventie en bij de globale meting, doch daalt in elke leeftijdsklasse bij de kennis van primaire kankerpreventie. 
Om de elaboratie van de sterkte van de werbanden te bestuderen, wordt nu naar de verschillen in gemiddelde kennisscores en naar de eta-coéfficiënten gekeken. Bij de twee indicatoren van kennis van primaire kankerpreventie zijn de eta-coëfficiënten wrij stabiel en blijven de verschillen klein in alle leeftijdsklassen. Deze stabiliteit wordt ook teruggevonden in de synthesemaat van kennis van primaire kankerpreventie. Er kan dus worden geconcludeerd dat er geen interactie-effect bestaat wan leeftijd op de samenhang tussen geslacht en kennis van primaire kankerpreventie.

Bij de kennis van de waarschuwingssignalen zijn de verschillen groter ( $>5$ schaalpunten), doch de eta-coëfficiënten blijven vrij stabiel. De samenhang met geslacht is echter zeer onstabial naar leeftijdsklasse bij kennis van de vroegtijdige opsporingsonderzoeken. De samenhang verdwijnt - zoals hoger reeds besproken - in de leeftijdsklasse 35-50 jaar, wordt gereprocuceerd in de leeftijdsklasse 51-70 jaar en wordt aanzienlijk sterker bij de jongeren 118-34 jaar). Deze onstabiliteit wordt ook teruggevonden in de synthesematen kennis van secundaire kankerpreventie en de globale kennismeting. Het gevonden verband wordt gereproduceerd in de leeftijdsklasse $51-70$ jaar leta respectievelijk 0.18 en 0.17 ), wordt kleiner in de leeftijdsklasse 35-50 jaar (eta respectievelijk 0.11 en 0.12 ) en groter in de leeftijdsklasse 18-34 jaar leta respectievelijk 0.21 en 0.20 ). Er kan dus worden geconcludeerd dat er een (zij het beperkt) interactie-effect bestaat van leeftijd op de samenhang tussen geslacht en kennis van secundaire kankerpreventie.

\section{Figuur 7.1}

Kennis van kankerpreventie naar geslacht, controlerend voor leeftijd
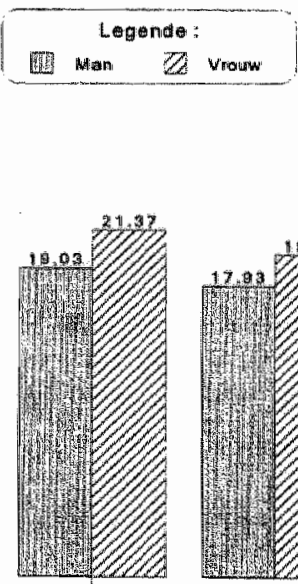

rim.

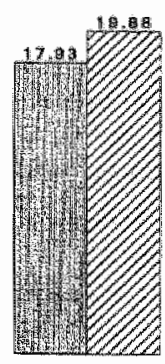

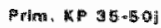

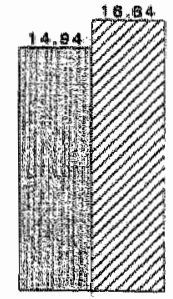

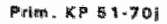

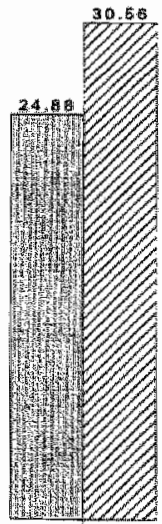

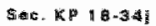

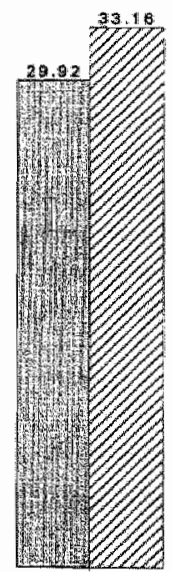

SED. KP 3:S-5OJ

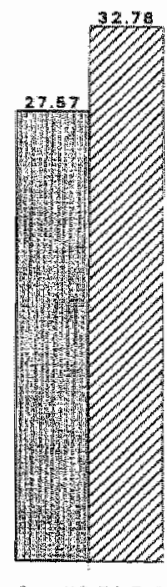

sac. $\times 5+701$

- De invloed van socio-demografische factoren - 
Samenvattend kan worden gesteld dat er duidelijke verschillen in kennis van kankerpreventie te constateren zijn tussen mannen en vrouwen. Vrouwen weten meer van kankerpreventie af dan mannen. Zij weten significant meer over de risicofactoren, over het gewenst kankerpreventief gedrag, over de waarschuwingssignalen en over de vroegtijdige opsporingsonderzoeken dan de mannen. Deze verschillen in kennis zijn echter het meest uitgespraken bij de kennis van secundaire kankerpreventie en dit verschil wordt vooral verklaard door een verschil in kennis van de waarschuwingssignalen voor kanker.

In het algemeen kan worden vastgesteld dat de zero-order correlaties (bijna altijd) worden gerepliceerd, wanneer er wordt gecontroleerd naar leeftijdsklasse. De invloed van geslacht op kennis van kankerpreventie blijkt dus vrij robuust te zijn. Leeftijd blijkt slechts een zeer beperkt interactie-effect te hebben op de samenhang tussen geslacht en kennis van kankerpreventie. De invloed van leeftijd op zich wordt in de volgende paragraaf verder besproken.

\subsubsection{Leeftijdsverschillen in kennis van kankerpreventie}

Tabel 7.4 presenteert de onderzoeksresultaten van kennis van kankerpreventie naar leeftijdscategorie op populatieniveau. Er wordt een overzicht gegeven wan de gemiddelde scores van kennis van kankerpreventie naar leeftijdsklasse, samem met de zero-order correlaties (Eta-coëfficiënten) en het resultaat van de significantietoets (Kruskal Wallis).

Tabel 7.4

Gemiddelde scores van kennis van kankerpreventie, naar leeftijdsklasse

\begin{tabular}{|c|c|c|c|c|c|c|c|}
\hline Kennisschalen & $\begin{array}{l}18-30 j \\
(n=433)\end{array}$ & $\begin{array}{l}31-40 j \\
(n=359)\end{array}$ & $\begin{array}{l}41-50 j . \\
(n=329)\end{array}$ & $\begin{array}{l}51-60 j \\
(n=272)\end{array}$ & $\begin{array}{l}61-70) \\
(n=238)\end{array}$ & Eta & $\begin{array}{c}\text { Krus- } \\
\text { kal- } \\
\text { Wallis }\end{array}$ \\
\hline \multicolumn{8}{|c|}{ KENNIS VAN PRIMAIRE KANKERPREVENTIE : } \\
\hline Risicofactoren & 26.03 & 24.49 & 22.34 & 18.94 & 17.68 & 0.25 & $* *$ \\
\hline Gewenst gedrag & 14.87 & 14.64 & 14.55 & 13.19 & 13.35 & . & n.s. \\
\hline \multicolumn{8}{|c|}{ KENNIS VAN SECUNDAIRE KANKERPREVENTIE : } \\
\hline Waarschuwingssign. & 23.86 & 28.55 & 31.60 & 33.25 & 31.82 & 0.23 & $* *$ \\
\hline Vroegtijdige Opsp. & 29.63 & 32.30 & 32.86 & 29.54 & 25.97 & 0.13 & $*$ \\
\hline \multicolumn{8}{|c|}{ SYNTHESE VAN KENNIS VAN KANKERPREVENTIE : } \\
\hline Prim Kankerpreventie & 20.45 & 19.56 & 18.44 & 16.06 & 15.51 & 0.19 & $* *$ \\
\hline Sec. Kankerpreventie & 26.74 & 30.42 & 32.23 & 31.39 & 28.90 & 0.15 & $*$ \\
\hline Globale meting & 23.60 & 24.99 & 25.34 & 23.73 & 22.21 & 0.10 & * * \\
\hline
\end{tabular}

Noot: de kennisscores lopen wan-100 (zeer inadequate kennis van kankerpreventiel tot +100 (zeer adequate kennis van kankerpreventie) 
Op populatieniveau wordt voor drie van de vier onderzochte indicatoren van kennis van kankerpreventie vastgesteld dat er een significant verband bestaat met leeftijd. Ook alle synthesematen wan kennis van kankerpreventie hangen significant samen met leeftijd. De vastgestelde verbanden züjn evenwel niet eenduidig te interpreteren voor al de kennismetingen.

De kennis van het gewenst kankerpreventief gedrag correleert niet significant met leeftijd. Het kennisniveau van het gewenst gedrag is over het algemeen - dus voor alle leeftijdsklassen - relatief laag. Tussen leeftijd en kennis van risicofactoren bestaat er een lineair verband met een negatieve correlatie: hoe hoger de leeftijd, hoe lager de kennis. Dit negatief lineair verband wordt gereproduceerd in de relatie tussen leeftijdsklassen en de synthesemaat kennis van primaire kankerpreventie.

Bij de indicatoren voor kennis van secundaire kankerpreventie zijn de verbanden met leeftijd evenwel niet lineair. Tussen leeftijd en kennis van de waarschuwingssignalen zien we tot de leeftijdsklasse 51-60 jaar een toename van de kennis van 23.86 naar 33.25 en nadien terug een daling naar 31.82 in de leeftijdsklasse $61-70$ jaar. Tussen leeftijd en kennis van de vroegtijdige opsporingsonderzoeken is er eerder eem curvilineair verband: de kennisscore stijgt tot de leeftijdsklasse 41-50 jaar van score 29.63 naar 32.86 en daalt nadien tot een gemiddelde score van 25.97 in de leeftijdsklasse $61-70$ jaar. Dit laatste curvilineair verband wordt ook gereproduceerd in de relatie tussen leeftijdsklassen en de synthesematen kennis van secundaire kankerpreventie en de globale meting kennis van kankerpreventie. Het curvilineair verband tussen leeftijd en de globale synthesemeting van kennis van kankerpreventie verbergt evenwel het lineair verband tussen leeftijd en kennis van primaire kankerpreventie.

Worden deze versichillen in kennis tussen de leeftijdsklassen vergeleken, dan valt op dat deze groter zijn dan bij de analyse naar geslacht. Deze grotere verschillen worden ook aangegeven door de hagere eta-coëfficiënten. Eén uitzondering varmt de glabale synthesemeting van kennis van kankerpreventie. Hier worden relatief kleine kennisverschillen vastgesteld en een eta-coëfficiënt van 0.10 . Uit de analyse van de achterliggende dimensies in kennis van kankerpreventie kan worden afgeleid dat hier sprake is van een gedeeltelijk verborgen relatie: de sterkere verbanden tussen leeftijd en respectievelijk kennis van primaire kankerpreventie (eta $=0.19$ ) en kennis van secundaire kankerpreventie (eta $=0.15$ ) heffen mekaar bij samenvoeging gedeeltelijk op. Deze sterkere verbanden verbergen op hun beurt de nog sterkere verbanden bij twee originele indicatoren van kennis van kankerpreventie. Het sterkste verband met leeftijd wordt immers vastgesteld bij de kennis van de risicofactoren leta $=0.25$ ) en bij de kennis van de waarschuwingssignalen (eta $=0.23$ ).

Er kan nu de vraag worden gesteld of de vastgestelde (complexe) relatie tussen leeftijd en kennis van kankerpreventie vrij stabiel is naar geslachtsspecificatie, of m.a.w. deze verbanden zich repliceren bij zowel de mannelijke als de vrouwelijke subpopulatie. Zo dit het geval is, dan is sprake van robuuste verbanden. Hier wordt dit gecontroleerd door een opsplitsing van de onderzoekspopulatie naar geslacht. De resultaten worden vermeld in tabel 7.5 (zie bijlage 4). Ter vergelijking werden de gemiddelde scores en de zero-order 
correlaties uit tabel 7.4 herhaald in tabel 7.5 (bijlage 4 ).

Een eerste belangrijke vaststelling is dat alle significante en niet significante zero-order verbanden worden gerepliceerd. Er is slechts één uitzondering, namelijk leeftijdsklasse heeft geen significante samenhang met de globale meting van kennis van kankerpreventie bij vrouwen. Het betreft hier evenwel een verberging van de mekaar neutraliserende invloeden van leeftijd op respectievelijk kennis van primaire kankerpreventie $(p<0.001)$ en kennis van secundaire kankerpreventie $(p<0.05)$. Ook de vorm van de verbanden wordt in belangrijke mate gerepliceerd. De lineaire verbanden blijven bij opsplitsing naar de geslachten (ongeveer) lineair en de curvilineaire verbanden blijven curvilineair (zle ook figuur 7.21 .

Wordt er gekeken naar de (replicatie van de) sterkte van de verbanden, dan valt op dat de eta-coëfficiënten over het algemeen zeer stabiel blijven. Bij de vrouwen (eta $=0.28$ ) is er well een sterker verband tussen leeftijd en kennis van risicofactoren dan bij de mannen feta $=0.24)$. Dit verschil wardt minder uitgesproken gerepliceerd in de samenhang tussen leeftijd en de synthesemaat kennis van primaire kankerpreventie (mannen eta $=0.19$ versus vrouwen eta $=0.21$ ). Anderzijds is er bij de mannen leta $=0.16$ l een sterker verband tussen leeftijd en kennis van de vroegtijdige opsporingsonderzoeken dan bij de vrouwen (eta $=0.12$ ). Dit verschil wordt nog groter (door interactie met kennis van de waarschuwingssignalen) in de samenhang tussen leeftijd en de synthesemaat kennis van secundaire kankerpreventie (mannen: eta $=0.19$ versus vrouwen: eta $=0.11$ ).

Samenvattend kan worden gesteld dat kennis van kankerpreventie leeftijdsgebonden is, doch dat de interpretatie van de samenhang niet eenduidig is. Het significant verband tussen leeftijd en de globale meting van kennis van kankerpreventie is zwak, doch de sterkte van de samenhang is gedeeltelijk verborgen door mekaar opheffende invloeden van twee dimensies van kennis van kankerpreventie. Jongeren weten meer over primaire kankerpreventie dan ouderen, doch over secundaire kankerpreventie zijn het vooral de middenleefijidsklassen die meer weten dan de jongeren en de ouderen.

In het algemeen kan worden gesteld dat de zero-order correlaties tussen leeftijd en kennis wan kankerpreventie worden gerepliceerd, wanneer wordt gecontroleerd voor geslacht. De invloed van leeftijd op kennis van kankerpreventie bijkt dus vrij robuust te zijn. Uit tabel 7.5 (zie bijlage 4 ) en figuur 7.2 blijkt ook dat er beperkte interactie-effecten zijn van de variabele geslacht op de samenhang tussen leeftijd en kennis van kankerpreventie. 
Figuur 7.2

Kennis van kankerpreventie naar leeftijd, controlerend voor geslacht

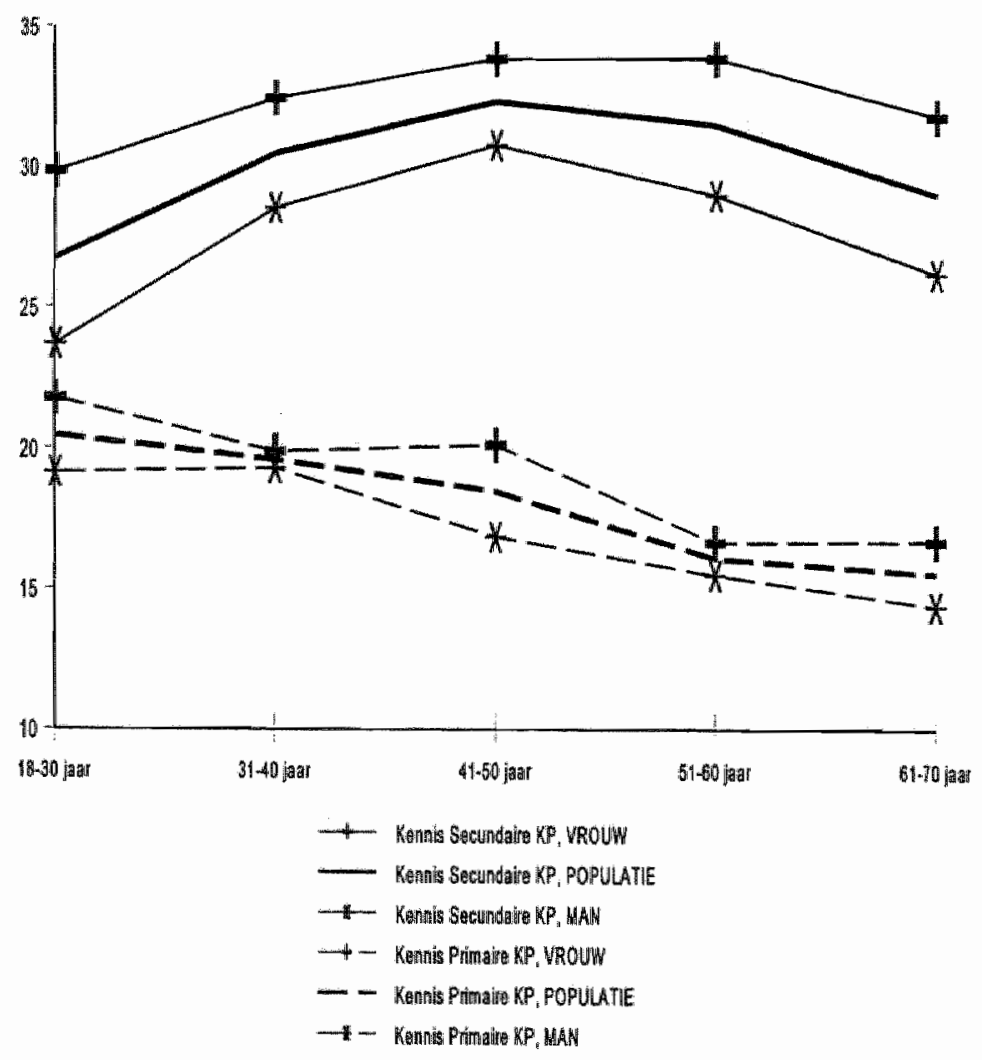

- De invloed van socio-demografische factoren - 


\subsubsection{De invloed van de leefsituatie (partner) op kennis van kankerpreventie}

In deze paragraaf staat de invloed van de partner op de kennis van kankerpreventie centraal. Tabel 7.6 presenteert de onderzoeksresultaten van kennis van kankerpreventie naar leefsituatie. Er wordt een overzicht gegeven van de gemiddelde scores van kennis van kankerpreventie naar respondenten met en zonder partner, samen met de zero-order correlaties (Eta-coëfficiënten) en het resultaat van de significantietoets (Mann-Whitney test).

Tabel 7.6

Gemiddelde scores van kennis van kankerpreventie, naar al of niet aanwezigheid van een partner

\begin{tabular}{|c|c|c|c|c|}
\hline Kennisschalen & $\begin{array}{c}\text { Met } \\
\text { partner } \\
(n=1368)\end{array}$ & $\begin{array}{l}\text { Zonder } \\
\text { partner } \\
(n=263)\end{array}$ & Eta & $\begin{array}{c}\text { Mann- } \\
\text { Whitney } \\
\text { test }\end{array}$ \\
\hline \multicolumn{5}{|c|}{ KENNIS VAN PRIMAIRE KANKERPREVENTIE : } \\
\hline Risicofactoren & 22.74 & 21.54 & - & $n \cdot s_{n}$ \\
\hline Gewenst gedrag & 14.48 & 13.06 & 0.05 & * \\
\hline \multicolumn{5}{|c|}{ KENNIS VAN SECUNDAIRE KANKERPREVENTIE : } \\
\hline Waarschuwingssignalen & 29.82 & 25.86 & 0.09 & $* * *$ \\
\hline Vroegtiddige opsporing & 30.84 & 27.60 & 0.07 & ** $*$ \\
\hline \multicolumn{5}{|c|}{ SYNTHESE VAN KENNIS VAN KANKERPREVENTIE : } \\
\hline Primaire Kankerpreventie & 18.61 & 17.30 & - & $n, s$. \\
\hline Secundaire Kankerpreventie & 30.33 & 26.73 & 0.09 & *** \\
\hline Globale meting & 24.47 & 22.02 & 0.09 & - \\
\hline
\end{tabular}

Noot: de kennisscores lopen van - 100 (zeer inadequate kennis van kankerpreventie) tot +100 (zeer adequate kennis van kankerpreventie)

Een eerste opvallende observatie is dat de kennisverschillen tussen respondenten met of zonder partner consistent in dezelfde richting gaan : respondenten met een partner hebben steeds een hogere gemiddelde kennisscore dan respondenten zonder partner. Het verband met kennis van de risicofactoren is evenwel niet significant. Deze niet-significantie wordt ook gerepliceerd in de synthesemaat kennis van primaire kankerpreventie. Voor de overige drie indicatoren en twee synthesematen van kennis van kankerpreventie is deize samenhang wel significant.

De vastgestelde significante verschillen in de kennisscores zijn evenwel vrij beperkt. Deze kleine verschillen tussen de gemiddelde kennisscores leiden eveneens tot wrij kleine eta- 
coëfficienten, variêrend van 0.05 tot 0.09 . Het niveau van kennis van de waarschuwingssignalen verschilt het meest tussen de respondenten met en zonder partner, namelijk ongeveer 4 punten op de kennisschaal.

Het zeer zwakke verband tussen kennis van kankerpreventie en de al dan niet aanwezigheid van een partner doet de vraag rijzen of een mogelijke samenihang niet verborgen wordt door interactie met een derde variabele. In de eerste plaats kan worden gedacht aan geslacht. in de vorige paragraaf is immers gebleken dat vrouwen meer kennis van kankerpreventie hebben dan mannen. Het zou bijgevolg ook kunnen dat mannen meer onder invloed staan van hun wrouwelijke partner dan omgekeerd. Dit kan worden getest door de onderzoekspopulatie constant te houden naar geslacht. De analyseresultaten worden vermeld in tabel 7.7 (zie bijlage 4). Ter vergelijking werden de gemiddelde scores en de zeroorder correlaties: (Eta-coëfficiẻnten) uit tabel 7.6 herhaald in tabel 7.7 (zie bijlage 4).

Een eerste belangrijke observatie is dat respondenten mét een partner steeds een hogere gemiddelde kennisscore hebben dan de respondenten zonder partner. Op basis van de significantietoetsen tekent zich echter een zeer duidelijk verschil af tussen mannen en vrouwen.

Hoewel de vrouwelijke respondenten met een partner steeds een hogere kennisscore hebben dan diegenen zonder partner, zijn bij alle kennismetingen deze werschillen niet meer statistisch significant. Er kan dus wordn geconcludeerd dat de kennis van kankerpreventie van vrouwen niet onderhevig is aan de invloed van hun partner. Wat de vrouwen betreft, kan dus over alle zero-order verbanden worden geconcludeerd dat het om schijnverbanden gaat.

Bij de mannelijke respondenten blijft een verband met kennis van de risicofactoren van kanker achterwege en verdwijnt het zero-order verband bij kennis van gewenst gedrag. Er kan bijgevolg worden besloten dat de indicatoren van kennis van primaire kankerpreventie geen significant verband vertonen met de aan- of afwezigheid van een partner.

Bij de indicatoren van kennis van secundaire kankerpreventie, alsook bij de synthesemaat van kennis van secundaire kankerpreventie, valt op dat er steeds een sterker verband optreedt met aan of afwezigheid van een partner (zie de grijs gekleurde cellen in tabel 7.7 ; zie: bijlage 41 . Op het niveau van de totale populatie bleef de samenhang gedeeltelijk verborgen " doch de analyse bij de mannen wijst duidelijk op een specificatie van het verband: de invloeden van de partner worden sterker. Vooral bij de kennis van de waarschuwingssignalen is deze verandering van samenhang het meest opmerkelijk, de Etacoêfficiênt vergroot van 0.09 naar 0.15 . Deze versterkte invloed van de partner op kennis van kankerpreventie bij mannen wordt ook gerepliceerd bij de globale meting van kennis van kankerpreventie.

Deze interessante vaststelling scherpt de nieuwsgierigheid naar verdere exploratie van deze hypothese. Is deze inwloed vrij consistent naar leeftijd? Of m.a.w. worden oudere mannen evenveel beilnvloed door hun partner in hun kennis van secundaire kankerpreventie als jongere mannen. Om deze onderzoeksvraag te kunnen toetsen, werd de onderzaeks- 
populatie veder opgedeeld in drie leeftijdsklassen. De resultaten worden vermeld in tabel 7.8 (zie bijlage 4 ). Ter vergelijking werden de gemiddelde scores en de zero-order correlaties (Eta-coëfficiënten) uit tabel 7.7 (zie bijlage 4 ) herhaald in tabel 7.8 (zie bijlage 4 ).

Een eerste belangrijke observatie is dat mannen mèt een partmer steeds een hogere gemiddelde kennisscore hebben dan mannen zonder partner. Op basis van de significantietoetsen tekent zich echter een verschil af naar leeftijdsklasse. In de leeftijdsklasse $18-34$ jaar worden de significante verbanden tussen leefsituatie en respectievelijk kennis van de waarschuwingssignalen en de synthesemaat van kennis van secundaire kankerpreventie gereproduceerd en verdwijnt het significant verband met kennis van de vroegtijdige opsporingsonderzoeken. In de twee andere leeftijdsklassen valt op dat de verschillen tussen de gemiddelde kennisscores van mannem met en mannen zonder partner kleiner worden en dat alle significante verbanden veranderen in niet significantie.

Samenvattend kan worden geconcludeerd dat er bij vrouwen geen invloed uitgaat van de leefsituatie op hun kennis van kankerpreventie. Bij mannen heeft de leefsituatie wel een invloed op hun kennis van kankerpreventie, doch enkel en alleen op de kennis van secundaire kankerpreventie en niet op de kennis van primaire kankerpreventie. Deze inwtoed is echter enkel significant in de jongere leeftijdsklasse (18-34 jaar) en niet in de oudere leeftijdsklassen. Met een boutade zou kunnen worden gesteld dat vrouwen de kennis van secundaire kankerpreventie van mannen beïnvloeden, doch dat hun invloed beperkt is in de tijd.

\subsection{De samenhang van kennis van kankerpreventie met de socio-demografische determinanten nader bekeken}

Welke socio-demografische determinant beinvloedt nu het meest de kennis van kankerpreventie? Deze vraag is hoger nog niet aan de orde geweest. Het is een vraag naar de relatieve sterkte van de verbanden die in deze paragraaf werden besproken.

Door de vergelijking van de reeds hoger gepresenteerde correlatiecoëfficiënten (Etacoëfficiẻnten) kan een eerste aanzet tot antwoord op deze vraag worden gegeven. Tabel 7.9 geeft een overzicht van deze correlaties. Om de interpretatie van deze tabel te vergemakkelijken, werd telkens de sterkste correlatie met de overeenstemmende kennismeting met een grijze achtergrond afgedrukt.

Wat direct opvalt is dat bij alle kennismetingen steeds geslacht of leeftijd de sterkste samenhang vertoont met kennis van kankerpreventie. De leefsituatie komt altijd - met Litzondering van kennis van het gewenst gedrag - op de derde plaats, wat de sterkte wan de samenhang met kennis betreft.

Wordt er gekeken naar de 'globale meting" van kennis van kankerpreventie, dan valt op dat geslacht hiermee de sterkste samenhang vertoont. De samenhang van de sociodemografische determinanten met de globale meting verbergt echter gedeeltelijk de sterkte van de invloed van leeftijdsklasse. Deze invloed komt beter naar voor bij de onderscheiden 
dimensies van kennis van kankerpreventie. Met kennis van secundaire kankerpreventie correleert leeftijdsklasse bijna even sterk als geslacht en met kennis van primaire kankerpreventie heeft leeftijdskiasse bijna twee keer zo'n sterke samenhang als geslacht.

\section{Tabel 7.9}

Zero-order verbanden (Eta-coęfficiënten) tussen de sociodemografische determinanten en kennis van kankerpreventie

\begin{tabular}{|c|c|c|c|}
\hline Kennisschalen: & Geslacht & $\begin{array}{c}\text { Leeftijds- } \\
\text { klasse }\end{array}$ & Leefsituatie \\
\hline \multicolumn{4}{|c|}{ KENNIS VAN PRIMAIRE KANKERPREVENTIE } \\
\hline Risicofactoren & $0.07 * *$ & 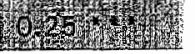 & n.s. \\
\hline Gewenst gedrag & 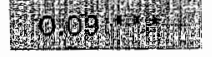 & n.s. & $0.05 *$ \\
\hline \multicolumn{4}{|c|}{ KENNIS VAN SECUINDAIRE KANKERPREVENTIE } \\
\hline Waarschuwingssignalen & $0.18 *$ & & $0.09 * * *$ \\
\hline Vroegtijdige opsporing & $0.11 * *$ & Her & $0.07 *$ \\
\hline \multicolumn{4}{|c|}{ SYNTHESE VAN KENNIS VAN KANKERPREVENTIE } \\
\hline Primaire Kankerpreventie & $0.10^{* * *}$ & 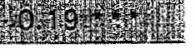 & n.s. \\
\hline Secundaire Kankerpreventie & my & $0.15 * *$ & $0.09 *$ \\
\hline Globale meting & Mather & $0.10 * *$ & $0.09 * *$ \\
\hline
\end{tabular}

Noot: Enkel de significante verbanden worden weergegeven. De significantie werd getoetst door middel van Mann-Whitney of Kruskal-Wallis

De invloed van leeftijdsklasse op kennis van kankerpreventie wordt het meest expliciet zichtbaar wanneer er wordt gekeken naar de individuele indicatoren van kennis van kankerpreventie. Met nilet minder dan drie van de vier indicatoren van kennis van kankerpreventie heeft leeftijdskiasse de sterkste correlatie. Enkel bij kennis van het gewenst gedrag * waar het kennisniveau trouwens laag is en zwak samenhangt met de sociodemografische determinanten - vertoont leeftijdsklasse geen significante samenhang . Vooral bij de kennis van de risicofactoren van kanker is de samenhang met leeftijdsklasse het meest uitgesproken (Eta $=0.25$ ). Ook als er een rangorde wordt opgesteld van de sterkste verbanden uit deze tabel, valt op dat de top drie steeds gevormd wordt door samenhangen met leeftijdsklasse.

Op basis van de gegevens uit tabel 7.9 kan worden geconcludeerd dat in de eerste plaats leettijdsklasse en in de tweede plaats geslacht de sterkste samenhang vertonen met kennis van kankerpreventic. 
Tabell 7.10

Zero-order correlaties (Pearson's r) en partiêlle correlatiecoëfficiênten tussen de socio-demografische determinanten en kennis van kankerpreventie

\begin{tabular}{|c|c|c|c|c|c|c|}
\hline \multirow[t]{2}{*}{ Kennisschalen } & \multicolumn{2}{|c|}{ Geslacht } & \multicolumn{2}{|c|}{ Leeftijd } & \multicolumn{2}{|c|}{ Leefsituatie } \\
\hline & $\begin{array}{l}\text { zero- } \\
\text { order }\end{array}$ & $\begin{array}{c}\text { partiêlle } \\
\text { (1) }\end{array}$ & $\begin{array}{l}\text { zero: } \\
\text { orden }\end{array}$ & $\begin{array}{c}\text { partiele } \\
(2)\end{array}$ & $\begin{array}{l}\text { zera- } \\
\text { order }\end{array}$ & $\begin{array}{c}\text { partiäle } \\
\text { (3) }\end{array}$ \\
\hline \multicolumn{7}{|c|}{ KENNIS VAN PRIMAIRE KANKERPREVENTIE } \\
\hline Risicofactoren & +.07 & +.08 & $\begin{array}{l}-.25 \\
* *\end{array}$ & Why & n.s. &. .06 \\
\hline Gewenst gedrag & $\begin{array}{l}+.09 \\
* *\end{array}$ & Hog & n.s. & -.05 & n.s. & n.s. \\
\hline \multicolumn{7}{|c|}{ KENNIS VAN SECUNDAIRE KANKERPREVENTIE } \\
\hline Waarschuwingssignalen & $\begin{array}{l}+.18 \\
* *\end{array}$ & $\begin{array}{l}+.18 \\
* \quad\end{array}$ & $\begin{array}{l}+.22 \\
* * *\end{array}$ & 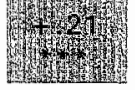 & -.09 & $\begin{array}{c}-.07 \\
* *\end{array}$ \\
\hline Vroegtijdige opsporing & $\begin{array}{l}+.11 \\
* *\end{array}$ & 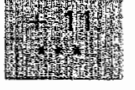 &. .06 & $\begin{array}{c}.06 \\
*\end{array}$ & $* .07$ & -.07 \\
\hline \multicolumn{7}{|c|}{ SYNTHESE VAN KENNIS VAN KANKERPREVENTIE } \\
\hline Primaire Kankerpreventie & $\begin{array}{l}+.10 \\
*\end{array}$ & $\begin{array}{l}+.10 \\
* *\end{array}$ & $\begin{array}{l}.19 \\
* * *\end{array}$ & $\begin{array}{l}1 \\
4\end{array}$ & .05 & -.06 \\
\hline $\begin{array}{l}\text { Secundaire } \\
\text { Kankerpreventie }\end{array}$ & $\begin{array}{l}+.17 \\
* * *\end{array}$ & 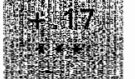 & +.08 & +.08 & -.09 & $\begin{array}{c}-.08 \\
* *\end{array}$ \\
\hline Globale meting & $\begin{array}{l}+.16 \\
* * *\end{array}$ & Ty & n.s. & n.s. & -.09 & -.09 \\
\hline
\end{tabular}

Noot: Enkel de significante verbanden worden weergegeven.

(1) controlerend voor leeftijd en leefsituatie

(2) controlerend voor geslacht en leofsituatie

(3) controlerend voor leeftijd en geslacht

Deze resultaten houden evenwel geen rekening met eventuele interactie-effecten tussen de socio-demografische determinanten in hun beïnvloeding van kennis van kankerpreventie. Om deze interactie-effecten onder controle te houden, wordt in tabel 7.10 de partiële correlatiecoëfficiënten (partiële Pearson's r) gepresenteend, waarbij steeds wordt gecontroleerd voor twee socio-demografische determinanten. Om de interpretatie van deze tabel te vergemakkelijken werd net als in tabel 7.9 de sterkste partiêle correlatie met de overeenstemmende kennismeting met een grijze achtergrond afgedrukt.

Wordt er naar de verschuivingen in significantie én sterkte van de coëfficiênten tussen de zero-order-verbanden en de partiële correlaties gekeken, dan valt de stabiliteit op. Zowel het significantieniveau als de grootte en de richting van de zero-order-verbanden worden 
gereproduceerd in de partiele correlatiecoêfficienten. Dit wijst erop dat de bestaande samenthang tussen de afzonderlijke socio-demografische determinanten met kennis van kankerpreventie wordt bevestigd na controle voor de andere soclo-demografische determinanten en dat de interactie zeer beperkt is. Er zijn in dit algemeen patroon slechts twee vitzonderingen. De kennis van de risicofactoren van kanker wordt na controle voor leeftijd en geslacht wel - zij het matig - positief beinwloed door de aanwezigheid van een partner. Verder wordt de kennis van het gewenste kankerpreventief gedrag na controle voor geslacht en leefsituatie - zij het ook met mate - negatief beïnvioed door leeftijd. Hoe ouder de leeftijd, hoe minder men weet over het gewenst gedrag.

Wordt de sterkte van de partiële correlatiecoëfficiënten voor elke kennismeting afzonderlijk vergeleken, dan is het algemene patroon van tabel 7.10 ongeveer hetzelfde als dat van tabel 7.9. In het allgemeen beschouwd zijn het steeds geslacht of leeftijd die de sterkste samenhang vertonen met kennis van kankerpreventie. De leefsituatie komt vrijwel altijd op de derde plaats wat de samenhang met kennis betreft. De kennis van de vroegtijdige opsporingsonderzoeken voor kanker blijkt in tabel 7.10 echter veel minder sterk beïnvloed door leeftijd als werd vastgesteld in tabel 7.9. Dit is evenwel wat misleidend. Het heeft immers te maken met het feit dat leeftijd in tabel 7.10 als intervalvariabele wordt gebruikt en Pearson's r een "lineaire" correlatiemaat is. Omdat uit tabel 7.4 blijkt dat leeftijd een curvilineaire relatie vertoont met kennis van de vroegtijdige opsporingsonderzoeken, is een relatief zwakke Pearson's $r$ dan ook te verwachten.

Wordt er gekeken naar de "globale meting", dan valt de afwezigheid van de invloed van leeftijd op kennis van kankerpreventie op. Er is hier echter sprake van een duidelijk woorbeeld van een verborgen samenhang. De samenhang wordt verborgen door een positteve beïnvloeding van de kennis van secundaire kankerpreventie - dus de kennis stijgt met de leeftijd - en een negatieve beinvloeding van de kennis van primaire kankerpreventie dus de kennis daalt met de leeftijd.

\subsection{Samenvatting en discussie}

Op basis van socital-psychologische madellen over de determinanten van lonigezond gedrag, alsook op basis van een aantal empirische studies over kennis van kankerpreventie kon een samenhang worden verwacht tussen socio-demografische determinanten en kennis. van kankerpreventie. Uit de literatuur kwam niet altijd duidelijk naar voor hoe deze relaties eruit zien. De vorm, richting en sterkte van de relaties tussen de socio-demografische determinanten en kennis van kankerpreventie bleken in de literatuur niet eenduidig en soms zelfs tegenstrijdig. Er konden dan ook niet altijd scherpe onderzoekshypothesen worden geformuleerd.

In dit hoofdstuk werd vastgesteld dat op grond van de socio-demografische positie in de samenleving er categorieên zijn met een significant grotere of kleinere kennis van kankerpreventie dan andere categorieën. Dit verschil in kennis van kankerpreventie werd geanalyseerd aan de hand van drie cnderzoekshypothesen. 


\section{- ad onderzoekshypothese 1 .}

De eerste hypothese betrof de invloed van geslacht op kennis van kankerpreventie, waarbij werd voorspeld dat vrouwen een grotere kennis van kankerpreventie zouden hebben dan mannen. Deze hypothese kan zonder meer worden aanvaard. De empirische bevindingen uit dit onderzoek zijn consistent met deze uit eerdere studies (zie hoger).

Voor alle kennismetingen hadden vrouwen een significant hogere kennisscore dan de mannen. Vrouwen weten dus meer van kankerpreventie af dan mannen. Zij weten significant meer over risicofactoren, over gewenst kankerpreventief gedrag, over waarschuwingssignalen en over vroegtijdige opsporingsonderzoeken dan mannen. De verschillen in kennisniveau zijn echter het meest uitgesproken bij de kennis van "secundaire kankerpreventile' en dit verschil wordt vooral verklaard door een verschil in kennis van de waarschuwingssignalen voor kanker.

De gevonden relaties tussen geslacht en kennis van kankerpreventie zijn over het algemeen ook consistent bij elaboratie naar leeftijd. In het algemeen kan worden vastgesteld dat de zero-order correlaties worden gerepliceerd, wanneer er wordt gecontroleerd naar leeftijdsklasse. De invloed van geslacht op kennis van kankerpreventie blijkt dus vrij robuust te zijn. Leeftijd blijkt slechts een zeer beperkt interactie-effect te hebben op de samenhang tussen geslacht en kennis van kankerpreventie.

\section{- ad onderzoekshypothese 2 -}

De tweede hypothese betrof de invloed van leeftijd op kennis van kankerpreventie. Op grond van tegenstrijdige resultaten in bestaand empirisch onderzoek werd er geen verband verwacht tussen leeftijd en kennis wan kankerpreventie, althans wat betreft de "globale meting" van kennis van kankerpreventie. Hoewel de samenhang tussen leeftijd en de 'globale meting" van kennis van kankerpreventie deels verborgen was door tegengestelde effecten binnen de afzonderlijke kennismetingen, kan de hypothese toch zonder meer worden verworpen.

Voor alle kennismetingen - de kennis van thet gewenst kankerpreventief gedrag uitgezonderd - wordt een significante samenhang vastgesteld met leeftijd. Leeftijd heeft. evenwel geen eenduidige relatie met kennis van kankerpreventie. Dit gebrek aen eenduidigheid bleek ook al uit de empirische bevindingen van eerdere studies (zie hoger). In deze studie konden deze verschillen in kaart worden gebracht door de relaties van leeftijd met de verschillende indicatoren van kennis van kankerpreventie systematisch te vergelijken naar vorm, richting en sterkte. Leeftijd heeft in deze studie een lineaire negatieve samenhang met kennis van 'primaire kankerpreventie". De jongste leeftijdscategorie heeft de grootste kennis van primaire kankerpreventie en de kennisscore daalt gradueel met de toenemende leeftijd. Dit negatief lineair verband komt het sterkst tot uiting bij de kennis van risicofactoren van kanker. Met kennis van 'secundaire kankerpreventie' heeft leeftijd evenwel een curvilineaire samenhang. De kennisscare stijgt gradueel tot de leeftijdsklasse van 41-50 jaar, om nadien weer gradueel te dalen. 
Ook hier zijn de vastgestelde relaties tussen leeftijd en kennis van kankerpreventie over het algemeen ook consistent bij elaboratie. In het algemeen kan worden vastgesteld dat de zero-order correlaties worden gerepliceerd wanneer er wordt gecontroleerd naar geslacht. Zowel de sterkte alls de vorm van de samenhang van leeftijd met kennis van kankerpreventie blijkt vrij robuust te zijn. Het geslacht blijkt slechts een beperkt interactieeffect te hebben op de samenhang tussen leeftijd en kennis van kankerpreventie.

\section{- ad onderzoekshypothese 3 -}

De derde hypothese betrof de invloed van de leefsituatie op kennis van kankerpreventie. Er werd voorspeld dat respondenten mét een partner een grotere kennis van kankerpreventie zouden hebben dan deze zonder partner, en dat de invloed van de partner sterker zou zijn voor mannen dan voor vrouwen. Over het algemeen kan worden gesteld dat de invloed van de leefsituatie op kennis van kankerpreventie wrij zwak is. Hoewel de samenhang tussen leefsituatie en de 'globale meting' van kennis van kankerpreventie significant is, kan er deels ook worden gesproken van een schijnverband.

De kennis van "primaire kankerpreventie" hangt niet samen met de leefsituatie en de kennis van 'secundaüre kankerpreventie' hangt maar zeer matig samen met de leefsituatie. De relatie gaat daarbij echter wel in eenzelfde richting: respondenten met een partner hebben steeds een hogere gemiddelde kennisscore dan respondenten zonder partner.

Bij elaboratie nalar geslacht bleek deze samenhang bovendien enkel aanwezig bij mannen. Voor vrouwen kan worden geconcludeerd dat het verband tussen leefsituatie en kennis van kankerpreventie nihil is en dat er bijgevolg sprake is van een schijnverband. Bij mannen werden de zero-order verbanden met leefsituatie enkel gereproduceerd voor kennis van secundaire kankerpreventie.. Bij verdere elaboratie naar leeftijd bleek deze relatie enkel significant in de leeftijdsklasse 18-34 jaar.

Wanneer de invloed van de drie socio-demografische determinanten op kennis van kankerpreventie onderling wordt vergeleken, wordt vastgesteld dat vooral de invloed van geslacht en leeftijd substantieel zijn. Ook hier dient een onderscheid te worden gemaakt in het domein waarop de kennis betrekking heeft. Leeftijd heeft immers twee keer zo"n sterke samenhang met kennis van "primaire kankerpreventie" dan geslacht, en ongeveer een evensterke samenhang met kennis van "secundaire kankerpreventie" als geslacht. Geslacht correleert evenwel iets sterker met kennis van secundaire kankerpreventie. Door de tegengestelde invloeden van leeftijd op kennis van respectievelijk primaire en secundaire kankerpreventie, wordt de invloed van leeftijd op de globale meting van kennis van kenkerpreventie enigszins verborgen en lijkt het alsof vooral geslacht het sterkst samenhangt met de kennis van kankerpreventie.

Samenvattend kan worden gesteld dat slechts één onderzoekshypothese zonder meer kan worden aanwaard, namelijk dat vrouwen een grotere kennis van kankerpreventie hebben dan mannen. De twee owerige onderzoekshypothesen dienen te warden geherformuleerd of gespecificeerd. De analyses van de onderzoeksresultaten over de invloed van leeftijd en leefsituatie op kennis van kankerpreventie nopen eerder tot nuancering van de hypothesen 
dan tot radicale verwerping of aanvaarding.

Op basis van deze onderzoeksresultaten blijkt de relatie tussen socio-demografische determinanten en kennis van kankerpreventie zeer complex te zijn. Dit bevestigt andermaal de complexiteit van de invlaed van de socio-demografische positie in de samenleving. Het is meestal niet éen kenmerk dat verantwoordelijk is voor een bepaalde sociale predispositie ten aanzien van (kennis van) kankerpreventie maar een cluster van verscheidene kenmerken die maken dat mensen al dan niet bevoor- of benadeeld zijn door hun maatschappelijke positie en die mensen helpen bij of belemmeren in het maken van keuzes ten behoeve van hun gezondheid. De variabele samenhang van de socio-demografische determinanten met kennis van kankerpreventie is bovendien gerelateerd aan het domein van kennis van kankerpreventie dat wordt onderzocht.

Daarbij mag worden verondersteld dat mensen met veel (adequatel kennis van kankerpreventie ook op een meer adequate wijze keuzes kunnen maken met betrekking tot het kankerpreventief handelen dan mensen met weinig (adequate) kennis van kankerpreventie. Of anders uitgedrukt, zou kunnen worden gesteld dat de saciodemografische determinanten via (het bevorderen van) de kennis van kankerpreventie de autonomie van het individu bevorderen of beperken om kankerpreventief te kunnen handelen. Sommige socio-demografische categorieën zijn m.a.w. beter uitgerust om keuzes te kunnen maken inzake kankerpreventie dan andere categorieën.

Deze bevindingen wijzen op de noodzaak om zeer doelgericht te werk te gaan bij het concipiëren en uitvoeren van kankerpreventiecampagnes. Het volstaat daarbij niet allieen een interventie af te stemmen op de doelgroep, de vorm en de kwaliteit van de interventie dient evenzeer rekening te houden met de specificiteit van het voorlichtingsdomein inzake kankerpreventie. Algemene boodschappen voor een algemeen publiek lijkt op grond van de onderzoeksresultaten op zijn minst een bevoor- of benadeling in te houden ten aanzien van bepaalde socio-demografische categorieën. In een periode van beperkte financiële middelen lijkt een selectievere aanpak sociaal meer gerechtvaardigd. Dit impliceert dat men bij kankerpreventiecampagnes voorafgaand veel meer aandacht moet besteden man de analyse wan de doelgroep die men met betrekking tot een specifiek kankerpreventief domein wenst te beïnvloeden, vooraleer men verder alle stappen van de gedragsbeïnvloeding gaät kunnen concipiëren (cfr. McGuire, 1985; zie ook Kok, 19931. Als deze doelgroep aan de hand van de socio-demografische kenmerken kan worden afgebakend, zal men ook veel concreter kunnen vaststellen hoe bij deze doelgroep de aandacht karn worden getrokken voor een kankerpreventieve boodschap, welke 'bron' (voorlichter of organisatie) het meest gezag heeft bij de doelgroep, welke 'boodschap' door deze doelgroep begrepen wordt en welk 'communicatiekanaa!' het meest optimaal werkt opdat de doelgroep zou worden bereikt. De voorlichtingsboodschap kan immers pas effect hebben als de doelgroep eraan blootgesteld wordt en deze er aandacht aan besteedt. Een belangrijke voorwaarde om dit te kunnen bereiken is dat heel het concept van de voorlichting aansluit bij de doelgroep. 



\section{Hoofdstuk 8}

\section{Kennis van kankerpreventie en het verband met de sociaal-economische determinanten "}

8.1 Probleemstelling en onderzoekshypothesen

8.1.1 Opleiding en kennis van kankerpreventie

8.1.2 Inkomen en kennis van kankerpreventie

8.1.3 Beroep en kennis van kankerpreventie

8.1.4 Geïntegreerde SES-indicatoren en kennis van

kankerpreventie

8.2 Overzicht van het onderzoeksmateriaal en de analyseopzet

8.3 Sociaal-economische ongelijkheid en kennis van kankerpreventie

8.3.1 De invloed van opleidingsniveau

8.3.2 De invloed van inkomen

8.3.3 De invloed van beroepsstatus

8.3.4 De invloed van een geïntegreerde sociaaleconomische status

8.3.5 De invloeden van de sociaal-economische indicatoren op kennis van kankerpreventie onderling vergeleken

8.4 Elaboratie van de samenhang van kennis van kankerpreventie met de geïntegreerde sociaal-economische status, naar leeftijd en geslacht

8.5 De invloeden van socio-demografische en sociaal-economische determinanten onderling vergeleken en de gezamenlijke inwloed van deze determinanten op kennis van kankerpreventie

8.6 Samenvatting en discussie

\subsection{Probleemstelling en onderzoekshypothesen}

Gezondheidsrisico's en gezondheidsbeleving hebben, zoals in het vorige hoofdstuk reeds werd aangegeven, onder andere te maken met het feit of iemand man of vrouw is, jong of oud is, maar ook met zijn/haar sociaal-economische positie in de samenleving. De samenhang tussen sociaal-economische positie en gezondheid ward reeds in veel gezondheidsonderzoek vastgesteld. Het inzicht dat sociaal-economische omstandigheden van invloed zijn op het ontstaan van ziekten is zo oud alls de geneeskunde zelf. Onderzoek naar de samenhang tussen bepaaide levensomstandigheden en het voorkomen van ziekte

Elly Kerkhofs van het Steunpunt 'Samenleving en Gezondheid' van de Vrije Universiteit Brussel wordt bedankt voor de hulp bij de selectie van relevante literatuur woor dit hoofdstuk.

- De invloed wan de sociaal-economische factoren. 
werd reeds verricht voordat de sociologie als empirische wetenschap tot ontwikkeling was gekomen (zie o.m. Tellegen, 1970: 16 e.v.). Het was met name de epidemiologie die reeds in de jaren vijftig en zestig in diverse studies een samenhang vaststelde tussen sociale determinanten en het ontstaan van ziekten. Toch heeft het epidemiologisch onderzoek voor de samenhang tussen sociaal-economische positie en gezondheid tot weinig duidelijke conclusies geleid. Ten dele was dat toe te schrijven aan de gebruikte methoden die uitsluitend beschrijvend van aard waren, zodat gevonden correlaties veelal verschillende interpretaties toelieten. Zelfs indien duidelijk bleek dat gevonden correlaties als een causaal verband konden worden geïnterpreteerd, bleef nog onduidelijk wat dan oorzaak en gevolg was: leidt een sociale positie (of "sociaal-economische status") tot ongezondheid of leidt ongezondheid tot een 'slechtere" sociale positie? Verder bleven ook de beïnvloedingsmechanismen van de sociale positie op ziekte en gezondheid nog onbeantwoord. Vaak was het onduidelijk in welke mate de gevonden samenhangen toe te schrijwen waren aan verschillen in voeding, lichaamsbeweging, raokgewoonten, werkomstandigheden of aan verschillen in sociale relaties of sociaal geinduceerde stress.

Deze kritieken op thet epidemiologisch onderzoek werden vooral geformuleerd vanuit de medische sociologie, die vanaf de jaren zestig en zeventig een smelle groei kende als nieuwe empirische wetenschap binnen de gezondheidswetenschappen. Zij was primair niet zozeer geifnteresseerd in de fysieke, doch wel in de sociale beïnvloedingsprocessen. Zij richtte zich in haar studie niet zozeer op de wantoestanden inzake de fysieke woon- en werkomstandigheden, dan wel op het sociale gedrag, de sociale relaties en de socialle systemen. In een eerste fase is de medische sociologie zich vooral gaan toeleggen op "ziektegedrag". Uit onderzoek in de Verenigde Staten bleek o.m. dat personen uit lagere sociale klassen zich in het algemeen minder snel in verband met bepaalde aandoeningen tot een arts wenden dan personen uit de hogere sociale klassen (Zola, 1964). Dit verschijnsel werd recentelijk nogmaals bevestigd in Vlaanderen (Peersman en De Maeseneer, 1995). In een onderzoek bij een representatief staal van de Gentse bevolking tussen 40 en 50 jaar werd aangetoond dat - indien rekening wordt gehouden met de gezondheidstoestand - het aantal huisartsconsultaties bij mensen voor wie het remgeld te hoog is, lager is dan bij de andere respondenten.

De gezondheidssociologie besteedt de afgelopen jaren ook meer en meer aandacht aan deze sociaal-economische positie in de samenleving en aan het verband tussen de 'sociaaleconomische status' en gezondheid, waarbij de verschillen vrijwel steeds in het nadeel zijn wan mensen met een lageré social-economische status in de samenleving (zle ondermeer Gunning-Schepers, Spruit en Krijnen, 1989; Mackenbach, 1991; Louckx, 1995; Raes e.a., 1993; en van der Heijden, 1990). De verschillen in gezondheid hangen dus samen met de maatschappelijke ongelijkheid, soms ook maatschappelijke gelaagdheid of stratificatie genoemd. De gelaagde structuur van de maatschappij ontstaat doordat schaarse goederen als bezit, arbeid, opleiding, kennis en macht ongelijk verdeeld zijn (van Berkel-van Schaik en Tax, 1990: 3). Naarmate mensen over meer of minder schaarse goederen kunnen beschikken, memen zij een hogere of lagere positie in de maatschappij in. Aan de positie van mensen in deze maatschappelijke stratificatie is ook een bepaalde waardering of status verbonden, waardoor mensen die over relatief veel schaarse goederen beschikken en een hogere positie innemen, meer aanzien genieten dan mensen die over minder schaarse 
goederen beschikken. De positie van mensen in de sociale stratificatie met het daaraan verbonden aanzien of prestige wordt in de gezondheidssociologie meestal sociaaleconomische status (SES) genoemd.

In thet onderzoek over de samenhang tussen sociaal-economische status en gezondheid zijn global twee richtingen te onderscheiden (van der Heijden, 1990: vi). Enerzijds is er onderzoek dat zich richt op het daadwerkelijk vaststellen van mogelijke gezondheidsverschillen tussen categorieën van ongelijke sociaal-economische status en anderzijds zijn er meer theoretische studies die zoeken naar de mogelijke verklaringen van dergelijke verschillen en op de problemen omtrent conceptualisering en operationalisering van de sociaal-economische status.

In tal van studies werden er gezondheidsverschillen vastgesteld met betrekking tot zeer uiteenlopende gezondheidsaspecten, zowel op het vlak van de mortaliteĭt lbv. Kunst en Mackenbach, 1991; Lagasse e.a., 1990; Marmot, 1989; Spruit, 1990), als de morbiditeit (bv. Kunst en Mackenbach, 1990; Mackenbach en van der Maas, 1989; Vuylsteek, 1984)". Bovendien werden er ook sociale verschillen geconstateerd bij aanvullende gezondheidsindicatoren, zoals risicogedragingen (bv. Helmert e.a. 1995; Deliens en Pierret, 1996), gezondheidsklachten (bv. Mackenbach en wan der Maas, 1989), lichamelijke beperkingen (bv. De Nooze en Deliens, 1996), preventief gezondheidsgedrag (bv. Pill e.a., 1995), enz. In al deze onderzoeken zijn de verschillen steeds in het nadeel van de laagste sociale categorieën in de samenleving. Voorts blijkt ook dat de lagere sociale categorieên een lagere medische consumptie vertonen (Peersman en De Maeseneer, 1995) en een minder vlotte toegang hebben tot de gezondheidszorg dan de hogere sociale categorieên (Louckx, 1995).

Ook met betrekking tot kankerpreventie zijn er tal van studies waarin er verschillen werden vastgesteld naar sociaal-economische status. Zo bijvoorbeeld wordt er in studies over de participatie aan cervixkankerscreening steeds eenzelfde profiel vastgesteld, namelijk dat de lagere sociale kllassen significant minder vaak participeren aan screening dan de hogere sociale klassen. Een literatuurstudie van Baele en Verbinnen (1995) inventariseerde tal van studies waarin een samenhang werd aangetoond tussen opleidingsniveau en thietIparticipatie aan cervixkankerscreening, maar ook studies waarin een samenthang werd aangetoond tussen inkomen of armoede en (niet-) participatie aan cervixkankerscreening. In een recent onderzoek van Deliens en Pierret (1996) werd ook eren significant verband vastgesteld tussen beroepsniveau en deeiname aan een algemeen kankerpreventief onderzoek. Ook bijvoorbeeld met betrekking tot de participatie aan borstkankerscreening zijn er studies waarin eenzelfde samenhang met sociaal-economische status wordt vastgesteld (Sutton e.a., 1994; Vernon e.a., 1990). Niet alleen met betrekking tot secundaire kankerpreventie wordt er sociale ongelikheid vastgesteld, ook met betrekking tot primaire kankerpreventie wordt dit vastgesteld. Zo bijvoorbeeld werden er in Groot* Brittannië onder ambtenaren significante verbanden vastgesteld tussen beroepsniveau en

I

Voor uitvoerige literatuuroverzichten van de bestaande studies over SES en gezondheid, zie ondermeer Mackenbach en van der Maas (1989), van der Heijden (1990) en Raes e.a. (1993). 
respectievelijk roken, alcoholgebruik en gebruik van vezelrike voeding (volkoren brood) (Marmot e.a., 1991). Voor deze drie risico- of gezondheidsgedragingen met betrekking tot kanker werd steeds een lineair verband vastgesteld met beroepsniveau. De samenhang toont daarbil steeds een gezondheidsnadeel voor de laagste beroepsniveaus en een gezondheidsvoordeel voor de hoogste beroepsniveaus. Zo bijvoorbeeld liep het percentage rokers op van $8.3 \%$ in niveau 1 thoogste beroepsklassel, naar $10.2 \%$ in niveau $2,13 \%$ in niveau $3,18.4 \%$ in niveau $4.21 .9 \%$ in niveau 5 , to $33.6 \%$ in niveau 6 llaagste beroepsklasse).

Voor de sociaal-economische gezondheidsverschillen worden er in de literatuur een drietal verklaringstheorieien naar voor geschoven: artefact verklaringen, theorieèn betreffende sociale selectie en causatieverklaringen (Stronks, van de Mheen en Mackenbach, 1993: 1319: zie ook Rutter, Quine en Chesham, 1993: 7-81.

Een eerste theorie, de artefact-verklaring, steit dat de vastgestelde gezondheidsverschillen eigenlijk artefacten zijn van de wijze waarop sociale klasse of sociaal-economische status (SES) in onderzoek wordt gemeten. In werkelijkheid zouden die verschillen niet of minder optreden. De vertekening bij de metingen kan optreden wanneer bijvoorbeeld bij het berekenen van het aantal overledenen in een bepaalde SES-categorie in de teller en noemer verschillende methoden voor de vaststelling van sociaal-economische status gebruikt worden. Zo wordt in de Engelse sterftestatistieken het beroepsniveau van een overledene na zijin overlijden vastgesteld door navraag te doen bij verwanten. Gegevens over het aantal personen in een bepaalde sociaal-economische status-categorie zijn daarentegen uit de valkstelling afkomstig. De beroepsgegevens zijn derhalve vit twee verschillende bronnen afkomstig, met als gevolg dat de mogelijkheid tot vertekening bestaat.

Een tweede theorie is de selectieverklaring. Deze stelt dat sociaaleconomische gezondheidsverschillen verklaard kunnen worden uit het effect van de gezondheid op de sociaal-economische positie. Sociaal-economische gezondheidsverschillen ontstaan, zo is de gedachte, als gevolg van de invloed van gezondheid op SES of als gevolg van het feit dat zich tijdens sociale mobiliteit selectie op gezondheid voordoet. Ten gevolge hiervan zouden personen met een slechte gezondheid minder vaak stijgen en/of vaker dalen op de maatschappelijke ladder dan personen met een goede gezondheid.

De derde theorie, de causatieverklaring, wordt algemeen beschouwd als de belangrijkste verklaring. Deze veronderstelt dat de sociaal-economische positie een effect heeft op de gezondheid. Deze invloed loopt echter niet direct, doch via meer specifieke intermediaire determinanten die leiden tot gezondheid of ziekte. Social-economische gezondheids verschillen ontstaan, zo luidt deze verklaring, omdat lagere sociaal-economische categorieên in ongunstiger omstandigheden leven, en bovendien vaker gezondheids-schadend gedrag en minder vaak gezondheidsbevorderend gedrag vertonen dan hogere SES-categorieën. De intermediaire determinanten kunnen worden onderverdeeld in een drietal factoren: gedragsfactoren, materiële of structurele factoren en psychosociale factoren. Rook-, drink,en eetgewoonten, lichamelijke activiteit of vrijetijdsbesteding en consumptie van preventieve en curatieve gezondheidszorg zijn voorbeelden van gedragsfactoren. Structurele aspecten van de levensomstandigheden die voor de verklaring van sociaal-economische 
gezondheidsverschillen van belang zijn, zijn onder meer de fysieke omstandigheden waarin lemand woont (bv. een vochtige woning) en werkt (bv. zware lichamelijke arbeid) of de financiële toegankelijkheid van bepaalde zorgvoorzieningen. De psychosocialle factoren omvatten stressoren (langdurig belastende omstandigheden en life-events) en factoren die de invloed wan deze factoren op gezondheid modificeren (sociale steun, coping stijl en enkele persoonlijkheidskenmerken). Voorbeelden van stressoren zijn langdurige werkloosheid, overlijiden van partner en echtscheiding. De verwachting is dat een deel van de bestaande gezondheidsverschillen verklaard kan worden door het feit dat lagere sociaaleconomische categorieèn meer aan belastende omstandigheden blootgesteld zijn, bowendien minder goed toegerust zijn on met deze stressoren om te gaan, waardoor het ongezondheidseffect ervan in lagere klassen groter is dan in hogere.

Men kan zich bijgevolg afvragen of er bij de Vlaamse bevolking ook sprake is van sociaaleconomische ongelijkheid in de spreiding van kennis van kankerpreventie.

Die sociaal-economische positie in de samenleving kan worden beschreven aan de hand van een aantal indicatoren, de $\mathrm{zgn}$. sociaal-economische achtergrondgegevens van de respondenten. De indicatoren die men meestal gebruikt om de sociaal-economische positie te meten zijn: opleiding, inkomen en beroep (van Berkel-van Schaik en Tax, 1990). Aan de hand van deze drie sociaal-economische determinanten kan de unvloed van sociaaleconomische status (SES) op de kennis van kankerpreventie systematisch worden onderzocht.

In de volgende paragrafen worden eerst de hypothesen ontwikkelld over de invloed van respectievelijk opleiding, inkomen, beroep(sstatus) en twee geïntegreerde SES-variabelen op de kennis van kankerpreventie. Voor de ontwikkeling van deze onderzoekshypothesen wordt vertrokken vanult het algemeen patroon dat in de vorige paragraaf werd beschreven en dat meestal wordt teruggevonden in onderzoek over sociaal-economische status en gezondheid. Vooraf wordt eerst nog een overzicht gepresenteerd van de vastgestelde empirische relaties tussen kennis van kankerpreventie en de drie social-economische determinanten die in de analyses zullen worden opgenomen. Hieruit kunnen dan de concrete onderzoekshypothesen worden geformuleerd.

\subsubsection{Opleiding en kemnis van kankerpreventie}

Over de relatie tussen opleiding en kennis van kankerpreventie werden geen empirische gegevens teruggevonden die representatief zijn voor Vlaanderen. Wel werden er representatieve gegevens gevonden over de samenhang tussen opleiding en kennis vam ziekte en gezondheild. Deze gegevens zijn afkomstig van een gezondheidsenquête die werd verricht eind van de jaren zeventig in het kader van het Nationaal Onderzoeksprogramma in de Sociale Wetenschappen over "Eerstelijnsgezondheidszorg" (Nuvens e.a., 1978 en Nuyens, 1980). De kennis over ziekte en gezondheid bleek ongelijk gespreid naar opleidlingsniveau. Medische kennis was groter bij hoog geschoolden dan bij laag geschoolden. De verklaring voor de relatie tussen opleidingsniveau en kennis werd in dit onderzoek gezocht in een differentieel leervermogen bij deze bevolkingscategorieën. Hoog 
geschoolden hebben een groter vermogen om medische kennis te assimileren dan laag geschoolden. Wat de kennis van medische voorzieningen betreft, bleek dat vooral voorzieningen met een somatische, curatieve inslag goed gekend waren, in tegenstelling tot voorzieningen die eerder gericht zijn op psychosociale problematiek. Bovendien stelde men vast dat precies de minst geschoolden over de minste informatie beschikten. Ook de ziekteopwattingen die werden onderzocht waren ongelijk gespreid naar opleidingsniveau. De onderzoekers stelden vast dat er medisch-wetenschappelijk gezien bij de bevolking vooral irrationele opwattingen bestaan. Deze irrationele ziekteopvattingen kwamen vaker voor bij lager geschoolden dan bil hoog geschoalden.

Samenvattend kwam uit deze studie van Nuyens e.a. (1978) naar voor dat mensen uit sociaal-cultureel hogere milieus zich karakteriseren door meer kennis over ziekte en gezondheidsvoorzieningen dan mensen uit sociaal-cultureel lagere milieus. De kennis van de sociaal-cultureel hogere milieus sluit het nauwst aan bij de wetenschappelijke normen van het professionele gezondheidszorgsysteem. Voor de sociaal-cultureel lagere milieus geldt het omgekeerde: hun kennis wijkt sterk af van de gangbare rationele normen en waarden van het professionele gezondheidszorgsysteem, wat resulteert in een grotere afstand tussen beide categorieën. De auteurs besluiten hieruit dat er voor deze categorieën dan ook meer sociale drempels zijn naar het gezondheidszorgapparaat, dan voor de sociaalcultureel hogere millieus.

In buitenlandse studies werd de relatie tussen opleiding en kennis van kankerpreventie wel reeds empirisch vastgesteld. Welke zijn nu deze meer specifieke empirische gegevens die er bekend zijn over de relatie tussen opleiding en kennis van kankerpreventie?

In onderzoeken bij een algemene bevoliking werden inzake kankerpreventie uitgesproken kennisverschillen naar opleidingsniveau vastgesteld. In de Verenigde Staten stelden Brown e.a. (1990) op basis van gegevens verzameld in 1987 met de representatieve "National Health Interview Survey" een invloed vast van opleiding op de kennis van preventie inzake colorectaal- en prostaatkanker. Het aantal jaren dat iemand naar school was geweest, correleerde positief met de kennis fin met het gedrag inzake wroegtijdige opsporing van colorectaalkanker en prostaatkanker. Wanneer opleiding werd opgenomen als een dichotome variabele, namelijk het al dan niet hebben behaald van een diploma van "High School", werd de samenhang tussen opleiding en de kennis van preventie inzake colorectaal- en prostaatkanker nog sterker. Ook Polednak (1990) vond in een studie bij twee populaties (in Long Island, NY en in Connecticut) met een relatief hoog risico op colorectaalkanker eenzelfde samenhang tussen opleidingsniveau en kennis van de warschuwingssignalen voor colorectaalkanker, alsook tussen opleidingsniveau en kennis van onkele epiderniologische waarden inzake colorectaalkanker. Het aantal correcte antwoorden op vragen over de waarschuwingssignalen voor en de frequentie van voorkomen van colorectaalkanker hing positief samen met het opleidingsniveau.

Ook Berman en Wandersman (1991) stelden in hun studie over kennis van waarschuwingssignalen voor kanker een significante correlatie $\| r=30\rangle$ vast tussen opleiding en de herkenining van waarschuwingssignalen voor kanker. In een onderzoek over zonnen en huidkankerpreventie vonden Berwick e.a. (1992) een positief verband tussen 
opleidingsniveau en de door de onderzoekers ontwikkelde 'solar knowledge index'. Mensen met veel kennis over" "veilig zonnen" waren meer opgeleid dan mensen met weinig kennis inzake veilig zonnen.

In Canberra (Australië) werd een verband vastgelegd tussen het al dan niet hebben van een diploma van hoger onderwijs en kennis van kanker(preventie), waarbij de kennis werd gemeten met een 10-itemschaal met voornamelijk items over longkanker, borstkanker en darmkanker (Dent en Goulston, 1982: 238-239). In deze studie vonden de onderzoekers evenwel geen significant verband tussen 'de leeftijd waarop de school werd verlaten' en de kennis van kankerpreventie. De gemiddelde kennisscores varieerden zeer weinig voor een grote meerderheid van personen die hun studies stopten tussen 14 en 18 jaar oud. Zij stelden echter well vast dat diegenen die de school verlieten voor hun 14 de jaar een aanzienlijk lagere kennisscores hadden dan de andere respondenten.

In de Verenigde Staten werden ook onder kankerpatiënten verschillen inzake kennis van kanker vastgesteld (Loehrer e.a., 1991: 1669-1670). Naarmate de "formele opleiding" van de patiënten daalde, werden er meer misvattingen geconstateerd over de oorzaken van kanker en over de behandelingswijzen. De misvattingen dat 'blauwe plekken' of aanstotingen porzaak zijn van kanker en dat kanker besmettelijk is, leefden meer onder patiënten met een lage opleiding dan onder patiënten met een hoger opleiding. Bovendien was er bij de laagopgeleiden meer geloof en vertrouwen in alternatieve kankertherapieën dan onder de hoogopgeleiden.

Samenvattend kan worden gesteld dat de verbanden die in al deze empirische studies over de relatie tussen opleiding en kennis van kanker(preventie) worden teruggevonden, steeds gelijklopend zijn. Er wordt vrijwel altijd een lineair verband vastgesteld dat gat in de volgende richting: "hoe hoger de opleiding, hoe groter de kennis van kankerpreventie". Er kan biligevolg best een lineair verband worden geformuleerd voor deze te toetsen hypothese.

Hypothese 1: "Hoe hoger het opleidingsniveau van de respondent, hoe hoger de score op kennis van kankerpreventie."

\subsubsection{Inkomen en kennis van kankerpreventie}

Over de relatie tussen inkomen en kennis van kankerpreventie zijn evenmin empirische gegevens bekend voor Vlaanderen. Inkomen wordt ook in gezondheidsonderzoek in het buitenland - in vergelijking met opleiding - minder vaak opgenomen als indicator voor sociaal-economische status. Toch werd een beperkt aantal surveys teruggevonden waarin dit wel werd gedaan en waarin de relatie tussen inkomen en kennis van kankerpreventie empirisch werd wastgesteld. De meeste van deze studies werden hoger reeds geciteerd. zodat hier enkel wordt ingaan op de relevante resultaten met betrekking tot de samenhang tussen inkomen en kennis van kankerpreventie. Welke zijn nu deze meer specifieke empirische gegevens die er bekend zijn over de relatie tussen inkomen en kennis van kankerpreventie ? 
In onderzoeken bij een algemene bevolking werden er in de Verenigde Staten de volgende resultaten vastgesteld. Brown e.a. (1990) stelden in hun onderzoek op basis van gegevens uit de representatieve 'National Health Interview Survey' een invloed vast van 'gezinsinkomen" op de kennis van preventie inzake colorectaal- en prostaatkanker. Ook. Berman en Wandersman (1991) stelden in hun onderzoek over kennis van waarschuwingssignalen voor kanker een significante correlatie $(r=0.34)$ vast tussen inkomen en de herkenning van waarschuwingssignalen voor kanker..

Ook in Australie vonden Dent en Goulston (1982) in een survey georganiseerd in Canberra een significant verband tussen het inkomen (gemeten als inkomen van het gezinshoofd) en kennis van kankerpreventie. Respondenten uit gezinnen met een hoog inkomen hebben een significant hogere kennisscore dan deze uit gezinnen met een laag inkomen.

Samenvattend kan worden gesteld dat de verbanden die in deze empirische studies over de relatie tussen inkomen en kennis van kankerpreventie worden teruggevonden, steeds gelijklopend zijn. Er wordt vrijwell altijd een lineair verband vastgesteld dat gaat in de volgende richting: "hoe hoger het inkomen, hoe groter de kennis van kankerpreventie"." Er kan bijgevolg voor de te toetsen hypothese ook een lineair verband worden geformuleerd.

Hypothese 2: "Hoe hoger het inkomen van de respondent, hoe hoger de score op kennis van kankerpreventie."

\subsubsection{Beroep en kennis van kankeroreventie}

Over de relatie tussen beroep of beroepsstatus en kennis van kankerpreventie werden evenmin empirische gegevens teruggevonden die representatief zijn voor Vlaanderen. Wel zijn er interessante gegevens bekend over de samenhang tussen beroepsniveau en participatie aan kankerpreventie. De gegevens zijn afkomstig van een onderzoek bij 5053 Vlaamse werknemers ( +45 jaar) van een Belgisch semi-overheidsbedrijf (Deliens en Pilerret, 19961. Het betreft een semi-overheidsbedrijf met zeer veel vestigingen die een heel goede spreiding kennen over geheel Belgie. In het betreffende bedrijf zijn de beroepen ingedeeld in 4 hiërarchisch gerangschikte niveaus, zodat een analyse naar beroepsniveau mogeitik was. Naar aanleiding van een "gratis" kankerpreventiefonderzoek dat werd aangeboden door de wergever en dat kon plaatsgrijpen tijdens de werkuren, werd er een significant verband vastgesteld tussen het beroepsniveau en de participatie aan het kankerpreventief onderzoek. De participatie varieerde van $29 \%$ in niveau 4 llagste beroepsniveaul, $33 \%$ in niveau $3,37 \%$ in niveau 2 tot $40 \%$ in niveau 1 (hoogste bercepsniveau). Het verband tussen beroepsniveau en de (non-lparticipatie aan het kankerpreventief onderzoek was dus duidelijk lineair: hoe hoger het beroepsniveau, hoe hoger de participatie. Uit deze resultaten blijkt dus dat het beroepsniveau, los van het inkomen dat het genereert - het onderzoek was immers gratis -, een invloed heeft op de participatie aan kankerpreventie.

Uit hetzelf de onderzoek van Deliens en Pierret (1996) blijkt verder ook dat er een significant verband bestaat tussen het beroepsniveau en het risicogedrag voor kanker. Er vertonen meer werknemers uit de laagste beroepsniveaus risicogedrag met betrekking tot kanker dan 
uit de hogere beroepsniveaus. Dit werd zowel wastgesteld woor roken als voor overmatig alcoholgebruik. Zo bijvoorbeeld stijgt het percentage dat overmatig alcohol drinkt (meer dan gemiddeld 3 glazen per dag) van $10 \%$ in niveau 1 (hoogste beroepsniveau), naar $18 \%$ in niveau 2, en verder naar $21 \%$ in zowel niveau 3 als niveau 4 (laagste beroepsniveau).

In het buitenland werden geen studies teruggevondien die de relatie tussen beroepsniveau of beroepsstatus en kennis van kankerpreventie empirisch hebben onderzocht. In Australië wordt in één studie wel een vergelijking gemaakt tussen de kennis van kankerprewentie van arbeiders en van bedienden. Dent en Goulston (1982) vonden in hun studie evenwel geen significante kennisverschillen inzake kankerpreventie tussen arbeiders (blue collar workers) en bedienden (white collar workers).

Op basis van het algemeen patroon dat hoger werd beschreven en dat meestal wordt teruggevonden in onderzoek over sociaal-economische status en gezoncheid en op basis van de empirische studies over de relatie tussen opleiding (of inkomen) en kennis van kankerpreventie kan toch ook hier een lineair verband worden verwacht in de volgende richting: "hoe hoger het beroep of de beroepsstatus, hoe groter de kennis van kankerpreventie". Er kan bijgevolg best een lineair verband worden geformuleerd voor de te toetsen hypothese met betrekking tot beroepsstatus en kennis van kankerpreventie.

Hypothese 3: "Hoe hoger de status van het beroep van de respondent, hoe hoger de score op kennis van kankerpreventie."

\subsubsection{Geïntegreerde SES-indicatoren en kennis van kankerpreventie}

Tot nu toe werden hypothesen geformuleerd over de samenhang tussen één bepaalde sociaal-economische determinant en kennis van kakerpreventie. Deze afzonderlijke sociaaleconomische determinanten kunnen ook worden beschouwd als indicatoren van het complexe concept "sociaal-economische status" of SES. SES is een begrip waarmee bepaalde vormen van sociale ongelijkheid in de samenleving worden aangeduid. Deze sociale ongelijkheid verwijst naar (Berting, 1981: 313):

\footnotetext{
zowel de ongelijke verdeling in de samemleving van schaarse en hooggewaardeerdo gaederen, zoals macht, inkomen, vermogen, opleidingskansen, kennis en privileges, die toebehoren of toegeêigend worden door de bezetters van onderscheiden sociale posities:

- als de ongelijke waardering en behandeling van personen en categorieën op grond van hun maatschappelijke positie en hun leefstijl.
}

Het begrip status refereert naar een sociale stratificatie of een sociale ordening van maatschappelijke posities die hiërarchisch geordend kunnen worden van laag naar hoog of wan hoog naar laag. Vaak maakt men in empirisch onderzoek een onderscheid in drie SESklassen, namelijk lage SES, midden SES en hoge SES.

In veel empirisch gezondheidsonderzoek - ondermeer de hierboven besproken onderzoeken richt men zich op één bepaalde afzonderlijke dimensie van sociale ongelijkheid, hetzif omdat 
men deze dirnensie als zodanig van belang acht, hetzij omdat men meent dat een bepaalde dimensie van sociale ongelijkheid een geschikte maat is voor het vaststellen van de sociale ongelijkheid in ziekte en gezondheid. Een voorbeeld van zo'n dimensie is het beroepsprestige (Berting, 1981:314; zie ook Elchardus, 1979). Gesteld wordt dat in onze samenleving het beroep een goede indicator is voor iemands malatschappelijke positie en de ordening wan de beroepen volgens hun maatschappelijke prestige of status zou in deze opvatting een goede maat zijn voor een sociale stratificatie of ordening. Andere belangrijke dimensies van sociale ongelijkheid zijn die naar (politieke) macht, bezit en inkomen, leefstijl of kennis (Berting, 1981: 316-319).

SES is dus een meerdimensioneel begrip dat samenhangt met de mate waarin mensen kunnen beschikken over schaarse goederen, zoals kennis, arbeid en bezit (vergelijk van Berkel-van Schaik en Tax, 1990). Ook kennis van kankerpreventie is een meerdimensioneel begrip dat op allerlei manieren met SES kan samenhangen. In samenhang met de verschillende dimensies van SES werd er hoger impliciet een keuze gemaakt voor drie SESindicatoren, namelijk opleiding, inkomen en beroep. De relaties van deze drie indicatoren onderling, met SES en met de vele aspecten van kanker en kankerpreventie is complex. Aspecten van de verschillende dimensies van sociale ongelijkheid zijn evenwel verwerkt in de indicatoren opleiding, beroep en inkomen. In paragraaf 8.2 zal hierover verder worden uitgewijd.

Toch gaat men in 'empirisch' onderzoek over sociale ongelijkheid en gezondheid vaak voorbij aan deze meerdimensionele problematiek. SES wordt in de meeste studies gemeten aan de hand van éen indicator, ofwel opleidingsniveau, ofwel inkomen, ofwel beroepsniveau. Zelden wordt er in gezondheidsonderzoek gebruik gemaakt van een samengestelde variabele waarin de verschillende SES-indicatoren worden gecombineerd in een hiërarchische SES-schaal. Door de keuze van één indicator riskeert men een grotere conceptuele en analytische bias te creëren (van Berkel-van Schailk en Tax, 1990). Men operationaliseert SES aan de hand van één indicator of dimensie en komt na analyse van de onderzoeksresultaten well tot algemene conclusies over de relatie tussen SES en gezondheld. Om deze vertekeningen te voorkomen zullen in deze studie ook twee samengestelde SES-concepten worden gebruikt om de basishypothese uit dit hoofdstuk te toetsen. De siamengestelde variabele SESa is geconstrueerd op basis van opleiding ến inkomen; de samengestelde variabele SESb op basis van opleiding, inkomen ên beroep.

Teneïnde de hoger vermelde onderzoeksvraag over SES en kennis van kankerpreventie te kunnen onderzoeken, diende dus ook het gecombineerde effect van zowel opleiding, inkomen als beroepsstatus op kennis van kankerpreventie te worden onderzocht. Om dit. te kunnen doen werden de respondenten op basis van verschillende sociaal-economische determinanten van laag naar hoog hiërarchisch geordend naar sociaal-economische status volgens 9 socialie klassen".

Het begrip "sociale klasse" wordt hier gebruikt in zijn statistische betekenis, m.n. statistische aggregaten waarvan de gremzen door de onderzoekers op inductieve wijze worden vastgelegd.

- De invloed van de sociaal-economische factoren - 
Om een mogelijke methodologische vertekening in het onderzoek van het verband tussen sociaal-economische status en kennis van kankerpreventie te onderwangen, worden in dit onderzoek systematisch alle indicatoren van SES gerelateerd aan kennis van kankerpreventie en daarnaast wordt ook het verband met de twee gecombineerde parameters onderzocht.

Over de invloed van deze samengestelde of geïtegreerde SES-indicatoren op kennis van kankerpreventie kunnen de volgende onderzoekshypothesen worden geformuleerd:

Hypothese 4: "Hoe hoger de sociaal-economische status 'SESa' (een ordening op basis van apleiding én inkomenl van de respondent, hoe hoger zijn sicore op kennis van kankerpreventie."

Hypothese 5: "Hoe hoger de sociaal-economische status 'SESb" leen ordening op basis wan opleiding, inkomen én beroepsstatus) van de respondent, hoe hoger ziin score op kennis van kankerpreventie."

\subsection{Overzicht van het onderzoeksmateriaal en de analvseopzet}

Voor de vaststelling van verschillen in kennis van kankerpreventie naar de socialaleconomische determinanten zal worden gebruik gemaakt van de "adequate kennisschalen" (zie hoger hoofdstuk 6).

De sociaal-economische determinanten werden in de enquête uitvoerig bevraagd. Voor de analyses werd gekozen voor volgende kenmerken: opleiding of het hoogst behaalld diploma, het inkomen en het beroepsprestige. Deze kenmerken kunnen ook worden beschouwd als drie verschillende indicatoren van één samengesteld concept, namelijk sociaal-economische status".

Opleiding is eerder een "individuele" of persoonsgebonden indicator die de betrokkene rechtstreeks vorming en kennis verstrekt. Een differentiële opleiding leidt ook tot een differentieel vermogen om (nieuwe) informatie te verwerken en te assimileren of om (nieuwe) vaardigheden te verwerven. Door de opleiding krijgt men toegang tot bepaalde schaarse sociaal-culturele goederen (bv. bepaalde sporten, literatuur, theater, muziek, enz.), waardoor men in de samenleving een bepaalde sociaal-culturele positie verwerft. Dit leidt tot een leefstijl die vergelijkbaar is met deze van mensen in gelijkaardige sociaal culturele

1 Voor deze conceptualisering van thet begrip SES werd gebruik gemaakt van de omschrijving van SES zoals deze door de Nederlandse programmacommissie "Sociaal-economische gezondheidsverschillen" bondig en duidelijk werd samengewat (van der Heijden, 1990: v): "Het begrip sociaaleconomische status is gebaseerd op de gedachte dat kenmerken van sociaal-economische aard een sterke invloed hebben op de positie die leden van de samenleving in de sociale rangorde innemen. De meest gebruikte indicatoren voor SES zijn: beroep, in de zin van uitgeoefende functie, waarbij een indeling plaatsvindt naar 'beroepsprestige"; opleidingsniveau; en de hoogte van het inkomen". 
posities, doch verschillend van mensen met andere (hogere of lagere) sociaal-culturele posities in de maatschappij. Onder leefstijl wordt een bepaalde configuratie van allerlei gedragspreferenties, zoals consumptiestijl, taalgebruik, bepaalde aspiraties, bepaalde interpretaties van het maatschappelijk gebeuren, enz. verstaan. Een hoge opleiding en een bepalalde leefstijl werstrekken direct ook een hoge sociale status aan de persoon, dioch dienen niet noodzakelijk te leiden tot een hoge 'economische' status. Omgekeerd kan iemand met een bescheiden opleiding toch zeer veel geld verdienen en daardoor een hoge economische status verwerven.

De indicator opleiding werd in dit onderzoek geoperationaliseerd door de vraag naar het hoogst behaalde diploma, waarbij een keuze diende te worden gemaakt uit acht antwoordcategorieën (zie ook hoofdstuk 4). Bij de analyse wordt ook gewerkt met een gehercodeerde variabele in drie categorieên (zie de tabellen 8.1 en 8.2 in bijlage 5 ).

Inkomen is een indicator van SES in de mate dat dit inkomen leidt tot een bepaalde maatschappelijke status. Inkomen is een voorwaarde om een bepaalde materiële leefstijl te kunnen ontwikkelen. Omdat het inkomen van mensen vooral een maatschappelijke status verwerft via het bestedingspatroon, hoeft dit inkomen niet individueel verworven te zijn, maar kan het bestedingspatroon ook worden gerealiseerd met het inkomen van anderen, bijwoorbeeld de partner of de ouders. Inkomen kan m.a.w. eerder worden beschouwd als een 'collectieve' indicator. Daarom werd in dit onderzoek het 'gezinsinkomen' als inkomensindicator gebruikt.

De indicator inkomen werd in dit onderzoek geoperationaliseerd door verscheidene inkomensvragen. Omdat mensen over het algemeen terughoudend zijn bij het verstrekken van gegevens over hun inkomen, werd bij het opstellen van de vragen bijzondere aandacht besteed aan deze non-respons problematiek (zie hoofdstuk 4). Voor de operationalisering van dat inkomen werd - gezien inkomen leidt tot een bepaalde SES via de bestedingen gebruik gemaakt van een 'gestandaardiseerd' inkomen gebaseerd op het totale gezinsinkomen gedeeld door het aantal gezinsleden. De gezinsleden werden daarbij gewogen met een factor 1 voor de volwassenen en een factor 0.5 voor de kinderen $(-18$ jaar). Deze variabele 'standaardinkomen' werd ten behoeve van de analyses ook gehercodeerd in respectievelijk 9 en 3 categorieën van ongeveer even grote groepen (zie ook de tabellen 8.1 en 8.2 in bijlage 5 ).

De derde gebruikte indicator voor sociaal-economische status is het beroep. Dit beroep is het belangrijkste raakvlak tussen de private en de publieke sfeer (Elchardus, 1979). Het beroep beinvloedt zowell de dagelijkse ervaring als de waardering die daaraan wordt gehecht. Het bepaalt dan ook in belangrijke mate de kansen op zowel sociaal-culturele als sociaal-economische participatie in de maatschappij. Een beroepsstatus is echter niet alleen persoonsgebonden, maar wordt deels ook verstrekt door de directe omgeving, bijvoorbeeld de partner of de ouders (Osborn en Morris, 1979). Beroep kan dus eveneens worden beschouwd als een 'collectieve' indicator voor SES. Omdat het beroepsprestige ook aan de partmer kansen biedt op zowel socialal-culturele als sociaal-economische participatie in de maatschappij, werd in dit onderzoek ook het beroepsprestige van de partner in rekening gebracht. Een bijkomend voordeel door het beroep te beschouwen op collectief niveau, is 
dat hierdoor economisch niet-actieve respondenten (bv. huisvrouwen) ook een beroepsstatus kan worden toegekend, zodat bij de analyse een belangrijke populatiereductie kan worden vermeden.

De indicator beroep werd in dit onderzoek geoperationaliseerd door een open vraag naar het beroep van de respondent én het beroep van de (eventuele) partner. Omdat beroep op zich enkel te beschouwen is als een nominale classificatie, werd voor de operationalisering van beroep als indicator van sociaal-economische status gebruik gemaakt van de door de bevolking gepercipieerde status van dat beroep of het $\mathrm{zgn}$. beroepsprestige (Elchardus, 1979) ${ }^{1}$. Door het gebruik van de beroepsstatus als indicator van SES kunnen strikt genomen slechts de actieve leden van de samenleving worden geclassificeerd en geordend. Andere mensen zoals werklozen, huisvrouwen en gepensioneerden of andere inactieven werden in dit onderzoek ingedeeld volgens hun laatst uitgeoefende beroep of - indien er geen beroep werd opgegeven - naar het beroep van de partner. Indien de respondent een partner had, werd voor de finale geoperationaliseerde indicator "beroepsprestigle gebrulk gemaakt van de gemiddelde status van het beroepsprestige van de respondent en van zijn/haar partner. Deze variabele 'gemiddelde beroepsstatus" werd ten behoeve van de analyses ook gehercodeerd in respectievelijk 9 en 3 categorieën van ongeveer even grote groepen (zie ook de tabellen 8.1 en 8.2 in bijlage 5 ).

Conceptueel kan dus een dubbel onderscheid worden gemaakt bij de in dit onderzoek gebruikte indicatoren voor SES. Het betreft hier evenwel "graduele" onderscheiden en geen absolute. Enerzijds dragen bepaalde indicatoren eerder bij tot het verwerven van schaarse materiële goederen (economische dimensie) en/of tot het verwerven van schaarse sociaalculturele goederen (culturele dimensie). Anderzijds kan een onderscheid worden gemaakt in de mate dat de indicator eerder individueel, dan wel collectief gegenereerd wordt. Schematisch wordt deze conceptuele uitwerking van sociaal-economische status in dit onderzoek voorgesteld in figuur 8.1 .

Figuur 8.1

Conceptueel kader van de indicatoren van sociaal-economische status.

\begin{tabular}{|c|c|c|c|}
\hline & & \multicolumn{2}{|c|}{ Maatschappelijke participatie: } \\
\hline & & 'economisch' & "cultureel" \\
\hline \multirow[t]{2}{*}{ Niveau: } & 'individueel' & $\begin{array}{c}\text { Beroepsstatus } \\
\text { Inkomen }\end{array}$ & $\begin{array}{c}\text { Beroepsstatus } \\
\text { Opleiding }\end{array}$ \\
\hline & $\begin{array}{l}\text { 'collectief' } \\
\text { (partner, gezin) }\end{array}$ & $\begin{array}{l}\text { Beroepsstatus } \\
\text { linkomen }\end{array}$ & Beroepsstatus \\
\hline
\end{tabular}

1 Zle voor de concrete verwerking van deze gegevens en de keuze van de beroepsprestigeschaal hoofdstuk 4 . 
Op basis van de afzonderlijke sociaal-economische indicatoren zijn ook twee variabelen geconstrueerd die de bevraagde gegevens combineren op twee verschillende wijzen. Bij de analvse zullen de volgende samengestelde SES-Concepten worden gebruikt":

1. SESa ( $=$ opleiding + inkomen):

samengesteld op basis van 'opleiding' en 'inkomen'; de tweede indicator is eerder een indicator van de econamische dimensie van SES, de eerste eerder wan de culturele dimensie van SES izie figuur 8.1).

2. SESb (= opleiding + inkomen + beroepsprestige): samengasteld op basis van 'inkomen", 'opleiding" én 'beroepsstatus'; de eerste indicator is eerder een indicator van de economische dimensie van SES, de tweede eerder van de culturele dimensie van SES en de derde indicator heeft zowel een economische als een culturele dimensie (zie figuur 8.1 ).

Door het gebruik van deze samengestelde SES-variabelen wordt een meer omvattender stratificatie mogelijk van mensen die zowel qua opleiding als qua inkomen (of opleiding, inkomen ên beroepsprestige) in de hoogste klasse zitten tegenover mensen die op alle twee (of drie kenmerken) laag scoren. De sociale klassen worden hierdoor intern homogener en extern heterogener. De non-respons geregistreerd bij de originele variabelen zijn oorzaak van de weergegeven non-respons bij SESa en SESb (zie tabel 8.1).

Net als in het vorige hoofdstuk zullen de onderzoeksresultaten worden gepresenteerd aan de hand van de gemiddelde kennisscores per subpopulatie. Daarbij wardt meestal gebruik gemaakt een SES-indeling in drie ordinale klassen: Lage SES, Midden SES en Hoge SES. Soms zal, bijvoorbeeld om de lineariteit beter na te gaan, de indeling in 9 ordinale klassen worden gebruikt. Elke klasse wordt dan nogmaals ingedeeld in drie subklassen. De gevonden frequenties van alle bij de analyse gebruikte sociaal-economische indicatoren worden weergegeven in tabel 8.1 en tabel 8.2 (zie bijlage 5 ).

Omdat de in dit hoofdstuk geformuleerde hypothesen een lineair verband voorop stellem, kunnen deze worden getoetst door de berekening van een associatiemaat tussen twee variabelen.

Omdat bepaalde SES-indicatoren een ordinaal meetniveau hebben en de meeste van de SESvariabelen niet normaal verdeeld zijn, wordt gekozen voor de associatiemaat Kendall's tau. In het statistisch programma SPSSWIN (SPSS, 1993) worden zowel Kendall's tau als Spearman's rho voorzien in zowel de procedure "crosstabs" als in de procedure "correlate".

Zie ook bijlage $2 \mathrm{~b}$ voor gedetailleerde informatie over de operationalisering van SESa en SESb in dit onderzoek. 
Kendall's tau draagt de voorkeur boven Spearman's tho $\left(r_{s}\right)^{\prime \prime}$ om de volgende redenen:

- Kendall"s tau is zowel toepasbaar op ordinale variabelen met weinig categorieën, als op ordinale variabelen met veel categorieën (de Vaus, 1991);

- Kendall's tau is vrij ongevoelig voor scheve, niet-normale verdelingen (Blalock, 1979):

- ten slotte heeft Kendall's tau een eigen significantietest, zodat bij analyse geen aparte significantieprocedure moet worden verricht (Blalock, 1979; Tacq, 1980).

Tabel 8.1

Frequentieverdeling van de saciaal-economische kenmerken ün drie klassen ${ }^{2}$

\begin{tabular}{|l|c|c|l|c|c|}
\hline & $\begin{array}{c}\text { Absolute } \\
\text { frequentie }\end{array}$ & $\begin{array}{c}\text { Relatieve } \\
\text { frequentie }\end{array}$ & & $\begin{array}{c}\text { Absolute } \\
\text { frequentie }\end{array}$ & $\begin{array}{c}\text { Relatieve } \\
\text { frequentie }\end{array}$ \\
\hline $\begin{array}{l}\text { Opleiding } \\
\text { LO/LSO }\end{array}$ & 680 & 41.7 & $\begin{array}{l}\text { SESa (*) } \\
\text { Laag }\end{array}$ & & \\
HSO & 558 & 34.2 & Midden & 379 & 29.4 \\
HO & 392 & 24.0 & Hoog & 533 & 32.7 \\
Non-respons & 1 & - & Non- & 240 & 14.7 \\
& & & respons & & \\
\hline Inkomen & & & SESb (*) & & \\
Laag & 504 & 30.9 & Laag & 408 & 25.0 \\
Midden & 539 & 33.0 & Midden & 468 & 28.7 \\
Hoog & 348 & 21.3 & Hoog & 452 & 27.7 \\
Non-respons & 240 & 14.7 & Non-respons & 303 & 18.6 \\
\hline Beroepsprestige & & & & & \\
Laag & 512 & 31.4 & & & \\
Midden & 502 & 30.8 & & & \\
Hoog & 510 & 31.3 & & & \\
Non-respons & 107 & 6.6 & & & \\
\hline
\end{tabular}

(*) SESa $=$ opleiding + inkomen

* * SES = opleiding + inkomen + beroepsprestige

1 In het statistisch computerprogramma SPSSWIN (SPSS, 1993) worden oolk de associatiematen Gamma en Somer's D voorzien. Zij kwamen NIET in aanmerking woor analyse omdat zij enkel bij de procedure "crosstabs" worden voorzien, en bovendien enkel berekend worden bij een boperkt aantal kolommen in de kruistabel. Deze procedures worden bil de analyse van de kennisschalen met hun groat aantall waarden begrijpelijkerwijze niet uitgevoerd.

2 Zie bijlage 2b voor de exacte operationalisering van de variabelen SESa en SESb

- De invloed van de socialal-economische factoren 
Voor de berekeningen van deze associatiematen en de bijpassende significantietoets wordt er - in tegenstelling tot de presentatie van de gemiddelden in drie klassen steeds glebruik gemaakt van het ordinale niveau van de variabele in negen klassen. Op die wijze wordt het informatiegehalte van de associatiematen verhoogd en worden de SES-indicatoren met een indeling in eenzelfde aantal klassen zoveel mogelijk vergelijkbaar gehouden qua differentiële ordening.

In paragraaf 8.4 zal bij de analyse ook gebruik worden gemaakt van de elaboratietechniek, zoals deze hoger in hoofdstuk 7 reeds werd beschreven.

Om de invloeden van de sociaal-economische determinanten met deze van de sociodemografische determinanten op kennis van kankerpreventie met elkaar te vergelijken moet men kunnen beschikken over vergelijkbare associatiecoëfficiënten. Daarom werden ook eta-coëfficiënten berekend van de samenthang tussen de sociaaleconomische subpopulaties en kennis van kankerpreventie. Om de opsplitsing van de onderzoekspopulatie zo vergelijkbaar mogelijk te maken, werd daarbij steeds - uiteraard op uitzondering wan geslacht - de onafhankelijke variabele (leeftijd, opleiding, inkomen, beroepsstatus, SESa en SESb) gehercodeerd in drie categorieën.

Om de gezamenlijke invloed van de socio-demografische determinanten en de sociaaleconomische determinanten nader te anderzoeken schiet te elaboratietechniek tekort. De elaboratietechniek laat immers niet toe om voor meer dan 1 a 2 variabelen tegelijk te controleren. Daarom werd voor de analyses in dit hoofdstuk over de verschillende kennisschalen een multiple regressie-analyse uitgevoerd. Met de keuze van deze analysetechniek worden de volgende doelstellingen nagestreefd (vergelijk Tacq, 1992: 112 en de Vaus, $1991: 213-214$ ):

- De informatie van alle socio-demografische en sociaal-economische determinanten wordt gebundeld en (aan de hand van de multiple correlatiecoëfficiënt R) wordt de sterkte van de samenhang tussen de gehele set van sociale determinanten en de kenmis van kankerpreventie kan nagegaan; als die multiple correlatiecoëfficiënt

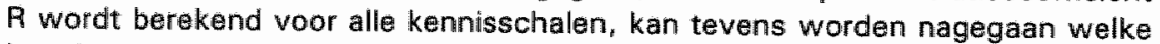
kennisschaal het sterkst correleert met de sociale determinanten. Er kan op die manier achterhaald worden welke kennisschaal het best kan worden voorspeld of geschat aan de hand van de gehele set van sociale determinanten.

- Tevens kan (aan de hand van de regressiecoëfficiënten) worden nagegaan welke de afzonderlijke impact is van elke sociale determinant afzonderlijk op kennis van kankerpreventie. Door vergelijking van de gestandaardiseerde regressiecoëfficiënten (beta-coëfficiënten) kan worden nagegaan welke sociale determinant het meeste impact heeft op kennis van kankerpreventie of het meest bijdraget tot de voorspelling van de kennis van kankerpreventie.

De kennisschalen die in dit analysemodel de afhankelijke variabele vormen werden een kwantificeerbaar meetniveau "toegeschreven" (zie hoger) en benaderen de normale verdeling (zie de grafieken in bijlage 2a). Omdat het 'basisformat' van deze analyses 
een convergente causale structuur heeft en de uitkomstvariabelen een kwantitatief meetniveau hebben, kon deze analysetechniek worden gekozen (Taca, 1992).

Omdat de onafhankelijke variabelen bij multiple regressie interval of dichotoom $(0,1)$ geschaald moeten zijn, konden de sociale determinanten leeftijd, inkomen, beroepsprestige, geslacht en de al of niet aanwezigheid van een partner zondermeer worden opgenomen in het analysemodel. De waarden van de variabelen geslacht en de al of niet aanwezigheid van een partner werden wel gehercodeerd naar 0 en 1 . Het opleidingsniveau en de geintegreerde variabele SESb die ordinaal geschaiald zijn, dienden te worden gehercodeerd tot dummy variabelen. Voor opleidingsniveau werd de hierrarchische ordening in dire klassen (zie tabel 8.1) als volgt gehercodeerd naar 2 klassen: LO/LSO (code O) en HSO en HO (code 1). Voor de geïntegreerde variabele SESb werd gebruik gemaakt van de ordinale variabele in 29 klassen (zie bijlage $2 \mathrm{~b}, \mathrm{p} .7$ ) en nadien als volgt samengevoegd in ongeveer twee gelijke subpopulaties: code $2 \mathrm{t} / \mathrm{m}$ 15 (code O) als lage SES, code $16 \mathrm{t} / \mathrm{m} 30$ (code 1) als hoge SES. Door de constructie van deze dummy variabelen worden deze nominale variabelen kunstmatig op een hoger meetniveau getild (Tacq, 1992: 30). Het nominale meetniveau wordt kwantitatief beschouwd, zodat ze kunnen worden opgenomen in een multiple regressie-analyse.

\subsection{Sociaal-economische ongellikheid en kennis van kankerpreventie}

\subsubsection{De invloed van opleidingsniveau}

Tabel 8.3 presenteert de onderzoeksresultaten van kennis van kankerpreventie naar opleidingsniveau. Er wordt een averzicht gegeven van gemiddelde scores van kennis van kankerpreventie naar drie opleidingsklassen. Tevens worden de rangcorrelatiecoëfficiënten (Kendall's tau) van de samenthang tussen de kennisscores en de oorspronkelijke variabele opleidingsniveau in acht klassen samen met het resultaat van de significantietoets (Significantietest van tau) gepresenteerd.

Uit tabel 8.3 blijkt dat de mensen die ten hoogste lager secundair onderwijs hebben afgewerkt de laagste kennis van kankerpreventie hebben en de mensen met een hoger onderwijsdiploma de hoogste gemiddelde kennisscores hebben. Op populatieniveau werd - met uitzondering voor de kennis van de waarschuwingssignalen - voor elke onderzachte indicator van kennis van kankerpreventie en alle synthesematen een significant verband met het opleidingsniveau vastgesteld. De vastgestelde significante verbanden zijn allemaal lineair en gaan consistent in dezelfde richting : naarmate het opleidingsniveau hoger wordt, stijgt ook de gemiddelde kennisscore.

Worden de afzonderlijke indicatoren van beide kennisdomeinen bekeken dan worden: er toch belangrijke verschillen vastgesteld in de samenhang met opleidingsniveau. Bij de twee indicatoren voor kennis van primaire kankerpreventie zijn de verschillen in beide gevallen statistisch significant. Het verschil in kennisscore is echter iets meer uitgesproken bij de kennis van de risicofactoren dan bij de kennis van het gewenst kankerpreventief gedrag. Bij de twee indicatoren voor kennis van secundaire 
kankerpreventie is het verschil tussen beide indicatoren het meest uitgesproken. Bij de kennis van de waarschuwingssignalen wordt immers geen significant verband vastgesteld, terwijl de grootste verschillen in kennisscores worden vastgesteld bij de kennis van de vroegtijdige opsporingsonderzoeken. Het gemiddeld niveau van kennis van de vroegtijdige opsporingsonderzoeken tussen de laagste en hoogste opleidingscategorie verschilt met meer dan 13 punten op de kennisschaal. De kleinere verschillen tussen de gemiddelde kennïsscores worden ook bevestigd door een vrij lage rangcorrelatiecoefficiënt voor de samenhang tussen opleiding en kennis van het glewenst kankerpreventief gedrag $(r=0.12)$. De grotere verschillen tussen de gemiddelde kennisscores worden bevestigd door hogere rangcorrelatiecoëfficiënten voor de samenhang tussen opleiding en respectievelijk kennis van de risicofactoren $(r=0.17)$ en kennis van de vroegtijdige opsporingsonderzoeken $(r=0.22)$.

Tabel 8.3

Gemiddelde scores van kennis van kankerpreventie, naar opleidingsniveau

\begin{tabular}{|c|c|c|c|c|c|}
\hline Kennisschalen: & $\begin{array}{l}\text { LO/LSO } \\
(n=680)\end{array}$ & $\begin{array}{c}\text { HSO } \\
(n=558)\end{array}$ & $\begin{array}{c}\text { HO } \\
(n=392)\end{array}$ & $\begin{array}{c}\text { Kendall's } \\
\text { Tau }\end{array}$ & $\begin{array}{l}\text { Sign. } \\
\text { toets }\end{array}$ \\
\hline \multicolumn{6}{|c|}{ KENNIS VAN PRIMAIRE KANNERPREVENTIE: } \\
\hline Risicofactoren & 19.64 & 23.68 & 25.95 & 0.17 & $* *$ \\
\hline Gewenst gedrag & 12.64 & 13.56 & 17.96 & 0.12 & $* * *$ \\
\hline \multicolumn{6}{|c|}{ KENINIS VAN SECUNDAIRE KANKERPREVENTIE : } \\
\hline Waarschuwingssignalen & 29.63 & 27.74 & 30.42 & - & n.s. \\
\hline Vroegtijdige opsporing & 25.44 & 30.27 & 38.75 & 0.22 & $* * *$ \\
\hline \multicolumn{6}{|c|}{ SYNTHESE VAN KENNIS VAN KANKERPREVENTIE : } \\
\hline Primaire Kankerprewentie & 16.14 & 18.62 & 21.96 & 0.18 & $* * *$ \\
\hline Secundaire Kankerpreventie & 27.54 & 29.01 & 34.59 & 0.14 & $* * *$ \\
\hline Globale meting & 21.84 & 23.82 & $28: 27$ & 0.18 & $* *$ \\
\hline
\end{tabular}

Noot: de kennisscores lopen van - 100 (zeer inadequate kennis van kankerpreventie) tot +100 (zeer adequate kennis van kankerprewentie)

Uit de synthesematen van kennis van kankerpreventie blijkt dat opleidingsniveau sterker samenhangt met kennis van primaire kankerpreventie $(r=0.18)$, dan met kennis van secundaire kankerpreventie $(r=0.14)$. Deze minder sterke samenhang van opleiding met kennis van secundaire kankerpreventie wordt evenwel veroorzakt door de afwezigheid van een verband tussen opleiding en 'kennis van de waarschuwingssignalen'.

Hieruit kan worden geconcludeerd dat onderzoekshypothese $\gamma$ over het algemeen wordt bevestigd. Er is een pasitieve samenhang tussem opleidingsniveau en kennis van 
kankerpreventie. De samenhang van opleidingsniveau met kennis van kankerpreventie wordt in de eerste plaats veroorzaakt door de samenhang met kennis van primaire kankerpreventie. en pas in de tweede plaats door de samenhang met de kennis van secundaire kankerpreventie.

\subsubsection{De invloed van inkomen}

Uit tabel $8.4^{\prime}$ blijkt dat de mensen uit de laagste inkomensklasse de laagste kennis van kankerpreventie hebben en de mensen uit de hoogste inkomensklasse de hoogste gemiddelde kennisscores helbben. Op populatieniveau werd - met uitzondering van de kennis van de waarschuwingssignalen - voor elke onderzochte indicator van kennis van kankerpreventie en alle synthesematen een significant verband met het opleidingsniveau vastgesteld. De vastgestelde significante verbanden zijn allemaal lineair en gaan consistent in dezelfde richting : naarmate het inkomen hoger is, stijgt ook de gemiddelde kennisscore.

Tabel 8.4

Gemiddelde scores van kennis van kankerpreventie, naar standaardinkomen

\begin{tabular}{|c|c|c|c|c|c|}
\hline Kennisschalen : & $\begin{array}{l}\text { Laag } \\
(n=461)\end{array}$ & $\begin{array}{l}\text { Midden } \\
(n=456)\end{array}$ & $\begin{array}{c}\text { Hoog } \\
(n=474)\end{array}$ & $\begin{array}{c}\text { Kendall's } \\
\text { Tau }\end{array}$ & $\begin{array}{l}\text { Sign. } \\
\text { toets }\end{array}$ \\
\hline \multicolumn{6}{|c|}{ KENNIS VAN PRIMAIRE KANKERPREVENTIE : } \\
\hline Risicofactoren & 20.73 & 22.23 & 24.92 & .10 & $* *$ \\
\hline Gewenst gedrag & 12.87 & 14.22 & 15.92 & .07 & $* * *$ \\
\hline \multicolumn{6}{|c|}{ KENNIS VAN SECUNDAIRE KANKERPREVENTIE : } \\
\hline Waarschuwingssignalen & 28.96 & 29.66 & 29.80 & - & n.s. \\
\hline Vroegtijdige opsporing & 27.05 & 30.17 & 34.37 & .11 & *** \\
\hline \multicolumn{6}{|c|}{ SYNTHESE VAN KENNIS VAN KANKERPREVENTIE: } \\
\hline Primaire Kankerpreventie & 16.80 & 18.22 & 20.42 & .10 & $* *$ \\
\hline Secundaife Kankerpreventie & 28.01 & 29.92 & 32.08 & .07 & $* * *$ \\
\hline Globale meting & 22.40 & 24.07 & 26.25 & .10 & $* * *$ \\
\hline
\end{tabular}

Noot: de kennisscores lopen van - 100 (zeer inadequate kennis van kinkerpreventie) tot +100 (zeer adequate kennis wan kankerpreventie)

Als de afzonderlijke indicatoren van beïde kennisdomeinen worden bekeken, dan worden er beperkte verschillen vastgesteld in de samenhang met opleidingsniveau. Bij de twee

1 In tabel 8.4 worden de onderzoeksresultaten op eenzelfde wijze gepresenteerd als in tabel 8.3 . 
indicatoren voor kennis van primaire kankerpreventie zijn de verschillen in beide gevallen statistisch significant. Het verschil in kennisscore is echter lets meer uitgesproken bij de kennis van de risicofactoren dan bij de kennis van het gewenst kankerpreventief gedrag. respectievelijk 4 en 3 schaalpunten verschil tussen de laagste en hoogste inkomensklasse. Deze kleine verschillen tussen de gemiddelde kennisscores worden ook bevestigd door vrij lage rangcorrelatiecoëfficiênten woor de samenhang tussem opleiding en respectievelijk keninis van de risicofactoren $(r=0.10)$ en kennis van het gewenst kankerpreventief gedrag $(r=0.07)$. Tussen de twee indicatoren voor kennis van secundaire kankerpreventie is er een belangrijker verschil in de samenhang met inkomen. Bij de kennis van de waarschuwingssignalen wordt immers geen significant verband vastgesteld, terwijl er wel een significante samenhang is met de kennis van de vroegtijdige opsporingsonderzoeken. Het gemiddeld niveau van kennis van de vroegtijdige opsporingsonderzoeken tussen de laagste en hoogste opleidingscategorie verschilt met 7 punten op de kennisschaal. Dït lets grotere verschil tussen de gemiddelde kennisscores wordt ook bevestigld door een iets sterkere correlatie $(r=0.11)$.

Uit de synthesematen van kennis van kankerpreventie blijkt dat de kennisverschillen ongeveer even groot zijn bij kennis van primaire kankerpreventie dan bij kennis van secundaire kankerpreventie. Er is echter wel een klein verschil in sterkte van de rangcorrelatiecoëfficiënten, respectievelijk $r=0.07$ voor de samenhang tussen inkomen en kennis van secundaire kankerpreventie en $r=0.10$ voor de samenhang tussen inkomen en kennis van primaire kankerpreventie. Dit wijst op een iets sterkere lineariteit in de samenhang tussen inkomen en kennis van primaire kankerpreventie. Deze minder sterke samenhang van inkomensniveau met kennis van secundaire kankerpreventie wordt evenwel veroorzaakt door een afwezigheid van een verband tussen inkomensniveau en 'kennis van de waarschuwingssignalen'.

Er kan hieruit worden geconcludeerd dat onderzoekshypothese 2 over het algemeen wordt bevestigd. Er is een positieve samenhang tussen inkomensniveau en kennis van kankerpreventie. De samenhang van inkomensniveau met kennis van kankerpreventie wordt echter in de earste plaats veroorzaakt door de samenthang met kennis van primaire kankerpreventie en in de tweede plats door de samenhang met kennis van secundaire kankerpreventie. Globaal genomen komt uit tabel 8.4 eenzelfde patroon naar voor als bii de analyse naar opleidingsniveau (zie tabel 8.3). Alleen zijn de verschillen minder uitgesproken dan bij de analyses near opleidingsniveau en zijn de correlaties ook minder sterk.

\subsubsection{De invloed van beroepsistus}

Uit tabel 8.5 blijkt dat de mensen met een lage beroepsstatus de laagste kennis van kankerpreventie hebben en de mensen met een hoge beroepsstatus de hoogste gemiddelde kennisscores hebben. Op populatieniveau werd voor elke onderzochte indicator van kennis van kankerpreventie en alle synthesematen een significant verband met het beroepsprestige vastgesteld. De significante verbanden zijn allemaal lineair en gaan consistent in dezelfde richting : naarmate het beroepsprestige hoger wordt, stijgt ook de gemiddelde kennisscore. 
Wordt in tabel 8.5 de afzonderlijke indicatoren van beide kennisdomeinen bekeken, dan worden er toch opmerkelijke verschillen vastgesteld in de samenthang met beroepsprestige. Bij de twee indicatoren voor kennis van primaire kankerpreventie zijn de verschilien iets groter bij de kennis van het gewenst kankerpreventief gedrag dan bij de kennis van de risicofactoren. Het verschil in correlatiesterkte is dan ook niet zo groot, respectievelijk $r=0.12$ en $r=0.09$. Bij de twee indicatoren voor kennis van secundaire kankerpreventie zijn de verschillen echter meer uitgesproken. Bij de kennis van de waarschuwingssignalen wordt een zeer zwakke correlatie met beroepsprestige vastgesteld $(r=0.06)$. De samenhang tussen beroepsprestige en kennis van de vroegtijdige opsporingsonderzoeken is relatief sterk $(r=0.20)$. Het gemiddeld niveau van kennis van de vroegtijdige opsporingsonderzoeken tussen de laagste en hoogste beroepsprestigeklasse verschilt met 11.5 punten op de kennisschaal.

\section{Tabel 8.5}

Gemiddelde scores van kennis van kankerpreventie, naar beroepsprestige

\begin{tabular}{|c|c|c|c|c|c|}
\hline Kennisschalen: & $\begin{array}{c}\text { Laag } \\
(n=512)\end{array}$ & $\begin{array}{c}\text { Midden } \\
(n=502)\end{array}$ & $\begin{array}{c}\text { Hoog } \\
(n=510)\end{array}$ & $\begin{array}{c}\text { Kendall's } \\
\text { Tau }\end{array}$ & $\begin{array}{l}\text { Sign. } \\
\text { toets }\end{array}$ \\
\hline \multicolumn{6}{|c|}{ KENNIS VAN PRIMAIRE KANKERPREVENTIE : } \\
\hline Risicofactoren & 20.90 & 21.67 & 24.53 & 0.09 & $* * *$ \\
\hline Gewenst gedrag & 12.02 & 14.55 & 16.46 & 0.12 & *** \\
\hline \multicolumn{6}{|c|}{ KENNIS VAN SECUNDAIRE KANKERPREVENTIE : } \\
\hline Waarschuwingssignalen & 27.99 & 30.09 & 30.74 & 0.06 & $* * *$ \\
\hline Vroegtijdige opsporing & 25.09 & 29.96 & 36.59 & 0.20 & $* * *$ \\
\hline \multicolumn{6}{|c|}{ SYNTHESE VAN KENNIS VAN KANKERPREVENTIE : } \\
\hline Primaire Kankerpreventie & 16.46 & 18.11 & 20.50 & 0.12 & *** \\
\hline Secundaire Kankerpreventie & 26.54 & 30.02 & 33.67 & 0.16 & $* * *$ \\
\hline Globale meting & 21.50 & 24.07 & 27.08 & 0.17 & *** \\
\hline
\end{tabular}

Noot: de kennisscores lopen van -100 (zeer inadequate kennis van kankerpreventie) tot +100 (zeer adequate kennis van kankerpreventie)

Uit de synthesematen van kennis van kankerpreventie blijkt dat de kenniswerschillen meer uitgesproken zijn bij kennis van secundaire kankerpreventie dan bij kennis van primaire kankerpreventie. Deze versichillen tussen de gemiddelde kennisiscores worden ook bevestigd door een verschil in sterkte van de rangcorrelatiecoëfficiënten, respectievelijk $r=0.16$ voor

In tabel 8.5 worden de onderzoeksresultaten op eenzelfde wijze gepresenteerd als in tabel 8.3. 
de samenhang tussen beroepsprestige en kennis van secundaire kankerpreventie en $r=0.12$ voor de samenthang tussen beroepsprestige en kennis van primaire kankerpreventie. Deze sterkere samenhang van beroepsprestige met kennis van secundaire kankerpreventie wordt vooral veroorzaakt door een sterk verband tussen beroepsprestige en "kennis van de vroegtijdige opsporingsonderzoeken' en veel minder door het verband tussen beroepsprestige en 'Kennis van de waarschuwingssignalen'."

Hieruit kan worden geconcludeerd dat onderzoekshypothese 3 wordt bevestigd. Er is een positieve samenhang tussen beroepsprestige en kennis van kankerpreventie. De samenhang ven beroepsprestige met kennis van kankerpreventie wordt in de eerste plaats veroorzaakt door de samenhang met kennis van secundaire kankerpreventie en pas in de tweede plaats door de samenhang met kennis van primaire kankerpreventie.

Uit tabel $8.5 \mathrm{kom}$ niet eenzelfde patroon naar woor als in de tabellen 8.4 en 8.3 . Het verband tussen beroepsprestige en de globale meting van kennis van kankerpreventie is qua sterkte het best vergelijkbaar met dat wat teruggevonden werd bij de samenhang met opleiding (tabel 8.3). Dalartegenover stat dat de relatieve impact van de afzonderlijke kennisdomeinen in deze relatie anders is dan deze bij de relatie tussen kennis van kankerpreventie en respectievelijk opleiding en inkomen. Het beroepsprestige heeft een sterkere samenhang met kennis van secundaire kankerpreventie dan met kennis van primaire kankerpreventie, terwijl dit bij opleiding en inkomen net andersom is.

\subsubsection{De invloed van een geïntegreerde 'Sociaal-economische status'}

Tabel $8.6^{1}$ presenteert de onderzoeksresultaten van kennis van kankerpreventie naar de geintegreerde sociaal-economische status 'SESa' (een stratificatie gebaseerd op opleiding én inkomenj. Hieruit blijkt dat de mensen met een lage SES in alle kennisschalen de laagste kennis van kankerpreventie hebben en de mensen met een hoge SES de hoogste gemiddelde kennisscores hebben. Op populatieniveau wordt voor elke onderzochte indicator van kemnis van kankerpreventie - met uitzondering van de kennis van de waarschuwingssignalen - en alle synthesematen een significant verband met SES vastgesteld. De vastgestelde verbanden zijn allemaal lineair en gaan consistent in dezelfde richting : naarmate de SES hoger wordt, stijgt ook de gemiddelde kennisscore.

Worden de afzonderlijke indicatoren van beide kennisdomeinen bekeken, dan worden er ook hier verschillen vastgesteld in de samenhang met SES. Bij de twee indicatoren voor kennis van primaire kankerpreventie zijn de verschillen in beide gevallen statistisch significant. Het verschil in kennisscore is echter lets meer uitgesproken bij de kennis van de risicofactoren dan bij de kennis van het gewenst kankerpreventief gedrag. Bij de twee indicatoren voor kennis van secundaire kankerpreventie valt op dat er geen significant verband wordt vastgesteld tussen SES en kennis wan de waarschuwingssignalen, en dat de grootste verschillen in kennisscores worden vastgesteld bij de kennis van de vroegtijdige

1 In täbel 8.6 worden de onderzoeksresultaten op eenzelfde wijze gepresenteerd als in tabell 8.3.

- De invloed van de socialleconomische factoren - 
opsporingsonderzoeken. Het gemiddeld niveau van kennis van de vroegtijdilge opsporingsonderzoken tussen de laagste en hoogste SES-klasse verschilt met 10 punten op de kennisschaal. Het kleinere verschil tussen de gemiddelde kennisscores van kennis van het gewenst kankerpreventief gedrag wordt ook bevestigd door een vrij lagle rangcorrelatiecoëfficiënt $(r=0.11)$. De grotere verschillen tussen de gemiddelde kennisscores worden bevestigd door hogere rangcorrelatiecoëfficiënten voor de samenhang tussen SES en respectievelijk de kennis van de risicofactoren $(r=0.15)$ en kennis van de vroegtijdige opsporingsonderzoeken $\{r=0.19)$.

\section{Tabel 8.6}

Gemiddelde scores van kennis van kankerpreventie, naar de geïntegreerde sociaaleconomische status gebaseerd op opleiding én inkomen (SESa)

\begin{tabular}{|c|c|c|c|c|c|}
\hline Kennisschalen : & $\begin{array}{l}\text { Lage SES } \\
\qquad(n=479)\end{array}$ & $\begin{array}{l}\text { Midden } \\
\text { SES } \\
(n=379)\end{array}$ & $\begin{array}{c}\text { Hoge } \\
\text { SES } \\
(\mathrm{m}=533)\end{array}$ & $\begin{array}{c}\text { Kendall"s } \\
\text { Tau }\end{array}$ & $\begin{array}{l}\text { Sign. } \\
\text { toets }\end{array}$ \\
\hline \multicolumn{6}{|c|}{ KENNIS VAN PRIMAIRE KANKERPREVENTUE : } \\
\hline Risicofactoren & 19.84 & 22.33 & 25.40 & 0.15 & *** \\
\hline Gewenst gedrag & 12.53 & 13.46 & 16.62 & 0.11 & *** \\
\hline \multicolumn{6}{|c|}{ KENNIS VAN SECUNDAIRE KANKERPREVENTIE : } \\
\hline Waarschuwingssignalen & 29.62 & 28.73 & 29.88 & . & n.s. \\
\hline Vroegtijdige opsporing & 25.71 & 29.48 & 35.71 & 0.19 & ** : it \\
\hline \multicolumn{6}{|c|}{ SYNTHESE VAN KENNIS VAN KANKERPREVENTIE : } \\
\hline Primaire Kankerpreventie & 16.19 & 17.90 & 21.01 & 0.16 & *** \\
\hline Secundaire Kankerpreventie & 27.66 & 29.11 & 32.80 & 0.13 & *** \\
\hline Globale meting & 21.92 & 23.50 & 26.90 & 0.16 & $*$ \\
\hline
\end{tabular}

Noot: de kennisscores lopen van -100 (zeer inadequate kennis van kankerpreventie) tot +100 (zeer adequate kennis van kankerpreventie)

Uit de synthesematen van kennis van kankerpreventie blijkt dat de kennisverschillen ongeveer even groot zijn bij kennis van primaire kankerpreventie als bij kennis van secundaire kankerpreventie. Wanneer de correlatie wordt berekend op basis van de 9 ordinale SES-klassen, dan is er toch een licht verschil in sterkte van de rangcorrelatiecoëfficiënten, respectievelijk $r=0.13$ voor de samenhang tussen SES en kennis van secundaire kankerpreventie en $r=0.16$ voor de samenhang tussen SES en kennis van primaire kankerpreventie. Deze minder sterke samenhang van SES met kennis: van secundaire kankerpreventie wordt evenwell veroorzaakt door een afwezigheid van een verband tussen SES en 'kennis van de waarschuwingssignalen'. 
Hieruit kan worden geconcludeerd dat de onderzoekshypothese 4 wordt bevestigd. Er is een positieve samenhang tussen SES (SESa) en kennis van kankerpreventie. De samenhang van SES met kennis van kankerpreventie wordt echter in de eerste plaats veroorzaakt door het verband met kennis van primaire kankerpreventie en pas in de tweede plaats door het verband met kennis wan secundaire kankerpreventie.

Tabel $8.7^{1}$ presenteert de onderzoeksresultaten van kennis wan kankerpreventie naar de ged'ntegreerde sociaal-economische status 'SESb' leen stratificatie gebaseerd op opleiding, inkomen en beroepsstatus). In tabel 8.8 (zie bijlage 5) wordt dit - om de lineariteit van het verband beter te kunnen analyseren - nogmaals overgedaan, doch SESb wordt gepresenteerd in 9 ordinale SES-klassen.

\section{Tabel 8.7}

Gemiddelde scorres van kennis van kankerpreventie, naar de gleïntegreerde sociaaleconomische status gebaseerd op opleiding inkomen én beroepsstatus (SESb)

\begin{tabular}{|c|c|c|c|c|c|}
\hline Kennisschalen: & $\begin{array}{l}\text { Lage SES } \\
(n=408)\end{array}$ & $\begin{array}{l}\text { Midden } \\
\text { SES } \\
(n=468)\end{array}$ & $\begin{array}{c}\text { Hoge } \\
\text { SES } \\
(n=452)\end{array}$ & $\begin{array}{c}\text { Kendall's } \\
\text { Tau }\end{array}$ & $\begin{array}{l}\text { Sign. } \\
\text { toets }\end{array}$ \\
\hline \multicolumn{6}{|c|}{ KENNIS VAN PRIMAIRE KANKERPREVENTIE : } \\
\hline Risicofactoren & 19.79 & 22.11 & 25.64 & 0.14 & * * * \\
\hline Gewenst gedrag & 11.69 & 114.21 & 17.03 & 0.13 & $* *$ \\
\hline \multicolumn{6}{|c|}{ KENNIIS VAN SECUNDAIRE KANKERPREVENTIE : } \\
\hline Waarschuwingssignalen & 27.51 & 31.06 & 30.32 & 0.05 & * * \\
\hline Vroegtijdige opsporing & 24.41 & 29.86 & 37.46 & 0.23 & $* * *$ \\
\hline \multicolumn{6}{|c|}{ SYNTHESE VAN KENNIS VAN KANKERPREVENTIE : } \\
\hline Primaire Kankerpreventie & 5.74 & 18.16 & 21.34 & 0.16 & ** \\
\hline Secundaire Kankerpreventie & 25.96 & 30.46 & 33.89 & 0.17 & $*$ \\
\hline Globale meting & 20.85 & 24.31 & 27.62 & 0.19 & $*$ \\
\hline
\end{tabular}

Noot: de kennisscores lopen van - 100 (zeer inadequate kennis van kankerpreventie) tot +100 (zeer adequate kennis van kankerpreventie)

Uit tabel 8.7 blijkt dat de mensen met een lage SES in alle kennisschalen de laagste kennis van kankerpreventie hebben en de mensen met een hoge SES de hoogste gemiddelde kennisscores hebben. Op populatieniveau wordt voor elke onderzochte indicator van kennis. Van kankerpreventie en voor alle synthesematen een verband met SES vastgesteld. De

1. In tabel 8.7 worden de onderzoeksresultaten op eenzelfde wijze gepresenteerd als in tabel 8.3 .

- De invloed van de sociaal-economische factoren - 
vastgestelde verbanden zijn - op éen uitzondering na - allemaal ineair en gaan consistent in dezelfde richting : naarmate de SES hoger wordt, stilgt ook de gemiddelde kennisscore. Alle verbandem zijn statistisch significant. Alleen is de samenhang tussen SES en kennis van de waarschuwingssignalen eerder curvilineair van vorm: de kennis is het laagst in de lage SES-klassen en het hoogst in de midden SES-klasse. Tabel 8.7 bevestigt in het algemeen het beeld dat reeds uit tabel 8.6 naar voor kwam. Alleen is nu het verband tussen SES on de kennis van de waarschuwingssignalen statistisch significant - doch zeer zwak - en wijzigde ook de vorm van dit verband. Verder zijn de kennisverschillen over het algemeen groter en worden deze grotere verschillen ook bevestigd door iets sterkere correlatiecoëfficiënten.

Uit de synthesematen van kennis van kankerpreventie blikt dat de kennisverschillen ongeveer even groot zijn voor de drie synthesematen van kennis van kankerpreventie. Deze gelijke verschillen tussen de gemiddelde kennisscores worden ook bevestigd door ongeveer dezelfde rangcorrelatiecoëfficiënten, respectievelijk $r=0.17$ voor de samenhang tussen SES en kennis van secundaire kankerpreventie en $r=0.16$ voor de samenhang tussen SES en kennis van primaire kankerpreventie. De samenhang tussen SES en de globale meting is evenwel het sterkst met $r=0.19$.

Er kan hieruit worden geconcludeerd dat ook onderzoekshypothese 5 wordt bevestigd. Er is een positieve samenhang tussen SES (SESb) en kennis van kankerpreventie. De samenhang tussen SES en kennis van kankerpreventie wordt evenwichtig veroorzaakt door zowell het verband met kennis van primaire kankerpreventie als door het verband met kennis van secundaire kankerpreventie. Beide dimensies van kennis van kankerpreventie hebben samengevoegd everwel een nog sterkere samenhang met SES.

Om de lineariteit van de samenhang tussen SES en kennis van kankerpreventie meer in detaill te onderzoeken, wordt in tabel 8.8 (zie bijlage 5) en figuur 8.2 een overzicht gepresenteerd van de gemiddelde scores van kennis van kankerpreventie naar dezelfde geïntegreerde sociaal-economische status "SESb' (een stratificatie gebaseerd op opleiding, inkomen én beroepsstatus), doch in negen hiërarchische SES-klassen.

In tabel 8.8 (zie bijlage 5) en figuur 8.2 valt op dat de kennis stijgt naarmate de SESi stijgt. Enkel bij de eerste stijgende trap in SES (van LL-SES naar ML-SES) is er een vrij consistent patroon van daling van kennis van kankerpreventie. Voor deze merkwaardige vaststelling werd geen theoretische verklaring gevonden. Wel zou deze lichte daling kunnen worden verklaard door het interactie-effect met geslacht. In vorig hoofdstuk werd immers gezien dat vrouwen meer kennis van kankerpreventie hebben dan mannen. Bij de controle van de geslachtsverdeling bleek dat er in deze kleine subpopulaties geen evenredigheid bleek tussen mannen en vrouwen. In LL-SES waren immers $55.2 \%$ vrouwen en in ML-SES slechts $47.3 \%$ vrouwen. Vermoed kan worden dat het relatief groot aantal vrouwen - met hun meerkennis - oorzaak zijn van de hogere gemiddelde kennisscore in de laagste SES-klasse t.o.v. de op één na laagste SES-klasse. Bij controle van geslacht bleek dat de gemiddelde kennisscore tussen deze eerste twee SES-kllassen consistent stijgt bij de mannen, doch dat dit (nog steeds) niet het geval is bij de vrouwen. Voor deze laatste vaststelling kon geen verdere verklaring worden bedacht, laat staan getoetst. In paragraaf 8.4 wordt verder 
ingegaan op de elaboratie van de samenhang tussen SES en kennis van kankerpreventie naar geslacht, alsook naar leeftijd.

Figuur 8.2

Kennis van kankerpreventie, naar de geîntegreerde sociaal-economische status gebaseerd op opleiding, inkamen én beroepsstatus (SESb)

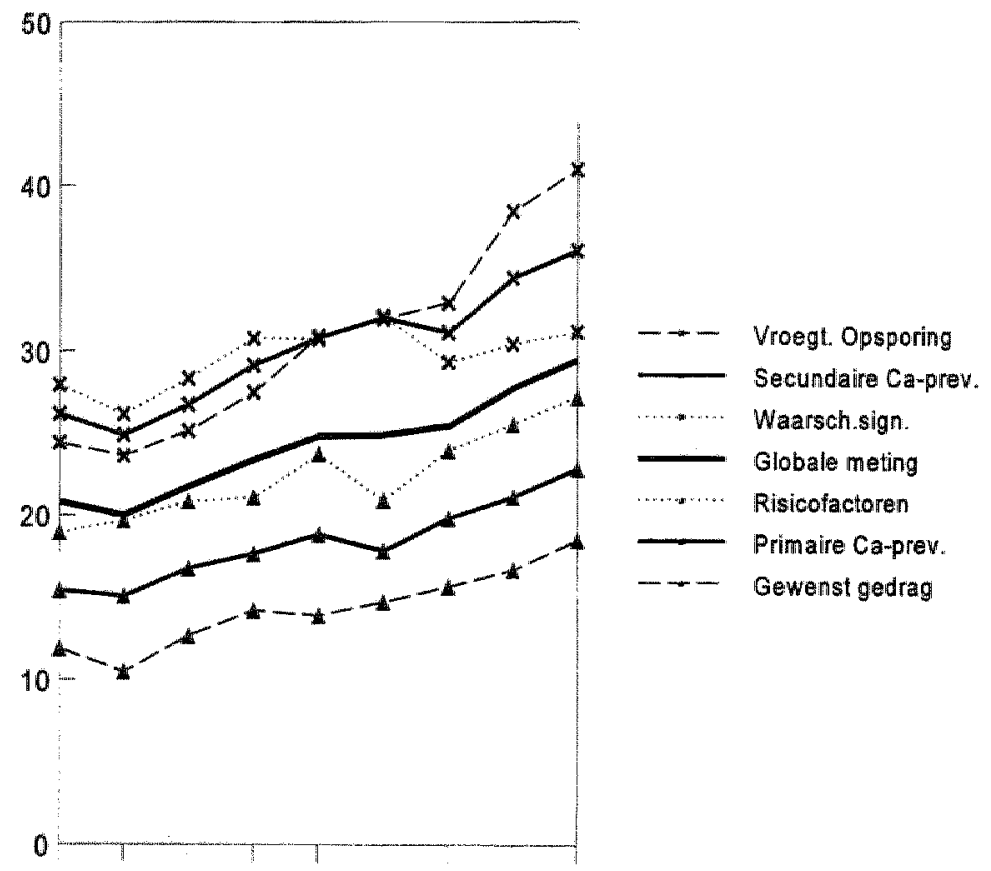

LL ML HL LM MM HM LH MH HH

Moten: de kennisscores lopen van - 100 (zeer inadequate kennis) tot +100 (zer adequate kennis)

$\begin{array}{llllll}\text { LL } & \text { lage-lage SES } & \text { LM } & \text { lage-midden SES } & \text { LH } & \text { lage-hoge SES } \\ \text { ML middan-lage SES } & \text { MM } & \text { midden-midden SES } & \text { MH } & \text { midden-hoge SES } \\ \text { HL hoge-lage SES } & \text { HM } & \text { hoge-midden SES } & \text { HH } & \text { hoge-hoge SES }\end{array}$

- De invloed van de saciaal-economische factoren- 
Over het algemeen kan worden gesteld dat de lineariteit in de onderzoekshypothese over SES en kennis van kankerpreventie kan worden bevestigd. De kennis van de waarsichuwingssignalen is de enige kennisschaal die in belangrijke mate een afwijking van deze lineaire vorm vertoont. De drie subpopulaties met een hoge SES hebben - tegen de verwachting in - een lagere kennis van de waarschuwingssignalen woor kanker dan de respondenten uit de hoge-midden klasse.

\subsubsection{De invloeden van de sociaal-economische indicatoren op kennis van kankerpreventie onderling vergeleken}

Welke socio-economische determinant of welke indicator van SES hangt nu het meest samen met kennis van kankerpreventie ? Deze vraag is hoger nog niet aan de orde geweest. Het is een vraag naar de relatieve sterkte van de verbanden die in dit hoofdstuk werden besproken. Door de vergelijking van de hoger reeds gepresenteerde correlatiecoefficiënten (Kendall"s Tau) kan een antwoord op deze vraag worden gegeven. Tabel 8.9 geeft een overzicht van deze correlaties. Om de interpretatie van deze tabel te vergemakkelijken werd telkens de sterkste correlatie met de overeenstemmende kennismeting met een grijze achtergrond afgedrukt.

Tabell 8.9

Correlaties (Kendall's Tau coëfficiënten) van kennis van kankerpreventie met de sociaal-economische determinanten

\begin{tabular}{|c|c|c|c|c|c|}
\hline Kennisschalen : & $\begin{array}{l}\text { Opleiding } \\
\text { in } 8 \text { klassen } \\
\text { (n }=1630)\end{array}$ & $\begin{array}{c}\text { Standaard- } \\
\text { inkomen in } \\
9 \text { klassen } \\
(n-1391)\end{array}$ & $\begin{array}{l}\text { Gemiddelde } \\
\text { Beroepsstatus } \\
\text { in } 9 \text { klassen } \\
(n=1524)\end{array}$ & $\begin{array}{l}\text { SESa in } \\
9 \text { klassen } \\
(n=1391)\end{array}$ & $\begin{array}{l}\text { SESb in } \\
9 \text { klassen } \\
(n=1328)\end{array}$ \\
\hline Pisicofactoren & 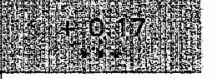 & +0.10 & +0.09 & +0.15 & +0.14 \\
\hline Gewenst gedrag & +0.12 & +0.07 & +0.12 & +0.11 & $44^{4}$ \\
\hline $\begin{array}{l}\text { Waarschuwings- } \\
\text { signallen }\end{array}$ & n.s. & n.s. & 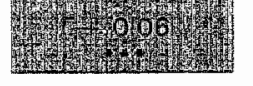 & $\mathrm{n} . \mathrm{s}$ & +0.05 \\
\hline $\begin{array}{l}\text { Vroegtijdige } \\
\text { opsporing }\end{array}$ & +0.22 & +0.11 & +0.20 & +0.19 & 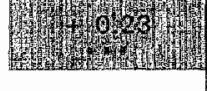 \\
\hline $\begin{array}{l}\text { Primaire } \\
\text { kankerpireventie }\end{array}$ & Mry & +0.10 & +0.12 & +0.16 & +0.16 \\
\hline $\begin{array}{l}\text { Secundaire } \\
\text { kankerpreventie }\end{array}$ & +0.14 & +0.07 & +0.16 & $\begin{array}{c}0.13 \\
-+\end{array}$ & 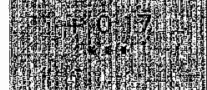 \\
\hline Globale meting & +0.18 & $\begin{array}{r}+0.10 \\
*\end{array}$ & $\begin{array}{r}0.17 \\
+\quad \\
\end{array}$ & $\begin{array}{r}0.16 \\
- \\
\end{array}$ & 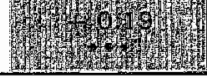 \\
\hline
\end{tabular}

Noten: * $0.001<p \leq 0.01$ en * $* 0.001$ 
Op é̉n kemnisschaal na, vertonen alle kennisschalen een significante samenhang met de onderzochte indicatoren van SES. Het significantieniveau is daarbij steeds hoog I $s$ $0.001)$. Enkel de kennis van de waarschuwingssignalen vormt een uitzondering. Deze kennisschaal correleert enkel (en zeer zwak) met de beroepsstatus en met de geïntegreerde SES-indicator 'SESb'. Alle vastgestelde correlaties zijn bovendien positief, zodat nogmaals wordt bevestigd dat de hoofdhypothese van dit hoofdstuk mag worden aanvaard.

Wordt er gekeken naar de sterkte van de correlaties, dan walt direct op dat bij vier van de zeven kennismetingen de geintegreerde sociaal-economische status op basis van zowel opleiding., inkomen als beroepsstatus (SESb) de meest sterke samenhang vertoont met kennis van kankerpreventie. Blijkbaar heeft de sociale positie op basis wan de drie SESindicatoren samen een sterkere samenhang met kennis van kankerpreventie dan de sociale positie die enkel wordt geïndiceerd door eén van de indicatoren.

Vervolgens heeft het opleidingsniveau de op eén na sterkste samenhang met kennis van kankerpreventie. Het opleidingsniveau heeft de sterkste samenhang met kennis van de risicofactoren en met de synthesemaat van kenmis van primaire kankerpreventie. Verder vertoont opleidingsniveau de op één na sterkste samenhang met kennis van het gewenst kankerpreventief gedrag, met de kennis van de vroegtijdige opsporingsonderzoeken en met de globale kennismeting van kankerpreventie.

De beroepsstatus heeft de sterkste - zij het een zeer bescheiden - samenhang met kennis van de waarschuwingssignalen. Het standaardinkamen hangt ontegensprekelijk het minst sterk samen met kennis van kankerpreventie. De correlatiecoëfficiënten worden nooit groter dan $r=0.11$.

Worden de vier afzonderlijke indicatoren van kennis van kankerpreventie vergeleken, dan valt op dat 'kennis van de vroegtijdige opsporingsonderzoeken' met alle sociaal-economische determinanten de sterkste correlaties vertoont. Kennis van de risicofactoren van kanker vertoont de tweedle sterkste samenhang met de sociaal-economische determinanten en kennis van het gewenst kankerpreventief gedrag komt op de derde plaats. De kennis van de waarschuwingssignalen hangt vrijwel niet samen met de saciaal-economische determinanten.

Wordt er gekeken naar de drie synthesematen van kennis van kankerpreventie, dan valt op dat in het algemeen de globale meting het sterkst samenhangt met SES. Het valt ook op datt het opleidingsniveau sterker samenhangt met kennis van primaire kankerpreventie dan de geïntegreerde sociaal-economische status "SESb". Met kennis van secundaire kankerpreventie correleert deze laatste SES-indicator well het sterkst $(r=0.17)$.

Samenvattend kan op basis van de gegevens uit tabel 8.9 worden geconcludeerd dat de geintegreerde sociaal-economische status op basis van zowel opleiding, inkomen als beroepsstatus (SESb) in het algemeen de sterkste samenhang vertoont met kennis van kankerpreventie. Deze vaststelling wijst erop dat de afzonderlijke indicatoren van SES - in de betekenis van 'criteriumvaliditeit" (zie hoger hoofdstuk 6) - minder valide zijn om SES te indiceren dan de samengestelde SES-indicator op basis van zowel opleiding, inkomen als 
beroepsstatus. Als enkelvoudige indicator van SES lijkt het opleidingsniveau in vergelijking met inkomen en beroepsstatus de meest valide indicator van SES te zijn.

De hier gepresenteerde resultaten houden evenwel nog geen rekening met eventuele interactie-effecten met de socio-demografische determinanten in thun beïnvloeding van kennis van kankerpreventie.

\subsection{Elaboratie van de samenhang van kennis van kankerpreventie met de geintegreerde sociaal-economische status, naar leeftijd en geslacht}

Er kan met andere woorden de vraag worden gesteld of de gevonden samenhang tussen SES en kennis van kankerpreventie vrij stabiel is of m.a.w. dit verband zich repliceert bij specifieke subpopulaties. Zo dit het geval is, dan is het verband robulst. De robuustheid van dit verband kan in deze paragraaf worden nagaan door te controleren op respectievelijk geslacht en leeftijdsklasse. Ten einde de overzichtelijkheid te behouden, wordt de elaboratie van het verband tussen SES en kennis van kankerpreventie beperkt tot de analyse van de synthesematen van kennis van kankerpreventie. Tevens zall voor deze elaboratie-analyse slechts één indicator van SES worden opnemen, namelijk de SES-indicator met de sterkste correlatie met kennis van kankerpreventie (de geïntegreerde sociaal-economische status op basis van zowel opleiding, inkomen als beroepsstatus, SESb).

Worden de gevonden verbanden teruggevonden bij de twee geslachten of is de invloed van SES op kennis van kankerpreventie bij mannen anders dan bij vrouwen? Om deze onderzoeksvraag te kunnen toetsen, werd de onderzoekspopulatie opgedeeld naar gesllacht. De resultaten van de gemiddelde kennisscores worden samen met de rangcorrelatiecoëfficiënten (Kendall's Tau) vermeld in tabel 8.10. Ter vergelijking worden ook de gemiddelde scores en de zero-order correlaties gepresenteerd die hoger in tabel 8.7 reeds werden gepresenteerd. Alle correlatiecoëfficiënten werden berekend op basis van de samenhang tussen de kennisschalen en die SES-variabele 'SESb' in 9 ordinale klassen.

Een eerste belangrijke vaststelling in tabel 8.10 is dat alle significante zero-order verbanden warden gerepliceerd met eenzelfde significantieniveau ( $\leq \leq .001)$. Ook de richting en de vorm van de verbanden worden gerepliceerd. Alle positieve lineaire verbanden blijven positief en lineair. Voor alle kennismetingen geldt dus zowel voor mannen als voor vrouwen dat de kennis van kankerpreventie stijgt naarmate hun sociaal-economische status stijgt (zie ook figuur 8.3 ).

Worden echter de (replicatie van de) sterkte van de relaties bekeken, dam vallen er tussen vrouwer en mannen in de (veranderingen van de) correlatiecoëfficiërnten opmerkelijke verschillen op. Bij mannen wordt het verband sterker en bij vrouwen wordt het zwakker. Het verschil in sterkte is het meest uitgesproken bij de globale kennismeting. 
Tabel 8.10

Gemiddelde scores van kennis van kankerpreventie, naar SES gebaseerd op opleiding, inkomen én beroepsstatus (SESb); controlerend voor geslacht

\begin{tabular}{|c|c|c|c|c|c|}
\hline Kennisschalen: & $\begin{array}{c}\text { Lage } \\
\text { SES } \\
(n=408)\end{array}$ & $\begin{array}{c}\text { Midden } \\
\text { SES } \\
(n=468)\end{array}$ & $\begin{array}{c}\text { Hoge } \\
\text { SES } \\
(n=452)\end{array}$ & $\begin{array}{l}\text { Kendall's } \\
\text { Tau }\end{array}$ & $\begin{array}{l}\text { Sign. } \\
\text { Tau }\end{array}$ \\
\hline \multicolumn{6}{|c|}{ SYNTHESE VAN KENNIS VAN KANKERPREVENTIE : } \\
\hline $\begin{array}{l}\text { Primaire Kankerpreventie } \\
\text { Totale populatie }\end{array}$ & 15.74 & 18.16 & 21.34 & .16 & $* * *$ \\
\hline $\begin{array}{l}\text { Man } \\
\text { Virouw }\end{array}$ & $\begin{array}{l}13.99 \\
17.33\end{array}$ & $\begin{array}{l}17.25 \\
19.22\end{array}$ & $\begin{array}{l}20.53 \\
22.15\end{array}$ & $\begin{array}{l}.19 \\
.13\end{array}$ & $* * *$ \\
\hline $\begin{array}{l}\text { Secundaire Kankerprev. } \\
\text { Totale populatie }\end{array}$ & 25.96 & 30.46 & 33.84 & .17 & $* * *$ \\
\hline $\begin{array}{l}\text { Man } \\
\text { Vrouw }\end{array}$ & $\begin{array}{l}22.08 \\
29.48\end{array}$ & $\begin{array}{l}28.47 \\
32.77\end{array}$ & $\begin{array}{l}32.99 \\
34.80\end{array}$ & .22 & $* *$ \\
\hline $\begin{array}{l}\text { Globale meting } \\
\text { Totale populatie }\end{array}$ & 20.85 & 24.31 & 27.62 & .19 & *** \\
\hline $\begin{array}{l}\text { Man } \\
\text { Vrouw }\end{array}$ & $\begin{array}{l}18.03 \\
23.40\end{array}$ & $\begin{array}{l}22.86 \\
26.00\end{array}$ & $\begin{array}{l}26.76 \\
28.47\end{array}$ & $\begin{array}{l}.24 \\
.15\end{array}$ & $* * *$ \\
\hline
\end{tabular}

Noot : de kennisscores lopen van - 100 (zeer inadequate kennis van kankerpreventie) tot +100 (zeer adequate kennis van kankerpreventie)

SES heeft bij de mannen de zwakste samenhang met kennis wan primaire kankerpreventie $(r=0.19)$ en de sterkste samenhang met de globale kennismeting $(r=0.24)$. Bij de vrouwen hangt SES in gelijke mate (maar vrij zwak) samen met kennis wan primaire kankerpreventie als met kennis van secundaire kankerpreventie (beide $r=0.13$ ). Bij de globale kennismeting is de samenhang een klein beetje sterker $(r=0.15)$.

Deze specificatie van de samenhang tussen SES en kennis van kankerpreventie wordt nog het best gedllustreend door figuur 8.3. De volle lijnen in figuur 8.3 geven de resultaten weer op populatieniveau; de stippellijnen deze van de vrouwen en de onderbroken lijnen deze van de mannen. Het valt op dat alle vastgestelde verbanden lineair zijn en dat de onderbroken lijnen van de mannen steiler oplopen dan de stippellijnen van de vrouwen. Uit figuur 8.3 blijkt ook dat er interactie-effecten zijn van de variabele geslacht op de samenhang tussen SES en kennis van kankerpreventie. Deze interactie-effecten zijn evenwel sterker bij kennis van secundaire kankerpreventie dan bij kennis van primaire kankerpreventie. In figuur 8.3 valt immers op dat de lijnen van kennis van primaire kankerpreventie duidelijk minder parrallel lopen dan de lijnen van kennis van secundaire kankerpreventie.

Samenvattend mag worden geconcludeerd dat de invloed van sociaal-economische status. op kennis van kankerpreventie vrij robuust is. Er kan worden gesteld dat er sociale 
ongelijkheid bestaat in kennis van kankerpreventie en det er een beperkte interactie is met de invloed van geslacht op kennis van kankerpreventie. De positieve lineaire verbanden worden weliswaar gerepliceerd bil zowel de mannen als de vrouwen, doch de sterkte van de samenhang tussen SES en kennis van kankerpreventie is verschillend naar gesilacht. De samenhang is sterker bij de mannen dan bij de vrouwen.

Worden de gevonden verbanden teruggevonden in alle leeftijdsklassen of is de invloed van SES op kennis van kankerpreventie verschillend naar leeftijdsklasse? Zijn er m.a.w. interactie-effecten van leeftijd op de relatie tussen SES en kennis van kankerpreventie. Orn deze analyse te verrichten, werd de onderzoekspopulatie opgedeeld in drie leeftijdsklassen, respectievelijk 18-34 jaar, 35-50 jaar en 51-70 jaar.

Figuur 8.3

Kennis van kankerpreventie, naar de geïntegreerde sociaal-economische status (gebaseerd op opleiding, inkomen én beroepsstatus) en geslacht

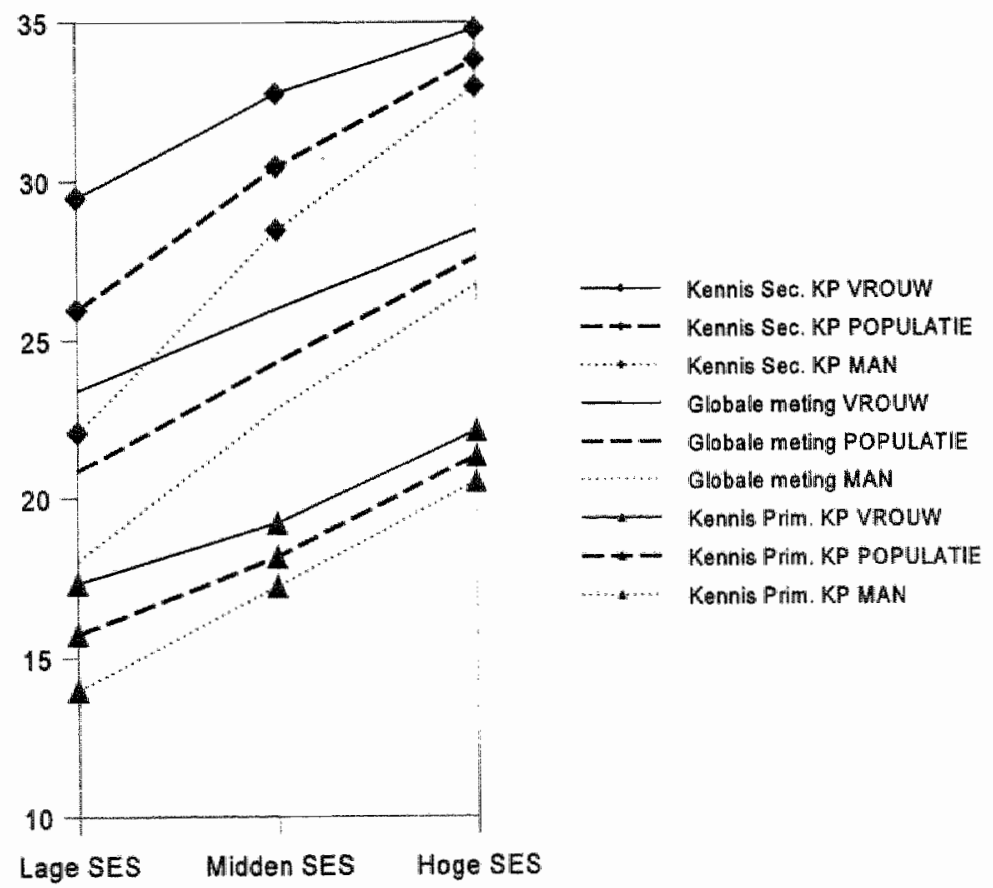

Noot: de kennisscores lopen van -100 ( inadequate kennis) tot +100 (adequate kennis) - De invloed van de sociaal-economische factoren - 
Een eerste belangrijke vaststelling in tabel $8.11^{\mathrm{D}}$ is dat alle significante zero-order verbanden worden gerepliceerd met eenzelfde significantieniveau ( $p \leq 0.001)$. Enkel in de leeftijdsklasse 51-70 jaar daalt het significantieniveau wan de samenhang tussen SES en kennis van primaire kankerpreventie in beperkte mate. Ook de richting en de vorm van de verbanden worden gerepliceerd. Alle positieve lineaire verbanden blijven positief en lineair. Voor alle kennismetingen geldt dus voor de drie afzonderinke leeftijdsklassen dat de kennis van kankerpreventie stijgt naarmate de sociaal-economische status stijgt lzie ook figuur 8.4).

Tabel 8.11

Gemidldelde scores van kennis van kankerpreventie, naar sociaal-economische status gebaseerd op opleiding, inkomen én beroepsstatus (SESb); controlerend voor leeftijd

\begin{tabular}{|c|c|c|c|c|c|}
\hline Kennisschalen: & $\begin{array}{c}\text { Lage } \\
\text { SES } \\
(n=408)\end{array}$ & $\begin{array}{l}\text { Midden } \\
\text { SES } \\
(n=468)\end{array}$ & $\begin{array}{c}\text { Hoge } \\
\text { SES } \\
(n=452)\end{array}$ & $\begin{array}{c}\text { Kendalls's } \\
\text { Tau }\end{array}$ & $\begin{array}{c}\text { Sign. } \\
\text { Tau }\end{array}$ \\
\hline \multicolumn{6}{|c|}{ SYNTHESE VAN KENNIS VAN KANKERPREVENTIE : } \\
\hline \multicolumn{6}{|l|}{ Primaire Kankerpreventie } \\
\hline Totalle populatie & 15.74 & 18.16 & 21.34 & .16 & $* *$ \\
\hline 18-34 jaar & 17.23 & 18.68 & 23.38 & .18 & $*$ \\
\hline 35-50 jaar & 16.55 & 18.88 & 21.01 & .12 & $* * *$ \\
\hline $51-70$ jaar & 14.44 & 16.83 & 17.97 & .10 & ** \\
\hline \multicolumn{6}{|l|}{ Secundaire Kankerprev. } \\
\hline Totale populatie & 25.96 & 30.46 & 33.89 & .17 & $*$ \\
\hline 18-34 jaar & 22.94 & 27.76 & 32.75 & .20 & $* *$ \\
\hline 35-50 jaar & 25.98 & 31.28 & 35.48 & .21 & $* *$ \\
\hline $51-70$ jaar & 27.49 & 32.41 & 32.92 & .11 & $* *$ \\
\hline \multicolumn{6}{|l|}{ Globale meting } \\
\hline Totale populatie & 20.85 & 24.31 & 27.62 & .19 & *** \\
\hline 18-34 jaar & 20.08 & 23.22 & 28.06 & .22 & $* *$ \\
\hline $35-50$ jaar & 21.26 & 25.08 & 28.24 & .21 & $* *$ \\
\hline $51-70$ jaar & 20.97 & 24.62 & 25.44 & .12 & *** \\
\hline
\end{tabular}

Noot: - de kennisscores lopen van - 100 (zeer inadequate kennis van kankerpreventie) tot +100 (zeer adequate kennis wan kankerpreventie)

Wordt echter gekeken naar de (replicatie van de) sterkte van de relaties, dan zij er een aantal verschillen tussen de leeftijdsklassen in de (veranderingen van del correlatiecoefficiënten. SES heeft in de leeftijosklasse 51-70 jaar duidelijk de zwakste samenhang

1 In tabel 8.11 worden de onderzoeksresultaten op eenzelfdie wijze gepresenteerd als in tabel 8.10. 
met kennis van kankerpreventie. Dit geldt voor alle synthesematen, namelijk zowel voor kennis van primaire kankerpreventie, kennis van secundaire kankerpreventie als de globale kennismeting (respectievelijk $r=0.10, r=0.11$ en $r=0.12$ ). Deze correlaties zijn duidelijk ook minder sterk dan deze op populatieniveau. In de leeftijdsklasse 35-50 jaar is de samenhang tussen SES en kennis van kankerpreventie duidelijk zwakker bij de kennis van de primaire kankerpreventie dan bij de kennis van secundaire kankerpreventie. Worden de correlaties in de leeftijdsklasse 35.50 jaar met deze op populatieniveau vergeleken, dan wordt de samenhang versterkt bij de globale meting en de kennis van secundaire kankerpreventie (respectievelijk $r=0.21$ vs $r=0.19$, en $r=0.21$ vs $r=0.17$ ), maar verzwakt de samenhang bij kennis van primaire kankerpreventie $(r=0.12$ vs $\mathrm{r}=0.161$. In de leeftijdsklasse 18-34 jaar wordt de sterkste samenhang vastgesteld, namelijk een correlatie van $r=0.22$ tussen SES en de globale kennismeting. Worden de correllaties in de leeftijdsklasse 18-34 jaar met deze op populatieniveau vergleleken, dan worden de samenhangen systematisch versterkt bij zowel kennis van primaire kankerpreventie, kennis van secundaire kankerpreventie als de globale kennismeting (respectievelijk $r=0.18$ vs $r=0.16 ; r=0.20$ vs $r=0.17 ; r=0.22$ vs $r=0.19$ ). In de jongste leeftijdsklasse wordt dus duidelijk het sterkste verband tussen SES en kennis van kankerpreventile vastgesteld en in de oudste leeftijdsklasse het zwakste. Het verschil in sterkte is thet meest uitgesproken bij de globale kennismeting.

Figuur 8.4

Kennis van kankerpreventie, naar sociaal-economische status Igebaseerd op opleiding, inkomen én beroepsstatus) en leeftijdsklasse

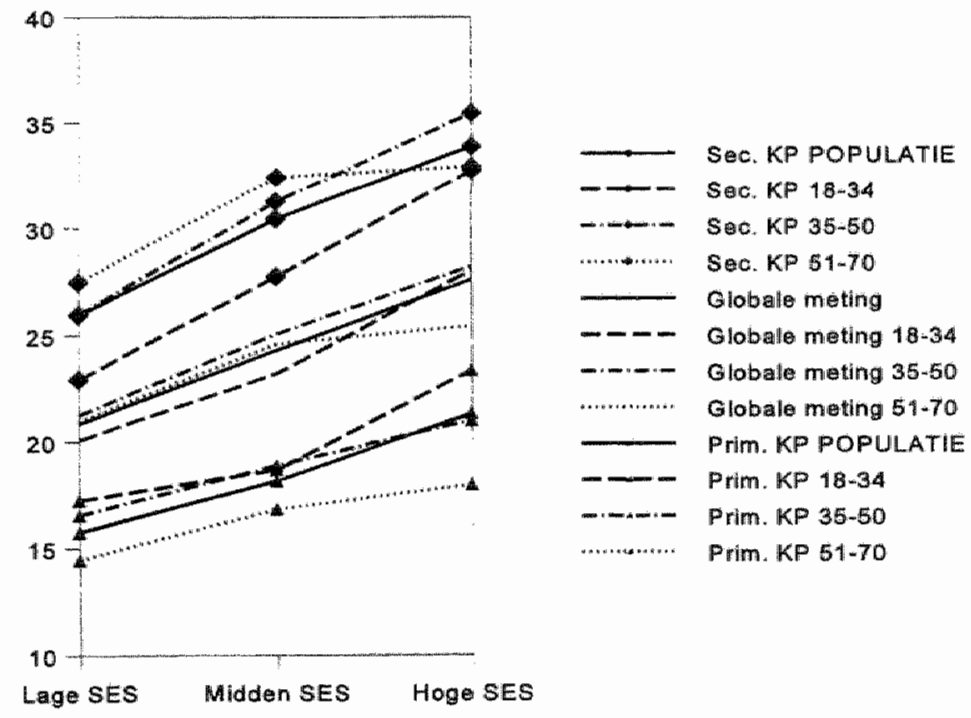

- De invloed van de socilaal-economische factoren - 
Deze specificatie van de samenhang tussen SES en kennis van kankerpreventie wordt het best geillustreerd door figuur 8.4. De dikste volle lijnem in figuur 8.4 geven de resultaten weer op populatieniveau; de stippellinen deze van de leeftijdsklasse 5 1-70 jaar, de met een stip onderbroken lijnen deze van de leeftijdsklasse 35-50 jaar, en de gewone onderbroken lijnen deze van de leeftijdsklasse 18-34 jaar. Alle vastgestelde verbanden zijn lineair en de gewone onderbroken lijnen van de jongste leeftijdsklasse lopen duidelijk steller op dan deze van de twee andere leeftijdsklassen. Uit figuur 8.4 blijkt ook dat er interactie-effecten zijn van leeftijd op de samenhang tussen SES en kennis van kankerpreventie. De lijnen van de verschillende leeftijdscategorieën lopen niet geheel parrallel. Deze interactie-effecten zijn ongeveer even sterk bij de kennis van primaire kankerpreventie als bij kennis van secundaire kankerpreventile.

Samenvattend kan worden geconcludeerd dat de invloed van sociaal-economische status op kennis van kankerpreventie wrij robuust is. Er bestaat sociale ongelijkheid in kennis van kankerpreventie, malar de sterkte van de samenhang tussen SES en kennis van kankerpreventie is verschillend naar leeftijdsklasse. De samenhang is duidelijk sterker bij jongeren dan bij ouderen.

\subsection{De invloeden van socip-demografische en sociaal-economische determinanten onderling vergeleken en de gezamenliike invlaed van deze determinanten op kennis var kankerpreventie}

Tot nu toe is er een hele reeks analyses glemaakt van bivariate verbanden van sociale determinanten met kennis van kankerpreventie. Er werden aok reeds onderlinge vergelijkingen gemaakt van de sterkte van deze verbanden. In dit hoofdstuk werd er aandacht besteed aan de sociaal-economische determinanten en in het vorige hoofdstuk aan de socio-demografische determinanten. Beide sets van determinanten werden echter nog niet onderling vergeleken in hun samenhang met kennis van kankerpreventie. Teneinde dit te kunnen realiseren worden in deze paragraaf de resultaten gepresenteerd van twee verschillende analyses. Er wordt gestart met de vergelijking van de zero-order correlaties. Een dergelijke analyse houdt evenwel geen rekening met de bestaande interactie-effecten, zoals die hoger reeds werden vastgesteld. Om de analyses te vervolledigen en deze interactie-effecten onder controle te houden, zal ook een multiple regressie-analyse worden uitgevoerd.

In tabel 8.12 worden de Eta-coëfficiënten gepresenteerd van de samenhang tussen keninis: van kankerpreventie en alle in dit onderzoek geanalyseende sociale determinanten in maximum drie ordinale klassen]. Hoger werd bij de bivariate analyses al uitwoerig ingegaan op de richting en vorm van de rellaties. Hier wordt de analyse beperkt tot het vergelijken van de sterkte van de verbanden. 


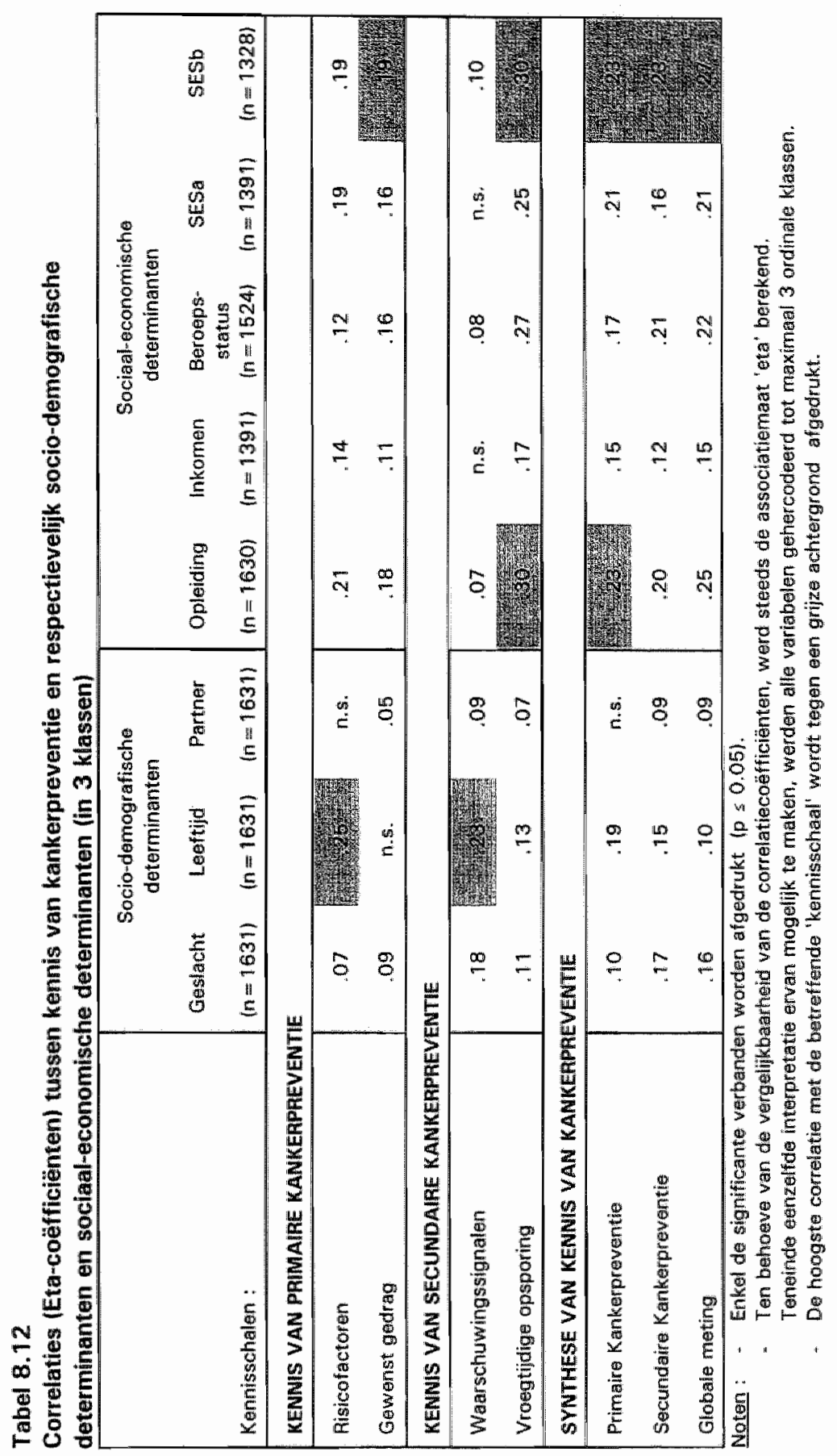


In tabel 8.12 worden eerst de drie synthesematen van kennis van kankerpreventie vergeleken. Hierbij valt op dat - op éen uitzondering na - alle sociale determinanten significant correleren met de drie synthesematen. Enkel het al dan niet hebben van een partner heeft geen invloed op de kennis van primaire kankerpreventie. De sociodemografische determinanten correleren opvallend minder sterk met de kennis van kankerpreventie dan de sociaal-economische determinanten. Zeer opvallend is verder dat de geintegreerde indicator van SES op basis van opleiding, inkomen én beroepsstatus (SESb) in vergelijking met alle andere sociale determinanten het sterkst correleert met de drie synthesematen van kennis van kankerpreventie. Het al dan niet hebben van een partnei correleert in vergelijking met alle andere sociale determinanten duidelijk het minst met de drie synthesematen van kennis van kankerpreventie.

Worden de afzonderlike indicatoren van kennis van kankerpreventie bekeken, dan valt op dat SESb, opleiding en leeftijd de sterkste correlaties vertonen met kemnis van kankerpreventie. De kennis van de risicofactoren correleert het sterkst met leeftijd $(r=0.25)$ en met opleiding $(r=0.21)$. De kennis van het gewenst kankerpreventief gedrag correleert het sterkst met SESb $(r=0.19)$ en met opleiding $(r=0.18)$. De kennis van de waarschuwingssignalen correleert het sterkst met leeftijd $(r=0.23)$ en met geslacht $(r=0.18)$ en de kennis van de vroegtijdige opsporingsonderzoeken correleert het sterkst met opleiding $(r=0.30)$, SESb $(r=0.30)$ en met beroepsistatus $(r=0.27)$.

Zoals hoger reeds werd aangehaald, houdt de onderlinge vergelijking van de sociale determinanten in hun samenhang met kennis van kankerpreventie geen rekening met de bestaande interactie-effecten. Vooraleer de impact van de afzonderlijke sociale determinanten onderling te vergelijken met controle van de overige sociale determinanten, worden in tabel $\mathbf{8 . 1 3}$ de multiple correlatiecoëfficiënten gepresenteerd die de samenhang weergeven tussen de waargenomen kennis van kankerpreventie en de geschatte kennis van kankerpreventie op basis van alle gebundelde informatie uit de oorspronkelijk verzamelde gegevens over de sociale determinanten, met name geslacht, leeftijd, partner, opleiding, inkomen en beroepsstatus. Op die manier kan worden bepaald welke kennismeting het best kan worden voorspeld of geschat op basis van de gehele set van sociale determinanten.

Uit tabel 8.13 blijkt dat alle multiple correlatiecoëfficiënten statistisch significant zijn (ps 0.0011 . De multiple correlatiecoëfficiënten variëren van minimum $\mathbb{R}=.22$ tot maximum $R=.34$. Enkel kennis van de waarschuwingssignalen en kennis van het gewenst kankerpreventief gedrag hebben een multiple correlatiecoëfficiënt kleüner dan $R=.30$. Vooral de kennis wan het gewenst kankerpreventief gedrag kan op basis van de onderzochte sociale determinanten in vergelijking met de andere kennismetingen minder goed worden voorspeld. De kennis van de vroegtijdige opsporingsonderzoeken kan op basis van de onderzochte sociale determinanten het best worden voorspeld $(R=.34)$. De multiple correlatiecoëfficiênten van de synthesematen van kennis van kankerpreventie zijn allemaal groter of gelijk aan .30 
Tabel 8.13

Multiple correlatiecoëfficiënten van de kennis van kankerpreventie, naar geslacht, leeftijd, partner, opleiding, inkomen en beroepsstatus

\begin{tabular}{|c|c|c|c|c|}
\hline Kennisschalen: & ค & $\mathbb{R}^{2}$ & $F$ & SigntF \\
\hline \multicolumn{5}{|c|}{ KENNIIS VAN PRIMAIRE KANKERPREVENTIE : } \\
\hline Risicofactoren & .30 & .09 & 21.49 & $\cdots$ \\
\hline Gewenst gedrag & .22 & .05 & 11.26 & $* *$ \\
\hline \multicolumn{5}{|c|}{ KENNIS VAN SECUNDAIRE KANIKERPREVENTIE : } \\
\hline Waarschuwingssignalen & .28 & .08 & 19.13 & $* *$ \\
\hline Vroegtijdige opsporing & .34 & 12 & 29.72 & $\cdots$ \\
\hline \multicolumn{5}{|c|}{ SYNTHESE VAN KENNIS VAN KANKERPREVENTIE : } \\
\hline Primaire Kankerpreventie & .30 & .09 & 21.56 & $* \cdots$ \\
\hline Secundaire Kankerpreventie & .31 & .10 & 23.77 & $* *$ \\
\hline Globale meting & .33 & .11 & 26,62 & $* * *$ \\
\hline
\end{tabular}

Het aandeel verklaarde variantie van de kennisschalen varieert van $5 \%$ bij de kennis van het gewenst gedrag tot $12 \%$ bij de kennis van de vroegtijdige opsporingsonderzoeken. Van de synthesematen van kennis van kankerpreventie wordt ongeveer $10 \%$ variantie verkllaard door de sociale determinanten. Dit is over het algemeen betrekkelijk weinig, doch vergelijkbaar met het resultaat van een Australische studie, waarin de sociale determinanten $9 \%$ van de variantie van de kennis van kankerpreventie bepaalden (Dent en Goulston, 1982: 239). Een dergelijke laag percentage verklaarde variantie hoeft overigens niet te verbazen, er bestaat conceptueel immers geen direct causaal verband tussen de sociale determinanten en de kennisvariabelen, zoals dit wel het geval is tussen bijvoorbeeld enerzijds attitude, sociale invloed, eigen effectiviteit en anderzijds de gedragsintentie (Ajzen en Fishbein, 1980; de Vries, 1993). Het gaat hier om de samenhang tussen kennis van kankerpreventie en sociale determinanten die hoger werden omschreven als "predisponerende" factoren (zie hoofdstuk 1). Tussen beide hoeft bijgevolg geen directe causale relatie te bestaan.

In tabel 8.13 werden de regressiecoëfficiënten en de beta-coëfficiënten van de uitgevoerde regressie-analyses bewust niet gepresenteerd. Voor de doelstelling die bij analyse van tabel 8.13 werd nagastreefd, was dit ook niet nodig. Bovendien werden ook geen regressiecoëfficiënten gepresenterd, omdat de vergelijking van de impact van de afzonderlijke onafhankelijke variabelen in het analysemodel enkel zinwol kan gebeuren bij 'afwezigheid van multicollineariteit', m.a.w. wanneer de onafhankelijke variabelen niet' met

- De invloed van de sociaal-economische factoren - 
mekaar correleren (Tacq, 1992: 39-41). De eis van afwezigheid van multicollineariteit geldt in principe voor alle dependente analysetechnieken die de convergente structuur in zich dragen. Dus ook bil de multiple regressie-analyse is deze eis zeer belangrijk. Immers pas bij afwezigheid van samenhang tussen de onafhankelijke variabelen betekent het dat deze determinanten 'los van elkaar' en zonder overlap (geen multicollineariteit) een verklaring bieden voor de uitkomstvariabele, c.q. kennis van kankerpreventie.

Tabell 8.14

Correlatiematrix van de sociale determinanten van kennis van kankerpreventie

\begin{tabular}{|c|c|c|c|c|c|c|c|}
\hline & GESLACHT & WEELT. & EARINER & SESB & OELEID. & INKOMEN & $\begin{array}{r}\text { BEROERS- } \\
\text { STATUS }\end{array}$ \\
\hline GESLACET & $\begin{array}{l}1,0000 \\
(1631) \\
P=000\end{array}$ & & & & & & \\
\hline 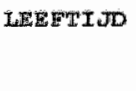 & $\begin{array}{l}.0093 \\
(1631) \\
E=.707\end{array}$ & $\begin{array}{l}1,0000 \\
(1.631) \\
2=000\end{array}$ & & & & & \\
\hline PARTMER & $\begin{array}{r}-.0325 \\
(1631) \\
0=.190\end{array}$ & $\begin{array}{l}-0960 \\
(1631) \\
E=000\end{array}$ & $\begin{array}{l}1,0000 \\
\{1631\} \\
\$=000\end{array}$ & & & & \\
\hline SESp & $\begin{array}{r}.0206 \\
(1328) \\
P=.454\end{array}$ & $\begin{array}{r}-1789 \\
(1328) \\
=000\end{array}$ & $\begin{array}{l}-.0654 \\
(1328) \\
2=.017\end{array}$ & $\begin{array}{l}1,0000 \\
(1328) \\
E=000\end{array}$ & & & \\
\hline OPLELD. & $\begin{array}{l}.0071 \\
(1630) \\
E=.776\end{array}$ & $\begin{array}{l}-4094 \\
(1,630) \\
E \approx, 000\end{array}$ & $\begin{array}{r}-.0077 \\
-630) \\
(163.755\end{array}$ & $\begin{array}{l}5319 \\
(1328) \\
\mathrm{E}=, 000\end{array}$ & $\begin{array}{l}1,0000 \\
(1630) \\
\mathrm{P} .000\end{array}$ & -- & -- \\
\hline INROMEM & $\begin{array}{l}-0599 \\
(1391) \\
2=.009\end{array}$ & $\begin{array}{l}-1406 \\
(1391) \\
P=, 000\end{array}$ & $\begin{array}{r}.0896 \\
(1391) \\
P=.001\end{array}$ & $\begin{array}{r}4681 \\
(1328) \\
\mathrm{P}=, 000\end{array}$ & $\begin{array}{l}.2940 \\
(1391) \\
P=000\end{array}$ & $\begin{array}{l}1,0000 \\
11391, \\
P=, 000\end{array}$ & \\
\hline $\begin{array}{l}\text { BAROEPS- } \\
\text { STATUS }\end{array}$ & $\begin{array}{r}.0031 \\
(1524) \\
\text { p. } 904\end{array}$ & $\begin{array}{l}-.0719 \\
1.524) \\
\mathrm{P}=, 005\end{array}$ & $\begin{array}{l}-1269 \\
15241 \\
2=000\end{array}$ & $\begin{array}{l}, 7398 \\
(1328) \\
P=, 000\end{array}$ & $\begin{array}{l}.4264 \\
(1523) \\
P-000\end{array}$ & $\begin{array}{r}3079 \\
13287 \\
2=.000\end{array}$ & $\begin{array}{l}1,0000 \\
(1524) \\
P=, 000\end{array}$ \\
\hline
\end{tabular}

Uit de correlatiematrix in tabel 8.14 blijkt dat met de groep van sociale determinanten van kennis van kankerpreventie [de mogelijke onafhankelikke variabelen in het regressiemodel] in de gepresenteerde regressie-analyses helemal niet is voldaan aan de eis van afwezigheid van multicollineariteit. Vooral rechtsonderaan in tabel 8.14 vallen de lcursief afgedrukt) vrij sterke onderlinge correlaties op tussen opleiding, inkomen, beroepsstatus en SESb. Deze sterke correlaties waren echter ook te verwachten. Het gaat immers om

Tacq (1992: 39) noemt de techniek van multiple regressie-analyse "berucht" omdat bij het nalezen van honderden voorbeeiden van multiple regressie-analyse de aanwezigheid van multicollineariteit eerder regel dan uitzondering bleek. Hij vond in de literatuur slechts éen woorbeeld waarin de afwezigheid van multicollineariteit op inhoudelijke gronden konden worden beschouwd en waarbij de empirische correlaties tussen de variabelen ook ongeveer nul waren.

- De invloed van de sociaal-economische factoren . 
verschillende indicatoren van eenzelfde concept, namelijk sociaal-economische status. Ook vanuit theoretische overwegingen kon dus een (sterke) samenhang worden verwacht tussen deze variabelen. Om dit probleem van multicollineariteit op te lossen, moet bijgevolg een keuze worden gemaakt voor eén indicator van SES. Er werd gekozen voor de SES-indicator met de sterkste correlatie met kennis van kankerpreventie (zie tabel 8.12 of tabel 8.9), namelijk de geïntegreerde SES-indicator op basis van opleiding, inkomen én beroepsstatus (SESb).

Worden in deze correlatiematrix in tabel 8.14 enkel de geselecteerde sociale determinanten bekeken (cfr. de geglevens boven de onderbroken lijn), dan valt op dat er van de zes correlaties slechts drie significant zijn en dat de significante verbanden bovendien vrij zwak zijin. Omdat de variabelen geslacht, leeftijd, partner en SESb slechts vrij zwak onderling gecorreleerd zijn ên omdat door het opnemen van deze set van sociale determinanten toch de belangrijkste doelstelling van deze paragraaf kan worden onderzocht - we zijn immers vooral geinteresseerd in het relatieve belang van SES t.o.v. de socio-demografische determinanten - werden nieuwe regressie-analyses uitgevoerd enkel op basis van deze vier onafhankelijke variabelen. Door enkel deze vier sociale determinanten als "predictoren' in de regressie-analyse op te nemen, kan in belangrijke mate tegemoet worden gekomen aan de eis van "afwezigheid van multicollineariteit" en kan toch de tweede belangrijkste doelstelling van de multivariate analyseworden ge realiseerd, namelijk het nagaan van thet relatieve belang van de afzonderlijke sociale determinanten (zie hoger). De resultaten van deze "herschikte' multiple regressie-analyses worden gepresenteerd in tabel 8.15 (zie bijlage 5). In tabel 8.15 zijn alle gepresenteerde waarden van $\mathbb{R}^{2}$ statistisch significant ( $p$ $<0.0011$.

Wat opvalt in de gepresenteerde regressies in tabel 8.15 (zie bijlage 5) is dat de regressiecoëfficiënten van de variabele partner in geen van de zeven vergelijkingen statistisch significant van nul verschillen en dat in alle zeven vergelijkingen de regressiecoëfficiënten van SES en van geslacht wel statistisch significant zijn. De regressiecoëfficiënten van leeftijd zijn slechts in vier van de zeven vergelijkingen statistisch significant. Er valt ook op dat de richting van alle regressiecoëfficiënten bijna altijd dezelfde is als deze die kan worden verwacht op basis van de resultaten van de bivariate analyses. De regressiecoëfficiënten voor eenzelfde sociale determinant gaan bij de zeven kennisschalen consistent in dezelfde richting. Enkel bij leeftijd is de richting van de regressiecoëfficiënten niet consistent. Dit kan worden verklaard doordat leeftijd niet met alle kennisschalen eenzelfde lineaire relatie heeft (zie hoofdstuk 7). Bij de kennisschalen die een (quasi) lineaire relatie hebben met leeftijd - namelijk kennis van risicofactoren, kennis van gewenst gedrag, kennis van de waarschuwingssignalien en kennis van primaire kankerpreventie - bevestigt de richting van de regressiecoëfficiënten steeds het resultaat van de bivariate analyses (zie tabel 8.4 in hoofdstuk 7). Voor de overige drie schalen die met leeftijd eerder een curvilineaire relatie vertonen, was de richting ook moeilijker voorspelbaar.

De gestandaardiseerde regressiecoëfficiënten of Beta-gewichten geven het best de relatieve sterkte van de sociale determinanten van kennis van kankerpreventie weer. Bij de kennis van de risicofactoren heeft leeftijd $(\beta=-.22)$ ontegensprekelijk de beste 
predictieve kracht en is de bijdrage van SES $(\beta=.10)$ en geslacht $(\beta=.07)$ ongeveer even graot. Bij de kennis van het gewenst kankerpreventief gedrag heeft $S E S \mid B=.16 \|$ de beste predictieve kracht, gevolgd door geslacht $(\beta=.10)$. Bij de kennis van de waarschuwingssignalen van kaniker heeft leeftijd $\| \beta=.21)$ de beste predictieve kracht, gevolgd door geslacht $(\beta=.16)$ en SES $(\beta=.12)$. Bii de kennis van de vroegtijdige opsporingsonderzoeken voor kanker heeft SES $(\beta=.30)$ de beste predictieve kiracht, op afstand gevolgd door geslacht $(\beta=.09)$.

Uit al deze regressievergelijkingen blijkt dat SES veruit de belangrijkste predictor is van kennis van kankerpreventie. Leeftjji komt als tweede belangrijkste predictor van kennis van kankerpreventie naar voor. Wanneer de synthesematen samen worden bekeken, heeft SES de grootste predictieve kracht in vijf van de zeven regressievergelijkingen. In drie van de zeven regressievergelijkingen heeft leeftijd de grootste predictieve kracht. Belangrijk om vast te stellen, is ook dat SES voor alle drie de synthesematen van kennis van kankerpreventie de grootste predictieve kracht heeft. Voor de kennis van primaire kankerpreventie heeft leeftijd $(\beta=-.16)$ evenwel een even grote predictiekracht als SES $\{\beta=.16)$. Voor de kennis van secundaire kankerpreventie heeft SES $(\beta=.25)$ duidelijk meer predictiekracht dan geslacht $(\beta=.15)$ en meer dan dubbel zo veel predictiekracht als leeftijd $(\beta=.09)$. Wordt tenslotte gekeken naar de globale meting van kennis van kankerpreventie, dan heeft SES $(\beta=.24)$ veruit die belangrijkste predictiekracht, gevolgd door geslacht $(\beta=.15)$.

Geslacht is naast SES de enige variabele die een significante bijdrage levert tot de predictie van alle kennisschalen. Deze bijdrage is evenwel eerder bescheiden, vooral dan voor de kennisschalen met betrekking tot primaire kankerpreventie. Leeftijd levert een substantielere bijdrage tot de predictie van de kennisschalen. Opvallend daarbij is dat leeftijd weil een predictor is van kennis van primaire kankerpreventie en van kennis van secundaire kankerpreventie, doch niet van de globale meting van kennis van kankerpreventie. De verklaring hiervoor ligt verscholen in de verschillende richtingen van de effecten van leeftijd op de afzonderlijke indicatoren van kennis van kankerpreventie en in de vorm van de verbanden. Naarmate de leeftijd stijgt, verhoogt de kennis van de waarschuwingssignalen $(\beta=+0.21)$, maar verlaagt de kennis van de risicofactoren $(\beta=$ $-0.22)$. Beide tegengestelde effecten heffen mekaar blijkbaar op bij de gllobale meting. Leeftijd heeft bovendien met de globale kennisschaal een sterk curvilineair verband, zodat dit verband evenmin in een regressie-analyse wordt opgespoord. Uit het feit dat leeftijd hier geen significante predictiekracht heeft, mag niet worden geconcludeerd dat leeftijd niet belangrijk zou zijn. Door gebruik te maken van de kennisschalen van de afzonderlijke dimensies van kennis van kankerpreventie, kan trouwens worden afgeleid dat leeftijd wel degelijk predictieve kracht heeft.

Samenvattend kan worden gesteld dat van de onderzochte sociale determinanten van kennis van kankerpreventie de sociaal-economische status veruit de grootste impact heeft op kennis van kankerpreventie. Verder hebben respectievelijk leeftijd en geslacht een additieve impact op kennis van kankerpreventie. De af- of aanwezigheid van een partner blijkt geen additieve impact te hebben op kennis van kankerpreventie. 


\subsection{Samenvatting en discussie}

In zeer veel studies is de relatie aangetoond tussen sociaal-economische status en gezondheid (Mackenbach, 1991 en 1993). Hoewel in veel studies ook een samenhang werd aangetoond tussen sociaal-economische status en respectievelijk kanker en deeiname aan kankerpreventie, wordt er in onderzoek relatief weinig aandacht besteed aan de factoren die bijdragen tot deze sociale ongelijkheid. Eên van de mogelijke factoren is een differentiële spreiding van kennis van kankerpreventie. Deze kennis is éen van de cognitieve "bouwstenen' am het gedrag van mensen te helpen veranderen of te bestendigen. In dit hoofdstuk stond de samenhang tussen SES en kennis van kankerpreventie centraal. Hangt m.a.w. de kennis van kankerpreventie van mensen samen met hun sociaal-economische status in de samenleving? Of kan in Vlaanderen worden gesproken van een ongelijke verdeling van de kennis van kankerpreventie naar sociaaleconomische positie in de samenleving?

Deze onderzoeksvragen kunnen zondermeer positief worden beantwoord. In de verbanden tussen kennis van kankerpreventie en de verschillende sociaal-economische determinanten die in dit onderzoek werden opgenomen, werd een consistent patroon gevonden. Lage sociale klassen hebben steeds de laagste kennis en de hoge sociale klassen steeds de hoogste kennis van kankerpreventie. De hogere saciale klassen weten significant meer dan de lagere sociale klassen over risicofactoren, over het gewenst kankerpreventief gedrag, over de waarschuwingssignalen voor kanker en over de vroegtijdige opsporingsonderzoeken. In onderhavig onderzoek is m.a.w. een ongelijke sociale spreiding van de kennis van kankerpreventie bij de Vlaamse bevolking aangetoond. Bij wijze van samenvatting worden de onderzoekshypothesen en de onderzoeksresultaten systematisch overlopen en worden er vervolgens een aantal kanttekeningen gemaakt.

- ad onderzaekshypothese 1 -

De eerste onderzoekshypothese betrof de relatie tussen opleidingsniveau en kennisi van kankerpreventie, waarbij werd voorspeld dat naarmate het opleidingsniveau stijgt, ook de kennis wan kankerpreventie zou stijgen. Deze hypothese wordt over heel de lijn bevestigd en de resultaten zijn consistent met deze uit eerdere studies.

De positieve samenhang tussen opleidingsniveau en kennis van kankerpreventie wordt echter in de eerste plaats veroorzaakt door het verband met kennis van primaire kankerpreventie en pas in de tweede plaats door het verband met kennis van secundaire kankerpreventie. Deze minder sterke samenhang van opleiding met kennis van secundaire kankerpreventie wordt evenwel veroorzaakt door de afwezigheid van een verband tussen opleiding en 'kennis van de waarschuwingssignalen voor kanker'. Hierdoor wordt de sterkste samenhang (max. $\mathbb{r}=.22$ ) met de kennis van de vroegtijdige opsporingsonderzoeken enigszins verborgen. 
- ad onderzoekshypothese 2 -

De tweede onderzoekshypothese betrof de relatie tussen inkomen en kennis van kankerpreventie, waarbij werd voorspeld dat naarmate het inkomen toeneemt, ook de kennis van kankerpreventie zou stijgen. Deze hypothese wordt ook bevestigd en de resultaten zijn eveneens consistent met deze uit eerdere studies. Globaal genomen wordt een gelijkaardig patroon vastglesteld alls bij de samenhang tussen opleiding en kennis van kankerpreventie. De kennisverschillen zijn echter minder uitgesproken en de correlaties duidelijk minder sterk (max. $r=.11)$.

De positieve samenhang tussen inkomensniveau en kennis van kankerpreventie wordt - net zoals bij opleiding - in de eerste plaats veroorzaakt door het verband met kennis van primaire kankerpreventie en pas in de tweede plaats door het verband met kennis van secundaire kankerpreventie. Deze minder sterke samenhang van inkomensniveau met kennis van secundaire kankerpreventie wordt ook hier veroorzaakt door de afwezigheid van een verband tussen inkomensniveau en 'kennis van de waarschuwingssignalen'.

\section{- ad onderzoekshypothese 3 -}

De derde onderzoekshypothese betrof de relatie tussen beroepsstatus en kennis van kankerpreventie, waarbij werd voorspeld dat naarmate de beroepsstatus stijgt, ook de kennis van kankerpreventie zou stïgen.. Deze hypothese wordt eveneens bevestigd. Het verband tussen beroepsprestige en de globale meting van kennis van kankerpreventie is qua sterkte het best vergelijkbaar met dat wat teruggevonden werd bij de samenhang met opleiding. Dit betekent dat de kennisverschillen meer uitgesproken en de correlaties sterker zijn dan bij de samenhang tussen inkomen en kennis van kankerpreventie. Het sterkste verband wordt wastgesteld bij de samenhang tussen beroepsstatus en kennis van de vroegtijdige opsporingsonderzaeken $(r=.20)$.

In tegenstelling tot de relaties met opleiding en inkomen, wordt de samenhang van beroepsprestige met kennis van kankerpreventie in de eerste plaats veroorzaakt door het verband met kennis van secundaire kankerpreventie en pas in de tweede plaats door het verband met kennis van primaire kankerpreventie. Deze sterkere samenhang van beroepsprestige met kennis van secundaire kankerpreventie wordt vooral veroorzaakt door een sterk verband tussen beroepsprestige en 'kennis van de vroegtijdige opsporingsonderzoeken' en minder door thet verband tussen beroepsprestige en 'kennis van de waarschuwingssignalen".

\section{- ad onderzoekshypothesen 4 en 5 -}

De vierde en wijfde onderzoekshypothesen betroffen de relaties van kennis van kankerpreventie met twee geintegreende indicatoren van sociaal-economische status, namelijk enerzijds oplelding samen met inkomen en anderzijds opleiding samen met inkomen én beroepsstatus. Deze variabelen werden construeerd om na te gaan of een sociale positie bepaald door een cumulatie van sociale kenmerken een sterkere samenhang zou vertonen met kennis van kankerpreventie dan de afzonderlijke indicatoren van SES. 
Daarbij werd voorspeld dat naarmate de sociaal-economische status stijgt, ook de kennis van kankerpreventie zou stijgen. Ook deze twee hypothesen worden bevestigd.

Voor de beïde geîntegreerde SES-indicatoren werd ook een positieve samenhang met kennis van kankerpreventie gevonden. In het algemeen zijn de kennisverschillen echter groter, wanneer wordt getoetst met SES op basis van opleiding, inkomen en beroepsstatus, dan wanneer wordt getoetst met SES op basis van opleiding en inkomen. Deze grotere kennisverschillen werden ook bevestigd door sterkere correlatiecoëfficiënten $(\max , r=.23)$.

De samenhang van SES (op basis van opleiding, inkomen én beroepsistatus) met kennis van kankerpreventie wordt evenwichtig veroorzaakt door zowel het verband met kennis van primaire kankerpreventie als het verband met kennis van secundaire kankerpreventie. Beide relaties hebben samengevoegd evenwel een nog sterkere samenhang met de globale meting van kennis van kankerpreventie.

De geintegreerde sociaal-economische status op basis van zowel opleiding, inkomen als beroepsstatus (SESb) vertoont in het algemeen ook een sterkere samenhang met kennis van kankerpreventie dan de afzonderlijke indicatoren opleiding, inkomen en beroepsstatus. De afzonderlijke SES-indicator 'opleidingsniveau' heeft de op één ma sterkste samenhang met kennis van kankerpreventie en als afzonderlijke indicator heeft opleiding een sterkere samenhang met kennis van kankerpreventie dan beroepsstatus en inkomen. Inkomen hangt ontegensprekelijk het minst sterk samen met kennis van kankerpreventie.

Samenvattend kan men stellen dat de vooropgestelde lineariteit in de samenhang tussen de sociaal-economische determinanten en kennis van kankerpreventie wordt bevestigd in dit onderzoek. Het positief lineair verband tussen SES en kennis van kankerpreventie bleek na controle voor geslacht en leeftijd ook zeer robuust te zijn. Zowel nà controle voor geslacht als nà controle voor leeftijdsklasse worden de vastgestelde verbanden gerepliceerd in de onderzochte subpopulaties, naar gesllacht en leeftijdsklasse. Ook de richting en de worm wan de verbanden worden gerepliceerd bij de onderzochte subpopulaties. Alle positieve lineaire verbanden blijven positief en lineair.

Er werden echter ook interactie-effecten vastgesteld met geslacht én met leeftijd. De positieve lineaire verbanden worden weliswaar gerepliceerd bij zowel mannen als vrouwen, doch de sterkte van de samenhang tussen SES en kennis van kankerpreventie is verschillend naar geslacht. De samenhang is duidelijk sterker bij mannen dan bij vrouwen. Controlerend naar leeftijdsklasse bleek de samenhang tussen SES en kennis van kankerpreventie duidelijk sterker bij jongeren dan bij ouderen.

Om de relatieve impact van alle socialle determinanten op kennis wan kankerpreventie te kunnen analyseren, werden multiple regressie-analyses uitgevoerd. De multiple regressieanalyses van de kennisschalen naar zowel de socio-demografische als de sociaaleconomische determinanten toonden aan dat de zero-order relaties die in hoofdstukken 7 én 8 werden besproken niet geheel onafhankelijk van elkaar zijn. Uit deze analyses bleek dat de sociaal-economische status de grootste impact heeft op kennis van kankerpreventie 
en dat verder respectievelijk leeftijd en geslacht een additieve impact hebben op kennis van kankerpreventie. De af- of aanwezigheid van een partmer bleek geen additieve impact te hebben op kennis van kankerpreventie. De sociaal-economische status is dus veruit de belangrijkste sociale determinant van kennis van kankerpreventie.

Het aandeel van de variantie van (de globale meting van) kennis van kankerpreventie dat kon worden verklaard door de sociale determinanten bleek vrij matig te zijn, namelijk $11 \%$. Hieruit concluderen dat meer doelgerichtheid bij voorlichtingscampagnes weinig zal baten voor de lagere sociale kllassen, zou een verkeerde gevolgtrekking zijn. Het betekent enkel dat een heroriëntering van de bestaande kankerpreventiecampagnes naar deze specifieke doelgroepen toe een onvaldoende voorwaarde is om een effectieve verhoging van kennis van kankerpreventie te bereiken. Deze resultaten kunnen de overheid en de GVO-ers ertoe inspireren om bij het ontwerpen van voorlichtingscampagnes inzake kankerpreventie meer specifieke aandacht te hebben voor deze differentiële sociale effecten van hun campagnes bij de bevolking. Wil men bij de lagere sociale klassen evenveel bereiken als bij de hogere sociale klassen, dan zal men meer aandacht moeten schenken aan het doelgroepgericht ontwarpen en uittesten van het voorlichtingsmateriaal en de interventiestrategie. Vooraf zal men veel nauwgezetter moeten nagaan welke communicatiekanalen dienen te worden gebruikt, hoe de boodschap moet worden geformuleerd en hoe deze boodschap zal moeten worden gepresenteerd aan de doelgroep.

Concluderend kan worden gesteld dat niettegenstaande er de afgelopen decennia massaal veel voorlichting inzake kankerpreventie plaatswond in Vlaanderen, en niettegenstaande deze voorlichting ook via populaire media zoals radio en T.V. Werd verricht, niet alle Vlamingen in gelijke mate de vruchten hebben geplukt van deze inspanningen. Mensen met een lage sociaal-economische status hebben significant minder kennis van kankerpreventie dan mensen met een hoge sociaal-economische status. Deze sociaal ongelijke verdeling van kennis van kankerpreventie wordt zowel vastgesteld in het domein van de primaire kainkerpreventie als in het domein van de secundaire kankerpreventie. Dit betekent dus een dubbel nadeel voor personen met een lage sociaal-economische status. Zij zijn niet alleen minder goed geïnformeerd of 'cognitief uitgerust' om kanker te helpen voorkomen door bijvoorbeeld hun leefstijl aan te passen; zij zijn ook minder geinformeerd of 'cognitief uitgerust' om, zo dit nodig en nuttig is, kanker wroegtijdig te laten opsporen, zadat ze een even grote overlevingskans hebben als mensen met een hoge social-economische status. Deze resultaten zijn consistent met ander GVO-onderzoek waarin werd aangetoond dat de inspanningen inzake gezondheidsvoorlichting vooral effect hebben bij categorieën die dit het minst nodig hebben, terwiijl ze weinig effect hebben bij de zogenaamde achtergestelde groepen (De Walle-Sevenster en Kok, 1991 en Uniken Venema en Garretsen, 1995). Dat dit aanleiding kan geven tot zeer ernstige gezondheidsrisico's, werd ondermeer aangetoond in de Verenigde Staten, waar de overlevingskansen bij kanker bij de armen voor 50\% worden toegeschreven aan een laattijdige diagnose (Loehrer e.a., 1991: 1665). Dat patiênten met een lage sociaal-economische status meer kans maken om een diagnose te krijgen in een vergevorderd stadium van kanker, suggereert dat er voor mensen met een lage sociaal-economische status "barrieres" zijn voor een adequate vroegtijdige opsporing en dat daarbij ook inadequate kennis inzake kankerpreventie of inadequate opvattingen over kanker een rol spelen. 


\title{
Hoofdstuk 9
}

\section{Samenvatting en algemene discussie}

\author{
9.1 Samenvatting van de onderzoeksresultaten \\ 9.2 Restricties van het onderzoek \\ 9.3 Implicaties voor beleid en voorlichtingspraktijk
}

Inleiding. Onderhavig onderzoek leidde in meerdere opzichten tot interessante en soms verrassende resultaten. $\mathrm{Ze}$ worden samengevat in paragraaf 9.1 . Tevens worden in paragraaf 9.2 de beperkingen van thet onderzoek aangegeven. Tot slot wordt er wat meer afstand van de empirische bevindingen genomen en worden in paragraaf 9.3 de mogelijke implicaties van die resultaten voor het beleid en voor de voorlichtingspraktijk besproken.

\subsection{Samenvatting van de onderzoeksresultaten}

Gezandheildswoorlichting en -opvoeding (GVO) kan bijdragen aan verandering in gedrag. Hiermee kunnen mensen worden aangezet om gezonder te gaan leven en zodoende kanker te voorkomen. Met GVO kunnen mensen oolk aangezet worden om te participeren aan vroegtijdige opsporing van kanker, zodat uiteindelijk een vermindering van ziekte en sterfte door kanker kan worden bereikt. In GVO en kankerpreventie speelt voorlichting aan het algemene publiek een vooraanstaande rol. Hoewel men zich vragen kan (en moet) stellen over de zin van voorlichtingscampagnes om kennis van kankerpreventie te verhogen, is het de facto zo dat in Vlaanderen de meeste interventies (nog steeds) gericht zijn op kennisoverdracht.

Het doel van deze studie was drievoudig: ontwikkelen van een instrument om kennis van kankerpreventie te kunnen meten, evaluatie van (het niveau van) de kennis van kankerpreventie onder een representatief staal van de Vlaamse bevolking (18-70 jaar) en de studie van de sociale determinanten van deze kennis van kankerpreventie in Vlaanderen. Meer in het bijzonder beoogde deze studie een antwoord te geven op volgende onderzoeksvragen:

1. Hoe kan kennis van kankerpreventie (in globaliteit) op een valide en betrouwbare wijze worden gemeten?

II. Heeft de Vlaamse bevolking een adequate kennis ${ }^{3}$ van kankerpreventie?

Met "adequate kennis' wardt in deze studie bedoeld het vermogen van de respandenten om medisch gewenste kennis inzake kankerpreventie te kunnen onderscheiden wan foutieve of medisch ongewenste kennis inzake kankerprewentie. Met de term 'gewenste medische kennis' inzake kankerpreventie wordt bedoeld de kennis die conform is met de internationale medische richtlijnen of aanbevelingen inzake kankerpreventie. 
1. Zijn er binnen kennis van kankerpreventie bepaalde kennisdomeinen of aspecten van kankerpreventie beter gekend dan andere?

2. Bestaan er misvattingen over kankerpreventie?

3. Kan de Vlaamse bevolking factoren die echt iets te maken hebben met kankerpreventie goed onderscheiden van factoren die geen rol spelen bij kankerpreventie?

III. Is kennis van kankenpreventie gelijkmatig verspreid in de Vlaamse bevolking of zijn er categorieên met een significant grotere of kleinere kennis van kankerpreventie dan andere categorieën?

1. Hangt kennis van kankerpreventie van mensen samen met hun socio-demografische positie in de samenleving? is er m.a.w. een ongelijke verdeling van kennis van kankerpreventie naar geslacht, leeftijd en leefsituatie?

2. Hangt kennis van kankerpreventie van mensen samen met hun sociaal-economische status in de samenleving? is er m.a.w, een ongelijke verdeling wan kennis wan kankerpreventie naar opleiding, inkomen en beroepsstatus?

Hoofdstuk 1 gaf een algemene inleiding over de probleemstelling van dit onderzoek. Het uitgangspunt van deze studie was de vaststelling dat men in Vlaanderen, ondanks jarenlange sensibilisatie en voorlichting inzake kankerpreventie, niet weet of al deze inspanningen hebben geleid tot een adequate kennis van kankerpreventie bij de bevalking. Bovendien laten de relatief beperkte buitenlandse studies op het gebied van kennis van kankerpreventie bij de bevolking fragmentarische en soms tegenstrijdige resultaten zien. In bepaalde studies wordt een bevredigend kennisniveau vastgesteld, terwijl in andere studies dan weer een inadequate kennis wordt vastgesteld.

In hoofdstuk 2 was de vraag aan de orde waarom het maatschappelijk en wetenschappelijk relevant is orm 'kennis van kankerpreventie' te meten. Om een antwoord te kunnen geven op deze vraag werd een aantal belangrijke ontwikkelingen in de gezondheidszorg beschreven. Hierdoor kon deze studie van (kennis van) kankerpreventie worden gesitueerd in haar historisch en maatschappelijk kader en kon de beleidscontext worden aangegeven. Tevens werd de wetenschappelijke onderbouw van de gezondheidsvoorlichting inzake kankerpreventie geschetst. Het (kunnen) meten van kennis van kankerpreventie bleek daarbij instrumenteel noodzakelijk bij het opzetten en evalueren van interventies met het oog op het bevorderen van kennis inzake kankerpreventie.

In hoofdstuk 4 werd de vraag behandeld hoe het survey-onderzoek bij 1631 Vlamingen is geconcipieerd, opgezet en uitgevoerd. Daarbij werd uitvoerig ingegaan op de selectie van de onderzoekselementen lontwerp van de steekproef, het bepalen van de steekproefomvang, de respons en non-respons, enz.) en werd met positief resultat de representativiteit van de steekproef naar geslacht, leeftijd, provincie en gemeentetype onderzocht. Ook aan de ontwikkeling en testing van de gebruikte vragenlijst werd de nodige aandacht besteed. Verder werden de procedures van de dataverwerking en de controle van de gegevens, alsook de algemene principes voor de statistische toetsingsprocedures beschreven.

Om een betrouwbaar antwoord te kunnen geven op de onderzoeksvragen II en III dient men eerst te beschikken over een instrument om deze kennis van kankerpreventie te meten londerzoeksvraag D. De ontwikkeling van dit instrument en het onderzoek van een aantal 
kwaliteitseisen kwamen aan bod in de hoofdstukken 3 en 6 . In hoofdstuk 3 was de vraag aan de orde 'hoe' kennis van kankerpreventie op een valide en betrouwbare maniel kan worden gemeten in empirisch onderzoek. Om deze vraag te beantwoorden, werd vertrokken van een analyse van de begrippen 'kankerpreventie' en 'kennis van ...' en werd aangegeven hoe medisch gewenste kennis kan worden gemeten of getoetst. Hiervoor waren 'kennisnormen' noodzakelijk. De selectie van deze kennisnormen werd gebaseerd op bestaande nationale en internationale consensusrapporten over de medische richtlijnen of aanbevelingen inzake kankerpreventie. Teneinde een valide meetinstrument te kunnen ontwikkelen, werd kennis van kankerpreventie geconceptualiseerd aan de hand van twee dimensies, namelijk kennis van primaire kankerpreventie en kennis van secundaire kankerpreventie. Vervolgens werden vier indicatoren geoperationaliseerd: kennis van de risicifactoren van kanker, kennis van het gewenst kankerpreventief gedrag "kennis van de waarschuwingssignalen voor kanker en kennis van de vroegtijdige opsporingsonderzoeken voor kanker. Elke indicator werd in de vragenlijst gemeten met 25 items. Om de misvattingen over kankerpreventie te kunnen onderzoeken bevatte deze vragenlijst ook "fioutieve" items die volgens de medische aanbevelingen niets met kankerpreventie te maken hebben.

In hoofdstuk 6 werden de kennisschalen geconstrueerd en werden de betrouwbaarheid en de validiteit van deze kennisschalen onderzocht. In het algemeen kon worden vastgesteld dat de geconstrueerde schalen goede resultaten geven op het getoetste betrouwbaarheidcriterium van de interne consistentie van de meetschalen. De zeer hoge Cronbach's alpha-waarden blijken bovendien consistent of robuust bij analyse van de betrouwbaarheid van de kennisschalen in subpopulaties. Ook het validiteitsonderzoek gaf bevredigende resultaten. Het gebruik van de 'adequate' kennisschalen - en dus van de combinatie van medisch gewenste 'juiste' en medisch ongewenste 'foutieve' items bij de kennismeting leidde tot een meer valide meting van kennis van kankerpreventie dan het afzonderlijk gebruik van een kennisschaal waarmee alleen kennis van 'juiste' items werd getoetst. De validering van de adequate kennisschalen werd verder met bevredigende resultaten empirisch-statistisch anderzocht door respectievelijk de methode van 'criteriumvalidering" en "begripsvalidering".

In de hoofstukken 5 en 6 werd een antwoord geformuleerd op de onderzoeksvraag /l, of de Vlaamse bevolking een adequate kennis heeft van kankerpreventie. In hoofidstuk 5 werd een beschrijvende analyse gepresenteerd van de 'Kennis van kankerpreventie 100-items vragenlijst'. De onderzoeksresultaten toonden aan dat de Vlaamse bovolking een zekere mate van adequate kennis van kankerpreventie heeft. In het algemeen tonen de beschrijvende resultaten echter een bont geschakeerd beeld van de kennis van kankerpreventie in Vlaanderen. Een aantal concrete aspecten in verband met kankerpreventie is zeer goed gekend; andere aspecten zijn dan weer veel minder of nauwelijks gekend. Zo bijvoorbeeld is roken zeer goed gekend als risico op llongikanker, maar wordt 'overmatig gebruik van dierlijke vetten' of 'zwaarlijvigheid' matig herkend als risicofactor van kanker; evenmin worden 'regelmatig eten van bruin brood' of 'regelmatig eten van ongepelde rijst' herkend als preventieve voedingsgewoonte. Er werd ook vastgesteld dat de aanbevelingen waarover in medische kringen een (redelijke) consensus bestaat vrij goed gekend zijn door de bevolking lbv. het baarmoederhalsuitstrijkje als 
vroegtijdig opsporingsonderzoek naar balarmoederhalskanker, de mammografie als woegtijdig opsporingsonderzoek naar borstkanker of stoppen met roken als gewenst gedrag ter voorkoming van longkankerh, terwijl deze waarover weinig consensus bestaat in medische kringen, minder goed gekend zijn (bv. de richtlijnen over aanvangsleeftijd en trequentie van vroegtijdige opsporing, de risicofactoren inzake voedingl.

Aan de hand van de gemiddelde kennisscores kon in hoofdstuk 6 onderzoekswraag //. 1 worden getoetst, namelijk of er binnen de kennis van kankerpreventie bepaalde kennisdomeinen van kankerpreventie beter gekend zijn dan andere domeinen. Lit de gemiddelde schaalscores bleek dat er in Vlaanderen een duidelijk verschil is in kennisniveau tussen kennis van primaire kankerpreventie en kennis van secundaire kankerpreventie. Het laatste kennisdomein is beduidend beter gekend dan het eerste. De kennis van secundaire kankerpreventie kan worden toegeschreven aan een evenwichtig verspreide kennis van de twee indicatieve kennisdomeinen. De respondenten weten namelijk ongeveer evenveel over de vroegtijdige opsporingsonderzoeken van kanker als over de waarschuwingssignalen van kanker. Hetzelfde kan evenwel niet worden gezegd van de kennis van primaire kankerpreventie. Hier wordt de score gevormd door een relatief hoge kennis van de risicofactoren en een relatief lage kennis van het gewenst kankerpreventief gedrag. De respondenten zijn zich dws meer bewust van wat hen kan aanzetten om naar de dokter te gaan, dan van wat ze zelf kunnen doen aan hun leef-en eetgewoonten. Bovendien werd ook vastgesteld dat binnen het domein van primaire kankerpreventie de 'verboden' beter gekend zijn dan de 'geboden', mensen herkennen namelijk beter risicofactoren van kanker dan gewenst kankerpreventief gedrag.

Er werden ook een hele reeks misvattingen vastgesteld inzake kankerpreventie londerzoeksvraag (1.2). De misvattingen over kankerpreventie kunnen echter niet worden gellokaliseerd in én kennisdomein. In het domein "primaire kankerpreventie" situeren de meeste misvattingen zich vooral bij de kennis van het gewenst kankerpreventief gedrag en minder bij de kennis van de risicofactoren. Niet minder dan 11 van de 17 'foutieve" items die niets met kankerpreventie te maken hebben, worden door een meerderheid foutief herkend ais gewenst kankerpreventief gedrag. Zo bijvoorbeeld wordt het "regelmatig eten van vis" of het 'vermijden van stress' door zelfs meer dan $65 \%$ van de respondenten verkeerdelijk herkend als een gewenst kankerpreventief gedrag. In het domein 'secundaire kankerpreventie' situeren de meeste misvattingen zich voorall bij de kennis van de vroegtijdige opsporingsonderzoeken en minder bij de kennis van de waarschuwingssignalen van kanker. Vijf van de 18 'foutieve' items werden door een meerderheid van de respondenten foutief herkend als vroegtijdig opsporingsonderzoek voor kanker.

In deze studie kon ook het "onderscheidingsvermogen" tussen medisch gewenste of "juiste" kennis en medisch ongewenste of "foutieve' kennis worden onderzocht londerzoekswraag II. 3). Dit gebeurde door de scores op de kennisschalen gebaseerd op de "juiste" items te vergelijken met de scores op de foutperceptieschalen gebaseerd op "foutieve" items idie dus niets te maken hebben met kankerpreventie). In het aigemeen kon in deze studie worden vastgesteld dat de respondenten met grotere zekerheid weten dat jets wél met kankerpreventie te maken heeft, dan dat iets niet met kankerpreventie te maken heeft. Het onderscheidingsvermogen verschilt evenwel sterk naargelang van het domein en de 
gebruikte indicator van de kennis van kankerpreventie. Het onderscheidingsvermogen is relatief klein bij de kennis van de primaire kankerpreventie /voor de kenmis van de risicofactoren en de kennis van het gewenst kankerpreventief gedrag respectievelijk 45 en 28 schaalpuntem), en vrij groot bij de kennis van secundaire kankerpreventie (voor de kennis wan de waarschuwingssignalen van kanker en de kennis van de vroegtijdige opsporings onderzoeken respectievelijk 58 en 60 schaalpunten/. Binnen het kennisdomein van "primaire' kankerpreventie kan de Vlaamse bevolking m.a.w. minder goed een onderscheid maken tussen aspecten die echt iets te maken hebben met kankerpreventie en aspecten die helemaal geen rol spelen bij kankerpreventie, dan binnen het kennisdomein van 'secundaire" kankerpreventie.

In de hoofdstukken 7 en 8 werd onderzoeksvraag /WI onderzocht, namelijk of de kennis van kankerpreventie lonlgelijk verspreid is in de Vlaamse bevalking. Op basis van een aantal sociaal-psychologische gedragsmodellen en een aantal beschrijvende empirische studies over kennis van kankerpreventie kon een samenhang worden verwacht tussen sociale determinanten en kennis van kankerpreventie. In hoofdstuk 7 werd aangetoond dat de kennis van kankerpreventie in de Vlaamse bevolking ongelijk gespreid is naar de sociodemografische positie van respondenten in de samenleving (onderzoekswraag $1 / 1$. 1). De eerste hypothese die werd getoetst in dit hoofdstuk betrof de invloed van ges/acht op kennis van kankerpreventie, waarbij werd voorspeld dat vrouwen een grotere kennis van kankerpreventie zouden hebben dan mannen. Deze hypothese kon zonder meer worden aanvaard. De empirische bevindingen uit dit onderzoek zijn consistent met deze uit eerdere studies. Voor alle kennismetingen hadden vrouwen een significant hogere kennisscore dan de mannen. Vrouwen weten dus meer over kankerpreventie dan mannen. Deze verschillen in kennisniveau zijn echter het meest uitgesproken bil de kennis van "secundaire kankerpreventie". De gevonden relaties tussen geslacht en kennis van kankerpreventie zijn over het algemeen ook consistent bij elaboratie naar leeftijd.

De tweede hypothese die werd getoetst in hoofdstuk 7 betrof de invloed van leeftijd op kennis van kankerpreventie. Op grond van tegenstrijdige resultaten in het bestaand empirisch onderzoek werd er 'geen' verband verwacht tussen lleeftijd en kennis van kankerpreventie, althans wat de 'globale meting' van kennis van kankerpreventie betreft. Hoewel de samenhang tussen leeftijd en de 'globale meting' van kennis van kankerpreventie deels verborgen was door tegengestelde effecten van leeftijd op de twe dimensies van de kennis leen negatieve samenhang met kennis van primaire kankerpreventie en een positieve samenhang met kennis van secundaire kankerpreventiel, kon deze hypothese toch zonder meer worden verworpen. Leeftijd heeft in deze studie evenwel geen eenduidige relatie met kennis van kankerpreventie. Leeftijd heeft een lineaire negatieve samenhang met 'kennis van primaire kankerpreventie'. De jongste leeftijdscategorie heeft de grootste kennis van primaire kankerpreventie en de kennisscore daalt gradueel met de toenemende leeftijd. Met "kennis van secundaire kankerpreventie" heeft leeftijd evenwel een curvilineaire samenhang. De kennisscore stijgt gradueel tot de leeftijdsklasse van 41-50 jaar, om nadien weer gradueel te dalen. De vastgestelde relaties tussen leeftijd en kennis van kankerpreventie zijn over het algemeen ook consistent bij elaboratie naar geslacht. 
De derde hypothese die werd getoetst in hoofdstuk 7 betrof de invloed van de leefsituatie op kennis van kankerpreventie. Er werd vaorspeld dat respondenten met een partner een grotere kennis van kankerpreventie zouden hebben dan deze zonder partner, en dat de invloed van de partner sterker zou zijn voor mannen dan voor vrouwen. Over het algemeen kon worden vastgesteld dat de irivloed van de leefsituatie op kennis van kankerpreventie vrij zwak is. Hoewel de samenhang tussen leefsituatie en de 'globalle meting' van kennis van kankerpreventie significant is, kan er deels ook worden gesproken van een schïnverband'. De kernis van 'primaire' kankerpreventie wordt niet beïnvloed door de leefisituatie en de kennis van 'secundaire" kankerpreventie wordt maar zeer matig beïnvloed door de leefsituatie. De invloed gaat daarbij echter wel in eenzelfde richting: respondenten met een partner hebben steeds een hogere gemiddelde kennisscore dan respondenten zonder partner. Bij elaboratie naar geslacht, bleek deze invloed bovendien enkel aanwezig bij mannen. Voor de vrouwelijke respondenten kon worden geconcludeerd dat de invloed van hun partner op hun kennis van kankerpreventie vrijwel nihil is. Bij de mannelijke respondenten was de invloed van de partner enkel significant voor kennis van 'secundaire" kankerpreventie en niet voor kennis van 'primaire' kankerpreventie.

Wanneer de inwloed van de drie socio-demografische factoren op de kennis van kankerpreventie onderling wordt vergeleken, kan worden vastgesteld dat vooral de invloeden van geslacht en leeftijd substantieel waren. Ook hier dient een onderscheid te worden gemaakt in het domein waarop de kennis betrekking heeft. Leeftijd correleert in vergelijking met geslacht immers twee keer zo sterk met "kennis van primaire kankerpreventie', doch ongeveer even sterk met 'kennis van secundaire kankerpreventie". Door de tegengestelde effecten van leeftijd op kennis van respectievelijk primaire en secundaire kankerpreventie wordt de invloed van leeftijd op de globale meting van kennis van kankerpreventie enigszins verborgen en lijkt het alsof vooral geslacht het sterkst samenhangt met de kennis van kankerpreventie.

In hoofdstuk 8 werd een uitvoerige analyse gewijd aan de invlloed van sociaal-economische status (SES) op de kennis van kankerpreventie (onderzoeksvraag (II.2). Op basis van de literatuur werd voorspeld dat naarmate de sociaal-economische status stijgt, ook de kennis van kankerpreventie zou stijgen. Deze hypothese werd systematisch getoetst aan de hand van drie enkelvoudige SES-indicatoren, namelijk opleidingsniveau, inkomen en beroepsstatus, en twee samengestelde SES-indicatoren lopleiding samen met inkomen; en opleiding samen met inkomen en beroepsstatusl. De hypothese werd bevestigd in alle uitgevoerde analyses. De resultaten zijn daarmee consistent met deze uit eerdere studies. De 'sterkte' van de samenhang tussen SES lop basis van opleiding, inkomen én beroepsstatusl en kennis van kankerpreventie wordt evenwichtig gevormd door de beide afzonderlijke kennisdimensies. De samenhang tussen SES en kennis van primaire kankerpreventie is namelijk even sterk als deze tussen SES en kennis van secundaire kankerpreventie. De globale meting van kennis van kankerpreventie - dus de geïntegreerde meting van zowel kennis van primaire kankerpreventie als kennis van secundaire kankerpreventie vertoont evenwel een nog sterkere samenhang met SES dan deze met de twee afzonderlijke dimensies van kennis van kankerpreventie. Verder kan worden gesteld dat de vooropgestelde lineariteit in de samenhang tussen sociaal-economische status en kennis van kankerpreventie wordt bevestigd in dit onderzoek. Het positief lineair verband tussen SES 
en kennis van kankerpreventie bleek na controle voor geslacht en leeftijd ook zeer robuust te zijn.

Om de relatieve impact van alle sociale determinanten op kennis van kankerpreventie te kunnen analyseren en om de interactie-effecten onder controle te kunnen houden, werden multiple regressie-analyses uitgevoerd. De multiple regressie-analyses van de kennisschalem naar zowel de socio-demografische als de sociaal-economische factoren toonden wan dat de zero-order relaties niet geheel onafhankelijk van elkaar zijn. Uit deze analyses bleek verder dat de sociaal-economische status de grootste impact heeft op kennis van kankerpreventie en dat respectievelijk leeftijd en geslacht een additieve impact hebben op kennis van kankerpreventie. De aan- of afwezigheid van een partner blijkt geen additieve impact te hebben op kennis van kankerpreventie. De sociaal-economische sitatus is dus veruit de belangrijkste sociale determinant van kennis van kankerpreventie.

Op basis van de onderzoeksresultaten blijken de relaties tussen de sociale determinanten en kennis van kankerpreventie vrij complex te zijn. Dit bevestigt de complexiteit van de invloed van een sociale positie in de samenleving. Het is meestal niet één sociaal kenmerk dat verantwoordelijk is voor een bepaalde sociale predispositie ten aanzien van (kennis wan) kankerpreventie. Het is een cluster van verscheidene factoren die maken dat mensen al dan niet bevoor- of benadeeld zijn door hun maatschappelijke positie en die mensen helpen of beletten in het maken van keuzes ten behoeve van hun gezondheid. De variabele impact van de sociale determinanten op kennis van kankerpreventie is bovendien sterk gerelateerd aan het domein van kennis van kankerpreventie dat wordt onderzocht.

\subsection{Restricties van het onderzoek}

Zoals elke studie heeft ook het hier gepresenteerde onderzoek zijn beperkingen. Op methodologisch vlak zijn er een aantal kanttekeningen te maken bij de ontwikkelde methode om kennis van kankerpreventie te meten. Verder dient gewezen op de beperkte theoretische draagwijdte van het onderzoek.

In de meeste onderzoeken naar 'kennis van kankerpreventie' wordt gebruik gemaakt van één of meerdere enkelvoudige variabelen of wordt kennis gemeten met een schaal die inhoudelijk slechts één bepaald aspect wan kankerpreventie meet. In het bestaand empirisch onderzoek wordt bijgevolg gebruik gemaakt van meetinstrumenten met een gebrekkige conceptualisering van het complexe concept "kennis van kankerpreventie". Dergelijke gebrekkige conceptualisering heeft vergaande gevolgen voor oventuele theorie-ontwikkeling over kennis van kankerpreventie. Als een complexe theoretische eigenschap met meerdere dimensies slechts door één van deze dimensies wordt geïndiceerd en er nadien conclusies

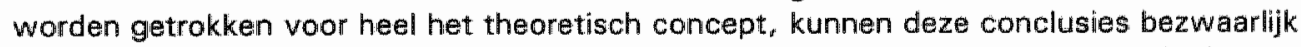
valide worden genoemd (Billiet, 1993). Verder doen er zich bij de bestaande methodes orm kennis van kankerpreventie te meten ook problemen voor van systematische onderrapportering ( $\mathrm{bv}$. bij open vragen) of ovemapportering (bv. door een 'instemmende responseset' of door 'sociale wenselijkheid"), waardoor de kennis van kankerpreventie vaak te laag of te hoog wordt ingeschat. Een belangrijke uitdaging voor deze studie was dan ook het 
ontwikkelen van een meetinstrument om "kennis van kankerpreventie" in haar globaliteit en in haar diversiteit te meten. Daarbif werd een meetinstrument geambieerd met een grotere validiteit en betrouwbaarheid dan de instrumenten die tot nog toe over deze problematiek in empirisch onderzoek werden gebruikt. Op basis van een analyse van het begrip "kennis van kankerpreventie' werd een meervoudig meetinstrument geconceptualiseerd en op basis van een kritische doorlichting van de bestaande meetmethodes werd een nieuwe meetprocedure geoperationaliseerd.

In dit proefschrift werden de geconstrueerde schalen van kennis van kankerpreventie onderzocht volgens een aantal gangbare kwaliteitseisen van meeteigenschappen. In het algemeen kan worden gesteld dat de kennismetingen bij de Vlaamse bevolking een hoge mate van validiteit en betrouwbaarheid bereikten. Door het gemengd voorleggen van zowell 'juiste" als "foutieve' items werd bij de meting een belangrijk deel van de systematische fouten die leiden tot ongeldigheid gecorrigeerd. Het kwaliteitsonderzoek van de meetschalen heeft aangetoond in welke mate de metingen als betrouwbaar en valide kunnen worden beschouwd.

Met het onderzoek van de betrouwbaarheid en validiteit van deze meetschalen is uiteraard niet alles gezegd over de $k$ waliteit van dit meetinstrument. Vervolgonderzoek van deze schalen is mogelijk en noodzakelijk. In het kadeir van toekomstig onderzoek verdienen volgende kwaliteitseisen verdere aandacht:

- het stabiliteitscriterium of de test-hertest-betrouwbaarheid

- de eis van de "criteriumvaliditeit'

- de 'gevoeligheid voor verandering'.

Test-hertest-betrouwbaarheid is een aanvullende test van betrouwbaarheid die ook kan worden onderzocht. Het onderzoekt de consistentie van de betrouwbaarheid over de tijd. Letterlijk drukt de betrouwbaarheid in deze betekenis uit, hoe goed een schaal met zichzelf correleert bij herhaalde metingen bij eenzelfde steekproef. Doordat de factor tijd met het gebruikte onderzoeksdesign onmogelijk kon worden onderzocht, werd deze test niet verricht. Een dergelijk onderzoek kan het best worden opgezet via een experimenteel onderzooksdesign. Daarbij dient men de 'Kenniis voor kankerpreventie 100-item vragenlijst' op twee verschiltende tijdstippen aan eenzelfde groep voor te leggen. Als de metingen stabiel zijn, zouden de gemiddelde scores van de twee metingen niet significant mogen verschillen. Hoewel een schaal met een hoge interne consistentie meestal ook goede testhertest-betrouwbaarheid oplevert (zie Spector, 1992: 65), verdient het toch aanbeveling om de consistentie over de tijd te onderzoeken.

Het onderzoek van de criteriumvaliditeit is met deze studie evenmin afgerond. Criteriumvaliditeit werd in hoofdstuk 6 onderzocht door voorspelde verbanden tussen het construct 'kennis van kankerpreventie' en respectievelijk geslacht en opleidingsniveau te testen. Het meetinstrument is valide als het in staat is te discrimineren tussen van elkaar verschillende groepen respondenten (bijvoorbeeld tussen dokters en 'leken' of tussen patiënten en 
gezonde personen!". Deze valideringsmethode is gebaseerd op de hypothese dat bepaalde groepen respondenten hoger zullen scoren dan andere. In dit onderzoek werd dit onderzocht door mannen met vrouwen te vergelijken en door te vergelijken naar opleidingsniveau. De hypothese dat vrouwen hoger zouden scoren dan mannen was evenwel geen sterk gefundeerde hypothese en was uiteindelijk ook eén van de onderzoekshypothesen van onderhavige studie. Hetzelfde kan worden gezegd van de wergelijking van opleidingscategorieên. Deze vorm van validiteit zou op een meer overtuigende wijze kunnen worden onderzocht door de "Kennis woor kankerpreventie 100 -item vragenlijst' voor te leggen aan bijvoorbeeld een groep van huisartsen en de meetresultaten te vergelijken met deze van een doorsnee bevolking. De populatile huisartsen mag geacht worden om uit hoofde van hun medische opleiding en beroep een hogere kennis van kankerpreventie te hebben dan de algemene bevolking. De gemiddelde scores op de kennisschalen dienen dan significant hoger te zijn dan de gemiddelde scores van de algemene bevalking.

Aan de traditionele kwaliteitseisen van meetinstrumenten - nl. validiteit en betrouwbaarheil zou ook "gevoeligheid" voor verandering" kunnen worden toegevoegd (König-Zahn, Furer en Tax, 1993: 17$)^{2}$. Zeker in het voorultzicht van het gebruik van de hier ontwikkelde meting van kennis van kankerpreventie voor effectevaluatie van voorlichtingscampagnes lijkt een verder onderzoek van de gevoeligheid voor verandering nuttig. Wil men effecten van campagnes kunnen evalueren, dan zouden de in dit proefschirift ontwikkelde schalen om kennis van kankerpreventie te meten met andere woorden gevoelig moeten zijn voor positieve en negatieve veranderingen in de kennis van de bevolking. Dit kwaliteitscriterium 'gevoeligheid voor verandering' is sterk verwant met het begrip 'discriminante validiteit" (zie hoger). Sommige auteurs bespreken het zelfs onder de hoofding van discriminante validiteit. Toch is de "gevoeligheid voor verandering" niet essentieel voor de validiteit van een meting. Of deze gevoeligheid voor verandering nu al dan niet als een apart beoordelingscriterium dient te worden beschouwd, is voorlopig nog erg controversieel ${ }^{3}$. Bovendien is er nog geen eenduidigheid over adequate statistische methoden waarmee dit criterium kan worden bestudeerd (Wilkin, Hallam en Doggett, 1992: 34). Het is dan ook niet verwonderlijk dat in de tot nog toe verschenen publicaties waarin gezondheidsmetingen worden besproken,

In het Niederlands spreekt men daarom ook van 'discriminante validiteit' of 'discriminerende validiteit' (König-Zalhn, Furer en Tax, 1993: 18). Dit onderscheidend vermogen van een instrument wordt in het Engels aangeduid met de term 'known-groups validity' (zie bijvoorbeeld Speictor, 1992:49).

In het Engels wordt deze eigenschap 'responsiveness" of 'sensitivity to change" genoemd. Dit begrip heeft evenwel niets te maken met het meer algemeen gekende medisch-klinische of epidemiologische begrip 'sensitivity' dat verwijst naar het vermogen van een (screenings-ytest om mensen die een aandoening of ziekte hebben ook werkelijk op te sporen met de test.

Voor een discussie hierover en suggesties over mogelijke invullingen en formaliseringen van de "gevoeligheid voor verandering' kan worden verwezen naar Streiner en Norman 1989; hoofdsituk 11: zie ook Wilkin, Hallam en Doggett, 1992: 341. 
dit criterium vijwel geheel buiten beschouwing wordt gelaten'. Daarom werd in deze studie de gevoeligheid voor verandering evenmin als een afzonderlike eigenschap behandeld. Wanneer er in de volgende jaren meer eenduidigheid ontstaat over de mogelijke methodes orn deze gevoeligheid voor verandering te onderzoeken, lijkt het aangewezen om - indien mogelijk - ook de meetschalen van kennis van kankerpreventie aan een kwaliteitsonderzoek dienaangaande te onderwerpen.

Bij de toetsing van de onderzokshypothesen over de sociale determinanten van kennis van kankerpreventie bleek overduidelijk dat een grondige conceptualisering en operationalisering essentieel zijn voor een juiste interpretatie van de onderzoeksresultaten. Door de ewenwichtige opbouw van het meetinstrument 'kennis van kankerpreventie' konden bili de analyses van de invloed van de socio-demografische en sociaal-economische determinanten de verschillende kennisdomeinen op systematische wijze met elkaar worden vergeleken. Hierdoor konden een aantal (semil-) verborgen relaties (bv. de invloed van leeftijd op kennis van kankerpreventie) en schijnverbanden (bv. de invloed van de partner op keninis van kankerpreventie) worden opgespoord. Indien er minder systematisch aandacht zou zijn besteed aan de differentiatile binnen het complexe concept "kennis van kankerpreventie", zouden er verkeerde conclusies zijn getrokken en zouden er niet valide verbanden in kaart zijn gebracht.

Hiermee wordt aanbeland bij de theoretische restrictie van dit onderzoek. Het ultieme doel van voorlichting inzake kankerpreventie aan de bevolking is niet "kennis" over kankerpreventie verhogen maar wel (participatie aan) kankerpreventie of kankerpreventief gedrag bevorderen. Bij kankerpreventie gaat het immers niet om de kennis maar om het gedrag van mensen. Een belangrijke bijdrage van het gedragswetenschappelijk onderzoek over kankerpreventie is met name kennis te vergaren over de determinanten van dit kankerpreventief gedrag. Het succesvol bestrijden van kanker door het bevorderen van zowel gezonde leef- of eetgewoonten als de participatie aan vroegtijdige opsporing van kanker verondersteit immers een goed wetenschappelijk inzicht in de determinanten van kankerpreventie, in de samenhang van deze determinanten en in de mogelijkheden deze determinanten met doelgerichte interventies te beirnvloeden (zie bv. Conner en Norman, 1996; de Vries, 1993; Schaalma, 1993). In deze zin is de bijdrage van dit proefschrift earder beperkt. De studie was immers uitsluitend gericht op één mogelijke sociaalcognitieve determinant van kankerpreventie, namelijk 'kennis van kankerpreventie".

Om de relatie tussen een veronderstelde oorzaak en haar effect op een valide en betrouwbare wijze te kunnen vaststellen, zijn er eerst betrouwbare en valide metingen noodzakelijk om zowel de predictor als het effect te kunnen meten. Deze studie was daaram genoodzaakt om veel aandacht (en tijd) te besteden aan de ontwikkeling en het onderzoek van de kw wliteit van de metingen wan 'kennis van kankerpreventie:. Nadien pas kon het kennisniveau worden vastgesteld en kon de samenhang met een aantal socio-

Zie bijwoorbeeld de besprekingen van de gezondheidsschalen bij Furer, König-Zahn en Tax, 1995; König-Zahn, Furer en Tax, 1993; König-Zahn, Furer en Tax, 1994; McDowell en Newell, 1987; Wilkin, Hallam en Doggett, 1992. 
demografische en sociaal-economische determinanten systematisch in kaart worden gebracht. Daarbij had dit onderzoek zowel aandacht voor het al dan niet bestaan van deze relaties als voor de richting, worm en sterkte van de relaties. Tevens werd in dit onderzoek de relatieve impact van de sociale determinanten op kennis van kankerpreventie vergeleken.

Een verantwoord beleid inzake kankerpreventie kan echter geenszins exclusief gebaseerd worden op de sociaal-cognitieve determinant 'kennis van kankerpreventie', Voor een wetenschappelijke fundering van kankerpreventie is er nood aan breder opgezet onderzoek naar de determinanten van kankerpreventie alsook naar de effectiviteit van de preventieve interventies. Im de complexe oorzakelijkheid tussen determinanten en (gezondheids)gedrag. c.q. kankerpreventief gedrag, nemen sociale en sociaal-cognitieve determinanten zeer waarschijnlijk een belangrijke plaats in, maar de kennis hierover is nog onvolledig. In hoofdstuk 1 werd al aangegeven dat dit proefschrift zich niet wilde mengen in de discussie over de rol en de betekenis van kennis in de gedragsverandering van mensen. De meeste sociaal-psychologische handboeken over gedragsverandering blijven daarover nogal onduidelijk en in plaats van te zoeken naar de betekenis van kennis met betrekking tot gedrag, gaan zij eerder op zoek naar het belang van andere sociaal-cognitieve determinanten, zoals attitude of sociale invloed (zie bijvoorbeeld Conner en Norman, eds., 1996; Damoiseaux e.a., 1993; Rutter, Quine en Chesham, 1993). Hierdoor werden echter een aantal interessante onderzoeksvragen over kennis van kankerpreventie niet behandelld in deze studie. Het betreft ondermeer de volgende:

- In welke mate bepaalt de voorlichting inzake kankerpreventie de kennis van kankerpreventie?

- In welke mate hangt de kennis van kankerpreventie samen met de toegankelijkheid wan de informatie?

- In welke mate hangt de kennis van kankerpreventie samen met de ervaring met kanker en kankerpreventie?

- In welke mate wordt de kennis van kankerpreventie bepaald door sociale invlloeden uit de directe omgeving?

- Is er direct effect van kennis van kankerpreventie op de participatie(trouw) inzake kankerpreventie?

- In welke mate is er een indirect effect van de kennis van kankerpreventie. op de initiatie en het behoud van kankerpreventief gedrag via attitude, sociale norm en eigen effectiviteit t.a. $v$. kankerpreventie?

- In welke mate spelen ervaring en eigen vaardigheden daarbil een interveniërende rol?

De meeste van deze onderzoeksvragen zijn (rechtstreeks) af te leiden uit een aantal sociaalpsychologische verklaringstheorieen voor (on)gezond gedrag, zoals het 'Health Bellef Model' van Janz en Becker (1984), de "Theory of Reasoned Action' van Fishbein en Ajzen (1975) of de "Theory of Planned Behavior" van Ajzen en Madden (1986). Deze onderzoeksvragen kunnen worden beschouwd als uitdagingen voor vervolgonderzoek.

Onderhavige studie vult dus slechts een klein gedeelte in van het kennishiaat aver de determinanten van (kennis van) kankerpreventie. De specifieke doelstelling de sociaalcognitieve determinant 'kennis van kankerpreventie' beter te begrijpen en te verduidelijken, impliceerde ook een andere restrictie wan het onderzoek. Het kankerpreventief gedrag of de 
participatie aan kankerpreventie die men beoogt te beïnvloeden door het bevorderen van de kennis van kankerpreventie, beperkt zich tot de problematiek van 'beredeneerd' gedrag of gedrag waarover mensen opvattingen hebben die in het kader van een survey-interview op een relatief betrouwbare wijze kunnen worden gerapporteerd. Als mensen het kankerpreventieve gedrag beredeneren en gemotiveerd zijn, plus de mogelijkheid krijgen om $z$ zich te engageren om verkregen informatie te verwerken en om te zetten in gedrag, kumnen kennis en andere cognitieve determinanten een positief effect hebben op de participatie aan kankerpreventie. In sommige gevallen is (gezondheids)gedrag evenwel van nature uit automatisch of spontaan, waardoor er geen afweging gebeurt van allerlei voor- en nadelen van een bepaald gedrag en waardoor omglevingsfactoren een directere invloed kunnen hebben op het gedrag van mensen (Norman en Conner, 1996:219). Het kankerpreventief gedrag wordt m.a.w. niet alleen en niet noodzakelijk bepaald doar cognitieve factoren of determinanten. Door de exclusieve aandacht voor de sociaal-cognitieve determinant 'kennis van kankerpreventie" bleven de andere niet-cognitieve determinanten van kankerpreventie volledig buiten beschouwing'. Sommige van deze determinanten, zoals de sociaal-culturele of de sociaal-structurele determinanten ${ }^{2}$ kunnen zelfs meer nog dan bepaalde sociaalcognitieve determinanten een directe rol spelen om mensen al dan niet aan te zetten tot participatie aan kankerpreventie.

\subsection{Implicaties voor beleid en voorlichtingspraktijk}

Politici en (potentiële) financiers van GVO dringen meer en meer aan op effectiviteit en efficièntie inzake gezondheidsvoorlichting Jlonkers e.a., 1988; Haddix e.a., 1996; Herwig. 1993). Om een uitspraak te kunnen doen over het al dan niet succesvol zijn van de gezondheidsvoorlichting, wordt een 'evaluatieonderzoek' van de GVO-interventie meer en meer noodzakelijk geacht (van den Heuvel, 1995; van Dongen, 1993). De beschikbaarheid van betrouwbare en valide meetinstrumenten die het effect van een interventie kunnen meten is een noodzakelijke voorwaarde om de effectiviteit van GVO te kunnen aantonen. Terzelfdiertijd wordt vanuit de sociale gezondheidswetenschappen meer en meer de noodzaak aangevoeld om bij empirisch onderzoek gebruik te maken van valide en betrouwbare meetinstrumenten, zodat de interpretatie van onderzoeksresultaten minder kan worden aangevochten op basis van een falend meetinstrument (König-Zahn e.a., 1993; McDowell en Newell, 1987; Wilkin, Hallam en Doggett, 1992). Dit proefschrift leverde een bijdrage tot de ontwikkeling van een valide en betrouwbaar meetinstrument om kennis van

1

Voor een zeer volledig overzicht van zowel persoonlijke, familiale, sociale, culturele als structurele determinanten van gezondheidsgedrag, zie de vier volumes van het handboek van Gachman, ed. (1997).

2

Gedacht kan worden aan wet- en regelgeving (bv. werbod op tabaksreclame), het treffen van voorzleningen en maatregelen inzake kankerpreventie (bv. in de voedingssector) en het creëren wean woorwaurden (bv. subsidies) die noodzakelijk zijn om bepaalde kankerpreventieve activiteiten to kunnen ontwikkelen. In die zin is voorlichting inzake kankerpreventie maar een onderdeel van de kankerprewentieve sector die een veel ruimer terrein bestrijkt. 
kankerpreventie te kunnen onderzoeken. In de hoofdstukken 1 en 2 werden enkele aanknopingspunten beschreven voor het gebruik van een dergelijk meetiristrument in het kader van de voorlichtingspraktijk inzake kankerpreventie. In deze paragraaf wordt hier verder op ingegaan.

In het kader van wetenschappelijke begeleiding van GVO die voorzien dient te worden bij het opzetten en uitvoeren van interventies inzake kankerpreventie (cff. de GVO-cyclus van Kok, 1987a; Damoiseaux e.a., 1993; zie ook hoofdstuk 2), heeft het hier ontwikkelde meetinstrument ${ }^{\prime}$ toepassingsmogelijkheden bij effectonderzoek. Om vragen naar de effectiviteit van een voorlichtingsprogramma op een wetenschappelijke manier te kunnen beantwoorden, dient het effect te worden onderzocht (Herwig, 1993; van Dongen, 1993). Het beoogde effect kan gericht zijn op veranderingen in het gedrag van de doelgroep, maar ook op veranderingen in het kennisniveau. Om zicht te krijgen op het effect van de voorlichting kan men bijvoorbeeld bij de doelgroep een voor- en nameting van het kennisniveau organiseren en door vergelijking van de twee metingen het effect kwantificeren. Door afname van de kennisvragenlijst voor en na de interventie kan met andere woorden worden nagegaan of de interventie een effect heeft gehad op de kennis van de doelgroep en zo ja, welk effect. Het kenniseffect van een interventie kan eventueel ook worden gemeten door vergelijking van de meetresultaten met een controlegroep (bij wie geen interventie plaatsvond?.

In onderhavig onderzoek werd veel zorg en tijd besteed aan het trekken van een representatieve steekproef. Deze representatieve steekproef was noodzakelijk om via statistische toetsing te kunnen naglaan of de gevonden resultaten veralgemeend mochten worden naar de totale Vlaamse bevolking. Dergelijk bevolkingsonderzoek is vrij omslachtig. tijdrovend en erg duur, maar het is de enige mogelijkheid om representatieve onderzoeksgegevens voor de hele Vlaamse bevolking te genereren. Ook on de verdeling van schaalscores te kunnen bepalen - of met andere woorden om de kennisschalen te normerenwas het noodzakelijk om te beschikken over een grote en representatieve steekproef (Spector, 1992) ${ }^{2}$. Hierdoor waren betrouwbare analyses van subpopulaties mogelijk. Enkel door een representatief beeld van het niveau en de spreiding van kennis van kankerpreventie in de bevolking kunnen immers goede evaluaties worden gemaakt van de geregistreerde kennis van subpopulaties.

Het meetinstrument ontwikkeld in dit proefschrift kan in zijn totaliteit worden gebruikt, maar de individuele schalen kunnen ook afzonderlijk toegepast worden, bijworbeeld in het kader van een meer specifieke voorlichtingscampagne gericht op éen indicator (bv. een voorlichtingscampagne over risicafactoren van kanker). Verder kunnen met de beschikbare data eventueel ook verkorte of aangepaste schalen worden geconstrueerd. Deze dienen dan well eerst op hun betrouwbaarheid en validiteit te worden onderzocht, vooraleer ze worden toegepast.

Dit lijkt evident, doch in de praktijk van de schaalconstructie is dit niet altijd het geval. Veel meetschalen worden immers vaak genormeerd bij 'selecte' populaties (bv. studentenpopulaties). waardoor de generaliseerbaarheid vaak te wensen overlaat (Spector, 1992:67). 
Door de toepassing van het meetinstrument bij een representatieve steekproef in Vlaanderen zijn dus uitspraken mogelik over het niveau van kennis van kankerpreventie in Vlaanderen. De kennisscores die werden geregistreerd in dit onderzaek kunnen ook een referentiewaarde vormen voor planning en/of evaluatie van voorlichting inzake kankerpreventie in Vlaanderen. Zij kunnen als norm worden gehanteerd voor nieuw op te zetten kankerpreventiecampagnes die een 'resultaatevaluatie' van de voorlichting beogen. De betekenis van een score op een kennisschaal kan immers enkel worden bepaald in relatie tot een referentiekader. Het gebruik van deze normen maakt met andere woorden een betrouwbare positionering mogelijk van het kennisniveau van specifieke doelgroepen of regio's. Het onderzoek naar de kennis van kankerpreventie bij de Vlaamse bevolking kon via onderzoek naar geslacht, leeftijd, beroepsstatus, opleiding, inkomen en sociaal-economische status ook gemiddelde kennisscores op subpopulatieniveau vastleggen. Deze gegevens kunnen als toetsnormen worden gebruikt bij interventies bij deze specifieke doelgroepen. De beschikbaarheid van deze normatieve gegevens op subpopulatieniveau verhoogt de kans op betekenisvolle vergelikingen en interpretatie van toekomstige onderzoekgegevens (Spector, 1992: 68). De gemiddelde kennisscores in deze studie kunnen daarbij als toetsnormen worden gehanteerd door zowel de bevoegde overheden als door particuliere preventieverenigingen.

Oolk in het kader van een globale evaluatie van het actuele (of toekomstige) voorlichtingsbeleid inzake kankerpreventie in Vlaanderen bevat het in dit proefschrift ontwikkelde meetinstrument mogelijke toepassingen. Het overzicht wordt hier beperkt tot een opsomming van een aantal concrete doelstellingen die kunnen worden geëvalueerd door het gebruik van het ontwikkelde meetinstrument (vergelijk Mootz en van de Vathorst, 1992).

Een eerste doelstelling is van algemene aard. De bevraging van de kennis van kankerpreventie van de bevolking kan worden beschouwd als een (beleids)instrument om het kennisniveau van de bevolking empirisch vast te stellen. De gegevens over kennis van kankerpreventie kunnen in dit verband gezien worden als aanvulling op andere, reeds langer bestaande gegevens zoals doodsoorzakenstatistieken en de registratie van de kankers en de kankermorbiditeit. Resultaten van bevolkingsstudies zoals deze kunnen behulpzaam zijn om de allocatie van publieke middelen in de gezondheidszorg te evalueren en zo nodig te heroriênteren.

Als tweede mogeilike doelstelling kan het meten van kennis van kankerpreventie ook informatie opleveren over de verdeling van deze kennis volgens verschillende regio's of provincies. Wanneer er zich bij meting op eenzelfde tijdstip en met eenzelfde instrument significante regionale verschillen voordoen, dan zijn in principe uitspraken mogelijk over ongellike geografische verdeling van kennis van kankerpreventie. Daarna kan dan worden gezocht naar mogelijke verklaringen en oplossingen voor dergelijke ongelijke verdeling. Een ongelijke inplanting van voorlichtingscampagnes inzake kankerpreventie kan een mogelijke oorzaak zijn en 'achtergestelde regio's' kunnen worden geïdlentificeerd.

Hiermee nauw verwant is een derde mogelijke doelstelling van het meten van kennis van kankerpreventie, namelijk informatie verzamelen over lonlgelijke verdeling van de kennis van kankerpreventie naar sociale categorieën. Na meting van kennis van kankerpreventie in een bepaalde doelgroep en na vergelijking (met de normen) kan men daardoor 'achtergestelde 
groepen' identificeren. Het signaleren van achtergestelde groepen aan beleidvoerders kan dus een bellangrijke reden zijn om kennis van kankerpireventie te meten. Door belleidvoerders in de politiek, de administraties of in de particuliere kankerverenigingen kunnen dergelijke onderzoeksresultaten in overweging worden genomen om in de toekomst eventueel selectievere preventiecampagnes te plannen en te organiseren. Zulke vaststellingen kumnen ook aanleiding geven tot het overwegen en ontwikkelen van aangepaste interventies bij de betreffende doelgroepen (Deliens, 1991; De Walle-Sevenster en Kok, 1991; Uniken Venema en Garretsen, 1995).

Naast het signaleren van achtergestelde regio's of groepen is het signaleren van verschillen tussen verschillende kennisdomeinen van kankerpreventie een vierde mogelijke doelstelling. Wanneer er significante kennisverschillen worden vastgesteld tussen bijvoorbeeld primaire kankerpreventie en secundaire kankerpreventie, kan dit - zeker in een situatie van beperkte. budgettaire mogelijkheden - aanleiding geven tot het verschuiven van de prioriteiten in het kankerpreventiebeleid en het eventueel veranderen van de inhoud van de voorlichtingsboodschappen die worden gebruikt tijdens campagnes. Het meten van kennis van kankerpreventie kan dus hulp bieden bill de keuze én de ontwikkeling van de boodschap". Eens de doelpopulatie en het beoogde (gedrags)objectief werden vastgesteld, kan men de juiste boodschap trachten te identificeren voor de voorlichting. Het vastleggen van de juiste boodschap zal ondermeer in functie van de aanwezige (adequate) kennis moeten gebeuren.

Voorts is het kunnen vaststellen van trends in de tijd een vijfde mogelijke doelstelling varn het meten van kennis van kankerpreventie. Door middel van een (tussentijdse) evaluatie van bepaalde voorlichtingscampagnes kan een daling of een stijging in bepaalde domeinen van kemnis vastgesteld worden. Op die manier kan men bewaken of de geleverde inspanningen de verwachte resultaten opleveren. Tevens kan door tussentijdse metingen ook het 'rendement" van de voorlichtingsactiviteiten worden geëvalueerd. Dergelijk tussentijds evaluatieonderzoek biedt met name de mogelijkheid tot kwaliteitsverbetering van de voorlichtingspraktijk (Herwig, 1993:46). Trends uit het verleden bieden tot op zekere hoogte verder de mogelijkheid om bepaalde voorspellingen te maken in verband met toekomstige ontwikkelingen, waardoor een langetermijnplanning van voorlichting inzake kankerpreventie mogelijk wordt.

Het in dit onderzoek vastgestelde kennisniveau van kankerpreventie bij de Vlaamse bevolking laat ook toe enkele kanttekeningen te maken bij de voorlichtingspraktijk inzake kankerpreventie en bij het gevoerde beleid terzake.

De onderzoeksresultaten wijzen op een duidelijke overschatting van de screeningsfrequentie voor baarmoederhalskanker en borstkanker. Met betrekking tot de twee meest aanbevolen screeningsonderzoeken, namelijk het baarmoederhalsuitstrijkje en de mammografie, kon zeer duidelijk een verkeerde perceptie van de richtlijnen over zowel 'aanvangsleeftijd' als

Om een duidelijk onderscheid te maken tussen beide GVO-activiteiten spreekt men in de angelsaksiche literatuur van 'getting the right message' en 'getting the message right" (zile hoofdstukken 7 en 8 in Egger, Donovan en Spark, 1993). 
'frequentie' worden vastgesteld. Voor het baarmoederhalsuitstrijkje wordt de frequentie te hoog ingeschat. Voor de mammografie wordt de beginleeftijd te laag ingeschat en de frequentie te hoog. Dat deze misperceptie aanleiding kan geven tot overconsumptie van deze preventieve geneeskundige onderzoeken hoeft geen betoog. Deze misvattingen zouden te wijten kunnen zijn aan een mogelijke (sterke) inwloed van het reeds bestaande kankerpreventief gedrag op de kennis van kankerpreventie. Uit tall van onderzoeken over participatie aan secundaire kankerpreventile is immers gebleken dat er ten aanzien van screening van baarmoederthalskanker voor sommige categorieẻn vrouwen duidelijk sprake is van overscreening (Arbyn e.a., 1996). De kennis zou met andere woorden ook kunnen zijn beinvloed door het gedrag zelf. De vraag stelt zich of de gerapporteerde (wenselijke) screeningsfrequentie voor baarmoederhalskanker lof borstkanker/ meer overeenkomt met het actuele gedrag dan met de medische aanbeveling. Als dat laatste zo is dan wordt er waarschijnijijk inadequate informatie over baarmoederhals- en borstkankerscreening verkregen via de zorgverlener en is het aangewezen om bij voorlichtingscampagnes meer (complementaire) aandacht te schenken aan voorlichting van de voorlichters (bv. de artsen). Bij het concipiëren van voorlichtingscampagnes rond kankerpreventie dient men zich van het hier gesignaleerde gevaar bewust te zijn, zoniet kan het effect van de voorlichting eerder negatief zijn en aanleiding geven tot een inadequal (screenings) gedrag.

In het onderzoek werd ook vastgesteld dat de aanbevelingen of richtijnen waarover in medische kringen een consensus bestaat door de bevolking vrij goed gekend zijn (bv. baarmoederhalsuitstrijkje als vroegtijdig opsporingsonderzoek wan baarmoederhalskanker, mammografie als vroegtijdig opsporingsonderzoek van borstkanker of stoppen met roken ter preventie van longkankerl, terwijl deze waarover in medische kringen weinig consensus bestaat minder goed gekend zijn (bv. de richtlijnen over aanvangsleeftijd en frequentie van vroegtijdige opsporing van baarmoederhalskanker of borstkanker, de risicofactoren inzake voeding). Deze resultaten wijzen op het belang van duidelijke en vooral eenduidige medische richtijnen met betrekking tot kankerpreventie. Met betrekking tot het ontwikkelen van een doeltreffender beleid inzake kankerpreventie is het belangrijk dat de kennis en vaardigheden die in de medische wetenschappen worden ontwikkeld en geobjectiveerd $(b v$. via consensusrapporten of standaarden) door middel van eenduidige richtijinen of aanbevelingen toegankelijk worden gemaakt voor de preventiesector en de zorgverieners. Dit bevordert de overdracht wan gewenste medische kennis naar de bevolking toe. Verder dient de verspreiding van deze richtlijnen of aanbevelingen naar de bevolking te gebeuren met dezelfde boodschappen die dan op en consequente wijze worden gebruikt in de voorlichtingsactiviteiten.

Eén van de methoden om eenduidige richtlijnen of aanbevelingen toegankelijk te maken voor de preventiesector en de zorgverleners is bijvoorbeeld het ontwikkelen van een 'standaardenbeleid" voor de voorlichting inzake kankerpreventie. Het doel van bijvoorbeeld het standaardenbeleid van het Nederlandse Huisartsen Genootschap is het opstellen van wetenschappelijke richtlijnen voor het dagelijks handelen van huisartsen, die tevens een instrument vormen voor deskundigheidsbevordering (Grol, 1989; NHG-bestuur, 1989). Door het ontwikkelen van zulke standaarden weten de huisartsen, maar ook de bevolking en andere zorgverleners (bv. de specialist), wat er tot het takenpakket van de huisarts behoort. Doordat deze standaarden in nauw overleg met de huisartsen zelf worden ontwikkeld, 
bevordert dit de toegankelijkheid van de richtlijnen af aanbevelingen voor de zorgverleners en verhoogt dit ook de kans op een eenduidige verspreiding naar de bevolking ${ }^{1}$. Een analoge methodiek zou ook kunnen worden ontwikkeld inzake kankerpreventie. In het licht van de bevindingen van onderhavige studie kan worden gesteld dat de bestaande inspanningen die worden verricht om bijvoorbeeld aanbevelingen voor kankerpreventile te ontwikkelen, meer zouden moeten worden alangemoedigd en gesystematiseerd door de overheid en de medische wetenschappen. Tevens kan worden gezocht naar methodes om de communicatie van deze richtlijnen naar de bevolking beter te kunnen stroomlijnen. Het ontwikkelen en implementeren van standaarden voor kankerpreventie is één mogelijke denkpiste. In de Verenigde Staten is een dergelijk standaardenbeleid reeds ontwikkelld voor de academische opleiding van GVO-ers en preventiewerkers (Capwell ${ }^{1997) .}$

Verder komt uit de onderzoeksresultaten overduidelijk naar voor dat inzake primaire kankerpreventie mensen meer weten over wat volgens de richtlijnen niet wenselijk is (zgn. "verboden"), dan wat volgens de kankerprewentieve richtlijnen wel wenselijk is (zgn. 'geboden'). De score van kennis van primaire kankerpreventie wordt namelijk gevormd door een relatief hoge kennis van de risicofactoren en een relatief lage kennis van het gewenst kankerpreventief gedrag. Respondenten wisten dus beter wat ze vanuit kankerpreventieve overwegingen niet mogen doen in hun leef- of eetgewoonten dan wat ze wel mogen of moeten doen. Deze vaststelling is een oud zeer in de gezondheidsvoorlichting inzake primaire preventie (Bloom, 1996). Het kan vermoedelijk worden verklaard doordat jarenlang in preventiecampagnes meer nadruk werd gelegd op wat 'verboden' is, dus wat ongezond is in de leef-en eetgewoonten, dan op de mogelijke en gewenste altematieven. De boodschappen waren eerder negatief van teneur en minder positief. Pas in de afgelopen jaren wordt de bevolking ook meer en meer benaderd met positieve preventieboodschappen, dus met boodschappen over wat men wél bij voorkeur eet of doet. Zo wordt bij dieetadvies niet meer uitsluitend gezegd dat men geen of minder vet mag eten, maar dat meln bij voorkeur meer vezelrijke woedingstoffen eet. Deze verschuiving van aandacht in voorlichting is eem resultaat van een meer algemene wijziging in het gezondheidsdenken in onze samenleving (Westendorp, 1990: 6-18). De accentverschuiving in het gezondheidsdenken is inmiddels op verschillende terreinen merkbaar. Zo was er de afgelopen decennia in de

De standaarden inzake kankerpreventie, volgens de methodiek ontwikkeld door het Nederlandset Huisartsen Genootschap, kunnen op verscheidene manieren een hulp zijn (vrij naar NHG-bestuur, 1989). Allereerst kan een standaard voor de hulpwerlener of preventiewerker een houvast zijn, lets waaraan hij kan refereren in zijn contacten met de patiënt of met de bevolking makar ook mot andere hulpverleners (bv. specialisten). Tegenover de patiënt of de bevolking kan de standaard gepresenteerd worden als een wetenschappelijk verantwoorde manier om een bepaald preventieprobleern aan te pakken. In de tweede plaats is een standaard ook een uitcaging voor de arts en zijn praktijkorganisatie. Er wordt hem eern duidelijk omschreven doel voor ogen gehouden, waarnaar hij via bijscholing en adequate praktikorganisatie kan streven. De derde hulp die standaarden kunnen biedien, ligt meer op het collectieve wlak. Door standaarden te antwikkelen en te implementeren wordt de kankerpreventie onderbouwd en uitgebouwd. De prewentie krigt een eigen, herkenbaar gezicht. Dat leidt tot een grotere eenduidigheid in de boodschap en een stroomlining in de overdracht naar de bevolking. Dit laatste veronderstelt dat naast de artsen ook voorlichtingsorganisaties dienen te worden betrokken bij een dergelijk standaardenbeleid. 
definitie van gezondheid een geleidelijke overgang van een negatieve naiar een positieve invulling. Ook institutioneel kon in Vlaanderen de afgelopen jaren, ondermeer door de oprichting van het Vlaams Instituut voor Gezondheidspromotie, een groeiende aandacht voor gezondheidspromotie worden vastgesteld.

Een volgende kanttekening betreft de vaststelling van een zeer matige kennis van voedingsgewoonten die kunnen worden gerelateerd aan kanker(preventie). Zo worden overmatig alcoholgebruik, overmatig gebruik van dierlike vetten of 2 waarlijvigheid matig herkend als voedingsgewoonte die een verhoogd risico op kanker inhoudt. Terzelfdertijd worden regelmatig eten van bruin brood of regelmatig eten van ongepelde rijst onvoldoende herkend als wenselijke eetgewaonten ter preventie van kanker. De gebrekkige kennis van de aan kanker gerelateerde voedingscomponenten is zorgwekkend". Hoewel men in de medische wetenschappen nog steeds onzeker is over welke kankerwerwekkende agentia in de voeding echt belangrijk zijin, wordt het toch waarschijnlijk geacht dat bepaalde voedingscomponenten meebepalend zijn voor het ontstaan van kanker (Benito e.a., 1992; Eylenbosch e.a., 1988: 40). Er bestaat een ruime consensus over de wenselijkheid orm het gebruik van dierlijke vetten en alcoholische dranken te beperken en om het verbruik van vezelrijke voedingsproducten, zoals vers fruit, verse groenten, bruin brood en ongepelde rijst aar te moedigen.

De gebrekkige kennis van aan kanker gerelateerde voedingscomponenten is echter wel begrijpelijk (Beijer e.a., 1994). Ten eerste is het moeilijk om de invloed van voeding op het ontstaan van kanker aan te geven. Kanker is vrijwel nooit het gevolg van én enkele oorzaak. Ten tweede heeft voeding in tegenstelling tot bijvoorbeeld roken niet enkel een negatieve invloed op de gezondheid, maar kan het ook een beschermende factor tegen kanker zijn. Ten derde wordt er in kranten en tijdschriften regelmatig over dit onderwerp geschreven. De berichten over stoffen die kankerverwekkend zijn of over diëten die kankerbeschermend zouden zijn, zijn niet altijd eenduidig en berusten niet altijd op goed of afgerond onderzoek. Zo worden er naast adequate informatie ook veel misvattingen over voeding en kanker in omloop gebracht. Ten vierde zijn er ook verschillende sectoren met uiteenlopende belangen begaan met vaedingsvoorlichting. De belangen van de voedingssector of de distributiesector zijn zeker niet altijd gelijklopend met deze van de gezondheidszorg en de gezondheidsvoorlichting. Bovendien hebben meerdere studies aangetoond dat het beinvloeden van voedingsgewoonten een bijzonder moeilijke opdracht is. Ook de vaststelling in onderhavig onderzoek dat er in Vlaanderen een gebrekkige kennis is van kankerpreventieve voedingsgewoonten doet een gebrekkige effectiviteit van de gezondheidsvoorlichting inzake voedingsgewoonten vermoeden.

De vraag blijt hoe voedingsgewoonten efficiënter kunnen worden beinvloed. Omdat voedingsconsumptie een veel complexer 'gedrag' is dan bijvoorbeeld roken of participatie aan vroegtijdige opsporing van baarmoederhalskanker, vraagt dit bij het opzetten van GVO

i1

De meeste van de aan kanker gerelateerde voedingscomponenten zijn niet alleen in relatie tot kanker van belang. Zij beperken ook de risico's van andere veel voorkomende ziekten, zoals harten vaatziekten, diabetes of maag-en darmziekten (Beiler e.an, 1994: 21). 
om meer reflectie en meer anderzaek van de determinanten van voedingsgewoonten (Brug. van Assema en Kok, 1998). De GVO-aanpak is bijgevolg complexer dan bij veel andere risicogedragingen en ze vraagt zeker ook om een 'intersectorale' benadering (Chapman, 1990; Maes, 1996/ ${ }^{\prime}$. De traditionele medische sector en de sector van de gezondheidsvoorlichting alleen kunnen dit probleem niet aan. Voor het opstellen van aanbevelingen en het afstemmen van de voorlichtingsboodschappen is coördinatie vereist tussen alle betrokken sectoren, inclusief de voedingsindustrie, de distributiesector, de landbouw en andere voorlichtingsorganisaties (bv. consumentenvoorlichting).

De verbanden die er werden vastgesteld tussen de sociale determinanten en kennis van kankerpreventie geven eveneens aanleiding tot een aantal kanttekeningen.

Het gezondheidswetenschappelijk onderzoek inzake kankerpreventie, zoals in dit proefschrift geconcipieerd en verricht, beoogt een analyse van complexe gegevens op populatieniveau. De verbanden of invloeden die daarbij worden onderzocht, zijn niet minder complex dan invloeden of relaties die worden onderzocht in om het even welke andere wetenschappelijke discipline. Preventiewerkers en beleidsverantwoordelijken verwachten evenwel van bevolkingsonderzoek vaak eenvoudige antwoorden op complexe vragen. Dit onderzoek kon evenmin tot eenvoudige antwoorden komen. Zoals is gebleken, werd de problematiek van kennis van kankerpreventie geconfronteerd met een complexiteit van zowel het centrale onderzoeksconcept als van de samenhang met de sociale determinanten. Verder moeter bij de onderstaande aanbevelingen, gebaseerd op de onderzoeksresultaten over de samenhang tussen de sociale determinanten en kennis van kankerpreventie, ook de hoger vermelde restricties van dit onderzoek indachtig blijven.

In de afgelopen jaren is uit tal van onderzoek gebleken dat kankervoorlichting en vroegtijdige opsporing van kanker betere resultaten hebben opgeleverd bij de sociaal-economisch hogere categorieën dan bij de sociaal-economisch lagere categorieën (zle hoofdstuk 8). De problematiek van socialle ongelijkheid inzake kankerpreventie wordt ook in Vlaanderen meer en meer op de beleidsagenda geplaatst (Bonte e.a., 1991; Kankerpreventie in Vlaanderen, 1996). Hier rijst de vraag welke specifieke interventies noodzakelijk zijn om deze sociale ongelijkheid weg te werken. Omdat in dit onderzoek overduideilijk is gebleken dat er ook sprake is van sociale ongelijkheid inzake kennis van kankerpreventie is eén van de mogelijke middelen het wegwerken van het ongelijke kennisniveau. Hoewell de oorzakelijkheid tussen voorlichting en kennis van kankerpreventie in dit proefschrift niet is onderzocht, werd vastgesteld dat in Vlaanderen - niettegenstaande de massale voorlichting over kankerpreventie die ook via de populaire media werd verspieid (bv. via radio of T.V.) - miet alle Vlamingen in gelijke mate de vruchten van deze inspanningen hebben geplukt. Mensen met

1

De bevoegdheden in verband met voeding zijn in België sterk verdeeld over de federale en de regionale owerheden. Meer en meer worden ook Europese reglementeringen van toepassing. Verder zijn ook verschillende sectoren en organisaties betrokken bij de voorlichting aan de bevolking. Gezien de versnippering van de bevoegdheden over diverse departementen en beleidsniveaus en gezien de betrokkenheid van verschillende sectoren bij de voorlichting, is het voeren van een coherent voedingsbeleid in Belgie geen eenvoudige zaak (Maes, 1996: 195). 
een lage sociaal-economische status hebben significant minder kennis over kankerpreventie dan mensen met een hoge sociaal-economische status. Deze sociaal ongelijke verdeling van kennis van kankerpreventie wordt zowel vastgesteld in het domein van primaire karikerpreventie als in het domein van secundaire kankerpreventie. Dit betekent dus een dubbel nadeel voor personen met een lage sociaal-economische status. Zij zijn riet alleen minder goed geïnformeerd of "cognitief uitgerust" om kanker te helpen voorkomen door bijvoorbeeld hun leefstijl aan te passen; zil zijn ook minder geinformeerd of "cognitief uitgerust" om kanker vroegtijdig te laten opsporen, zodat ze een even grote overlevingskans zouden krijgen als mensen met een hoge sociaal-economische status.

Uit het onderzoek is gebleken dat de 'achtergestelde' categorieën inzake kennis van kankerpreventie in de eerste plaats kunnen worden geïdentificeerd aan de hand van hun sociaal-economische status en pas in tweede instantie door socio-demografische kenmerken. Interessant hierbij was ook dat de geintegreerde sociaal-economische status op basis van zowell opleiding, inkomen als beroepsstatus in het algemeen een sterkere samenhang vertoonde met kennis van kankerpreventie dan de afzonderlijke indicatoren opleiding, inkomen of beroepsistatus. Dit onderzoeksresultaat ondersteunt daarmee de aanbeveling dat SES in sociaal-medisch onderzoek het best wordt geoperationaliseerd door een gecombineerde indicator op basis wan opleiding, inkomen en beroepsstatus (Van Berkelvan Schaik en Tax, 1990). Deze vaststelling wijst er verder op dat men bij identificatie van "achtergestelide" categorieën best ook meerdere SES-indicatoren gebruikt en zich niet beperkt tot één. Dat de relatie tussen SES en gezondheid een 'continue' lineaire relatie is en niet een binaire relatie - krijgt doar het onderzoek complementaire ondersteuning (Carroll en Smith, 1997). Op basis van de bevindingen is het niet zo dat éen bepaalde SES-categorie kan worden afgebakend met een slechte kennis over kankerpreventie en andere categorieën met een redelijk adequate kennis. De kennis van kankerpreventie is ongelijkmatig gespreid en stijgt gradueel naarmate de SES gradueel stijgt. Dit onderzoeksresultaat biedt aanvullende ondersteuning aan de consistente stroom van kwantitatieve studies die ook een graduele relatie tussen ziekte/gezondheid en SES aantonen (Carroll en Smith, 1997: 276). Toekomstig onderzoek over kennis van kankerpreventie in Vlaanderen zal kunnen aanwijzen of deze kennisverschillen stabiel zijn, dan wel groter of kleiner worden. Ten behoeve van interventies is het dus heel belangrijk om een beter zicht te krijgen op de relatie tussen SES en participatie aan kankerpreventie. De bevindingen suggereren dat daarbij ook rekening dient te worden gehouden met een ongelijke socio-economische verdeling van de kennis inzake kankerpreventie. Gedragsgerichte interventies die het wegwerken wan sociale ongelijkheid inzake kankerpreventie tot doel hebben, kunnen bijgevolg best worden ondersteund door interventies die zich ook tot doel stellen de kennisongelijkheden te reduceren.

Meer in het algemeen wijzen de onderzoeksresultaten op de noodzaak om bij GVO meer "doelgroepgericht" te werk te gaan, zowell bij het concipiëren als bij het uitvoeren van voorlichtingscampagnes inzake kankerpreventie. Het valstaat daarbiij niet alleen de vorm en de kwalliteit van een interventie en/of boodschap af te stemmen op de doelgroep. Ook inhoudelijk dient men rekening te houden met de specificiteit van het voorlichtingsdomein inzake kankerpreventie. Algemene boodschappen voor een algemeen publiek lijken op grond van de onderzoeksresultaten op zijn minst een bevoor- of benadeling in te houden ter 
aanzien van bepaalde sociale categorieën. Een meer doelgroepgerichte aanpak lijkt sociaal meer gerechtvaardigd. Dit impliceert dat men bij voorlichtingscampagnes inzake kankerpreventie " vooraleer alle stappen van de gedragsbeinvloeding worden geconcipieerd, veel meer aandacht moet besteden aan de analyse van de doelgroep die men met betrekking tot een specifiek kankerpreventief domein wenst te beinvlloeden (McGuire, 1985; Kok, 1993; zie ook Egger, Donovan en Spark, 1993). Als de doelgroep aan de hand van de sociale kenmerken kan worden afgebakend, zal men ook veel concreter kunnen vaststellen hoe bij de doelgroep de aandacht kan worden gewekt voor een kankerpreventieve boodschap, welke "bron" (voorlichter of organisatie) het meeste gezag heeft bij de doelgroep, welke 'boodschap' door de doelgroep begrepen wordt en welk 'communicatiekanaal" het meest optimaal werkt opdat de doelgroep zou worden bereikt (Kok, 1993). De voorlichtingsboodschap kan immers pas effect hebben als de doelgroep eraan blootgesteld wordt en deze er aandacht aan besteedt. Een belangrijke voorwaarde om dit te kunnen bereiken, is dat heel het concept van de woorlichting aansluit bij de doelgroep. Dat dergelijke goed geconceptualiseerde en goed uitgevoerde voorlichting (onder welbepaalde voorwaarden) ook bij sociaal achtergestelde categorieën effectief kan zijn, werd al meerdere malen aangetoond op het vlak van alcohol-, tabaks- en drugspreventie (Simons-Morton, Donohew en Crump, 1997 \%.

Tot slot van dit hoofdstuk kan er n.a.v. het in Vlaanderen vastgestelde niveau van kennis van kankerpreventie een kritische socio-culturele kanttekening worden geplaatst bij het gevoerde beleid terzake.

De ontwikkelingen in de gezondheidszorg en de kankerpreventie, zoals beschreven in hoofdstuk 2, worden niet alleen bepaald door beroepsgroepen of beleidsverantwoordelijken, maar evenzeer door sociaal-culturele processen. De beleidskeuzes van politici en van beroepsgroepen hangen immers samen met wat er aan opvattingen leeft bij de bevolking. Daarom kan één van de belangrijkste resultaten van deze studie, met name de vaststelling dat secundaire kankerpreventie beter gekend is dan primaire kankerpreventie, ook worden gesitueerd in een ruimer kader van maatschappelijke veranderingen, met name de 'medicalisering' van de samenleving. In neutrale zin betekent de term "medicalisering' het proces van uitbreiding waardoor steeds meer terreinen in de maatschappij onderworpen worden aan medische definierring en jurisdictie (Velle, 1991: 30-31). De vraag kan worden gesteld of de combinatie van een relatief hoge kennis van secundaire kankerpireventie met een relatief lage kennis van primaire kankerpreventie in Vlaanderen aanleiding kan zijn woor eerly verdere medicalisering van de samenleving? Hiermee wordt bedoeld dat kankerpreventie meer en meer het terrein dreigt te worden van het medisch corps en minder en minder van de bevolking, die via aanpassing van eigen leefstijl en zelfredzaamheid ook kanker kan helpen voorkomen. Een aantal resultaten van deze studie wijst duidelijk in die richting. De aspecten die vooral gericht zijn op het voorkomen van kanker - en dus op het voorkomen van medische consumptie (voor diagnose of behandeling) - waren diuidelijk minder goed gekend dan de aspecten die gericht zijn op vroegtijdige opsporing. Van de opsporingsonderzoeken voor borst- en baarmoederhalskanker waren bovendien de opsporingstechnieken die een tussenkomst vergen van een arts (nl. mammografie en baarmoedierhalsuitstrijkjel beter gekend dan de opsporingstechniek die gebaseerd is op de zelfredzaamheid (nl. het borstzelfonderzoek). Verder wordt ook vastgesteld dat de kennis 
van de richtlijnen voor vroegtijdige opsporing van baarmoederhalskanker en borstkanker een medische overconsumptie van de preventieve geneeskundige diensten in de hand kan werken. Tot slot was ook het "onderscheidingsvermogen" (het vermogen om onderscheid te kunnen maken tussen factoren die echt iets te maken hebben met kankerpreventie en factoren die geen rol spelen bij kankerpreventie) in het kennisdomein van secundaire kankerpreventie beduidend groter dan in het kennisdomein van primaire kankerpreventie.

Deze tendens naar medicalisering van preventie lijkt enigszins paradoxaal. Preventie is immers niet alleen gericht op het voorkomen van een vroegtijdig overlijden aan kanker, maar ook op het verkorten van de periode van athankelijkheid van het medisch corps IDufour, 1997:97; zie ook Moss, 19961. Anders gezegd, van kankerpreventie wordt ook verwacht dat het miet alleen de levensverwachting van de bevolking verlengt, maar ook dat de levenskwaliteit wordt verbeterd doordat minder mensen ziek worden. In hoofdstuk 2 werd ook beschreven dat de preventiesector juist is ontstaan als reactie van de overheid, de gezondheidswerkers en de bevolking op de medicalisering van de gezondheidszorg en de samenleving. Het blijkt nu dat het door de overheid geïnitieerde proces om medicalisering tegen te gaan via preventie en gezondheidspromotie - althans wat de sector van de kankerpreventie betreft - eerder faalt. De bevolking is immers meer vertrouwd met secundaire dan met primaire kankerpreventie. Zij weet dus meer over de gemedicaliseerde vormen van kankerpreventie dan over de niet-gemedicaliseerde vormen van kankerpreventie.

Secundaire kankerpreventie is in tegenstelling tot primaire kankerpreventie logischerwijze het meest uitgesproken gemedicaliseerd. Het betreft immers het opsporen van ziekten in een vroeg, presymptomatisch stadium en het beoogt de voortgang van een ziekte te vertragen of tot stilstand te brengen in een stadium dat de ziekte nog geen verschijnselen geeft en de patiënt nog geen medische hulp inroept (Moss, 1996). Met de vroegdiagnose van een aandoening beoogt men in dit vroeg stadium een medische behandeling te starten, zodat er een grotere kans op volledige genezing is. Zo bijvoorbeeld beoogt men door screening van baarmoederhalskanker pre-cancereuze letsels van de baarmoederhals vroegtijdig te ontdekken en te behandelen, zodat evolutie naar een invasieve kanker wardt vermeden (Arbyn e.a., 1996: 26). Secundaire preventie is vrijwel exclusief gesitueerd in de medische sector en de opsporing van kanker leidt tot een actie of behandeling door de curatieve geneeskunde. Het feit dat mensen meer kennis hebben van secundaire kankerpreventie dan van primaire kankerpreventie impliceert dat zij beter cognitief zijn uitgerust om te participeren aan deze secundaire kankerpreventie dan aan de primaire kankerpreventie. Mocht secundaire kankerpreventie (potentieel) de grootste gezondheidswinst opleveren, dan konden de inspanningen die geleid hebben tot deze meerkennis in secundaire kankerpreventie maatschappelijk worden verantwoord. Helaas is het anders. Meer en meer is men ervan overtuigd dat de grootste gezondheidswinst moet worden verwacht van primaire kankerpreventie (bv. door niet roken, door matig alcoholgebruik, gezonde voeding, enz.). temeer omdat de vroegtijdige opsporing van kanker en de bestaande therapieên alleen in bepaalde orgaanlokalisaties resultaten opleveren (Eylenbosch e.a., 1988. 11. Aldus gaat de beleidskeuze in de aanpak van de problematiek van kankerpreventie primair over "wie" het preventief gedrag of de preventieve zorg op zich zal nemen (de burger of de patient) en 'waar' deze preventieve zorg zal plaatsvinden (in het dagelijkse leven of in de consultatieruirnte van een arts). 
Men begrijpe deze slotbeschouwing evenwel niet verkeerd. Er wordt hier geenszins gewaarschuwd voor een 'imperialistische' machtsovername van kankerpreventie door het medisch corps (Zola, 1973: 128). De maatschappelijke veranderingen inzake gezondheid en preventie grijpen op subtiele wijze plaats. Het is een diffuus fenomeen dat de opvattingen van mensen in onze samenleving beïnvloedt waardoor er een legitieme basis wordt gecreëerd voor het medisch corps om de zorg voor kankerpreventie op zich te nemen. In dit onderzoek zijn er duidelijke aanwijzingen voor deze legitimerende opvattingen bij de Vlaamse bevolking. Terzelfder tijd is de geneeskunde ook bereid om zich met dit maatschappelijk probleem in te laten'. De medicalisering van kankerpreventie is dus evenzeer een gevolg van het medisch en sociaal vermogen van de geneeskunde, als van het verlangen en de wensen van de samenleving zelf. In het gebrek aan aandacht voor primaire kankerpreventie schuitt evenwel het gevaar dat zowel beleidsmensen als medici hierdoor draigen voorbij te gaan aan oplossingen die misschien meer woor de hand liggen ${ }^{2}$, doch waarvoor er onvoldoende legitimiteit is bij de publieke opinie of waar de weerstanden van sterke economische sectoren misschien groter zijn.

De bevindingen in dit proefschrift mogen preventiewerkers en beleidsmensen evenwel niet afschrikken of ontmoedigen. Er is immers een oud Keltisch spreekwoord dat zegt "Is e an oighreachd an t-slainte" of vrij vertaald "Gezondheid is een overerving" (Downie, Tannahill en Tannahill, 1996: vi). Gezondheid en gezondheidsvoorlichting dienen dus niet enkel te worden beoordeeld op korte termijn, pas op langere termijn laten (aangehouden/GVOinspanningen sporen na in de gezondheidsoverwegingen en in het gedrag van de bevolking en van haar zorgverleners.

Een editoriaal van een themanummer over "preventieve geneeskunde" van het tijdschrift Medisfeer (maandelijks verspreid bij huisartsen en specialisten in Vlaanderen) spreekt in dit verband boekdelen: "Dit nummer... wil de aandacht vestigen op het belang van preventie in de medische toepassingen van vandaag en, meer nog, in die van morgen. We zijn er immers van overtuigd dat: het hier geen simpel modeverschijnsel betreft maar dat de preventie deel uitmaakt van een heuse revolutie in de medische praktijk. De druk van de economische realiteit enerzijds en de verandering van de patiënt in een 'verzorgingsconsument' anderzijds hebben de arts ertoe aangezet zijn rol in een breder perspectief te plaatsen: zo zal de zorgenverstrekker uitgroeien tot een beheerder van de gezondheid van de patiënten. Daarbij zal hij een combinatie brengen van predictieve, preventieve en curatieve geneeskunde ... Dile veranderingen lijken onvermijdelijk en in plaats van ze te beschouwen als bijkomende lastem voor de arts, benaderen we ze liever als nileuwe uitdagingen waarbiji eenieder uiteindelijk bat zal hebben. De glezondheil van de patient zal verbeteren, de rol van de arts heropgewaardeerd en het budget van de sociale zekerheid letwat binnen de perken gehouden ${ }^{*}$ (Medi-sfeer, 1997, n ${ }^{\circ} 67$, p.3).

Gedacht kan worden aan strengere reglementeringen inzake voeding, zoals bijwoorbeeld een verplichte en duidelijke vermelding van het vetgehalte op de voedingsverpakking. 


\section{.}




\section{Bibliografie'}

Aakster, C.W. 11981), Gezonoheidszarg en samenlewing, Van Gorcum, Assen, 197 p.

Aakster , C. W., Kuiper, G. red. (1984), Leerboek medische sociologie, Wolters-Noordholf, Groningen, 413 p.

Aelwoet, W. Bogaerts, K., Capet, F., red. (1996) Gezondhejdsindicatoren 1994, Ministerie van de Wlamse Gemeenschap, Administratie Gezondheidszorg, $79 \mathrm{p}$.

Ajzen, 1., Fishbein, M. (1980), Understanding attitudes and predicting social behavior, Prentice-Hall, Englewood Cliffs, New Jersey, $278 \mathrm{p}$.

Ajzen, 1., Madiden. T.J. (11986), Prediction of goal-directed behaviar: attitudes, intentions and perceivect behavioral control, in: Joumal of Experimental Social Psychology, 22, pp. 453-474.

Albinski, M. (1974], Survey research. Een methode van sociaa/wetenschappelijk onderzioek, Het Spectrum, Utrecht Antwerpen, $205 \mathrm{p}$.

American Cancer Society 11991\%, Cancer Facrs and Figures - 1991, American Cancer Society, New York.

American Cancer Society 11984). Cancer Facts and Figures - 1984, American Cancer Society "New York.

American Cancer Society 119811, Cancer Facts and Figures - 1981, American Cancer Society, New York.

Americian Cancer Society (1980a), Guidelines for the cancer-related health checkup: recommendations and rationale, in: Ca-A Cancer Journal for Clinicians, 30, pp. 194-240.

American Cancer Society (1980b)" Public attitudes towards cancer and cancer tests, in: CA-A Cancer Joumal for Clinicians, 30 , pp. 92-98.

American College of Physicians (1981), Periodic Health Examination: A guide for designing individualized preventive health care in the asymptomatic patient, in: Annals of Intema/ Medicine, vol. $95 \mathrm{n}^{\circ} 6$, pp. 729.732. Ashton, J., ed. (1992), Heakthy cities, Open University Press, Milton Keynes Philadelphia, 235 p.

Arbyn, M. e.an (1996), Screening maar baarmoederhaiskanker in de Vlaamse Gemeenschap, in: Kankerpreventie in Waanderen, Verslagboek studiedag 27 april 1996. Vlaamse Adviescommissie voor kankerpreventie en Vlagmse Kankerliga, Brussel, 209 p., pp. 13-49.

Ashtan, D. (1989), Preventing Cancer, in: Ashton, D., Corporate Healthcare Revolution. Strategies far preventive medicine at work, Kogan Page, pp. 304 326.

Baele, J. Verbinnen, F. 11995h, Indicatoren wan niet-dweiname aan cerwixkankerscreening en interventiestrategieên ter bevordening van dee/name: een fiteratusustudie. Onderzoek in opdracht van do Provincie Vlaams-Brabant, K.U.L. - V.U.B., 115 p.

Bandura, A.(1986), Social foundations of thought and action. New York. Prentice-Hall, Englewood Cliff, $617 \mathrm{p}$.

Basset, L.W., Butler, D.L. 119911, Mammography and early breast cancer detection, un: American Family Physician, 43, n' 2 , pp. $547-557$.

Bij meer dan drie auteurs wordt alleen de eerste auteur vermeld, gevolgd door "e.a." 
Beckers, R.F. (1994!, Kankersterfte in de Vlaamse Gemeenschap, in: Archives of Public Health, $52, n^{\circ} 11.12$, pp. 547.566.

Beijer, S., e.a. (1994), Voedingsgids voor mensen met kanker, De Toorts, Haarlem, 166 p.

Belgisch Werk Tegen Kanker (11992), Kanker in België 1987-1989, Nationaal Kankerregister, Ministerie van Volksgezandheid en van het Leefmilieu, Brussel, $35 \mathrm{p}$.

Belgisch Werk Tegen Kanker (1991), Dossier kankeropsporing, in: Cha/lenge, $n^{\circ} 23$, pp. 4-15.

Belgisch Werk Tegen Kanker (1988), Kanker in Belgiê 1985, Nationaal Kankerregister, Ministerie van Volksgezondheid en van het Leefmillieu, Brussel, $31 \mathrm{p}$.

Belgisch Werk Tegen Kanker (1986), Kanker in België 1984. Natianaal Kankerregister, Ministerie van Volksgezondhied en van het Leefmilieu, Brussel, 31 p.

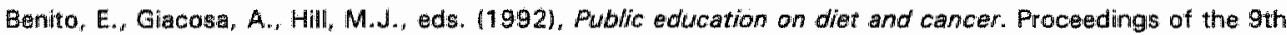
Annulal Symposium of the European Drganization for Cooperation in Cancer Prevention Studies (ECP), Kluwer Academic Publishers, Dordrecht - Boston - London, $198 \mathrm{p}$.

Benthem, R., red. (1989), Voorlichting en moeilijk bereikbare groepen, Wilhelmina Rouwenhorst Lezing op 28 oktober 1988, Nederlandse Vereniging voor Gezandheidsvoorlichting en -opvoeding, Utrecht, $38 \mathrm{p}$.

Berman, S.H., Wandersman, A. (19911, Measuring knowledge of cancer, in: Sociale Science and Medicine, 32, $n^{2} 11$, pp. 1245-1255.

Berman, S.H., Wandersman, A. (1990), Fear of cancer and the knowledge of cancer: a review and proposed relevance to hazardous waste sites, in: Sociale Science and Medicine. 31, $n^{\circ} 1$, pp. 81-90.

Berting, J. (1981), Saciale stratificatie, in: L. Rademakers, red., Socialogische Grondbegrippen, deel 1, Het Spectrum, Utrecht/Antwerpen, pp. 313-343.

Berwick, M.. Fine, J.A., Bolognia, J.L. (1992), Sun exposure and sunscreen use following a community skin cancer screening, in: Preventive Medicine, 21, pp. 302-310.

Bettinghaus, E.P. (1986), Health promotion and the knowledge-attitude-behavior continuum, in: Preventive Medicine, 15, pp. 475-491.

Billiet, J. (1994), Opinie-onderzoek en de privacy wet: de toestand is onthoudbaer maar nier hopeloos, voordracht gehouden op de studiedag "Wot en weterischap: een verbroken evenwicht ?", 14 juni 1994, Brussel, org. Steunpunt Werkgeleglentheid Arbeid Vorming.

Billiet, J. 1993), Methoden wan Socias/-Wetenschappelijk onderzoek: ontwerp en dataverzameling, Acco, Leuven/Amersifoort, $320 \mathrm{p}$.

Billiet., J., Carton, A., Huys, R. 11990), Onbekend of onbemind: een sociologisch anderzoek naar de houding van de Belgen tegenover migranten. Leuven, Sociologisch Onderzoeksinstituut.

Billiet, J., Loosveldt, G., Waterplas, L. (1984), Het survey-interview onderzocht. Effiecten van het gebruik van wragentijasten op de kwaliteit wan de antwoorden, Sociologisch Onderzoeksinstituut/Afdeling Sociologische Theorie en Methoden - K.U.L.. Leuven, 272 p.

Blalock. H.M. (1991), Understanding Social Inequalities, Sage publications, Newbury Park - London- New Delhi, $258 \mathrm{p}$. 
Blalock, H.M. (1979), Social Statistics, revised second edition, McGiraw-Hill International Book Company, London e.a. . $625 \mathrm{p}$.

Bleyen, L. e.a. (1994), Primaire preventie, in : Vereniging voor kankerbestrijding witboek ower kankerbestrijoling in Belgie. Owerzicht en vooruitzichten. deel 1 , hoofdstuk $3, \mathrm{pp} .3 / 1-3 / 9.4$.

Bloom, J.R., e.a. (1987), Cancer awareness and secondary prevention practices in Black Americans: Implications for intervention, in: Family and Community Health, $10, \mathrm{pp}, 19-30$.

Bloom, M. (1996), Primary prevention practicies, Sage publications, Thousand Oaks - London-New Delhi, 258 $442 p$.

Bonte, J., Cochez, A., Hens, M. eds. (1991), Secundaire preventie wan baarnoederha/skanker, Wiaamse Adviescommissie voor Kankerpreventie (V.A.C.K.). Universitaire Pers Leuven, 126 p.

Bostick, F.M., e.a. (1993), Knowledge, attitudes, and personal practices regarding prevention and detection of cancer, in: Preventive Medicine, 22, pp. 65-85.

Boudon, R. (1981), De logica van tret sociale. Een inleiding tot het sociologisch denken, Samsom, Alphen aan den Rijn I Brussel, 219 p. loorspr. 'La logique du social, introduction a l'analyse sociologique', Librairie Hachette, Paris, $1979 \%$.

Bouter, L.M., van Dongen, M.C.J.M. \{1990), Het belang van een grondige probleemanalyse bij GVO -planning. in: Gedrag en Gezonaherd, 18, m 4/5, pp. 197-209.

Branca, P. (1980), Towards a socilal history of medicine, in: Binneweld, J.M.W., red., Gezondheidszorg en maatschappelike ontwikkeling, Martinus Nijhoff, Den Haag, pp. 9-26.

Branckaerts, J. (1982), Medicalisering, in: Nuyens, Y., red., Sociologie en gezondheidszorg 1. Verkenningen in de medische sociologie, Van Loghum Slaterus, Antwerpen Deventer, 170 p., pp. 31-46.

Brown, M.L., e.a. (1990). The Knowledge and Use of Screening Tests for Colorectal and Prostate Cancer: Data from the 1987 National Health Interview Survey, in: Preventive Medicine, 19, pp. 562.574.

Brug, J., wan Assema, P., Kok, G. (1998), Misconceptie van consumptie wan vet, groente en fruit Oorzaken en implicaties voor voedingsvoarlichting, in: TSG - Tijdschrift voor Gezondheidswetenschappen, vol. 76. pp. 17.23 .

Bryant, H. Mah, Z. (1992), Breast Cancer Screeming Attitudes and Behawiors of Fural and Urban Women, in: Preventive Medicine, 21, pp. 405418.

Canadian Task Force on the Periodic Health Examination (1979), The periodical health examination, in: Canadian Medical Association Joumal, 121, na 3, pp. 1193-1254.

Capwell, E.M. 11997), Health Education Graduate Standards: expansion of the framework, in: Heath Education and Behawior, vol. $24, n^{\circ} 2$, pp. 137-150.

Carroll, D., Smith, G.D. (1997), Health and socio-economic position, in: Joumal of Hea/th Psychology (specilal issue on 'health variations'), $2, \mathrm{~m}^{\circ} 3, \mathrm{pp} .275 \times 282$,

Carton, A., Billiet, J., Swyngedouw, M. (1992), Onderzoek naar de palitieke houdingen van de Warmingen: steekproeftrekking en non-respans, ISPO, Bulletin ni 4, Leuven. Sociologisch Onderzoeksinstituut.

Centrale Raad voor de Volksgezondheid (1962). Advies betreffende de gezondheïlswoorlichting en -opvoeding in Medierland, $203 \mathrm{p}$. 
Chamberlain, Jn, Moss, S., eds. (1996), Evafution of Cancer Screening, Springer, London e.a., 195 p.

Champion, V.L. (1992), Relationship of age to factors influencing breast self-examination practice, in: Health Care for Women International, 13, pp. 1-9.

Chapman, S. 11990 , Intersectoral action to improve nutrition: the roles of the state and the private sector. A case study from Australia, in: Health Promotion Imternational, voll.5, n' 1 , pp. 35-44.

Ciba Foundation (1985), The Value of Preventive Medecine, Symposium 110, Pitman, London, 258 p.

Claus L.M. 119821. The growth of a sociological discipline. On the development of medical sociology in Europe. Volume 1: The general study, Sociological Research Institute, K.U. Leuven, $199 \mathrm{p}$.

Claus, L.M. 119821. The growth of a sociological discipline. On the development of medical socialogy in Europae. Volume /I : Case: studies, Sociological Research Institute, K.U. Leuven, $167 \mathrm{p}$.

Clover, K., e.a. (1991), Community knowledge of cancer, in: Health Promotion International, 6, n², pp. 93101.

Cockerharn, W.C. (1992), Medica/ Sociology, Prentice Hall, Englewood Cliffs, New Jersey, 336 p. (5th edition).

Codv, R., Lee, Ch. (1990), Behaviors, beliefs, and intentions in skin cancer prevention, in: Joumal of Behawora/ Medicine, 13, pp. 373-389.

Commissie van de Europese Gemeenschappen (1987), EEG-Programma "Europa Tegen Kanker", Commissie van de Europese Gemeenschappen, Brussel, 26 februari 1987.

Commissie van de Europese Gemeenschappen (1987b), Europa Tegen Kanker. De Europeanen en kankerpreventie : Een opinie-onderzoek. Een werkdocument van de diensten van de Europese Commissie, 18 p. + tabellen.

Commissie van de Europese Gemeenschappen (1989), Programma "Europa Tegen Kanker", hoofdlijnen wan een actieprogramma 1990-1994. Commissie van de Europese Gemeenschappen, Brussel, 5 juni 1989, 22 p.

Commissie Preventie, red. (1990), Algemene preventie in de huisartsenpraktijk, Wetenschappelijke Vereniging der Vlaamse Huisartsen (W.V.V.H.), Prima Linea, Antwerpen, 390 p.

Cammission of the European Communities (1989a), Europeans and cancer prevention. Behaviour finked with cancer. Attention paid to the cancer risk. Awereness of the European Programme and Code against cancer, december 1989, Brussels, $6 \mathrm{p}$. en Vil p.

Commission of the European Communities (1989b), General practitioners and prevention of cancer in the European Community. Main results of a survey carried out in the European Community from August to October 1988, Brussels.

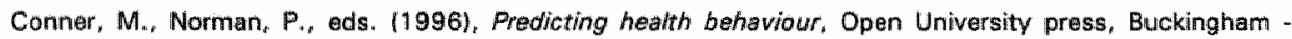
Philadelphia, $230 \mathrm{p}$.

Conner, M., Sparks, P. (1996). The theory of planned behaviour and health behaviours, in: Conner, M., Norman, P.., ods., Predicting health behaviour, Open University press, Buckingham - Philadelphia, 230 p.x pp. $121-162$.

Casijin, J. (1992), Het Gezonde Steden Project. Achtergronden en praktijk, Van Gorcum, Assen / Maastricht, $81 \mathrm{p}$. 
Cox, D. O., van Houten, M., Rolle. T. (1992), red., Voorlichtingskunde. Ontwikkelingen in theorie en praktijk. Van Gorcum, Assen / Maastricht, $159 \mathrm{p}$.

Damoiseaux, V., van der Molen. H.T., Kok, G.J. (1993), red., Gezondheidswoorfichting en gedragsverandering. Van Gorcum - Open Universiteit, Assen - Heerlen, 499 p.

Damoiseaux, V. 19987), Massamedia en GVO, in: Damoiseaux, V., e.a., red., Gezondheidsvoorlichting en Opvoeding. Van analyse tot effecten, Van Gorcum, Assen \& Maastricht, 195 p., pp. $97 \cdot 122$.

Damoiseaux, V.. e.a. 41987 , red.. Gezondheidswoorlichting en -Opvoeding. Van analyse tot effecten, Van Gorcum, Assen / Maastricht, 195 p.

Dean, K., ed. (1993), Population Health Research. Linking theory and methods, Sage Publications, London e.a.n $246 \mathrm{p}$.

De Bakker, D.H., Claessens, A.A.M.C., van der Velden, J. (1992), Man-vrouw werschillen in gezondheid en medische consumptie, Nationale studie van ziekten en verrichtingen in de huisartspraktijk. NIVEL, Utrecht, 106 p. + bijllagen.

Deleeck, $H_{.}$, Bergman, J., Van Heddegem, P., Vereycken, L. (1980), De sociale zekerhoid tussen droom en daad: theorie, onderzaek, beleid. Antwerpen, Van Loghum Slaterus.

De Leeuw, E., red.(1991), Gezonde Steden. Lokale gezondheidsbevordering in thearie, politick en praktijk, Van Gorcum, Assen / Maastricht, 313 p.

Deliens, L., Pierret, J. (1996), Socio-economische starus en (non-jparticipatie aan kankerpreventie bij werknemers ( $N=5053)$, VUB i.s.m. Experconsutt, Brussel, $95 \mathrm{p}$.

Deliens, L. (1995b), The Mos SF-36 applied in Flanders. An investigation of the reliability and walidity of the health measurements of the MOS SF-36, presentation at the "4th Symposium on Public Health", 21 oktober 1995, U.C.L., Brussels.

Dellens, L., Louckx, F., Maes, R. (1994), Meten wan kennis over kankerpreventie. Een pillootstudie bij eerstejaarsstudenten van de VUB, in: Nieuw Tijdschrift van de Vrije Universiteit Brussel, 7, pp. 29.57.

Deliens, L., e.a. (1992), Cancer Prevention in the Training of General Practitioners, in: British Journal of General Practice, october 1992 , p. 439.

Deliens, L. (1991), Strategieën om niet-of onvoldoende gescreende wrouwen to bereiken, in: Bionte, d. Cochez, A., Hens, M. eds., Secundaire preventie van baarmoederhalskanker, Vlaamse Adviescommissie voor Kankerpreventie (V.A.C.K. ), Universitaire Pers Leuven, 126 p., pp. 23-26.

Deliens, L., Schol ${ }_{t}$ S. $(1990)$, Vrouwen en kankerpreventie. Knelpunten bij vroegtijdige opsporing wan baarmoederhalskanker, in: Scheys, M., red. "Rapporten en perspectieven omtrant wouwenstudies, 2, VUB Press, Brussel, pp. 127-148.

Demeester, W. (1997), Krijtlijnen woor de uitbouw van een preventieve gezondheidszorg in Vlaanderen. Beleidsnota wan de Vlaarnse minister van Financiün, Begrating en Gezondheidsbeleid.

Denis, L., e.a. 1988), Kankerpreventie in Vlaanderen 1983 - 1988, Vlaamse Adviescommissie voor Kankerpreventie (V.A.C.K.), Brussel, 100 p.

De Nooze, P., Deliens, L. (1996), De rol van sociaal-economische kenmerken bil man-vrouw verschillen in ervaren gezondheid, in: Louckx, F., e.a., eds., Hoe politiek is het persoonlijke? Vrouwen en sociatat. economische gezondheidsverschillen, VUBPress, Brussel, 254 p., pp.17-50. 
Dent, O., Goulstion, K. 11982), A short scale of cancer knowledge and some socio-demographic correlates, in: Sociale Science and Medicine, 16, pp. 235-240.

Detiege, L. 11993), Beleidsbrief Preventieve gezondheidszory 1993\%1997. Vlamse Raad, zitting 14 april 1993. Stuk 314 (1992-1993) - Nr. 1.42p.

De Vaus, D.A. 19911, Surveys in social research, Allen \& Unwin UCL Press, London, $379 \mathrm{p}$.

DeVellis, R.F. 11991), Scale Development. Theory and Applications, Sage Publications, London, 121 p.

De Vries, H. (1993), Determinanten van gedrag, in: Damoiseaux, V., e.a. red., Gezondheiofsvoorfichting en gedragsverandering, Van Gorcum, Assen, pp. 109-132.

De Vries, H. 11992), Theoriean over voorlichting en gedragswerandering, in: Meertens, R.W., von Grumbkow, I. eds., Sociale Psycholagie, Wolters-Noordhott, Groningen, Open Universiteit, 498 p. (2de druk), pp. 147165.

De Walle-Sevenster, J., Kok, G.⿲. 119911, Gezondheidsbevordering en amoede. NKB Uitgeverij, Bleiswijk.

Dooghe, G.. Vanderleyden, \&. (1976), Levenswoorwaarden en behoeften van bejaarden, CBGS studies en documeriten $n^{\circ} 7,278 \mathrm{p}$

Dooghe, G., Vanden Boer, L. , Vanderleyden, L. 11988), De Leefsituatie van Bejaarden, CBGS monografie $1988 / 1,315 \mathrm{p}$

Downite, R.S., Tamnahill, C., Tannahill, A. (1996), Health Promotion. Models and Values, Oxford University Press, Oxford o. a., 218 p.

Dufour, A. (1997) Besluit: Preventieve geneeskunde en eerstelinsgeneeskunde, in: Medi-Steer, $n^{\circ} 67$, pp. 9798 (themanummer over preventleve geneeskunde).

Effectiviteit wan GVO/preventie (1988), Wilhelmina Rouwenhorst Lezing op 7 januari 1988, Nederlandse: Vereniging vaor Gezondheidswoorlichting en -opvoeding, Utrecht, $66 \mathrm{p}$.

Eggler, G., Donovan , R., Spark , R. (1993), Heath and the media. Principles and practices for thealth promotion, McGraw Hill Book Company, Sydney, $190 \mathrm{p}$.

Elehardius, M. (1979), Een intemationale beroepenclassificatie (I.B.K.) en een gestandaardiseerdie internationale beroeparestigeschad 1G.1.B.S.4, C.B.G.S. rapport 3017979, Centrum vocr Bevolkings- en Gezinsstudien, Ministerie van Volksgezondheid en het Gezin, $91 \mathrm{p}$.

Erven, H.M.A.W. 1989), Preventie in de eerstelinszorg. Uitgeverili voor Gezondheidsbevordering. Rijswilk, Gi 1 .

Europere kankercode (1988), brochure van de Europese Gerneenschappen.

Eylenbosch, W. d., a. (1988). Prmaire preventie van kanker, Vaamse Adviescommissie voor Kankerpreventie (VACK), Brussel, $43 \mathrm{p}$.

Fahrenfort, M. 119841. Medicalisering, in: Aakster, C.W., Kuiper, G., red. Leerboek medische sociologie, Wolters-Noordhoff, Gromingen, 413 p., pp. 32-44.

Fajardo, H.L., 0. (1992), Factors influencing Women to Undergo Screening Mammography, in: Radiology, 184. pp. 59-63 
Fishbein, M., Ajzen, 1. (1975), Belief, atturude, intention and behavior: An introduction to theory and research, Addison-Wesley Publishing Company, Reading, Massachusetts e.a., $578 p$.

Foets, M., van der Velden, J. 1990), Een Nationale Studie van ziektem en warrichtingem in de huisartspraktijk. Basisrapport. Meetinstrumenten en procedures. Nederlands instituut woor onderzoek van de eerstelijnsgezondheidszorg (NIVEL), $140 \mathrm{p}$.

Fowler, F.J. (1993), Survey Research Methods, Sage Publications, London, 156 p. 12 nd editioni.

Freidson. E. (1970). Profession of medicine: a study of the sociology of applisd Knowledge, Harper 8 Row, New York (Nederlandse vertaling: De medische professie. De Tijdstroom, Lochem, 1981).

Freund, P.E.S., McGuire, M.B. 11991), Heath, Hhess and the Social Body. A critical Sociology, Prentice Hall, Engliewood Cliffs; New Jersey, 402 p.

Gadourek. 1. (1976), Sociologische onderzoekstechnieken. Inleiding tot de werkwifze bij het sociral- en gedrags werenschappelifk onderzoek. Van Loghum Slaterus, Deventer, 415 p. (Eerste bijdruk).

Gochmian, D.S., ed. 11997). Handbook of Health Behavior Research I. Personal and Social Determinants. Plenum Press, Now York - London, $505 \mathrm{p}$.

Goldthorpe, J.H. (1980), Social morbidity and class strumture in modern Britain, Clarendon Press, Oxford.

Green, L.W., e.a. (1980), Heakh Education Planning. A Diagnostic Approach, The Johns Hopkins Uniwersity, Mayfield Publishing Company, Mounttain View, California, $306 \mathrm{p}$.

Grol R. (1989), De verspreiding van NHG-standaarden onder huisartsen, in: Huisarts en Wetenschap, 32 , pp. $494-497$.

Gunning-Schepers, L.J., Spruit, I.P., Kuijnen, J.H. 11989), Socio Economic Inequalities in Health. Questions on trend's and explanations, Sociaal-economische gezondheidsverschillen 2, Programmacommissie Sociableconomische gezondheidsverschillen, Den Haag, $200 \mathrm{p}$.

Haddix, A.C., e.d. (1996), Prevention Effectiveness, Oxford University Press, New York - Oxford, 227 p.

Martan, L.C., Bernstein, A.B., Kessler, L.G. (1991), Cervical cancer screening: Who is not screened and why ?, in: American Joumal of Public Health, 81, pip, $885-890$.

Hayes, D., Ross, C. (1987). Concern with appearance, health beliefs, and eating habits, in: wouknal of Heath and Social Behawior, 28 , pp. $120-130$.

Hedrick, T.E., Bickman, L. Rog, D.J. (1993), Apphed Research Design. A practica/ guide, Sage Publications, London a. $141 \mathrm{p}$.

Helmert, U., Shea, S., Maschewsky-Schneider, U. 11995;, Social class and cardiovascular disease risk factor changes in West germany 1984-1991, in: European Journal of Public Health, 5, pp. 103-108.

Hennig, P., Knowles, A. 119901, Factors influencing women over 40 years to talke precautions againet wervieal Cancer in: Journal of Applied Social Psychology, 20, pp. 1612-162"1.

Henry, G. (1990), Practical Samping, Newbury Park, Sage Publications, London e.a., 139 p.

Herwig, N. (1993), De balans: effectiviteit in vogelvlucht, in: Damoiseaux. V., van der Mollen, H.T., Kok, G.u." (1993), red., Gezondheidswoorlichting en gedragsverandering, Van Goncum - Open Universiteit, Assen - Heerlen. 499 p., PP. $45-58$. 
Mill, D. (1977), Community education about cancer, in: Australian Family Physician, 6, pp. 252-266.

Hoefnagels, H. (1977), Kritische sociologie, in: Rademaker, L., Bergman, H., red, Sociologische stromingen, Het Spectrum/Intermediair, Aula-boeken 588, pp. 245-271.

Howe, H.L. 11981, Social Factors Associated with Breast Self-Examination Among High Risk Women, in: American doumal af Public Health, 71, pp. 251-255.

Huizingh, E. (1989), Inteiding SPSS/PC + en data entry, Addison-Wesley Publishing Company, Amsterdam vat.al., $302 \mathrm{p}$.

Ilich, I. (1975), Grenzen san de geneeskunde. Het medisch bedrijf - een bedreiging voor de gezondhejd?. Het Wereldvenister, Bussum, 1978, 319 p. (corspr. Medical Nemesis. The expropriation of health, Marion Boyars, London, 1975).

Integrale kwaliteitszorg in gezondheids- en welzijnsvoorzieningen (1993), Garant, Leuven/Apeldoorn, 353 blz.

Janz, N.K., Becker, M.H. (1984), The health belief model: a decade later, in: Heatth Education Quarterly, 11 , pp. $1-47$.

Jepson, Ch., e.a. $(1991 \%$, Black-White differences in cancer prevention knowledge and behavior, in: American Joumal of Public Health, 81, pp. 501-504.

Jonkers, R., e.a., red. (1988), Effectivitert wan gezondheidsvaorlictiting en -opvoeding, Uitgeverij voor Gezondheidsbevordering, Rijswijk, $335 \mathrm{p}$.

Joung, 1. (1996). Marital status and health. Descriptive and explanatory studies, Erasmus Universiteit Rotterdam, Proefschrift, $229 \mathrm{p}$.

Kankerpreventie in V/aanderen (1996), Verslagboek studiedag 27 april 1996, Vlaamse Adviescommissie voor kankerpreventie en Vlaamse Kankerliga, Brussel, $209 \mathrm{p}$.

Klinkert, J.J. (1988), Inleiding in de medische sociologie, Van Gorcum, Assen Maastricht, 4de herziene druk, 193 p.

Kok, G.J. (1993), Theorieën van verandering, in: Damoiseaux, V., van der Molen, H.T., Kok, G.J. (1993), red., Gezondheidswoorlichting en gedragsverandering, Van Gorcum - Open Universiteit, Assen / Heerlen, 499 p.,pp. $221-236$.

Kok, G.J., Meertens, R.W., Wilke, H.A.M. (1992), Voorfichting en verandering, Wotters-Mloordhoff, Groningen, twoede druk, $181 \mathrm{p}$.

Kok, G.J., eal. (1991), Planned health education and the role of self-efficacy: Dutch research, in: Heatth Education Research, vol. 6, 2, pp. 231-238.

Kok, G.J. (11987a), Gezondheidswoorlichting en mpvoeding, GVO, in: Damoiseaux, V., e.a. (red.), Gezondheidswoorlichting aphoeding. Van snalyse tot effecten, Van Gorcum. Assen/Maastricht, 195 p. pp. 1-12.

Kok, G.J. (1987b). Theorieên over gedragsbeïnvloeding, in: Damoiseaux, V., e.a. (1987), red., Gezondheids* woorlichting en -Opvoeding. Van analyse tot effecten, Van Gorcum, Assen Maastricht, 195 p., pp. 53-76.

Kok, G.J., Oostween. T. (1987), Modellen ter verklaring van gezondheidsgedrag $\|_{\text {": }}$ Recente ontwikkelingen van belang voor GVO, in: GVOJPreventie, $8, n^{\circ} 4$, pp. $225-233$.

Kok, G.J. (1985), Een modal van gedragswerandering wia voorlichting, in: Nederfands Tijdschrift voor Psychologie, 40, pp. 71-76. 
König-Zahn, C.. Furer, J.W., Tax, D. (1993), Het meten van de gezondheidstoestand. doel 1. Algeniene gezoncheid, Van Gorcum, Assen, $152 \mathrm{p}$.

Kristal, A.R., e.a. 11990\%, Nutrition knowledge, attitudes and perceived norms as correlates of selecting low-fat diets; in: Health Education Research. 5, pp. 467.477.

Kunst, A. Mackenbach, J. (19911, De omwang van sterfteverschillen in relatie met het opleidingsniveau: wen wergelifjking wan 9 geindustrialiseerde landen, in: Raes, V., Kerkhofs, E., Louckx, F., red, Sociale ongehjkheio en verschillen in gezonotheid, VuBPress, Brussel, 176 p. , pp. 59-74.

Kunst, A., Mackenbach, J. (1990), Uschemische hartziekte: van managers- tot volksziekte. Een overzicht van de bevindingen uit de internationale literatuur, in: Mackenibach, $d_{*}$ ed., Sociaal-ecomomischs gezondheidsverschilen onderzocht. Deel $N$, Sociaal-economische gezondheidsverschillen 7 , Progitammacommisisie Sociaal-economische gezondheidsverschillen, Den Haag, 69 p.. pp. $29-49$.

Lagasse, R., e.a. (1990), Health and social inequities in Belgium, in: Sociale Science and Medicime, 31, pp. $237-248$.

Lalonde, M. 11974), A new perspective on the health of the Canadians, Ottawa Ministry of National Health and Welltare.

Lambrechts. M.C. (1995), Inventaris van een alcohol en drugbeleid in de onderneming. V.A.D.-comtacten 1985-1994, voordracht op de studiedag "Een terugblik 1985-2005 een vooruitblik. De aanpak van alcohol en andere drugs op het werk", op 30.03 .95 te Antwerpen.

Lapre, F.M., Rutten, F.F.H. Hagen, J.H. (1988), red., De economie van de preventieve gezondheridszorg. Preadviezen voor het congres wan de Vereniging voor Gezondheidseconomie, 10 juni 1988. De Tijdstroom, Lochem Gent, $122 \mathrm{p}$.

Leemans, S., Pattyn, M., Rousseau, S. Van Der Haegen, H. 119901, De Belgische Stadsgewesten 1981, NiS, Statistische Studiên or 89.

Lemeshow, S., Hosmer, D., Klar, J. en Lwanga, S. 11992), Adequacy of Sample Size in Heakth Studies, Chichester, John Wiley \& Sons.

Lesthaeghe, R., Page, H. (1977), Intwitheve inleiding tat de multivariate ana/yse, collegedictaat, V.U.B.

Loehrer, P.J." a. 11991\%, Knowladge and Beliefs About Cancer in a Socioeconomically Disadvantaged Population, in: Cancer, 68, $n^{01} 1$, p. $1665-1671$.

Looze, M. 119941, "Het Rijksriegister: een rijk register voor wetenschappelikk onderzock?", Situdiedag Wet en Wetenschap: een verbroken evenwicht, Steumpunt Werkgelegenheid-Arbeid-Vorming, KULeuwen, 14 juni 1994.

Louckx, F., e.a., eds. 119961. Hoe politiek is het persoonlike? Vrouwen en sociast-economische gezondheidsverschillen; VUBPress, Brussel, 254 p.

Louckx, F., red. (1995). Gevelarchitectur van de we/vaartstaat. Ongelike tomgang tot de gezondheldszorg. VuBPress, Brussel, $174 \mathrm{p}$.

Luther, S.L., Price, J.H., Rose, C.A. (1982), The public's knowledge about cancer, in: Cancer Nursing, 5, pp. $109-116$.

Mackenbach, $ل$ ل (1993), Sociaal-economische gezondheidsverschilien in Nederland: een overzictht wan recente empirische bevindingen, in: Rees, $V$., Kerkhofs, E., Louckx, F. (1991), red., Sociale ongelikheid en werschillen in gezondheid, VUBPress, Brussel, 176 p., pp. 27-58. 
Mackenbach, I.P., ed. 11991 , Socia-economic heath differences. Proceedings of a symposium, tebruary 1991 , Ministerie van WVC, Rijewhilk.

Mackinbach, J.P., ed. (1990). Sociableconomische gezondheidsverschilfen onderzocht. Deel H. Sociaaleconomische gezondheidswerschillen 7. Programmacommissie Sociaal-economische gezondheïdsverschillen. Den Haag, $69 \mathrm{p}$.

Mackenbach, J., van der Maes, P.J. 11989y, Social inequality and differences in health: a survey of principal research findings, in: Gunning-Schepers, LwJ., Spruit, I.P., Krijnen, J.H. (1989), Socio Economic hequatities in Health. Questions on trends and explanations, Sociaalleconomische gezondheidsverschillen 2, Den Haag. 200 p. pp. 25 im. 80 .

Maes, L. (1996), Primaire preventie van voedingsgerelateerde aandoeningen, in: Kankerpreventie in Waanderen, Verslagboek studiedag 27 april 1996, Vlaamse Adviescommissie woor kankerpreventie en Vlaamse Kankerliga, Brussel, 209 p., pp. $192-204$.

Maes, R. 11992), Kennis van kanker(preventiel bij VUB-studenter. Een exploratief empirisch onderzoek, Eindyerhandeling tot het behalen van het diploma van Licentiaat in de Gezondheidswetensichappen, Vrije Universiteit Brussel $121 \mathrm{p}$, bufllagen (Promotoren: F. Louckx en L. Deliens).

Marmot, M.G. A. (1991), Health inequalities among British civil servants: the Whitehall II study, in: The Lancet. 337 : June 8, pp. 1387-1393.

Marmot, M.G. (1989), Social class and mortality, 敞: Gunning.Schepers, L.J., Spruit, I.P., Krijnen, J.H., Socio Economic Inequalities in Health. Questions on trends and explanations, Sociaal*economische gezondheidsvarschillen 2, Den Haag, 200 p. . pp. 95-111.

Marynissen, R. (1993), Panel Studie van Belgische Huishoudens, Steunpunt gezinsdemografisch Panel, U.I.A., Promotor Prof. dr. T. Jacobs (mondelinge mededeling).

Matthijs, K. (1988), Belgoscopie. De Belgen, de Vhamingen en de Walen. Wie ze zijh, waar ze wonen en hoe ze feven, Lannoo, Tielt, $312 \mathrm{p}$.

Matthijs, K. (1994). Statistisch zakboek van Belgiẽ, Inbel/Lannoo, Brussel, $256 \mathrm{p}$.

McCarthy, M. (1982), Epidemiology and policies for health planning; London, King Edward's Hospital Fund for London.

McDonald, J.u. (1993). Primary health care. Medicine in its place, Earthscan Publ. Ltd, London, 196 p.

McDowell, $I_{4,7}$ Newell, C. (1987), Measuring Health. A guide to rating scales and questionnaires, Oxtord University Pross, Now York, 342 p.

MCGuire, W.w. (1985). Attitudes and attitudie change, in: Lindzew, G., Aronson, E., eds, Handbook of Social Psychology, 3rdi Ed., Vol. II, Random House, New York, pp. 233-346.

Mckeown. Th. (1976), The role of medicine, Basil Blackwell, Oxtord.

Michielutte, R., Diseker, R.A. 11982), Facial differences in knowledge of cancer: A pilot study, in: Social Science and Medicine, $16, \mathrm{pp} .245-252$.

Miller, D.C. 19911, Handbook of resiearch design and social measturement. Fifth Edition, Sage Publications, London e.a., $704 \mathrm{p}$.

Mol, A., van Lieshout, P. (1989), Ziek is het woord niet. Medicalisering, normalisering en de veranderende taal van huisartsgeneeskunde en geestelijke gezonatheidszorg, $1945-1985$. Sun. Nijmegen, 300 p. (proetschrift). 
Mollemian, G.R.M., van Nies, H.A.M. 119951, Trendonderzoek NVPG. Een onderzoek onder gvo-ers, preventiewerkers en patiëntenvoorlichters in Nederland, Nederlandse Vereniging voor Proventie on GWo, Nijmegen/leiden, $132 \mathrm{p}$.

Moors, J., Muilwijk, J. (1975), Steekproeven: een inleiding tot de praktijk Amsterdam., Agon Elsewier.

Mootz, M., van de Vathorst, S. (1992), Gezondheidsmeting: een begrippenkader, in: Gurning Schepars, L.J." Mootz, M., eds., Gezondheidsmeting. Bohn Stafleu Van Loghum, Houtem, 207 p., pp. 14-27.

Morton, S. (1988), All around the thouse: is there any consensus on the major public mealth problems of housing in the U.K.?, in: Radical Community Medicine, $33, \mathrm{pp} .3-8$.

Moss, S. (1996), General principles of cancer screening, in: Chamberlain, J., Moss, S. eds , Ewaluation of Cancer Screening, Springer, London e.a., $195 \mathrm{p}$.

National Cancer Institute 1986), Technical Report: Cancer prevention awareness survey: Wawe U, Office of Cancer Communications.

Navanro, V. (1986), Crisis, health, and medicine. A social critique, Tavistock Publications, Niew York - London, $281 \mathrm{p}$.

NHG-bestuur (1989). Standaarden: het gezicht van die huisarts, in" Hivisarts en Werenschap, $32, n^{\circ} 1, p .3$.

Nithuis, F. 119871, De gezondheidskundige anallyse, in: Damoiseaulx, $V_{\text {, }}$, a, red., Gezondheidsvoorlichting en -Opwaeding. Van andiyse tot effecten, Van Gorcum, Assen / Maastricht, 195 p., pp. $13-30$.

Nulyens, Y. (1982), red., Sociologie en gezondheidszorg 1 . Verkenningen in de medische sociologie, Van Loghum Slaterus, Antwerpen Deventer, $170 \mathrm{p}$.

Nuyens, Y. (1980), De eerste lijn is krom. Gezondheidszorg tussen onderzoek en beleid. Vam Loghum Slaterus, Deventer, $270 \mathrm{p}$.

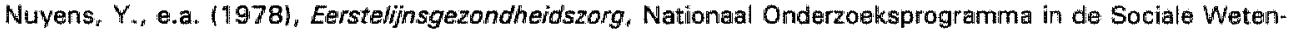
schappen, Programmatie van Wetenschapsbeleid, Brussel 8 delen, Boek 1.A 440 p.

Ogden, J., Mann, J., Eves, F. (1994), The Effects of Health Information on Knowledge, Health Beliefis and Screening Behaviourall Intentions for Cervical Cancer, in: International Jaurnal of Health Sciences, 5, m $4, \mathrm{pp}$. $147-152$.

Oostween, T., Kok, G.ل. 11987), Modellen ter verklaring van gezondheidsgedrag I: Mogelifkheden van thet Fishbein 8 : Ajzen model en het health belief model woor GVO, in: GVOrprewentie, $8, n^{\circ} 2, p p .59-69$.

Oosiveen, T., de Vries, N.K. (1987), Gedragsdeterminanten, in: Damoiseaux, V., e.A., rad.., Gezondheidswoorichting en -Opvoeding. Wan analyse tot effecten, Van Gorcum, Assan/Maistricht, 195 p.. pp. $31-51$.

Osborn, A.F., Morris, T,C. 11979). The rationale for a composite index of social class an its evaluation; in: British Joumal of Socioliogy, 30, pp. 39.60.

Qwretweit. J. (1992), Health Senvice Qwality. An introduction to quawty methods for health services, Blackwall Scientific Publications, Oxford, $186 \mathrm{p}$.

Pas. L. (1995). Praktijkaanpak van preventie in Vlaanderen vanuit international perspoctial bekeken, in: Bijblijuen. Cumulatief Geneeskundig Nascholingssysteem, 11, pp. 53-59. 
Pas, L., ed. (1993), General practice and cancer prevention in Europe. The involvement of general practitioners in cancer screening programs, Proceedings of the WONCA Satellite Confrerence, The Hague 12-15 June "93, Flemish Institute for General Practitioners, $203 \mathrm{p}$.

Paul, $\mathrm{E}_{\mathrm{n}}$, e. 11992), Verhalten und Einstellung gegenüber Hautkrebsvorsorge und -firuherkeninung in Abhängigkeit vom Kenntrisstand - Untersuchungen an Besuchern einer Industriemesse, in: Gesundh.. Wes, $54_{\text {: }}$ pp. $325-330$.

Peersman, W., De Maeseneer, J. (1995). Sociaal-economische status en differentieel gebruik van gezondheidgzorgvoorzieningen, in: Louclox, F. red., Gevefarchitectuur van de welwaartstaat. Ongelijke toegang tot de gezondheidszorg, NUBPress, Brussel, 174 p., pp. 65-81.

Peeters, R, e.a. 11994), Secundaite preventie, in : Vereniging voor kankerbestrijding, Wriboek over kankerbestrying in Behgie. Overzicht en voorufizichten. deel 1 , pp. 4/1-4/61.

Pill, R., Peters, T.ل., Robling, M.R. 11995), Sacial class and preventive health behaviour: a British example, in: Joumal of Epidemiologw and Community Health, 49, pp. $28-32$.

Polednak, A.P. (1990), Knowledge of Colorectal Cancer and Use of Screening Tests in Persons 40-74 Years of Age, in: Preventive Medicine, 19, pp. 213-226.

Prewention and health: Everybody's business. A reassessment of public and personal health (1989), Depiartment of Health and Social Security, London: Her Majesty's Stationery Office, Eight Impression, first published $1976,96 \mathrm{p}$.

Raes, $V_{n}$, Kerkhofs, $E_{+}$Louckx, F., red. (19931. Sociale ongelijkheid en werschillen in gezondheid. VuBPress, Brussel, $176 \mathrm{p}$.

Riley, M.W. 11993), A theoretical basis for research on thealth, in: Dean, K., ed. (1993), Population Health Research. Linking theory and methods, Sage Publications, London e.a., 246 p., pp. 37-53.

Robson. C. (1993), Real World Research. A Resource for Social Scientists and Practitioner-Researchers, Blackwell, Oxford \& Crambridge, 510 p.

Alogers, W.S. 119911. Explaining Health and Whess. An Exploration of Diversity, Harvester Wheatsheaf, New York a. $a_{*}, 274 \mathrm{p}$.

Rose, G. (1992). The strategy of preventive medicine, Oxforf University Press, Oxford Medical Publications, Oxford - New York - Tokyo, $138 \mathrm{p}$.

Rossed E., Louckx F., Delliens L. Lambrechts M.C. 11995\%, Studies omtrent" werk en alciahoigebruik, V.U.B. i.:.m. de Vereniging voor Alcohol- en andere Drugproblemen. Brussel, $133 p$.

Rouwenhorst. W. (1981), Om onze gezondheid. De rol van gezondheldsvoowichting en apvoeding (gvol. Samsom, Alphen aan den Riln Brussel, 265 p. (proefschrift)

Rudistam, K.E., Newton, R.R. 11992), Surwing your dissertation. A comprehensive Guide to Content and Process, Sage Publications, London, $221 \mathrm{p}$.

Rutiter, D.R., Quine; L., Chesham, D.J. (1993). Social Psychological Approaches to Health, Harvester Wheatsheaf, New York ot.ali, $268 \mathrm{p}$.

Sanson-Fisher, R. 11993\%, Primary and secondlary prevention of cancer; opportunities for behavioural scientists, in: Maes, $S_{n}$, Leventhal, $H_{n}$, Johnston, M., Jnternational Review of Health Psychology, vol. 2 , John Wiley \& Sons, Now York at.al., pp. 117-146. 
Scambler, G. (1987), ed. Sociological theory and medical sociology, Tavistock Publications, London New York, $261 \mathrm{p}$.

Schaapveld, K., Hirasing. R.A. 11993), Prewentiegids. Een praktisch owerzicht wan preventieorogramma soor husiartsen, verloskundigen en medewerkers in de jeugdgezondheidszorg, Van gorcum, Assen, 197 p.

Schaapveld, K., van de Water, H.P.A., Bergisma, E.W. 119911. Prioriteiten in preventie, in: Nederfands Tholschrift woor Geneeskunde, 135, pp. $1699 * 1702$.

Schreuder, F. (1991), Handboek gegevens analyse mer spss/pct, Academic Service, Schoonhoven, $308 \mathrm{p}$

Segers, J.H.G. (1989), Methoden voor de Sociale Werenschappen I. Infeiding tot de structuur wan hat onderzoeksproces en tot de methoden van datawerzamelen, Van Garcum, Assen Amsterdam, $336 \mathrm{p}$.

Seydel, E. (1989), Kanker en het algemene publiek. Experimenten me kankervooulichting, Uniwersiteit Twenta, 227 p. (proefschrift).

Siegel. S. Castellan ir., N.J. (1988), Nonparametric statistics for the behavioral sciences, Second edition, McGraw-Hill International Book Company, London e.a., 399 p.

Simons-Morton, B.C., Donohew, L., Crump. A.D. 19997$)$, Health Communication in the prevention of alcohol, tobacco and drug use, in: Health Education and Behavior, voll, $24, n^{\circ} 5$, pp. 544-55.4.

Spector, P.E. (1992), Summated rating scale construction. Series: Quantitative Applications in the Social Sciences $\mathrm{n}^{\circ} 82$, Sage, London et.al., $73 \mathrm{p}$.

SPSS (1993), SPSS for Windows. Release 6.0, SPSS Inc., 6 delen.

Spruit, I.P. (1990), Health and social inequities in the Netherlands, in: Social Sicience and Medicine, $31, \mathrm{pp}$. $319-329$

Streiner, D.L., Nomman, G.R. (1989). Health Measurement Scales, A practical guide to their developmont and use, Oxford Medical Publications, Oxford University Press, Oxford New York Tokyo, 175 p.

Stronks, K. van de Mheen, D., Mackenbach, J. (1993). Achtergronden van saciaal-economische gezondheidsverschillen. Een overziclint van de literatuur en een onderzoeksmodel, in: Raes, V., Kerkhofs, E. ,Louckx, F., red., Saciale ongelijkheid en werschillen in gezondheid, VUBPress, Brussel, 176 p. pp. 11-26.

Surkijni, J. (1993). Vreendelingenenquete, Centrum woor Socialogie, V.U. B. Promotor Prof. dir. R. Lesthaeghe (mandelinge mededeling).

Sutton, S. e.a. 11994). Prospective study of predictors of attendance for breast screening in inner London, in: Journal of Epidemiology and Communiry Health, 48, pp. 65-73.

Swanborn, P.G. 119811. Methoden van sociaaf-wetenschappelijk onderzoek. Inlering in antwerpstrategieän, Boom, Meppel Amsterdam, 412 p.

Tacq, J. (1992), Van probleem naar analyse. De keuze van een gepaste multivariate ana/ysetechniek bij exn social-wetenschappelijke probleemstelling. Rotterdams Institutut voor Sociologisch on Bestuurskundig Onderzoek, $394 \mathrm{p}$.

Taca, J. (1980), Associatiematen voor kruistabellen. Een handleiding bij het interpreteren van SPSS. output Sociologisch Onderzoeksinstituut, K.U.Leuwen, $134 \mathrm{p}$.

Tarimo, E., Creese. A., eds. 11990, Achieving Health for All by the year 2000. Midway reports of country experiences, World Health Organisation, Geneva, $262 \mathrm{p}$. 
Tellegen, E. (1970), Medische Sociologie. Een Hteratuurverkenning. N. Samsom nv, 134.p.

Tijmstra, T.J. (1984), Gezondheidsbevordering en preventie, in: Aakster, C.W., Kuiper, G., red. (1984), Leerboek medische sociologie. Woiters-Noordhoff, Groningen, 413 p., pp. 123-135.

Uniken Venema, H.P., Garretsen. H.F.L., red. 11995$)$, Het meten van de gezondheidstoestand 4. Gezondheidsonderzaek bij moeilijk bereikbare groepen, Van Gorcum, Assen/Mlaastricht, 115 p.

U.S. Preventive Services Task Force (1989), Guide to clinical preventive services, Williams and Willins, Baltimore, $419 \mathrm{p}$.

Van Assema, P., e.a. (1993). The determinants of four cancer-related risk behaviours, in: Health education research, $8, \pi^{\circ} 4, \mathrm{pp} .461-472$.

Van Assema, P., de Wries, $H_{\text {., }}$ Kok, G.J. (1990), Kenrils en opvattingen van de Nederlandse bevolking over de preventiemogelijkhtden van kanker, in: Tijdschrift voor Sociale Gezondheidszorg, 68, no 7, pp. 306-311.

Van Berkel-van Schaik, A.B., Tax. B. (1990), Naar een standaardoperationalisatie van sociaal-economische status voor epidemiologisch en sociaal-medisch anderzoek. Rapport op basis wan de werkzaamheden van de Subcommissie Socialal-Economische status van de Programmacommissie Sociaal-economische gezondheidswerschillen, Den Haag, 84 p. +45 p. biflagen.

Van Den Ende ${ }^{H}$. "Verhoef, M. (1975), Inductieve Statistiek voor gedragswetenschappen, Amsterdam, Agon Elsevier.

Van den Heuwel, W.ل.A. (1995), Evaluatieonderzoek, in: Van den Heuvel, W.J.A., e.a., eds., Interveniëren in de determinanten wan gezondheid: over obstakels en Jeermomenten, Van Gorcum, Assen, pp. 156-174.

Van Der Haegen, H., Pattyn, M., Cardyn, C. 11982), The Belgian Sett/ement System, Acta Geographica Lovaniensia nir 22.

Van der Heijden, P. (1990), Bibliagrafie. Sociaal-economische status en gezondheid. HVIVEL, Utrecht, 76 p.

Van der Pligt, J., de Vries, N.K. (1995), Opinies en attitudes. Metingen, modellen en theorie, Boom, Amsterdam / Meppel, 309 p.

Van der Zee, K.I., Bakker, A.B.,Sanderman, R. (1995), Sekseverschillen in de invloed van huwelijk en betaald werk op subjectief welbevinden, in: Gedrag en Gezondheid, 23, n 5, pp. 229-244.

Van Dongen, M. (1993), Evaluatie van GVO-Interwenties, in: Damoiseaux, V., wan der Molen, H.T., Kok, G.J. (1993), red., Gezondheidsvoorhichting en gedragsverandering, Van Gorcum - Open Universiteit, Assen - Heerlen, 499 p., pp. $186-220$.

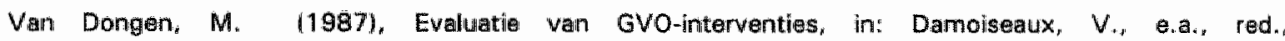
Gezondheidsvoorlichting en -Opvoeding. Van analyse tot effecten, Van Gorcum, Assen Maistricht, $195 \mathrm{p}$. pp. $141-182$.

Van Hal, G. e. a. (1991), Onderzoek naar de kennis rond kanker bij schoolgaande jongeren, Integrale Kankerstichting Antwerpen - Belgisch Werk tegen Kanker - O.C.M.W. Antwerpen, Antwerpen, 96 p.

Vanneste, D. (1989), Economische typering van de Belgische gemeenten: basis woor een ecanomische regionalo indeling. Leuven Geogratische papers 1, K.U.L., Leuwen.

Van Pernis, H., Keukens, R., Stapel, J. (1986), Sociologie voor gezondheidszorg en verpleegkunde, Van Loghum Slaterus, Deventer, $324 \mathrm{p}$. 
Velle, K. (1991), De nieuwe biechrvaders. De sociale geschiedenis wan de arts in Belgie, Kritak, Leuven, 352 p. (proefschrift)

Vareniging voor kankerbestrijding (1994), Witboek aver kankerbestrijding in Belgie. Overzicht an vorüzichten. 2 delen.

Vareniging waor kankerbestrijding (1991), Uw 100 vagen.

Verhak,. P.F.M., Bosman, J.M., van de Velden, J. (1992), Preventie. Nationale studie van ziekten en verfichtingen in de huisartspraktifk. Nederlands Instituut voor onderzoek van da eerstellins gezondheidszorg (NIVEL), Utrecht, $115 \mathrm{p}$.

Verhaak, P.F.M., de Vries, P.J. 119871, Meningen over preventie. ldeeên en taakopvartingen van huisantsen gerelateerd aan hun gedrag, Nederlands Institunit voor onderzoek van de erstelijns gezondheidszorg (NIVELI, Utrecht, $102 \mathrm{p}$.

Vernon, S.W. Laville, E.A., Jackson, G.L. (1990), Participation in breast screening programs: a review, in: Social Science and Medicine, 30, $n^{* 10}$ pp. 1107-1118.

Vinck, J. (1995), Gedragsverandering in het kader van primaire preventie en gezondheidspromotile, in: Gedrag en Gezondheid, $23, n^{\circ} 5, p p .206-216$.

Vlaamse Adviescommissie voor Kankerpreventie (1985). Kanker. Vroegrijdige opsporing en preventie, Brussel, $112 p$.

Vuylsteek, K. ("1984), Saciale ongelijkheid tegenover ziekte en dood, in: Tjdschrift voor Geneeskunde, 40, pp. $291-299$.

Wadsworth, M.E.J. 119911. The imprint of time. Childhood, history, and adult life, Clarendon Press, Oxford. $251 \mathrm{p}$.

Wallston, K.A., Wallston, B.S., De Vellis, R. (1978), Development of the multidimensional Health Locus of Control (MHLC) scalles, in: Healh Education Monographs, 6, pp. 160-170.

Ware, J. (1993), SF-36 Health Survey. Manual and interpretation Guide, The Health Institute, New England Medical Center, Boston, Massachusetts.

Weckx, H. 119911. Beleidsbrief Gezondheidspromotie: een aanbod en wen witdeging, Vlamse Raad, zitting 7 juni 1991. Stuk $515(1990-1991)-$ Nr. 1, 23 p.

Westendorp. $\mathrm{G}_{n}$ (1990). Gezondheidsbevordering, Van Gorcum - Uitgewerî voor Gezondheidsbevordering. Assen, $135 \mathrm{p}$.

Wieberdink, E.A.M. 11990, Voorlichting in de massamedia, in: Biblifven. Cumularief Geneseskumarg Nascholingssysteem, 6, n 9, pp. 5-14 (Themanummer over Gezandheidsvoorliehting).

Wilkin, D. Halliam, L., Doggett, M-A. (1992), Measures of need and outcome for primary health caire, Oxford Medical Publications, Oxford-New York-Tokyo, $301 \mathrm{p}$.

Wolinsky, F.D. (1993), Age, Period and Cohort Analysis of Health-Relatted Beheviour, in: Dean, K., ed. (1993). Population Heath Research. Linking theory and methods, Sage Publications, London e.a., 24.6 p., pp. 5.4 .73$.

World Health Organization (1985), Ottawa Charter for Health Promotion, in : Targets for health for all. Targets in support of the European strategy for health for all, World Health Organization, Regional Office for Europe, Copenthagen. 
World Heaith Organization 11978 . Primary Health Care: The AJma Ata Conference, WHO, Geneva.

Zola, 1. K. (1973), De medisch macht. De inwloed wan de gezondheidszorg op de maatschappi", Boom, Meppel, $142 \mathrm{p}$

Zola, 1. K. (1964). IIness behavior and the working class: Implications and recommendation, in: A. Shostak, W. Gamberg, eds., Bue colfar world, Englewood Cliffs, pp. 350-361. 


\section{Liist van figuren}

1.1 Traditioneel model van gezondheidsvoorlichting

1.2 Samenhang tussen sociale determinanten, kennis, attitude en gedrag

1.3 Samenhang tussen kennis van kankerpreventie en kankerpreventief gedrag

2.1 Massamediale voorlichting over kankerpreventie

2.2 Communicatiekanalen voor gezondheidswoorlichting

2.3 GVO-matrix van Kok (1987)

3.1 Zorgfuncties in relatie tot de fasen van het ziekteproces 38

3.2 Onderscheid tussen de 'individuele' en de 'collectieve' 40

$\begin{array}{lll}3.3 & \text { kankerpreventie } & 41\end{array}$

3.4 Typologie van 'kennisdomeinen' in het begrip kankerpreventie 42

3.5 Chronologisich overzicht 1979-1993 van consensusrapporten of referentiewerken met richtlijnen over kankerpreventie

3.6 Richtlijnen inzake kankerpreventie voor mannen en vrouwen, volgens kennisdomein en kankerlokalisatie

3.7 Richtlijnen voor vroegtijdige kankeropsporingsonderzoeken voor de 'algemene bevolking' : overzicht consensusrapporten 1979-1993

3.8 Indentificatie van de schalen om het concept 'kennis van kankerpreventie' te meten

3.9 Schematisch overzicht van de 'Kennis van kankerpreventie 100-items vragenlijst"

3.10 Overzicht van de itemlïjsten en de afgeleide scores van de 'Kennis van kankerpreventie 100-items vragenlijst'

4.1 Methode van vraagstelling voor het bepalen van de "inkomenspositie"

6.1 Kennis van kankerpreventie. Gemiddelde scores van de kennisschalen

7.1 Kennis van kankerpreventie naar geslacht, controlerend voor leeftijd

7.2 Kennis van kankerpreventie naar leeftijd, controlerend voor geslacht.

8.1 Conceptueel kader van de indicatoren van saciaal-economische status in dit onderzoek

8.2 Kennis van kankerpreventie, naar de geïntegreerde sociaaleconomische status gebaseerd op opleiding, inkomen én beroepsstatus (SESb)

8.3 Kennis van kankerpreventie, naar de geîntegreerde sociaaleconomische status (gebaseerd op opleiding, inkomen én beroepsstatus) en geslacht

8.4 Kennis van kankerpreventie, naar sociaal-economische status (gebaseerd op opleiding, inkomen én beroepsstatus) en leeftijdsklasse 


\section{Lijst van tabellen}

4.1 Responsratio en gebruik van vervangsteekproeven 71

4.2 Redenen van nonrespons, naar steekproef $\quad 72$

4.3 Verdeling van de steekproef-en onderzoekspopulatie, naar provincie

4.4 Verdeling van de steekproef-en onderzoekspopulatie, naar leeftijdscategorie

4.5 Verdeling van de steekproef-en onderzoekspopulatie, naar gemeentetype volgens Vanneste (1989)

5.1 Rangorde van de acht 'juiste' risicofactoren voor kanker volgens hun herkenning door de respondenten (in \%), naar zekerheidsscore $(n=163 \pi)$

5.2 Rangorde van de acht 'juiste' gewenste kankerpreventieve gedragingen volgens hun herkenning door de respondenten (in \%), naar zekerheidsscore $(n=1631)$

5.3 Rangorde van de zeven 'juiste' waarschuwingssignalen voor kanker volgens hun herkenning door de respondenten (in \%), naar zekerheidsscore $(n=1631$ )

5.4 Rangorde van de zeven 'juiste' medische onderzoeken voor vroegtijdige opsporing van kanker volgens hun herkenning door de respondenten (in \%), naar zekerheidsscore $(n=1631$ )

5.5 Kennis van de richtlijnen inzake 'frequentie' van de medische onderzoeken voor vroegtijdige opsporing van borst- en baarmoederhallskanker (in \%)

5.6 Kennis van de richtlijnen inzake 'aanvangsleeftijd' voor de vroegtijdige opsporing van borstkanker en baarmoederhalskanker d.m.v. respectievelijk een mammografie en een baarmoederhalsuitstrijkje (in \%)

5.7 Kennis van factoren m.b.t. primaire kankerpreventie $(n=1631)$

5.8 Kennis van factoren m.b.t. secundaire kankerpreventie $(n=1631$ )

5.9 Aantal respondenten (in \%) volgens hun kennis van de risicofactoren voor kanker, naar zekerheidsscore ( $n=1631$ ) [zie bijlage 3]

5.10 Aantal respondenten (in \%) volgens hun kennis van gewenst kankerpreventief gedrag, naar zekerheidsscore $(n=1631)$ [zie bijlage 3]

5.11 Aantal respondenten (in \%) volgens hun kennis van waarschuwingssignalen woor kanker, naar zekerheidsscore in $=1631$ ) [zie bijlage 3 ]

5.12 Aantal respondenten (in \%) volgens hun kennis van de wroegtïjige opsporingsonderzoeken voor kanker, naar zekerheidsscore $(n=1631)$ [zie bijlage 3]

5.13 Aantal respondenten (in \%) volgens hun kennis van kankerpreventie, naar zekerheidsscore en geslacht $(n=1631)$ (zie bijlage 3)

6.1 Overzicht van de kennisschalen en kennisscores met hun centrale tendentie, spreiding en rangorde $(n=1631)$ 
6.2 Betrouwbaarheid (Cronbach's Alpha) en spreiding (standaardafwijking, minimum en maximum waardel wan de kennisschalen $(N=1631)$

6.3 Correlatiematrix van de 8 items van de schaal "kennisscore risicofactoren"

6.4 Betrouwbaarheid (Cronbach"s Alpha) van de kennisschalen, naar subpopulaties $(N=1631)$

6.5 Samenhang (Mann-Whitney toets, respectievelijk Kruskal Wallis toets) van de adequate kennisschalen met socio-demografische factoren $(N=1631)$

6.6 Correlaties tussen de "adequate" schalen van kennis van kankerpreventie (Kendall's Tau, alle coirrelaties significant met $p<0.001$ )

6.7 De verdeling (Kolmogorov-Smirnov Goodness of Fit test) van de kennisschalen $(N=1631)$

7.1 Frequentieverdeling van de socio-demografische kenmerken ( $n=1631$ )

7.2 Gemiddelde scores van kennis van kankerpreventie, naar geslacht

7.3 Gemiddelde scores van kennis van kankerpreventie, naar geslacht en controllerend woor leeftijdsklasse [zie bijlage 4]

7.4 Gemiddelde scores van kennis van kankerpreventie, naar leeftijdsklasse

7.5 Gemididelde scores van kennis van kankerpreventie, naar leeftijdsklasse en controlerend voor geslacht [zie bijlage 4]

7.6 Gemiddelde scores van kennis van kankerpreventie, naar al of niet aanwezigheid van een partner

7.7 Gemiddelde scores van kennis van kankerpreventie, naar aan- of afwezigheid wan een partner; elaboratie naar geslachtsinvloed [zie bijlage 41

7.8 Gemiddelde scores van kennis van secundaire kankerpreventie bij mannen, naar aan- of afwezigheid van een partner; elaboratie naar leeftijdsinvloed [zie bijlage 4]

7.9 Zero-arder verbanden (Eta-coëfficiënten) tussen de socio-demagrafische determinanten en kennis van kankerpreventie

7.10 Zero-order correlaties (Pearson's r) en partiële correlatiecoëfficiënten tussen de socio-demografische determinanten en kennis van kankerpreventie

8.1 Frequentieverdeling van de sociaal-economische kenmerken in drie klassen

8.2 Frequentieverdeling van de sociaal-economische kenmerken in negen klassen [zie bijllage 5]

8.3 Gemiddelde sicores van kennis van kankerpreventie, naar opleidingsniveau 
8.4 Gemiddelde scores van kennis van kankerpreventie, naar standaardinkomen

8.5 Gemiddelde scores van kennis van kankerpreventie, naar beroepsprestige

8.6 Gemiddelde scores van kennis van kankerpreventie, naar de geïntegreerde sociaal-economische status gebaseerd op opleiding én inkomen (SESa)

8.7 Gemiddelde scores van kennis van kankerpreventie, naar de geintegreerde sociaal-economische status gebaseerd op opleiding. inkomen én beroepsstatus (SESb)

8.8 Gemiddelde scores van kennis van kankerpreventie, naar de geïntegreerde sociaal-economische status gebaseerd op opleiding. inkomen ên beroepsstatus in 9 klassen (SESb) [zie bijlage 5]

8.9 Correlaties (Kendall's Tau coëfficiënten) van kennis van kankerpreventie met de sociaal-economische factoren

8.10 Gemiddelde scores van kennis van kankerpreventie, naar sociaaleconomische status gebaseerd op opleiding, inkomen én beroepsstatus (SESb); controlerend voor geslacht

8.11 Gemiddelde scores van kennis van kankerpreventie, naar sociaaleconomische status gebaseerd op opleiding, inkomen én beroepsstatus (SESb); controlerend voor leeftijd

8.12 Correlaties (Eta-coëfficiënten) tussen kennis van kankerpreventie en respectievelijk socio-demografische en sociaal-economische determinanten (in 3 klassen)

8.13 Multiple correlatiecoëfficiënten van de kennis van kankerpreventie naar geslacht, leeftijd, partner, opleiding, inkomen en beroepsstatus

8.14 Correlatiematrix van de sociale determinanten van kennis van kankerpreventie

8.15 Multipele regressie-analyses van kennis van kankerpreventie met socio-demografische factoren en sociaal-economische status [zie bijlage 5] 
bijlage 1 :

bijlage 1a de conceptsteekproef

bijlage 1b de gerealiseerde steekproef

Bijlage 1

Verslag van de steekproef ${ }^{1}$

De steekproef werd conceptueel en in uitvoering gerealiseerd in samenwerking met Petra De Nooze. Zij was tijdens dit onderzoek als statistica werkzaam aan de Medisch-Sociale wetenschappen van de VU Brussel. 

Bijlage 1a: de "conceptsteekproef"

Inleiding. Met ons anderzoek beogen we expliciet generaliseerbaarheid van de onderzoeksresultaten voor geheel het universum, m.n. de Vlaamse bevolking. Voor deze doelstelling is het van bellang de steekproef zodanig te organiseren dat op legitieme wijze kan worden gegeneraliseerd en de kans op onjuiste generalisatie kan worden geminimaliseerd. De keuze woor een adequate steekproefmethode is dus uiterst belangrijk.

Centraal bij de steekproef is dat de elementen in beginsel representatief moeten zijn voor geheel het universum. Om een representatieve steekproef te kunnen verrichten in Vlaanderen moet eerst echter het universum of de onderzoekspopulatie nauwkeurig worden bepaald.

We gaan in deze bjjlage in op respectievelijk de onderzoekspopulatie, de grootte van de steekproef, de trekkingsmethode en de nauwkeurigheid van de resultaten.

\section{De onderzoekspopulatie}

Voor de definitie van de onderzoekspopulatie gebruiken we volgende selectiecriteria :

1. Inwoner zijn van een Vlaamse gemeente, dit zijn alle gemeenten die behoren tot de vijf Vlaamse provincies of het Vlaams Gewest;

2. Een leeftijd hebben tussen 18 en 70 jaar.

Volgens het geografisch criterium wordt Brussel buiten beschouwing gelaten. Deze ingreep is ook om onderzoekstechnische redenen te verantwoorden. In Brussel zijn een groot aantal inwoners franstalig. Om een ernstige non-repons te vermijden ten gevolge van taalproblemen wordt een extra inspanning geëist woor de vertaling van de vragenlijst en opleiding van anderstalige enquêteurs. Dit brengt een enorme meerkost met zich mee (Dooghe, e.a., 1988).

Door de leeftijdsondergrens te bepalen op 18 jaar worden kinderen niet bij het onderzoek betrokken. Kanker komt immers meestal voor bij volwassenen. Bovendien werschillen de kankers die men bij het kind aantreft van deze die men doorgaans bij de volwassene vaststelt zowel wat betreft de aard, de oorzaak en de lokalisatie van de kanker (Vereniging voor kankerbestrijding, 1991). 70 jaar ward als bovengrens voor de leeftijd genomen, omdat de richtlijnen voor secundaire kankerpreventie merstal die bovengrens hanteren. Zo bijvoorbeeld wordt een mammografie aangeraden voor vrouwen tussen 50 en 70 jaar. Deze laatste leeftijdscategorie is dus voor ons onderzoek nog steeds interessant. Oudere personen worden echter niet meer ondervraagd, $0 . m$. ook orndat zij veelal in instellingen verblijven. Hierdoor kan er een vertekening optrederi in de steekproef. 


\section{De steakproefgroptte}

Om tot geldige uitspraken te komen over de kennis van kanker en kankerpreventie wan de Vlaamse bevolking tussen 18 en 70 jaar is een aselecte steekproef noodzakelijk. De statistische berekening van de steekproefomvang vertrekt wan een enkelvoudige steekproef. De steekproefomvang wordt voor variabelen op ordinale meetschaal gegeven door :

$$
n=\frac{z_{1-a / 2}^{2} P(1-P)}{d^{2}} \quad \text { (Lemeshow, e.a., 1992) }
$$

waarin:

$n=$ de steekproefgrootte

$\mathrm{P}=$ de procentuele verhouding van voorkomen van een versehijnsel in de onderzoekspopulatie

d $=$ de precisie van de schatting

$\alpha=$ de onbetrouwbaarheidsdrempel

$z_{1-\alpha / 2}^{a}=$ een factor die afhankelijk is van de gewenste betrouwbaarheid $1-\alpha$

Deze formule geldt in de veronderstelling dat de steekproefgrootte $n$ relatief klein is ten opzichte van de populatieomvang $N$. In het algemeen wondt dit aangenomen vanaf $n<0,1 \mathrm{~N}$ (Moors en Muilwijk, 1975). Bij een steekproef aver het hele Vlaamse Gewest is deze veronderstelling meer dan realistisch.

Indien men enig idee heeft over de orde van grootte van de gezochte procentuele verhouding $P$ kan de steekproefomvang eenvoudig bepaald worden. Is dit niet het geval, zoals in dit onderzoek, kan gebruik worden gemaakt van het gegeven dat voor niet al te kleine en niet al te grote procentuelle verhoudling $P, P(1-P)$ zeer weinig fluctueert. Dit blijkt wit onderstaande tabel waarin $P(1-P)$ bepaald wordt voor een alantal waarden van $P$ :

\begin{tabular}{|c|c|c|c|c|c|}
\hline$P$ & 0,5 & 0,4 of 0,6 & 0,3 of 0,7 & 0,2 of 0,8 & 0,1 of 0,9 \\
\hline$P(1-P)$ & 0,25 & 0,24 & 0,21 & 0,16 & 0,09 \\
\hline
\end{tabular}

Wanneer $P$ varieert tussen 0,3 en 0,7 verandert $P(1-P)$ nauwelijks. De maximale waarde wardt bereikt voor $P=0,5$, dus keuze van deze waarde geeft altijd een bovengrens voor de noodzakelijke steekproeformvang (Moors en Muilwijk ${ }^{\prime}$ 1975).

In de sociale wetenschappen hanteert men gewoonlijk een onbetrouwbaarheidsdrempel $\propto$ van $5 \%$ (van den Ende en Verhoef, 1975). De factor $z^{2}$.a/2 heeft dan de waarde 1,96.

Met een 95\% waarschijnlijkheid dat de steekproef representatief is voor de hele onderzoekspopulatie (er van uitgaande dat er geen systematische fouten zullen voorkomen), kan de steekproefgrootte $n$ bepaald worden in functie van de precisie $d_{v}$ in het meest ongunstige geval $P=0,5$ :

\begin{tabular}{|l|c|c|c|c|c|}
\hline$d$ & 0.01 & 0.15 & $2 \%$ & $2,5 \%$ & $3 \%$ \\
\hline $\mathrm{n}$ & 9.604 & 4.269 & 2.401 & 1.537 & 1.067 \\
\hline
\end{tabular}

- Sociale determinanten van kennis van kankerpreventie in Vlaanderen - 
Bij de keuze van de steekproefgrootte dient ook het kostenaspect in overweging worden genomen. De optimale steekproefomvang is deze die bij zo laag mogelijke kosten zo nauwkeurig mogelijke resultaten bereikt. De voorbereidingskosten en de warnemingskosten samen kunnen voor ons onderzoek geschat worden op $20^{\prime} n 1.400$ BEF per enquête! Voor de verschillende mogelijke steekproefgroottes kunnen de kosten dan geraamd worden op:

\begin{tabular}{|l|c|c|c|c|c|}
\hline $\mathrm{n}$ & 9.604 & 4.269 & 2.401 & 1.537 & 1.067 \\
\hline kosten & 13.445 .600 & 5.976 .600 & 3.361 .400 & 2.151 .800 & 1.493 .800 \\
\hline
\end{tabular}

Een goede verhouding tussen de precisie enerzijds en de kosten anderzijds wordt gegeven bij een steekproefgrootte van 1537 personen. Om de nauwkeurigheid met $0,5 \%$ te verbeteren, lopen de kosten met meer dan 1 miljoen BEF op. Dit verschil in precisie weegt niet op tegen het hoge kostenverschil.

De berekening van de precisie is trouwens gebaseard op het meest ongunstige geval waarin de procentuele verhouding $P$ op 0,5 geschat wordt. Naarmate $P$ meer afwijkt van die waarde, neemt de nauwkeurigheid toe. Bij een steekproefgrootte van 1537 personen en $\alpha 5 \%$ bekomt men:

\begin{tabular}{|c|c|c|}
\hline$P$ & $1-P$ & $d$ \\
\hline 0,95 & 0,05 & 1,09 \\
\hline 0,90 & 0,10 & 1,50 \\
\hline 0,85 & 0,15 & 1,79 \\
\hline 0,80 & 0,20 & 2,00 \\
\hline 0,75 & 0,25 & 2,16 \\
\hline 0,70 & 0,30 & 2,29 \\
\hline 0,65 & 0,35 & 2,38 \\
\hline 0,60 & 0,40 & 2,45 \\
\hline 0,55 & 0,45 & 2,49 \\
\hline 0,50 & 0,50 & 2,50 \\
\hline
\end{tabular}

Anderzijds moet men rekening houden met het feit dat al deze berekeningen van de precisie gebaseerd zijn op een enkelvoudige steekproef. Dit type steekproef is echter niet haalbaar voor cen enquête van grote ruimtelijke omvang. Bij de bespreking van de trekkingsmethode zal daarom nagegaan worden welke de invloed is van de steekproefopzet op de nauwkeurigheid van de schatting.

"Deze schatting is gebaseerd op de reele kosten valn aen in intervitewtijd vergelijkbarm enquete wan het Interuniversitair Steunpunt Politieke- opinieonderzoek van de K.U.Leluven (Mlondelinge mededeling ven Ann Cartoni. 
Deze irvloed word het design effect genoemd. We kunnen hier reeds stellen dat het design effect in de meeste gevalen een ongunstige invloed heeft op de precisie.

\section{De trakkingsmethade}

Bij een enkelvoudige aselecte steekproef warden de te ondervragen personen rechtstreeks uit de gehele onderzoekspopulatie geloot, waarbij elk lid evenveel kans maakt te worden uitgekozen. Deze wijze vän steekproeftrekking varmt én der zuiverste methoden (Gadourek, 1976).

De toepassing hiervan heeft als madeel dat in bijna alle gemeenten personen zouden worden andervraagd. Dit is een tijdrovende en kostelijke aangelegenheid. Zowat in alle steekproeven met een sterke ruimtelike spreiding wordt daarom gebruik gemaakt van een "getrapte" steekproef. Eerst wordt een aselecte steekproef van gemeenten getrokken, en vervolgens een aselecte steekproef van personen in de uitgelote gemeenten.

Om toevalsafwijkingen te ondervangen zal deze getrapte steekproef gecombineerd worden met een stratificatie naar provincie, zodat het representatieve karakter van de steekproef niet in het gedrang komt (Dooghe en Vanderleyden, 1976). De typologie van gemeenten naar sociaal-economische status (Vanneste, 1989) zal gebruikt worden als tweede stratificatievariabele.

\subsection{De stratificatie}

Stratificatie betekent dat de onderzoekspopulatie verdeeld wordt in een aantal strata waarvan de omvang bekend is. Uit elk van de strata wordt dan een afzonderlijke steekproef getrokken en de schattingen die men hieruit verkrijgt, worden vervolgens gecombineerd tot schattingen van de hele onderzoekspapulatie IMoors on Muilwijk, 1975).

Een proportionele stratificatie zorgt voor een ewenredige representatie van de verschillende strata aveir de ganse steekproef. Bij steekproeven met een grote ruimtelijke spreiding is het nuttig om naar een administratieve eenheid - in ons geval de provincie - te stratificeren zodat bepaalde delen van het Vlaamse Gewest niet onder- respectievelijk oververtegenwoordigd zijn.

Voor dit onderzoek is het bovendien interessant om de kennis" en attitudescore te kunnen relateren aan een gemeentetype. Deze variabele zal als tweede stratificatievapiabele dienst doen. Er zijn vier verschillende indelingen van de Belgische gemeenten naar gemeentetype beschikbaar van een min of meer recente datum.

Een studie van Van der Haegen, Pattyn en Cardyn (1982) stelt een hiërarchie voor van grote, regionale en kleine steden, met daaronder 2 niveaus van dorpen. Voor een indeling in verschillende strat kan elk niveau als een cluster beschouwd worden. Zo een indeling is echter niet zo zinvol voor onze steekproef. Bijwoorbeeld een gemeente zoals Aartselaar, dat vlakbij Antwerpen ligt, wordt net als Brakel, een zeer landelijke gemeente in Oost-Vllaanderen, tot de categorie van de dorpen gerekend. Het kenuisniveau van kanker zou nochtans sterk kunnen verschillen omwille van de differentiële "nabilheid" van informatiekanalen. Een andere optie bij deze studie is een indeling volgens inwloedssferen van tenminste een bepaald niveau van steden als strata te beschouwen. Op het niveau van de grote steden onderscheild men alleen maar Artwerpen en Gent, en alle andere gemeenten vallen buiten hun invloedsfieer. We belkomen dus maar twee strata. De werkelijkheid is echter iets mesr gedifferentieerd. Kiezen we een niveau lager, dat van de regionale steden, dan bekomen we 13 
verschillende strata. Dit aantal is veel te groot woor de analyse van subpopulaties bij onze steekproefgrootte.

Een andere mogelijke indeling van de gemeenten is de studie van de Belgische stadsgewesten (Leemans, et.al., 1981). Voor Vlaanderen worden 8 stadsgewesten onderscheiden. Voor het gebruik. van deze indeling als strata in onze steekproef geldt een gelijkaardige opmerking als bij de vorige studie, namelijk dat de categorie "andere" alle gemeenten bevat die niet tot én wan de acht stadsgewesten behoren. Dit blijken heel wat gemeenten te zijn met een sterk uilteenlopend karakter.

Er bestaat ook nog een indeling naar verstedelijkingsgraad gebaseerd op de bevolkingsaantallen per gemeente (NIS, 1990). Of er een verband bestaat tussen de mate van verstedelijking en kennis van kanker is echter niet zo duidelijk. Daarom werd ook deze indeling niet weerhouden.

Door Prof. D. Vanneste (1989) werd een typologie opgesteld van de Belgische gemeenten op basis van 6 variabelen die samen een aanduiding geven varu de sociaal-economische status van een gemeente. Met behulp van een clusteranalyse worden de gemeenten ingedeeld in 6 verschillende types. Het verband tussen kennis van kanker en sociaal-economische status wordt, allieszins op individueel niveau, wel verwacht. Bovendien bevindt elke gemeente zich in juist éen cluster.

Met behulp van deze typologie, worden de gemeenten in zes homogene strata verdeeld.

\subsection{De getrapte steekproef}

Een tweetrapssteekproef gebeurt, zoals de naam het reeds aanduidt, in twee trappen. Eerst worden de gemeenten geselecteerd. Bij deze selectie worden aan een gemeente geen, één of meardere steekproefpunten toegekend. Gemeenten met hoge bevolkingsaantallen maken meer kans op een groter aantal steekproefpunten. In elk steekproefpunt wordt vervolgens een vast aantal personen getrokken.

Bij de steekproef van gemeenten wordt rekening gehouden met de ruimtelijke stratificatie naar provincie en naar sociaal-economische status van de gemeente. ln elk stratum wordt een afzonderlijke getrapte steekproef getrokken.

De verdeling van het aantal steekproefpunten - in totaal $102^{\circ}$ - over de strata, gebeurt in verhouding tot de bevolkingsaantallen. Om de steekproefpunten binnen éen stratum te verdelen, wordt galbruilk. gemaakt van een systematische trekking. Een systematische trekking garandeert dat de steekproef zo goed mogelijk over de onderzoekspopulatie gespreid is. Bij systematische trekking uit een gecumuleerde frequentieverdeling levert elke gemeente met een onderzoekspopulatie van tenminste de ophoogfactor een bijdrage. Een systematische trekking is in feite een impliciete stratificatie (Moors en Muilwijk, 1975).

Eens de gemeenten geselecteerd zijn, kan owergegaan worden tot het samenstellen van de steekproef van persomen tussen 18 en 70 jaßr.

1. Om de dataverzameling relatief snel te laten verlopen, kozen we voor een beperkt aantal interwiewg per enquẻteur, namelijk 15. Rekeninghoudende met de steekproeforrvang wan 1537 personem geett dit 102 steelkproefpunten. 
In elke geselecteerde gemeente wordt een vast aantal personen getrokken. Bij een steekproefgrootte van 1537 personen en 102 steekproefpunten, kunnen per steekproefpunt 15 personen worden getrokken. Het werken met een vast aantal doet geen afbreuk aan het zelfwegend karakter van de steekproet. Bij trekkingskansen die evenredig zijn met de grootte van de gemeenten, speelt de omvang van de steekproef in de tweede trap geen rol bij het schatten van het algemeen gemiddelde (Moors en Muilwijk, 1975).

\section{Nauwkeurigheid van de resultaten}

\subsection{Deelpopulaties}

De berekening van de steekproefgrootte gebeurde op basis van de totale onderzoekspopulatie. De gevonden nauwkeurigheid geldt dus alleen voor resultaten die voor de hele onderzoekspopulatie geidig zijn. Bij de analyse van een deelpopulatie zal de precisie van de resultaten uiteraard lager zijn dan bij de totale populatie (Henry, 1990). Enkele berekeningen van de precisie van vooraf in omvang gekende subpopulaties, zullen hieronder weergegeven worden.

De methode van berekenen verloopt op bijna dezelfde manier alls voor de hele onderzoekspopulatie (Moors en Muilwijk, 1975):

$$
d=\sqrt{z_{1-\alpha / 2}^{2} P(1-P) / a}
$$

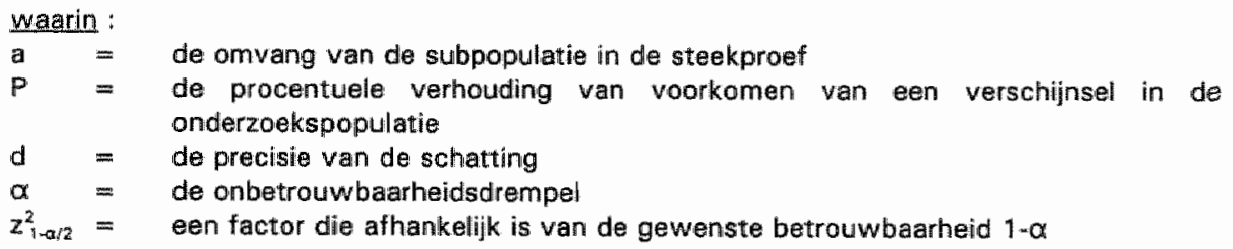

Aangezien a $<10 \%$ van de totale omvang wan de subpopulatie, kan ook hier, net zoals bil de bepaling van de steekproefgrootte, de eindigheidscorrectie weggelaten worden.

In de berekeningen wordt $\alpha$ vastgelegd op $5 \%$, waardoor $z_{\text {.ai } 2}^{2}$ gelijk wordt aan 1,96 . $P$ wordt geschat op 0,5 .

Naast de precisie, of de halve lengte van het betrouwbaarheidsinterval, zal oolk de standaardfout (SE) voor de verschillende deelpopulaties berekend worden (Moors en Muilwijk, 1975) :

$$
S E=\sqrt{P(1-P) / a}
$$

Wanneer in de analyse gebruik gemaakt wordt wan een vergelijkingshypothesetoets

$$
\begin{aligned}
& H_{0}: \pi_{1}=\pi_{2} \\
& H_{1}: \pi_{3}: \pi_{2}
\end{aligned}
$$

- Sociale determinanten van kennis van kankerpreventie in Vlaanderen - 
dlan wordt het aanvaardingsinterval gegeven door (Lemeshow, e.a., 1992):

$$
\left(0 \pm z_{1-\alpha / 2} \sqrt{\left.\frac{P(1-P)}{a_{1}}+\frac{P(1-P)}{a_{2}}\right)}\right.
$$

De halve lengte van dit aanvaardingsinterval wordt in een tabel van verschillen weergegeven. Deze waarden geven het kleinste verschil weer dat nodig is tussen twee deelpopulaties om statistisch significant te zijn.

De berekeningen worden uitgevoerd voor de verschillende provincies en voor de zes clusters.

De nauwkeurigheid van de 5 provincles varieert tussen 5 en 7 procentpunten (zie bijlage 7 . Dit betekent dat een betrouwbaarheidsinterval tussen 10 en 14 procentpunten lang zal zijn. Tussen twee provincies moet er tenminste een verschil zijn van 7 tot 9 procentpunten om significant te zijn. De precisie voor de verschillende clusters ligt begrepen tussen 5 en 9,5 procentpunten lzie bijlage In. De variatie is hier veel groter dan bij de provincies.

\subsection{Design effect}

Bij de berekening van de steekproefgrootte werd een aselecte steekproef werondersteld. Als de trekkingsmethode verschilt van een aselecte steekproef, verandert de optimale steekproefgrootte eveneens. Bij een getrapte steekproef bijvoorbeeld neemt de variantie $P(1-P) / n$ toe, terwijl bij een gestratificeerde steekproef deze variantie afneemt.

Het design effect wordt gedefinieerd als de werhouding tussen de variantie bij een bepaalde trekkingsmethode en de variantie bij een even grote aselecte steekproef (Moors en Muilwijk, 1975). Om de impact van de steekproefgrootte te bepalen, vermenigvuldigt men het design effect met de variantie.

Het design effect bij een gestratificeerde steekproef warieert tussen 0,5 en 0,95 . De exacte waarde hangt af van het aantal strata en de correlatie tussen de stratificatievariabele en de bestudeerde variabele.

Getrapte steekproeven hebben een design effect dat groter is dan 1. Het aantal steekproefpunten, de homogeniteit binnen de steekproefpunten en het al dan niet combineren met een stratificatie, heeft een belangrijke invloed op de juiste waarde (Henry, 1990).

In dit onderzoek wordt een stratificatie gecombineerd met een getrapte steekproef. Dilt kan de toename in variantie well reduceren maar niet volledig wegwerken.

Uit al het voorgaande blijkt duidelijk dat het inschatten wan het design effect nog vooraler het onderzoek heeft plaatsgehad, niet eenvoudig is. Gewoonlijk wordt het design effect dan ook als hulpmiddel gebruikt om achteraf de steekproefopzet te evalueren. Als men toch een idee wil krijgen over de grootteorde van het design effect, kan men gebruik maken van de vuistregel van Stuart die stelt dat in de meeste gevallen het design effect gelegen is tussen $(1,25)^{2}$ en $(1,50)^{2}$. Empirische 
studies bevestigen dat deze regell vrij nawwkeurig is (Henry, 1990).

Omdat de steekproefgrootte op 1530 personen omvat, zal de omgekeerde berekening gemaakt worden: welk verlies aan nauwkeurigheid kan bij de gegeven steekproefgrootte verwacht worden?

\begin{tabular}{|l|c|c|c|}
\hline & SRS & deff min & deff max \\
\hline SE & 1.29 & 1.61 & 1.94 \\
\hline$d$ & 2.53 & 3.16 & 3.80 \\
\hline INT & 5.06 & 6.32 & 7.60 \\
\hline
\end{tabular}

$\begin{array}{ll}\text { SRS } & =\text { aselecte steekproef } \\ \text { deff } \min & =\text { laagste waarde voor het design effect } \\ \text { deff } \max & =\text { hoogste waarde voor het design effect } \\ \text { SE } & =\text { standiardfout } \\ \text { d } & =\text { precisie van de schatting } \\ \text { INT } & =\text { interval }\end{array}$

De berekeningen worden gemaakt voor $P=0,5$. De standaardfout en de precisie, met inbegrip van het design effect, worden berekend met behulp van volgende formules (Henry, 1990):

$$
\begin{gathered}
d=\sqrt{z_{1-\alpha / 2}^{2} P(1-P) \text { deff } / n} \\
S E=\sqrt{P(1-P) \operatorname{deff} / n}
\end{gathered}
$$

Bij het laagste design effect verhoogt de precisie naar $3 \%$, wat op zich nog geen probleem is voor de nauwkeurigheid van do resultaten. Vermits bij deze trekking een tweetrapssteekproef gecombineerd wordt met een stratificatie gaan we ervan uit dat het design effect eerder aan de lage kant zal zijn. Er zijn dan ook geen grote nauwkeurigheidsverschillen te verwachten bij de analyse van de volledige onderzoekspopulatie.

Bij het onderzoek naar de deelpopulaties, waar de precisie altijd al lager is dan bij de volledige populatie, moet ook rakening worden gehouden met dit design effect.

- Sociale determinanten van kennis van kankerpreventie in Vlaanderen - 
Bijlage 1: De nauwkeurigheid naar provincies:

De steekproefgrootte in elke provincie:

\begin{tabular}{|l|c|c|}
\hline Provincie & steekproefpunten & a \\
\hline Antwerpen & 28 & 420 \\
Brabant & 17 & 255 \\
West-Vlaanderen & 19 & 285 \\
Oost-Vlaanderen & 23 & 345 \\
Limburg & 13 & 195 \\
\hline
\end{tabular}

De standaardfout en de precisie:

\begin{tabular}{|c|c|c|c|c|c|}
\hline & Antw. & Brab. & W-VI. & O-VI. & Limb. \\
\hline SE & 2.44 & 3.13 & 2.96 & 2.69 & 3.58 \\
\hline$d$ & 4.78 & 6.13 & 5.80 & 5.27 & 7.02 \\
\hline
\end{tabular}

De tabel van verschillen:

\begin{tabular}{|l|c|c|c|c|c|}
\hline & Antw. & Brab. & W-VI. & O-VI. & Limb. \\
\hline Antwerpen & - & 7.78 & 7.52 & 7.12 & 8.49 \\
\hline Brabant & & - & 8.45 & 8.09 & 9.32 \\
\hline W-Vlaanderen & & & - & 7.84 & 9.11 \\
\hline O-Vlaanderen & & & & - & 8.78 \\
\hline Limburg & & & & & - \\
\hline
\end{tabular}

- Sociale determinanten van kennis van kankerpreventie in Vlaanderen - 
Bijlage II: De nauwkeurigheid naar gementelijke clusters

De steekproefgrootte in elke cluster:

\begin{tabular}{|l|c|c|}
\hline & \# steekproefpunten & a \\
\hline cluster 1 & 25 & 375 \\
\hline cluster 2 & 27 & 405 \\
\hline cluster 3 & 7 & 105 \\
\hline cluster 4 & 14 & 210 \\
\hline cluster 5 & 19 & 285 \\
\hline cluster 6 & 8 & 120 \\
\hline
\end{tabular}

De berekening van de standaandfout en de precisie:

\begin{tabular}{|l|c|c|c|c|c|c|}
\hline & cluster 1 & cluster 2 & cluster 3 & cluster 4 & cluster 5 & cluster 6 \\
\hline SE & 2.58 & 2.48 & 4.88 & 3.45 & 2.96 & 4.56 \\
\hline$d$ & 5.06 & 4.86 & 9.56 & 6.76 & 5.80 & 8.94 \\
\hline
\end{tabular}

De tabel van de verschillen:

\begin{tabular}{|l|c|c|c|c|c|c|}
\hline & cluster 1 & cluster 2 & cluster 3 & cluster 4 & cluster 5 & cluster 6 \\
\hline cluster 1 & - & 7.02 & 10.82 & 8.45 & 7.70 & 10.28 \\
\hline cluster 2 & & - & 10.73 & 8.33 & 7.58 & 10.19 \\
\hline cluster 3 & & & & 11.71 & 11.19 & 13.10 \\
\hline cluster 4 & & & & & 8.91 & 11.21 \\
\hline cluster 5 & & & & & & 10.66 \\
\hline cluster 6 & & & & & & \\
\hline
\end{tabular}




\section{Bijlage 1b: de "gerealiseerde steekproef"}

Inleiding. In bijlage 1a werd de steekproef geconceptualiseerd. In deze bijlage 1b gaan we na hoe ze in ons onderzoek concreet werd geoperationaliseerd. In deze bijlage beschrijwen we respectievelijk het gebruikte steekproefkader, de concrete procedure van de steekproeftrekking, het steekproefplan en de non-iriespons.

\section{Het steekproefkader}

In de conceptsteekproef werd de onderzoekspopulatie omschreven als de personen woonachtig in het Vlaamse Gewest met een leeftijd tussen 18 en 70 jaar die niet verblijwen in een instelling. Om de steekproef te trekken is een administratief kader nodig dat idealiter perfect overeenkomt met de onderzoekspopulatie. Zowel in binnenlandse als buitenlandse surveys worden de bevolkingsregisters meestal als steekprosfbasis genomen.

Bij dergelijke steekproefkaders doen zich evenwel een aantal problemen voor. Onvolledigheid is een veel voorkomend euvel. Hieronder vallen zowel toevalligheden te wijten aan foutten of vergissingen als het systematisch ontbreken van deelpopulaties zoals illegalen. Een andere mogellike fout van het steekproefkader is dat sommige personen er meer dan eens in voorkomen, waardoor hun trekkingskans vergroot. Andere personen zijn dan weer onmogelijk te bereiken door een onjuist adres bijvoorbeeld. Het komt ook voor dat het kader personen bevat die buiten de onderzoekspopulatie vallen. In ons geval konden personen die in instellingen verblijen niet uit het bevolkingsregister geselecteerd worden.

Zolang de invloed op de uitkomsten gering is, kunnen deze problemen genegeerd worden en het kader als ideaal beschouwd worden (Moors en Mulllwijk, 1975).

\subsection{Het Rijksregister}

Het meest volledige en geschikte bevolkingsregister in Belgiê is ongetwijfeld het Rijksregister. Het Rijksregister bundelt informatie over elke persoon die opgenomen is in de bevalkings- en vreemdelingenregisters van de gemeenten. Artikel 3 van de wet van 8 augustus 1993 geeft een limitatieve opsomming van de bevolkingsgegevens die in het Rijksregister opgenomen en bewaard worden. Deze gegevens zijn (Loaze, 1994):

1. naam woornam

2. geboorteplaats en datum

3. het geslacht

4. de nationaliteit

5. de hoofdverblijfplaats

6. plaats en datum van overlijden

7. het beroep

8. de burgerlijke staat

9. de samenstelling van het gezin

Om steekproeven uit het Rijksregister te trekken volstond het in het verleden om een toestemming te bekomen van de gemeentelijke overheden van de in de steekproef opgenomen gemeenten. Op grond van die toestemming verleende het Rijksregister dan medewerking. Het voornaamste nadeel en de zwakke schakel van deze werkwijze was de (eventuele) willekeur van de gemeentelijke overheden (Billiet, 1994). 
Na het in voege treden van de Wet op de Bescherming van de Persoonlijke Levenssfeer 18 december $1992)$ is het Rijksregister zich minder soepel gaan opstellen om toegang te werlenen voor het wetenschappelijk onderzoek. Op het moment van onze steekproeftrekking werkte men aan een ontwerp van koninklijk besliuit om de voorwaarden vast te stellen waaraan wetenschappelijke instellingen moeten woldoen om toegang te hebben tot de gegevens opgenomen in het Rijksregister. Slechts na een eventuele bekendmaking in het Belgisch Staatsblad kan overwogen worden gevolg te geven aan een verzoek, en dit alleen na een gunstig advies van de Commissie voor de Bescherming van de Persoonlijke Levenssfeer en vervolgens na een beraadslaging van de Ministerraad. Aangezien op het ogenblik van de steekproef dit KB nog niet van kracht was, was er wat het wetenschappelijk. onderzoek betreft nog niets geregeld met betrekking tot de toegang tor het Rijksregister. Een verzoeksbrief gericht naar de directeur van het Rijksregister enerzijds en naar de Minister wan Binnenlandse Zaken anderzijds werden dan ook beiden negatief beantwoord.

\subsection{Het bevalkingsfegister van de gemeenten}

In afwachting van een regeling voor de toegang van het Rijksregister voor Wetenschappelijke Instellingen bleef als enige valabele mogelijkheid over om rechtstreeks een beroep te doen op de bevolkingsregisters van de gemeenten.

Vroeger volstond de toestemming van de gemeentebesturen om gebruik te maken van de bevolkingsen vreemdelingenregisters. Sinds de wet wan 16 juli 1992 kunnen deze registers ook niet meer zomaar geraadpleegd worden. Deze wet is echter onduidelijk, zodat de gemeenten ze erg verschillend interpreteren.

Een schriftelijke aanvraag werd gericht aan het college van burgemeester en schepenen van de geselecteerde gemeenten. Van de 89 gemeenten uit de steekproef reageerden 87 gemeenten positief. Slechts twee gemeenten weigerden hun toestemming, beiden op grond van de Wet ter Bescherming van de Persoonlijke Levenssfeer ( 8 december 1992\%.

\section{De steekproeftrekking}

De steekproeftrekking gebeurde in twee trappen. Eerst werden een aantal gemeenten geselecteerd; vervolgens werden binnen elke geselecteerde gemeente een aantal personen getroklken.

Om praktische redenen werd geopteerd woor 102 steekproefpunten, te verdelen over de gemeenten van het Vlaamse Gewest. Het aantal steekproefpunten is in verhouding tot de grootte van de gemeente, gemeten naar bevolkingsaantallen. Een grotere gemeente kan dus meer dan eén steakproefpunt hebben. In elk steekproefpunt werden dan 16 personen getrokken?.

\subsection{Trekking van gemeenten}

De gemeenten wan het Vlaamse Gewest werden ingedeeld in strata op basis van de provincie en het SES-gemeentetype. Op deze manier werden 30 verschillende strata bekomen 15 provincies $\times 6$ SESgemeentetypes).

Om de 50/50 werhouding tussen mannen en vrouwen in elk steekproefpunt gemakkelijker te kunner. reproduceren werd het aantal respondenten per steekproiefpunt opgetrokken van $15-$ zoals werd bepaald in de 'conceptsteekproet - naar 16. 


\begin{tabular}{|c|c|c|c|}
\hline Provinere & SES-GEMEENTETYPE & TOTALE BeVOLKING & \# STEERPRORTPUNTEN \\
\hline \multirow[t]{6}{*}{ Antwerpen } & 1 & 438063 & 11 \\
\hline & 2 & 288794 & 7 \\
\hline & 3 & 97756 & 2 \\
\hline & 4 & 142372 & 4 \\
\hline & 5 & 110926 & 3 \\
\hline & 6 & 48730 & 1 \\
\hline \multirow[t]{6}{*}{ Brabant } & 1 & 113431 & 3 \\
\hline & 2 & 57232 & 1 \\
\hline & 3 & 207519 & 5 \\
\hline & 4 & 230439 & 6 \\
\hline & 5 & 58368 & 1 \\
\hline & 6 & 24871 & 1 \\
\hline \multirow[t]{6}{*}{ West-Vlaanderen } & 1 & 182065 & 5 \\
\hline & 2 & 249820 & 6 \\
\hline & 3 & 0 & 0 \\
\hline & 4 & 60719 & 2 \\
\hline & 5 & 160384 & 4 \\
\hline & 6 & 116305 & 3 \\
\hline \multirow[t]{6}{*}{ Oost-Vlaanderen } & 1 & 160106 & 4 \\
\hline & 2 & 320738 & 8 \\
\hline & 3 & 12717 & 0 \\
\hline & 4 & 114974 & 3 \\
\hline & 5 & 259091 & 7 \\
\hline & 6 & 70916 & 2 \\
\hline \multirow[t]{6}{*}{ Limburg } & 1 & 91084 & 2 \\
\hline & 2 & 188220 & 5 \\
\hline & 3 & a & 0 \\
\hline & 4 & 5399 & 0 \\
\hline & 5 & 219042 & s \\
\hline & 6 & 36240 & 1 \\
\hline TOTAALL & & 4066321 & 102 \\
\hline
\end{tabular}

Sociale determinanten van kennis van kankerpreventie in Vlaanderen. 
De verdeling van de 102 steekproefpunten over de strata gebeurde op besis van de totale bevolking in elk stratum in verhouding tot de totale onderzoekspopulatie. Onderstaande tabel geeft een overzicht van de verdeling van de steekproefpunten over de verschillende strata

Bijwoorbeeld voor het stratum prowincie Antwerpen - SES gemeentetype 1 ziet de berekening er als volgt uit:

$$
438063 / 4066321 * 102=11
$$

Tot hiertoe werd bepald hoeveel steekproefpunten in elk stratum voorkomen. Nu kunnen de toegekende steekproefpunten in efk stratum verdeeld wonden over de gemeenten. Dit gebeurde d.m.v. een systematische trekking.

De hieronder beschreven berekeningen werden gemaakt voor elk stratum afzonderlijk. De gemeenten werden gerangschikt in opklimmende volgorde naar bevolkingsaantal. Vervolgens werden de cumulatieve bevolkingsaantallen berekend. Voor een svstematische trekking gaat men uit van een aselect begingetal en een ophoogfactor. Deze ophoogfactor wordt berekend door de totale onderzoekspopulatie in het stratum te delen door het aantal steekproefpunten. Het aselecte begingetal wordt bekomen door deze ophoogfactor te vermenigvuldigen met een randomgetal tussen o en 1:. De op deze wijze bekomen waarde geeft meteen al het eerste steekproefpunt aan. De overige steekproefpunten worden bekomen door bij de beginwaarde telkens de ophoogfactor bij te tellien. Door vergelijking van de op deze wijze bekomen waarden met de cumulatieve bevolkingsiaantallen, kan vastgesteld worden in welke gemeenten de bekomen steekproefpunten gelegen zijn.

Bij wijze van voorbeeld wordt hier het stratum provincie Antwerpen - SES gemeentetype I volledig uitgewerkt :

\begin{tabular}{|c|c|c|c|c|}
\hline GEMAENTE & $\begin{array}{c}\text { BEWOLKAMGS- } \\
\text { AANTAL }\end{array}$ & $\begin{array}{l}\text { CUMULATEVE } \\
\text { BEWOLKHAGS- } \\
\text { AANTALLEN }\end{array}$ & $\begin{array}{l}\text { SYSTEMMTISCHE } \\
\text { STEERPROEF }\end{array}$ & $\begin{array}{l}\text { AANTAL } \\
\text { STEEKPEIOEF-PUNTTEN } \\
\text { PER GEMEENTE }\end{array}$ \\
\hline Wiñgem & 5678 & 5678 & 2977 & 1 \\
\hline Herentals & 17409 & 23087 & & 0 \\
\hline Mortsel & 17831 & 40918 & & 0 \\
\hline Turnhout & 27367 & 68285 & 42800 & 1 \\
\hline Mechelen & 51655 & 119940 & 82624 & 1 \\
\hline Antuverpen & 318123 & 438063 & 122448 & 8 \\
\hline & & & 162272 & \\
\hline & & & 202096 & \\
\hline & & & 241920 & \\
\hline & & & 289744 & \\
\hline
\end{tabular}

Het softwarepalkket Microsoft Excell for Windows warmee de steekproef werd verricht, heefteen functie dis tomlaat oen fandomgetal te kiezen. 


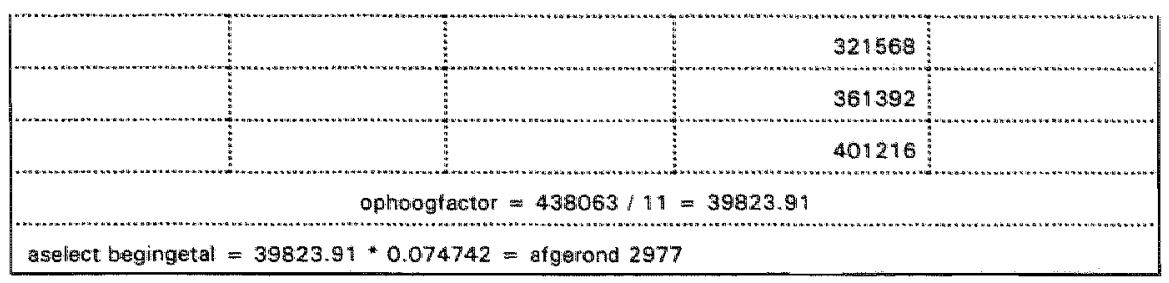

Een belangrijk voordeel van het toepassen wam een systematische trekking wordt bekomen door de ordeming in het steekproefkader. Dit garandeert dat de steekproef zo goed mogelijk gespreid is over de gemeenten. Bij een systematische trekking over een gecumuleerde frequentieverdeling levert tiedere gemeente met een aantal inwoners van tenminste de ophooglactor een bijdrage. Bij aselecte steekproeven daarentegen kunnen bepaalde deelpopulaties toevallig slecht of helemaal niet in de steekproef vertegenwoordigt zijn (Moors en Muilwijk, 1975\%.

Na toepassing van deze berekeningen op elk van de strata, werden volgende 89 gemeenten geselecteerd:

\begin{tabular}{|c|c|c|c|}
\hline $\begin{array}{c}\text { GESELECTEERDE } \\
\text { GEMEENTEN IN DE } \\
\text { PROWINCIE ANTWWERPEN }\end{array}$ & $\begin{array}{l}\text { AANTAL } \\
\text { STEEKPROEFPUNTEN }\end{array}$ & $\begin{array}{l}\text { GESELECTE ERDE } \\
\text { GEMEENTEN IN DE } \\
\text { PRONINCIE BRABANT }\end{array}$ & $\begin{array}{c}\text { AANTAL } \\
\text { STEEKAPFOEFPUNTEN }\end{array}$ \\
\hline Antwerpen & 8 & Diest & 1 \\
\hline Arendonk & 1 & Geetbets & 1 \\
\hline Beerse & 1 & Grimbergern & 9 \\
\hline Eoechout & 1 & Halle & 1 \\
\hline Bornem & 1 & Hoeilaart & 9 \\
\hline Brasschaiat & 1 & Holsbeek & 1 \\
\hline Brecht & 1 & Lesuren & 1 \\
\hline Edeglem & 1 & Lulbbeek & 1 \\
\hline Essien & 1 & Machelen & 1 \\
\hline Heist old Berg & \# & Meise: & 1 \\
\hline Hoogstraten & 1 & OudinHevarlee & 1 \\
\hline Lier & 1 & Owerijse & $\mathbb{1}$ \\
\hline Mechelen & 4 & Ternat & 1 \\
\hline Ranst & $\|$ & Terviren & 9 \\
\hline Rijkevorsel & $\|$ & Tienten & 1 \\
\hline Schelle & 1 & Tremelo & 1 \\
\hline Sehoten & 1 & Wilwoorde & 1 \\
\hline Tumnhout & 1 & & \\
\hline
\end{tabular}




\begin{tabular}{|c|c|c|c|}
\hline 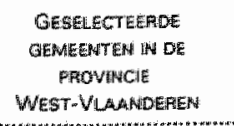 & 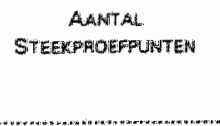 & 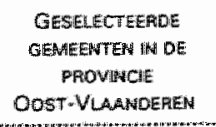 & $\begin{array}{l}\text { AANTAL } \\
\text { STEEKPROEFPUNTEN }\end{array}$ \\
\hline Brugge & 2 & Aatst & 2 \\
\hline De Haan & 1 & Beveren & 1 \\
\hline Deerlik & 1 & Deinze & 1 \\
\hline Diksmuide & 1 & Denderleeuw & 1 \\
\hline Houthullst & 1 & Dendemonde & 1 \\
\hline leper & 1 & Evergen & 1 \\
\hline Hzegem & 1 & Gient: & 4 \\
\hline Koksijde & 1 & Geraards-bergen & 1 \\
\hline Kortrijk & $\uparrow$ & Haaliten & 1 \\
\hline Milenentit & 1 & Kruibeke & 1 \\
\hline Oostende & 2 & Lowendiegmm & 1 \\
\hline Roeselare & 1 & Maldegen & 1 \\
\hline Veurne & 1 & Nevele & 9 \\
\hline Waregem & 1 & Ninove & 1 \\
\hline Wervik. & 1 & St-Githis-Waas & 1 \\
\hline Wielsbeke & 1 & St-Niklaas & 1 \\
\hline Wingenes & 1 & Warschoot & 1 \\
\hline Zedelgem & 1 & Wetteren & 1 \\
\hline 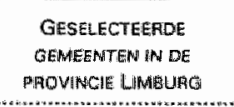 & $\begin{array}{c}\text { AANITAL STEEKPFOEF- } \\
\text { PUMTENA }\end{array}$ & $\begin{array}{l}\text { WEFWOLG } \\
\text { PPROWINCIE LIMEUAG }\end{array}$ & $\begin{array}{c}\text { AANTAL STEEKPROEF } \\
\text { PUUNTEN }\end{array}$ \\
\hline Alken & 1 & Neerpelt & 1 \\
\hline Baringen & 1 & Fiemst & 1 \\
\hline Genk & 1 & St-Truiden & 1 \\
\hline Hamont-Achel & 1 & Tessenderto & 1 \\
\hline Hasselt & 1 & Tongeren & 1 \\
\hline Houthaten-Hellichteren & 1 & & \\
\hline Lonaken & 4 & & \\
\hline Mansmechelen & 1 & & \\
\hline
\end{tabular}


Twee wan de 89 gemeenten weigerden thun medewerking nil. Bornem en Oud-Heverlee. Zij werdern beiden vervangen door een gemeente uit hetzelfde stratum met een bevolkingsaartal dat het dichtst bij de oorspronkelijk geselecteerde gemeente gelegen is. Bornem werd op deze wijze vervangen door Zwijndrecht en Oud-Heverlee door Steenokkerzeel. Beide nieuw geselecteerde gemeenten gaven wel hun toestemming om in hun gemeente een steekproef te trekken.

\subsection{Trekking van personen}

Om budgettaire redenen was het mogelijk om per steekproefpunt 16 personen i.p. $w_{\text {. de }}$ vooropgestelde 15 personen (zie bijlage 1a) te selecteren. In gemeenten met meer dan 1 steekproefpunt werden bijgevolg $\times$ keer 16 personen geselecteerd.

Om voldoende vervangingsadressen te hebben ten behoeve van de non-respons werden voor elke persoon nog 3 vervangingsadressen opgevraagd. Dit betekent dus dat in een gemeente met maar bén steekproefpunt reeds 64 adressen geselecteerd dienden te worden. Voor een gemeente met meer dan één steekproefpunt werden $x$ keer 64 adressen opgevraagd.

Voor elke geselecteerde gemeente maakten wil zelf een systematische trekking ${ }^{\prime}$ van 64 lof een veelvoud) personen opgesplitst naar geslacht en evenredig met de leeftijdsstructuur van de bevolking. Dit resulteerde in een lijst van het aantal te trekken mannen per geboortejaar en het aantal te trekken vrouwen per geboortejaar.

Hieronder volgt als voorbeeld een uittreksel voor de gemeente Arendonk:

\begin{tabular}{|c|c|c|}
\hline GEEOORTEJAAR & AANTAL TE TREKKEN MANNEN & AANTAL TE TREXKEN WROUWEN \\
\hline 1976 & 1 & $\|$ \\
\hline 1975 & 1 & 0 \\
\hline 1974 & 1 & 1 \\
\hline 1973 & 0 & 1 \\
\hline 1972 & 1 & 1 \\
\hline 1971 & 2 & 1 \\
\hline 1970 & 0 & $\sharp$ \\
\hline 1969 & 1 & 1 \\
\hline 1968 & 1 & 1 \\
\hline 1967 & 1 & 1 \\
\hline 1986 & 1 & \pm \\
\hline
\end{tabular}

Deze systematische trekking gebeurt op dezelfde wijze als die van gemeenten. De mannen worden gerangschikt per geboortejaar in opklimmende volgorde. Vervolgens wordt de ophoogfactor berakend en een aselect begingetal op basis van een randomnummer tussen 0 en 1 en de ophoogfactor. De systematische trekking geeft dan aan uit wellke geboortejaren een persoon getrokiken dient te worden in evenredigheid met de leeftijdsstructuur van de bevolking. 
Het was de bedoeling dat de gemeenten op basis van deze tabel en steekproeftrekking verrichten. Deze tabel hielp ans ook om nadien een selectie te maken van de steekproefpersonen en hun vervangingen.

De gegevens die werden opgevraagd in de betreffende gemeenten omvatten: naam en voornaam, geboortejaar, gesillacht en adres van de steekproefeenheid.

\subsubsection{De trokking in de gemeenten}

Een belangrijk nadeel van steekproeftrekking in de gemeenten is het feit dat de technische middelen voor de registratie van gegewens in de gemeenten zeer uiteenlopend zijn. Dit maakte het onmogelijk om de trekking telkens op dezelffie wijze uit te voeren.

Volgende scenario's zijn mogelijk (Looze, 1994):

1. De gemeente beschikt niet over informaticamateriaal. In dat geval bevinden de bevolkingsgegevens zich onder de vorm van steekkaarten in een fichebak.

2. De gemeente is aangesloten op een erkend subregionaal centrum. De subregionale informaticacentra zijn gemachtigd bijwerkingen afkomstig van de gemeenten over te maken aan het Rijksregister. In deze subregionale centra wordt een volledige copie van alle informatie opgenomen en bijgehouden die voor de betrokken aangesloten gemeenten in het Rijksregilster geregistreerd zijn.

3. De gemeente beschikt over een eigen computer waarop het gemeentelijk bevolkingsbestand geregistreerd is dat simultaan met de gegevens van het Rijksregister bijgewerkt wordt.

Door middel van een telefonisch onderhoud met het hoofd van de dienst bevolking werden we op de hoogte gebracht van de beschikbare technische middelen in de gemeente. Afhankelijk daarvan werd afgesproken hoe de trekking zou verlopen.

Gemeenten die niet over informatica-materiaal beschikten (of niet goed wisten hoe ze er een steekproef mee konden trekken) selecteerden de personen ofwel uit hun fichebak, ofwel uit hun kiezersijsten.

Een trekking wit een fichebak verliep als volgt:

Eerst wordt de verhouding gemaakt wan het aantal inwoners t.o.v. het aantal te trekken personen. Voor de gemeente Wetteren bilvoorbeeld betekent dit: $22778 / 64=356$. Om de 356 kaarten moet er één getrokken worden. Op een teststaal hebben wij gemeten dat 356 steekkaarten $9.5 \mathrm{~cm}$ vertegenwoordigen. Praktisch betekent dit dat een gemeenteambtenaar om de $9.5 \mathrm{~cm}$ een steekkaart trekt. Is de getrokken persoon jonger dan 18 jaar of ouder dan 70 jaar dan wordt de daaropvolgende steekkaart getrokken. Deze procedure wordt herhaald totdat or 64 steekproefpersonen geselecteerd zijn. 
In andere gevallen werd gebruik gemaakt van de lijst van de kiezers voor het Europees Parlement op 12 juni 1994. Deze omvatten de totale bevolking van Belgische nationaliteit van 18 jaar en ouder. Door een besluit van het Ministerie van Binnenlandse Zaken is het sinds enkele jaren formeel onmogelijk geworden om kiezerslijsten te gebruiken voor steekproeven. Kiezerslijsten mogen alleen nog gebruikt worden in het kader van verkiezingen bw. om te controleren of men als individuele burger ingeschreven is of in het kader van de campagnes van politieke partijen (Billiet, 1994). Sommige gemeenten vonden het werken met de kiezerslijsten echter gemakkeijjker. Ook hier werd een trekking uitgevoerd on de $x$ personen op dezelf de wijze berekend als voor de fichobak."

De personen zijn via een oplopend nummer zeer makkelijk terug te winden. Indien een persoon ouder dan 70 of jonger dan 18 blijkt te zijn, dan wordt de volgende op de lijst genomen.

Gemeenten die aangesloten zijn op een subregionaal centrum moesten daar hun aanvraag tot gegevens richten. Ten behoeve van de steekproef lieten ze een lijst trekken van alle personen uit hun gemeente die op een bepaalde dag(en) geboren zijin. Bijwoorbeeld: alle inwoners geboren tusen I en 5 julli.

In beide gevallen wordt vervolgens op basis van hogergenoemd overzicht de steekproef samengesteld evenredig naar leeftijd en geslacht. Vervangingen werden geselecteerd volgens twee criteria: van hetzelfde geslacht zijn en van een leeftijd die afwijkt van de steekproefindividu van maximaal $+/-5$ jaar.

Naar gemeenten die beschikten over een gemeentelijk bevolkingsbestand op computer werd onze lijst opgestuurd. Van hen kon onmiddellijk een goede steekproef worden bekomen. 


\section{Qverzicht van het steekproefplan}

\begin{tabular}{|c|c|c|c|}
\hline Prouviluticre & SES-GEMEENTETYPE & AANTAL GEMEEETTEN & AANTAL RESPONGENTEN \\
\hline \multirow[t]{6}{*}{ Antwerpen } & 1 & 4 & 176 \\
\hline & 2 & $\pi$ & 112 \\
\hline & 3 & 2 & 32 \\
\hline & 4 & 4 & 64 \\
\hline & 5 & 3 & 48 \\
\hline & 6 & ॥ & 16 \\
\hline \multirow[t]{6}{*}{ Brabant: } & 1 & 3 & 48 \\
\hline & 2 & 1 & 16 \\
\hline & 3 & 5 & 80 \\
\hline & 4 & 6 & 96 \\
\hline & 5 & 1 & 16 \\
\hline & 6 & 1 & 16 \\
\hline \multirow[t]{6}{*}{ West-Vlatanderen } & 1 & 3 & 80 \\
\hline & 2 & 6 & 96 \\
\hline & 3 & - & - \\
\hline & 4 & 2 & 32 \\
\hline & 5 & 4 & 64 \\
\hline & 6 & 3 & 48 \\
\hline \multirow[t]{6}{*}{ Oost-Vlaanderen } & 1 & 1 & 64 \\
\hline & 2 & 8 & 128 \\
\hline & 3 & $a$ & 0 \\
\hline & 4 & 3 & 48 \\
\hline & 5 & 6 & 112 \\
\hline & 6 & 2 & 32 \\
\hline \multirow[t]{6}{*}{ Lintinburg } & 1 & 2 & 32 \\
\hline & 2 & 5 & 80 \\
\hline & 3 & - & - \\
\hline & 4 & 0 & 0 \\
\hline & 5 & 5 & 80 \\
\hline & 6 & 1 & 16 \\
\hline TOTAAL & & 89 & 1632 \\
\hline
\end{tabular}




\section{De non-respons}

Ondanks de voorzorgsmaatregelen om uitval te beperken, kon gemiddeld toch in meer dan $30 \%$ van de gevallen de gegevens van de geselecteerde persoon niet worden bekomen en moest beroep worden gedaan op de reservesteekproeven.

Controle van mogelijke vertekeningen naar geslacht leverde geen significante verschillen op. Opsplitsing naar sociaal-economische status gaf evenmin significante verschillen wear.

Een opsplitsing naar leeftijd toonde aan dat wooral woor jonge volwassenen tussen 18 en 34 jaar woor meer dan $70 \%$ de gegevens van de geselecteerde persoon kon bekomen worden. Bij de leeftijdscategorie van 35 tot 50 jaar kwamen tot $25 \%$ antwoorden van een eerste vervangingsperoon. De leeftijdscategorie van 51 tot 70 jaar tenslotte had het meeste aantal vervangingsadressen nodig. Bijna $7 \%$ van de antwoorden $\mathrm{kwamen}$ van een 3 de vervanging of meer.

\begin{tabular}{|c|c|c|c|}
\hline$\%$ & 18 TOT 34 & 35 TOT 50 & 51 TOT 70 \\
\hline GESELECTEERDE PERSOON & 72.2 & 65.4 & 67.3 \\
\hdashline 1 STE VERVANGING & 17.1 & 24.9 & 19.4 \\
\hline 2 DE VERWANGING & 5.3 & 6.7 & 6.7 \\
\hdashline 3 DE VERVANGING OF MEER & 5.5 & 3.0 & 6.7 \\
\hline Chi $^{2}=19.25459 ; \mathrm{p}=0.00375$ & & & \\
\hline
\end{tabular}

Bij een opsplitsing naar provincie bleek Oost-Vlaanderen de laagste non-respons te hebben. De hoogste non-respons werd gevonden in Vlaams-Brabant en in West-Vlaanderen. In deze provincies werden ook de hoogste percentages 3 de of meer vervanging oopgetekend.

\begin{tabular}{|c|c|c|c|c|c|}
\hline$\%$ & ANTWERPEN & $\begin{array}{l}\text { VLAAAMS- } \\
\text { BRABAANT }\end{array}$ & $\begin{array}{c}\text { WEST- } \\
\text { VILAANDEREN }\end{array}$ & OOST-VLAANDEREN & LIMBUARG \\
\hline $\begin{array}{l}\text { GESELECTEERDE } \\
\text { PERSOON }\end{array}$ & 70.5 & 65.3 & 62.5 & 72.1 & 70.2 \\
\hline $\begin{array}{c}1 \text { STE } \\
\text { VERVANGING }\end{array}$ & 17.4 & 22.9 & 20.9 & 20.6 & 22.1 \\
\hline $\begin{array}{c}2 \mathrm{DE} \\
\text { VERVANGINE }\end{array}$ & 6.7 & 4.8 & 10 & 4.4 & 4.3 \\
\hline $\begin{array}{c}3 \text { DE }+ \\
\text { WERVANGING }\end{array}$ & 5.4 & 7 & 6.6 & 2.9 & 3.4 \\
\hline
\end{tabular}

$\mathrm{Chi}^{2}=26.38135 ; \mathrm{p}=0.00948$ 
bijllage 2 :

bijlage $2 \mathrm{a}$ kennis van kankerpreventie

bijlage $2 b$ sociaal-economische status

Bijlage 2

Operationalisering en scoring van de belangrijkste onderzochte eigenschappen 


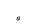




\section{Bijlage 2a: Operationalisering en schaalconstructies van}

\section{"Kennis van kankerpreventie 100-item gezondheidsvragenlijst"}

\section{Inleiding :}

Kennis van kankerpreventie wordt in de meeste onderzoeken gemeten door enkelvoudige variabelen. Door in onderzoek enkelvoudige variabelen als meetinstrument te nemen, wordem enkel deelaspecten van kennis van kankerpreventie gemeten. De onderzoeker moet dan bij de interpretatie van de onderzoeksresultaten zelf tot een synthese van de gemeten kennis trachten te komen. De "Kennis van kankerpreventie 100 item gezondheidsvragenlijst" bestudeert twee dimensies en vier indicatoren van kennis van kankerpreventie:

\begin{tabular}{|c|c|c|c|}
\hline Dimensies: & Indicatoren : & \multicolumn{2}{|c|}{ \#items : } \\
\hline \multirow{4}{*}{$\begin{array}{l}\text { kennis van primaire } \\
\text { kankerpreventie }\end{array}$} & \multirow[t]{2}{*}{ kennis van risicofactoren van kanker } & \multirow[t]{2}{*}{25} & 8 juiste \\
\hline & & & 17 foute \\
\hline & \multirow[t]{2}{*}{ kennis van kankerpreventieve gedragingen } & \multirow[t]{2}{*}{25} & 8 juiste \\
\hline & & & 17 foute \\
\hline \multirow{4}{*}{$\begin{array}{l}\text { kennis van secundaire } \\
\text { kankerpreventie }\end{array}$} & \multirow{2}{*}{$\begin{array}{l}\text { kennis van waarschuwinglssignalen voor } \\
\text { kanker }\end{array}$} & \multirow[t]{2}{*}{25} & 7 juiste \\
\hline & & & 18 foute \\
\hline & \multirow{2}{*}{$\begin{array}{l}\text { kemnis van opsporingsonderzoeken voor } \\
\text { kanker }\end{array}$} & \multirow[t]{2}{*}{25} & 7 juiste \\
\hline & & & 18 foute \\
\hline
\end{tabular}

Voor elke indicator kunnen valgende scores worden berekend:

1. de kennisscore (KS), enkel gebaseerd op de herkenning van de juiste items

2. de foutperceptie (FP), enkel gebaseerd op de perceptie van de foutieve items als juiste items

3. de adequate kennisscore (AKS), gebaseerd op zowel de juiste als de foutieve items

De vier indicatoren samen vormen synthesematen wan kennis van kankerpreventie. Er kunnen ook telkens drie synthesematen worden berekend:

1. de synthesemaat voor kennis van primaire kankerpreventie

2. de synthesernat voor kennis van secundaire kankerpreventie

3. de globale synthesemaat voor kennis van kankerpreventie

De scoring van de items is een drie-stappen proces:

1. eerst lkrijgen alle origine waarden die werden gebruikt in de vragenlijst een bepaalde score van -2 tot +2

2. vervolgens dienen alle ontbrekende waarden te worden gescoord met de waarde van 0

3. tenslotte kuninen de verschillende kennisscores worden berekend. 


\section{Schaalconstructie "STAPPEN 1 en $2^{\text {* }}$ :}

\section{Codeerschema:}

vracenlis:

code 1

code 2

code 3

coide 4

code 5

code WN

zekerheidsscore:

$-2$

$-1$

0

$+1$

$+2$

0 geen ...

wellicht geen ...

wellicht wel, wellicht niet... wellicht wel...

zeker ...

\section{Schaalconstructie kennisscores per indicator:}

3.1. Kennisscore (KS):

\section{$\left(\sum\right.$ zekerheidsscores op juiste items) * 50 /N}

$N=$ aantal juiste items in de vragenlijst

$\Rightarrow>$ de score loopt van minimum -100 tot maximum +100

3.2. Foutperceptie (FP):

\section{$\left(2\right.$ zekerheidsscores op foute items) ${ }^{*} 50 / \mathrm{N}$}

$N=$ aantal foutieve items in de vragenlijst

$=>$ de score loopt van minimum -100 tot maximum +100

3.3. Adequate kennisscore (AKS):

\section{[Kennisscore - Foutperceptie] / 2}

$=>$ de score loopt van minimum -100 tot maximum +100 


\section{Schaalconstructie van de synthesematen :}

4.1. Synthesemaat kennisscore (zie ook figuur 17)

\section{Kennis van kankerpreventie $=\left[K S_{f i}+K S_{p a}+K S_{p w a}+K S_{p o}\right] / 4$}

$\mathrm{KS}_{\mathrm{rt}} \quad=$ kennisscore risicofactoren

$\mathrm{KS}_{\mathrm{gg}} \quad=$ kennisscore gewenst gedrag

$\mathrm{KS}_{\mathrm{ws}} \quad=$ kennisscore waarschuwingssignalen

$\mathrm{KS}_{\mathrm{vo}} \quad=$ kennisscore vroegtijdige opsporingsonderzoeken

$=>$ de score loopt van minimum -100 tot maximum +100

4.2. Synthesemaat foutperceptie (zie ook figuur 16 )

Foutperceptie van kankerpreventie $=\left[\mathrm{FP}_{\mathrm{st}}+\mathrm{FP}_{\mathrm{gS}}+\mathrm{FP}_{\mathrm{ws}}+\mathrm{FP}_{\mathrm{ugg}}\right] / 4$

$\mathrm{FP}_{f t} \quad=$ adequate kennisscore risicofactoren

$\mathrm{FP}_{\mathrm{gg}} \quad=$ adequate kennisscore gewenst gedrag

$\mathrm{FP}_{\mathrm{ws}} \quad=$ adequate kennisscore waarschuwingssignalen

$\mathrm{FP}_{\mathrm{va}} \quad=$ adequate kennisscore vroegtijdige opsporingsonderzoeken

$=>$ de score loopt van minimum -100 tot maximum +100

4.3. Synthesemaat adequate kennisscore

4.3.1. Kennis van primaire kankerpreventie (zie ook figuiur 13):

Adequate kennis van primaire kankerpreventie $=\left[\mathrm{AKS}_{s t}+\mathrm{AKS}_{99}\right] / 2$

$\mathrm{AKS}_{\mathrm{rt}} \quad=$ adequate kennisscore risicofactoren

$\mathrm{AKS}_{\mathrm{gg}} \quad=$ adequate kennisscore gewenst gedirag

$=>$ de score loopt van minimum -100 tot maximum +100

4.3.2. Kennis van siecundaire kankerpreventie (zile ook figuur 14):

Adequate kennis van secundaire kankerpreventie $=\llbracket A K S_{w s}+A K S_{\mathrm{vg}} \rrbracket / 2$

$A K S_{w a s}=$ adequate kennisscore inzake waarschuwingssignalen

$A K S_{v 0}=$ adequate kennisscore inzake vroegtijdige opsporingsonderzoeken

$=>$ de score loopt van minimum -100 tot maximum +100

4.3.3. Globale synthesemaat "Kennis van kankerpreventie" (zie ook figuur 15):

Adequate kennis van kankerpreventie $=\left[\mathrm{AKS}_{\mathrm{ft}}+\mathrm{AKS} \mathrm{S}_{\mathrm{gg}}+\mathrm{AKS}_{\mathrm{kg}}+\mathrm{AKS}_{\mathrm{vg}}\right] / 4$

$=>$ de score loopt van minimum -100 tot maximum +100

- Sociale determinanten van kennis van kankerpreventie in Vlaanderen - 


\section{Vermijibare risicofactoren voor kanker:}

1. overmatig gebruik van dierlijke vetten in de woeding

2. roken

3. passief roken (bloodstelling alan tabaksrook uit de directe omgeving)

4. overdadige blootstellingl aan de zon

5. overmatig gebruik van alcohol

6. zwatarlivigheid of obesitas

7. eerste kind na de leeftijd van 30 jaar; woor vrouwen

8. sexuele omgang met meerdere partners zonder condoom; voor vrouwen

\section{Foutieve items:}

1. overmatig sporten

2. overmatig gebruik van vitaminen

3. overmatig gebruik van pasta's (bv spagetti) in de voeding

4. niet verzorgen van een keelontsteking

5. overmatig gebruik van schoonheidsproducten

6. veelvuldig $z$ wemmen in bezoedeld water

7. niet verzorgen van een huidontsteking

8. overmatig gebruik van laxeermiddelen ter bevordering van de stoelgang

9. niet verzargen van een aanhoudende diarree

10. langdurig werken voor een computerscherm

11. epileren van de borstharen bij vrouwen

12. langdurige borstwoeding

13. sterilisatie bij mannen

14. sexuele omgang met meerdere partners zonder condoom; woor mannen

15. gebruilk van een spiraaltje als voorbehoedsmiddel bij wrouwen

16. overmatig gebruik van antibiotica

17. onrege/matige nachtrust

\section{Codeerschema:}

vragenliist:

code 1

code 2

code 3

code 4

code 5

code WN

Kennisscore juiste items:

\begin{tabular}{c} 
Zekerheidsscore : \\
\hline-2 \\
-1 \\
0 \\
+1 \\
+2 \\
0
\end{tabular}

[L zelkerheidsscores op juiste items] * 50/8

\section{Sornscore foutperceptie:}

[L zekerheidsscores op foutieve items] $50 / 17$

voor de verdeling van deze kennisscore zile figuur 2

\section{Adequate kennisscore: $\quad$ [Kennisscore - Foutperceptie] / 2}

voor de verdeling van deze kennisscore zie figuur 3 
Figuur 1 : Kennis risicofactoren

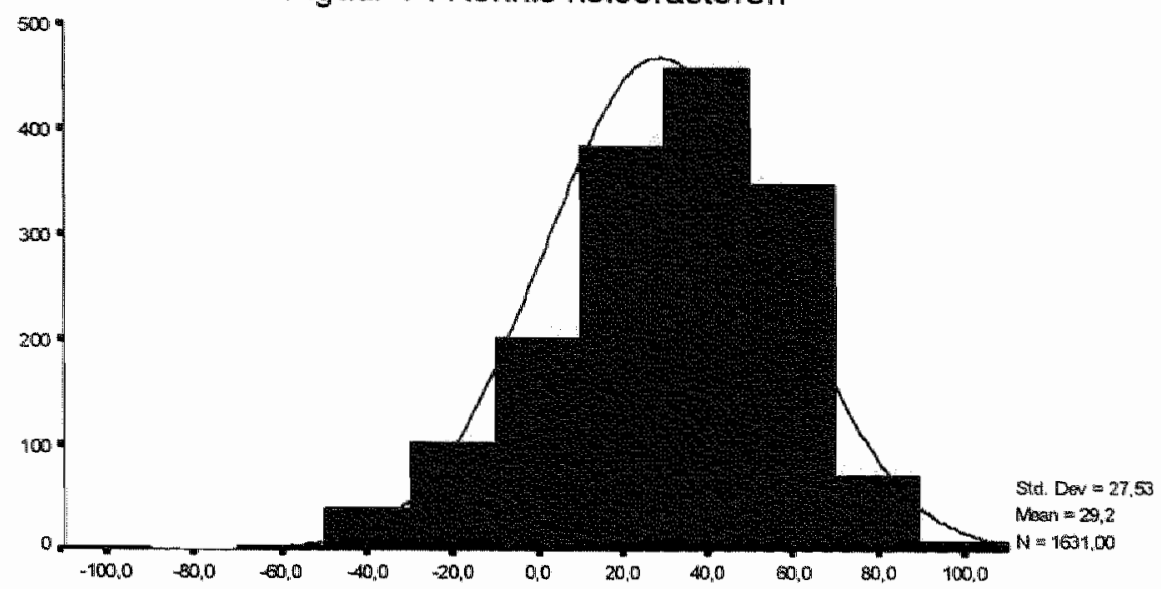

Kennis 'echte' isicofactoren $(N=8)$

Figuur 2 : Foutperceptie risicofactoren

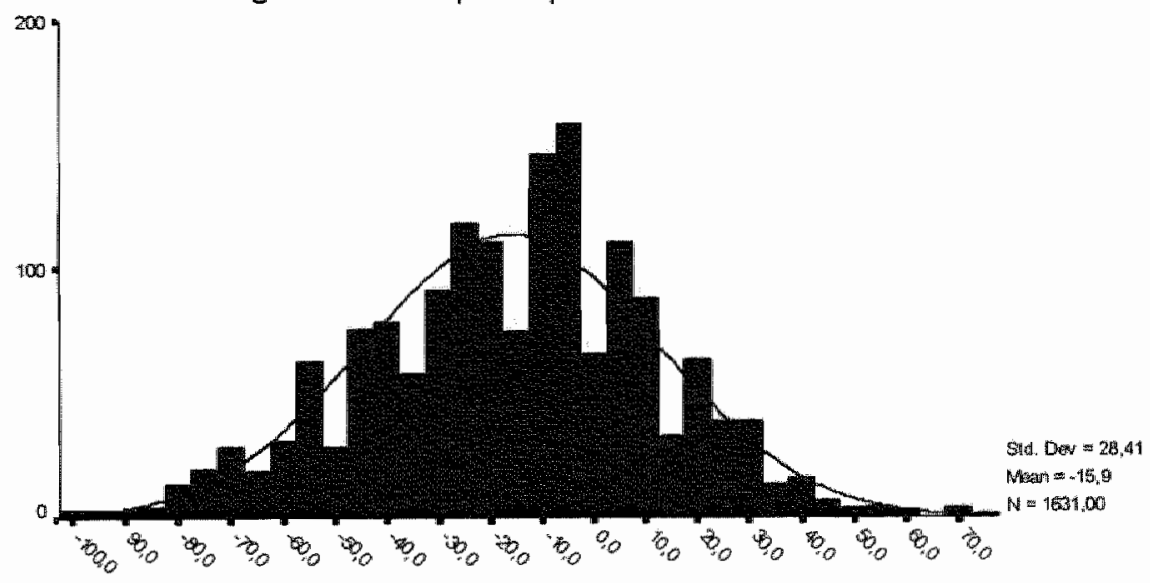

Soms core foutieve' risicofactoren $(N=47)$

- Socialle determinanten van kennis van kankerpreventie in Vlaanderen. 
Figuur 3 : Adequate kennis van risicofactoren $(N=25)$

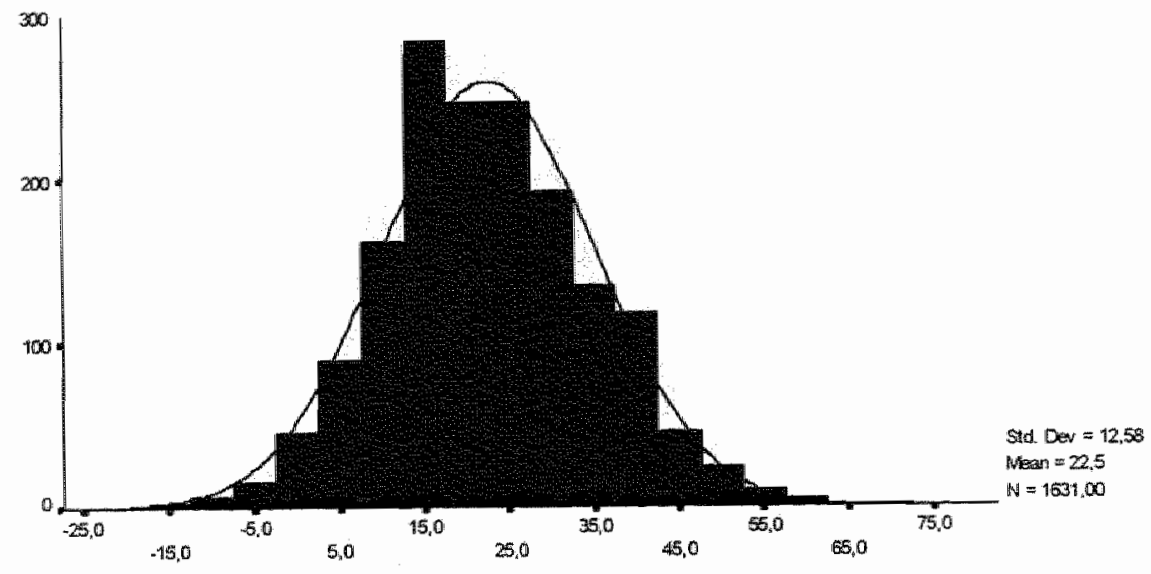

Adequate kennisscore nisicofactorem

Gewenst (kanker oreventief) gedrag:

1. regelmatig eten van vers fruit

2. regelmatig eten van verse groenten

3. overdadige blootstelling aan de zon vermijden

4. regelmatig eten van bruin brood

5. regelmatig eten wan angepelde rijst

6. met mate drinken van allcoholische dranken

7 . stoppen met roken of niet roken

8. vermijden van overgewicht

\section{Foutieve items:}

1. matig gebruik van medicijnen

2. regeimatige lichaemsbeweging

3. regelmatig gebruik van witamine $C$

4. regelmatig eten van pasta's (bv spagetti)

5. regelmatig goed ontsparnen

6. regelmatig drinken van verse melk

7. voldoende nachtrust

8. regelmatig aten van yoghurt

9. regeimatig aten van vis

10. regelmatig wandelen

11. regelmatig sporten

12. regelmatig gebruik van ijzerpillen

13. dagelijks drinken van eén liter water

14. vermijden van stress

15. mext müte eten van zout

16. met mate drinken wan koffie

17. goede huidverzorging

- Sociale determinanten van kennis van kankerpreventie in Vlaanderen. 


\section{Codeerschema:}

vragenliist:

code 1

code 2

code 3

code 4

code 5

code WN zekerheidsscore:

$-2$

$-1$

0

$+1$

$+2$

0

Kemnisscore juiste items: $\quad[$ zekerheidsscores op juiste items] *50/8

voor de verdeling van deze kennissciore zie figutur 4

Somscore foutperceptie : $\quad\left[\sum\right.$ zekerheidsscores op foutieve items] * 50/17

voor de verdeling van deze kennisscore zie figutur $\mathbf{5}$

Adequate kennisscore: $\quad$ [Kennisscore - Foutperceptie] / 2

voor de verdeling van deze kennisscore zie figuur 6

Figuur 4 : Kennis gewenst preventief gedrag

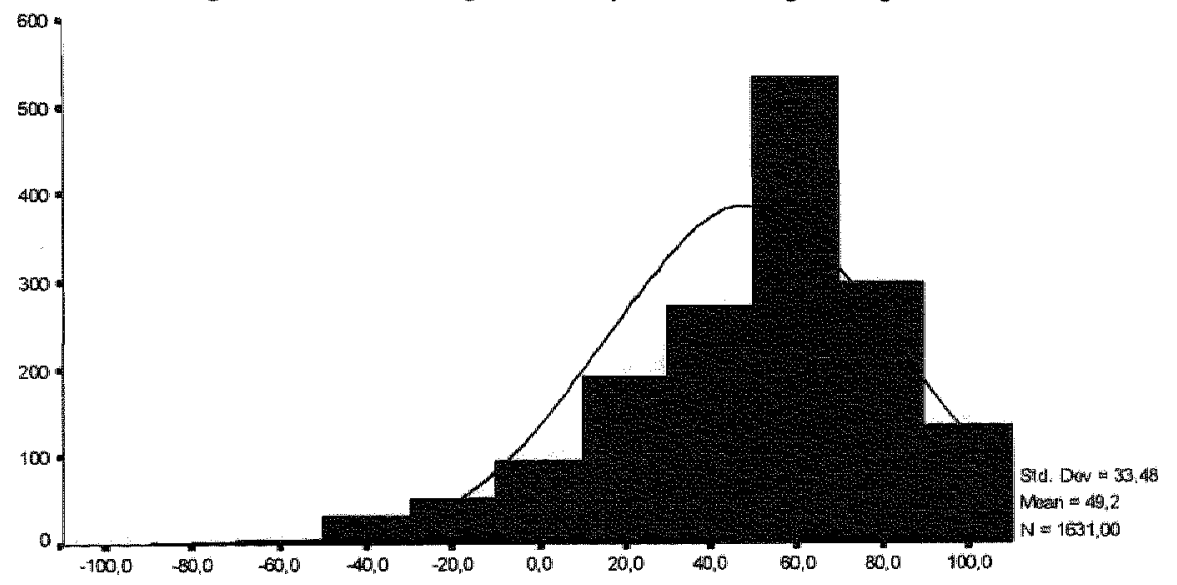

Kennis 'echte' gewenste gedrag $(N=8)$ 
Figuur 5 : Foutperceptie gewenst preventief gedrag

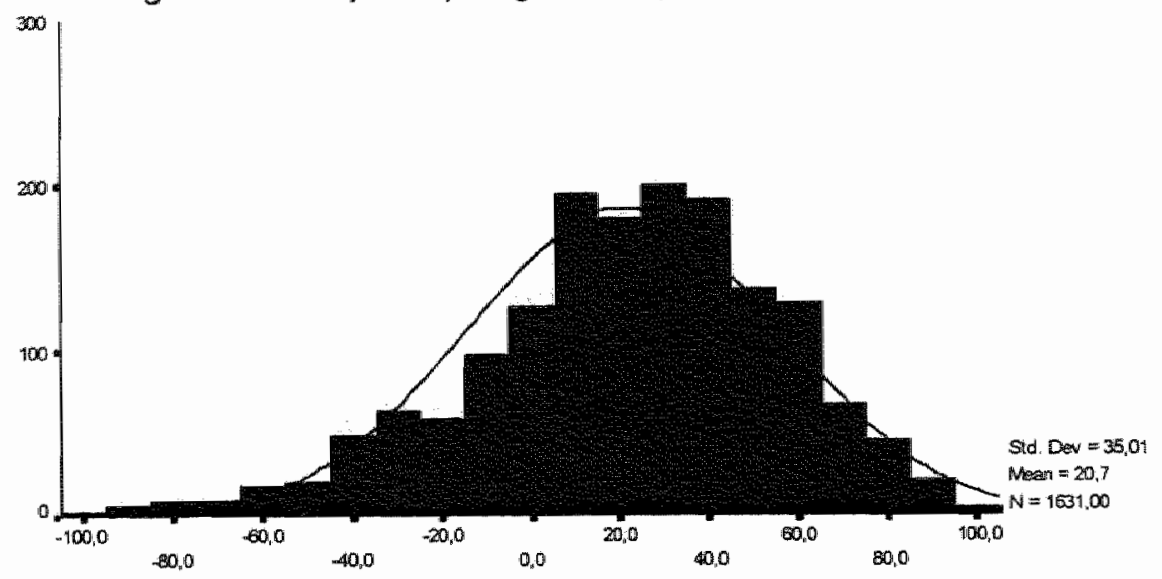

Somscore toutieve gewenst gedrag $(\mathbb{N}=17)$

Figuur 6 : Adequate kennis gewenst preventief gedrag

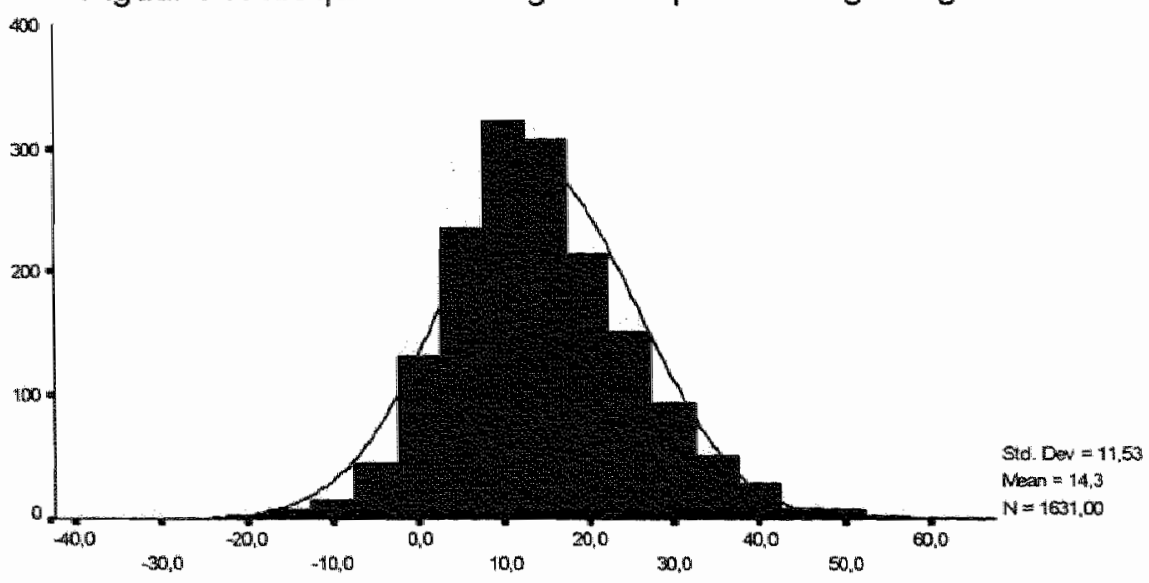

Adequate ke rnis gewenst gedrag $(N=25)$

- Socialle determinantem van kennis van kankerpreventie in Vlaanderen- 


\section{Waarschuwingssignalen voor kanker :}

1. aanhoudende wijziging in plas- of stoelgangpatroon

2. een wonde die niet geneest

3. abnormaal anaal of vaginaal bloedverlies (bloedverlies via de aars of de schede)

4. verdikking of knobbeltje in de borst

5. onverklaarbare gewichtsvermindering

6. duidelijke verandering in wrat of moedervlek

7. aanhoudende hoest of heesheid

\section{Foutieve items:}

1. hoofdpijn

2. gevoel van "wegdraaien" of duizeligheid

3. pijn in de hart-of borststreek

4. lage rugpijnen

5. braakneigingen of maagstoornissen

6. spierpiljnen

7. kortademigheid

8. warme of koude opwellingen

9. gevoelloosheid of tintelingen in bepaalde lichaamsdelen

10. zwaktegevoel in bepaalde lichaamsdelen

11. zwaartegevoel in armen of benen

12. werlies van sexuele interesse

13. gevoel van verminderde energie

14. hartkloppingen of ritmestoornissen

15. gevoel van rusteloasheid

16. gebrekkige eetlust

17. rusteloze of gestoorde slaap

18. brak in de keel

\section{Cadeerschema:}

vragenliist:

code 1

code 2

code 3

code 4

code 5

code WN

Kennisscore iuiste items :

voor de verdeling van deze kennisscore zie figuur 7

Somscare foutperceptie : $\quad[2$ zekerheidsscares op foutieve itemsI * $50 / 18$

voor de verdieling van deze kennisscore zie figuur 8

Adecuatekennisscore: $\quad$ [Kennisscore - Foutperceptie]/2

voor de verdeling van deze kennisscore zie figuur 9

- Sociale determinanten van kennis van kankerpreventie in Vlaanderen - 
Figuur 7 : Kennis "echte" waarschuwingssignalen $(N=7)$

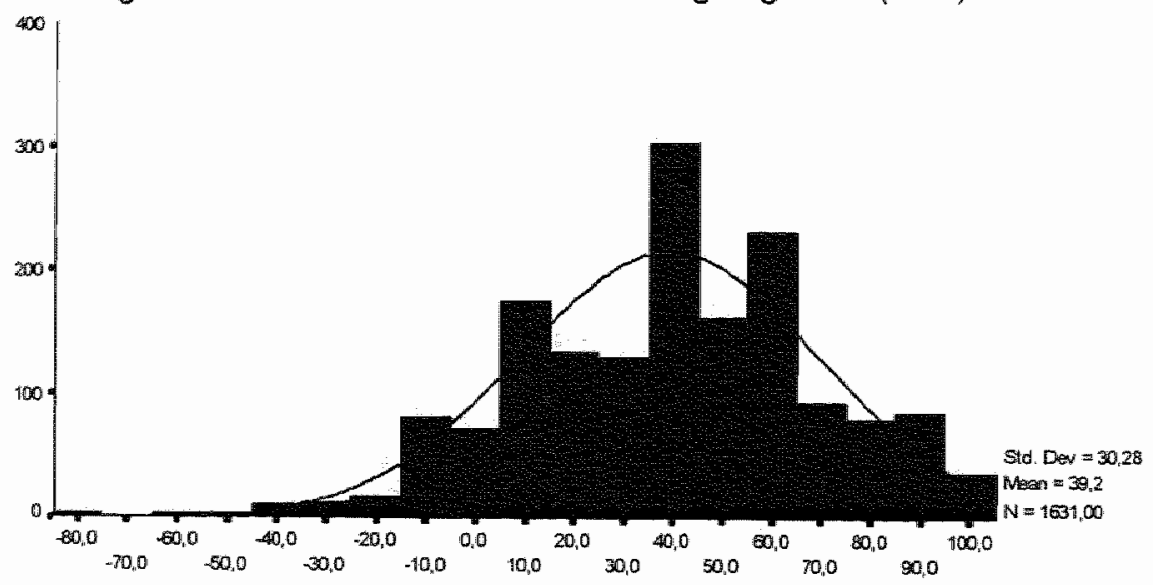

Kennis "echte" waars chumingssiginalen ( $\mathrm{N}=7$ )

Figuur 8 : Foutperceptie waarschuwingssignalen $(\mathrm{N}=18)$

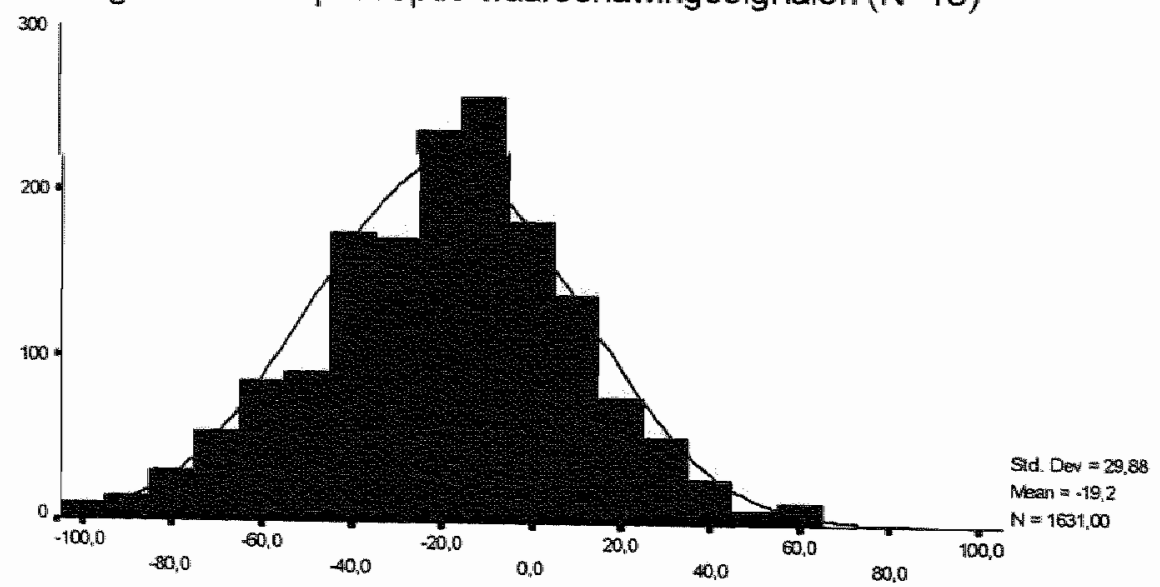

Somscore foutieve' watschuwingssignalen $(N=18)$

- Sociale determinanten van kennis van kankerpreventie in Wlaanderen - 
Figuur 9 : Adequate kennis van waarschumingssignalen $(\mathrm{N}=25)$

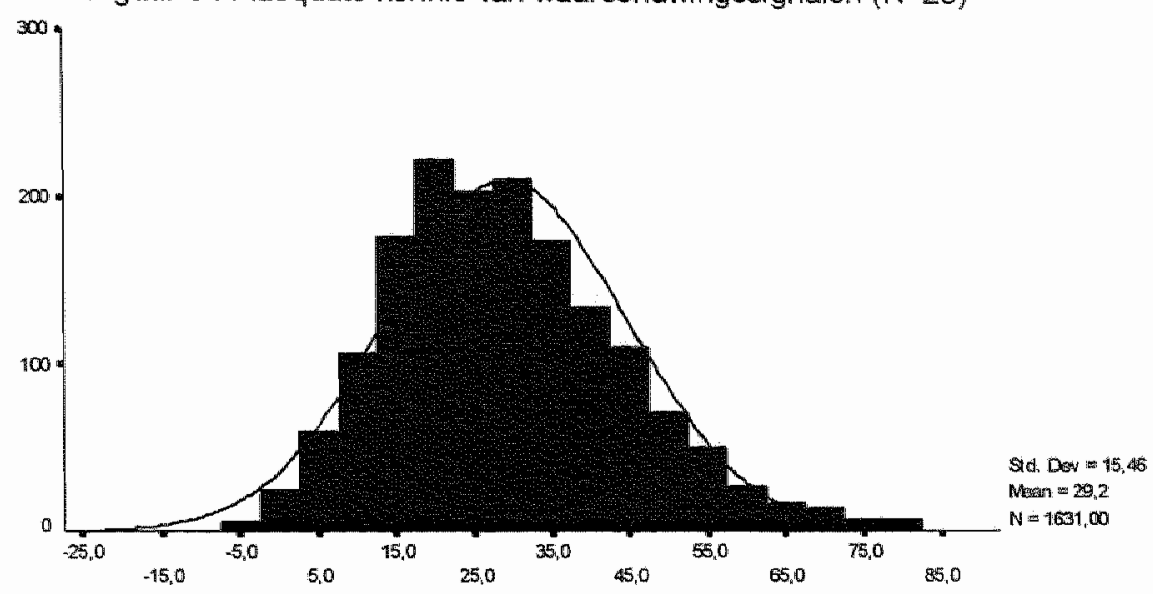

Adequate kenniss core waars chuwingssignalen

\section{Vroegtiidige opsporingsanderzoeken yoor kanker :}

\section{Instructie enouêteur:"}

1. baarmovederhalsuitstrijkje

2. opsporen wan bloed in de stoelgang

3. borstzelfonderzoek voor vrouwein

4. rectaal onderzoek; dit is thet met een vinger betasten wan de dikkedarm vila die aars

5. borstondierzoek door de dokter

6. mammografie voor vrouwen; dit is een radiografie van de borst

7. huidinspectie door de dokter, bil veranderende moedervlek of wrat

\section{Foutieve items:}

1. radiografie van de liongen

2. onderzaek van de longen met een stethoscoop *

3. urinie-onderzoek

4. gewichtsmeting

5. blloeddrukmeting met een spatel sligm wan de baarmoederhals afschrapen zgn. occult-bloedtest: zelf met de vingers betasten van de borst instrument voor het beluisteren van geluiden in het lichaam 
6. electrocardiogram af EKG

7. ADS bloedtest

8. betasten van de blaas

9. chografie

10. syphilis bloedtest

11. keveluitstrikje

12. onderzoek var het hart met een stethoscoop *

13. hom monal bloedonderzoek

14. elektro-encefalogram of $E E G$

15. TBC- of tuberculose test

16. urine-zwangerschapstest

17. drukmeting van de oogbol met een klein apparaatje

18. inspanningstest door polsslagmeting na 10 diewe kniebuigingen

\section{Codeerscherma:}

yragenlijst:

coode 1

ciodie 2

code 3

code 4

code 5

code WN film of registratie wan de hartwerking door het: plaatsen van electrodes op de borst

zichtbaar maken van een orgaan via een TV-scherm

met spatel keelshijm afschrapen

instrument woor het beluisteren van

geluider in het lichaam

bepalen van homonen in het bloed

film of registratie van de hersen-activiteit door het platatsen van electrodes op het hoofd

microscopisch onderzoek van opgehoeste fluimen uit de longen

Kennisscore iuiste items: $\quad[2$ zekerheidsscores op juiste items $] * 50 / 7$

woor de verdeling van deze kennisscore zie figuur 10

Somscore foutpercentie: [N zekerheidsscares op foutieve items] $50 / 18$

voor de verdeling van deze kennisscore zie figuur 11

Adequatekennisscore: $\quad$ [Kennisscore - Foutperceptie]/2

woor de verdeling van deze kennisscore zie figuur 12

- Sociale determinanten van kennis van kankerpreventie in Vlaanderen - 
Figuur 10 : kennis opsporingsonderzoeken

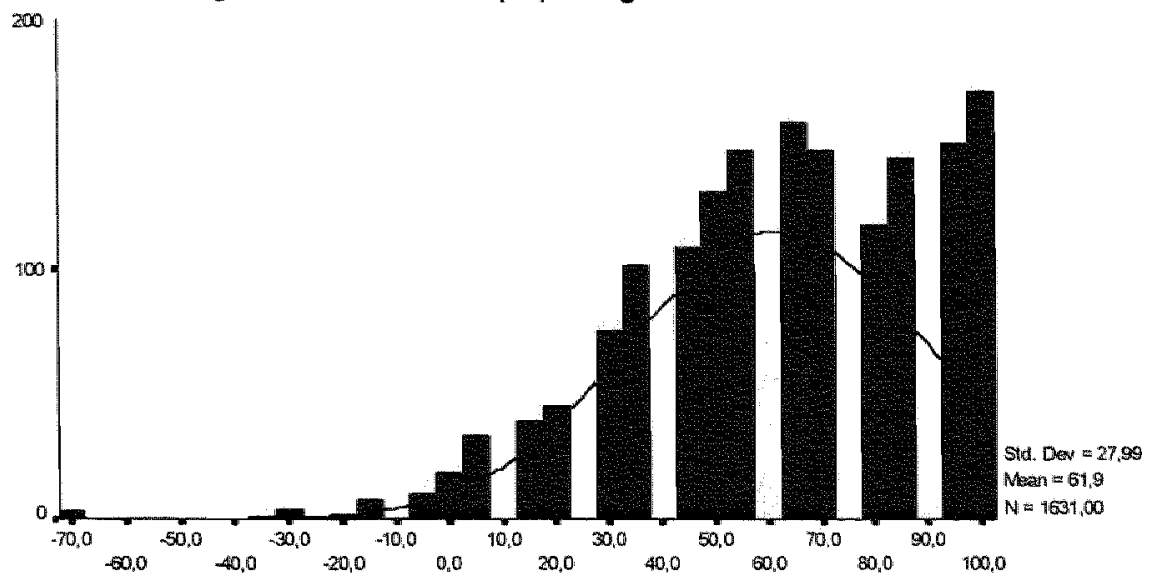

Kennis "echte' opsponngsondierzoeken $(\mathrm{N}=7)$

Figuur 11 : Foutperceptie opsporingsonderzoeken

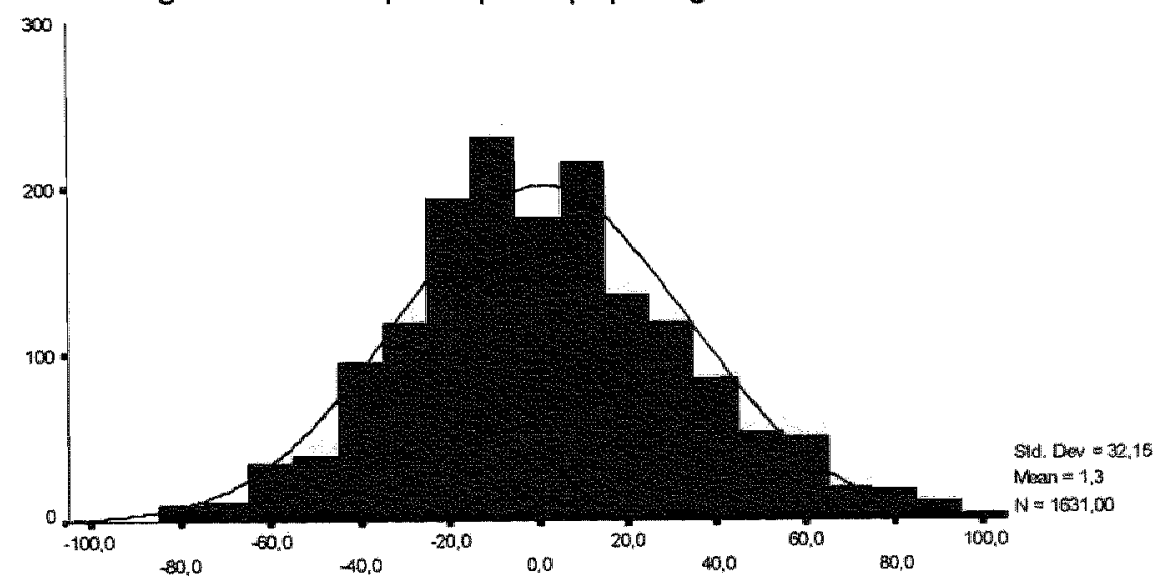

Soms core 'foutiteve' ops porings onderzoeken $(\mathbb{N}=18)$ 
Figuur 12 : Adequate kennis opsporingsonderzoken

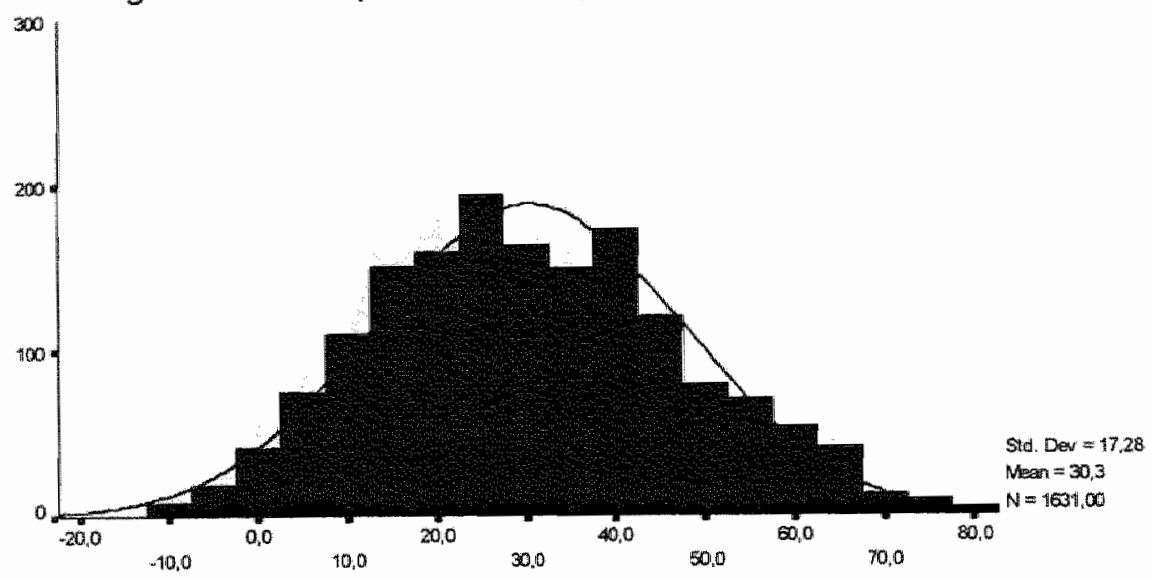

Adequate kennis ops poringsonderzoken $(k=25)$

Figuur 13 : Kennis primaire kankerpreventie

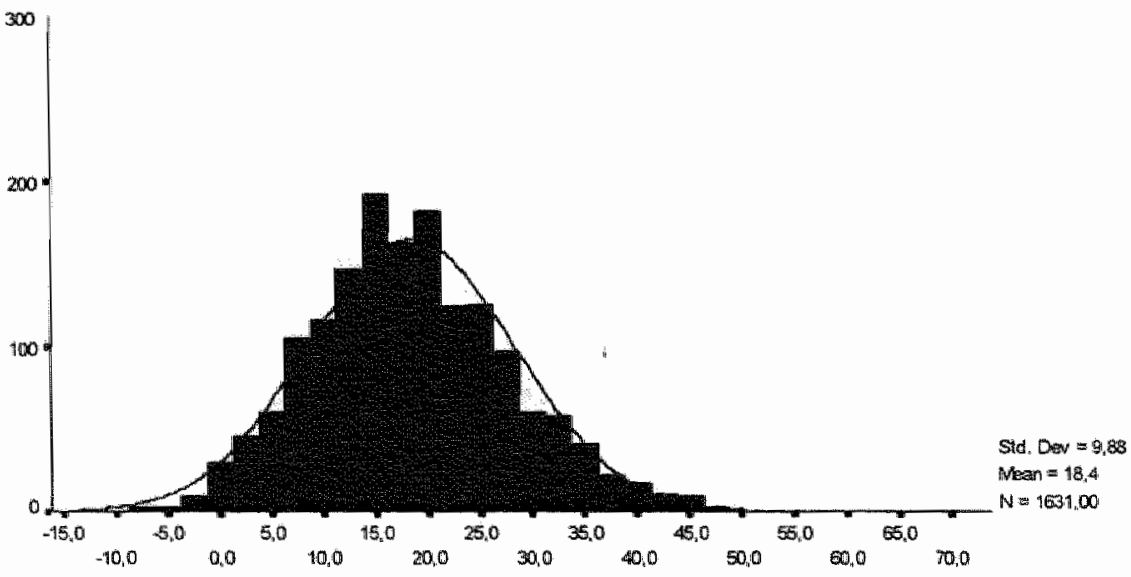

Kennis van primaire kankerpreventie 
Figuur 14 : Kennis van secundaire kankerpreventie

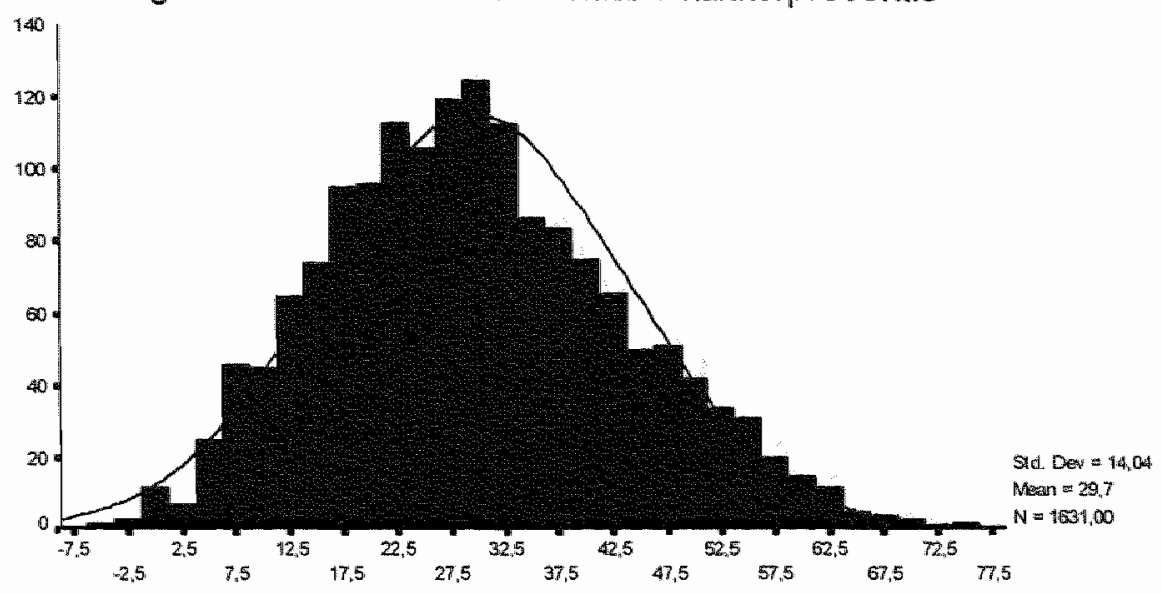

Kennis van secundaire kankerpreventie

Figuur 15 : Synthesemaat adequate kennis

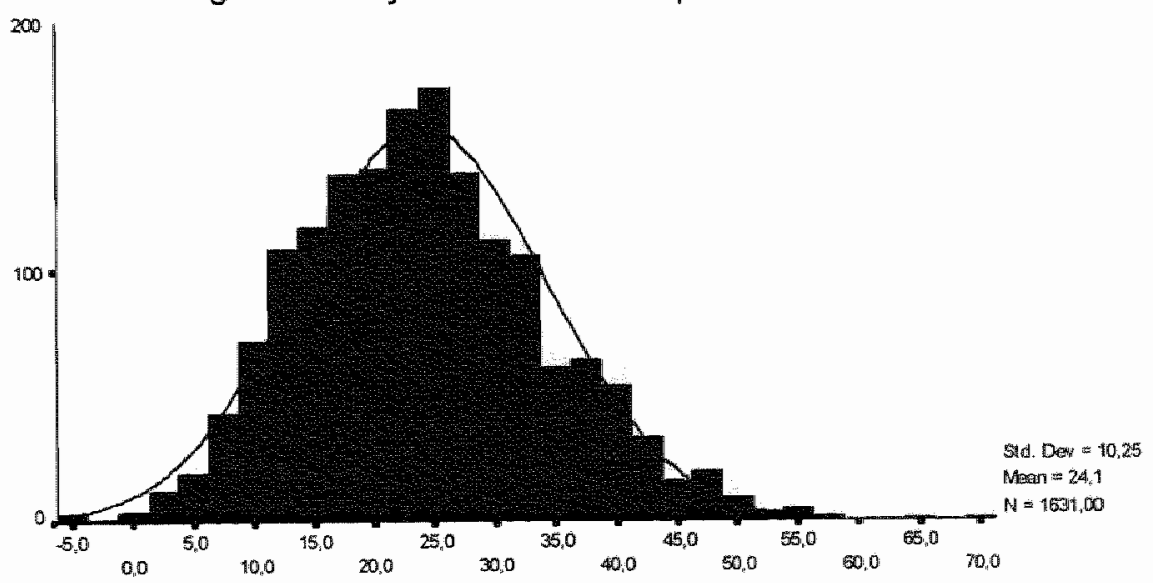

Synthesemaat adequate kennis van kankerprevente 
Figuur 16 : Synthesemaat foutperceptie

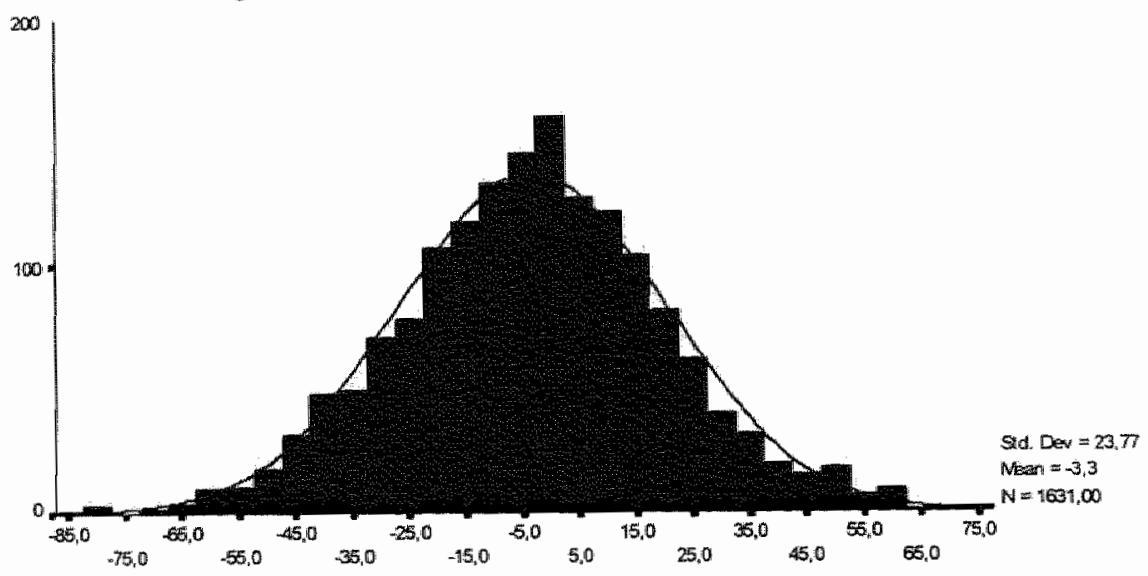

Synthesemaat foutperceptie

Figuur 17 : Synthesemaat 'echte' kennisscores

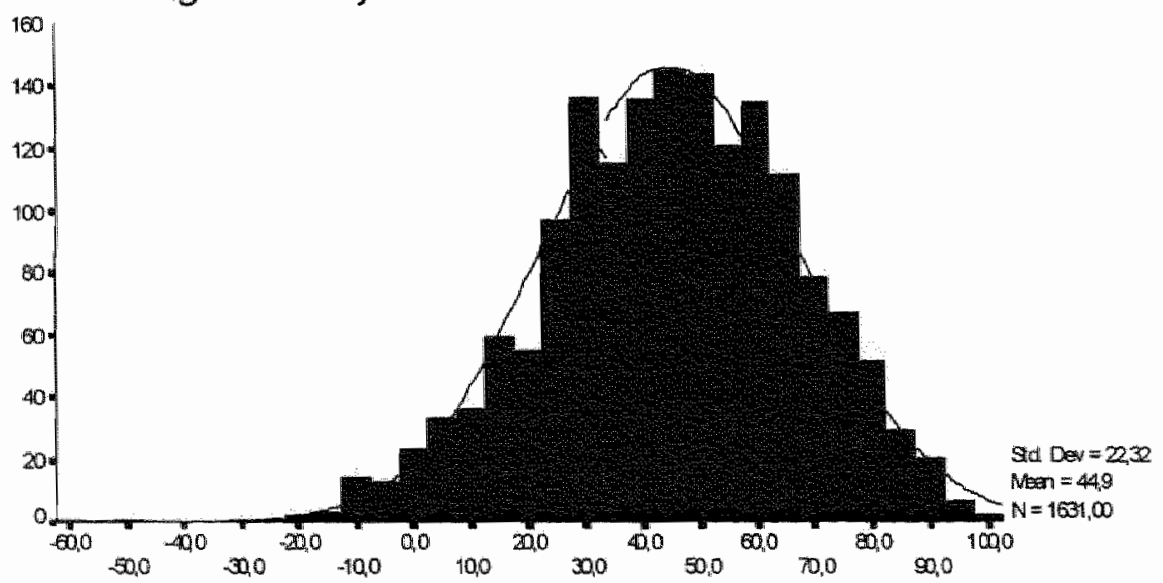

Synthes emat 'echte' Kemissoores 


\section{Bijlage 2b: Operationalisering en schaalconstructie van} Sociaal-Economische Status (SES)

\section{Conceptualisering en indicering :}

SES van de respondent, beschouwd als een meervoudige of complexe variabele

$\begin{array}{ll}3 \text { dimensies: } & \text { A. inkomen } \\ & \text { B. opleiding } \\ & \text { C. beroep }\end{array}$

3indicatoren (1 per dimensie):
A. beschikbaar inkomen voor de respondient (binnen thet gezinsinkomen)
B. hoogst behaalde diploma van de respondent
C. status van het beroep van de respondent en/of zijn partner

\section{Instructies voor de registratie:}

\section{1. waarde inkomensniveau $=$}

Er is op twee manieren informatie verkregen over het inkomen. Ongeveer $50 \%$ van de steekproefpopulatie heeft een absoluut inkomen gerapporteerd (interval variabele) en nog eens 35 \% heeft zijn/haar inkomen gesitueerd op een ordinale schaal van 16 categorieên. Beide groepen moeten worden samengevoegd en een score krijgen op eenzelfde inkomensvariabele.

a) Intervalvariabele:

stap 1 'totale gezinsinkomen" [E36]/ "aantal standaardpersonen in gezin" [E131] [= E361]

$$
\begin{aligned}
& \text { P.S. volwassene }=1 \text { standaardpersoon } \\
& \text { kinderen }<18 \text { jaar }=0,5 \text { standaardpersoon }
\end{aligned}
$$

stap 2 samenvoeging met gestandaardiseerde inkomensgegevens van ordinale schail

$$
[E 361+E 392=>E 362]
$$

stap 3 datareductie tot ordinale variabele van 8 klassen [E362 $\Rightarrow>$ [E363KLAS]

b) Ordinale schaal:

deze schaal ziet er als volgt uit:

- inkomensklasse 1

- inkomensklasse 2

- inkomensklasse 3

- inkomensklasse 4

- inkomensklasse 5

- inkomenskllasse 6

- inkomensklasse 7

- inkomensklasse 8

$<10.000$ per maand
$10.000-19.999$
$20.000-29.999$
$30.000-39.999$
$40.000-49.999$
$50.000-59.999$
$60.000-69.999$
$70.000-79.999$


- inkomensklassie 9

- inkomensklasse 10

- inkomensklasse 11

- inkomensklasse 12

- inkomensklasse 13

- inkomenskiasse 14

- inkomensklasse 15

- inkamensklasse 16

$$
\begin{aligned}
& 80.000-89.999 \\
& 90.000-99.999 \\
& 100.000-109.999 \\
& 110.000-119.999 \\
& 120.000-129.999 \\
& 130.000-139.999 \\
& 140.000-149.999 \\
& 150.000 \text { of meer }
\end{aligned}
$$

Om het standaardinkomen te berekenen, nemen we de middelste waarde in elke klasse

stap 1 'middelste waarde klasseinkomen gezin" / "aantal standaardpersonen in gezin" [= E392]

P.S. volwassene $=1$ standaardpersoon

kinderen $<18$ jaar $=0,5$ standaardpersoon

stap 2 samenwoeging met gestandaardiseerde inkomensgegevens intervalvariabele $[E 392+E 361=>E 362]$

stap 3 datareductie tot ordinale variabele van 8 klassen [E392 $=>$ E363KLAS] (zie tabel 1)

Tabel 1

Standaardinkomen in 8 klassen

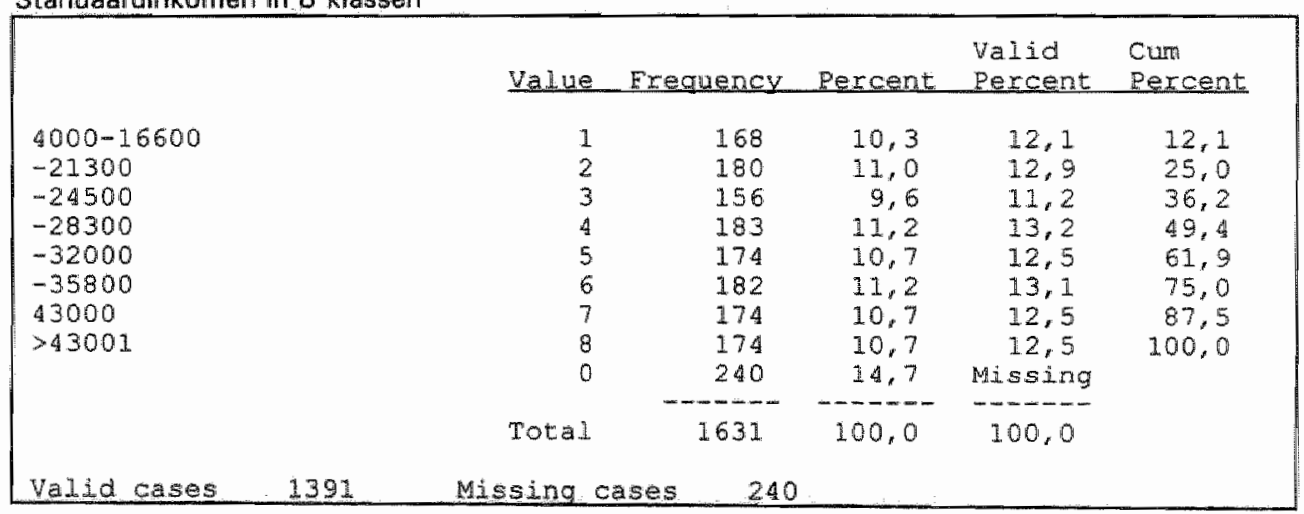

- Sociale determinanten van kennis van kankerpreventie in Vlaanderen - 


\section{2. waarde opleidingsniveau respondent $[\mathrm{E} 14]=$ (zie tabel 2)}

Tabel 2

Hoogst behaalde diploma van de respondent

\begin{tabular}{|c|c|c|c|c|c|}
\hline & Value & Erequency & Percent & $\begin{array}{l}\text { Walid } \\
\text { percont }\end{array}$ & $\begin{array}{l}\text { Cum } \\
\text { Rercent }\end{array}$ \\
\hline LO & 1 & 308 & 18,9 & 18,9 & 18,9 \\
\hline LSO techn-beroeps & 2 & 260 & 15,9 & 16,0 & 34,8 \\
\hline Iso algemeen & 3 & 112 & 6,9 & 6,9 & 41,7 \\
\hline HSO techn-beroeps & 4 & 365 & 22,4 & 22,4 & 64,1 \\
\hline HSO eIgemeen & 5 & 193 & 11,8 & 11,8 & 76.0 \\
\hline HOKT & 6 & 229 & 14.0 & 14,0 & 90,0 \\
\hline HOLT & 7 & 60 & 3,7 & 3,7 & 93,7 \\
\hline Javersitair & 8 & 103 & 6,3 & 5,3 & 100.0 \\
\hline \multirow[t]{2}{*}{ geen antwoord } & 9 & 1 & 1 & Missing & \\
\hline & Total & 1631 & 100,0 & 100,0 & \\
\hline Valid cases & Missing 0 & ases & & & \\
\hline
\end{tabular}

\section{3. waarde van beroepsprestige $=$}

a) Intervalvariabele:

Niet alle respondenten hebben of hadden een beroep. Omdat de status van het beroep varn de partner ook wordt meegedragen met de respondent en omgekeerd, en om toch niet al te veel informatie te verliezen bij de operationele definitie, wordt gestreefd am zo veel mogelijk een beroepsprestige te bepalen. We baseren ons daarom op zowel het beroep van de respondent, als op deze van de eventuele partner. Volgende situaties doien zich voor:

$1^{\circ}$ Indien geen partner of partner is huiswrouw of student $=>$ beroepsprestige van de respondent wordt weerhouden [E33bis]

$2^{\circ}$ Indien wel partner en respondent is huiswrouw of student $=>$ beroepsprestige van de partner wordt weerhouden [E35bis] $\left[1^{\circ}+2^{\circ}=>\right.$ E332]

$3^{\circ}$ Indien wel partner en respondent is noch huisvrouw, noch student $=>$ [beroepsstatus respondent + beroepsstatus partner $] / 2\left[\|^{\circ}+2^{\circ}+3^{\circ}=>\right.$ E333 $]$ 
b) Ordinale schaal:

datareductie in 15 ongeveer gelijke klassen [E333 $=>$ E333KLAS] (zïe tabel 3 )

Tabet 3

Gemiddeld beroepsprestige van de respondent en zijn/haar partner, in 15 klassen

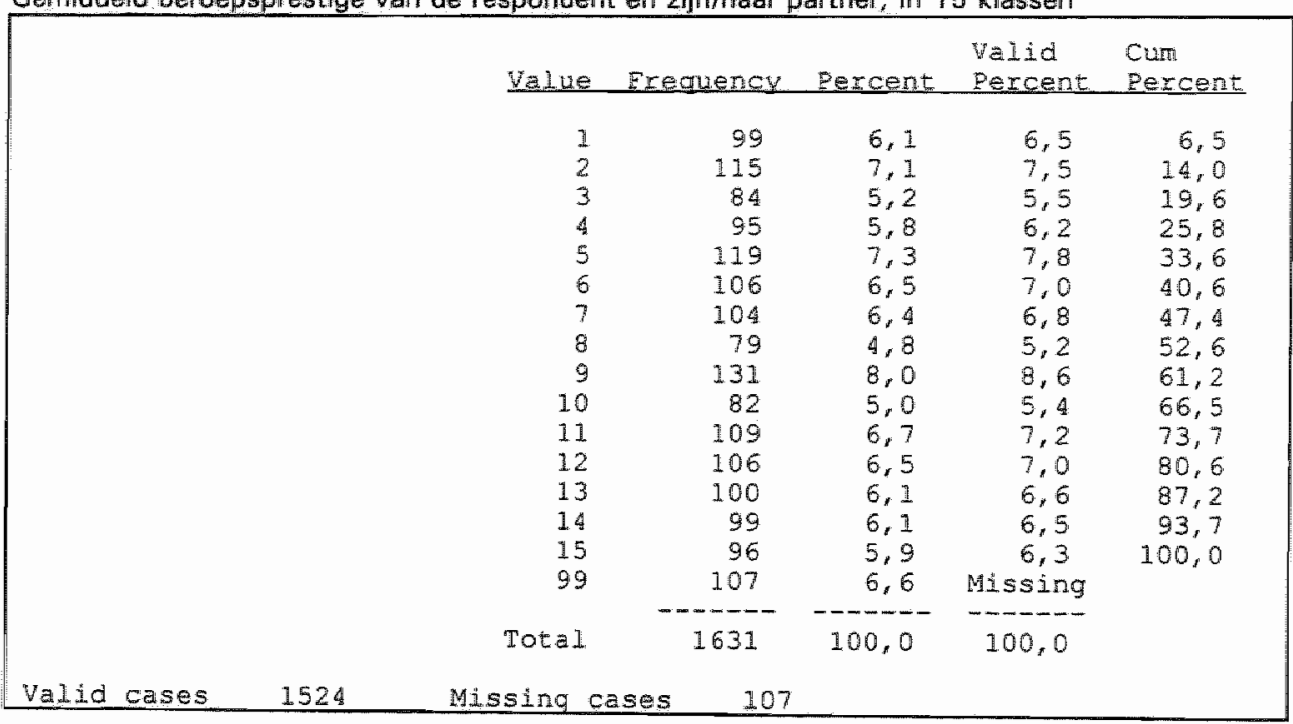

- Sociale determinanten van kennis van kankerpreventie in Vlaanderen - 


\section{Operationele definitie:}

stap 1 waarde oplaiding [E1 4] + waarde inkomen [E363KLAS] = waarde SESa

a) $\Rightarrow$ ordinale variabele met 15 klassen $=$ SESa (in 15 klassen) [E50] (zie tabel 4)

$=>\quad$ minimum waarde $=2$

maximum waarde $=16$

Tabel 4:

Sociaal-economische status van de respondent, in 15 klassen (gebaseerd op inkomen en opleiding)

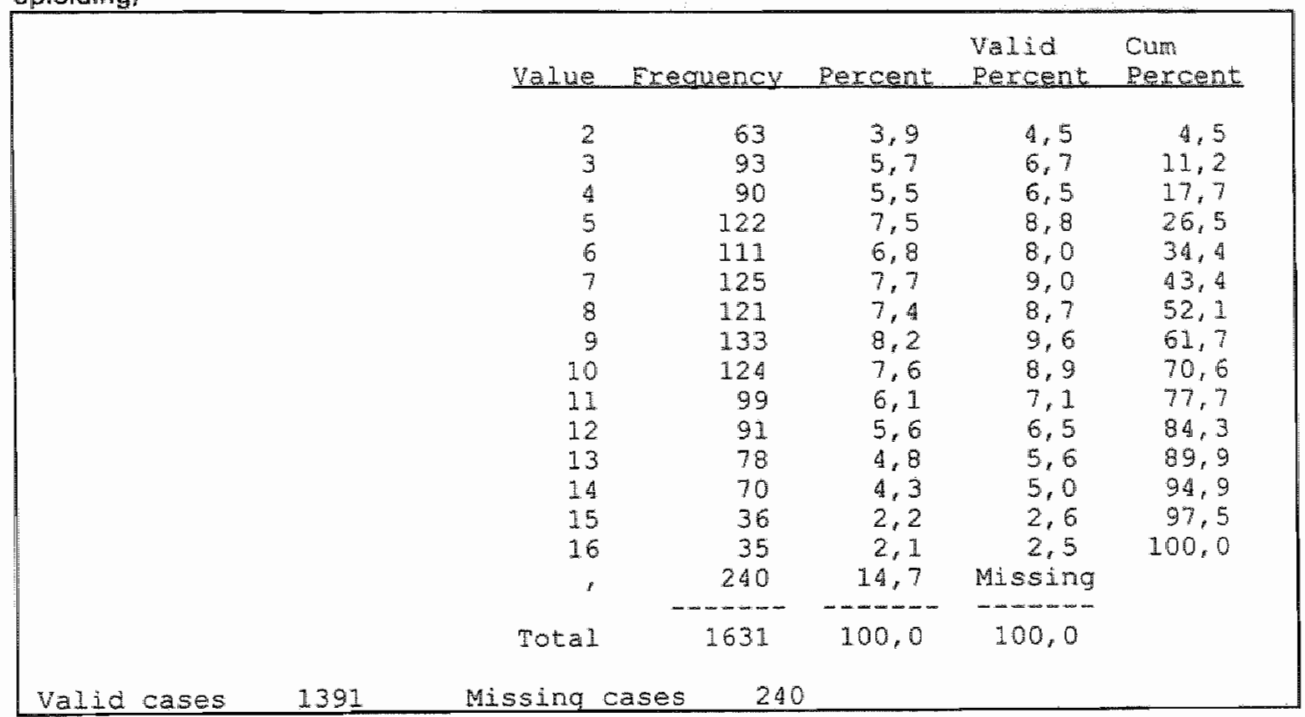

b) datareductie in 9 ongeveer gelijke klassen = SESa (in 9 klassen) [E51]: (zie tabel 5 )

1. Lower lower SES

2. middle lower SES

3. upper lower SES

4. lower middle SES

5. middlle middle SES

6. upper middle SES

7. lower upper SES

8. middle upper SES

9. upper upper SES

P.S. met 9 klassen, kan deze ordinale wariabele ook met parametrische toetsen wonden geanalyseerd.

- Socialle determinanten van kennis wan kankerpreventie in Vlaanderen. 
Tabel 5

Sociaal-economische status van de respondent, in 9 klassen (gebaseerd op inkomen en opleiding)

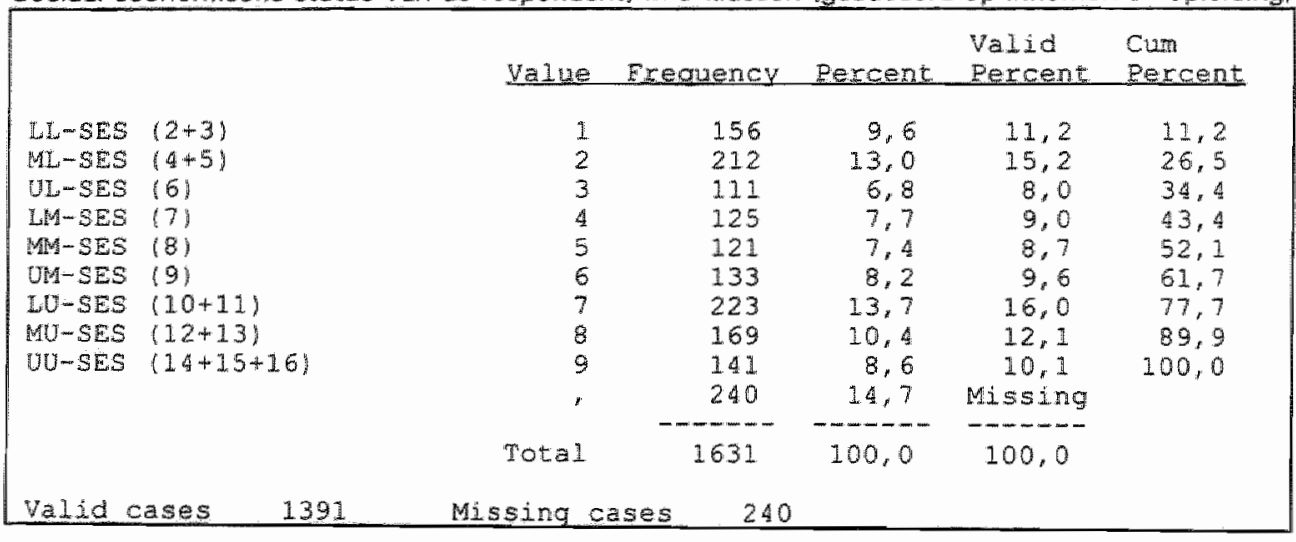

- Saciale determinanten van kennis wan kankerpreventie in Vlaanderen - 
stap 2 [(waarde gpleiding + waarde inkomen)[E50] - 11 + waarde berogesprestige [E333KLAS]

a) $\quad=>$ ordinale variabele met $29 \mathrm{klassen}=$ SESb (in $29 \mathrm{klassen}$ ] [E52] (zie tabel 6)

$$
\begin{aligned}
=> & \text { minimum waarde }=2 \\
\text { maximum waarde } & =30
\end{aligned}
$$

Tabel 6

Sociaal-economische status wan de respondent, in 29 klassen (gebaseerd ap inkomen, opleiding

\begin{tabular}{|c|c|c|c|c|}
\hline Velue & Exequency & Percent & $\begin{array}{l}\text { yeda } \\
\text { Pecent }\end{array}$ & $\begin{array}{l}\text { Cum } \\
\text { Percent }\end{array}$ \\
\hline 2 & 16 & 1.0 & 1,2 & 1,2 \\
\hline 3 & 19 & 1,2 & 1,4 & 2,6 \\
\hline 4 & 20 & 1,2 & 1,5 & 4,1 \\
\hline 5 & 40 & 2,5 & 3,0 & 7,2 \\
\hline 6 & 50 & 3,1 & 3,8 & 10,9 \\
\hline 7 & 65 & 4,0 & 4,9 & 15,8 \\
\hline 8 & 66 & 4,0 & 5,0 & 20,8 \\
\hline 9 & 14 & 4,5 & 5,6 & 26,4 \\
\hline 10 & 58 & 3,6 & 4,4 & 30,7 \\
\hline 11 & 62 & 3.8 & 4.7 & 35,4 \\
\hline 12 & 50 & 3,1 & 3,8 & 39,2 \\
\hline 13 & 64 & 3,9 & 4,8 & 44,0 \\
\hline 1.4 & 55 & 3,4 & 4,1 & 48,1 \\
\hline 15 & 55 & 3,4 & 4,1 & 52,3 \\
\hline 16 & 75 & 4,6 & 5.6 & 57,9 \\
\hline 17 & 50 & 3,1 & 3.8 & 61,7 \\
\hline 18 & 57 & 3,5 & 4,3 & 66,0 \\
\hline 19 & 52 & 3,2 & 3.9 & 69,9 \\
\hline 20 & 54 & 3,3 & 4,1 & 73,9 \\
\hline 21 & 53 & 3,2 & 4,0 & 77,9 \\
\hline 22 & 53 & 3,2 & 4,0 & 81,9 \\
\hline 23 & 34 & 2,1 & 2,6 & 84,5 \\
\hline 24 & 33 & 2,0 & 2,5 & 07,0 \\
\hline 25 & 46 & 2,8 & 3.5 & 90,4 \\
\hline 26 & 39 & 2,4 & 2,9 & 93,4 \\
\hline 27 & 30 & 1,8 & 2,3 & 95,6 \\
\hline 28 & 18 & 1,1 & 1.4 & 97,0 \\
\hline 29 & 22 & 1,3 & 1,7 & 90,6 \\
\hline 30 & 18 & 1,1 & 1,4 & 100,0 \\
\hline \multirow[t]{2}{*}{, } & 303 & 18,6 & Missing & \\
\hline & $-m--m---$ & $-\infty-\infty-\infty-1$ & $-----\cdots$ & \\
\hline Total & 1631 & 100,0 & 100,0 & \\
\hline
\end{tabular}
en beroepsprestige) 
b) datareductie in 9 ongeveer gelike klassen = SESb (in 9 klassen) [E53]: (zie tabel 7)
1. Iower lower SES
2. middle lower SES
3. upper lower SES
4. lower middle SES
5. middle middle SES
6 6. Upper middle SES
7. lower upper SES
8. middle upper SES
9. upper upper SES

\section{Tabell 7}

Sociaal-economische status van de respondent, in 9 klassen Igebaseerd op inkomen, opleiding en beroepsprestige)

\begin{tabular}{|c|c|c|c|c|c|c|c|c|}
\hline & & & Uave & Exe & nuency & Percent & $\begin{array}{l}\text { Vald } \\
\text { pexcent }\end{array}$ & $\begin{array}{l}\text { Cum } \\
\text { Percent }\end{array}$ \\
\hline$\omega L-S E S$ & 12 & -61 & 1 & & 145 & 8,9 & 10.9 & 10,9 \\
\hline$M L-S E S$ & $17-$ & -81 & 2 & & 131 & 8,0 & 9.9 & 20,8 \\
\hline$y z-5 E S$ & $19=$ & $-10)$ & 3 & & 132 & $B_{n} \mathbb{H}$ & 9.9 & 30,7 \\
\hline $\mathbb{L} W=S E S$ & 11 & $-13)$ & 4 & & 176 & 10,8 & 13,3 & 44,0 \\
\hline$M M-S E S$ & 114 & -161 & 5 & & 185 & 11,3 & 13,9 & 57,9 \\
\hline UM-SES & 117 & $-18)$ & 6 & & 107 & 6.6 & 8,1 & 66,0 \\
\hline $\mathrm{LU} U \mathrm{UES}$ & 179 & $-21)$ & 7 & & 159 & 9,7 & 12,0 & 77,9 \\
\hline$M U-3 E S$ & 122 & $-24)$ & 8 & & 120 & 7,4 & 9.0 & 87.0 \\
\hline \multirow[t]{4}{*}{$00-5 E S$} & 125 & $-30 j$ & 9 & & 173 & 10,6 & 13,0 & 100,0 \\
\hline & & & , & & 303 & 18,6 & Missing & \\
\hline & & & & & $m--m$ & $---\infty-\infty$ & ------- & \\
\hline & & & Total & & 1631 & 100,0 & 100,0 & \\
\hline Valid & cases & 1328 & Missimg & cases & 303 & & & \\
\hline
\end{tabular}




\section{bijlage 3 :}

tabel 5.9 aantal respondenten volgens hun kennis van de risicofactoren voor kanker

tabel 5.10 aantal respondenten volgens hun kennis van het gewenste kankerpreventieve gedrag

tabel 5.11 aantal respondenten volgens hun kennis van de waarschuwingssignalen voor kanker

tabel 5.12 aantal respondenten volgens thun kennis van de vroegtij̈lige opsporingsonderzoeken voor kanker

tabell $\mathbf{5 . 1 3}$ aantal respondenten volgens hun kennis van kankerpreventie, naar zekerheidsscore en geslacht

Bijlage 3

Bijlagen bij hoofdstuk 5 

Tabel 5.9 Aantal respondenten (in \%) volgens hun kennis van de risicoractoren voor kanker, naar zekerheidsscore $(\mathbb{N}=1631)$

\begin{tabular}{|c|c|c|c|c|c|c|c|c|}
\hline Pisicofactor: & Ra & {$[\mathrm{MI}$} & {$[S D \rrbracket$} & score 1 & score 2 & $\begin{array}{c}\operatorname{sicote} 3 \\
+\end{array}$ & $\begin{array}{c}\text { scioras } \\
+\end{array}$ & $\begin{array}{l}\operatorname{scor} 05 \\
+4\end{array}$ \\
\hline overdadig blootstelling a/d zon " & 2 & 4.078 & 0.91 & 2.6 & 3.6 & 12.0 & 47.3 & 34.6 \\
\hline $\begin{array}{l}\text { Wermatig gebruik van schoom- } \\
\text { meidsproducten }\end{array}$ & 15 & 2.831 & 0.98 & 12.0 & 18.8 & 46.5 & 19.4 & 3,3 \\
\hline $\begin{array}{l}\text { overm, gebruik van laxect- } \\
\text { middelen t.b.W. de ontlasting }\end{array}$ & 13 & 3.002 & 0.95 & 7.0 & 19.1 & 45.5 & 23.4 & 5.0 \\
\hline niet werzorgen $v$. huidontsteking & 5 & 3.537 & 1.01 & 4.2 & 12.0 & 23.4 & 46.8 & $\pi i 3$ \\
\hline $\begin{array}{l}\text { veelvuldig zwemmen in } \\
\text { bezoedelid water }\end{array}$ & 8 & 3.358 & 1.04 & 5,3 & 14.6 & 31.0 & 37.3 & 118 \\
\hline langdurige borstwoeding & 23 & 2.085 & 0.92 & 32.6 & 31.3 & 31,9 & 3.5 & 0.7 \\
\hline avermatig sponten & 25 & 1.716 & 0.90 & 51.7 & 31.1 & 11.7 & 4.8 & 0.7 \\
\hline nilet verzorgen $v$. koelontstek ing & 12 & 3.077 & 1.1 .4 & 11.0 & 20.1 & 27.0 & 33.8 & 8.0 \\
\hline $\begin{array}{l}\text { selk suele omgang met meerdere } \\
\text { parthers zonder condoom; als } \\
\text { risico woor vrowwen }\end{array}$ & 9 & 3.337 & 1.39 & 15.0 & 14.5 & $18: 4$ & 26.1 & 26.0 \\
\hline $\begin{array}{l}\text { eerste kind na de leeftijd wan } 30 \\
\text { jaar; alls risico voor vrouwen }\end{array}$ & 20 & 2.335 & 1.03 & 24.7 & 3.2 .6 & 29.1 & 91.5 & 2.0 \\
\hline $\begin{array}{l}\text { passief roken; blootstelling aan } \\
\text { "abaksrook uit de omgeving }\end{array}$ & 3 & 4.008 & 0.95 & 1.9 & 6.0 & 15.3 & 42.9 & 33.8 \\
\hline sterilisatie bij mannen & 22 & 2.176 & 0.94 & 29.9 & 28.6 & 36.2 & 4.5 & 0.7 \\
\hline roken * & 1 & 4.663 & 0.67 & 0.8 & 1.0 & 3.8 & 19.9 & 74.5 \\
\hline overmatig gebruik van antibiotica & 10 & 3.153 & 0.97 & 5.8 & 15.1 & 45.4 & 25.4 & 8.3 \\
\hline $\begin{array}{l}\text { epileren van de borstharen bil] } \\
\text { wrouwen }\end{array}$ & 16 & 2.513 & 7.00 & 20.3 & 23.2 & 44.2 & 9.6 & 2.7 \\
\hline $\begin{array}{l}\text { owerm. gebruilk wan dierlijke } \\
\text { vetten in de woeding * }\end{array}$ & 6 & 3.511 & 1.05 & 4.6 & 12.9 & 25.2 & 41.4 & 15.9 \\
\hline averm. gebrulk wan witaminen & 19 & 2.356 & 0.99 & 23.1 & 31.3 & 3.3 .7 & 10.5 & 1.3 \\
\hline zwarlijwigheid & 14 & 2.966 & 1.12 & 119 & 226 & 29.7 & 29.9 & 6.6 \\
\hline oniegelmatige nachtrust & 18 & 2.394 & 9.04 & 22.1 & 34.4 & 27.9 & 13.1 & 2.5 \\
\hline $\begin{array}{l}\text { seksuel omgang ind meardere } \\
\text { parthers zonder condoom; alls } \\
\text { risico voor mannen }\end{array}$ & 11 & 3.110 & 1.39 & 17.5 & 18.1 & $2 \pi .1$ & 21.8 & 21.2 \\
\hline $\begin{array}{l}\text { niet verzorgen wan een } \\
\text { aanhoudende diarree }\end{array}$ & 7 & 3.479 & 1.016 & 5.2 & 13.1 & 25.8 & 40.66 & 15.4 \\
\hline $\begin{array}{l}\text { Overmatig gebruik van pasta's } \\
\text { Gv. spaghettil in de voeding }\end{array}$ & 24 & 2.0516 & 0.93 & 32.3 & 37.2 & 24.0 & 6.5 & 1.0 \\
\hline $\begin{array}{l}\text { Hangdurig werken voor een } \\
\text { computerscherm }\end{array}$ & 21 & 2.304 & 1.0 .2 & 25.6 & 33.0 & 28.6 & 11.0 & 1.8 \\
\hline overm. glebruik van alcohol & 4 & 3.769 & 1.05 & 3.9 & 9.1 & 19.1 & 41.9 & 25.9 \\
\hline gebruik van hest "spiraaltje & 17 & 2.441 & 0.99 & 21.9 & 25,3 & 41.2 & 10.0 & 1.6 \\
\hline
\end{tabular}

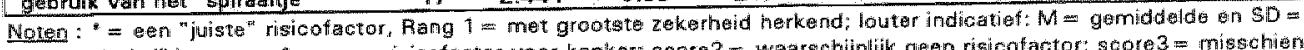

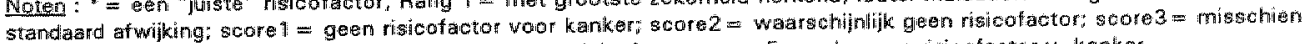

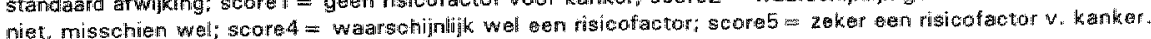


Tabel 5.10 Aantal respondenten in \%) volgens hun kennis van het gewenst kankerpreventief gedrag, naar zelkerheidsscore $[N=1631$ ]

\begin{tabular}{|c|c|c|c|c|c|c|c|c|}
\hline Prevantilef gedrag: & Rang & mI & {$[\mathrm{SD}]$} & score 1 & scone? & $\begin{array}{c}\text { scores } \\
-+\end{array}$ & $\begin{array}{c}\text { score } 4 \\
+\end{array}$ & $\begin{array}{c}\text { sciore } 5 \\
++\end{array}$ \\
\hline rengetinuatige lichas mabeweging & 14. & 3.557 & 1.22 & 8.3 & 13.1 & 96.7 & 38.3 & 23.6 \\
\hline matig gebruik wan medicinen & 17 & 3.467 & 1.17 & 7.4 & 14.4 & 21.6 & 37.2 & 19.4 \\
\hline goand huidverzorging & $\mathrm{B}$ & 3.815 & 1.04 & 3.9 & 8.5 & 16.1 & 45.1 & 20.4 \\
\hline regelm. eten wan vers frut & 3 & 4.211 & 0.97 & 2.1 & 5.8 & 9.2 & 34.7 & 48.2 \\
\hline regelmatig oten wan vi:gi & 7 & 3.865 & 1.07 & 2.9 & 9.9 & 20.1 & 34.1 & 33.7 \\
\hline regeim. gebruik wain ijzerpilten & 24 & 2.766 & 0.92 & 8.6 & 27.7 & 45.9 & 14.3 & 3.6 \\
\hline $\begin{array}{l}\text { rengelm, eten vant ongepelde } \\
\text { rijet }\end{array}$ & 20 & 3.272 & 1.06 & 5.1 & 16.9 & 37.7 & 26.5 & 13.9 \\
\hline met matie drinken wan kaffie & 23 & 3.094 & 1.14 & 9.2 & 22.0 & 29.9 & 28.0 & 10.9 \\
\hline $\begin{array}{l}\text { regelmatig eten wan bruin } \\
\text { brood }\end{array}$ & 13 & 3,626 & 1.11 & 5.4 & 11.0 & 21.8 & 39.1 & 22.7 \\
\hline $\begin{array}{l}\text { regelmutig eten wan werse } \\
\text { groonten }\end{array}$ & 4 & 4. 145 & 0.99 & 3.2 & 4.8 & 9.4 & 39.3 & 43.2 \\
\hline regellmatig eten wam yoghurt & 12 & 3.630 & 1.10 & 4.8 & 90.6 & 24.8 & 36.1 & 23.6 \\
\hline wermijuterth van overgewwicht * & 9 & 3.779 & 1.07 & 3.4 & 10.5 & 19.6 & 38.1 & 28.5 \\
\hline regelmatigy sporten & 11 & 3.656 & 1.115 & 5.8 & 12.2 & 18.7 & 37.1 & 26.2 \\
\hline $\begin{array}{l}\text { ovardadige blootstelling aan } \\
\text { de zon vermijicn }\end{array}$ & 2 & 4.303 & 0.88 & 1.7 & 32 & 7.7 & 37.6 & 49.7 \\
\hline met mate enen van zout & 15 & 3.500 & 1.15 & 6.2 & 14.3 & 24.2 & 34.0 & 21.3 \\
\hline voldoenider nechtrust & 19 & 3.353 & 1.17 & 7.4 & 16.4 & 28.6 & 28.9 & 18.7 \\
\hline $\begin{array}{l}\text { met matte drinken van } \\
\text { alcoholische dranken }\end{array}$ & 6 & 3.869 & 1.06 & 3.4 & 9.0 & 16.1 & 40.2 & 31.3 \\
\hline $\begin{array}{l}\text { stoppen met ioken of nilet } \\
\text { token }\end{array}$ & 1 & 4.676 & 0.68 & 1.0 & 0.7 & 4.2 & 18.0 & 76.1 \\
\hline 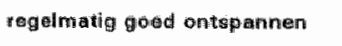 & 10 & 3.774 & 1.07 & 4.3 & 8.0 & 21.3 & 38.6 & 27.7 \\
\hline 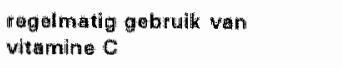 & 21 & 3.254 & 11.03 & 5.6 & 15.6 & 37.5 & 30.5 & 10.9 \\
\hline $\begin{array}{l}\text { regeimatig aten van pasta's } \\
\text { (bv spagthetti) }\end{array}$ & 26 & 2.469 & 0.94 & $16 \cdot 6$ & 33.1 & 39.2 & 9.1 & 2.0 \\
\hline regelmatig wandelen & $18:$ & 3,378 & 1.11 & 6.7 & 14.9 & 27.3 & 36.2 & 14.9 \\
\hline 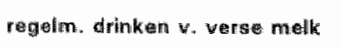 & 22 & $3.1+3$ & 1.05 & 6.5 & 20.7 & 37.6 & 25.4 & 9.8 \\
\hline $\begin{array}{l}\text { dagellikg dininken van ón liter } \\
\text { water }\end{array}$ & 16 & 3.479 & 1.15 & 6.2 & 13.9 & 27.2 & 311.1 & 21.5 \\
\hline vermiljden van stress & 5 & 3.881 & 1.08 & 3.9 & 7.7 & 19.1 & 35,0 & 34.3 \\
\hline
\end{tabular}

Moblati:" " wen "juist" kankerpreventief gedrag, Pang 1 - met grootste zekerheid herkend; louter indicatiof: $M=$ gemiddelde

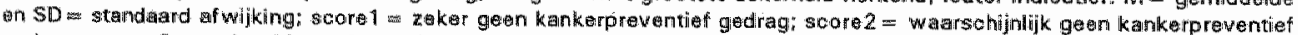

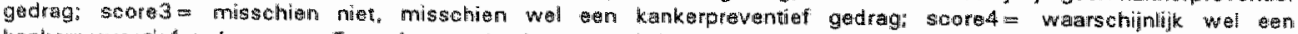
kamkerprewentief gedrag; score5 = zelker een kankerprewentiaf godrag. 
Tabel 5.11 Aantal respondenten (in \%) volgens hun kennis van de waarschuwingssignalen voor kanker, naar zekerheidsscore $(\mathrm{N}=1631$ )

\begin{tabular}{|c|c|c|c|c|c|c|c|c|}
\hline Waarschuwingssignaal: & Rang & $\| M !$ & {$[S \mathrm{~S}\}$} & scote & soore 2 & $\begin{array}{c}\text { scores } \\
-+ \\
-+\end{array}$ & $\begin{array}{c}15 c 0 r a 4 \\
+ \\
\end{array}$ & $\begin{array}{c}\text { seores } \\
++4 \\
\end{array}$ \\
\hline hoofdpijn & 24 & 2.124 & 1.09 & 37.8 & 26.8 & 22.4 & 114 & 1.7 \\
\hline $\begin{array}{l}\text { gevael wan "wegdnazien" of } \\
\text { duizeligheid }\end{array}$ & 21 & 2.372 & $\$ .04$ & 24.0 & 31.5 & 29.7 & 43.0 & 18 \\
\hline pilin in de hant-of borststireelk & 13 & 2.796 & 1.14 & 16.5 & 22.8 & 29.8 & $26 \cdot 4$ & 4.5 \\
\hline fage pugpijnen & 78 & 2.479 & 11.01 & 18.5 & 33.0 & 32.5 & 14.0 & 2.0 \\
\hline $\begin{array}{l}\text { athoudende wijziging in plas- } \\
\text { of stoelgangpatroon }\end{array}$ & 5 & 3.555 & 0.93 & 3.5 & 7.6 & 31.6 & 44.5 & 12.8 \\
\hline $\begin{array}{l}\text { brairkneigingen of } \\
\text { maagstoornissen }\end{array}$ & \& & 3.159 & 0.99 & 6.5 & 16.1 & 390 & 31.6 & 6.6 \\
\hline spierpijnen & 22 & 2.275 & 0.96 & 23.1 & 38.2 & 28.1 & 9.4 & 1.2 \\
\hline kortademigheid & 15 & 2.701 & 1.06 & 15.5 & 26.5 & 33.7 & 24.3 & 3.1 \\
\hline warmte of koude opwellingen & 25 & $2 \times 103$ & 0.91 & 29.1 & 38.3 & 26.7 & 4.9 & 1.0 \\
\hline wen wonde die niet geneest & 7 & 3.337 & 1.08 & 7.4 & 13.7 & 28.4 & 38.9 & 11.6 \\
\hline $\begin{array}{l}\text { gevoelloosheid of tintelingen } \\
\text { in bepaaldie lichaamsdelen }\end{array}$ & 14 & 2.788 & 1.02 & 12.4 & 24.2 & 39.4 & 20.11 & 3.9 \\
\hline $\begin{array}{l}\text { zwaktegewoel in brepastede } \\
\text { licheamsdelen }\end{array}$ & 11 & 2.915 & 0.98 & 9.9 & 19.6 & 42.9 & 24.5 & 3.2 \\
\hline $\begin{array}{l}\text { zwaartegevoel in armen of } \\
\text { themen }\end{array}$ & 17 & 2.578 & 0.95 & 14.1 & 30.6 & 40.6 & 128 & 1.9 \\
\hline verlies van sexuele interresse & 23 & 2.248 & 0.95 & 25.5 & 34.0 & 31.5 & 8.1 & 0.9 \\
\hline $\begin{array}{l}\text { abnormaal anaal of vaginaal } \\
\text { bloedverlies lbloedverlies via } \\
\text { de azs of de schedel }\end{array}$ & 4 & 3.838 & 0.87 & 1.8 & 3.9 & 24.9 & 47.5 & 21.9 \\
\hline $\begin{array}{l}\text { gevoel van wertininderde } \\
\text { energie }\end{array}$ & 9 & 3.139 & 0.98 & 6.3 & 16.7 & 40.0 & 30.8 & 16.2 \\
\hline $\begin{array}{l}\text { weidiktking of knobbrellye in die: } \\
\text { borst * }\end{array}$ & 1 & 4.394 & 0.68 & 0.2 & 0.6 & 8.7 & 41.0 & 49.7 \\
\hline $\begin{array}{l}\text { hartkloppingien of } \\
\text { ritmestoonniss an }\end{array}$ & 16 & 2.668 & 1.05 & 14.5 & 29.11 & 35.9 & 185.9 & 4.6 \\
\hline gevoul wan rustelloosheid & 19 & 2.4 .27 & 0.96 & 78.7 & 34.8 & 34.9 & 10.4 & 1.7 \\
\hline 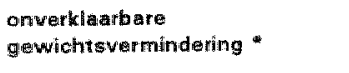 & 3 & 3.915 & 0.88 & 1.7 & 3.8 & 24.5 & 47.3 & 25.8 \\
\hline $\begin{array}{l}\text { duidelijke verandering in aen } \\
\text { moederwlek }\end{array}$ & 2 & 4.012 & 0.93 & 1.7 & 4,0 & 20.11 & 39.7 & 34.5 \\
\hline gebrekkige entust & 10 & 3.064 & 0.99 & 6.3 & 19.3 & 44.1 & 22.5 & 7.8 \\
\hline Fusteloze of gastoorde slape & 20 & 2.394 & 0.89 & 16.1 & 38.5 & 36.5 & 7.5 & 1.3 \\
\hline $\begin{array}{l}\text { anhoudend hoest of } \\
\text { heeshed }\end{array}$ & 6 & 3.438 & 1.03 & 4,8 & 12.3 & 30.8 & 38.4 & 13.7 \\
\hline brok in de keel & 12 & 2.874 & 1.12 & 13,0 & 23.0 & 35.0 & 21.6 & 7.4 \\
\hline
\end{tabular}


Tabel 5.12 Aantal respondenten (in $\%$ wolgens hun kennis van de vroegtijdige opsporingsanderzoeken voor kanker, naar zekerheidsscore $(\mathrm{N}=1631)$

\begin{tabular}{|c|c|c|c|c|c|c|c|c|}
\hline Opsporings onderzoek: & ng: & {$[\mathrm{M}]$} & ISOl & sicore 7 & scorez & $\begin{array}{c}\text { score } 3 \\
-\end{array}$ & $\begin{array}{c}\text { core } \\
+ \\
\end{array}$ & $\begin{array}{c}\operatorname{sen} 5 \\
+\div \\
\end{array}$ \\
\hline AllDS-tent & 17 & 2.969 & 1.51 & 27.8 & 12.0 & 15.8 & 24.1 & 20.2 \\
\hline electroncindiogram of EKG & 20 & 2.582 & 1.30 & 27.6 & 23.3 & 20.5 & 20.5 & B. 1 \\
\hline 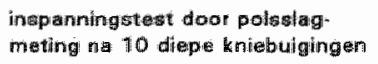 & 24 & 2.106 & 1.04 & 35.1 & 34.5 & 23.2 & 8.3 & 2.0 \\
\hline radiagrafie wan de longen & 4 & 4.297 & 0.82 & 1,4 & 1.9 & 8.6 & 41.6 & 46.4 \\
\hline $\begin{array}{l}\text { onderzek wain het huart met eem } \\
\text { stethoscoop }\end{array}$ & 22 & 2.377 & 1.20 & 29.8 & 27.8 & 22.6 & 1.4 .3 & 5.4 \\
\hline maimmografie voor vrouwen & 1 & 4.578 & 0.68 & 0.5 & 0.9 & 5.2 & 27.2 & 66,2 \\
\hline gewientameting & 19 & 2.671 & 1.22 & 21.8 & 23.1 & 28.6 & $19: 2$ & 7.3 \\
\hline $\begin{array}{l}\text { dpukmeting van de oogboll met } \\
\text { ean klein apparatje }\end{array}$ & 20 & 2.582 & 1.05 & 19.7 & $23: 0$ & 40.0 & 14.0 & 3.2 \\
\hline baamoederhalsuitsit rijlkjo * & 2 & 4.565 & 0.71 & 0.6 & 0.9 & 6.3 & 25.6 & 66.5 \\
\hline $\begin{array}{l}\text { onderzook wan de longen met } \\
\text { aen gtethoscoop }\end{array}$ & 76 & 3.146 & 1.32 & 15.5 & 17.2 & 22.2 & 27.5 & 17.7 \\
\hline $\begin{array}{l}\text { keeluhtstrijkje: dit it met enen } \\
\text { opatel keelslijm aftsehrapen }\end{array}$ & 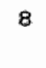 & 4.029 & 0.93 & 1.9 & 4.2 & 18: 1 & 40.5 & 35.3 \\
\hline $\begin{array}{l}\text { borstzalfonderzoek voor } \\
\text { vroumfen }\end{array}$ & 5 & 4.227 & 0.87 & 1.1 & 2.9 & 13.7 & 36.7 & 45.6 \\
\hline elaktro-encefialogram of EEG & 74 & 3.243 & 1.23 & 11.2 & 15.8 & 27.9 & 28.0 & 17.2 \\
\hline urine-onderzeel & 11 & 3.527 & 1.09 & 5.6 & 11.0 & 27.3 & 37.1 & 18.9 \\
\hline Iwangerschapstest & 23 & 2.365 & 1.24 & 32.7 & 24.6 & 22.7 & 13.5 & 6.5 \\
\hline borstonderzoek door de dokter & 3 & 4.334 & 0.81 & 0.8 & 2.5 & 9.4 & 37.2 & 50.2 \\
\hline $\begin{array}{l}\text { opsporen van bloed im the } \\
\text { stowgang * }\end{array}$ & 7 & 4.090 & 0.88 & 0.9 & 3.7 & $\pi 8.0$ & 40.2 & 37.2 \\
\hline blouddrukimeting & 25 & 2.096 & 1.08 & 36 & 30.4 & 22.7 & 6.4 & 3.7 \\
\hline wethogirafie & 9 & 3.860 & 1.11 & 5.1 & 16.7 & 18.4 & 367 & 33.1 \\
\hline recteral anderzoelik & 10 & 3.7 है 1 & 1.05 & 3,5 & B. 1 & 24.2 & 37.2 & 27.0 \\
\hline betraterten van de blams: & 13 & 3.326 & 1.10 & 7.1 & 13.4 & 34.3 & 30.2 & 15.0 \\
\hline $\begin{array}{l}\text { bepaten van hormonen in het } \\
\text { blowd }\end{array}$ & 15 & 3.1159 & 1.05 & 7.7 & 15.2 & 40.3 & 27.0 & 9.8 \\
\hline syphillis test & 18 & 2803 & 1.23 & 20.3 & 17.7 & 33.0 & 19.6 & 9,4 \\
\hline TBC of uberetulose tost & 12 & 3.327 & 1.30 & 93.2 & 13.7 & 20.6 & 32.1 & 20.4 \\
\hline $\begin{array}{l}\text { huidingpectie dear de doktar, bij } \\
\text { varanderend moedervlek }\end{array}$ & 6 & 4.115 & 0.8 & 1.1 & 3.8 & 15.5 & 41.6 & 38.0 \\
\hline
\end{tabular}

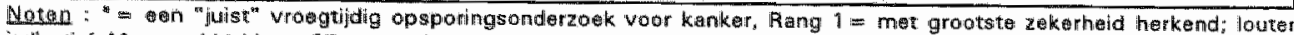

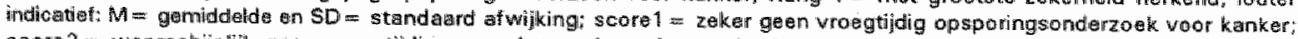
score 2 warsehijhlijk geen vroegtijdig opsporingsondezoek voor kanker; score $3=$ misschien niet, misschien wel een vroegtijdig opsporingsonderzoek voor kamker"; scare 4 = warsohijnlijk wel een wroegtijdig opsporingsonderzoek woor kanker; scores = zekar een wrougtijutig opsporimgsonderzosk voor kanker. 
Tabel 5.13 Aantal respondenten (in \%) wolgens hun kennis van kankerpreventie, naar zekerheidsscore en geslacht $(N=1631)$

\begin{tabular}{|c|c|c|c|c|c|}
\hline & \multicolumn{2}{|c|}{ "Scone4 } & \multicolumn{2}{|c|}{$\begin{array}{l}\text { Score5 } \\
\text { "zeker" }\end{array}$} & \multirow{2}{*}{$\begin{array}{l}\text { Sign. } \\
\text { (Chis }\end{array}$} \\
\hline & Mian & Vrouw & Witan & Vrouw & \\
\hline \multicolumn{6}{|c|}{ KENNIS VAN DE RISICOFACTOREN VOOR KANKER : } \\
\hline overdiadig blootstelling a/d zon & 46.9 & 47.7 & 30.0 & 39.2 & 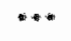 \\
\hline $\begin{array}{l}\text { seksuele omgang met meerdere partners } \\
\text { zonder condoom; als tisico voor wrouwen }\end{array}$ & 24.1 & 28.2 & 23.1 & 28.9 & $\cdots$ \\
\hline $\begin{array}{l}\text { eerste kind na de leettijd van } 30 \text { jaar; als } \\
\text { rilisico voor vrawwen }\end{array}$ & 11.9 & 11.1 & 20 & 2.1 & $*$ \\
\hline $\begin{array}{l}\text { passief roken; blootstelling aan } \\
\text { tabaksirook uit de omgeving }\end{array}$ & 42.4 & 43.5 & 32.2 & 35.5 & n.\&. \\
\hline roken & 19.0 & 20.8 & 73.6 & 75.4 & * \\
\hline $\begin{array}{l}\text { overm. glebrullk wan dienijke vetten in da } \\
\text { voeding }\end{array}$ & 41.3 & $4 \pi .6$ & 76.0 & 15.8 & n.s. \\
\hline zwaarlijuigheid & 31.1 & 28.6 & 7.0 & 6.1 & n.s. \\
\hline overm. gebruik vam alcohol & 42.6 & 41.2 & 23.6 & 28.3 & $*$ \\
\hline \multicolumn{6}{|c|}{ KENNIS VAN HET GEWENST KANKERPREVENTIEF GEDRAG: } \\
\hline regelm. eten van vers fruit & 34.0 & 35.4 & 45.8 & 50.6 & * \\
\hline regelm, eten wan ongepelde rijist & 24.1 & 28.9 & 12.0 & 15.7 & $*$ \\
\hline regrelmatig elen van bruin brood & 35.4 & 42.7 & 20.5 & 24.8 & $* * *$ \\
\hline regelmatig eten varn werse groenten & 39.4 & 39.2 & 40.4 & 4.6 .0 & $\cdot$ \\
\hline wermijden wan overgewicht & 38. & 37.3 & 25.7 & 31.3 & n.s. \\
\hline $\begin{array}{l}\text { overdadige blootstelling an de zon } \\
\text { varmijden }\end{array}$ & 40.2 & 35.1 & 46.3 & 53.0 & nis. \\
\hline $\begin{array}{l}\text { met mate dinken van alcoholiscthe } \\
\text { dranken }\end{array}$ & 36.5 & 42.0 & 29.4 & 3.2 & " \\
\hline stoppen met roken off niet roken & 18.4 & 17.5 & 75.1 & 77.2 & n.t. \\
\hline
\end{tabular}

- Sociale determinanten van kennis van kankerpreventie in Vlaanderen - 
Tabel 5.13 Aantal respondenten (in \%) volgens hum kennis van kankerpreventie,

- vervolg naar zekerheidsscore en geslacht ( $N=1631$ )

\begin{tabular}{|c|c|c|c|c|c|}
\hline & \multicolumn{2}{|c|}{$\begin{array}{l}\text { Scored } \\
\text { "warachijnilik" }\end{array}$} & \multicolumn{2}{|c|}{$\begin{array}{l}\text { Scone } 5 \\
\text { "zeker" }\end{array}$} & \multirow{2}{*}{$\begin{array}{l}\text { Sign. } \\
\text { (Chiz) }\end{array}$} \\
\hline & Mian & Vrouw & Man & Wroliw & \\
\hline \multicolumn{6}{|c|}{ KENNIS VAN DE YHARSCHUWINOSSIGNALEN VOOR KANKER: } \\
\hline $\begin{array}{l}\text { arnhoudende wijziging in plias of } \\
\text { stoelgamgpatroon }\end{array}$ & 42.1 & 46.8 & 10.7 & 14.9 & * \\
\hline ben wonde die miet geneest & 36.0 & 41.9 & 10.7 & 12.5 & * \\
\hline $\begin{array}{l}\text { abnormaal ana all of vaginall bloedverlites } \\
\text { (bloedverlies via de arars of de schede) }\end{array}$ & 49.0 & 46.0 & 18.1 & 25.7 & $*$ \\
\hline verdikking of k rubbutitje in de bonst & 45,3 & $36 \mathbf{6 i}$ & 4.2 .8 & 56.5 & $*$ \\
\hline onverkfazbatue gewichtsvermindering & 46.3 & 482 & 23.1 & 28.4 & * \\
\hline duidelijke verandering in een moedervlek & 37.7 & 41.7 & 26.0 & 42.8 & $* *$ \\
\hline gantinoudende hoest of herecheid & 37.5 & 39.3 & 11.8 & 15.5 & * \\
\hline \multicolumn{6}{|c|}{ KENINSS VAN DE VROEGTIJDIGE OPSPORINGSONDERZOEKEN VOOR KANKER: } \\
\hline mammografie voor vrouwen & 30,8 & 23.6 & 60.3 & 72.1 & $*$ \\
\hline baarmoederhalsuitstrijkje & 33.7 & 17.6 & 54.1 & 78.9 & $* *$ \\
\hline $\begin{array}{l}\text { borstrelfonderzolk voor } \\
\text { vrouwen }\end{array}$ & 41.5 & 31.9 & 39.4 & 51.7 & H* \\
\hline borsitanderzoelic deor de dokter & 39.4 & 34.9 & 45.0 & 55.3 & $\because+$ \\
\hline opuspreren varn bloed in de etoelgang & 43.1 & 37.3 & 32.2 & 42.1 & $* *$ \\
\hline rectadil ondlenzoek & 36.2 & 38.2 & 25.4 & 28.5 & n.s. \\
\hline $\begin{array}{l}\text { huldinspectie door de dokter, bij } \\
\text { veranderende moederviek }\end{array}$ & 44.1 & 39.2 & 30.3 & 45.5 & *** \\
\hline
\end{tabular}

\footnotetext{
- Sociale determinanten van kennis van kankerpreventie in Vlaanderen -
} 
bijlage 4 :

tabel 7.3 gemiddelde scores van kennis van kankerpreventie, naar geslacht en giecontroleerd voor leeftijdsklasse tabel 7.5 gemiddelde scores van kennis van kankerpreventie, naar leeftijdsklasse en gecontroleerd voor geslacht tabel 7.7 gemiddelde scores van kennis van kankerpreventie, naar aan- of afwezigheid van een partner; elaboratie naar geslachtsinvloed

tabel 7.8 gemiddelde scores van kennis van secundaire kankerpreventie bij mannen, naar aan- of afwezigheid van een partner; elaboratie naar leeftijdsinvloed

Bijlage 4

Bijlagen bij hoofdstuk 7 

Tabel 7.3 Gemiddelde scores van kennis van kankerpreventie.

naar geslacht en controlerend voor leeftijdsklasse

\begin{tabular}{|c|c|c|c|c|}
\hline Kennisschatlen : & Man & Wroun & Etra & $\begin{array}{l}\text { Wann:- } \\
\text { Whitney }\end{array}$ \\
\hline \multicolumn{5}{|c|}{ KENNIS VAN PRIMAIRE KANKERIPREVENTIE } \\
\hline Risicofactoren & 21.62 & 23.47 & 0.07 & $*$ \\
\hline $18-34$ jasir & 24.71 & 26.93 & 0.09 & $*$ \\
\hline 35.50 jaar & 2766 & 24.30 & 0.10 & $*$ \\
\hline 51.70 ja:ar & 17.93 & 18.75 & $=$ & $n . s$. \\
\hline Gewenst gedrag & 13.21 & 15.29 & 0.09 & $\because *$ \\
\hline $18-34$ jaar & 13.35 & 15.82 & 0.71 & $*$ \\
\hline $35-50$ jaar & $1: 4.21$ & 115.47 & 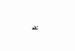 & n.s. \\
\hline $517 \times 70$ ja.ar & 11.95 & 14.52 & 0.12 & $*$ \\
\hline \multicolumn{5}{|c|}{ KENNMIS WAN SECUNDAIRE KANIKERPREVENTIE } \\
\hline Wararschuwingssignalen & 26.41 & 31.94 & 0.18 & $\cdots$ \\
\hline $18-34$ jaar & 22.05 & 27.79 & 0.20 & $* *$ \\
\hline 35.50 jaar & 28.61 & 32.67 & 0.14 & $*$ \\
\hline $51-70$ jaar & 29.20 & 35.83 & 0.20 & $\cdots$ \\
\hline Vroegtijdige opsporing & 28.34 & 32.29 & 0.11 & $\cdots *$ \\
\hline 18.34 jaa & 27.72 & 33.34 & 0.17 & $\ldots$ \\
\hline 35.50 jaar & 37.24 & 33.65 & - & m.s. \\
\hline $51-70$ jaar & 25.95 & 29.72 & 0.11 & $*$ \\
\hline \multicolumn{5}{|c|}{ SYNTHESE VAN KENNIS VAN KANKERPREVENTIE } \\
\hline Primaire Kankerpreventie & 17.41 & 19.38 & 0.10 & $* *$ \\
\hline $18-34$ jarar & 19.03 & 21.37 & 0.12 & $*$ \\
\hline $35-50$ jaat & 17.93 & 19.88 & 0.10 & * \\
\hline $51-70$ jaar & 94.94 & 16.64 & 0.09 & 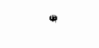 \\
\hline Secundaire Kankerpraventie & 27.38 & 32.01 & 0.17 & $*$ \\
\hline 18-34 joar & 24.88 & 30.56 & 0.21 & $\cdots$ \\
\hline $35-50$ ja ar & 29.92 & 3.3 .76 & 0.11 & $*$ \\
\hline $51-70$ fear & 27.57 & 32.7 & 0.10 & $\cdots$ \\
\hline Globale meting & 22.39 & 25.75 & 0.16 & $* *$ \\
\hline $18-34$ jaar & 21.96 & 25.97 & 0.20 & $* *$ \\
\hline $35-50$ jaar & 23.93 & 26.52 & 0.12 & $*$ \\
\hline $51 \times 70$ jaiar & 21.26 & 24.71 & 0.17 & $* *$ \\
\hline
\end{tabular}

Noot: de kennisscores lopen van - 100 (ze inadequate kennis van kankerpreventie) tot +100 (zeer adequate kennis van kankerpreventie?

- Sociale determinanten van kennis van kankerpreventie in Vlaanderen - 
Tabel 7.5 Gemiddelde scores van kennis van kankerpreventie, naar leettijdsklasse en controlerend voor geslacht

\begin{tabular}{|c|c|c|c|c|c|c|c|}
\hline Kentrisschaten: & $\begin{array}{l}(8-30 \text { ja } \\
\{n=433 \mid\end{array}$ & $\begin{array}{c}31-40 \text { jear } \\
(n=359)\end{array}$ & $\begin{array}{c}41-50 \text { jaar } \\
(n=329)\end{array}$ & $\begin{array}{c}51-60 \mathrm{jaa} \\
(m=272)\end{array}$ & $\begin{array}{l}61-70 \text { jaar } \\
(n=238)\end{array}$ & Etra & $\begin{array}{l}\text { Krus } \\
\text { kal } \\
\text { Waltis }\end{array}$ \\
\hline \multicolumn{8}{|c|}{ KENNIS WAN PRIMAIHE KANKERPREWENTIE : } \\
\hline Rüsicof actoren & 26.03 & 24.49 & 22.34 & 18.94 & 17.68 & 0.25 & $*$ \\
\hline man & 24.68 & 24.69 & 19.79 & 18.86 & 16.90 & 0.24 & $*$ \\
\hline wrouswir & 27.41 & 24.28 & 24.90 & 19.02 & 18.44 & 0.28 & $\leftrightarrow$ \\
\hline Gewenst gedray & 94.87 & 14.64 & 14.55 & 13.19 & 93.35 & - & $\mathrm{ns}_{\mathrm{n}}$ \\
\hline man & 13.63 & 13.85 & 13.84 & 12.08 & 11.81 & - & n.s. \\
\hline vrouw & 16.12 & 15.44 & 15.26 & 14.23 & 14.87 & - & n.s. \\
\hline \multicolumn{8}{|c|}{ KENNIS VAN SECUNDAIRE KANKERPREVENTIE : } \\
\hline Waarschulwingssign. & 23.86 & 28.55 & 31.60 & 33.25 & $3 \sharp .82$ & 0.23 & $\cdots$ \\
\hline $\operatorname{man}$ & 21.08 & 26.26 & 29.41 & 30.07 & 28,22 & 0.24 & $\cdots$ \\
\hline vious & 26.68 & 30.87 & 33.81 & 315.24 & 36.35 & 0.23 & $* *$ \\
\hline Vroegtifige Opsp. & 29.63 & 32.30 & 32.86 & 29.54 & 25.97 & 0.13 & 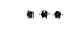 \\
\hline marn & 26.31 & 30.74 & 32.00 & 27.73 & 23.97 & 0.16 & $* *$ \\
\hline vrouw & 32.98 & 33.89 & 33.72 & 31.24 & 27.95 & 0.12 & $*$ \\
\hline \multicolumn{8}{|c|}{ SYNTHESE VAN KENNIS NAN KANKERPREVENTIE : } \\
\hline Prim.Kanikerpreventie & 20.45 & 19.56 & 18.44 & 16.06 & 15.511 & 0.19 & 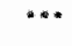 \\
\hline man & 19.15 & 19.27 & 16.82 & 15.47 & 114,36 & 0.19 & 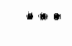 \\
\hline wrouw & 21.77 & 19.86 & 20.08 & 16.62 & 16.65 & 0.21 & $\cdots$ \\
\hline sec. Kartatiprevertio & 26.74 & 30.42 & 32.23 & 31.39 & 28.90 & 0.15 & $*$ \\
\hline man & 23.70 & 28.50 & 30.70 & 28.90 & 26.09 & 0.19 & 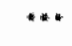 \\
\hline wrouw & 29.83 & 32.38 & 33.76 & 33.74 & 31.65 & 0.11 & * \\
\hline Ghabale mating & 23.60 & 24.99 & 25.34 & 23.73 & 22.21 & 0.10 & "* \\
\hline $\operatorname{man}$ & 24.43 & 23.89 & 23.76 & 22.18 & 20.22 & 0.13 & $*$ \\
\hline srouw & 25.80 & 26.12 & 26.92 & 25.18 & 24.15 & $=$ & n.s. \\
\hline
\end{tabular}

Noat: de kannisscores lopen vam - 100 (zer inadequate kennis van kankerpreventie) tot +100 (zeer adequate kennis van kankerpreventie) 
Tabel 7.7 Gemiddelde scores van kennis van kankerpreventie, naar aan- of afwezigheid van een partner; ellaboratie naar geslachtsinvloed

\begin{tabular}{|c|c|c|c|c|}
\hline Kennisschalen: & $\begin{array}{l}\text { Met partner } \\
(n=1368)\end{array}$ & $\begin{array}{c}\text { Zondel } \\
\text { partmer } \\
(\mathrm{n}=263)\end{array}$ & Eta & $\begin{array}{c}\text { Mamno } \\
\text { Whitney } \\
\text { test }\end{array}$ \\
\hline \multicolumn{5}{|c|}{ KENNIS VAN PRIMAIRE KANKERPREVENTIE: } \\
\hline Risicofactoren & 22.74 & 21.54 & - & m.s. \\
\hline $\operatorname{man}$ & 21.78 & 20.86 & - & n.s. \\
\hline wrouw & 23.67 & 22.33 & - & n.s. \\
\hline Gewenst gedrag & 14.48 & 13.06 & 0.05 & * \\
\hline $\operatorname{man}$ & 13.46 & 12.01 & - & $\mathrm{n} . \mathrm{s}$ \\
\hline vrouw & 15.47 & 14.27 & * & n.s. \\
\hline \multicolumn{5}{|c|}{ KENINIS VAN SECUNDAIIRE KANKERPREVENTIE: } \\
\hline Waarschtwwingssignalen & 29.82 & 25.86 & 0.09 & $* *$ \\
\hline 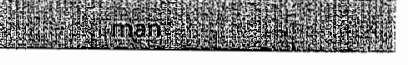 & 27.43 & 21.53 & 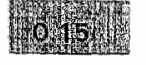 & $* *$ \\
\hline wrouw & 32.13 & 30.86 & - & n.s. \\
\hline Vroegtijdige opsporing & 30.84 & 27.60 & 0.07 & $* *$ \\
\hline 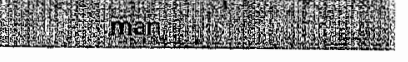 & 29.04 & 24.99 & 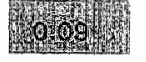 & * \\
\hline vrouw & 32.58 & 30.63 & - & n.s. \\
\hline \multicolumn{5}{|c|}{ SYNTHESEMATEN VANI KENNIS VAN KANKERPREVENTIE: } \\
\hline Prim. Kankerpreventie & 18.61 & 17.30 & - & n.s. \\
\hline $\operatorname{man}$ & 17.62 & 16.43 & - & n.s. \\
\hline vrouw & 19.57 & 18.30 & * & m.s. \\
\hline Sec. Kankerpreventie & 30.33 & 26.73 & 0.09 & $* *$ \\
\hline 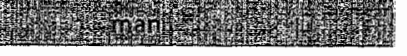 & 28.24 & 23.56 & 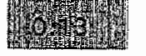 & **** \\
\hline vrouw & 32.35 & 30.74 & - & m.s. \\
\hline Globale meting & 24.47 & 22.02 & 0.09 & $* *$ \\
\hline W & 22.93 & 19.85 & 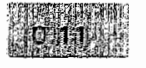 & $*$ \\
\hline vrouw & 25.95 & 24.52 & - & n.s. \\
\hline
\end{tabular}

Noot: de kennisscores lopen van - 100 (2eer inadequate kennis wan kankerpreventie) tot +100 (zeer adequate kennis van kankerpreventie)

- Sociale determinanten van kennis van kankerpreventie in Vlaanderen - 
Tabel 7.8 Gemiddelde scores van kennis van secundaire kankerpreventie bij mannen, naar aan- of afwezigheid van een partner; elaboratie naar leeftijdsinvloed

\begin{tabular}{|c|c|c|c|c|}
\hline Kennisschalen: & $\begin{array}{c}\text { Met } \\
\text { partner } \\
(n=673)\end{array}$ & $\begin{array}{c}\text { Zonder } \\
\text { partner } \\
(n=141)\end{array}$ & Eta & $\begin{array}{c}\text { Mann- } \\
\text { Whitney } \\
\text { test }\end{array}$ \\
\hline \multicolumn{5}{|c|}{ KENNIS VAN SECUNDAIRE KANKERPREVENTIE: } \\
\hline Waarschuwingssignalen & 27.43 & 21.53 & 0.15 & $* *$ \\
\hline 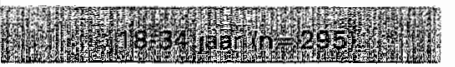 & 23.33 & 18.97 & 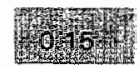 & $\cdot$ \\
\hline $35-50$ jaar $(n=268)$ & 28.96 & 25.60 & - & m.s. \\
\hline $51-70$ jaar $(n=250$ ) & 29.60 & 25.72 & - & n.s. \\
\hline Vroegtijdige opsporing & 29.04 & 24.99 & 0.09 & * \\
\hline 18-34 aar $(n=295)$ & 28.87 & 24.97 & - & n.s. \\
\hline $35-50$ jaar $(n=269)$ & 31.60 & 28.10 & - & $\mathrm{n}, \mathrm{s}_{\mathrm{n}}$ \\
\hline $51-70$ jaar $(n=250)$ & 22.44 & 21.73 & - & n.s. \\
\hline \multicolumn{5}{|c|}{ SYNTHESE VAN KENNIS VAN SECUNDAIRE KANKERPREVENTIE : } \\
\hline Tatale populatie & 28.24 & 23.56 & 0.13 & $* *$ \\
\hline my & 26.10 & 21.97 & 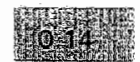 & * \\
\hline $35-50$ jaar $(n=269)$ & 30.28 & 26.85 & . & n.s. \\
\hline $51-70$ jaar $(\mathrm{m}=250 \mathrm{l}$ & 28.02 & 23.72 & - & m.s. \\
\hline
\end{tabular}

Nont : de kennisscores lapen van - 100 (zeer inadequate kennis van kankerpreventie) tot +100 (zeer adequate kenmis van kankerpreventie)

- Sociale determinanten van kennis van kankerpreventie in Vlaanderen - 
bijllage 5 :

tabel 8.2 frequentieverdeling van de sociaal-economische kenmerken in negen klassen

tabell 8.8 gemiddelde scores van kennïs van kankerpreventie, naar de gedintegreerde sociaal-economische status gebaseerd op opleiding, inkomen ến beroepsstatus in 9 klassen

tabel $\mathbf{8 . 1 5}$ multiple regressie-analyses van kennis van kankerpreventie met socio-demografische determinanten en sociaal-economische status

Bijlage 5

Bijlagen bij hoofdstuk 8 

Tabel 8.2 Frequentieverdeling van de sociaal-economische kenmerken in negen klassen

\begin{tabular}{|c|c|c|c|c|c|}
\hline & $\begin{array}{l}\text { Abs. } \\
\text { freq. }\end{array}$ & $\begin{array}{l}\text { Rel. } \\
\text { freq. }\end{array}$ & & $\begin{array}{l}\text { Abs. } \\
\text { frea. }\end{array}$ & $\begin{array}{l}\text { Ael. } \\
\text { freq. }\end{array}$ \\
\hline $\begin{array}{l}\text { Opleiding } \\
\text { (N= } 1630) \\
\text { 1. LO } \\
\text { 2. LSO-technisch/berceps } \\
\text { 3. LSO-alg. wormend } \\
\text { 4. HSO-technisch/beroeps } \\
\text { 5. HSO-alg. vormend } \\
\text { 6. HOKT } \\
\text { 7. HOLT } \\
\text { 8. Universitair } \\
\end{array}$ & $\begin{array}{r}308 \\
260 \\
112 \\
365 \\
193 \\
229 \\
60 \\
103 \\
\\
1\end{array}$ & $\begin{array}{r}18.9 \\
16.0 \\
6.9 \\
22.4 \\
11.8 \\
14.0 \\
3.7 \\
6.3\end{array}$ & $\begin{array}{l}\text { SESla) (N = } 13911 \text { ) } \\
\text { lopleiding + ink.) } \\
\text { 1. Laag-laag } \\
\text { 2. Midden-laag } \\
\text { 3. Hoog-laag } \\
\text { 4. Laag-midden } \\
\text { 5. Midden-midden } \\
\text { 6. Hoog-midden } \\
\text { 7. Laag-hoog } \\
\text { 8. Midden-hoog } \\
\text { 9. Hoog-hoog } \\
\text { non-respons }\end{array}$ & $\begin{array}{l}156 \\
212 \\
111 \\
125 \\
124 \\
133 \\
223 \\
169 \\
141 \\
\\
240\end{array}$ & $\begin{array}{r}11.2 \\
15.2 \\
8.0 \\
9.0 \\
8.7 \\
9.6 \\
16.0 \\
12.1 \\
10.1\end{array}$ \\
\hline $\begin{array}{l}\text { Inkomen } \\
\text { (N=1391) } \\
\text { 1. Laag-laag } \\
\text { 2. Midden-laag } \\
\text { 3. Hoog-laag } \\
\text { 4. Laag-midden } \\
\text { 5. Midden-midden } \\
\text { 6. Hoog-midden } \\
\text { 7. Laag-hoog } \\
\text { 8. Midden-hoog } \\
\text { 9. Hoog-hoog } \\
\text { mon-respons }\end{array}$ & $\begin{array}{l}151 \\
172 \\
138 \\
165 \\
173 \\
118 \\
162 \\
152 \\
160 \\
240\end{array}$ & $\begin{array}{r}10.9 \\
12.4 \\
9.9 \\
11.9 \\
12.4 \\
8.5 \\
11.6 \\
10.9 \\
11.5\end{array}$ & $\begin{array}{l}\text { SES(b) (N }=13.28 \text { ) } \\
\text { lopleiding + ink. + } \\
\text { beroep) } \\
\text { 1. Laag-laag } \\
\text { 2. Midden-laag } \\
\text { 3. Hoog-laag } \\
\text { 4. Laag-mididen } \\
\text { 5. Midden-midden } \\
\text { 6. Hoog-midden } \\
\text { 7. Laag-hoog } \\
\text { 8. Midden-hoog } \\
\text { 9. Hoog-hoog } \\
\text { non-respons }\end{array}$ & $\begin{array}{l}145 \\
131 \\
132 \\
176 \\
185 \\
107 \\
159 \\
120 \\
173 \\
303\end{array}$ & $\begin{array}{r}10.9 \\
9.9 \\
9.9 \\
13.3 \\
13.9 \\
6.1 \\
12.0 \\
9.0 \\
13.0\end{array}$ \\
\hline $\begin{array}{l}\text { Beroepsprestige ( } N=1524 \text { ) } \\
\text { 1. Laag-laag } \\
\text { 2. Midden-laag } \\
\text { 3. Hoog-laag } \\
\text { 4. Laag-midden } \\
\text { 5. Middin-midden } \\
\text { 6. Hoog-midden } \\
\text { 7. Laag-haog } \\
\text { 8. Middlen-hoog } \\
\text { 9. Hoog-hoog } \\
\text { non-respons }\end{array}$ & $\begin{array}{l}171 \\
160 \\
181 \\
170 \\
166 \\
166 \\
174 \\
163 \\
173 \\
107\end{array}$ & $\begin{array}{c}11.2 \\
10.5 \\
11.9 \\
11.2 \\
10.9 \\
10.9 \\
11.4 \\
10.7 \\
11.4\end{array}$ & & & \\
\hline
\end{tabular}

- Zie bijlage $2 b$ woor de exacte operationalisering van de variabelen SES(a) en SES(b).

- Sociale determinanten van kennis van kankerpreventie in Vlaanderen - 


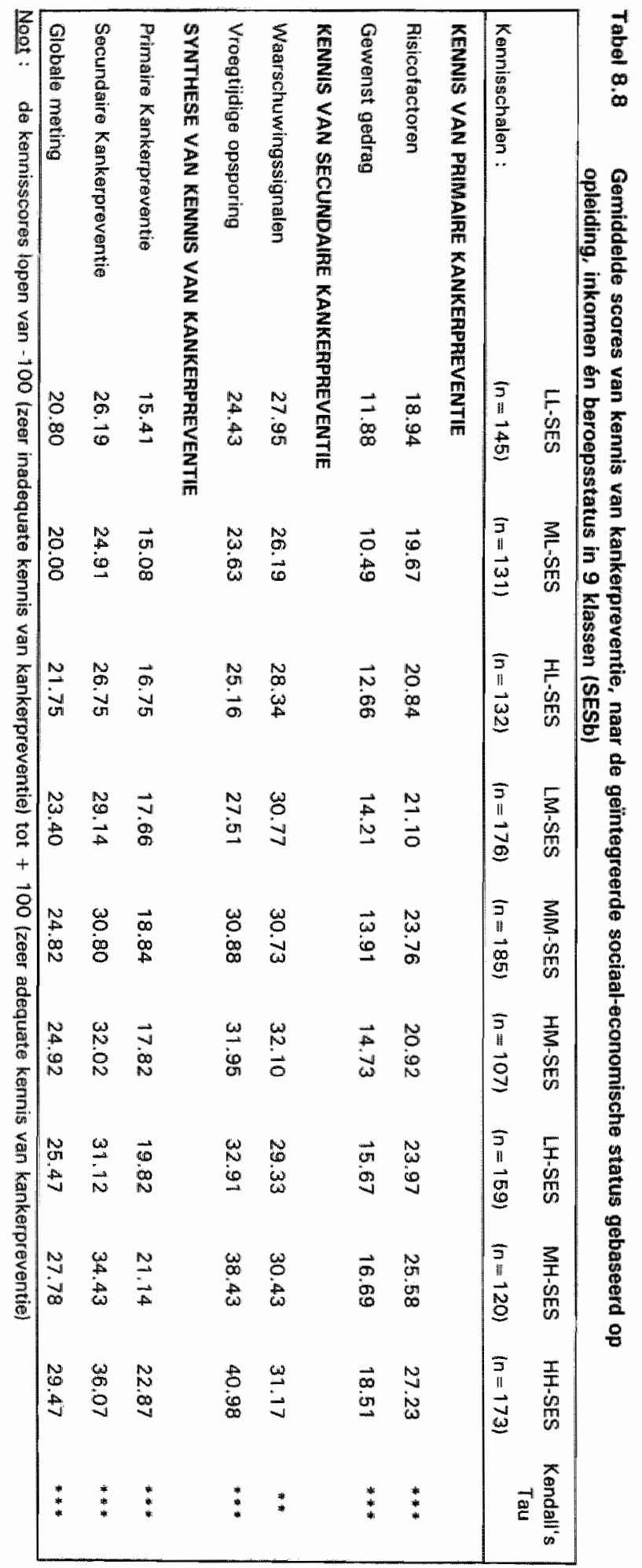


Tabel 8.15

Multiple regressie-analyses van kennis van kankerpreventie met socio-demografische determinanten en sociaal-economische status (1)

\begin{tabular}{|c|c|c|c|c|}
\hline Onathankelijke vartabele & $B$ & Beta & Tolerance & sign. 1 \\
\hline Geslacht (man, vrouw) & 1.77 & .07 & .997 & ** \\
\hline Leeftijd & -.20 & -22 & .967 & $\cdots$ \\
\hline Partner (met, zonder) & .1 .70 & $\therefore .04$ & .993 & M.s. \\
\hline SES(b) (laag; hoog: & 2.47 & .10 &, 963 & $* *$ \\
\hline (constante) & 29.63 & & & $*$ \\
\hline
\end{tabular}

KENNIS VAN GEWENST KANKERPREVENTIEF GEORAG

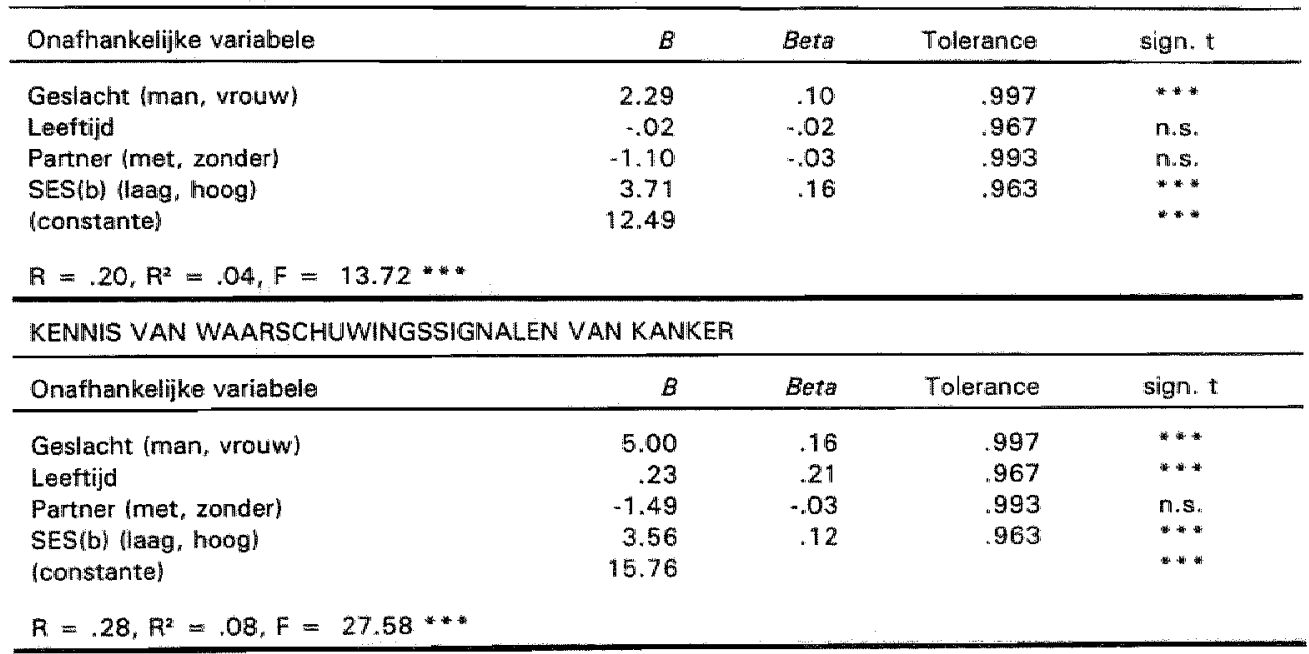

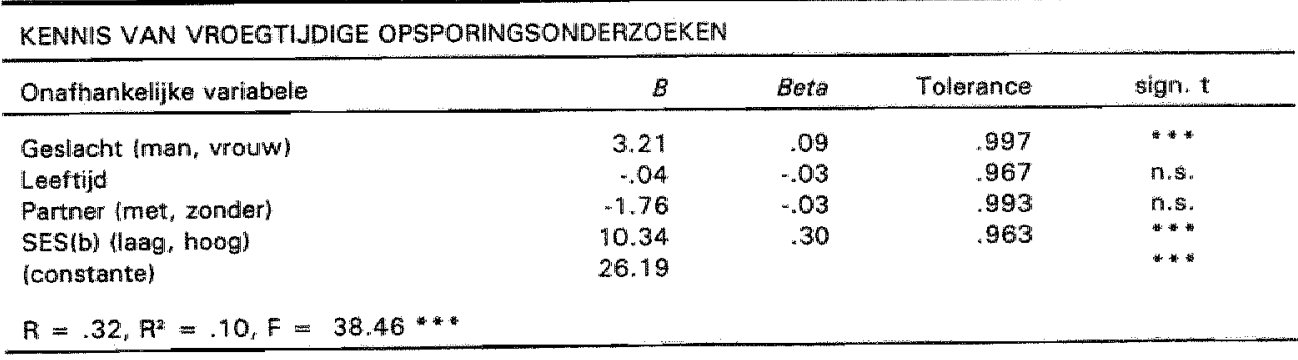

- Sociale determinanten van kennis van kankerpreventie in Vlaanderen - 
[vervolg tabel 8.15$]$

KENNUS VAN PRIMAIRE KANKEFPREVENTIE

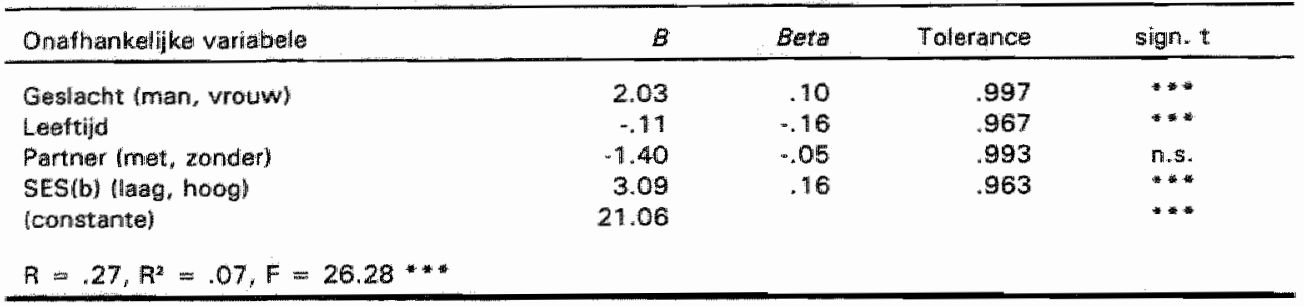

KENNIS VAN SECUNDAIRE KANKERPREVENTIE

\begin{tabular}{|c|c|c|c|c|}
\hline Onafhankelijke variabele & $B$ & Beta & Tolerance & sign. $t$ \\
\hline Gesiacht (man, vrouw) & 4.11 & .15 & .997 & $* *$ \\
\hline Leeftijd & .10 & .09 & .967 & $* *$ \\
\hline Partner (met, zonder) & -1.62 & .04 & .993 & n.s.n. \\
\hline SES(b) llaag, hoogl & 6.95 & .25 & .963 & $* *$ \\
\hline (constante & 20.98 & & & $* *$ \\
\hline \multicolumn{5}{|c|}{$R=.30, R^{2}=.09, F=31.78 *$} \\
\hline
\end{tabular}

GLOBALE METING VAN KENNIS VAN KANKERPREVENTIE

\begin{tabular}{|c|c|c|c|c|}
\hline Onafhanikellike wariabele & $B$ & Beta & Tolerance & sign. \\
\hline Geslacht (man, wrouw & 3.07 & .15 & .997 & * * \\
\hline Leeftijd & -.01 & -01 & .967 & $n_{x} s$. \\
\hline Partner (met, zonder) & -1.51 & -.05 & .993 & m.s. \\
\hline SES(b) (laag. hoog) & 5.02 & .24 & .963 & $*$ \\
\hline (constante) & 21.02 & & & $* *$ \\
\hline
\end{tabular}

Noten: $\quad \leqslant 0.001 * 0.001<p \leqslant 0.01$

1) De "tolerance" van de onathankelijke variabelen in de regressie wordt meestall gebruikt om de callineariteit te meten 15PSS, 1993: 355). Do tolerance-waarden in tabel 8.15 liggen allemaal zer dicht bij 7, zodat zeer weinig variantic van de betreffende onafhankelijke valiabele wordt verklaard door de overige onafhankelike variabelen. We mogem dus besluiten dat er in belangrikg mate is voldaan aan de assumptie van de afwezigheid van mult collineariteit.

Voor de 7 doorgevoerde regressie-analyses werd in belangrijke mate volidaan aan de vier assumpties van het regressiemodiel t.a.w. de storingstermen of rasiduen (Schreuder, 1991:263-265): het gemiddelde van alle residuen was gelijk aan nul de residuen waren bij verschillende waarnemingen vrij onafhankelifk van elkatr (Durbin-Watson test schommelde tussen 1.87 en 1.95); de wariantie van de (gestandaardiseerde) rasiduen blek op en scatterplot ongeveer even groot voor elke waarde van de (gestandaardiseerde) voorspelling op basis van de onafhankelike variabelen (assumptie van homoscedasticiteit); de residuen bleken altemal normaal verdeeld te zijn lgecontrolleerd met een "Normal P-P Plot of Standardized Residuals"). 


\section{Sociale determinanten van kennis van kankerpreventie in Vlaanderen (samenvatting)}

Gezondheidsvoorlichting en -opvoeding (GVO) kan bijdragen aan verandering in gedirag. Hiermee kunnen mensen worden aangezet om gezonder te gaan leven en zodoende kankef te voorkomen. Met GVO kuninen mensen ook aangezet worden om te participeren aan vroegtijdige opsporing van kanker, zodat uiteindelik een vermindering van ziekte en sterfte door kanker kan worden bereikt. In GVO en kankerpreventie speelt voorlichting aan het algemene publiek een vooraanstaande rol. Hoewel men zich vragen kan stellen over de zin van voorlichtingscampagnes om kennis van kankerpreventie te verhogen, zijn in Vlaanderen de facto de meeste interventies (nog steeds) gericht op kennisoverdracht. Het meten van kennis van kankerpreventie is dan ook noodzakelijk voor het opzetten en bij het evalueren van interventies met het oog op het bevorderen van kennis inzake kankerpreventie. Het uitgangspunt voor dit proefschrift was de vaststelling dat men ondanks jarenlange voorlichting inzalke kankerpreventie in Vlaanderen nog steeds niet weet of al deze inspanningen geleid hebben tot een adequate kennis bij de bevolking. Bovendien tonen de relatief beperkte buitenlandse studies ter zake fragmentarische en inconsistente (soms zelfs: tegenstrijdige) resultaten. In sommige studies wordt een voldoende kennisniveau vastgesteld, terwijl in andere dan weer een inadequate kennis wordt vastglesteld. Het doel van dit proefschrift was het toetsen van kennis van kankerpreventie bij de Vlaamse bevalking en het beschrijven van kennisverschillen tussen respondenten met een verschillende socio-demografïsche positie of sociaal-economische status. De empirische resultaten van onderhavig onderzoek zijn gebaseerd op een survey-onderzoek bij een representatieve steekproef van 1631 Vlamingen tussen 18 en 70 jaar. Meer in het bijzonder beoogde deze studie een antwoord te geven op volgende onderzoeksvragen:

1. Hoe kan kennis van kankerpreventie (in grabaliteit) op een valide en betrouwbare wijze wardien gemeten?

II. Heeft de Vlaamse bevolking een adequate kennis van kankerpreventie?

1. Zijn binnen kennis van kankerpreventie bepaalde kennisdomeinen of aspecten van kankerpreventie beter gekend dan andere?

2. Bestaan er misvattingen over kankerpreventie?

3. Kan de Vlaamse bevolking factoren die echt iets te maken hebbien met kankerpreventie goed onderscheiden van factoren die gean rol spelen bij kankerpreventie?

III. Is kennis wan kankerpreventie gelijkmatig verspreid in de Vaamse bevolking of zijn er categorieën met een significant grotere of kleinere kennis van kankerpreventie dan andere categorieën?

1. Hangt kennis van kankerpreventie van mensen samen met hun sociodemografische positie in de samenleving? is er m.a.w. een ongelijke verdeling van de kennis van kankerpreventie naar geslacht, leeftijd en leefsituatie?

2. Hangt kennis van kankerpreventie van mensen samen met hun socialeconomische status in de samenleving? Is er m.a.w. een ongelike verdeling van de kennis van kankerpreventie naar opleiding, inkomen en beroepsstatus? 
Om een betrouwbaar antwoord te kunnen geven op bovenstaande onderzoeksvragen was een betrouwbaar én geldig instrument am kennis van kankerpreventie te kunnen meten noodzakelijk (onderzoeksvraag: I). Dit proefschrift beoogde een bijdrage te leveren tot het ontwikkellen van een dergelijk meetinstrument. De conceptualisering van het meetinstrument vertrok vari een analyse van de concepten 'kankerpreventie" en 'kennis van ....'. Tevens werd aangegeven hoe medisch gewenste kennis kan worden gemeten of getoetst. Hierwoor was de besichikking noodzakelijk van 'kennisnormen'. De selectie van deze kennisnormen werd gebaseerd op bestaande nationale en internationale consensusrapporten over de medische richtlifinen of aanbevelingen inzake kankerpreventie. Teneinde een valide meetinstrument te kunnen ontwikkelen, werd kennis van kankerpreventie geconceptualiseerd aan de hand van twee dimensies, namelijk kennis van primaire kankerpreventie en kennis van secundaire kankerpreventie. Vervolgens werden vier indicatoren geoperationaliseerd door telkens 25 items: kennis van risicofactoren van kanker, kennis van gewenst kankerpreventief gedrag, kennis van waarschuwingssignalen voor kanker en kennis van vroegtijdige opsporingsonderzoeken voor kanker. Om de misvattingen over kankerpreventie te kunnen onderzoeken, bevatte de vragenlijst ook 'foutieve' items die volgens de medische aambevelingen niets met kankerpreventie te maken hebben. Er kon worden vastgesteld dat de geconstrueerde schallen om kennis van kankerpreventie te meten algemeen goede resultaten gaven op het getoetste betrouwbaarheidcriterium van interne consistentie. De zeer hoge Cronbach's alpha waarden blijken bovendien consistent of robuust bij analyse van de betrouwbaarheid van de kennisschalen in subpopulaties. Ook het validiteitsonderzoek gaf bevredigende resultaten. Het gebruik van de 'adequate' kennisschalen - en dus van de combinatie van medisch gewenste 'juiste' en medisch ongewenste 'foutieve' items bij de kennismeting - leidde tot een validere meting van kennis van kankerpreventie dan het afzonderlijk gebruik van een kennisschaal waarmee alleen kennis van "juiste" items werd getoetst. De validering wan de adequate kennisschalen werd verder met bevredigende resultaten onderzocht door respectievelijk de methode van 'inhoudsvalidering', 'criteriumvalidering' en 'begripsvalidering'.

De onderzoeksresultaten toonden aan dat de Vlaamse bevolking een zekere mate van adequate kennis van kankerpreventie heeft (onderzoeksvraag (I). In het algemeen tonen de beschrijvende resultaten echter een bont geschakeerd beeld. Een aantal concrete aspecten i. v.m. kankerpreventie is zeer goed gekend; andere aspecten zijn dan weer veel minder of nauwelijks gekend (onderzoeksvraag II/1). Zo bijvoorbeeld is roken zeer goed gekend als risico op (long)kanker, maar wordt 'overmatig gebruik wan dierlijke vetten' of 'zwaarlij vigheid' matig herkend als risicofactor van kanker, evenmin worden 'regelmatig eten van bruin brood' of 'regelmatig eten van ongepelde rijst' herkend als medisch gewenste preventieve voedingscomponenten. Verder werd ook vastgesteld dat de aanbevelingen waarover in medische kringen een consensus bestaat vrij goed gekend zijn door de bevolking lbv. baarmoederhalsuitstrijkje als wroegtijdig opsporingsonderzoek van baarmoederhalskanker "mammografie als vroegtijdig opsporingsonderzoek woor borstkanker, of stoppen met roken ter preventie van langkanker), terwijl deze waarover weinig consensus bestaat in medische kringen, minder goed gekend zijn (bv. de richtlijnen over aanvangsleeftijd en frequentie van vroegtijdige opsporing, de risicofactoren inzake voeding). Uit de gemiddelde schaalscores bleek dat er in Vlaanderen een duidelijk verschil is in kennisniveau tussen kennis van primaire kankerpreventie en kennis van secundaire kankerpreventie. Het laatste 
kennisdomein is beduidend beter gekend dan het eerste. Binnen het kennisdomein van secundaire kankerpreventie weten de respondenten evenveel over de vroegtijdige opsporingsonderzoeken van kanker als over de waarschuwingssignalen van kanker. Hetzelfde kan evenwel niet worden gezegd over de kennis van primaire kankerpreventie. De score wordt gevormd door een relatief hoge kennis van de risicofactoren (de 'verboden') en een relatief lage kennis van het gewenst kankerpreventie gedrag (de 'geboden').

Er werden ook een hele reeks misvattingen over kankerpreventie vastgesteld (onderzoeksvraag 1//2). Deze kunnen echter niet worden gelokaliseerd in éen kennisdomein. In het domein van de 'primaire kankerpreventie' situeren de meeste misvattingen zich vooral bij kennis van het gewenst kankerpreventief gedrag en minder bij de kennis van de risicofactoren. In het domein van de 'secundaire kankerpreventie' situeren de meeste misvattingen zich vooral bij de kennis van de vroegtijdige opsporingsonderzoeken en minder bij de kennis van de waarschuwingssignalen van kanker. In deze studie kon ook het vermogen van respondenten worden anderzocht om onderscheid te kunnen maken tussen medisch gewenste kennis en medisch ongewenste kennis (onderzoeksvraag II/3\%. Dit onderscheidingsvermogen werd onderzocht door de scores op de kennisschalen enkel gebaseerd op de "juiste" items te vergelijken met de scores op de foutperceptieschalen lenkel gebaseerd op 'foutieve' items, die dus niets te maken hebben met kankerpreventie). In het algemeen kon in deze studie worden vastgesteld dat de respondenten met grotere zekerheid weten dat lets wél met kankerpreventie te maken heeft, dan dat iets niet met kankerpreventie te maken heeft. Het onderscheidinglsvermogen verschilt evenwel sterk naargelang het domein en de gebruikte indicator van de kennis van kankerpreventie. Het onderscheidingsvermogen is relatief klein bij kennis van de primaire kankerpreventie en vrij groot bij de kennis van secundaire kankerpreventie. Binnen het kennisdomein van 'primaire kankerpreventie' kan de Vlaamse bevolking m.a.w. minder goed onderscheid maken tussen aspecten die echt lets te maken hebben met kankerpreventie en aspecten die helemaal geen rol spelen bij kankerpreventie, dan binnen het kennisoomein van 'secundaire kankerpreventie".

In dit proefschrift werd ook de invloed van sociale determinanten op kennis van kankerpreventie onderzocht (onderzoeksyraag III). Er kon worden alangetoond dat de kennis van kankerpreventie in de Vlaamse bevolking ongelijk gespreid is naar da sociodemografische positie van respondenten in de samenleving (onderzoeksvraag III/1). De empirische bevindingen over de invloed van ges/acht op kennis van kankerpreventie zijn consistent met deze uit eerdere studies. Voor alle kennismetingen hadden vrouwen een significant hogere kennisscore dan de mannen. Vrouwen weten dus meer over kankerpreventie dan mannen. Deze verschillen in kennisniveau zijn echter het meest uitgesproken bij kennis van 'secundaire kankerpreventie'. De gevonden relaties tussen geslacht en kennis van kankerpreventie zijn over het algemeen ook consistent bij elaboratie naar leeftijd. Leeftijd heeft in dit onderzoek geen eenduidige relatie met kennis van kankerpreventie. Leeftijd vertoont een negatief lineaire samenhang met kennis van 'primaire kankerpreventie". De jongste leeftijdscategorie heeft de grootste kennis van primaire kankerpreventie en de kennisscore daalt gradueel met toenemende leeftijd. Met kennis van 'secundaire kankerpreventie" heeft leeftijd evenwell een curvilineaire samenthang. De kennisscare stijgt gradueel tot de leeftijdsklasse van 41-50 jaar, om nadien weer gradueel 
te daler. De vastgestelde relaties tussen leeftijd en kennis van kankerpreventie zijn over het allgemeen ook corisistent bij elaboratie naar geslacht. Over het algemeen kon worden vastgesteld dat de invloed van de leefsituatie (aanwezigheid van een partner) op kennis van kankerpreventie wrij zwak is. Voor urouwen kon worden geconcludeerd dat de invloed van de partner op hun kennis van kankerpreventie vrijwel nihil is. Voor mannen was de invloed van de partner enkel significant voor hun kennis van secundaire kankerpreventie. Wanneer de invloed van de drie socio-demografische factoren op de kennis van kankerpreventie onderling wordt vergeleken, werd vastgesteld dat vooral de invloeden van geslacht en leeftijd substantieel waren. Ook hier dient een onderscheid te worden gemaakt in het domein waarop de kennis betrekking heeft. Leeftijd correleert in wergelijking met geslacht ongeveer even sterk met "kennis van secundaire kankerpreventie", doch twee keer zo sterk met "kennis van primaire kankerpreventie".

In dit proefschrift werd ook uitwoerig aandacht besteed aan de invloed van sociaaleconomische status (SES) op kennis van kankerpreventie (onderzoeksvraag |l1/2). Op basis van de literatuur werd voorspeld dat naarmate de sociaal-economische status stijgt ook de kennis wan kankerpreventie zou stijgen. Deze hypothese werd systematisch getoetst aan de hand van opleidingsniveau, inkomen en beroepsstatus en twee samengestelde SESindicatoren lopleiding samen met inkomen; en opleiding samen met inkomen én beroepsstatus). De hypothese werd bevestigd in alle uitgevoerde analyses. De resultaten zijn daarmee consistent met deze uit eerdere studies. De sterkte van de samenhang tussen SES en kennis van kankerpreventie is onafhankelijk van het kennisdomein. Verder kan worden gesteld dat de vooropgestelde lineariteit in de samenhang tussen de sociaal-economische status en kennis van kankerpreventie wordt bevestigd in dit onderzoek. Het positief lineair verband tussen SES en kennis van kankerpreventie bleek na controle voor geslacht en leeftijd ook zeer robuust te zijn. Om de relatieve impact van alle sociale determinanten op kennis van kankerpreventie te kunnen analyseren en om de interactie-effecten onder controle te kunnen houden werden multiple regressie-analyses uitgevoerd. Uit deze analyses bleek dat SES de grootste impact heeft op kennis van kankerpreventie en dat respectievelijk leeftijd en geslacht een additieve impact hebben op kennis van kankerpreventie. De aan- of afwezigheid van een partner blijkt geen additieve impact te hebben. De saciaal-economische status is dus veruit de belangrijkste sociale determinant van kennis van kankerpreventie.

Op basis van de onderzoeksresultaten blijken de relaties tussen de sociale determinanten en kennis van kankerpreventie vrij complex te zijn. Het is meestal niet éen kenmerk dat verantwoordelijk is voor een bepaalde sociale predispositie ten aanzien van (kennis van) kankerpreventie. Het is een cluster van kenmerken die maken dat mensen al dan niet bevoor- of benadeeld zijn door hun maatschappelijke positie en die mensen helpen of beletten in het maken van keuzes ten behoeve van hun gezondheid. De variabele impact van de sociale determinanten op kennis van kankerpreventie is bovendien sterk gerelateerd aan het domein van kankerpreventie waarop de kennis betrekking heeft. 


\section{Social determinants of knowledge of cancer prevention (summary)}

Health promotion can change the behaviour of the individual or of groups by leading them to make 'healthy choices'. People can be convinced of the possibility of living a more healthy life and consequently preventing cancer. Additionally, cancer morbidity and mortality can also be reduced by promoting participation in secondary cancer prevention programmes by means of cancer screening. Health education on cancer prevention has become an important method of health promotion and cancer prevention in Flanders (Belgium). Although the efficacy of improving knowledge as a method of changing risk behaviour into healthy behaviour can be questioned, most cancer prevention interventions in Flanders are actually based on the transference of medical guidelines. Therefore, measurement of knowledge of cancer prevention is needed. It is an essential instrument for effect-evaluation of health promotion interventions towards the public aimed at an improvernent of knowledge of cancer prevention. The starting point of this study is the fact. that in Flanders after many years of health education on cancer prevention towards the public no-one is aware of the effect of these efforts. No-one knows whether these afforts have led towards an increase in knowledge of cancer prevention amongst the Flemish population. Furthermore, the existing studies on knowledge of cancer prevention abroad show a fragmentary view and a lack of cohesion in the (sometimes contradictory) empirical results. Same studies show an adequate level of knowledge of cancer prevention among the public. Others do not. The aim of this study is to measure the knowledge of cancer prevention in Flanders (Belgium) and to describe the knowledge differences between people with different socio-demographic positions and between people of different socio-economic status. The empirical results of this study are based on data colllected in a survey-research among 1631 respondents (a representative sample of Flemish people aged 18 to 70 ). More precisely this study tries to answer the following research questions:

1. How can the complex construct "knowledge of cancer prevention" be measured with a satisfactory degree of reliability and validity?

11. Does the Flemish population have an adequate knowledge of cancer prevention?

1. Are there some domains or aspects of cancer prevention better known than others?

2. Do misunderstandings exist in people's knowledge of cancer prevention?

3. Is the public capable of discriminating between factors which are related to cancer prevention ('right" items) and those which aren"t ('false' items)?

111. Are there any social inequalities in knowledge of cancer prevention in Flanders? Are there subpopulations with significantly higher or lower level of knowledge of cancer prevention than others?

1. Is knowledge of cancer prevention determined by sacio-demographic position? In other words, is there an unequal distribution of knowledge of cancer prevention by gender, age and living arrangement "living with a partner, either married or unmarried)?

2. Is knowledgle of cancer prevention determined by socioneconomic position? in other words, is there an unequal distribution of knowledge of cancer prevention by education, income and professional status?

- Sociale determinanten van kennis vari kamkerpreventie in Vlaanderen - 
To give reliable answers to these research questions, we first needed to develop a reliable and valid instrument to measure 'knowledge of cancer prevention" (research question n' 1). The main aim of this dissertation is to contribute to the development of such an instrument. The starting point of the conceptualisation of the scale on knowledge of cancer preverition was an analysis of the constructs 'cancer prevention' and 'knowledge of ...' and a discussion of some methods for testing medical knowledge. One necessary condition for measuring knowledge is the existence of knowledge 'norms'. In this study the selection of these norms was based on the existing national and international reports on medical recommendations or guidelines for cancer prevention. To reach a high validity in measuring knowledge of cancer prevention two dimensions of knowledge of cancer prevention were conceptuallsed, namely knowledge of "primary" cancer prevention and knowledge of 'secondary' cancer prevention. Four indicators were selected to measure these dimensions, namely 'knowledge of risk factors of cancer' and 'knowledge of recommended cancerpreventive behaviour' to measure knowledge of primary cancer prevention, and 'knowledge of cancer early warning signs' and 'knowledge of cancer screening tests' to measure knowledge of secondary cancer prevention. All indicators were operationalised with 25 items in the "Knowledge of Cancer Prevention 100 items Questionnaire" . To be able to measure 'misperceptions' of cancer prevention false items were introduced into the questionnaire. The false items had nothing to do with cancer prevention. Overall, the constructed scales of knowledge of cancer prevention gave good results on the reliability test of internal consistency. We reached high values of Cronbach's alpha and these values were very consistent among different subpopulations. Also, the validation tests showed some validation evidence for the constructed scales. The mixed use of right and false items in the questionnaire increased the validity, by reducing the systematic measurement bias caused by a response-set or by socially desirable responding. Additionally, the validation tests provided evidence of content validity, criterion-related validity and construct validity.

Overall, the research results showed some evidence of a certain amount of adequate knowledge of cancer prevention in the Flemish population iresearch question $n^{\circ}$ III. Nevertheless, the descriptive item analysis showed a complex and broad spectrum of knowledge of cancer prevention in Flanders. Some aspects of cancer prevention are well known, others are not (research question $\left.n^{\circ} 11 / 1\right)$. For example, tobacco smoking is well known as a risk factor for lung cancer, but the respondents do not recognize 'diets high in animal fat' or "obesity" as risk factors for cancer, nor are fibre-containing food components like 'regularly eating of brown bread' or 'regularly eating of rough rice' recognized as protective factors for cancer. We noticed that those guidelines on cancer prevention that have a consensus among the medical profession are well known by the Flemish population (for instance the pap smear as screening test for the early detection of cancer of the cervix; mammography as a screening test for the early detection of breast cancer; quitting tobacco smoking to prevent lung cancerl, but those guidelines that are still under discussion are not ffor instance the guidelines on starting age and frequency of the pap smear; the guidelines on starting age and frequency of the mammography; various diet components that (might) have causative agents). The mean scores on the knowledge of cancer prevention scales proved a significant difference in level of knowledge between 'primary' cancer prevention and 'secondary' cancer prevention. The latter knowledge domain of cancer prevention is clearly better known in Flanders than the former. Inside the knowledge 
domain of 'secondary' cancer prevention the respondents had an equal level of knowledge of the two separate indicators, namely knowledge of cancer early warning signs and knowledge of cancer screening tests. The same could not be said of the knowledge domain of 'primary' cancer prevention. The mean score of knowledge of primary cancer prevention is based on a high level of knowledge of the risk factors of cancer (the "prohibitions') and a low level of knowledge of the recommended cancer-preventive behaviour the 'admissions').

The empirical results also confirmed the existence of misunderstandings in knowledge of cancer prevention in Flanders (research question $n^{\circ} 11 / 2$ ). In the domain of knowledge of "primary" cancer prevention most misunderstandings were discovered in the knowledge of recommended cancer-preventive behaviour, and less in the knowledge of the risk factors of cancer. In the domain of knowledge of 'secondary' cancer prevention most misunderstandings were found in the knowledge of cancer screening tests, and less in the knowledge of cancer early warning signs. A measurement of "discriminant ability" in knowledge of cancer prevention was also developed (research question $n^{\circ}(1 / 3)$. The discriminant ability could be evaluated by comparing the scores on the knowledge scales based (only) on the right iterns, with the scores on the 'false perception scales' (only based on false items, that had nothing to do with cancer preventioni. Overall, compared to the fallse items the respondents recognized the right items with a higher degree of certainty. Furthermore, the discriminant ability is different in the separate domains and indicators of knowledge of cancer prevention. The discriminant ability is (relatively) low in the knowledge of "primary" cancer prevention and (relatively) high in the knowledge of "secondary' cancer prevention. In other words, in the domain of 'primary' cancer prevention Flemish people are less able to distinguish the rights aspects of cancer prevention from those aspects that have nothing to do with cancer prevention, than in the domain of 'secondary' cancer prevention.

In this dissertation, also the impact of social determinants on knowledge of cancer prevention in Flanders was studied (research question $n^{\circ}$ (II). Empirical support for an unequal distribution of knowledge of cancer prevention by socio-demographic position was found (research question $n^{\circ}[11 / 1)$. The empirical results of the impact of gender on knowledge of cancer prevention were consistent with the results of previous studies. For all measures of knowledge of cancer prevention women had significantly higher mean scores than men. Gender differences in knowledge are most marked in the domain of 'secondary' cancer prevention. Controlling for the possible effect of age, the (strength of the) correlations between gender and knowledge of cancer prevention were not affected. Consequently, the relationship between gender and knowledge of cancer prevention is noticeably consistent. The effect of age on knowledge of cancer prevention was rather complex. Age had a negative linear relation with knowledge of 'primary' cancer prevention. The youngest age group had the highest score of knowledge of 'primary' cancer prevention and the level of knowledge decreased constantly with respect to the increase of age. However, age had a curvilinear relation with knowledge of "secondary" cancer prevention. The level of knowledge increased gradually up to the age group of a 41-50 vear and then decreased gradually. Controlling for the possible effect of gender, the correlations between age and knowledge of cancer prevention were robust. Overall, the correlations between living arrangement (living with a partnen) and knowledge of cancer prevention were very 
poor. For women, no empirical evidence was found for an effect of living arrangement on knowledge of cancer prevention. For men, the effect was only significant for knowledge of 'secondary" cancer prevention: men with a partner knew more of "secondary" cancer prevention than singles. Comparing the effects of the three socio-demographic determinants on knowledge of cancer prevention, only the effect of age and the effect of gender were substantial. Furthermore, the strength of the correlations is very much dependent on the domain of knowledge of cancer prevention. Compared with gender, age correlated twice as much with knowledge of 'primary' cancer prevention, but the strength of the association with knowledge of "secondary" cancer prevention was quite similar.

In this dissertation also the impact of 'socio-economic status' (SES) on knowledge of cancer prevention in Flanders was studied (research question $n^{\circ}$ III/2). Based on international literature and empirical results of other studies the following relation between SES and knowledge of cancer prevention was predicted: "the higher the socio-economic status of the respondents, the higher their knowledge of cancer prevention". This hypothesis was systematically tested with the SES indicators education, income, professional status and two combined SES indicators lone based on education and income, another based on education, income and professional statusi. The hypothesis was confirmed in all tests. The empirical results supported very strongly the predicted relation between SES and knowledge of cancer prevention that was found in previous studies. This research also discovered that the domain of the knowledge did not determine the strength of the association between SES and knowledge of cancer prevention. Additionally, we could also confirm the predicted linearity in the relation. Controlling for the possible effect of gender and age, the positive linear relation between SES and knowledge of cancer prevention was very consistent. Compared with all other SES indicators used in this study the combined SES indicator based on education, income and professional status had the strongest correlation with knowledge of cancer prevention. To test the independent impact of the different social determinants on knowledige of cancer prevention and to control the joint (interaction) effect of two or more of these predictors on knowledige of cancer prevention, several multiple regression analyses were conducted. The regression analyses showed that SES has the strongest impact on knowledge of cancer prevention. Age and gender have an additional impact on knowledge of cancer prevention, but the living arrangement has not. Compared with all other social determinants explored in this study SES can be considered as the most important social determinant of knowledgle of cancer prevention.

The findings in this study prove the complexity of the relations between the social determinants and knowledge of cancer prevention. Mostly, it is not one social characteristic that is responsible for a certain social predisposition towards knowledge of cancer prevention and towards cancer prevention participation. The social reality is much more complex. It is a cluster of social factors that makes a person either privileged or disadvantaged by his or her position in society. This privileged or disadvantaged position supports or prevents people from making choices that might increase or decrease their health status. Moreover, the separate impact of the social determinants on knowledge of cancer prevention is strongly related to the domain of knowledge of cancer prevention. 


\section{Dankwoord}

Het is genoegzaam bekend dat onderzoek niet in een ivoren toren kan worden gerealiseerd. Verborgen achter dit onderzoek zitten dan ook de medewerking en inzet van tal van personen en instellingen, die op één of andere wijze behulpzaam zijn geweest. De financiële middelen voor het realiseren van dit onderzoek kwamen van de Vlaamse Minister voor Volksgezondheid en Preventie en van de Onderzoeksraad van de Vrije Universiteit Brussel. Zonder deze financiële steun kon dit onderzoek geen doorgang vinden.

Voor deskundige feedback op de verschillende versies van het onderzoeksontwerp en de vragenlijst ben ik dank verschuldigd aan zeer veel onderzoeksinstituten, onder meer het Belgisch Werk Tegen Kanker, de Vakgroep Epidemiologie en Sociale Geneeskunde van de Universitaire Instelling Antwerpen, de Vakgroep Huisartsgeneeskunde en Eerstelijnsgezondheidszorg van de Universiteit Gent en de Vakgroep Gezondheidsvoorlichting en Opvoeding van de Universiteit Maastricht. De burgemeesters van de 89 gemeenten waar de interviews plaatsvonden, ben ik danik verschuldigd woor de toelating om hun bevolkingsregister te mogen raadplegen. Zonder hun medewerking had de steekproef nooit op een wetenschappelijk verantwoorde wijze tot stand kumnen komen. Ik ben ook dank verschuldigd aan allen die een bijdrage hebben geleverd aan het vooronderzoek, alsook aan de 108 interviewers en de 1631 respondenten die deelnamen aan de survey van het hoofdonderzoek. Zonder hun bereidwillige medewerking had de dataverzameling geresulteerd in een lege doos.

De hulp bij dit onderzoek heeft voor mij ook vele gezichten en namen. Helaas moet ik mij noodgedwongen beperken tot een selectie.

Eerst en vooral ben ik veel dank verschuldigd aan de promotores. Prof. dr. G.J. Kok was zo vriendelijk om in een gevorderd stadium van het onderzoek het promotorschap te aanvaarden en kritische kanttekeningen te maken bij het manuscript. Zowel bij het creëren van de financiële mogelijkheden, bij het opzetten van het onderzoek als bij de uitvoering ervan kon ik steeds rekenen op de steun van Prof. dr. F. Louckkx. Prof. dr. H. Philipsen dank. ik woor zijn deskundigheid bij het vaorzitten van de beoordelings en promotiecommissie. Voor de feedback op alle hoofdstukken uit dit proefschrift wens ik naast mijn promotores ook Françoise Driesens te bedanken. Eddy Van Nieuwenhuyzen dank ik voor zijn commentaren bij een eerdere versie van thet slothoofdstuk en Jane Mayes voor het nazicht van de literatuurlijst en haar correcties van de Engelse samenvatting. De leden van de beoordelingscommissie dank ik voor hum bereidheid om dit verslag te lezen en voor hun kritische kanttekeningen.

Ria Maes werkte in de beginfase van het onderzoek als werkstudente mee aan een pilootstudie over kennis van kankerpreventie bij 208 eerstejaarsstudenten. Dit onderzoek heeft belangrijke inzichten opgeleverd die de basis vormden voor het hoofdonderzoek. Ann Carton van het Sociologisch Onderzoeksinstituut van de K.U. Leuven heeft zich zeer verdienstelijk gemaakt bij de selectie en training van de interviewers. De collega's van de Medisch-Sociale Wetenschappen te Brussel hebben de immense organisatio van het 
veldwerk mee voor hun rekening genomen. Petra De Nooze dank ik tevens voor haar hulp bij het verrichten van de steekproef. Het gehele onderzoek werd administratief goed ondersteund door de secretaresses Lydia De Brandt en Patricia Kranskens. De statistici Prof. dr. L. Kaufman en Prof. dr. M. Despontin wil ik danken voor hun advies bij de statistische analyses van de onderzoeksgegevens.

Er wordt wel eens gezegd dat een doctoraat ook de verdienste is van de partner van de doctorandus. Met onderhavig proefschrift werd deze stelling meer dan ooit bevestigd. De bijdrage van Françoise Driesens reikt echter verder dan de gebruikelike plichtplegingen zoals geduld en morele steun. Zij stond in alle fasen van het onderzoeksproces klaar om met veel inzet en deskundigheid de rol te vervullen van interdisciplinaire 'sparring-partner". Zonder haar morele en intellectuele hulp had ik de 'negende ronde' nooit gehaald.

Alle mensen die in dit proefschrift geînvesteerd hebben, dank ik oprecht voor het mee helpen welslagen van deze onderneming. Ik hoop aan hun verwachtingen te hebben voldaan. De tekorten van dit onderzoek neem ik geheel voor mijn rekening. 


\section{Curriculum Vitae}

Luc Deliens werd geboren op 8 April 1959 te Brussel-Elsene. In 1977 behaalde hij aan het Sint-Jozefscollege het eindexamen Wetenschappelijke $B$. Aansluitend studeerde hij sociologie aan de Vrije Universiteit Brussel en verkreeg in 1981 het diploma van Licentiaat in de Sociologie met grote onderscheiding. Nadien studeerde hij polemologie en politieke sociologie aan de Rijksuniversiteit Groningen en aan het Inter-University Centre of PostGraduate Studies te Dubrovnik. In 1991 behaalde hij aan dle VU Brussel met grootste onderscheiding het diploma van Bijzonder Licentiaat in de Menselijke Ecologie en het International Certificate of Human Ecology van de World Health Organisation.

Professioneel was hij sinds 1983 achtereenvolgens verbonden aan de vakgroep Empirische Sociologie van de RU Groningen (o.l.w. Prof. dr. JE Ellemers en dr. H van Goor), het Centrum voor Socialogie van de VU Brussel (o.l.v. Prof. dr. F Louckx), de dienst Kankerpreventie van de VU Brussel (0.I.v. Prof. dr. W Betz) en de vakgroep Medisch-Sociale Wetenschappen van dezelfde universiteit (o.I.v. Prof. dr. F Louckx). Hij publicererde onder meer twee monografieën en tal van artikels in diverse boeken en in uiteenlopende sociaalwetenschappeiijke en medische tijdschriften.

Aan het eind van de jaren ' 80 begon hij met onderzoek over kankerpreventie. Het onderzoek dat resulteerde in het onderhavige proefschrift startte in 1993. Het maakte deel uit van een ruimere gezondheidsenquête die in opdracht van de toenmalige Vlaamse Minister voor Volksgezondheid en Preventie werd verricht. In 1994 ontving hij samen met de co-auteurs F Van Muilwijk en W Betz voor de publicatie "Ervaring met kankerpreventie tijdens de medische opleiding. " "Huisarts Nu, 1992, 21: 188-193) de tweejaarlijkse Upjohn Prijs voor het beste researchartikel in het tijdschrift van de Wetenschappelijke Vereniging der Vlaamse Huisartsen. Vanaf 1 januari 1997 coördineert hij een interuniversitair onderzoeksproject in opdracht van het Fonds voor Wetenschappelijk Onderzoek Vlaanderen over "Houdingen en handelwijzen van artsen rond het levenseinde van hun patiënten" (o.l.v. de professoren J De Maeseneer, F Louckx, B Van Camp en H Vanden Endent.

Luc Deliens woont in Brussel samen met Françoise Driesens en hun zoontje Quinten. 